DOE/RL-93-61

Revision 0

UC-630, 721

\title{
State Waste Discharge Permit Application for Industrial \\ Discharge to Land \\ 200 East Area W-252 Streams
}

Date Published

December 1993

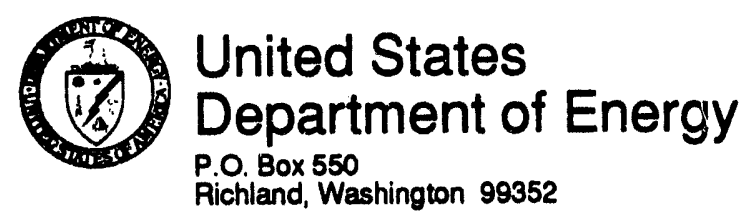

Richland, Washington 99352

Approved for Public Release

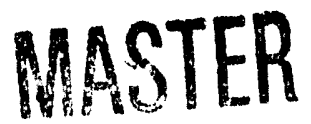


TRADEMARK DISCLAIMER

Reference herein to any specific commercial product, process,

or service by trade name, trademark, manufacturer, or

otherwise, does not necessarily constitute or imply its

endorsement, recommendation, or favoring by the United

States Government or any agency thereof or its coniractors or subcontractors.

This report has been reproduced from the best available copy. Available in paper copy and microfiche.

Available to the U.S. Department of Energy

and its contractors from

Office of Scientific and Technical Information

P.0. Box 62

Oak Ridge, TN 37831

(615) $576-8401$

Available to the public from the U.S. Department of Commerce National Technical Information Service

5285 Port Royal Road

Springfiold, VA 22161

(703) $487-4650$

Printod in the Unitod Statos of Amorica

DISCLM-5.CHP (8-91) 


\section{FOREWORD}

Fourteen liquid effluent streams were identified as Phase II streams in the Annual Status Report of the Plan and Schedule to Discontinue Disposal of Contaminated Liquid into the Soil Column at the Hanford Site (WHC 1988). Of these fourteen Phase II streams, one (209-E Laboratory reflector water) has been discontinued. Four streams (Plutonium-Uranium Extraction Plant cooling water which has been rerouted to the Plutonium-Uranium Extraction Plant chemical sewer, 242-S Evaporator steam condensate, T-Plant laboratory wastewater, and 284-W Power Plant cnoling water) were designated to be discharged to the 200 Area Treated Effluent Disposal Facility (Project W-049H), and will be permitted accordingly. The remaining nine Phase II streams were subsequently categorized as "Other" Phase II streams, and were identified as such in Table 3 of Consent Order No. DE 91 NM-177 (216 Consent Order) (Ecology and DOE-RL 1991). These nine streams include the following:

- 241-AY/AZ Tank Farm steam condensate (currently inoperative)

- 242-A Evaporator cooling water

- 242-A Evaporator steam condensate

- 241-A Tank Farm cooling water

- 244-AR Vault cooling water

- 284-E Power Plant waste water

- B Plant cooling water

- 183-D Filter backwash

- 400 Area secondary cooling water

Implementation of Best Available Technology/All Known and Reasonable Treatment and disposal for these streams, with the exception of the 400 Area secondary cooling water and the 183-D Filter Backwash, will be under Project W-252, and as such, these streams are identified as the "W-252 streams". Washington Administrative Code 173-216 State Waste Discharge Permit applications are required to be submitted to the Washington Department of Ecology by December 31, 1993 for the W-252 streams, in accordance with Table 3 of the 216 Consent Order.

This document constitutes the WAC 173-216 State Waste Discharge Permit application for these six W-252 liquid effluent streams:

- 242-A Evaporator cooling water;

- 242-A Evaporator steam condensate;

- 241-A Tank Farm cooling water;

- $\quad$ 244-AR Vault cooling water;

- 284-E Power Plant waste water;

- B Plant cooling water.

The 241-AY/AZ Tank Farm stenm condensate is currently inoperative. When operative, this stream is routed to a double-shell tank in the AY/AZ Tank Farm.

Therefore, the 241-AY/AZ Tank Farm steam condensate does not require a State Waste Discharge Permit application. The State Waste Discharge Permit application for the 400) Area secondary cooling water was submitted to Washington State Department of Ecology 
in December of 1992. The 183-D Filter Backwash is scheduled to cease discharge by June of 1994. A modification to the 216 Consent Order for not submitting a State Waste Discharge Permit application for the 183-D Filter Backwash has been submitted to the Washington State Department of Ecology and is scheduled to be approved in December 1993. The remaining six W-252 streams are commingled either before or at the discharge point into the 216-B-3-3 Ditch leading to the B Pond complex, and are therefore being addressed collectively under this State Waste Discharge Permit application. The six W-252 streams are planned to be rerouted, via a new pipeline under Project $X-009$, during 1994. This rerouting will eliminate discharges to the 216-B-3-3 ditch, the main lobe, and the A-lobe of the B Pond complex.

Analytical data from WHC 1992a has been presented in the State Waste Discharge Permit application for both the 242-A Evaporator cooling water and the 242-A Evaporator steam condensate streams. The 242-A Evaporator is currently in a facility shutdown mode and the Sampling and Analysis Plan data will not be available until the streams are sampled after planned facility restart in early 1994. Since both of the 242-A Evaporator streams will discharge to the $B$ Pond complex after facility restart, they have been included in this State Waste Discharge Permit application. The remaining four streams included in the State Waste Discharge Permit application are currently active.

Analytical data presented for the 241-A Tank Farm cooling water, 244-AR Vault cooling water, 284-E Power Plant waste water, and the B Plant cooling water streams are from validated round one sampling results collected and analyzed in accordance with the approved Sampling and Analysis Plans for those streams.

In addition to the six 200 East Area W-252 streams included in this State Waste Discharge Permit application three additional streams are currently routed to the B Pond complex for disposal. These three additional streams are not included in this State Waste Discharge Permit application because they are planned to be rerouted to the 200 Area Treated Effluent Disposal Facility (Project W-049H), and permitted as such. 


\section{CONTENTS}

\section{Page No.}

FOREWORD $\ldots \ldots \ldots \ldots \ldots \ldots \ldots \ldots \ldots \ldots \ldots \ldots \ldots \ldots \ldots \ldots \ldots \ldots$ ii

CONTENTS $\ldots \ldots \ldots \ldots \ldots \ldots \ldots \ldots \ldots \ldots \ldots \ldots \ldots \ldots \ldots \ldots \ldots$

GLOSSARY $\ldots \ldots \ldots \ldots \ldots \ldots \ldots \ldots \ldots \ldots \ldots \ldots \ldots \ldots \ldots \ldots \ldots$

METRIC CONVERSION TABLE $\ldots \ldots \ldots \ldots \ldots \ldots \ldots \ldots \ldots \ldots \ldots$ vii

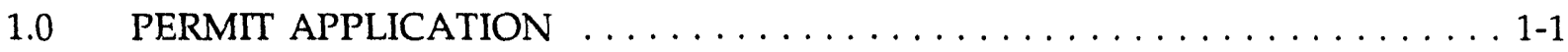

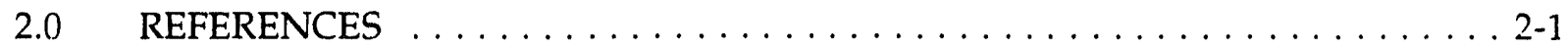

APPENDICES

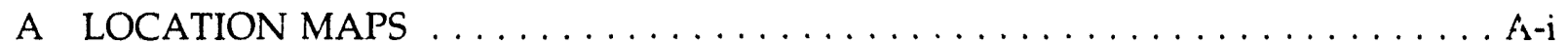

B PRODUCT OR SERVICE INFORMATION $\ldots \ldots \ldots \ldots \ldots \ldots \ldots \ldots \ldots \ldots$. $\ldots \ldots$

C PLANT OPERATIONAL CHARACTERISTICS $\ldots \ldots \ldots \ldots \ldots \ldots \ldots \ldots \ldots$.

D WATER CONSUMPTION AND WATER LOSS $\ldots \ldots \ldots \ldots \ldots \ldots \ldots \ldots \ldots$ D-i

E WASTEWATER INFORMATION $\ldots \ldots \ldots \ldots \ldots \ldots \ldots \ldots \ldots \ldots \ldots \ldots$

F STORMWATER $\ldots \ldots \ldots \ldots \ldots \ldots \ldots \ldots \ldots \ldots \ldots \ldots \ldots \ldots \ldots \ldots$

G OTHER INFORMATION $\ldots \ldots \ldots \ldots \ldots \ldots \ldots \ldots \ldots \ldots \ldots \ldots \ldots$ G-i

$\mathrm{H}$ SITE ASSESSMENT $\ldots \ldots \ldots \ldots \ldots \ldots \ldots \ldots \ldots \ldots \ldots \ldots \ldots \ldots \ldots \ldots$ 
DOE/RL 93-61, Rev 0

$12 / 93$

200 East Area W-252 Streams

This page intentionally left blank. 
DOE/RL 93-61, Rev 0

$12 / 93$

200 East Area W-252 Streams

\section{GLOSSARY}

\begin{tabular}{|c|c|}
\hline Alum & aluminum sulfate \\
\hline BAT/AKART & $\begin{array}{l}\text { best available technology/all known and reasonable } \\
\text { treatment }\end{array}$ \\
\hline $\mathrm{BCE}$ & B Plant chemical sewer \\
\hline BCS & B Plant condensate system \\
\hline Btu & British Thermal Unit \\
\hline CASS & computer automated surveillance system \\
\hline $\mathrm{CBC}$ & B Plant cooling water \\
\hline CFR & Code of Federal Regulations \\
\hline C.T. & cooling tower \\
\hline DOE & U.S. Department of Energy \\
\hline $\mathrm{DOE} / \mathrm{RL}$ & U.S. Department of Energy Richland Operations Office \\
\hline ECWS & emergency cooling water system \\
\hline EPA & U.S. Environmental Protection Agency \\
\hline ETF & effluent treatment facility \\
\hline gpm & gallons per minute \\
\hline HEPA & high-efficiency particulate air \\
\hline HEIS & Hanford Environmental Information System \\
\hline $\mathrm{HP}$ & high pressure \\
\hline HVAC & heating, ventilation, and air conditioning \\
\hline $\mathrm{H} / \mathrm{X}$ & heat exchanger \\
\hline JGV & jet gang valve \\
\hline LERF & Liquid Effluent Retention Facility \\
\hline LLW & low-level waste \\
\hline M & million \\
\hline $\mathrm{Ma}$ & million years \\
\hline $\mathrm{msl}$ & mean sea level \\
\hline $\mathrm{N} / \mathrm{A}$ & not applicable \\
\hline NCAW & neutralized current acid waste \\
\hline NPDES & National Pollutant Discharge Elimination System \\
\hline $\mathrm{OG}$ & operating gallery \\
\hline $\mathrm{ppb}$ & parts per billion \\
\hline psig & pounds per square inch gauge \\
\hline PUREX & plutonium-uranium extraction (Plant) \\
\hline RCRA & Resource Conservation and Recovery Act of 1976 \\
\hline SAP & sampling and analysis plan \\
\hline SARA & Superfund Amendment and Reauthorization Act of 1986 \\
\hline SEPA & State Environmental Policy Act of 1971 \\
\hline SIC & standard industrial classification \\
\hline SOW & statement of work \\
\hline SWDP & state waste discharge permit \\
\hline TEDF & Treated Effluent Disposal Facility \\
\hline TRUEX & transuranic extraction \\
\hline USGS & United States Geological Survey \\
\hline WAC & Washington Administrative Code \\
\hline WESF & Waste Encapsulation and Storage Facility \\
\hline Westinghouse Hanford & Westinghouse Hanford Company \\
\hline WTF & water treatment facility \\
\hline
\end{tabular}




\section{METR'C CONVERSION CHART}

\begin{tabular}{|c|c|c|}
\hline \multicolumn{3}{|c|}{ INTO METRIC } \\
\hline If you know & Multiply by & To get \\
\hline \multicolumn{3}{|c|}{ Length } \\
\hline inches & 2.54 & centimeters \\
\hline feet & 30.48 & centimeters \\
\hline \multicolumn{3}{|c|}{ Volume } \\
\hline gallons & 3.786 & liters \\
\hline cubic feet & 0.02832 & cubic meters \\
\hline \multicolumn{3}{|c|}{ Temperature } \\
\hline Fahrenheit & $\begin{array}{l}\text { Subtract } 32 \text { then } \\
\text { multiply by } 5 / 9 \text { ths }\end{array}$ & Celsius \\
\hline \multicolumn{3}{|c|}{ Pressure } \\
\hline inches water & 1.87 & $\mathrm{~mm} \mathrm{Hg}$ \\
\hline inches water & 249 & pascal $(\mathrm{Pa})$ \\
\hline \multicolumn{3}{|c|}{ OUT OF METRIC } \\
\hline \multicolumn{3}{|c|}{ Length } \\
\hline centimeters & 0.3937 & inches \\
\hline meters & 3.28 & feet \\
\hline \multicolumn{3}{|c|}{ Volume } \\
\hline milliliters & $1.247 \times 10^{-3}$ & cubic feet \\
\hline liters & 0.264 & gallons \\
\hline cubic meters & 35.31 & cubic feet \\
\hline \multicolumn{3}{|c|}{ Temperature } \\
\hline Celsius & $\begin{array}{c}\text { Multiply by } 9 / 5 \text { ths, } \\
\text { then add } 32\end{array}$ & Fahrenheit \\
\hline \multicolumn{3}{|c|}{ Pressure } \\
\hline $\mathrm{mm} \mathrm{Hg}$ & 0.5353 & inches water \\
\hline pascal $(\mathrm{Pa})$ & $4.02 \times 10^{-3}$ & inches water \\
\hline
\end{tabular}




\subsection{PERMIT APPLICATION}

This section presents the State Waste Discharge Permit application for the Project W-252 streams. The streams are included in Table 3 of the 216 Consent Order as "Other Phase II Streams."

\subsection{ORGANIZATION}

The Washington Administrative Code (WAC) 173-216 State Waste Discharge Permit application form for the W-252 streams generated in the 200 East Area and disposed of in the B Ponds Complex is enclosed in Section 1.2. Information required by the State Waste Discharge Permit application form is provided in the appendices, as noted in the completed form. The appendices follow precisely the format of the State Waste Discharge Permit application and are designed to read as a complete "stand-alone" State Waste Discharge. Permit application containing all of the required information for the six 200 East Are.d W-252 streams. Appendix A contains site location maps referenced in Section $A$ of the permit application form. Appendices $B$ through $\mathrm{H}$ correspond to Sections $B$ through $\mathrm{H}$ in the permit application form. Within each appendix, sections correspond directly to the respective questions on the application form. For example, question 1 in Section B of the application form is answered in Appendix B, Section 1.0. The question in the appendices are worded precisely as they are in the application form, and are highlighted in bold underline.

Many of the questions in the application form require separate responses for each of the six W-252 streams included in the permit application. For questions requiring separate responses for each of the six W-252 streams, subsections are utilized under each section to answer the questions for each of the streams. The order in which the streams are addressed in these subsections is consistent throughout the document. This order is as follows:

- 242-A Evaporator Cooling Water;

- 242-A Evaporator Steam Condensate;

- 241-A Tank Farm Cooling Water;

- 244-AR Vault Cooling Water;

- 284-E Power Plant Waste Water;

- B Plani Cooling Water.

All of the questions in the permit application are answered in the appendices to ensure continuity when reviewing the document. As a result, it is not necessary to refer to the application form itself when reviewing the remainder of the document. This organizational format allows the reviewer to read the permit appiication cover to cover without referring back to the application form itself. 
200 East Area W-252 Streams

1

2

3

4

\subsection{STATE WASTE DISCHARGE PERMIT APPLICATION FORM}

The following pages contain the State Waste Discharge Permit Application for the W-252 streams. 


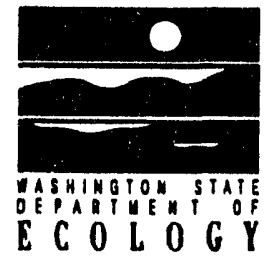

\section{STATE WASTE DISCHARGE PERMIT APPLICATION FOR INDUSTRIAL DISCHARGES TO LAND}

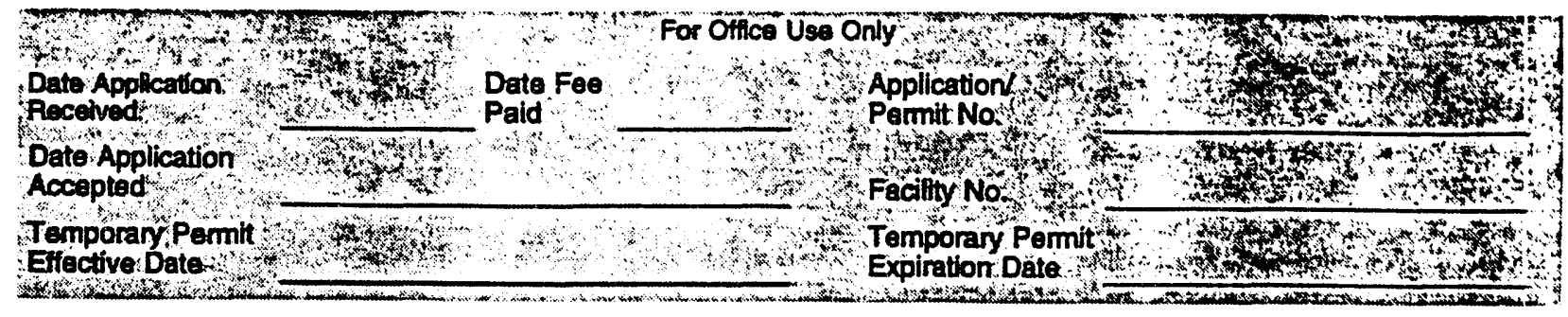

This application is for a waste discharge permit as required in accordance with provisions of Chapter 90.48 RCW and Chapter 173-216 WAC. Additional information may be required. Information previously submitted and applicable to this application should be referenced in the appropriate section.

\section{SECTION A. GENERAL INFORMATION}

\section{Company Name:}

2. Mailing Address:

3. Facility Address:
U.S. Department of Energy, Richland Operations Office

P.O. Box 550

\begin{tabular}{lc}
\hline Street & 99352 \\
Richland, Washington & Zip \\
\hline City/State & \\
200 East Area - Hanford Site & \\
\hline Street & Zip
\end{tabular}

4. Person to contact who is familiar with the information contained in this application: J.E. Rasmussen, Regulatory Permits Branch, Branch Chief (509) 376-2247 Name Title Telephone

5. Check One: $\quad$ Existing Discharge

Proposed Discharge

Anticipated, date of discharge:

I certify under penalty of law that this document and all attachments were prepared under my direction or supervision in accordance with a system designed to assure that qualified personnel properly gather and evaluate the information submitted. Based on my inquiry of the person or persons who manage the system, or those persons directly responsible for gathering the information, the information submitted is, to the best of my knowledge and belief, true, accurate, and complete. I am aware that there are significant penalties for

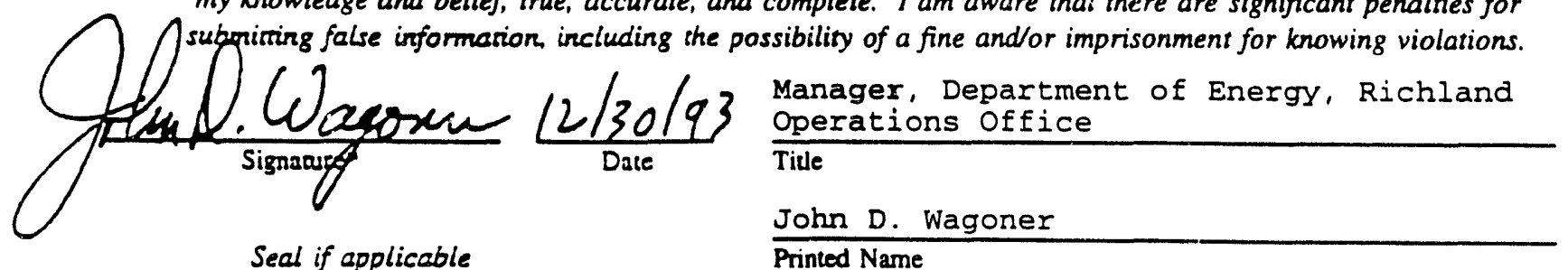

*Applications must be signed by either the owner, the principal executive officer or a duly authorized representative. 


\section{SECTION B. PRODUCT OR SERVICE INFORMATION}

1. Briefly describe all manufacturing processes and products, and/or service activities. Provide the applicable Standard Industrial Classification (SIC) Code(s) for each activity.

SIC No(s): See Appendix B, Section 1

Description: See Appendix B, Section 1

2. Include a production schematic flow diagram of the process and service activities described above on a separate sheet.

See Appendix B, Section 2

3. List raw materials and products:

\begin{tabular}{||r|l||}
\hline \multicolumn{2}{||c|}{ RAW MATERIALS } \\
\hline \multicolumn{1}{|c|}{ Type } & \multicolumn{1}{|c|}{ Quantity } \\
\hline & See Appendix B, Section 3 \\
\hline & \\
\hline & \\
\hline & \\
\hline & \\
\hline & PRODUCTS \\
\hline & \\
\hline & \\
\hline & \\
\hline & \\
\hline
\end{tabular}




\section{SECTION C. PLANT OPERATIONAL CHARACTERISTICS}

1. Identify the waste stream for each of the production processes or activities described in Section B.1. Assign an identification number.

\begin{tabular}{|c|c|c|c|}
\hline Process & Waste Stream Name & $\begin{array}{l}\text { Batch or } \\
\text { Continuous } \\
\text { Process }\end{array}$ & $\begin{array}{c}\text { Waste } \\
\text { Stream } \\
\text { ID \# }\end{array}$ \\
\hline \multicolumn{4}{|c|}{ See Appendix C, Section 1} \\
\hline & & & \\
\hline & & & \\
\hline & & & \\
\hline & & & \\
\hline & & & \\
\hline & & & \\
\hline & & & \\
\hline & & & \\
\hline
\end{tabular}

2. On a separate sheet, describe in detail the treatment and disposal of all wastewaters as described above. Include a schematic flow diagram for all wastewater treatment and disposal systems.

See Appendix C, Section 2

3. Indicate treatment provided to each waste stream identified above. See Appendix C, Section 3

\begin{tabular}{||l|l|l|l||}
\hline $\begin{array}{c}\text { Waste } \\
\text { ID \# }\end{array}$ & \multicolumn{1}{|c|}{ Treatment } & $\begin{array}{c}\text { Waste } \\
\text { Stream(s) } \\
\text { ID \# }\end{array}$ & \multicolumn{1}{||}{ Treatment } \\
\hline & Air flotation & & pH correction \\
\hline & Centrifuge & & Ozonation \\
\hline & Chemical precipitation & & Reverse osmosis \\
\hline & Chlorination & & Screen \\
\hline & Cyclone & & Sedimentation \\
\hline & Filtration & & Septic tank \\
\hline & Flow equalization & & Solvent separation \\
\hline & Grease or oil separation & & Bio. treatment, type: \\
\hline & Grease trap & & Rainwater diversion or storage \\
\hline & Grit removal & & Other chem. treatment, type: \\
\hline & Ion exchange & & Other phys. treatment, type: \\
\hline
\end{tabular}


4. Describe any planned wastewater treatment improvements or changes in wastewater disposal methods:

See Appendix C, Section 4

5. If production processes are subject to seasonal variations, provide the following information. Write "Yes" for each month waste stream is produced.

\begin{tabular}{|c|c|c|c|c|c|c|c|c|c|c|c|c|}
\hline \multirow{2}{*}{$\begin{array}{c}\text { Waste } \\
\text { Stream } \\
\text { ID \# }\end{array}$} & \multicolumn{12}{|c|}{ MONTHS } \\
\hline & $J$ & $F$ & M & A & $M$ & $J$ & $J$ & A & S & 0 & N & D \\
\hline \multicolumn{13}{|c|}{ See Appendix C, Section 5} \\
\hline & & & & & & & & & & & & \\
\hline & & & & & & & & & & & & \\
\hline & & & & & & & & & & & & \\
\hline & & & & & & & & & & & & \\
\hline & & & & & & & & & & & & \\
\hline & & & & & & & & & & & & \\
\hline & & & & & & & & & & & & \\
\hline
\end{tabular}

6. Shift information: See Appendix C, section 6

a. Number of shifts per work day:

b. Number of work days per week:

c. Average number of work days per year:

d. Maximum number of work days per year:

e. Number of employees per shift:

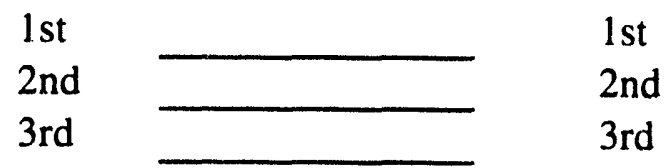

Shift start times

7. List all incidental materials like oil, paint, grease, solvents, soaps, cleaners, that are used or stored on-site. (Use additional sheets, if necessary.)

Material/Quantity Stored

See Appendix C, Section 7 
8. Describe any water recycling or material reclaiming processes:

See Appendix C, Section 8

9. Does this facility have: See Appendix C, Section 9

-Spill Control and Containment Plan (per 40 CFR 112)?

-Emergency Response Plan (per WAC 173-303-350)?

$\begin{array}{llll}\square & \text { Yes } & \square & \text { No } \\ \square & \text { Yes } & \square & \text { No } \\ \square & \text { Yes } & \square & \text { No }\end{array}$

-Runoff, spillage, or leak control plan (per WAC 173-216-110(f))?

\section{SECTION D. WATER CONSUMPTION AND WATER LOSS}

1. Water source(s): See Appendix D, Section 1

Public System (Specify)

$\square$ Private Well $\square$ Surface Water

a. Water Right Permit Number:

b. Legal Description:

$1 / 4 \mathrm{~S}$ $1 / 4 S$, Section, TWN, R

2. a. Indicate total water use: Gallons per day (average) See Appendix D, Section 2 Gallons per day (maximum)
b. Is water metered?
$\square$ Yes
$\square$ No

3. Attach a line drawing showing the water flow through the facility. Indicate source of intake water, operations contributing wastewater to the effluent, and treatment units labeled to correspond to the more detailed descriptions in Item C. Construct a water balance on the line drawing by showing average flows between intakes, operations, treatment units, and outfalls. If a water balance cannot be determined (e.g., for certain mining activities), provide a pictorial description of the nature and amount of any sources of water and any collection or treatment measures.

See Appendix D, Section 3 


\section{SECTION E. WASTEWATER INFORMATION}

1. Provide measurements for the parameters listed below, unless waived by the permitting authority. All analytical methods used to meet these requirements shall, unless approved otherwise in writing by Ecology, conform to the Guidelines Establishing Test Procedures for the Analysis of Pollutants Contained in 40 CFR Part 136.

\begin{tabular}{|l|l|l|l||}
\hline \multicolumn{1}{|c|}{ Parameter/CAS No. } & \multicolumn{1}{c|}{$\begin{array}{c}\text { Concentrations } \\
\text { Measured }\end{array}$} & \multicolumn{1}{|c|}{$\begin{array}{c}\text { Analytical } \\
\text { Method }\end{array}$} & $\begin{array}{c}\text { Detection } \\
\text { Limit }\end{array}$ \\
\hline pH & \multicolumn{3}{|c|}{ See Appendix E, Section 1 } \\
\hline Conductivity & & & \\
\hline Total Dissolved Solids & & & \\
\hline Total Suspended Solids & & & \\
\hline BOD (5 day) & & & \\
\hline COD & & & \\
\hline Ammonia-N & & & \\
\hline TKN-N & & & \\
\hline Nitrate-N & & & \\
\hline Ortho-phosphate-P & & & \\
\hline Total-phosphate-P & & & \\
\hline Total Oil \& Grease & & & \\
\hline Calcium/7740-70-2 & & & \\
\hline Magnesium/7439-95-4 & & & \\
\hline Sodium/7440-23-5 & & & \\
\hline Potassium/7440-09-7 & & & \\
\hline Chloride & & & \\
\hline Sulfate & & & \\
\hline Fluoride & & & \\
\hline Cadmium/7440-43-9 & & & \\
\hline Chromium/7440-49-3 & & & \\
\hline Lead/7439-92-1 & & & \\
\hline Mercury/7439-97-6 & & & \\
\hline Selenium/7782-49-2 & & & \\
\hline Silver/7440-22-4 & & & \\
\hline Copper/7440-50-8 & & & \\
\hline Iron/7439-89-6 & & & \\
\hline Manganese & & & \\
\hline Zinc/7440-66-6 & & & \\
\hline Barium/7440-39-3 & & & \\
\hline Total Coliform & & & \\
\hline \hline
\end{tabular}


2. Wastewater characteristics for toxic pollutants.

See Appendix E, Section 2

The intent of this question is to determine which chemicals are or might be present in the process water or wastewater. For each chemical listed below:

a. Use the letter $\mathrm{A}$ in the ABST column if the chemical is not likely to he present because it is not used in the production process or used on site.

b. Use the letter $\mathbf{S}$ in the ABST column if the chemical may be present hecause it is used on site, but the chemical is not used in the production process.

c. Use the letter $\mathbf{P}$ in the PRST column if the chemical is likely to be present because it is used in the production process, but the effluent has not heen tested.

d. Use the letter $\mathrm{K}$ in the PRST column if the effluent has been tested and found to be present.

Attach the analytical results.

Analytical Results

Wastewater Characterization for Toxic Pollutants

\begin{tabular}{|c|c|c|c|}
\hline ABST / PRST & CONSTITUENT/CAS No. & ABST / PRST & CONSTITUENT/CAS No. \\
\hline & $\begin{array}{l}\text { Acrylamide/79-06-1 } \\
\text { Acrylonitrile/107-13-1 } \\
\text { Aldrin/309-00-2 } \\
\text { Aniline/62-53-3 } \\
\text { Aramite/140-57-8 } \\
\text { Arsenic/7440-38-2 } \\
\text { Azobenzene/103-33-3 } \\
\text { Benzene/71-43-2 } \\
\text { Benzidine/92-87-5 } \\
\text { Benzo(a)pyrene/50-32-8 } \\
\text { Benzotrichloride/98-07-7 } \\
\text { Benzyl chloride/100-44-7 } \\
\text { 3is(chloroethyl)ether/111-44-4 } \\
\text { Bis(chloromethyl)ether/542-88-1 } \\
\text { Bis(2-ethylhexyl)phthalate/ } \\
\text { 117-81-7 } \\
\text { Bromodichloromethane/75-27-4 } \\
\text { Bromoform/75-25-2 } \\
\text { Carbazole/86-74-8 }\end{array}$ & & $\begin{array}{l}\text { 1,2 Dichloropropane/78-87-5 } \\
\text { 1,3 Dichloropropene/542-75-6 } \\
\text { Dichlorvos/62-73-7 } \\
\text { Dieldrin/60-57-1 } \\
\text { 3,3' Dimethoxybenzidine/119-90-4 } \\
\text { 3,3 Dimethylbenzidine/119-93-7 } \\
\text { 1,2 Dimethylhydrazine/540-73-8 } \\
\text { 2,4 Dinitrotoluene/121-14-2 } \\
\text { 2,6 Dinitrotoluene/606-20-2 } \\
\text { 1,4 Dioxane/123-91-1 } \\
\text { 1,2 Diphenylhydrazine/122-66-7 } \\
\text { Endrin/72-20-8 } \\
\text { Epichlorohydrin/106-89-8 } \\
\text { Ethyl acrylate/140-88-5 } \\
\text { Ethylene dibromide/106-93-4 } \\
\text { Ethylene thioureae/96-45-7 } \\
\text { Folpet/133-07-3 } \\
\text { Furmecyclox/60568-05-0 }\end{array}$ \\
\hline
\end{tabular}




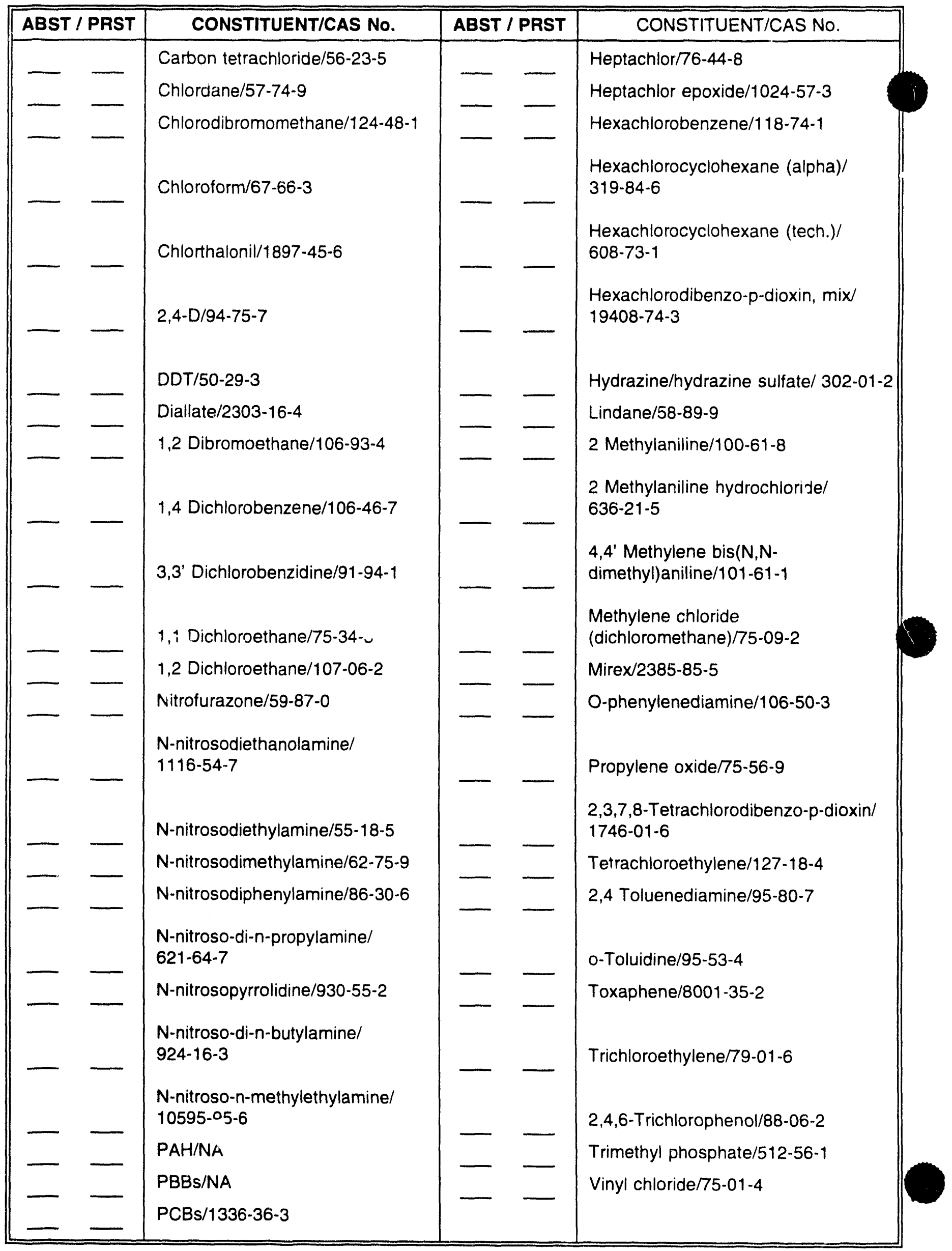




\section{SECTION F. STORMWATER}

1. Do you have a stormwater NPDES permit?

$\square$ Yes $\square$ No

See Appendix F, Section 1

2. Have you applied for a stormwater NPDES permit?

See Appendix F, Section 2

3. Are you covered or have you applied for coverage $\quad \square$ Yes $\square$ No under a general or group stormwater permit?

See Appendix F, Section 3

4. Describe the size of the stormwater collection area. See Appendix F, Section 4
a. Unpaved Area
b. Paved Area
c. Other Collection Areas (Roofs)

sq. ft.

sq. $\mathrm{ft}$.

sq. ft.

5. Describe the stormwater management systems.

see Appendix F, Section 5

6. Attach a map showing stormwater drainage/collection areas, disposal areas and discharge points.

See Appendix F, Section 6 


\section{SECTION G. OTHER INFORMATION}

1. Describe liquid wastes or sludges being generated that are not disposed of in the waste stream(s).

See Appendix G, Section 1

2. Describe storage areas for raw materials, products, and wastes.

See Appendix G, Section 2

3. Have you designated your wastes according to the procedures $\square$ Yes $\square$ No of Dangerous Waste Regulations, Chapter 173-303 WAC?

See Appendix G, Section 3

4. Waste hauled off-site by: $\square$ Wastehauler; $\square$ Self; $\square$ Other (identify)

See Appendix G, Section 4

Name

Name

Address

Address

City/State

$\overline{\text { City/State }}$

Telephone

Telephone

5. Have you filed a SARA Title 313 Disclosure?

$\square$ Yes $\square$ No See Appendix G, Section 5 


\section{SECTION H. SITE ASSESSMENT}

1. Give the legal description of the land treatment site(s). Give the acreage of each land treatment site(s). Attach a copy of the contract(s) authorizing use of land for treatment. See Appendix H, Section 1

2. List all environmental control permits or approvals needed for this project; for example, septic tank permits, sludge application permits, or air emissions permits.

See Appendix H, Section 2

3. Attach a topographic map with contour intervals used by USGS. Show the following on this map:

See Appendix H, Section 3

a. Location and name of internal and adjacent streets

b. Surface water drainage systems

c. Water supply and other wells within 500 feet of the site

d. Surface water diversions within 500 feet of the site

e. Chemical and product handling and storage facilities

f. Infiltration sources, such as drainfields, lagoons, dry wells, and abandoned wells within 500 feet of the site

g. Wastewater and cooling water discharge points with ID numbers (See Section C.1)

h. Other activities and land uses within $1 / 4$ mile of the site

4. Identify all wells within 500 feet of the site. Attach well logs when available and any available water quality data.

See Appendix H, Section 4

5. Describe soils on the site using information from local soil survey reports.

(Submit on separate sheet.)

See Appendix H, Section 5 
6. Describe the regional geology and hydrogeology within one mile of the site. (Submit on separate sheet.)

See Appendix, Section 6

7. List the names and addresses of contractors or consultants who provided information and cite sources of information by title and author.

See Appendix H, Section 7 
Baker, V.R., B.N. Bjornstad, A.J. Busacca, K.R. Fecht, E.P. Kiver, U.L. Moddy, J.C. Rigby, D.F. Stradling, and A.M. Tallman, 1991, "Quaternary Geology of the Columbia Plateau", in Quaternary Nonglacial Geology; Conterminous U.S., R.B. Morrison, Editor, Geology of North America, Geological Society of America, vol. K-2, Boulder, Colorado.

DOE, 1988, Site Characterization Plan, Reference Repository Location, Hanford Site, Washington; Consultation Draft, 9 Vols., DOE/RW-0164, U.S. Department of Energy, Office of Civilian Radioactive Waste Management, Washington, D.C.

DOE-RL, 1990, 216-B-3 Pond System Closure/Postclosure Plan, DOE/RL-89-28 U.S. Department of Energy, Richland Operations, Richland, Washington.

DOE-RL, 1993, Quarterly Report of RCRA Groundwater Monitoring Data for Period October 1, 1992 through December 31, 1992, DOE/RL-92-26-04, U.S. Department of Energy, Richland, Washington.

Ecology and DOE-RL, 1991, Consent Order No. DE 91NM-177, Washington State Department of Ecology and U.S. Department of Ecology, Olympia, Washington.

EPA, 1988, USEPA Contract Laboratory Statement of Work for Organics Analysis. Multi-Media, Multi-Concentration, United States Environmental Protection Agency, Washinton D.C.

Fecht, K.R., S.P. Reidel, and A.M. Tallman, 1987, Paleodrainage of the Colurnbia River System on the Columbia Plateau of Washington: A Summary, RHO-BW-SA-318P, Rockwell Hanford Operations, Richland, Washington.

Gephart, R.E., R.C. Arnett, R.G. Baca, L.S. Leonhart, and F.A. Spane Jr., 1979, Hydrologic Studies Within the Columbia Plateau, Washington: An Integration of Current Knowledge, RHO-BWI-ST-5, Rockwell Hanford Operations, Richland, Washington.

Hajek, B.F., 1966, Soil Survey: Hanford Project in Benton County, Washington, BNWL-243, Battelle Northwest Laboratories, Richland, Washington.

PNL, 1989, Hydrogeology of the 200 Areas Low-Leval Burial Grounds, An Interim Report, PNL-6820, Pacific Northwest Laboratory, Richland, Washington. 
PSPL, 1982, Skagit/Hanford Nuclear Project, Preliminary Safety Analysis Report, Vol. 4, App. 20, Amendment 23, Puget Sound Power and Light Company, Bellevue, Washington.

Reidel, S.P., and K.R. Fecht, 1981, "Wanapum and Saddle Mountains Basalt in the Cold Creek Syncline Area", in Subsurface Geology of the Cold Creek Syncline, RHO-BWI-ST-14, Rockwell Hanford Operations, Richland, Washington.

Smith, G.A., B.N. Bjornstad, and K.R. Fecht, 1989, "Neogene Terrestrial Sedimentation on and Adjacent to the Columbia Plateau; Washington, Oregon, and Idaho", in Volcanism and Tectonism in the Columbia River Flood-Basalt Province, Special Paper 239, S.P. Reidel and P.R. Hooper, editors, Geological Society of America, Boulder, Colorado, pp. 187-198.

WHC, 1988, Annual Status Report of the Plan and Schedule to Discontinued Disposal of Contaminated Liquid into the Soil Column at the Hanford Site, U. S. Department of Energy, WHC-EP-0196-1, Westinghouse Hanford Company, Richland, Washington.

WHC, 19913a, 242-A Evaporator Cooling Water Stream-Specific Report, WHC-EP-0342, Arddendum 21, Westinghouse Hanford Company, Richland, Washington.

WHC, 1990b, 242-A Evaporator Steam Condensate Stream-Specific Report, WHC-EP-0342, Addendum 26, Westinghouse Hanford Company, Richland, Washington.

WHC, 1990c, 241-A Tank Farm Ccoling Water Stream-Specific Report, WHC-EP-0342 Addendum 23, Westinghouse Hanford Company, Richland, Washington.

WHC, 1990d, 244-AR Vault Cooling Water Stream-Specific Report, WHC-EP-0342, Addendum 25, Westinghouse Hanford Company, Richland, Washington.

WHC, 1990e, 284-E Powerplant Wastewater Stream-Specific Report, WHC-EP-0342, Addendum 24, Westinghouse Hanford Company, Richland, Washington.

WHC, 1990f, B Plant Cooling Water Stream-Specific Report, WHC-EP-0342, Addendum 22, Westinghouse Hanford Company, Richland, Washington.

WHC, 1991a, Geology and Hydrology of the Hanford Site: A Standardized Text for Use in Westinghouse Hanford Company Documents and Reports, WHC-SD-ER-TI-003, Westinghouse Hanford Company, Richland, Washington. 
WHC, 1991b, Revised Stratigraphy for the Ringold Formation, Hanford Site, South Central Washington, WHC-SD-EN-EE-004, Ruv 0, Westinghouse Hanford Company, Richland, Washington.

WHC, 1991c, Geologic Setting of the 200 West Area: An Update, WHC-SD-EN-TI-008, Rev. 0, Westinghouse Hanford Company, Richland, Washington.

WHC, 1992a, Phase II Liquid Effluent Program (Project W-252) Wastewater Engineering Report and BAT/AKART Studies, WHC-SD-W252-ER-001, Rev. 0, Westinghouse Hanford Company, Richland, Washington.

WHC, 1992b, 241-A Tank Farm Cooling Water Sampling and Analysis Plan, WHC-SD-WM-EV-077 Rev. 2 Westinghouse Hanford Company, Richland Washington.

WHC, 1992c, 244-AR Vault Cooling Water Sampling and Analysis Plan, WHC-SD-WM-EV-076 Rev. 1, Westinghouse Hanford Company, Richland, Washington.

WHC, 1992d, Sampling and Analysis Plant of the 284-E Area Powerplant Process Waste Water Streams, WHC-SD-WM-PLN-034, Rev. 2, Westinghouse Hanford Company, Richland, Washington.

WHC, 1992e, B Plant Cooling Water Sampling and Analysis Plan, WHC-SD-WM-PLN-037, Rev. 2, Westinghouse Hanford Company, Richland, Washington.

WHC, 1992f, Geologic Setting of the 200 East Area: An Update, WHC-SD-EN-TI-012, Rev. 0, Westinghouse Hanford Company, Richland, Washington.

WHC, 1992g, Summary of the Geology of the 200-BP-1 Operable Unit, WHC-SD-EN-TI-037, Rev. 0, Westinghouse Hanford Company, Richland, Washington.

WHC, 1992h, Hydrogeologic Model for the 200 East Groundwater Aggregate Area, WHC-SD-EN-TI-019, Rev. 0, Westinghouse Hanford Company, Richland, Washington.

WHC, 1993a, Conceptual Design Report, Project X-009, First Lobe 216-B-3 Ponds Bypass, WHC-SD-X009-CDR-001, Rev. 0, Westinghouse Hanford Company, Richland, Washington.

WHC, 1993b, Hanford Site Stormwater Pollution Prevention Plan, WHC-SD-EN-EV-021, Rev. 0, Westinghouse Hanford Company, Richland, Washington. 
DOE/RL 93-61, Rev 0 $12 / 93$

200 East Area W-252 Streams

This page intentionally left blank. 
2

3

4

5

6

7

8

9
Appendix A

Appendix B

Appendix C

Appendix D

Appendix E

Appendix $\mathrm{F}$

Appendix G

Appendix $\mathrm{H}$

\section{APPENDICES}

Location Maps

Product or Service Information

Plant Operational Characteristics

Water Consumption and Water Loss

Wastewater Information

Stormwater

Other Information

Site Assessment 
DOE/RL 93-61, Rev 0 $12 / 93$

200 East Area W-252 Streams

This page intentionally left blank.

APP-ii 
DOE/RL 93-61, Rev 0

$12 / 93$

200 East Area W-252 Streams

APPENDIX A

LOCATION MAPS 
DOE/RL 93-61, Rev 0

$12 / 93$

200 East Area W-252 Streams

This page intentionally left blank. 
DOE/RL 93-61, Rev 0 $12 / 93$

200 East Area W-252 Streams

\section{CONTENTS}

\section{FIGURES}

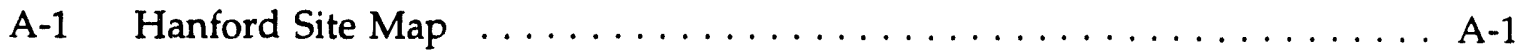

A-2 Project $\mathrm{W}-252$ Facilities Location Map $\ldots \ldots \ldots \ldots \ldots \ldots \ldots \ldots$ 
DOE/RL 93-61, Rev 0 $12 / 93$

200 East Area W-252 Streams

This page intentionally left blank. 


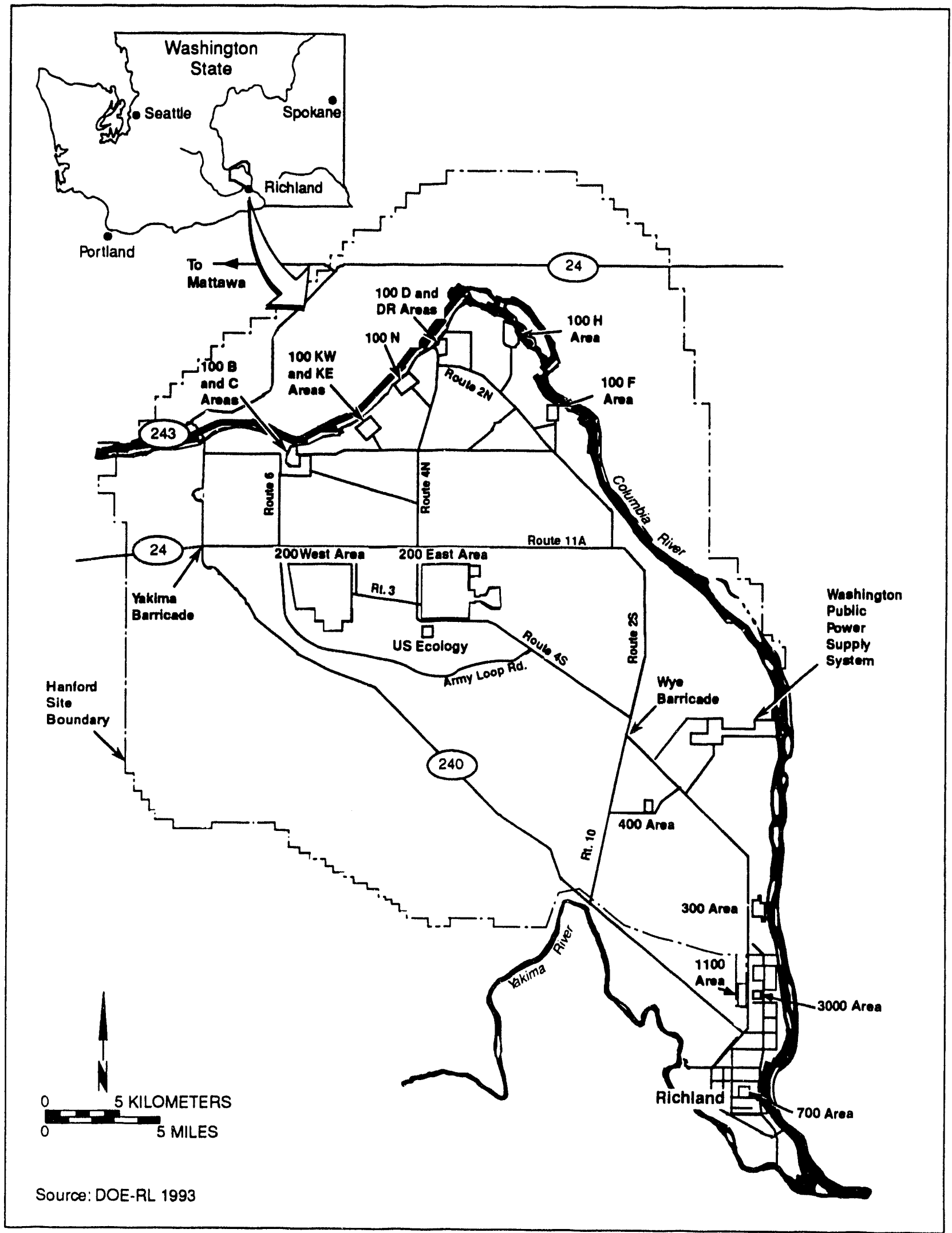

$9131728.013 / 47606 / 11-10-93$

Figure A-1. Hanford Site Map. 


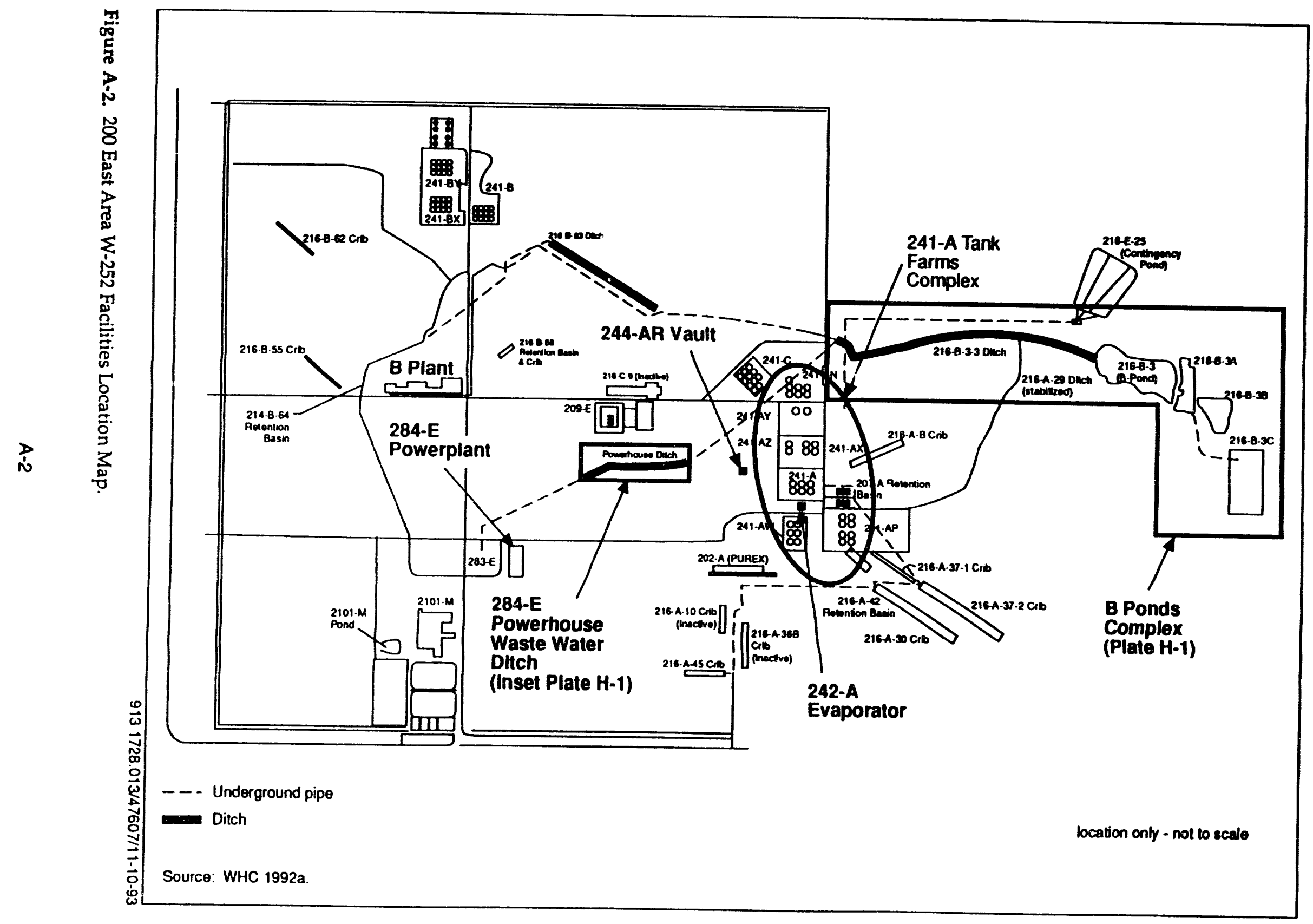


DOE/RL 93-61, Rev 0

$12 / 93$

200 East Area W-252 Streams

APPENDDX B

PRODUCT OR SERVICE INFORMATION 
DOE/RL 93-61, Rev 0 $12 / 93$

200 East Area W-252 Streams

This page intentionally left blank.

B-ii 
DOE/RL 93-61, Rev 0 $12 / 93$

200 East Area W.252 Streams

\section{CONTENTS}

1.0 BRIEFLY DESCRIBE ALL MANUFACTURING PROCESSES AND PRODUCTS, AND/OR SERVICE ACTIVTTIES. PROVIDE THE APPLICABLE STANDARD INDUSTRIAL CLASSIFICATION (SIC) CODE(S) FOR EACH ACTIVITY $\ldots \ldots \ldots \ldots \ldots \ldots \ldots \ldots \ldots$ B-1 1.1 242-A EVAPORATOR COOLING WATER . . . . . . . . . . . B B-3

1.1.1 242-A Evaporator Cooling Water Facility Description ..... B B-3

1.1.2 242-A Evaporator Cooling Water Process Description ..... B-3

1.1.3 242-A Evaporator Cooling Water Waste Water Source Description ...................... B-4

1.2 242-A EVAPORATOR STEAM CONDENSATE ............ B-13

1.2.1 242-A Evaporator Steam Condensate Facility Description . . B-13

1.2.2 242-A Evaporator Steam Condensate Process Description . . B-13

1.2.3 242-A Evaporator Steam Condensate Waste Water Source Description ........................

$1.3 \quad 241$-A TANK FARM COOLING WATER . . . . . . . . . . B B-20

1.3.1 241-A Tank Farm Cooling Water Facility Description . . . . B B-20

1.3.2 241-A Tank Farm Cooling Water Process Description .... . B-20

1.3.3 241-A Tank Farm Cooling Water Source Description . . . . . B-21

$1.4 \quad 244-A R$ VAULT COOLING WATER . . . . . . . . . . . . . B-30

1.4.1 244-AR Vault Cooling Water Facility Description . . . . . . B-30

1.4.2 244-AR Vault Cooling vater Process Description . . . . . . B-33

1.4.3 244-AR Vault Cooling Water Waste Water Source Description ...................... B-34

$1.5 \quad 284-E$ POWER PLANT $\ldots \ldots \ldots \ldots \ldots \ldots \ldots \ldots \ldots \ldots \ldots$ B-45

1.5.1 284-E Powerplant Facility Description . . . . . . . . . B B-45

1.5.2 284-E Powerplant Process Description . . . . . . . . . . . . B-46

1.5.3 284-F Powerplant Waste Water Source Description . . . . . . B-47

1.6 B PLANT COOLING WATER $\ldots \ldots \ldots \ldots \ldots \ldots \ldots \ldots$ B-56

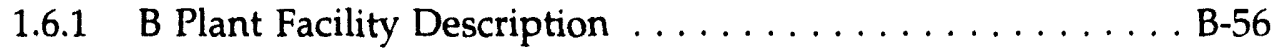

1.6.2 B Plant Process Description . . . . . . . . . . . . . B-57

1.6.3 B Plant Waste Water Source Description . . . . . . . . . . . B-59

2.0 INCLUDE A PRODUCTION SCHEMATIC FLOW DIAGRAM OF THE PROCESS AND SERVICE ACTIVITIES DESCRIBED ABOVE ON A

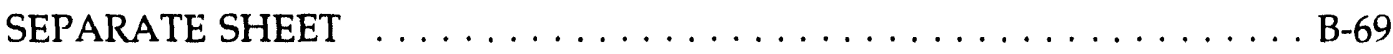

3.0 LIST RAW MATERIALS AND PRODUCTS . . . . . . . . . . . . . . B-69

3.1 242-A EVAPORATOR COOLING WATER . . . . . . . . . . . B-69

3.2 242-A EVAPORATOR STEAM CONDENSATE . . . . . . . . . . . B-69

3.3 241-A TANK FARM COOLING WATER . . . . . . . . . . . B-70

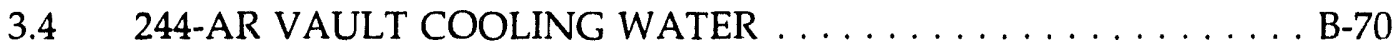

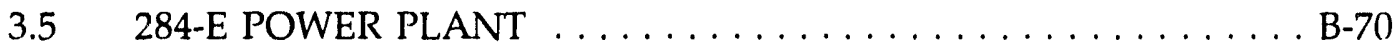

3.6 B PLANT COOLING WATER $\ldots \ldots \ldots \ldots \ldots \ldots \ldots \ldots$ B-71 


\section{CONTENTS (Cont.)}

\section{FIGURES}

B-1 Location of 242-A Evaporator in the 200 East Area . . . . . . . . . . . B-7

B-2 242-A Evaporator Complex Floor Plan - 242-A Building . . . . . . . . B B-8

B-3 Current Flow Schematic for the 242-A Evaporator Cooling

Water (Yearly Average Flows) . . . . . . . . . . . . . . . . . . . . B-9

B-4 242-A Evaporator Cooling Water Inputs and Outputs Schematic . . . . . . . B-10

B-5 Flow Schematic for Current Status of 242-A Evaporator

Cooling Water Effluents .......................... B-11

B-6 Current Flow Schematic for the 242-A Evaporator

Steam Condensate (Yearly Averige Flows) . . . . . . . . . . . . . B-16

B-7 242-A Evaporator Inputs and Outputs . . . . . . . . . . . . . . . B-17

B-8 Schematic for Current Status of 242-A Evaporator

Steam Condensate . . . . . . . . . . . . . . . . . . . . . B-18

B-9 Location of 241-A-Tank Farm Complex in the 200 East Area . . . . . . . . . B-24

B-10 241-AY and 241-AZ Tank Farm Complex Plot Plan . . . . . . . . . . . . B-25

B-11 Current Flow Schematic of the 241-A Tank Farm Cooling

Water System (Yearly Average Flows) . . . . . . . . . . . . . . . . B B-26

B-12 241-A Tank Farms Cooling Water Inputs and Outputs Schematic . . . . . . B-27

B-13 Flow Schematic for Current Status of 241-A Tank Farms

Cooling Water . . . . . . . . . . . . . . . . . . . . . B 28

B-14 244-AR Vault Location in the 200 East Area . . . . . . . . . . . . . . . B-38

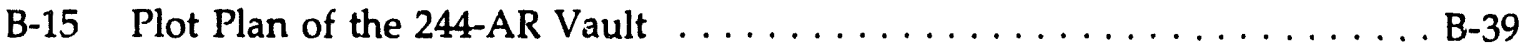

B-16 244-AR Vault Process Area Cross-Section $\ldots \ldots \ldots \ldots \ldots \ldots \ldots \ldots \ldots$. . . . . . . .

B-17 Current Flow Schematic of the 244-AR Vault

(Yearly Average Flows) . . . . . . . . . . . . . . . . . . . B-41

B-18 244-AR Vault Inputs and Outputs Water Schematic . . . . . . . . . . . . . B-42

B-19 Flow Schematic for Current Status of 244-AR Vault Effluents . . . . . . . . . B-43

B-20 Location of 284-E Powerplant in 200 East Area . . . . . . . . . . . . . . B-50

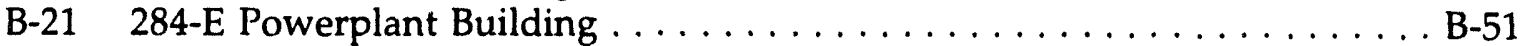

B-22 Flow Schematic of the 284-E Powerplant Waste Water . . . . . . . . . . . . . B-52

B-23 284-E Powerplant Inputs and Outputs Water Schematic . . . . . . . . . . B-53

B-24 Flow Schematic for Current Status of 284-E Powerplant Effluent . . . . . . . B-54

B-25 Location of the B Plant Within the 200 East Area . . . . . . . . . . . . B-63

B-26 B Plant and Related Facilities . . . . . . . . . . . . . . . . . . B-64

B-27 Current Flow Schematic of the B Plant and Related Facilities

(Yearly Average Flows) . . . . . . . . . . . . . . . . . . . . . . B-65

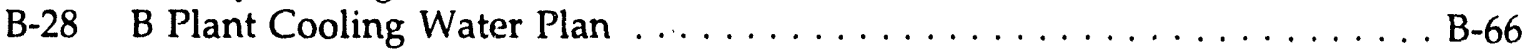

B-29 B Plant Cooling Water Treatment Facilities Inputs and

Outputs Water Schematic . . . . . . . . . . . . . . . . . . . . . B-67 


\section{CONTENTS (Cont.)}

\section{TABLES}

B-1 Waste Source Categories and Best Available Technology/All Known and Reasonable Treatment (BAT/AKART) Options/Alternatives .......... B-2

B-2 242-A Evaporation Cooling Water Sources . . . . . . . . . . . . . . . . B-12

B-3 242-A Evaporation Stream Condensate Effluent Sources . . . . . . . . . . . B-19

B-4 241-A Tank Farm Cooling Water Effluent Sources . . . . . . . . . . . . . . B-29

B-5 244-AR Vault Cooling Water Effluent Sources . . . . . . . . . . . . . . . B-44

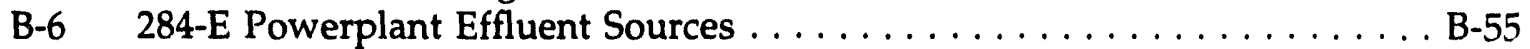

B-7 B Plant Cooling Water Effluent Sources . . . . . . . . . . . . . . B-68 
This page intentionally left blank. 
DOE/RL 93-61, Rev 0

\subsection{BRIEFLY DESCRIBE ALL MANUFACTURING PROCESSES AND PRODUCTS,} AND/OR SERVICE ACTIVITIES. PROVIDE THE APPLICABLE STANDARD INDUSTRIAL CLASSIFICATION (SIC) CODE(S) FOR EACH ACTIVITY.

This section describes the W-252 streams, their operation, and associated processes.

The following information was taken from the Phase II Liquid Effluent Program (Project W-252) Wastewater Engineering Report and BAT/AKART Studies (WHC 1992a). The sections, figures and tables, have been renumbered for use in this document.

Waste stream source types were categorized in the Phase II Liquid Effluent Program (Project W-252) Waste water Engineering Report and BAT/AKART Studies (WHC 1992a) into six categories denoted A through F and described in Table B-1, to evaluate the impact of the source waste streams. Table B-1 is provided as a reference when evaluating the process diagrams and assessing the potential stream impacts to the disposal site. 
TABLE B-1. Waste Source Categories and Best Available Technology/All Known and Reasonable Treatment (BAT/AKART) Options/Alternatives

\begin{tabular}{|c|c|c|}
\hline CATECORY & WASTE SOURCE TYRES & POTENTIAL BAT/AKART OPTIONS \\
\hline $\begin{array}{c}\text { A } \\
\text { Boiler } \\
\text { Discharge }\end{array}$ & $\begin{array}{l}\text { - } \quad \text { Steam Heating Condensate } \\
\text { - } \quad \text { Boiler Blowdown } \\
\text { - Water Softener Regenerant }\end{array}$ & $\begin{array}{ll}0^{2} & \text { Modify/adjust equipment to reduce/eliminate contaminants* } \\
1 & \text { Reuse, retum to steam plant or electric reboiler* } \\
2 & \text { Electric coil in duct* } \\
3 & \text { Air source heat pump with supplementary electric heat* } \\
4 & \text { Discharge untreated to collection/disposal facility or other } \\
\text { suitable disposal site (solar/percolation/spray pond) }\end{array}$ \\
\hline $\begin{array}{c}\text { B } \\
\text { Domestic } \\
\text { Waste water }\end{array}$ & $\begin{array}{l}\text { - Domestic Waste water=Gray } \\
\text { Water } \\
\text { - Related Floor Drains } \\
\text { - Air Conditioner Condensate }\end{array}$ & $\begin{array}{ll}0^{2} & \text { Modify/adjust equipment to reduce/eliminate contaminants* } \\
1 & \text { Existing septic system } \\
2 & \text { New septic system } \\
3 & \text { New treatment works on the Hanford Site } \\
4 & \text { Discharge untreated to collection/disposal facility or other } \\
& \text { suitable disposal site (solar/percolation/spray pond) }\end{array}$ \\
\hline $\begin{array}{l}\text { C } \\
\text { Miscellaneous } \\
\text { Clean } \\
\text { Effluent }\end{array}$ & $\begin{array}{l}\text { - } \quad \text { Floor Drains } \\
\text { - } \quad \text { Yard and Roof Stormwater } \\
\text { - } \quad \text { Air Compressor Condensate } \\
\text { - Others }\end{array}$ & $\begin{array}{ll}0^{2} & \text { Modify/adjust equipment to reduce/eliminate contaminants } \\
1 & \text { Collect and discharge stormwater to ground locally } \\
2 & \text { Collect and evaporate (solar or spray) } \\
3 & \text { Discharge untreated to collection/disposal facility } \\
4 & \text { Discharge untreated to collection/disposal facility or other } \\
\text { suitable disposal site (solar/percolation/spray pond) }\end{array}$ \\
\hline $\begin{array}{l}\text { D } \\
\text { Once-Through } \\
\text { Cooling } \\
\text { Water }\end{array}$ & - Once-through Cooling & $\begin{array}{ll}0^{2} & \text { Modify /adjust equipment to reduce/eliminate contaminants } \\
1 & \text { Closed loop - air cooled fan/dry coil* } \\
2 & \text { Closed loop - air cooled refrigerated* } \\
3 & \text { Cooling tower - closed or open loop } \\
4 & \text { Replace equipment with air cooled equipment* } \\
5 & \text { Recycle to supply water treatment* } \\
6 & \text { Discharge untreated to collection/disposal facility or other } \\
\text { suitable disposal site (solar/percolation/spray pond) }\end{array}$ \\
\hline $\begin{array}{l}\text { E } \\
\text { Evaporative } \\
\text { Cooling } \\
\text { Water }\end{array}$ & $\begin{array}{l}\text { Evaporative Cooling } \\
\text { Blowdown } \\
\text { - Cooling Tower Blowdown }\end{array}$ & $\begin{array}{l}0^{2} \text { Modify/adjust equipment to reduce/eliminate contaminants } \\
1 \text { Air cooled water chiller with electric heat* } \\
2 \text { Discharge untreated to collection/disposal facility or other } \\
\text { suitable disposal site (solar/percolation/spray pond) }\end{array}$ \\
\hline $\begin{array}{l}\text { F** } \\
\text { Potentially or } \\
\text { Slightly } \\
\text { Contaminated } \\
\text { Effluent }\end{array}$ & $\begin{array}{ll}\text { - } & \text { Floor Drains } \\
\text { - } & \text { Condensate } \\
\text { - } & \text { Yard or Roof Stormwater } \\
\text { - } & \text { Air Compressor Condensate } \\
\text { - Vacuum Pump Seal Water } \\
\text { - } \\
\text { - } \text { Oilter Backwash } \\
\text { Others }\end{array}$ & $\begin{array}{l}0^{2} \text { Modify/adjust equipment to reduce/eliminate contaminants } \\
1 \text { Retain entire stream and discharge or treat in-plant and } \\
\text { discharge to collection/disposal facility } \\
2 \text { On-line monitor entire stream and divert off-normal fraction, } \\
\text { treat in-plant and discharge to collection/disposal facility } \\
3 \text { Retain intermittent discharge, treat in-plant and discharge to } \\
\text { collecrion/disposal facility } \\
4 \text { Deflect stormwater to ground away from yard drains } \\
5 \text { Cleanup, encapsulate or replace contaminated piping/vessels/ } \\
6 \text { sumps etc. } \\
7 \text { Replace equipment with dry equipment* } \\
7 \text { Treat at other approved facility }\end{array}$ \\
\hline
\end{tabular}

Source: WHC 1992a

1 Categories are described in detail in WHC 1992a.

2 Examples include detainer on concentrator and plug floor drain.

- Denotes technology that achieves zero discharge.

** Denotes only category with existing or potential contaminant concentrations that may require treatment before disposal. 


\subsubsection{2-A Evaporator Cooling Water Facility Description}

The 242-A Evaporator facility is a waste management unit located in the 200 East Area of the Hanford Site. The primary processing unit commenced operation in 1977 and operated until March 1989. The Evaporator was used to reduce the volume of aqueous solutions of radioactive wastes by evaporating water from the solutions, reducing the storage volume requirements in the double-shell tank farm. At the time the Evaporator was shut down, the process condensate stream was determined to be a dangerous waste and discharge of the wastestream was halted. New facilities have been and are being constructed to allow the retention and treatment of the process condensate to permit restart of this facility. Life extension upgrades are also in progress that will ensure the safe and efficient operation of the evaporator through the year 2000 .

Figure B-1 shows the location of the 242-A Evaporator facility in the 200 East Area of the Hanford Site. Figure B-2 shows the 242-A Evaporator and its related facilities.

\subsubsection{2-A Evaporator Cooling Water Process Description}

Figure B-3 is a process flow diagram of the 242-A Evaporator Cooling Water System. The 242-A Evaporator concentrates radioactive liquid wastes from the waste tanks by boiling off the process water. The water vapor is condensed in shell-andtube primary, intermediate, and after condensers utilizing raw water from the 200 East Area. The cooling water effluent from the condensers is the primary contributor to the effluent stream, with a maximum flow of approximately 3,650 gallons per minute. The cooling water, in the tube side of the condensers, is maintained at a pressure of approximately 80 pounds per square inch gauge. The process condensate, containing radioactivity in the shell side, is maintained at a negative pressure of approximately 0.8 to 1.6 pounds per square inch atmosphere. This differential pressure across the tubes prevents the process condensate from entering the cooling water stream in case of tube wall failure or leakage. Overall, the 242-A Evaporator Cooling Water system is designed to prevent the condenser cooling water and other waste streams from contacting contami.tated surfaces, solutions, or vapors.

The condenser cooling water effluent is combined with eight low flow effluent streams as described below. This combined effluent is routed via a 24 -in diameter pipe to the 216-B-3 pond for disposal to the soil column. contributors:

The waste water effluent is comprised of the following nine stream

- $\quad$ Source 1: $\quad$ Condenser Cooling Water (design basis 3,650 gallons per minute, 400 gallons per minute annualized average)

- $\quad$ Source 2: $\quad$ Air Compressor Cooling Water (10 gallons per minute when operating) 
-

- $\quad$ Source 4:

- $\quad$ Source 5:

- $\quad$ Source 6:

- $\quad$ Source 7:

- $\quad$ Source 8:

- $\quad$ Source 9:
Emergency Steam Turbine Condensate, typically one day per month (approximately 64 gallons per day annualized average)

Steam Trap Condensate ( $<10$ gallons per day)

Compressed Air Dryer Discharge (permanently eliminated)

Water Filter Catch Pan Drainage ( $<10$ gallons per day)

Heating, Ventilation, and Air Conditioning Room Floor Drainage ( $<1$ gallon per day)

Steam System Relief Valve Discharge ( $<1$ gallon per day)

Compressed Air Receiver Condensate ( $<1$ gallon per day)

As reported in (WHC 1990a, Addendum 21), during evaporator processing operations, all nine contributors were potentially adding liquid to the stream. During shutdown and maintenance periods, the condenser cooling water and the water filter catch pan drainage will not contribute to the stream. The 242-A Evaporator runs in campaigns and not on a year-round basis, leading to wide variations in the average daily flowrate for this stream over selected periods of time. The total flow information, for the interval in which samples reported in WHC 1990a, Addendum 21 were taken, was utilized in calculating the average flowrate of 400 gallons per minute during this timeframe. The purpose of establishing the 400 gallons per minute rate is to calculate the annual toxic mass discharged in the evaluation of alternatives.

\subsubsection{2-A Evaporator Cooling Water Waste Water Source Description}

The waste water from the 242-A Evaporator Complex consists of nine streams. These are listed in Table B-2 and shown in Figures B-3, B-4, and B-5. Each of the source streams has been assigned to one of the six categories (A through $F$ ) described in Table B-1. Total flow based on average yearly flow is approximately 400 gallons per minute. Raw cooling water flows through the condensers. Upon restart of the evaporator, antifoam agents and a corrosion inhibitor will be added to the cooling water. An off-line radiation monitor and a proportional sampler are located downstream of the condensers.

1.1.3.1 Condenser Cooling Waste Water (Source 1). The condenser cooling waste water stream is considered a Category F waste, defined as once-through cooling water that is a potentially contaminated effluent that may pose some risk of contamination. Total flow based on average yearly flow is approximately 400 gallons per minute. Raw cooling water flows through the condensers. Upon restart of the evaporator, antifoam agents and a corrosion inhibitor will be added to the cooling water. An off-line radiation monitor and a proportional sampler are located downstream of the condensers. 
1.1.3.2 Minor Contributors. Discharges of the eight minor contributors are minimal and, with the exception of the air compressor cooling water (Source 2), intermittent in nature. These eight effluents contribute both raw water and utility steam condensate to the cooling water effluent stream as described in the following sections.

Air Compressor Cooling Water 'Source 2). Single pass raw water cools two air compressors supplying process and instiument air. One compressor is used as the on-line unit; the other is used as a standby unit. The air compressors are vertical, reciprocating, and nonlubricated and are designed to deliver 100 standard cubic feet per minute at 100 pounds per square inch gauge. Each compressor is cooled with a water jacket. The cooling water is required to keep the compressors at the proper operating temperature. If the cooling water is above the maximum temperature, an interlock will shut the compressors down. The source of the cooling water is raw water from the Columbia River that is supplied from the 200 East Area Powerhouse. The total compressor cooling water flow is estimated to be 10 gallons per minute. No chemicals are added to the stream and the stream is not in proximity to any waste or hazardous materials. This is considered a once-through cooling water, Category D, waste stream.

Emergency Steam Turbine Condensate (Source 3): A back-up steam turbine maintains ventilation in the facility in the event of a power outage and during maintenance to the primary fans. The raw water is provided from the 200 East Area Powerhouse. The maximum flow from this source is 8 gallons per minute when operating; the operation is sporadic other than a monthly operational check. Operational information indicates that the monthly operational check is for a four hour period and that typically, the unit operates for an additional four hours during power outages. The condensate is not in proximity to any waste processing or chemical handling, and there is no path for introduction of hazardous constituents. This is considered a boiler discharge, Category A, waste stream.

Steam Trap Condensate (Source 4): Steam, provided by the 200 East Area Powerhouse, is used in the heating, ventilation, and air conditioning system to heat incoming air for the facility. Steam traps, which remove steam condensate from the steam lines, are located within the heating, ventilation, and air conditioning room. These traps are automatically actuated by the buildup of condensate and empty into the heating, ventilation, and air conditioning drain lines. While the facility is being heated, the steam traps produce less than 10 gallons of condensate per day. The condensate is not in proximity to any waste processing or chemical handling, and no chemicals are added. This is considered a boiler discharge, Category A, waste stream.

Compressed Air Dryer Discharge (Source 5): An air dryer was previously used to process compressed air for use in the instrument air system. Fresh atmospheric air was filtered before compressing. No chemicals were added. The steam discharged less than 10 gallons per day (WHC 1990a) when it operated. This stream was considered a miscellaneous clean, Category $C$, waste stream. This source was permanently eliminated by replacing the dryer with an electric heater. 
Water Filter Catch Pan Drainage (Source 6): Raw water is filtered to protect spray nozzles in process equipment. Filters are located in the heating, ventilation, and air conditioning room. Runoff only occurs during routine maintenance such as filter changes. Runoff from the filters and strainers is collected in a catch pan, with a drain to the main cooling water drain line. The source of the raw water is from the Columbia River via the 200 East Area Powerhouse. The estimated intermittent flow is less than 10 gallons per day. No chemicals are added and the pans are not in proximity to any hazardous material. This is considered a miscellaneous clean, Category C, waste stream.

Heating, Ventalation, and Air Conditioning Room Floor Drainage (Source 7): There are two floor drains in the heating, ventilation, and air conditioning room that serve the air washers (evaporative coolers). Potential sources are leaks from the steam lines for building heating, the raw water main, and some fire protection water lines that run through the room. There are no chemicals or hazardous materials stored or used in the room. The flow rate is intermittent and not calculable; less than gallon per day is assumed. There is no source of hazardous material to contribute to this waste stream. This is considered a miscellaneous clean, Category $C$, waste stream.

Steam ystem Relief Valve Discharge (Source 8): There are several relief valves in the steam system used to heat the incoming air to the facility. The influent stream is provided from the 200 East Area Powerhouse which uses raw water from the Columbia River. These relief valves are located in the heating, ventilation, and air conditioning room. If the steam heating system pressure exceeds the settings, they vent through a drain funnel to the cooling water waste stream main drain. The contribution is less than gallon per day. The condensate is not in proximity to any waste processing or chemical handling, and no chemicals are added. This is considered a boiler discharge, Category A, waste stream.

Compressed Air Receiver Condensate (Source 9): The compressed air receiver, or storage tank, is a steel upright tank with a volume of 125 cubic feet. The tank contains a moisture trap and a drain valve. Moisture, which is in the compressed air, collects in the trap and is periodically drained. The contribution from this source is intermittent and estimated to be less than gallon per day. The source of the effluent is water vapor from the atmospheric air that has been compressed, contributing no hazardous waste. This is considered a miscellaneous clean, Category $C$, waste stream.

1.1.3.3 Utility Steam Condensate. The contribution of utility steam condensate to the evaporator cooling water effluent is minimal when compared with the volume of condenser cooling water effluent. This contribution of approximately 8 gallons of condensate per minute, is generated by the backup steam turbine when operated (Source 3), the steam trap condensate from the heating, ventilation, and air conditioning system (Source 4), and the relief valve condensate (Source 8 ) in event of overpressure in the heating, ventilation, and air conditioning system. These are considered as boiler discharge, Category A, waste streams. 


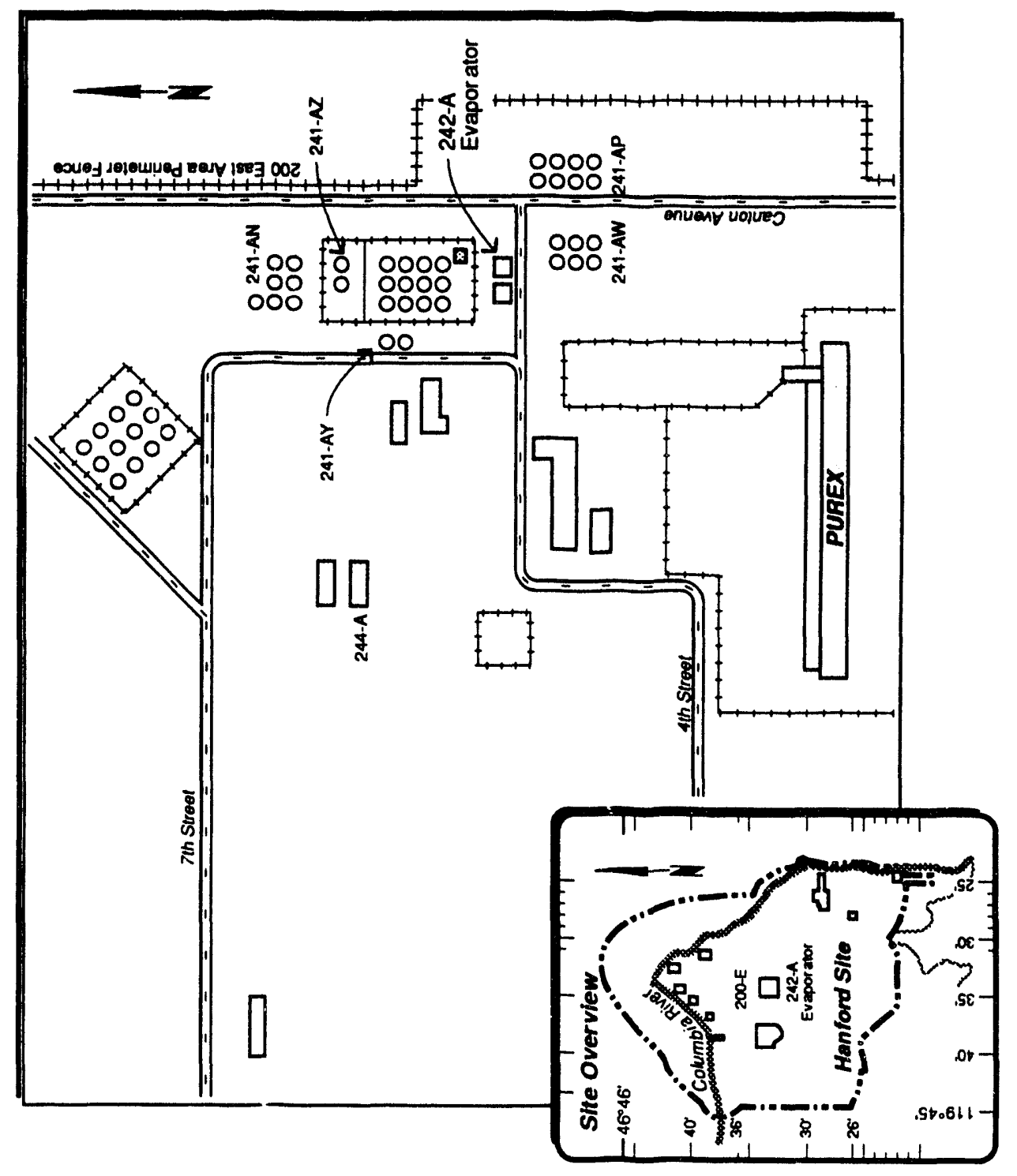

$9131728.013 / 46177 / 11-9-93$

Figure B-1. Location of the 242-A Evaporator in the 200 East Area. 


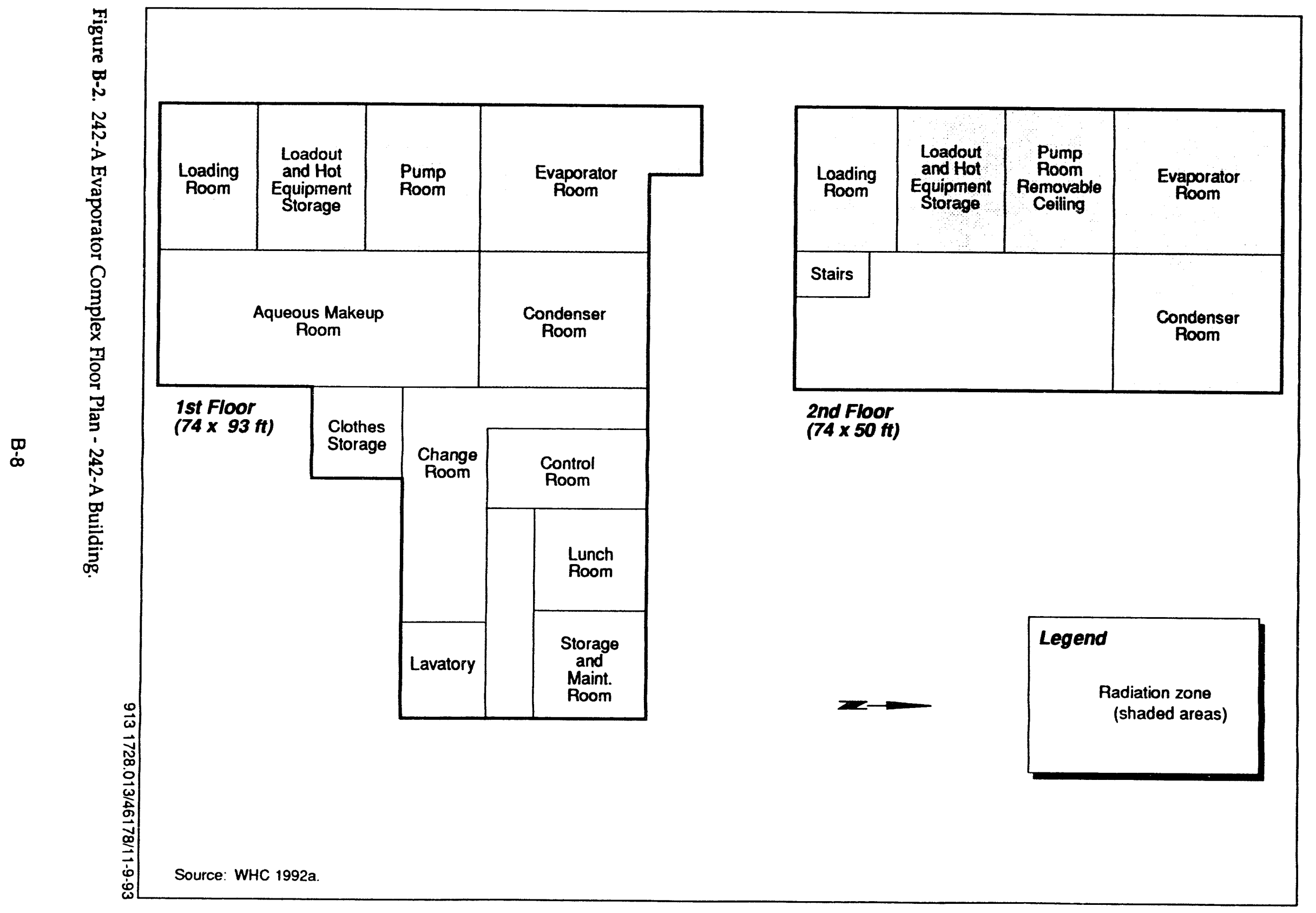




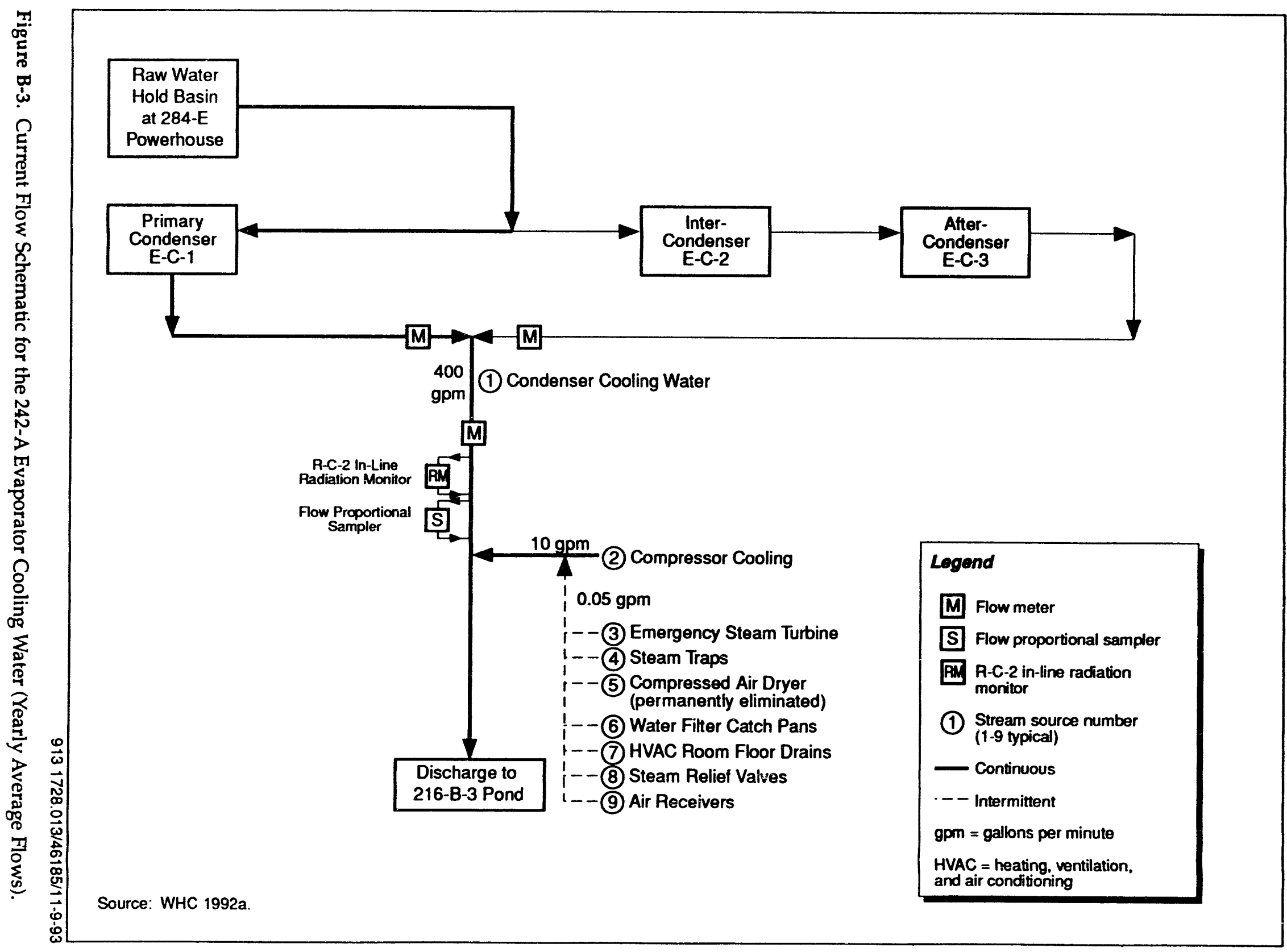




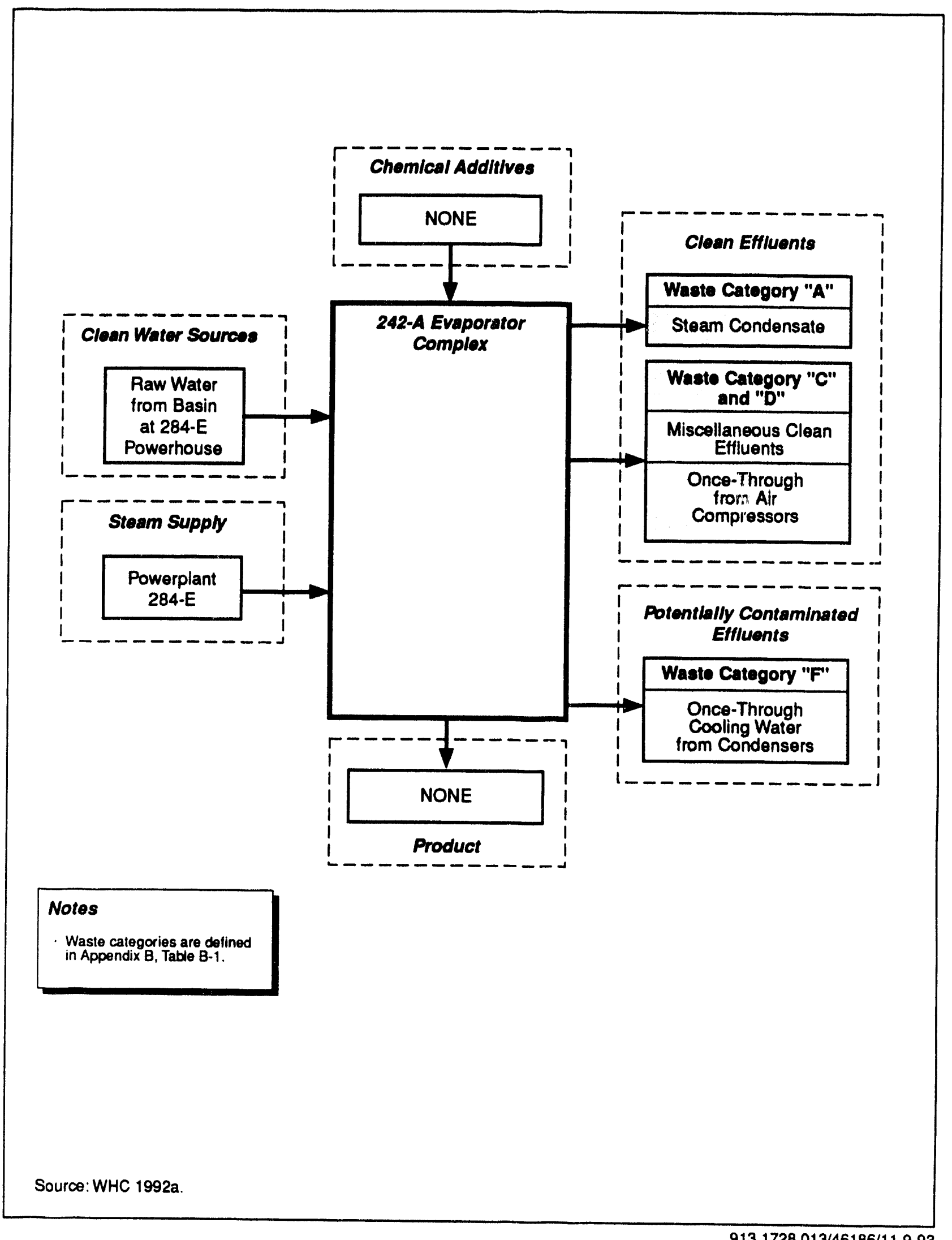

$9131728.013 / 46186 / 11-9-93$

Figure B-4. 242-A Evaporator Cooling Water Inputs and Outputs Schematic. 


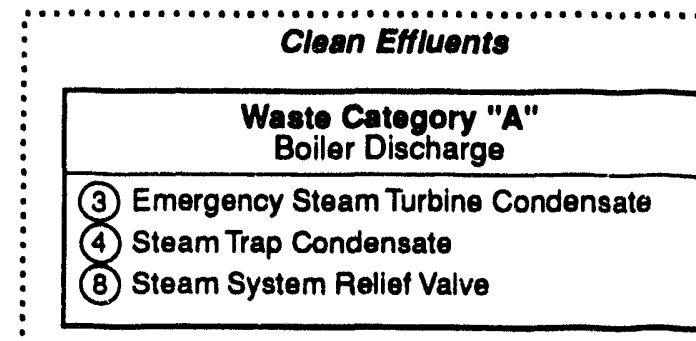
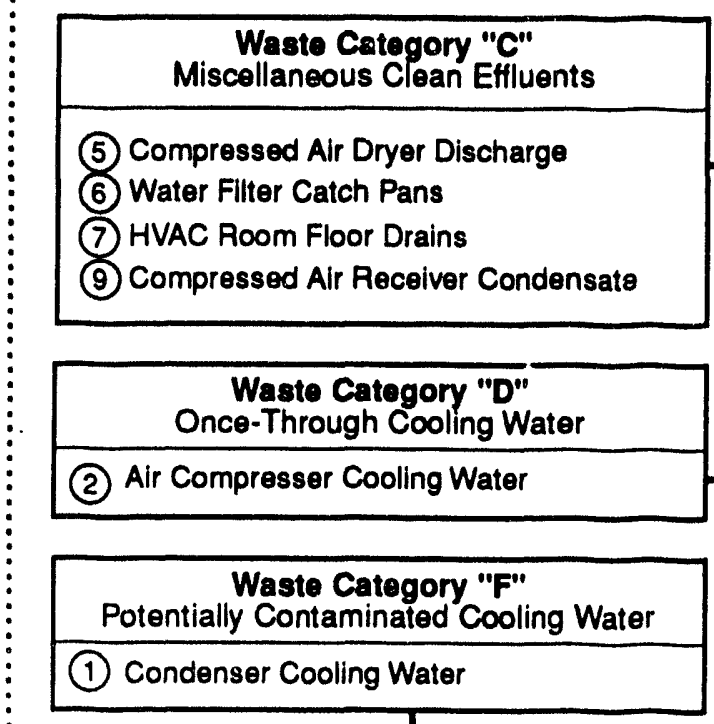

..

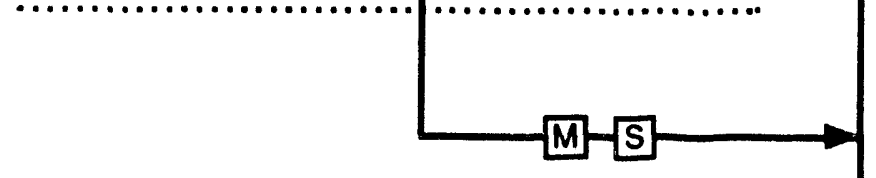

\section{Note}

- Waste categories are defined in Appendix B, Table B-1.

Source: WHC 1992a

\section{Legend}

M Flow monitor

S. Flow proportional sampler

(1) Source number (1-9 typical)

HVAC = heating, ventilation, and air conditioning

Figure B-5. Flow Schematic for Current Status of 242-A Evaporator Cooling Water Effluents. 
TABLE B-2. 242-A Evaporation Cooling Water Sources.

\begin{tabular}{|c|c|c|c|c|c|c|c|c|}
\hline \multirow{11}{*}{ 畧 } & $\begin{array}{c}\text { Source } \\
\text { No. }\end{array}$ & Source Stream & $\begin{array}{c}\text { Source } \\
\text { Building }\end{array}$ & $\begin{array}{c}\text { Source } \\
\text { Category [1] }\end{array}$ & $\begin{array}{c}\text { Effluent } \\
\text { Water Type }\end{array}$ & $\begin{array}{c}\text { Flow } \\
\text { Type [2] }\end{array}$ & $\begin{array}{l}\text { Estimated } \\
\text { Flowrate [3] } \\
(\mathrm{gpm})\end{array}$ & Status \\
\hline & 1 & Condenser Cooling Water & $242-A$ & $\mathbf{F}$ & Raw & I/C & 400 & Inactive \\
\hline & 2 & Air Compressor Cooling Water & $242-A$ & D & Raw & C & 10 & Active \\
\hline & 3 & Emerg. Steam Turbine Condensate & 242-A & A & $\begin{array}{l}\text { Steam } \\
\text { Condensate }\end{array}$ & I & Negligible & Active \\
\hline & 4 & Steam Trap Condensate & 242-A & A & $\begin{array}{l}\text { Steam } \\
\text { Condensate }\end{array}$ & I & Negligible & Active \\
\hline & 5 & Compressed Air Dryer Discharge [4] & $242-A$ & C & $\begin{array}{l}\text { Permanently } \\
\text { Eliminated }\end{array}$ & I & $\mathbf{0}$ & Eliminated \\
\hline & 6 & Water Filter Catch Pan Drainage & 242-A & C & Raw & $\mathbf{I}$ & Negligible & Inactive \\
\hline & 7 & $\begin{array}{l}\text { Heating, Ventalation, and Air } \\
\text { Conditioning (HVAC) Room Floor } \\
\text { Drainage }\end{array}$ & 242-A & C & $\begin{array}{l}\text { Raw/ } \\
\text { Condensate }\end{array}$ & $\mathbf{I}$ & Nebligible & Active \\
\hline & 8 & Steam System Relief Valve & 242-A & $\mathbf{A}$ & $\begin{array}{l}\text { Stearn } \\
\text { Condensate }\end{array}$ & $\mathbf{I}$ & Negligible & Active \\
\hline & 9 & Compressed Air Receiver Condensate & 242-A & C & Air Moisture & I & Negligible & Active \\
\hline & & & & & & & TOTAL 410 & \\
\hline
\end{tabular}

Source: WHC 1992a

\section{NOTES:}

[1] Source categories are defined in Table B-1.

[2] I=Intermittent, $C=$ Continuous, I/C=continuous when operating.

[3] Average flow rate is based on total annual flow. Includes substantial periods of nonoperation.

[4] Source permanently eliminated with the use of an electric heater.

$\mathrm{gpm}=$ gallons per minute 


\subsubsection{2-A Evaporator Steam Condensate Facility Description}

Section 1.1.1 and Figure B-1 describe the 242-A Evaporator facility. Figure B-6 is a flow schematic showing the eleven contributors that combine to make up the 242-A Evaporator Steam Condensate waste water stream.

\subsubsection{2-A Evaporator Steam Condensate Process Description}

The 242-A Evaporator started operation in 1977. The evaporator was used to reduce the volume of a liquid radioactive waste stream through evaporation and concentration, producing a concentrated slurry stream. The slurry was discharged from the 242-A Evaporator to double-shell storage tanks. Operation of the 242-A Evaporator effectively reduced the number of required double-shell tanks by 35 to 60 percent.

Figure B-7 shows a simplified block flow diagram of the Evaporator facility with current influent and effluent streams. The figure indicates the types of clean water that enter the facility and are eventually discharged as waste water. The figure also indicates waste water categories as defined in Table B-1.

Table B-3 lists the 11 individual effluents that collectively form the waste water stream. The table also gives the source and current status (active or inactive) of each effluent. This list of sources was derived from the 242-A Evaporator Steam Condensate Stream-Specific Report (WHC 1990b, Addendum 26). None of the 11 sources are currently active. However, it is anticipated that the facility will be fully operational in the near future. Table B-3 illustrates various parameters for these sources when the evaporator is operative, including flow (e.g., intermittent or continuous), the effluent water type, and the category to which each source belongs on the basis of data and/or assumptions regarding its characteristics. Identification of the different effluent water types facilitated subsequent calculations that were used to project modified stream characteristics based on reduction or elimination of individual sources. Assignment of waste water categories facilitated screening of Best Available Technology/All Known and Reasonable Treatment alternatives for individual waste waters. Table B-3 also provides estimated annual flowrates for the waste waters.

\subsubsection{2-A Evaporator Steam Condensate Waste Water Source Description}

Each of the eleven contributors that make up the 242-A Evaporator Steam Condensate has been assigned to one of six categories ( $A$ through $F$ ) as described in Table B-1. Figure B-8 shows the effluent streams grouped by assigned categories. This figure also shows the current route to disposal. The information shown in Figure B-8 represents the current process configuration and operating mode described in Section 1.2.2. Although the waste water streams are grouped by category in the figure, they retain the source numbers assigned previously in Table B-3. 
The following sections describe the individual waste water streams and characterize these individual streams in terms of impact on the overall waste water stream.

1.2.3.1 Reboiler Steam Condensate (Source 1). The 242-A Evaporator uses the latent heat liberated by condensing steam in a shell-and-tube heat exchanger (a reboiler) to heat the waste feed solution. The condensed steam is discharged through a weir (C-103). A portion of this -ondensate is pumped from upstream of the weir through a proportional sampler and radiation monitor $(\mathrm{R}-\mathrm{C}-1)$ and then returned to the condensate line upstream of the weir. From 1985 to 1988, the condensate flow from the reboiler a:'eraged 32.4 gallons per minute and over this four year period, the month with the highest flow of condensate averaged 68 gallons per minute. The condensate is considered a potentially or slightly contaminated effluent, Category $F$ waste stream.

The heated waste feed solution flows from the reboiler into a vapor/liquid separator vessel maintained at less-than-atmospheric pressure. Liquid from the bottom of the separator is returned to the reboiler for another heating cycle. Vapor from the top of the separator is condensed in a second, shell-and-tube heat exchanger that serves as a condenser. There is no contact ${ }^{-}$. ween the steam or vapor streams and the liquid streams in either heat exchanger. Concentrated liquid is discharged from the bottom of the 242-A Evaporator to the double-shell tank farm for storage.

1.2.3.2 Steam Condensate (Source 2A) and Raw Water (Source 2B) from Heating and Cooling Jackets. Tanks AE-101 and AE-104 are equipped with jackets that allow the contents to be maintained at desired temperatures. The flow of raw water or steam condensate from these jackets is combined and discharged with the steam condensate effluent. The flow from these jackets is approximately 1 gallon per minute for the 2 sources combined. The steam condensate (Source 2A) is considered a boiler discharge, Category A waste stream. The raw water (Source $2 \mathrm{~B}$ ) is considered a once-through cooling water, Category D waste stream.

1.2.3.3 Purging System Steam Trap Condensate (Source 3). A purging system is used to clear the instrument piping that is used to obtain specific gravity measurements of tank waste. The steam supply used for this system is equipped with a steam trap that drains less than 0.02 gallons per minute into the steam condensate effluent stream. Source 3 is considered a boiler discharge, Category A waste stream.

1.2.3.4 Vacuum Pump Seal Water (Source 4). The air sample pump has been replaced with a pump that does not require seal water. This waste water stream and any associated potential for contaminating the facility waste water stream have been permanently eliminated. The vacuum pump seal water was considered a miscellaneous clean effluent, Category $C$ waste stream.

1.2.3.5 Steam Strainer Condensate (Source 5). A steam ejector system maintains a reduced pressure atmosphere in the evaporator vessel. Steam strainers are located in the steam supply lines to the ejectors. Condensate from the strainers flows into a drain funnel that drains to the main steam condensate line to Tank C-103. 
this flow is negligible and has been assumed to be less than 0.02 gallons per minute (WHC 1992a). Source 5 is classified as boiler discharge, a Category A waste stream.

1.2.3.6 Steam Separator Condensate (Source 6). Condensate from the steam separator in the steam ejector system flows into the steam strainer drain funnel that drains to the main steam condensate line to Tank C-103. This flow is negligible and has been assumed to be less than 0.02 gallons per minute (WHC 1992a). Source 6 is classified as boiler discharge, a Category A waste stream.

1.2.3.7 Steam Separator Strainer Condensate (Source 7). Blowdown from the steam separator strainer flows into the steam strainer drain funnel that drains to the main steam condensate line to Tank C-103. This flow is negligible and has been assumed to be less than 0.02 gallons per minute (WHC 1992a). Source 7 is classified as boiler discharge, a Category A waste stream.

1.2.3.8 Seal Water Pressure Control Valve Discharge (Source 8). Seal water from the process pumps is bled into the waste stream when the seal water pressure exceeds 150 pounds per square inch guage. The valve remains open until the pressure falls below 150 pounds per square inch guage. The discharge from this waste stream flows into the steam strainer drain funnel that drains to the main steam condensate line to Tank C-103. This flow is negligible and has been assumed to be less than 0.02 gallons per minute (WHC 1992a). Source 8 is considered miscellaneous clean effluent, a Category $C$ waste stream.

1.2.3.9 Micro-filter Catch Pan Drainage (Source 9). Micro-filters filter the raw water used to spray the de-entrainer pad in the evaporator. Drainage from these filters flows into a catch pan and then flows into the steam strainer drain funnel that drains to the main steam condensate line to Tank C-103. This flow is negligible and has been assumed to be less than 0.02 gallons per minute (WHC 1992a). Source 9 is considered miscellaneous clean effluent, a Category $C$ waste stream.

\subsubsection{Seal Water Pumps and Filter Catch Pan Drainage (Source 10).}

Leakage from the pump seal water system and drainage from the seal water pump filters drain into a catch pan. The flow from the catch pan flows into the steam strainer drain funnel that drains to the main steam condensate line to Tank C-103. This flow is negligible and has been assumed to be less than 0.02 gallons per minute (WHC 1992a). Source 10 is considered miscellaneous clean effluent, a Category C waste stream.

\subsubsection{R-C-1 Sampler/Monitor Cooler Raw Water Discharge (Source 11).} Raw water used as coolant for the $\mathrm{R}-\mathrm{C}-1$ sampler flows into the steam strainer drain funnel that drains to the main steam condensate line to Tank C-103. This flow is negligible and has been assumed to be less than 0.2 gallons per minute (WHC 1992a). Source 11 is classified as once-through cooling water, a Category D waste stream. 


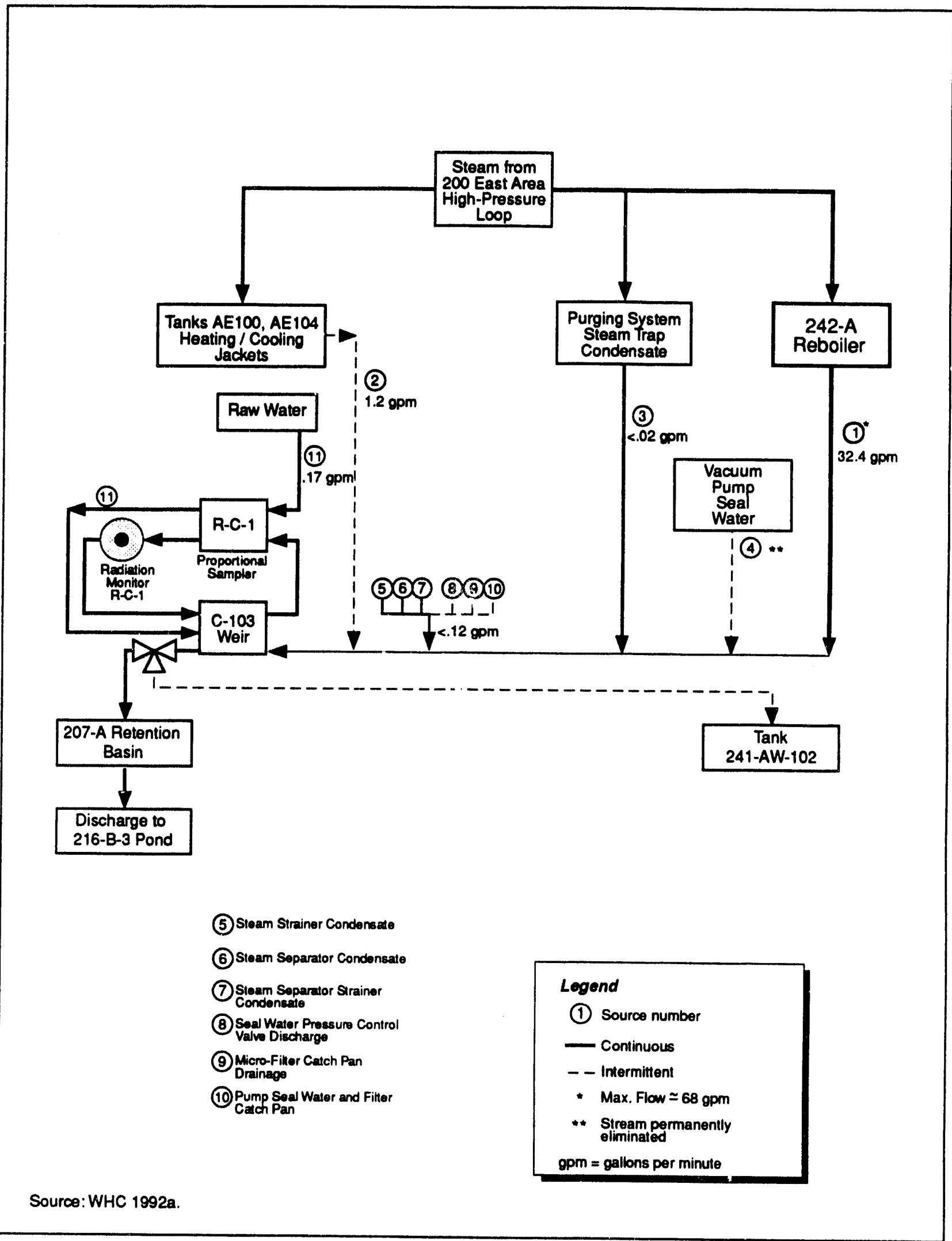

$9131728.013 / 46188 / 11-9-93$

Figure B-6. Current Flow Schematic for the 242-A Evaporator Steam Condensate (Yearly Average Flows). 


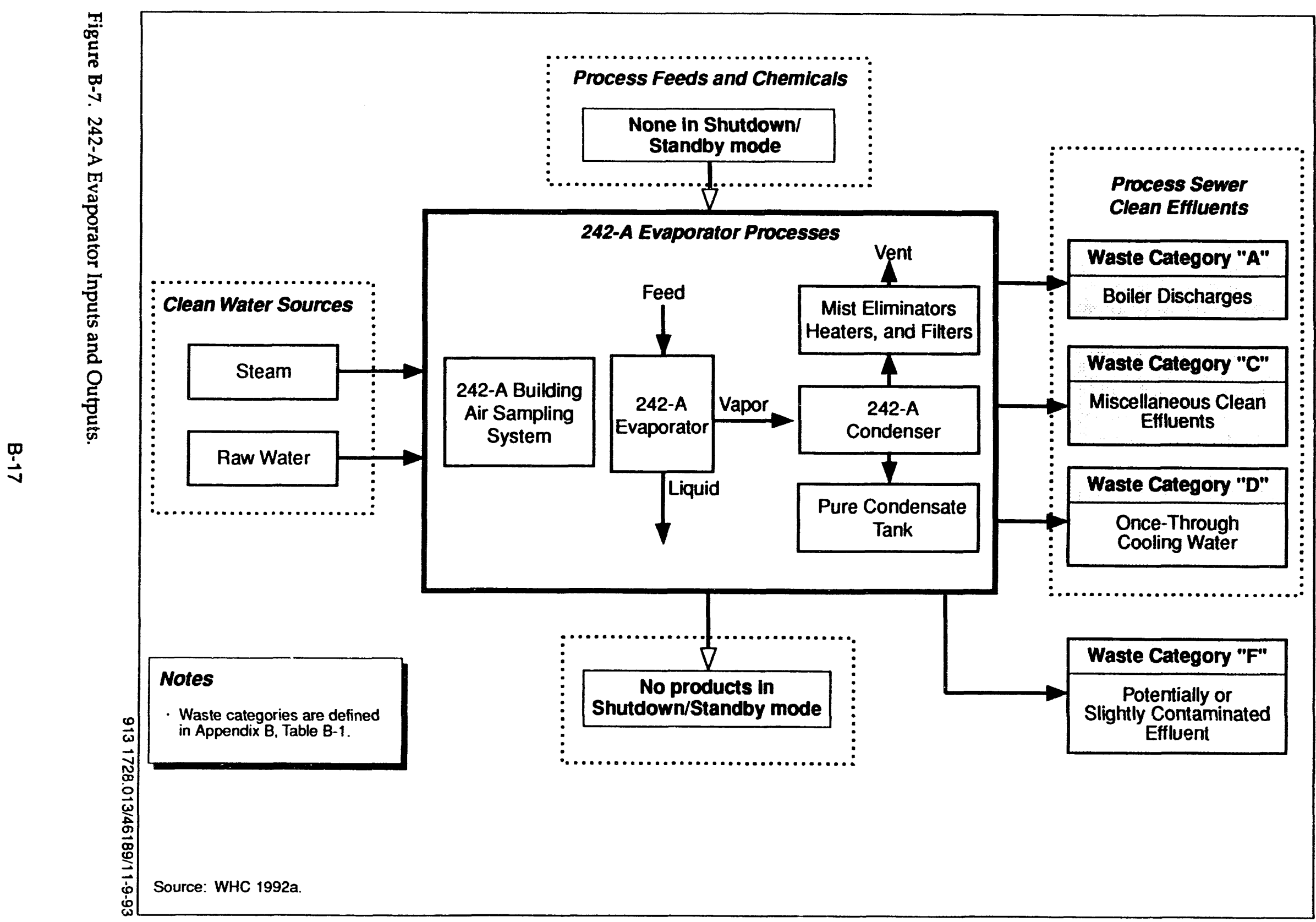




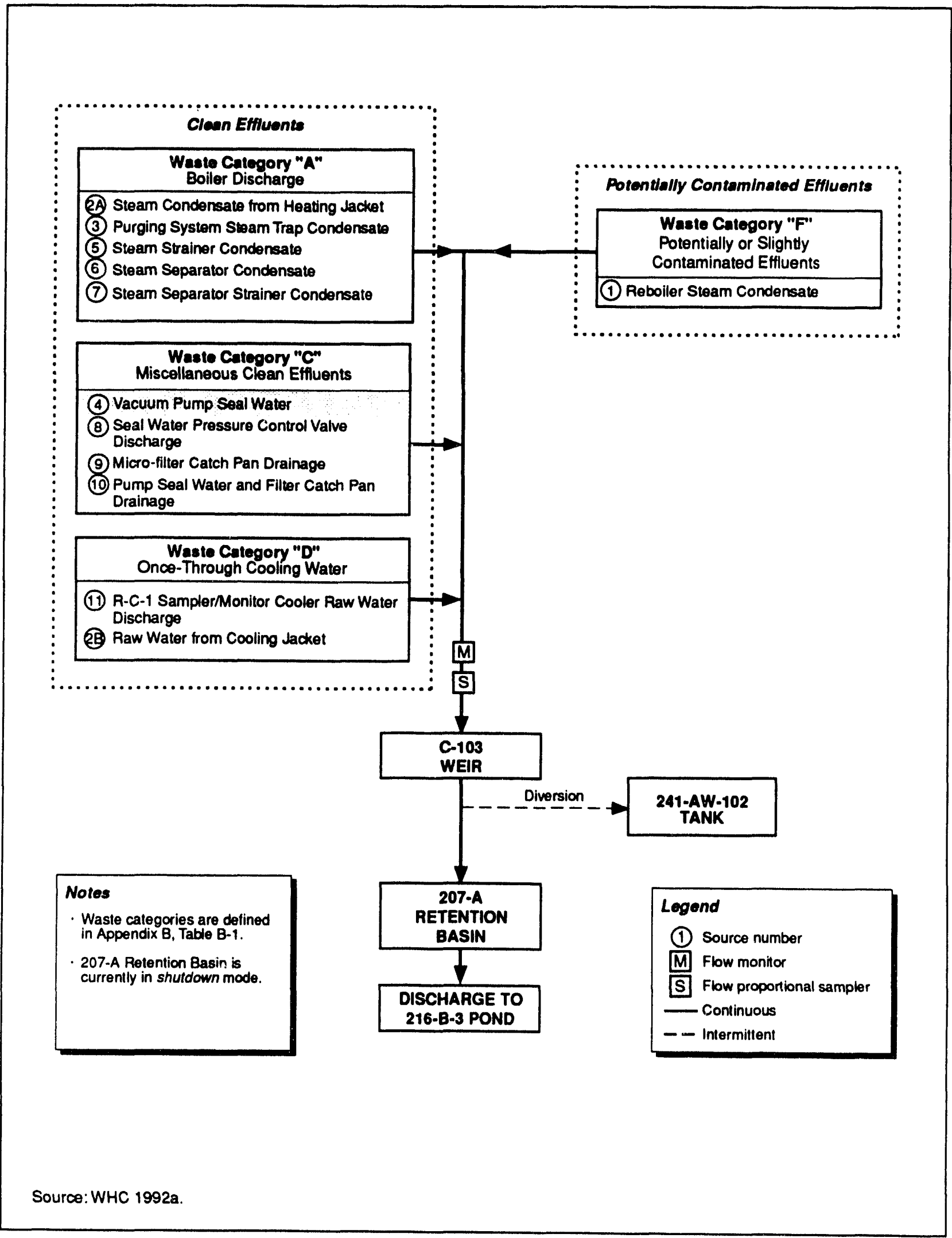

Figure B-8. Schematic for Current Status of 242-A Evaporator Steam Condensate. 
TABLB B-3. 242-A Evaporation Stream Condensate Effluent Sources.

\begin{tabular}{|c|c|c|c|c|c|c|c|}
\hline $\begin{array}{c}\text { Source } \\
\text { No. }\end{array}$ & Source Stream & $\begin{array}{c}\text { Source } \\
\text { Building }\end{array}$ & $\begin{array}{c}\text { Source } \\
\text { Category [1] }\end{array}$ & $\begin{array}{c}\text { Effluent Water } \\
\text { Type }\end{array}$ & $\begin{array}{c}\text { Flow } \\
\text { Type [2] }\end{array}$ & $\begin{array}{c}\text { Estimated } \\
\text { Flowrate [3] } \\
\text { (gpm) }\end{array}$ & Status [6] \\
\hline 1 & Reboiler Steam Condensate & 242-A & $\mathbf{F}$ & Condensate & $\mathbf{C}$ & $3.24 \mathrm{E}+01[5]$ & Inactive \\
\hline $2 A$ & Steam Condensate from Heating Jacket & 242-A & $\mathbf{A}$ & Condensate & $\mathbf{I}$ & $0.58 E+00$ & Inactive \\
\hline 2B & Raw Water from Cooling Jacket & 242-A & $\mathbf{D}$ & Raw Water & 1 & $0.58 \mathrm{E}+00$ & Inactive \\
\hline 3 & Purging System Steam Trap Condensate & 242-A & $\mathbf{A}$ & Condensate & C & $<2.00 \mathrm{E}-02$ & Inactive \\
\hline 4 & Vacuum Pump Seal Water [4] & 242-A & C & Raw Water & $\mathbf{I}$ & $1.50 \mathrm{E}+00$ & Inactive \\
\hline 5 & Steam Strainer Condensate & 242-A & $\mathbf{A}$ & Condensate & C & $<2.00 \mathrm{E}-02$ & Inactive \\
\hline 6 & Steam Separator Condensate & 242-A & $\mathbf{A}$ & Condensate & C & $<2.00 \mathrm{E}-02$ & Inactive \\
\hline 7 & Steam Separator Strainer Condensate & 242-A & $\mathbf{A}$ & Condensate & C & $<2.00 \mathrm{E}-02$ & Inactive \\
\hline 8 & Seal Water Pressure Control Valve Discharge & 242-A & C & Raw Water & $\mathbf{I}$ & $<2.00 \mathrm{E}-02$ & Inactive \\
\hline 9 & Micro Filter Catch Pan Drainage & 242-A & C & Raw Water & $\mathbf{I}$ & $<2.00 \mathrm{E}-02$ & Inactive \\
\hline 10 & Seal Water Pumps and Filter Catch Pan Drainage & 242-A & C & Raw Water & $\mathbf{I}$ & $<2.00 \mathrm{E}-02$ & Inactive \\
\hline 11 & R-C-1 Sampler/Monitor Cooler Raw Water Discharge & 242-A & $\mathbf{D}$ & Raw Water & C & $1.70 \mathrm{E}-01$ & Inactive \\
\hline & & & & & TOTAL & $3.54 \mathrm{E}+01$ & \\
\hline
\end{tabular}

Source: WHC 1992a

NOTES:

[1] Source categories are defined in Table B-1.

[2] I=Intermittent, $C=$ Continuous.

[3] Average flow rate is based on total annual flow divided by 526,000 minutes (one year).

14] This source stream has been permanently eliminated following completion of sampling period.

[5] This annualized flow based on Table A-1 from WHC 1990b, Addendum 26, Page A-3.

[6] Facility is currently not operational so all streams are listed as inactive. When the evaporator is operative all streams, with the exception of stream 4 , will be active. Stream 4 has been permanently eliminated. $\mathrm{gPm}=$ gallons per minute 


\section{$1.3 \quad$ 241-A TANK FARM COOLING WATER SIC Code: 9999}

\subsubsection{1-A Tank Farm Cooling Water Facility Description}

The 241-A Tank Farm complex consists of a number of individual double-shell and single-shell tank farms. Double-shell tank farms 241-AY and 241-AZ, referred to as the "aging waste" tanks, are capable of storing high-level radioactive waste. These tanks have a ventilation system and steam coils that are designed to allow heating the waste to maintain a desired water boil-off rate. The main purpose of the 241-A Tank Farm Cooling Water is to provide a cooling mechanism for the exhaust vapors emitted by the 241-AY/AZ Tank Farm so that water can be condensed and returned to the tanks.

The "aging waste" tanks are kept under slight vacuum by the ventilation system, and the exhaust of the vent system is directed to the shell side of the off-gas condensers. Cooling water flows through the tube side of the condensers to remove the heat from the vent gas, thus condensing the contaminated water vapor. The condensed vapor is returned to the waste tanks.

The 241-A Tank Farm is located in the 200 East Area of the Hanford Site north of the Plutonium-Uranium Extraction (PUREX) Plant, as shown in Figure B-9. The 241-A Tank Farm cooling water system includes an emergency cooling water system which contains cooling towers. Figure B-10 shows a plan view of the 241-A Tank Farm, Building A-401, which houses the "aging waste" storage tanks ventilation offgas condensers and Building A-701, which houses the air compressors and the emergency cooling water system cooling towers.

The 241-A Tank Farm cooling water is collected in an outdoor warm water sump from which the combined stream is discharged to the discharge site (216-B Pond) after it is monitored. The B Pond, which is a 100 -acre percolation pond, is also shown in Figure B-9.

\subsubsection{1-A Tank Farm Cooling Water Process Description} System.

Figure B-11 shows a flow schematic of the 241-A Tank Farm Cooling Water

The Tank Farm cooling water is normally a once-through operation with raw water pumped from the 284-E Powerhouse through the C Tank Farm to 241-A-401 and -701 Buildings. When raw water is not available, the emergency cooling water system provides cooling water for the facility. The emergency cooling water system recirculates cooling water through the emergency cooling water system cooling towers for two cycles of concentration.

The A-401 condenser system consists of three condensers, two in operation in series and one as standby. The cooling water flowrate averages about 600 gallons per minute through the condensers and represents over $98 \%$ of the total effluent discharged. The water in the condenser tube side is maintained at a higher pressure 
relative to the off-gas pressure at the shell side. This reduces the probability of leaking off-gas contaminant into the condenser cooling system.

Figure B-11 shows that source stream 2 is sampled with source stream 1. The condenser cooling water is sampled by a continuous proportional sampler located in the $A-401$ Building condenser-facility before it flows to the warm water sump. Other contributors flow into the warm water sump downstream of the sampler.

Building A-401 has floor drains in an operating gallery that contains pipes with non-radioactive fluids. A service sink and safety shower, located in this gallery, drain to the floor drains. This flow is small and sporadic and has been estimated to be less than 0.016 gallons per minute of water on a normal basis.

The A-701 building includes four air compressors. Cooling water is circulated through the compressor cylinders and cylinder heads to remove heat generated from the compressor process. After passing through the compressors, the cooling water flows into a drain pipe, and then to the warm water sump. The compressed air dryer condensate, which is considered to be pure water, is collected in a receiver tank and is discharged to the warm water sump. The total effluent flow from the A-701 Building facility is normally 10 gallons per minute, most of which is from the cooling water.

The emergency cooling water system is intended to provide cooling water to the condensers located in the 241-A-401 Building during an interruption of the raw water supply. During emergency cooling water system operation, cooling water from the condensers circulates through the cooling tower. The water is cooled by evaporation before returning to the cold water sump of the cooling tower where 90 gallons per minute of makeup water from a deep well is added for evaporation loss and blowdown. The water from the cold water sump is then returned to the condensers as the cooling water supply.

\subsubsection{1-A Tank Farm Cooling Water Source Description}

Water enters the 241-A Tank Farm Cooling Water system from three different supplies: raw water, sanitary water, and deep well water. Raw water from the Columbia River is used for once-through condenser cooling and compressor cooling. Sanitary water provides a back up for the compressor raw water cooling. Deep well water is for the emergency cooling water system cooling tower for makeup of the evaporation and blowdown losses. Raw water is the primary supply to the cooling system and contributes nearly 100 percent of the waste water stream.

The 241-A Tank Farm cooling water waste consists of seven contributors. They are identified by source numbers and are shown in Table B-4 and Figure B-11. Figure B-12 shows a simplified block flow diagram for the facility as well as various influent and effluent water sources. The boxes on the left side of the figure show the types of clean water that enter the facility and are eventually discharged as process waste water. The sources listed in Table B-4 are shown in Figure B-13 flow schematic and have been assigned to into one of the six categories ( $A$ through $F$ ) described in Table B-1. 
Normally Sources 1 through 3 are the only contributors and are piped to the warm water sump before discharge to 216-B-3 Pond at a total flowrate of approximate 610 gallons per minute. Because the emergency cooling water system is normally not in use, Sources 4 through 7 normally do not contribute to the effluent discharge. Waste water collected in the concrete warm water sump is typically clean and consistent with raw water quality (WHC 1992a).

1.3.3.1 A-401 Condensers Waste Cooling Water (Source 1). The Tank Farm cooling water is normally a once-through operation with raw water pumped from the 284-E Powerhouse through the C Tank Farm to 241-A-401. This effluent is consistent with raw water quality; however, due to the potential of radioactive contamination from the tank off-gas condensers, it is considered to be a Category $F$ waste.

1.3.3.2 A-401 Building Condensers-Facility Floor Drainage (Source 2). The 241-A-401 Building condenser-facility floor drain line is fed from drains in the operation gallery where cold (non-radioactive) pipes are located. Discharges to these drains consist of water from the service sink and safety shower. No chemicals are stored or used in the 241-A-401 Building Operating-Gallery and there is no connection from this drain to any radioactive or hazardous source. Therefore, it is unlikely for this contributor to be contaminated by radioactive or hazardous material. This effluent is considered a Category $C$ waste.

\subsubsection{A-701 Building Compressor-Facility Drainage Including Compressor} Cooling Water (Sources 3, 3A, and 3B). Once-through raw water is normally used for compressor cooling. Ti,e cooling water is not in direct contact with any contamination source. After passing through the compressors, the water flows into the drain pipe and to the warm water sump. This effluent is consistent with raw water quality and is considered a Category D waste. This effluent is referred to as Source 3.

Sanitary water is used for compressor cooling when raw water is not available. This effluent is consistent with the sanitary water quality and is considered a Category D waste. This effluent is referred to as Source 3A.

The condensate formed from the compressed air is collected in the receiver tank and is discharged periodically. There is also a source from the air dryer. This is considered to be pure water and is also discharged to the raw water sump. This effluent is consistent with the raw water quality and is considered a Category D Waste. This effluent is referred to as Source 3B.

1.3.3.4 Emergency Cooling Water System Sources 4 through 7. The emergency cooling water system is normally inactive with no flow addition to the 241-A Tank Farm cooling water waste stream. The best available data is that the emergency cooling water system is functionally tested once per month, but is rarely operated beyond that. When raw water is not available, cooling water from the condensers flow in the normal configuration to the warm water sump. It is then pumped to the emergency cooling water system cooling towers. Four contributors from emergency cooling water system are categorized as follows: 
- Cold water sump overflow (Source 4) - This effluent is considered a Category $\mathrm{F}$ waste due to the potential of radioactive contamination from the Tank off-gas condensers.

- $\quad$ Deep well makeup water bypass (Source 5) - This effluent is considered a Category $C$ waste as it is never mixed with water from the off-gas condensers in the cooling tower.

- Cooling Tower blowdown (Source 6) - The cooling tower is designed to operate at two cycles of concentration. This effluent is considered a Category F waste.

Drainage (Source 7) - This drain is used to periodically drain the cooling tower. This effluent is considered a Category $\mathrm{F}$ waste. 


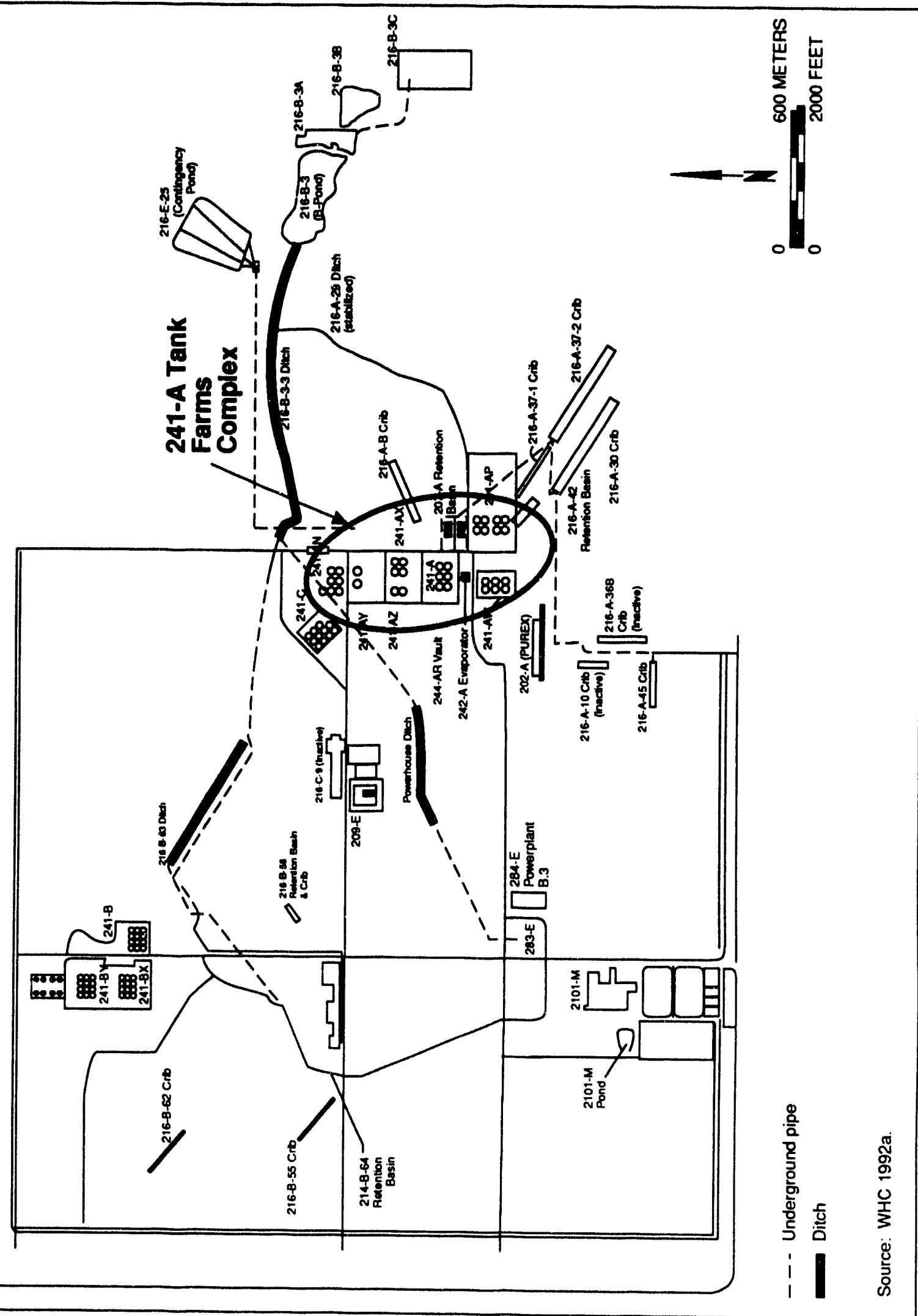

$9131728.013 / 46168 / 11-9-93$

Figure B-9. Location of 241-A Tank Farm Complex on the 200 East Area. 


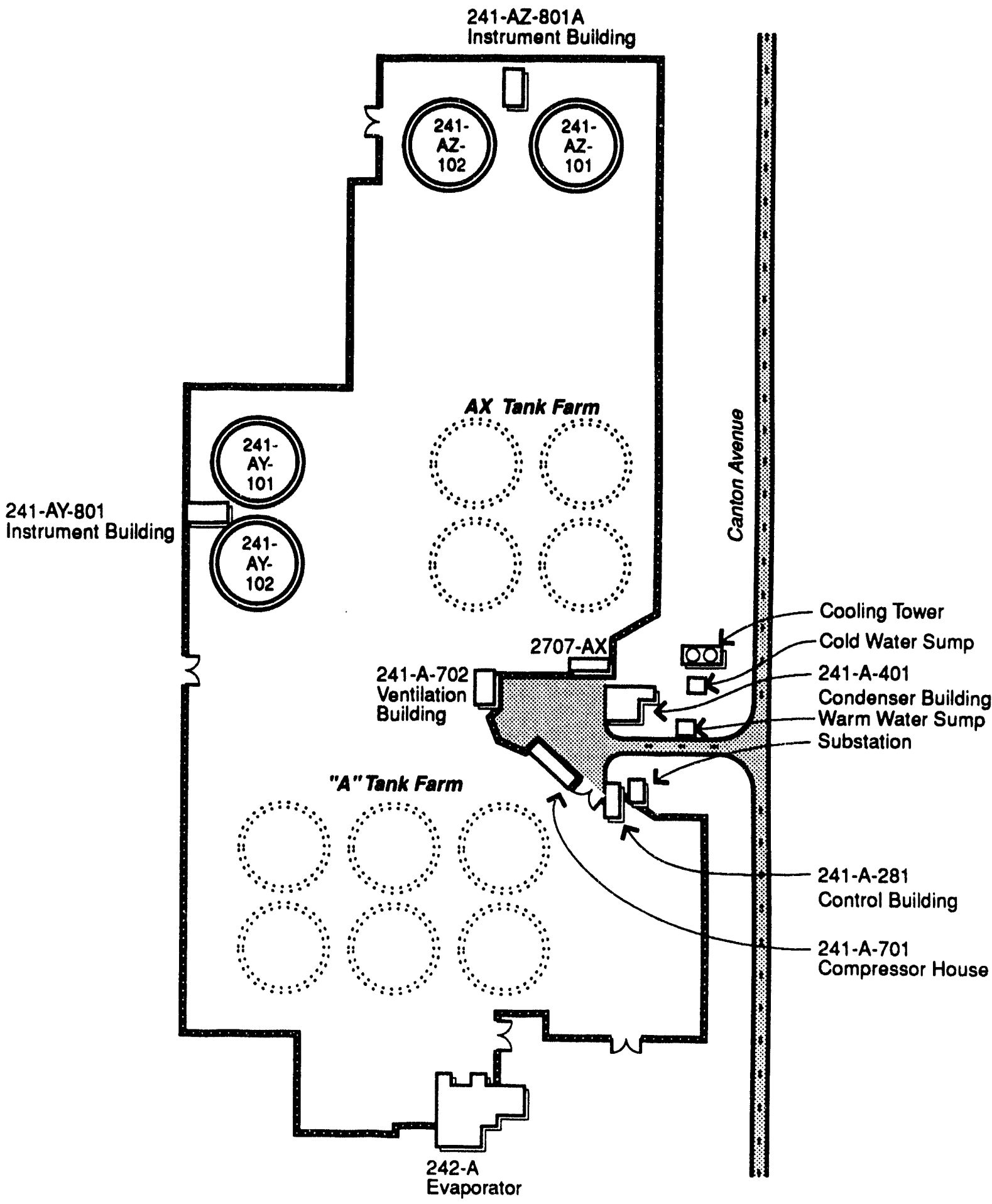

Source:WHC 1992a.

$9131728.013 / 46169 / 11-9-93$

Figure B-10. 241-AY and 241-AZ Tank Farm Complex Plot Plan. 


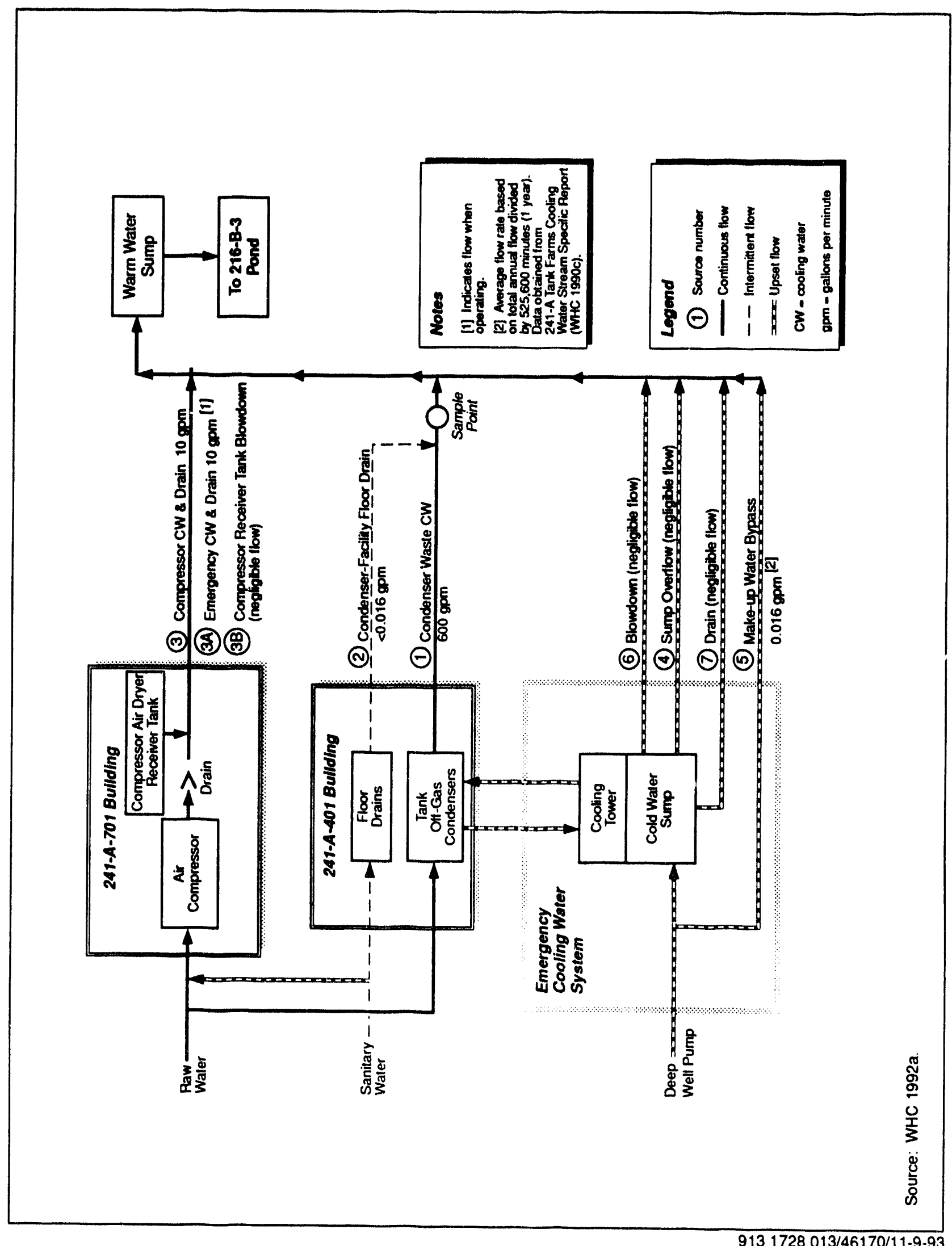

$9131728.013 / 46170 / 11-9.93$ Figure B-11. Current Flow Schematic of the 241-A Tank Farm Cooling Water System (Yearly
Average Flows). 


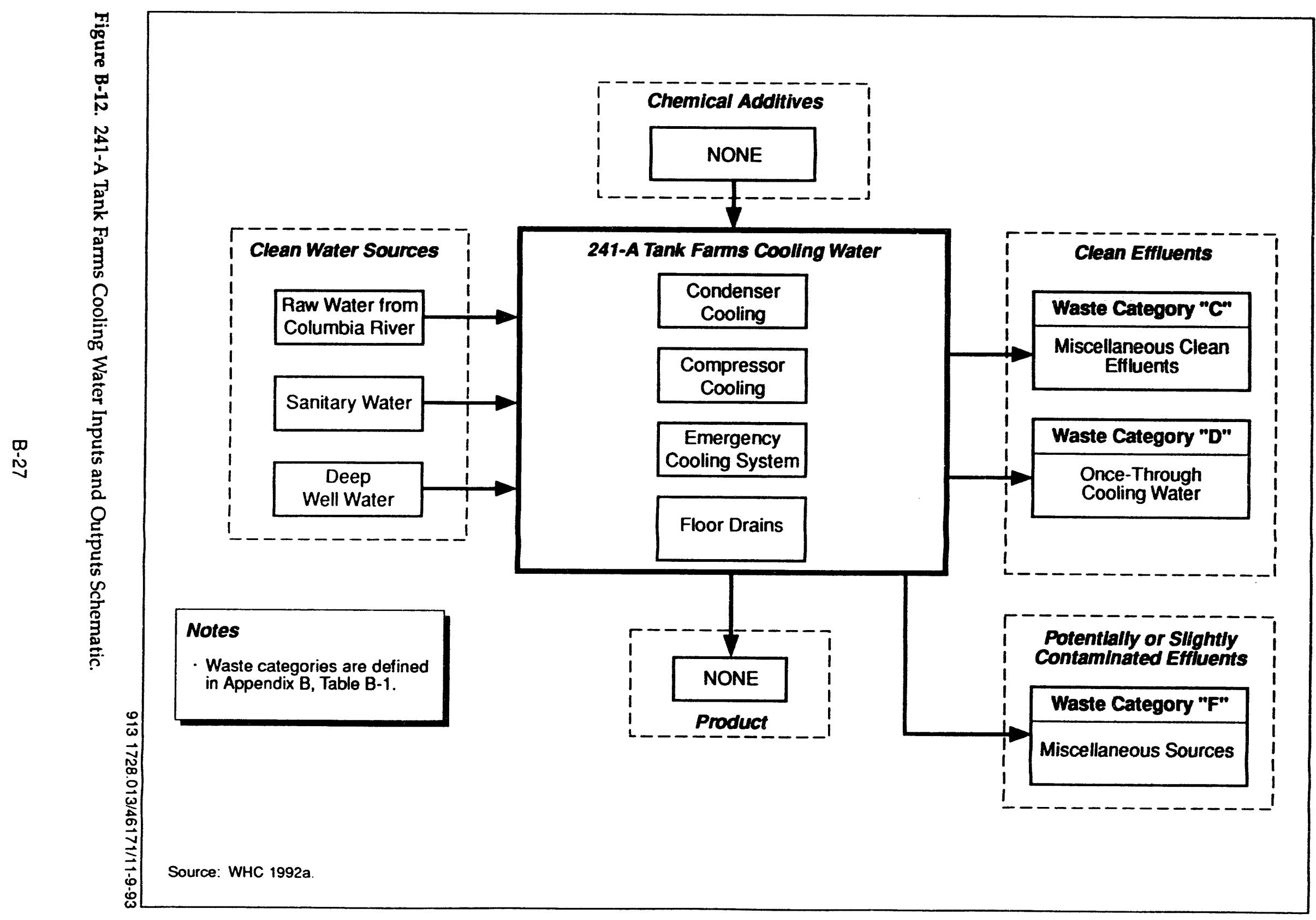




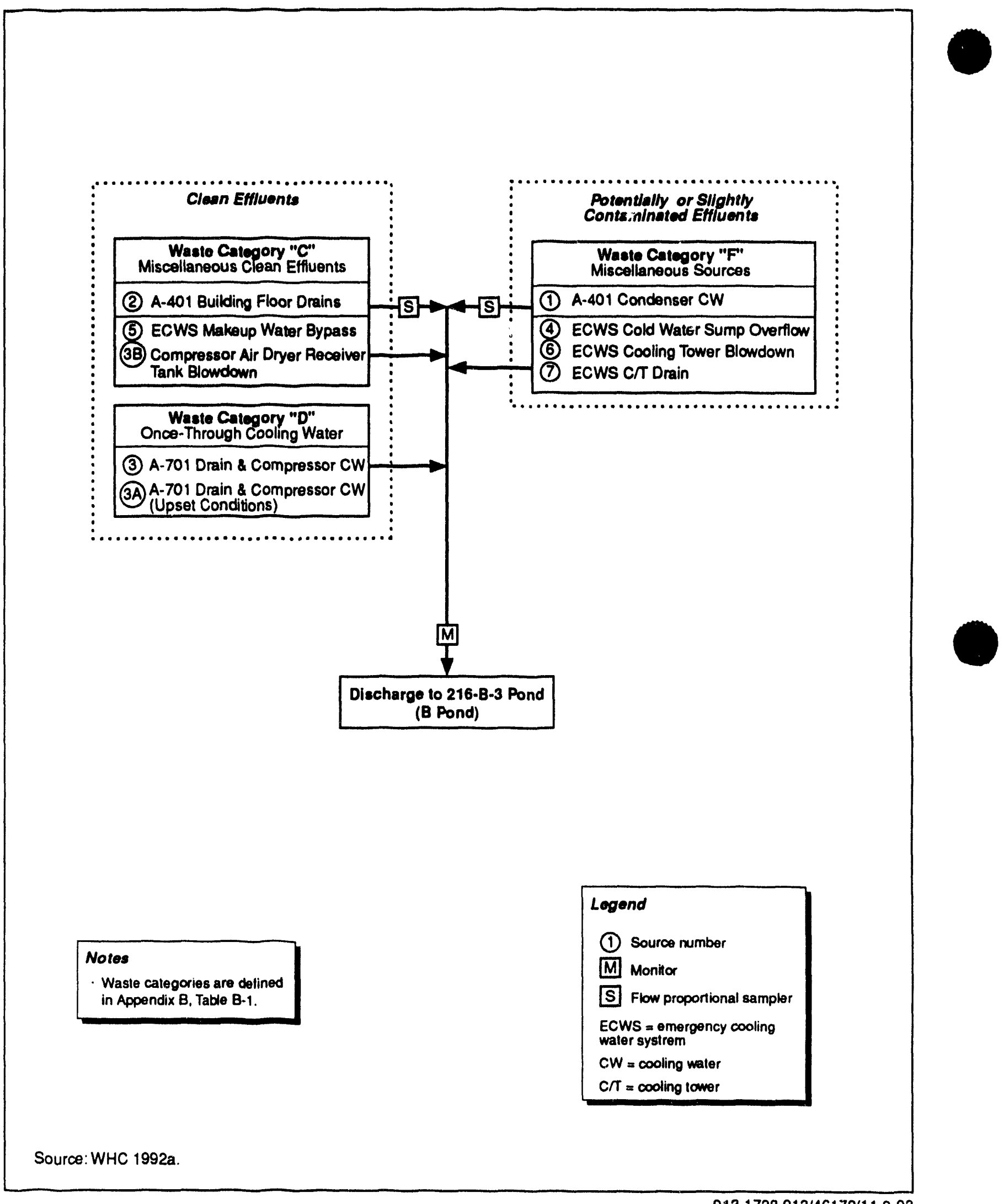

$9131728.013 / 46172 / 11-9-93$

Figure B-13. Flow Schematic for Current Status of 241-A Tank Farms Cooling Water. 
TABLE B-4. 241-A Tank Farm Cooling Water Effluent Source

\begin{tabular}{|c|c|c|c|c|c|c|}
\hline $\begin{array}{l}\text { Source } \\
\text { No. }\end{array}$ & Source Stream & $\begin{array}{c}\text { Source } \\
\text { Category } \\
\text { [2] }\end{array}$ & $\begin{array}{c}\text { Effluent } \\
\text { Water Type }\end{array}$ & $\begin{array}{c}\text { Flow } \\
\text { Type } \\
{[3]}\end{array}$ & $\begin{array}{c}\text { Estimated } \\
\text { Flowrate } \\
\text { (gpm) }\end{array}$ & Status \\
\hline 1 & A-401 Condensers Cooling Water & $\mathbf{F}$ & Raw & C & 600 & Active \\
\hline 2 & A-401 Building Condenser-Facility Floor Drain & C & Sanitary & I & $\begin{array}{l}\text { Negligible } \\
(<0.016)[5]\end{array}$ & Active \\
\hline 3 & $\begin{array}{l}\text { A-701 Building Compressor-Facility Drains, Including Compressor } \\
\text { Cooling Water }\end{array}$ & $\mathbf{D}$ & Raw & C & 10 & Active \\
\hline $3 \mathrm{~A}$ & $\begin{array}{l}\text { A-701 Building Compressor-Facility Drains, Including Compressor } \\
\text { Cooling Water }\end{array}$ & D & Sanitary [1] & $1 / \mathrm{C}$ & $10[4]$ & Standby \\
\hline 3B & Compressor Air Receiver Tank Blowdown & C & Condensate & I & Negligible & Active \\
\hline 4 & ECWS Cold Water Sump Overflow & $\mathbf{F}$ & Deep Well & $\mathbf{I}$ & Negligible & Standby \\
\hline 5 & ECWS Deep Well Makeup Water Bypass & C & Deep Well & $\mathbf{I}$ & 0.016 [5] & Standby \\
\hline 6 & ECWS Cooling Tower Blowdown & $\mathbf{F}$ & Deep Well & $\mathbf{I}$ & Negligible & Standby \\
\hline \multirow[t]{2}{*}{7} & ECWS Drain & $\mathbf{F}$ & Deep Well & I & Negligible & Standby \\
\hline & & & & TOTAL & 610 & \\
\hline
\end{tabular}

Source: WHC 1992a

NOTES:

[1] Sanitary water is used during emergency.

[2] Source category defined in Table B-1.

[3] I=Intermittent, $C=$ Continuous, $I / C=$ Continuous when operating.

[4] Indicates flow when operating.

[5] Average flow rate based on total annual flow divided by 525,600 minutes (1 year). Data obtained from 241-A Tank Farms Cooling Water Stream-Specific Report (WHC 1990c).

gpm $=\quad$ gallons per minute.

ECWS $=\quad$ Emergency Cooling Water System. 
The 244-AR Vault facility was originally used to prepare radioactive wastes for transfer to B Plant for removal of cesium and strontium. These radioactive wastes were generated by other Hanford site activities and were temporarily stored in underground storage tanks prior to being transferred to the 244-AR Vault tanks. Currently the 244-AR Vault is on standby with no radioactive waste operations in progress. However, to maintain the facility for future use, some operational requirements are being met. Cooling water is used to cool the blocks, oil coolers, and compressors that supply instrument air to the facility. Cooling water and heating steam are also supplied to the ventilation system to control the temperature of the inlet air to the facility. Discharges from these systems make up the facility's current (standby mode) waste streams. At present, no record sampling or radiation monitoring instruments are associated with these waste streams. This is due to the inactive nature of the facility, and the fact that the waste streams are discharged from a closed system that has minimal potential for contamination. Currently the effluent goes to B Pond.

Modifications have been undertaken for the 244-AR Vault to become an interim storage and transfer facility for neutralized current acid waste. Neutralized current acid waste consists of acid wastes that have been neutralized and are currently stored in double shell tanks. This neutralized liquid waste contains both transuranic and non-transuranic wastes. Neutralized current acid waste will be transferred and cooled at the $244-A R$ vault prior to treatment at B Plant. One important completed modification has been the installation of the closed-loop cooling system for the Vault tanks. The waste stream will be continuously monitored and sampled at the 2904-AR Building after combining all waste streams at Manhole number 1. A small portion of the effluent stream will be split, with part flowing to the proportional sampler and part flowing through the continuous radiation monitor.

The following section briefly describes the 244-AR Vault and its associated processes.

\subsubsection{4-AR Vault Cooling Water Facility Description}

The 244-AR Vault is located in the 200 East Area of the Hanford Site north of the PUREX Plant, as shown in Figure B-14. Figure B-15 gives a plan view of the 244-AR Vault. A process area cross-section is provided in Figure B-16. The major service areas associated with this facility are the canyon building, tank cells, service and control building, compressor shelter, and closed-loop cooling equipment building. Other associated services include: a wind reduction facility, filter building, instrument building, changehouse building, and standby generator building.

1.4.1.1 Canyon Building. The canyon building is a reinforced concrete structure built to enclose and provide access to tank cells. Three tank cells and a failed equipment storage cell are located below the canyon deck level. The canyon building and cells are ventilated with filtered and temperature controlled inlet air. Cover blocks separate the three process cells and failed equipment storage area from the canyon deck. The canyon building is equipped with a motor-driven 20-ton 
capacity bridge crane and two 1-ton monorail hoists to facilitate cover block and equipment handling. The wind reduction building provides weather protection when the canyon building doors are opened.

1.4.1.2 Tank Cells. Each cell has walls constructed of reinforced concrete and contains a sump, sump jet, cell spray system, radiation monitoring equipment, and the necessary piping and instrumentation required for the process tanks. The failed equipment storage area is located next to Cell 1 . The storage tubes are vented and drained to Cell 1 . The isolation of the tank cells from the canyon by shielding plugs, the ventilation air flow path from the canyon to the cells, and the High Efficiency Particulate Absorber Filtration System on the ventilation exhaust provides a secondary containment in the event of cell contamination.

Tank TK-001 (Figure B-16) is located within Cell 1 and is approximately 43,000 gallons capacity. This tank is the primary neutralized current acid waste storage tank within the 244-AR Vault facility and is equipped with upper and lower stainless steel cooling coils, a transfer pump, a transfer jet, an agitator, spray rings, a purge air system, a sampler, vessel vent and chemical addition lines, and instrumentation. In 1985, the upper coil failed a pressure test and was replaced by an inner coil surrounding the agitator.

Tank TK-002 is located within Cell 2 and is of a similar size and design as that of TK-001. TK-002 is a backup to TK-001 and is equipped with stainless steel upper and lower dual service (heating and cooling) coils, a transfer pump, a sluice pump, a transfer jet, an agitator, spray rings, a purge air system, a sampler, vessel vent and chemical addition lines, a radiation monitoring drywell, and instrumentation.

Tanks TK-003 and TK-004 are both contained within Cell 3. These tanks receive waste streams from the pretreatment facility prior to returning this waste to the tank farms. TK-003 and TK-004 have approximately 4700 gallons capacity each. Each tank is equipped with two transfer jets, an agitator, a spray ring, a purge air system, a sampler, vessel vent and chemical addition lines, and instrumentation. TK-003 also has a stainless steel cooling coil and a purge ring. TK-004 is equipped with a dual service (heating and cooling) coil and a radiation monitoring drywell.

1.4.1.3 Service and Control Building. The service and control building is attached to the south wall of the canyon building. It contains the control room and a sample room. The control room houses the jet gang valves (used to control the steam transfer jets), the raw water control station, steam control station, the heating, ventilation, and air conditioning equipment, process instrumentation and control panels, the instrument air dryer, switchgear, and motor control centers. Tank sampling equipment is inoperative and sampling operations are not presently required. The crane control room is adjacent to the east end of the service and control building.

1.4.1.4 Compressor Shelter. The compressor shelter is located at the west end of the canyon building and houses both the normal operating compressor and the back-up compressor. The operating compressor supplies 100 pounds per square inch 
guage process air to an air receiver via an aftercooler and a condensate and oil separator. The backup compressor and the after-cooler are cooled by raw water, while the main compressor is provided with a glycol cooled, closed-loop system.

1.4.1.5 Closed-Loop Cooling System. A closed-loop cooling system is designed to remove the approximately 1.9-million British Thermal Units per hour (Btu/hr) heat load from TK-001, $-002,-003$, and -004 . The system consists of redundant evaporative cooling units and recirculation pumps, air separator, make-up water treatment system, and radiation monitoring equipment. The cooling system equipment is installed in an instrument and equipment building located east of the compressor shelter next to the cooling towers.

The evaporative cooling units consist of redundant cooling towers. The closed-loop cooling water from the cell tanks is circulated through tubes in the heat exchanger within the cooling unit. Evaporative cooling water is cascaded over the tubes by a spray pump while air is forced upward over the tubes. Heat is removed from the closed-loop system by evaporation and the heat is discharged to the atmosphere. The remaining spray water falls to the sump and is recirculated. The only water consumed is the amount evaporated plus the small amount of blowdown which is bled to limit the concentration of impurities. The blowdown is discharged to the facility waste stream. For freeze protection during temporary shutdown periods, the immersion heaters in the units will maintain the sump water temperature at 40-45 degrees Fahrenheit.

Two identical 15 horsepower recirculation pumps are utilized to circulate the necessary cooling water to the cell tanks. Either pump can be used with either evaporative cooler.

An air separator and a compression tank are provided in the closed-loop piping to remove entrapped air, allow for expansion of the liquid in the closed-loop, and permit the addition of make-up water.

A packaged water treatment system is provided to control the water quality and reduce long-term corrosion. The system consists of water softening equipment and a chemical additive system with its associated metering pump. The softening unit has a 40 gallons per minute capacity and is used to supply water for cooling tower makeup and closed-loop fill.

A radiation detector is installed in the cooling water discharge header. If a leak occurs in one of the detector cooling coils and radioactive material enters the closed loop, the detector will alarm and automatically activate a three-way valve to divert the radioactive water into Cell 3 . The leaking coil will then be isolated and cooling water will be routed through the secondary coil. Accumulated water within the Cell 3 sump is transferred to the cell tank by a sump jet. Radioactive cooling water is disposed of in the AY Tank Farm.

Indicators, recorders, controllers, alarms, and interlocks are used as necessary to monitor flow, temperature, radiation, and pressure in the closed-loop cooling 
system. These instruments are used to alert operating personnel in the control room, and to measure and identify the condition of the system during operation.

\subsubsection{4-AR Vault Cooling Water Process Description}

This section describes the processes that are associated with the 244-AR Vault cooling water waste stream. Process changes and enhancements that have been completed to reduce contributions to the waste stream and to prepare the iacility for its future mission are described.

1.4.2.1 Primary Process. A flow schematic of the waste water flow paths of the 244-AR Vault facility is shown in Figure B-17. Figure B-18 shows the 244-AR Vault process and its relationship to the various influents and effluents.

Table B-5 lists the effluent source streams, depicted in Figure B-17 and B-19, and identifies the nature of the flow (e.g., intermittent, continuous), the effluent water type, and the category assigned to each source. The source categories of waste waters shown in the table are defined in Table B-1. Waste streams generated during facility operation as a functioning interim storage and transfer facility for neutralized current acid waste are designated as active. Some source streams have already been eliminated because the previous implementation of source controls.

1.4.2.2 Process Changes and Enhancements. Since fiscal year 1985, the 244-AR Vault systems have been upgraded and changes have been made to reduce potential radioactive discharges for facility operation. These changes are described below.

Cooling and heating coils have been pressurized with process air during facility standby/shutdown conditions at a pressure higher than the tank pressure to force any coil leakage toward the liquid waste and prevent contamination of the inside of the coil. A loss of process air will cause an alarm to annunciate in the control room and the Computerized Automated Surveillance System will alert operators of a potential coil leak.

Floor drains in the vicinity of the Jet Gang Valves have been blocked. If the jet gang valves leak or siphon, the effluents that drip to the floor would not flow to the 216-B-3 Pond. Collection and disposal of these leakages will be administratively controlled (i.e. collected and disposed according to written procedure rather than being sent to the cooling water waste stream).

The condensate from the $\mathrm{K}-1$ (operating areas) and $\mathrm{K}-2$ (canyon/process areas) inlet air systems is checked regularly in accordance with established procedures to ensure that the steam condensate and the cooling water are not contaminated.

Preventive maintenance and plant operating procedures have been implemented to ensure the integrity of the barriers that prevent contamination of the liquid effluents.

A closed-loop cooling system has been installed to replace the once-through vesse' cooling system. To date, this closed-loop system has not been used due to the 
inactive status of the facility. The once-through cooling system has been retained as an emergency backup to the closed-loop cooling system.

\subsubsection{4-AR Vault Cooling Water Waste Water Source Description}

The 244-AR Vault cooling water effluent consists of sixteen waste streams (WHC, 1990d, Addendum 25). The sources listed in Table B-5 and shown in the Figure B-19 flow schematic, are discussed below. Each of the source streams has been placed into one of the six categories, A through F, as described in Table B-1.

1.4.3.1 Heating, Ventalation, and Air Conditioning System Drainage (Sources 1 and 2). The 244-AR Vault heating, ventilation, and air conditioning system provides filtered and temperature-controlled inlet air to the 244-AR Vault. The cooling portion of the heating, ventilation, and air conditioning system lowers the temperature of the incoming air by spraying sanitary water into the incoming air. The recovered water is then recycled from an internal sump. The sump overflow constitutes Source 1. The flowrate is seasonal and dependent upon the extent of cooling required. Operation of the coolers in both the K-1 and the K-2 heating, ventilation, and air conditioning systems will generate an average annual flowrate of about 5 gallons per minute. During the peak summer seasons the flowrate can approach 20 gallons per minute. The heating portion of the $\mathrm{K}-1$ and $\mathrm{K}-2$ heating, ventilation, and air conditioning systems uses steam supplied from the 284-E Powerhouse to heat the incoming air. Temperature control valves regulate the steam flow to the heaters. The steam is in an enclosed system and is not exposed to the air. The steam condensate constitutes Source 2. Its flowrate varies and is negligible during the summer months. An average annual flowrate of 2 gallons per minute has been estimated. During the colder winter months the flow can increase by a factor of 2 or 3 depending upon the outside temperature, but is not expected to exceed 7 gallons per minute. These effluents are considered Category $\mathrm{E}$ and $\mathrm{A}$ respectively.

1.4.3.2 Compressor Cooling Water (Sources 3, 4, and 16). Two air compressors are available to service the 244-AR Vault facility. These compressors supply the instrument air for the 244-AR Vault facility. The main compressor has a closed-loop, glycol-cooled system. A once-through, raw water stream cools the backup compressor. This cooling water (Source 3) removes the excess heat from the backup compressor block and oil cooler. This effluent is considered a Category D waste. Sanitary water may be used when raw water is not available. The cooling water requirement for the backup water-cooled compressor can vary from 5 to 15 gallons per minute, but an annual average flowrate of 0.5 gallons per minute has been utilized since the backup compressor is only utilized about 5 percent of the time.

Blowdown from the air receiver and dryer serving both air compressors is administratively controlled. Source 4 consists of condensed air moisture (essentially pure water), which may be contaminated with small quantities of oil. This source is intermittent and the flowrate depends on compressed air demand and seasonal fluctuations in ambient air temperature and humidity. The annual average flowrate is estimated to be less than 0.075 gallons per minute. This effluent is considered a Category $C$ waste. Source 4 is planned for elimination when the closed loop glycol cooling system is operational as described in Section 1.4.3.8 in this Appendix. 
A separate, once-through stream of raw water (Source 16) cools the compressor aftercooler. The annual average flowrate for this raw water stream has been estimated at 3 galions per minute. This effluent is considered a Category D waste.

1.4.3.3 Evaporative Cooling Units Blowdown (Source 5 and 7). Cooling towers (2) will provide greater than 1.9 million British Thermal Units per hour evaporative cooling for the closed-loop cooling system. Closed-loop cooling system coils are located in the cooling tower. Softened raw water will be used for cooling tower makeup. A 4 gallons per minute blowdown (Source 5) will maintain an acceptable constituent concentration in the cooling tower water. The current anticipated blowdown rate will result in approximately 2 cycles of concentration. During actual operation, the cooling tower blowdown flowrate can be reduced if a higher number of cycles and resultant increase in constituent levels are determined to be acceptable.

The cooling towers will use softened raw water and will have an environmentally compatible chemical added in controlled amounts to control scaling, corrosion, and fouling and to maintain water quality. This additive will be selected at some future date prior to initiation of operations at the 244-AR Vault facility. The additive will be an effluent constituent at Manhole 1 because of the continuous blowdown. This effluent is considered a Category $\mathrm{E}$ waste.

An additional potential effluent is cooling tower overflow (Source 7). A maximum overflow condition would occur during system fill and could approach the softened water inlet flowrate of $\mathbf{4 0}$ gallons per minute. This is anticipated to be an infrequent upset condition resulting from a failure in the cooling tower level control system. The annual average flow resulting from this condition is estimated at 15 gallons per day (0.01 gallons per minute). This effluent is considered a Category E waste.

1.4.3.4 Vessel Vent Steam Heater Condensate (Source 6). The vessel vent system is designed to maintain a vacuum in the four tanks by removing and filtering contaminated offgases. To prevent condensation on the filters, the offgas passes through a steam heater. Condensate from the heater coils is routed to Manhole 1. Operations will maintain a positive pressure in the steam system relative to the tank, ensuring that the steam condensate is not contaminated if a leak occurs. The flow from this source is based on a supply of saturated steam at 177 pounds per hour which results in a 0.4 gallons per minute annual average flowrate. This effluent is considered a Category $\mathrm{F}$ waste.

1.4.3.5 Upset Vessel Cooling (Source 8). During an upset condition when the normal closed-loop cooling system makeup water is unavailable, another raw water source will be used. A manual effort is required to initiate the raw water supply to the cooling loop. This system would contribute up to 4 gallons per minute raw water to the 244-AR Vault waste stream, depending on the number of tanks used. This mode of operation is anticipated to be infrequent due to the reliability and redundancy built into the closed-loop and evaporative cooling systems. However, assuming it were to be utilized for about 2 days per year with an average operating 
flowrate of 4 gallons per minute, the annual average flow contribution to the waste stream is estimated to be about 0.02 gallons per minute.

This upset cooling capability would only be utilized on an infrequent emergency basis to allow sufficient cooling capability for waste transfer until re-establishment of closed-loop cooling. This effluent is considered a Category $F$ waste.

1.4.3.6 Closed-Loop Cooling Water System Drainage (Source 9). The closedloop cooling system removes approximately 1.9 million British Thermal Units per hour heat load from 244-AR Vault storage tanks TK-001, -002, -003, and -004. The system uses softened raw water as makeup. A radiation detector is installed in the cooling water discharge header. If a leak occurs in one of the cooling coils and radioactive material enters the closed loop, a radiation detector will alarm, automatically activate a three-way valve to divert the radioactive water into Cell 3 , and shutdown the circulating water pump. The leaking coil will be isolated. For TK-001 and -002, cooling water may be rerouted through a secondary coil. Any water accumulated within the Cell 3 sump will be transferred by sump jet into TK-003. There is no continuous bleed-off from the closed cooling loop to the facility cooling water waste stream. The closed loop discharge valve to Manhole 1 is locked closed to prevent inadvertent operation. Loop drainage would be accomplished under controlled conditions. The annual average flowrate is estimated to be less than 0.1 gallons per minute. This effluent is considered a Category F waste.

Heating steam is no longer provided to the tank coils. The steam supply lines to the coils have been disconnected.

1.4.3.7 Miscellaneous Effluents (Sources 10, 12, 14, and 15). Other intermittent effluients that could be generated as a result of facility operation would consist of eyerNash station drainage (Source 10), water softening equipment regenerant steam trap drainage (Source 12), water softening regenerant (Source 14) and raw water backflow preventer drainage (Source 15).

Effluent Sources 10,14, and 15 are classified as Category $C$ waste streams. Effluent Source 12 is classified as a Category A waste stream.

The eye wash station waste stream (Source 10) is planned to have intermittent flow of 0.001 gallons per minute, based on estimated yearly average flows. Steam traps from the steam jet lines (Source 12) contribute less than 1 gallon per minute continuous flow of steam condensate, based on yearly average flows.

Water softening regenerant waste stream (Source 14) contributes 0.16 gallons per minute based on estimated yearly average flows. The water softening regenerant waste stream is an administratively controlled intermittent (batch) wi:ste stream. There are currently no plans to reuse spent brine or to recycle flush water.

The backflow preventer drain waste stream (Source 15) is a planned intermittent discharge estimated at 0.0002 gallons per minute based on projected yearly average flows. 
1.4.3.8 Terminated Effluents Planned for Elimination (Sources 4, 11 and 13). Condensed moisture from Air Dryer (Source 4), jet gang valve Area Flow Drainage (Source 11) and TK-002 and -004 Heating Condensate (Source 13) are planned for elimination when the closed loop glycol cooling system is operational. Currently the closed loop glycol cooling system is approximately 95 percent complete, but a specific date for completion and start of operation has not been established. 


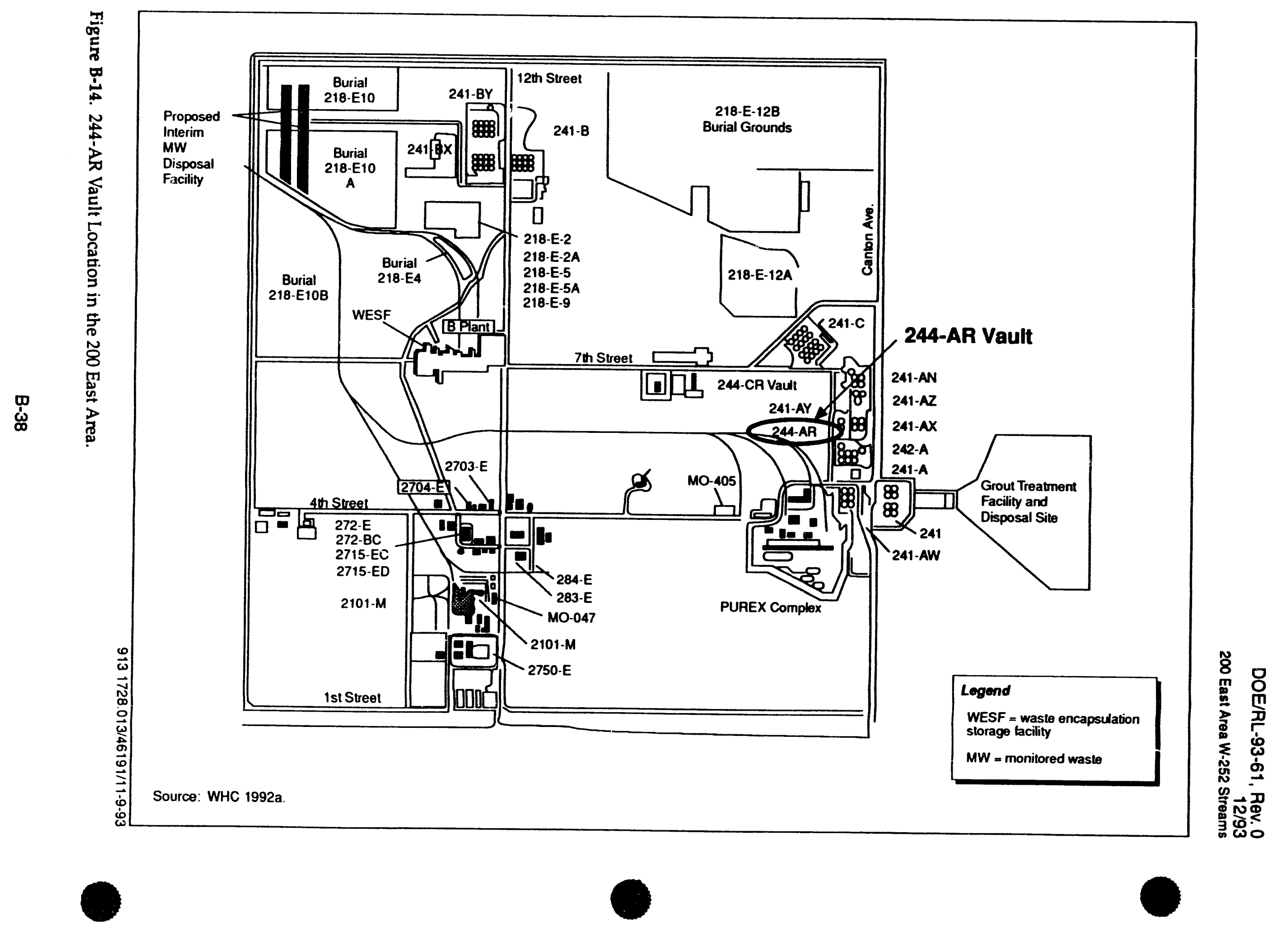




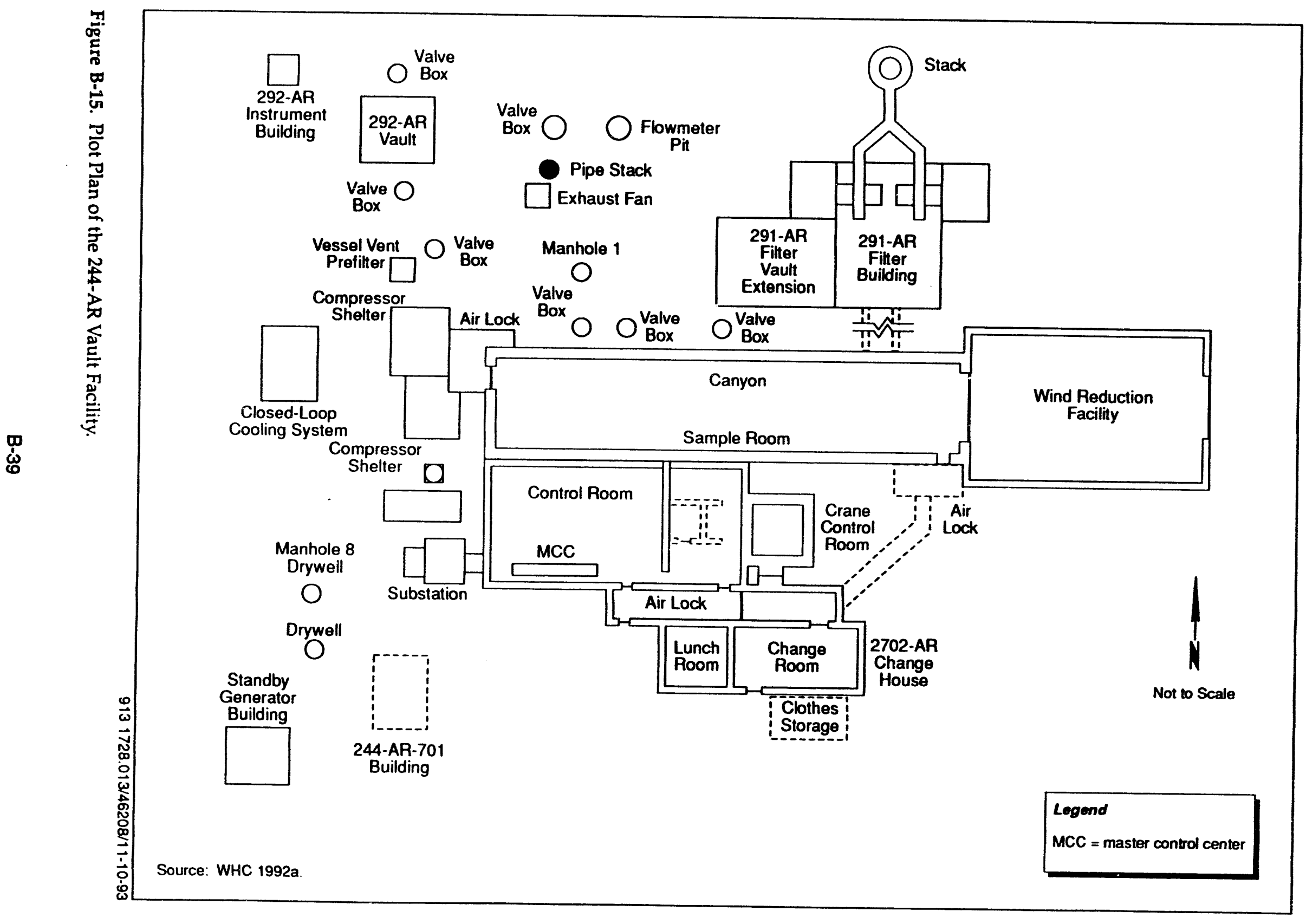




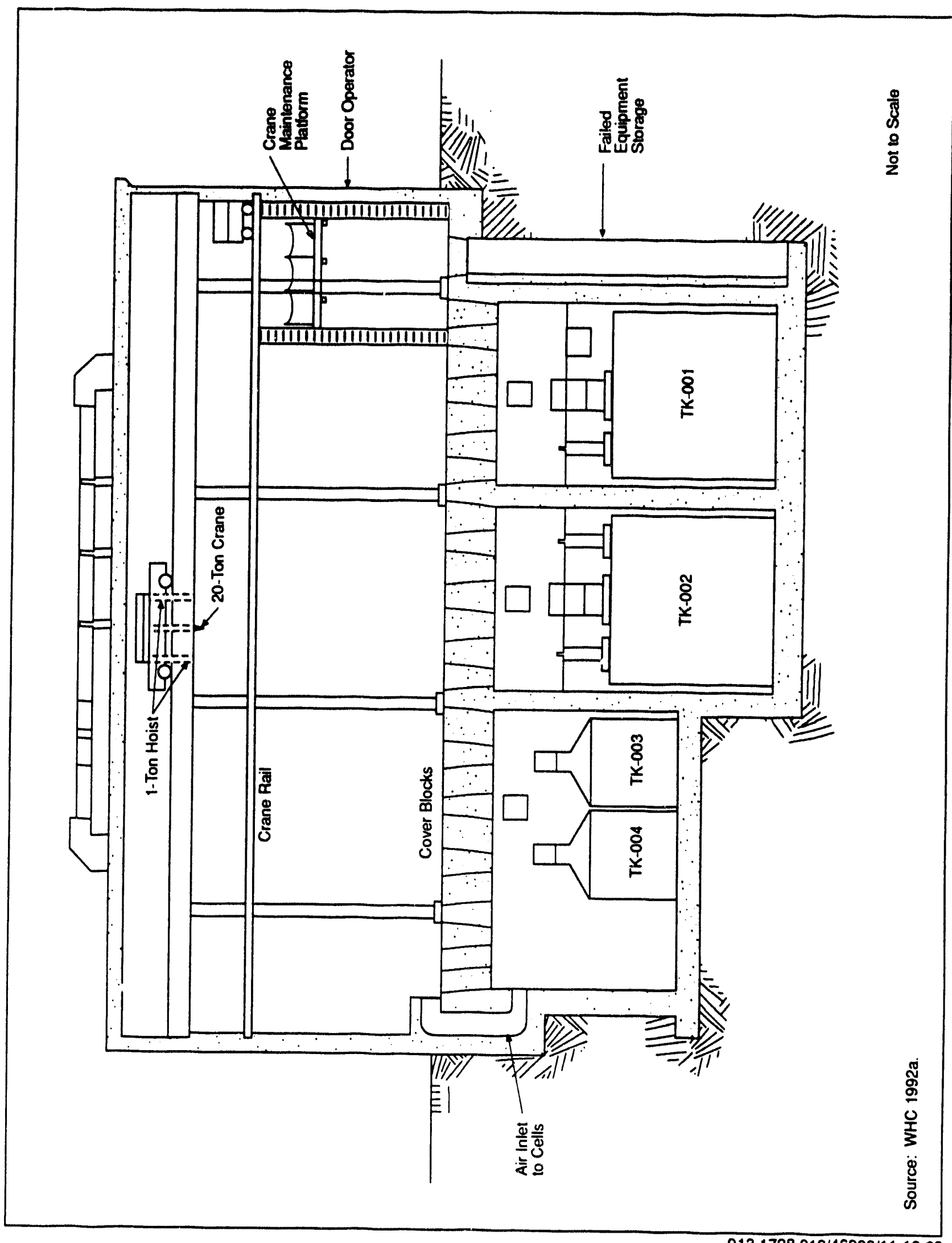

$9131728.013 / 46209 / 11-10-93$

Figure B-16. 244-AR Vault Process Area Cross Section. 


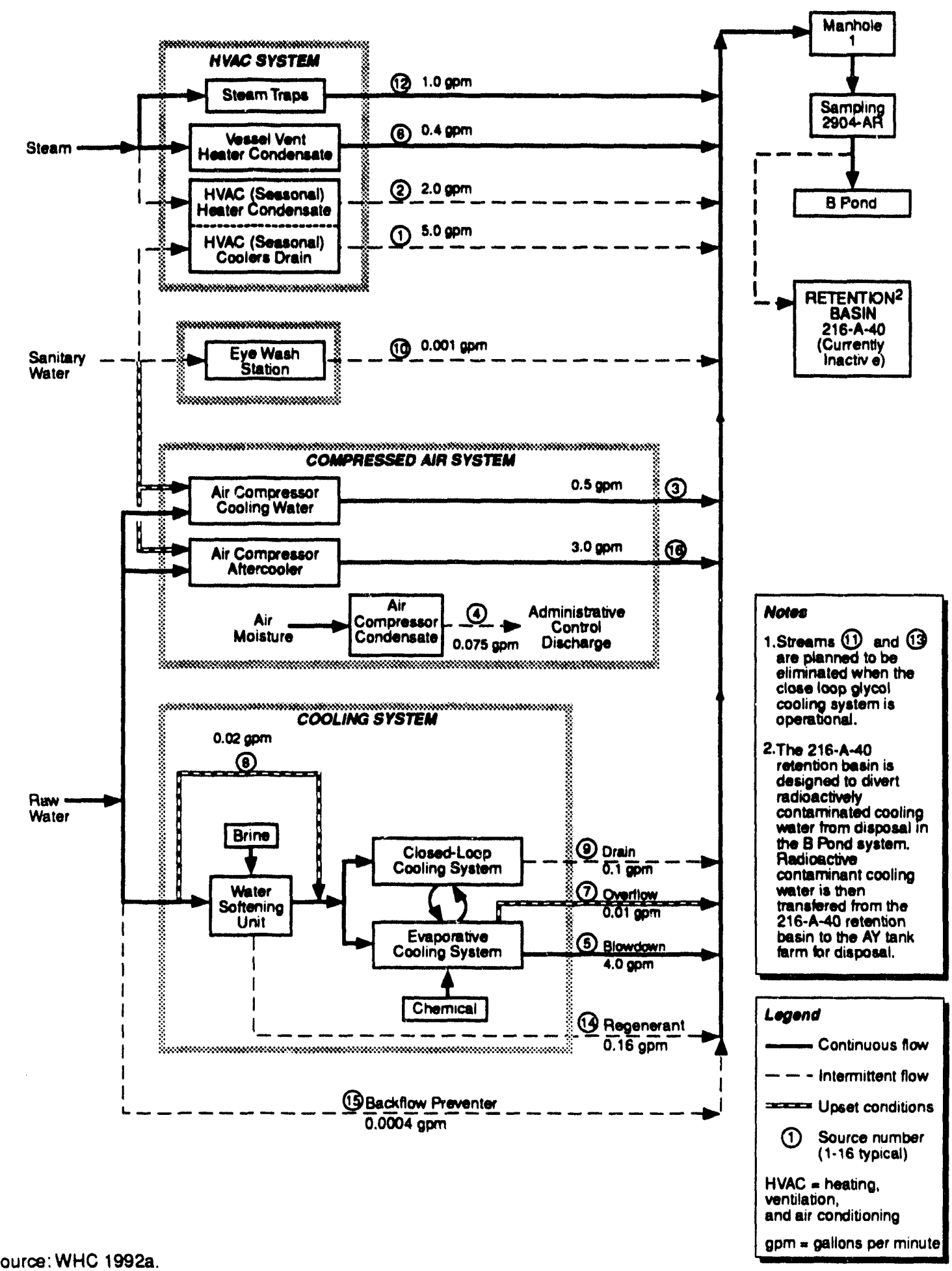

Source: WHC 1992a.

Figure B-17. Current Flow Schematic of the 244-AR Vault (Yearly Average Flows). 


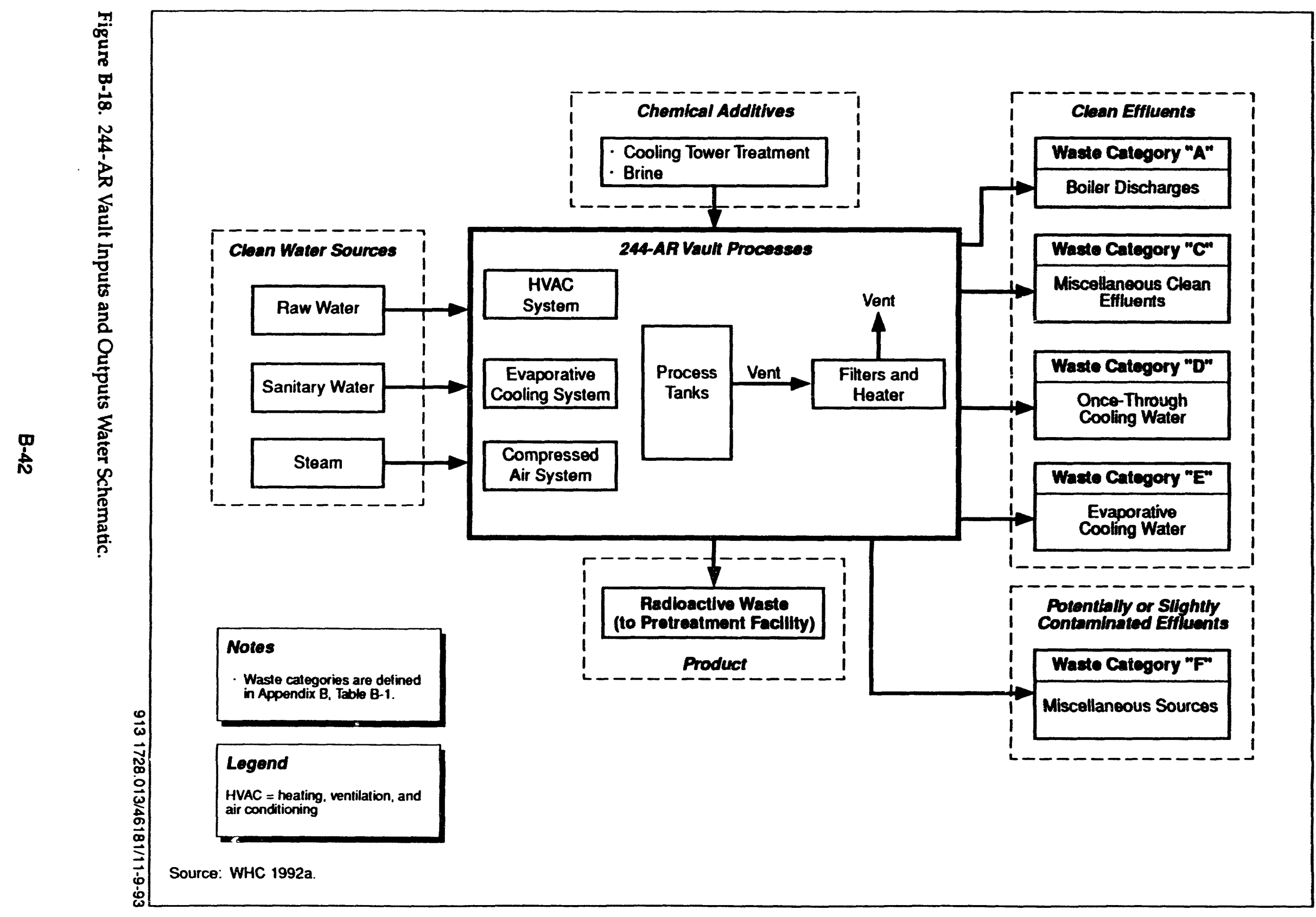




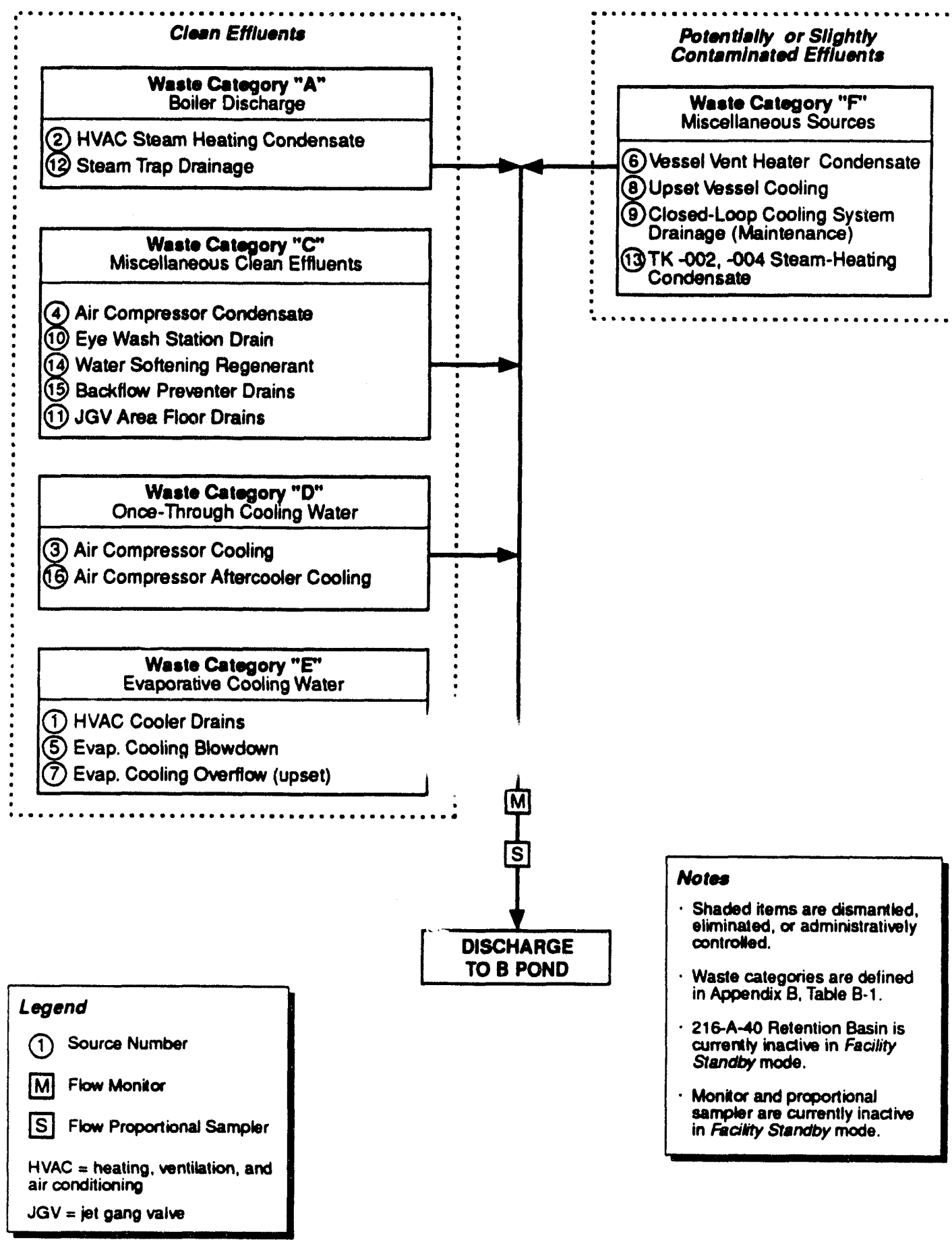

Source: WHC 1992a.

Figure B-19. Flow Schematic for Current Status of 244-AR Vault Effluents. 
TABLE B-5. 244-AR VAULT COOLING WATER EFFLUENT SOURCES

\begin{tabular}{|c|c|c|c|c|c|c|c|}
\hline $\begin{array}{c}\text { Source } \\
\text { No. }\end{array}$ & Source Stream & $\begin{array}{c}\text { Source } \\
\text { Building }\end{array}$ & $\begin{array}{c}\text { Source } \\
\text { Category } \\
{[3]}\end{array}$ & $\begin{array}{c}\text { Effluent } \\
\text { Water } \\
\text { Type }\end{array}$ & $\begin{array}{c}\text { Flow Type } \\
\text { [4] }\end{array}$ & $\begin{array}{l}\text { Estimated } \\
\text { Flowrate [5] } \\
\text { (gpm) }\end{array}$ & Status [6] \\
\hline 1 & HVAC System Cooler Drains [1] & 244-AR & $\mathbf{E}$ & Sanitary & I/C & $5.0 \mathrm{E}+00$ & Active \\
\hline 2 & HVAC System Heater Condensate [1] & 244-AR & $\mathbf{A}$ & Condensate & I/C & $2.0 \mathrm{E}+00$ & Active \\
\hline 3 & Air Compressor Cooling Water [1] & 244-AR & $\mathbf{D}$ & Raw [9] & C & $5.0 \mathrm{E}-01$ & Active [8] \\
\hline 4 & Air Compressor Condensate [2] & 244-AR & C & Air Moisture & $\mathbf{C}$ & $7.5 \mathrm{E}-02$ & Active \\
\hline 5 & Evaporative Cooling Blowdown & 244-AR & $\mathbf{E}$ & $2 \times$ Softened Raw & C & $4.0 \mathrm{E}+00$ & Active [P] \\
\hline 6 & Vessel Vent Heater Condensate & 244-AR & $\mathbf{F}$ & Condensate & C & $4.0 \mathrm{E}-01$ & Active [P] \\
\hline 7 & Evaporative Cooling System Overflow [2] & 244-AR & $\mathbf{E}$ & $2 \times$ Softened Raw & 1 & $1.0 \mathrm{E}-02$ & Active [P] \\
\hline 8 & Upset Vessel Cooling & 244-AR & $\mathbf{F}$ & Raw & $1 / C$ & 2.0E-02 & Active [P] \\
\hline 9 & Closed-Loop Cooling System Drain & 244-AR & $\mathbf{F}$ & Softened Raw & I & $1.0 \mathrm{E}-01$ & Active [P] \\
\hline 10 & Eye Wash Station [2] & 244-AR & C & Sanitary & $\mathbf{I}$ & $1.0 \mathrm{E}-03$ & Active [P] \\
\hline 11 & JGV Area Floor Drain [2] & 244-AR & C & Condensate & $\mathbf{I}$ & & Terminated [10] \\
\hline 12 & Steam Trap Drainage [1] [2] & 244-AR & $\mathbf{A}$ & Condensate & C & $1.0 \mathrm{E}+00$ & Active \\
\hline 13 & TK-002 \& 004 Heating Condensate [2] & 244-AR & $\mathbf{P}$ & Condensate & $\mathbf{I}$ & & Terminated [10] \\
\hline 14 & Water Softening Regenerant [2] & 244-AR & C & Raw [7] & I & $1.6 \mathrm{E}-01$ & Active [P] \\
\hline 15 & Backflow Preventer Drain [2] & 244-AR & $\mathbf{C}$ & Raw & $\mathbf{I}$ & $2.0 \mathrm{E}-04$ & Active [P] \\
\hline 16 & Air Compressor Aftercooler Cooling & 244-AR & $\mathbf{D}$ & Raw [9] & $\mathbf{I}$ & $3.0 \mathrm{E}+\infty 0$ & Active \\
\hline & & & & TOTAL & TOTAL & $1.62 \mathrm{E}+01$ & \\
\hline
\end{tabular}

Source: WHC 1992.

NOTES:

111 Sources 1, 2, 3, and 12 comprise the faclity standby mode wastestream as identified in the 244-AR Vault Stream-Specific Report (WHC 1990d Addendum 25).

(2) New source nol previously identified in the WHC 1990d Addendum 25.

[3] Source calegory defined in Table B-1.

[4] I=intermiltent, $C=$ continuous, $1 / C=$ =continuous when operating.

[5] Average flow rate based on tolal annual flow divided by 526,000 minules (1 year).

16] Any active source that is generated as a result of planned fulure facility usage is identified with a 'P:

17) Calcium, magnesium, and chloride concentrations are increased to reflect anticipated concentrations resulting from the water softening resin bed regeneration process.

(8) Water cooled air compressor is assumed to be utilized about $5 \%$ of the time.

(9) Sanilary water is available as backup.

[10] Streams 11 and 13 will be eliminated when the closed loop glycol cooling system is operational.

gpm $=$ gallons per minute

HVAC = Heating Ventilation, and Air Conditioning

JGV = Jet Gang Valve 


\subsection{4-E POWER PLANT}

SIC Code: 9999

\subsubsection{4-E Powerplant Facility Description}

The 284-E Powerplant is located in the 200 East Area of the Hanford Site, as shown in Figure B-20. Figure B-21 shows the location of the 284-E Powerplant in relation to the surrounding buildings including the 282-E Reservoir and the 283-E Water Treatment Facility. These facilities all share a common process drain which discharges to the 216-B-3-3 ditch via the powerhouse waste water ditch and piping. The powerhouse waste water ditch and associated piping conveying waste water from the 284-E powerplant facility to the 216-B-3-3 ditch is shown on Figure B-20. The 284-E Powerplant is the first to discharge to the process drain, followed by the 283-E WTF and the 282-E Reservoir overflow.

1.5.1.1 284-E Powerplant. Steam produced at the 284-E Powerplant is distributed to all facilities in the 200 East Area for both heating and process use. The 284-E Powerplant has a total capacity of 325,000 pounds of steam per hour with each boiler rated at 65,000 pounds per hour to establish and ensure a safety margin during operations. The 284-E Powerplant utilizes five coal fired boilers; three Erie City boilers and two Riley Stoker Corporation RX boilers. A backup oil-fired packaged boiler is no longer used. All three Erie City boiler units are water-tube, stoker-fired, three-drum Sterling type boilers using the dumping grate method for ash removal. The two $R X$ boilers are stoker-fired with water-tube designs utilizing a traveling grate that discharges ash from the front of the boiler into the ash hopper. Steam is produced from sanitary water that is dechlorinated then sent through a water softener to remove as many minerals as possible. The softened water is introduced into the coal-fired boilers and steam is produced. This steam ( 225 pounds per square inch) is superheated 52-54 degrees Fahrenheit before distribution in the 200 East Area.

The powerplant is a five story, steel frame, concrete block, windowless structure. Included with the building is a coal storage pit, coal unloading hoppers, conveyer belt inclines, switch and crusher houses, brine pit, ash disposal pit, stacks, and bag houses. The 284 East Building has a coal storage silo that is no longer used.

Located on the ground floor (designated the auxiliary floor) are the emergency generator, chemical injection pumps, boiler feed pumps, ash pits, air compressors, and ash handling pumps. The maintenance shop, lockers, and shower rooms are located on the auxiliary floor. The ion exchange resin tanks for the water softener are also located on the auxiliary floor.

The chemical storage room, battery and generator room, flash tank, heat exchanger, steam manifolds, forced draft fans, boiler control panels, and stokers are located on the second floor.

The third flcor is at the lower drum level and gives access to the flight conveyer, deaerator, and damper power cylinders. The fourth floor is at the upper drum level. The fifth floor is above the coal bunkers and contains the coal belt and belt tripper car. 
1.5.1.2 282-E Reservoir and 283-E Water Treatment Facility. Raw water from the Columbia River is pumped from the 100-B Area Pumphouse into the 282-E Reservoir. Water from the reservoir is then pumped to the settling basins in 283-E WTF where alum is added, before settling and filtration. Chlorine is added to the settling basins in the 283-E water treatment facility as well as into the clearwells to provide residual chlorine for end use. Three out of four flocculators preceding the sedimentation basins are presently operational with one in a maintenance mode. From the settling basin, the water overflows a weir into the multimedia gravity filters. After filtration, chlorine is added as the treated water is being pumped to clearwells. The filtered water, which is sanitary (potable) water, is used in 284-E and is also used in the 200-E Area. Cleaning of the settling basin is done four times a year to remove deposited solids. The solids are removed through a settling basin drain in the bottom of each settling basin.

The 283-E water treatment facility Filter backwash is the waste water produced by washing the multimedia filter. This backwash is currently discharged from the building to the

216-B-3-3 Ditch.

\subsubsection{4-E Powerplant Process Description}

This section describes the processes associated with the 284-E Powerplant waste water stream. Process changes that have been made to reduce contributions to the waste stream are described.

1.5.2.1 Primary Processes. A flow scher $" c$ of the 284-E Powerplant waste water and associated flow paths in the 282-E, 28 and 284-E facilities is shown in Figure B-22. The figure depicts the overall flow paths of the contributors to the effluent discharge into the 216-B-3-3 Ditch. This figure also shows the point at which the samples were taken for the effluent characterization chemical analyses reported in the 284-E Powerplant Waste Water Stream-Specific Report (WHC 1990e, Addendum 24).

The waste water discharged to the 216-B-3-3 Ditch includes boiler blowdown, miscellaneous clean and potentially contaminated effluents, and once-through cooling water. These categories of waste waters are defined in Table B-1. Figure B-23 shows the 284-E Powerplant water flow schematic and its relationship to the various influent and effluent sources. Table B-6 lists the potential effluent sources from the 284-E Powerplant waste water and describes their present status as either active or terminated. The source information was obtained from (WHC 1990e) and other information supplied by $284-E$ Powerplant operational personnel.

Water supply for the 200 East Area is drawn from the Columbia River at the 100-B Area or 100-D Area and pumped to a 25,000,000 gallon reservoir. Water is then pumped from there to the 3,000,000 gallon 282-E Reservoir in the 200 East Area.

Water from the 282-E Reservoir is pumped to the 283-E Water Treatment Facility.

The water pumped to 283-E water treatment facility is first mixed with a coagulant, aluminum sulfate (alum), in a flash mixer. The alum acts to destabilize or 
neutralize the charge of suspended particles and colloids, allowing them to agglomerate or attach to other particles. This water is then fed to the flocculator and through a settling basin. Overflow from the settling basin is filtered through a gravity multimedia filter. The filter media consists of a bottom layer of ceramic media, a gravel layer, a layer of sand, and a top layer of anthracite. The 283-E water treatment facility contains four flocculation basins and four filter treatment trains. Filtered water is then chlorinated and routed to two covered storage vessels (clearwells) with a total capacity of 400,000 gallons. The filters in this facility are periodically backwashed to remove sediments. The water used to backwash the filters constitutes the filter backwash and is discharged to 216-B Ditch.

The only function of the 284-E Powerplant is steam production. To make steam, sanitary water from $283-\mathrm{E}$ is sent through a water softener to remove the minerals that contribute to hardness, primarily calcium and magnesium.

Additionally, sodium sulfite is added before the softeners to destroy residual chlorine in the sanitary water. A treatment chemical, Polyquest 683 (less than 4 percent potassium hydroxide), is added to control corrosion and scale formation. The softened and treated water is then introduced into one of the 284-E Powerplant coal-fired boilers and boiled into steam. The treatment chemical, Super Filmeen 14, is added to the steam to control corrosion.

1.5.2.2 Process Changes to Eliminate Contributions to the 284-E Powerplant Waste Water. Several measures that are intended to control the discharge of contaminants to the 284-E Powerplant waste water have been implemented since 1985. These changes pertain to the operation of the 284-E Boiler and 283-E Water Treatment Facility. They are described below.

The boiler feed water has treatment chemicals added to reduce corrosion and scale formation. Three of these, Dearborn 4846,4856 , and 4812 , were previously used at the 284-E facility. They were replaced with the non-hazardous treatment chemical, Polyquest 683 , in 1990 . The treatment chemicals currently used are considered non-hazardous, pursuant to Washington Administrative Code 173-303.

Potassium permanganate has been used for water treatment at the 283-E Water Treatment Facility. Its use was discontinued in 1987. Barium chloride was used in very small quantities as a chemical reagent for testing water quality at the $283-\mathrm{E}$ facility. Methyl purple indicator replaced barium chloride in 1990 in order to reduce the total stream mass.

\subsubsection{4-E Powerplant Waste Water Source Description}

The 284-E Powerplant waste water consists of two continuous flow streams and six intermittent discharge waste streams. The sources listed in Table B-6 are shown in the flow schematics, Figures B-24 and B-25, and are discussed below. Each of the source streams has been categorized in one of the six Categories, A through $F$, described in Table B-1.

1.5.3.1 Reservoir Overflow (Source 1). The 282-E Reservoir contains river water pumped from the 100-B Area River Pumphouse. This reservoir has a capacity 
of 3,000,000 gallons and an overflow sized for a maximum flow of 7,000 gallons per mirute. The water level in the reservoir is maintained by manual adjustment of the inlet valve. Should the reservoir overflow, the water discharges into the 216-B-3-3 Ditch which also carries the other 284-E Powerplant Waste water contributors. The estimated annualized flow is 0.8 gallons per minute. The reservoir overflow is classified Category $\mathrm{C}$, a miscellaneous ciean effluent.

1.5.3.2 Filter Backwash (Source 2). Four gravity multimedia filters are used at 283-E water treatment facility to remove suspended solids from the treated water. Filter backwash is produced during routine water treatment operations. The backwash occurs as a batch operation, takes approximately 30 minutes, and generates 70,000 gallons of waste water. An average of four filter backwashes occur each month for each of the four filters. The filter backwash contains alum and filtered solids removed from the treated water. The barkwash currently is discharged directly to the 284-E Powerplant sewer line. The filter backwash contains metals removed from the raw water in addition to aluminum added as a treatment chemical. This waste contributor is classified Category F, a potentially or slightly contaminated effluent.

1.5.3.3 Cooling Water (Source 3). The main effluent from the 284-E Powerplant is cooling water. It is a constant flow discharge and averages $3,250,000$ gallons per month with two boilers on-line. Cooling water is used for equipment such as air compressors, turbines, generators, boiler water jackets, and feed pumps. These cooling waters are classified as Category $\mathrm{D}$, once-through cooling water.

1.5.3.4 Boiler Blowdown (Sources 4A and 4B). The boiler blowdown waste source consists of two separate operations: continuous (Source 4A) and batch (Source 4B). The continuous blowdown is set to 16 percent of the total boiler feed for a supply water solids concentration factor of 6 . This results in an estimated flow of 26.4 gallons per minute for a steam load of 65,000 pounds per hour. The blowdown removes the minerals that naturally concentrate in the bottom of the boiler.

The batch blowdown is a periodic discharge from an operation to remove solids from the boiler. This blowdown occurs once per shift; an operator opens a manual discharge valve fully then immediately closes it.

The 284-E Powerplant boiler blowdown flow rates are variable, but predictable, for various plant operation modes. The average monthly discharge of boiler blowdown is 100,000 gallons per month and contains boiler treatment chemicals. The 284-E Powerplant provides steam for heating of all 200 East Area facilities, both processes and buildings. The functions or processes associated with these facilities do not have the potential to generate radioactive airborne or liquid effluents. Therefore, radiation monitoring equipment is not used on the discharge of these streams. The flow rates vary seasonably, with winter flow rates being higher due to the increased demand for steam heating throughout the 200 East Area during the colder months.

These waste contributors are classified Category A, boiler discharge.

1.5.3.5 Water Softener Regenerant (Source 5). The water softener regenerant is a spent brine solution that has been used to regenerate the zeolite water softener 
units. The softener regenerant stream has the highest concentration of dissolved solids in comparison with all the other 284-E Powerplant waste water streams. This stream contains approximately 9 percent Sodium Chloride by weight. The flow rate for the softener regeneration contributor averages about 300,000 gallons per month, which is 3 percent of the total 284-E flow. Each regeneration uses 10,000 to 12,000 gallons total over a 3 hour period. A 9 percent brine solution is added only during 30 minutes of this time. A total of 330 gallons of brine is used per regeneration. A saturated brine solution is transferred to 284-E Powerplant from the brine pit, located to the northwest of the Powerplant. This saturated solution is diluted with sanitary water to a concentration of 9percent. Preset valves are used to maintain the diluted brine at a 9 percent concentration. This waste contributor is classified Category A, boiler discharge.

1.5.3.6 Clearwell Overflow (Source 6). Sanitary water overflows from the 283E Filter Plant Clearwells. The water level in the Clearwells has no control. Should the sanitary water overflow from the Clearwells, the water discharges into the process drain and is classified Category $C$, a miscellaneous clean effluent. This flow is considered to be less than 0.02 gallons per minute. There is no documented history of Clearwell overflow.

1.5.3.7 Settling Basin Drainage (Source 7). The settling basin drain is actually a clean out port. It is only used when the Basin and Clearwells are washed down and cleaned. This usage is administratively controlled and is utilized in operating the drain cycle. The effluent should contain metals removed from the raw water and alum added to the process. This waste contributor is classified Category $\mathrm{F}$, a potentially or slightly contaminated effluent. This flow has been considered to be $<0.02$ gallons per minute.

1.5.3.8 Floor and Trench Drainage (Sources 8A and 8B). Numerous floor and trench drains are located throughout the 283-E water treatment facility (Source $8 \mathrm{~A}$ ) and 284-E Powerplant (Source 8B) facilities. Sources of liquid waste to these drains include safety showers, raw and sanitary water. It is not anticipated that any of these three sources will be an entering point for a potentially regulated waste; however, at least one of these drains can be the point through which a regulated waste could enter this waste stream. It is proposed that administrative controls be implemented to ensure that no waste be discharged through such a point. To minimize this potential the pump wells (sumps) have been plugged. In addition, plugs have been installed in all floor and trench drains within 5 feet of any pump to provide additional engineering controls. It is assumed that this area gives an average annual flow of less than 0.2 gallons per minute. These waste contributors have very low potentials of contamination and are classified Category $\mathrm{C}$ waste, miscellaneous clean effluents. 
DOE/RL-93-61, Rev. 0

200 East Area W-252 Streams
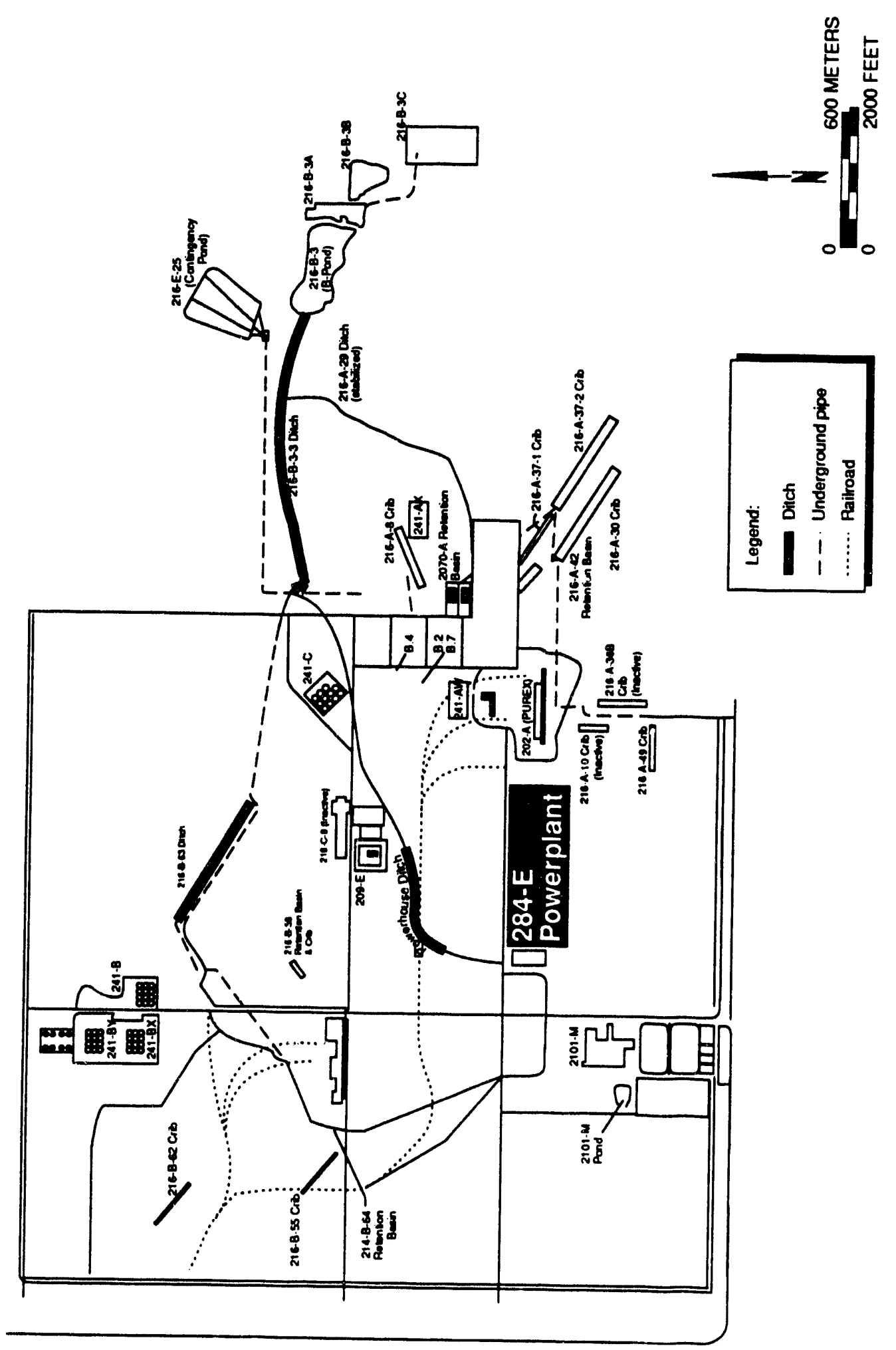

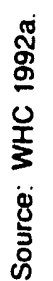

$9131728.013 / 46184 / 11-9.93$

Figure B-20. Location of 284-E Powerplant in 200 East A rea. 


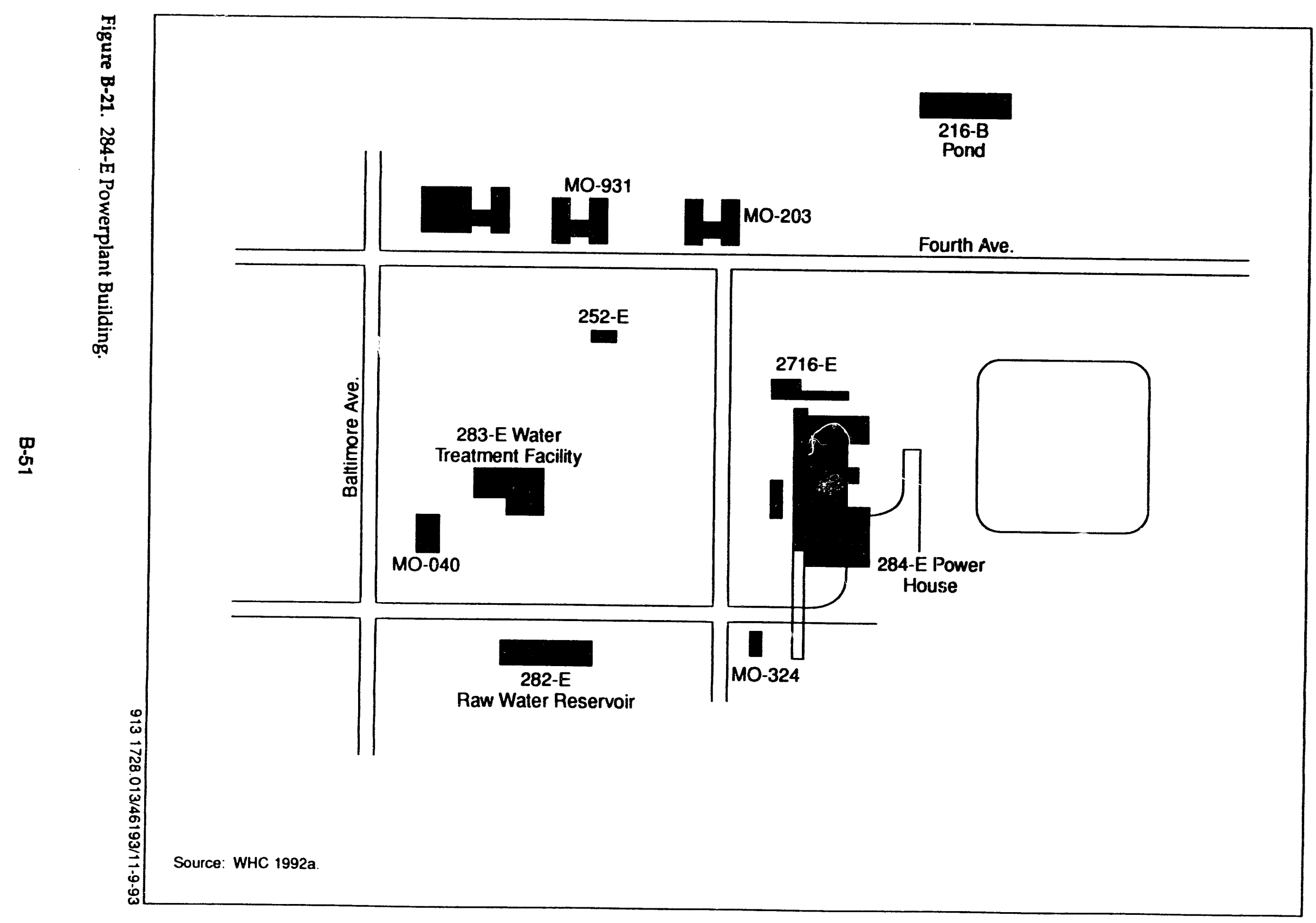




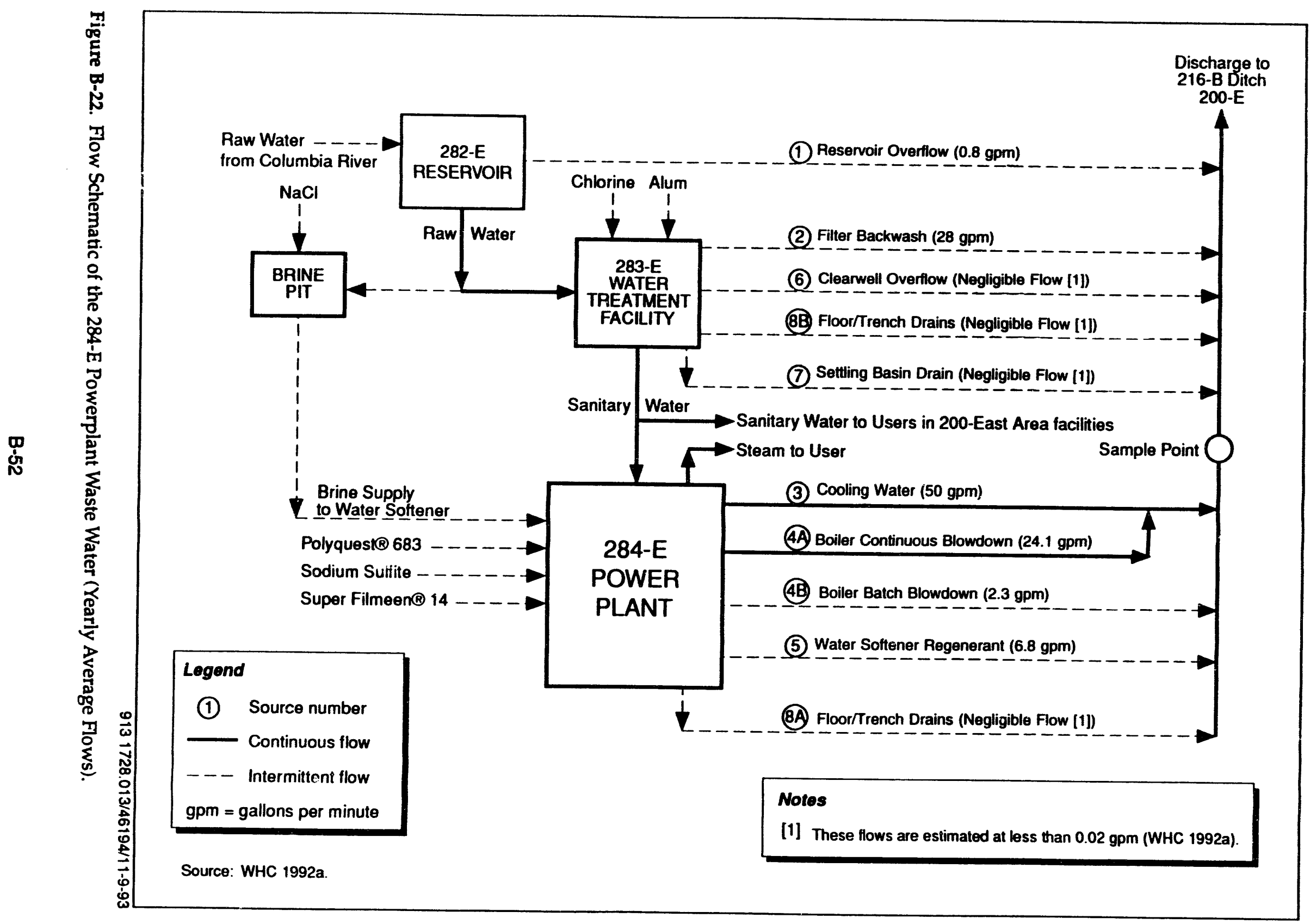




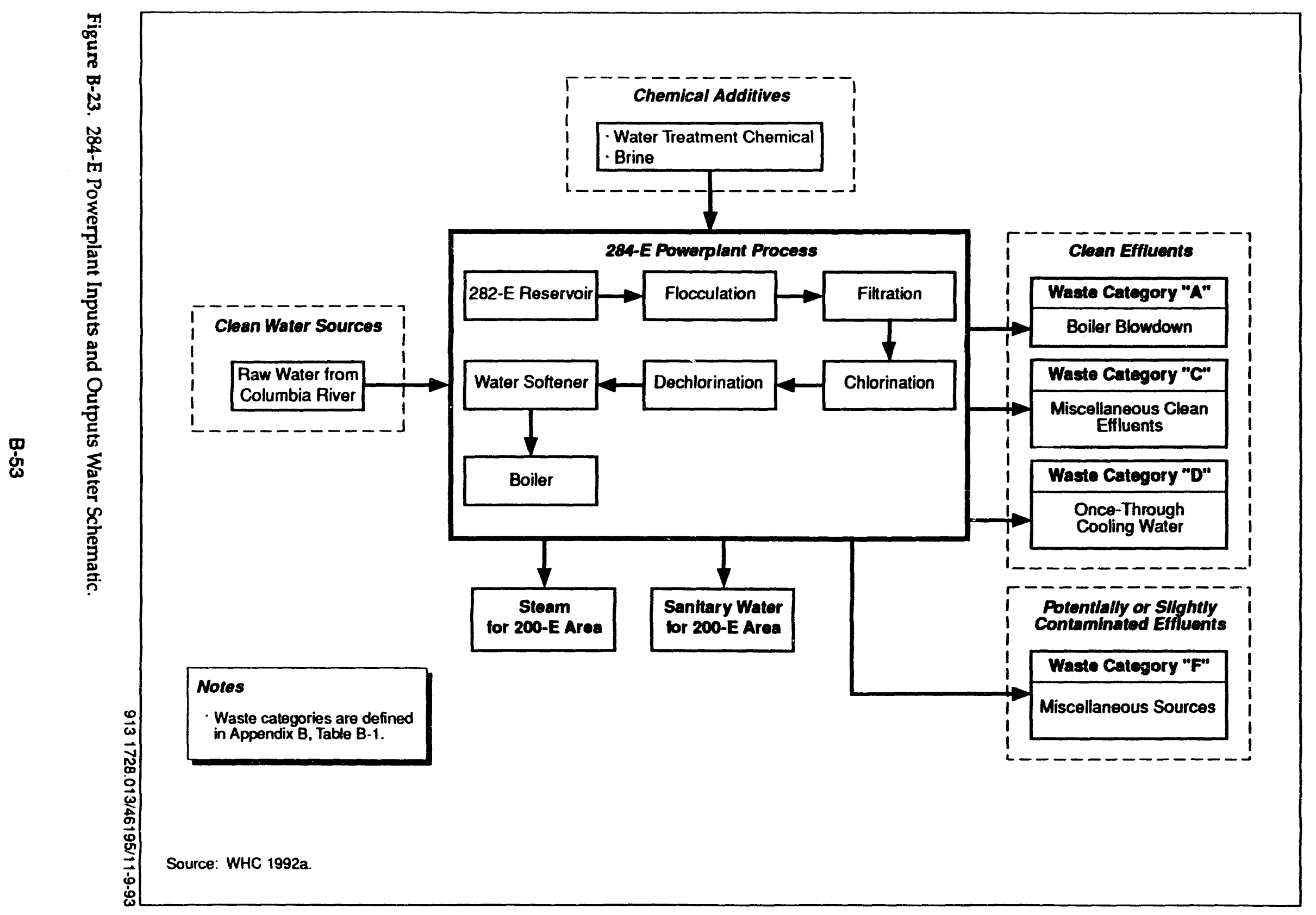




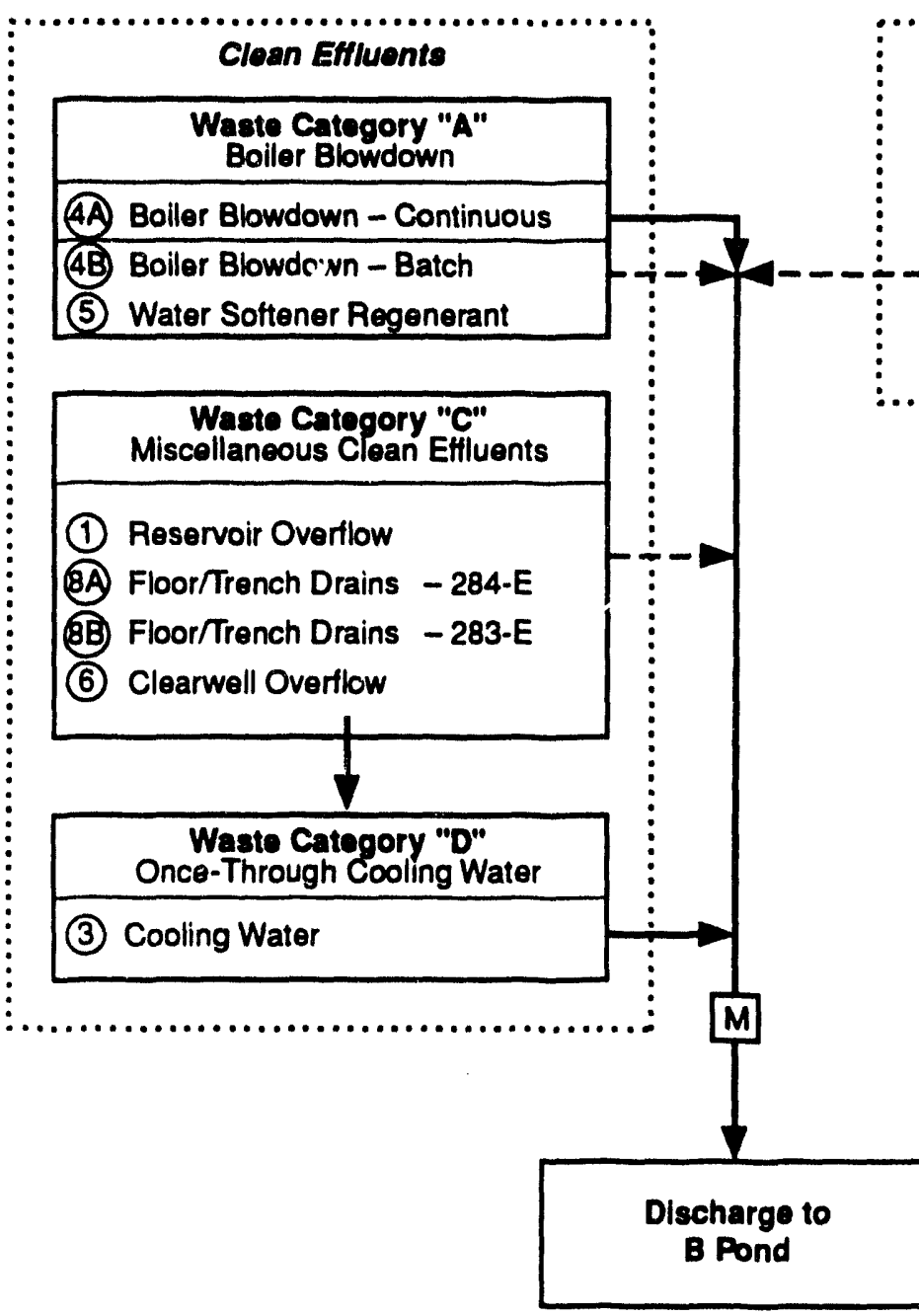

\section{Notes}

Waste categories are defined in Appendix B, Table B-1.
Potentially or Sllghtly Contaminated Effluents

\section{Waste Category " $F$ "}

Miscellaneous Sources

(2) Filter Backwash

(7) Settling Basin Drain 
Table B-6. 284-E Powerplant Effluent Sources

\begin{tabular}{|c|c|c|c|c|c|c|c|}
\hline \multirow{12}{*}{ 幽 } & Source Stream & $\begin{array}{c}\text { Source } \\
\text { Building }\end{array}$ & $\begin{array}{c}\text { Source } \\
\text { Category } \\
\text { [2] }\end{array}$ & $\begin{array}{c}\text { Effluent } \\
\text { Water Type }\end{array}$ & $\begin{array}{c}\text { Flow } \\
\text { Type } \\
{[3]}\end{array}$ & $\begin{array}{c}\text { Estimated } \\
\text { Flowrate } \\
\text { [4] (gpm) }\end{array}$ & Status \\
\hline & Reservoir Overflow [1] & 282-E & C & Raw & I & $8.0 \mathrm{E}-1$ & Active \\
\hline & Filter Backwash [1] & 283-E & $\mathbf{F}$ & Sanitary & $\mathbf{I}$ & $2.8 \mathrm{E}+1$ & Active \\
\hline & Cooling Water & 284-E & D & Sanitary & C & $5.0 \mathrm{E}+1$ & Active \\
\hline & Boiler Blowdown - continuous & 284-E & A & 6X Sanitary & C & $2.41 \mathrm{E}+1$ & Active \\
\hline & Boiler Blowdown - intermittent [1] & 284-E & $\mathbf{A}$ & 6X Sanitary & $\mathbf{I}$ & $2.3 E+0$ & Active \\
\hline & Water Softener Regenerant & 284-E & A & 36X Sanitary & 1 & $6.8 \mathrm{E}+0$ & Active \\
\hline & Clearwell Overflow [1] & 283-E & $\mathbf{C}$ & Sanitary & $\mathbf{I}$ & $\begin{array}{l}\text { Negligible } \\
\text { [5] }\end{array}$ & Active \\
\hline & Settling Basin Drain [1] & 283-E & $\mathbf{F}$ & Raw & I & $\begin{array}{l}\text { Negligible } \\
\text { [5] }\end{array}$ & Active \\
\hline & Floor/Trench Drains [1] & 284-E & C & Sanitary & $\mathbf{I}$ & $\begin{array}{l}\text { Negligible } \\
\text { [5] }\end{array}$ & Active \\
\hline & Floor/Trench Drains [1] & 283-E & C & Raw & I & $\begin{array}{l}\text { Negligible } \\
\text { [5] }\end{array}$ & Active \\
\hline & & & & & TOTAL & $1.1 \mathrm{E}+2$ & \\
\hline
\end{tabular}

Source: WHC 1992a

NOTES:

[1] Source not identified in the 284-E Powerplant Wastewater Stream-Specific Report (WHC 1990e).

[2] Source category defined in Table B-1.

[3] I = intermittent, $\mathrm{C}=$ continuous, $\mathrm{I} / \mathrm{C}=$ continuous when operating.

[4] Average flow rate based on total annual flow divided by 526,000 minutes (1 year). Data obtained from 284-E Powerplant Wastewater Stream-Specific Report (WHC 1990e).

[5] These flows are estimated at less than $<0.02 \mathrm{gpm}$ (WHC 1992a).

gpm $=$ gallons per minute.

HVAC = Heating, Ventilation, and Air Conditioning. 
DOE/RL 93-61, Rev 0

\subsection{B PLANT COOLING WATER}

SIC Code: 9999

\subsubsection{B Plant Facility Description}

The B Plant Area (Figure B-25) located in the 200 East Area at the Hanford Site was constructed in the mid 1940's as a fuel reprocessing facility. Figure B-26 shows the three main buildings: 221-B, 225-B (Processing Building - the Waste Encapsulation and Storage Facility), and 271-B (Office Building).

Several adjacent support facilities have been constructed to monitor and store the effluent B Plant Cooling Water discharge. The following is a brief description of the main B Plant Area buildings and the support facilities for the effluent B Plant cooling water operations:

1.6.1.1 221-B Processing Building. This building consists of a canyon and craneway, 40 process cells, a hot pipe trench, and a ventilation tunnel. The nonprocess portions of the building include an operating gallery, a pipe gallery, and an electrical gallery.

1.6.1.2 271-B Service Building. This service facility is attached to the 221-B building and includes offices, aqueous makeup facilities, and maintenance shops.

1.6.1.3 225-B Waste Encapsulation and Storage Facility. Built in 1974, this facility is separated into process hot cell areas, the canyon service areas, operating areas, building service areas, and the cesium and strontium capsule storage (pool cell) area.

1.6.1.4 282-B and 282-BA Deep Well Pumps. The well pumps are sources of emergency raw water supply.

1.6.1.5 Waste B Plant Cooling Water Support Facilities. The following is a brief summary of the eifluent B Plant cooling water support facilities:

207-B Retention Basin

- 207-BA

Sampling

Building

- 216-B-2-3 Ditch

- $216-\mathrm{B}-59$

Retention Building
Two open basins, each with 500,000 gallons capacity, for the combined 24 inch diameter effluent cooling water pipe.

This building contains a flow-proportional sampler and a flow-totalizer for the combined effluent B Plant cooling water stream.

The effluent B Plant cooling water discharge route, via an open ditch, to the 216-B-3 Pond.

This basin receives and stores any emergency diversion of the 15 inch diameter effluent cooling water pipe. 


\author{
216-B-3 Pond \\ 221-BA and \\ 221-BG \\ Monitoring \\ Buildings
}

This pond is the current and final discharge location of the waste B Plant cooling water.

Primary beta and gamma radiation monitoring stations for the 15 inch diameter and 24 inch diameter cooling water sewers, respectively.

\subsubsection{B Plant Process Description}

This section describes the processes that are associated with the B Plant and the B Plant cooling water system. Process changes that have been made to reduce contributions to the waste stream are described.

1.6.2.1 B Plant Processes. This process description of the B Plant is primarily derived from the Facility Effluent Monitoring Plan for the B Plant. Facilities for the B Plant were constructed in the mid 1940's to chemically process spent nuclear fuels. Following completion of extensive modifications in the early 1960's, the second mission of the B Plant was to remove radioactive cesium and strontium from the fission product waste stream following plutonium and uranium recovery from irradiated reactor fuels in the PUREX Plant. The recovered, purified, and concentrated strontium and cesium solutions were transferred to the waste encapsulation storage facility for conversion to solid compounds, encapsulation, and interim storage. The waste encapsulation storage facility was added to the B Plant in 1974. After strontium and cesium removal, the remaining waste was transferred from B Plant to the Tank Farm.

The B Plant is an operating facility that is required to ensure safe storage and management of the waste encapsulation storage facility cesium and strontium capsules, as well as radiological inventories remaining in the B Plant from previous campaigns. There are currently no production activities at the B Plant, but there are several operating systems required to accomplish the current B Plant mission; that is, treatment of low-level wastes generated at waste encapsulation storage facility and the B Plant.

Future B Plant process equipment that will impact the B Plant cooling water includes a transuranic extraction process pilot plant and the E-23-3 waste concentrator. A transuranic extractin process pilot plant with minimal cooling water requirement is being planned for inclusion in the waste encapsulation storage facility. The future operation of the Cell 23 waste concentrator will impact future cooling water requirements. The Cell 23 waste concentrator concentrates liquid low-level radioactive waste to minimize the waste stream that requires low-level radioactive disposal to the double-shell tank program.

1.6.2.2 B Plant conling water Process. A once-through cooling water system supplies water to B Plant vessel cooling coils, condensers, waste encapsulation storage facility process vessels, and waste encapsulation storage facility heat exchangers and discharges to the effluent B Plant cooling water pipelines. 
Figure B-27, a Flow Schematic for B Plant cooling water, shows the flow paths and major buildings in the B Plant Area. This figure depicts the overall flow paths of the effluent B Plant cooling water contributors to the final discharge location, the 216-B-3 Pond. The figure also shows the point at which the samples were taken for the chemical analyses reported in the B Plant Cooling Water Stream-Specific Report (WHC 1990f, Addendum 22).

Raw water is taken from the Columbia River and is pumped, via the $182-\mathrm{B}$ Export Pumping Station, to the 282-E Pumphouse and Reservoir in the 200 East Area. From the 282-E Facility, the water is pumped (below grade) north along Baltimore Avenue to the B Plant. The raw water for the 221-B Building enters the building at both the east and west ends via 12 inch and 10 inch diameter pipes, respectively (see Figure B-28).

A 10 inch diameter pipe, located in the B Plant operating gallery, runs the entire length of the 221-B Building and supplies cooling water to the process cell vessels (tank cooling coils and condensers). The pressure, at both the east and west ends of the 221-B Building operating gallery, is approximately 150 pounds per square inch guage.

In the event of loss of raw water supply from the 282-E Facility reservoir, the 221-B Building and the waste encapsulation and storage facility have two emergency wells. Two diesel-driven backup Emergency Well Pumps 282-B and 282-BA (see Figure B-28) can supply the necessary volume of raw water to meet the minimum process cooling requirements for the 221-B Building and the waste encapsulation storage facility. Each of these emergency wells is alternately tested at two week intervals and the test water is discharged to the effluent B Plant cooling water pipeline.

A low level waste handling system consists of a series of vessels (which are holding tanks), associated process equipment, and piping to treat process wastes generated in the B Plant/waste encapsulation and storage facility. Operation of the Cell 23 waste concentrator system generates the largest (18 million British Thermal Units per hour) cooling water demand. The Cell 23 waste concentrator is presently inactive, when operated the operation was intermittent. The intermittent operation would be approximately 48 hours per month. When the Cell 23 waste concentrator operates, the amount of cooling water usage increases by about 700 gallons per minute. This additional flowrate includes source streams 6 and 7.

The waste water now being discharged to the 216-B-3 Pond includes the B Plant cooling water and a temporary connection for the B Plant chemical sewer. See Appendix N of the 200 Area Treated Effluent Disposal Facility (Project W-049H) Waste Water Engineering Report (WHC 1992b) for additional BCE information. The chemical sewer is a Phase I liquid effluent as cited in WHC 1992b. The B Plant chemical sewer stream will be rerouted to the 200 Area Treated Effluent Disposal Facility when it becomes operational.

Additional source shanges to the B Plant cooling water stream that are currently being considered include the temporary rerouting of the B Plant process 
condensate and B Plant steam condensate streams to the B Plant cooling water pipeline. These temporary connections would be very similar to the previously completed temporary rerouting of the BCE stream to the B Plant cooling water pipeline. The reroute of the condensate streams to the B Plant cooling water effluent pipeline would be discontinued upon startup and operation of the 200 Area treated effluent disposal facility prior to October 1997; the streams would discharge to the 200 Area treated effluent disposal facility.

1.6.2.3 Process Changes to Eliminate Sources. Several measures have been implemented to control the discharge of contaminants to the B Plant cooling water effluent pipelines and the 216-B-3 Pond in the last five years. These measures include administrative spill control procedures and training on spill cleanup and reporting. Since 1987, B Plant has implemented a waste minimization program that limits all but essential flows to the B Plant cooling water effluent.

In 1988, instrumentation was installed at the 221-BA and 221-BG monitoring stations and at the 207-BA sampling building. Contamination detected in the 15-inch diameter effluent pipeline by either a beta or gamma monitor (221-BA) automatically activates a downstream diverter valve and reroutes the stream to the 216-B-59 retention basin. The $216-\mathrm{B}-59$ retention basin has a working capacity of 100,000 gallons and is constructed with a concrete liner and cover. The retention basin is about 30 feet wide by 120 feet long, 10 feet deep and is situated in a 100 foot wide by 200 foot long by 15 foot deep excavation. Procedures have been prepared for treating a contaminated effluent (WHC 1992a).

Cross-over pipelines with manually operated diversion valves are installed to permit isolation of sources contributing to the 15 inch diameter effluent pipeline. Non-contaminated source flows can be diverted from the 15 inch effluent pipeline to the 24 inch effluent pipeline if necessary, thereby reducing the total volume of contaminants retained by the 216-B-59 retention basin.

Cooling water samples at the 207-BA Building are taken for process control and monthly composites. The existing upstream radiation analyzer in the 221-BG Monitoring Station is used for on-line monitoring and control of the 24 inch diameter effluent pipeline. Administrative controls have been developed to locate and isolate a radiation leak detected in either the 15 inch diameter or 24 inch diameter effluent pipelines.

\subsubsection{B Plant Waste Water Source Description}

The effluent B Plant cooling water to the 216-B-3 Pond consists of eight continuous and intermittent discharge waste streams (WHC 1990f, Addendum 22). These streams are listed in Table B-7 and shown in Figure B-31. The source streams have been placed into one of the six categories (A through $F$ ) described in Table B-1

The cooling water discharged from B Plant enters either a 24 inch diameter or a 15 inch diameter effluent pipeline. These cooling water effluent pipelines flow east from B Plant and combine into a common 24 inch diameter effluent pipeline just north 
of the 216-B-59 Retention Basin (see Figure B-28). This single line is designated as the combined 24 inch diameter B Plant cooling water effluent pipeline.

Effluent sources currently contributing to the 24 inch diameter effluent pipeline on a once-through basis and considered to have a low potential for contamination, include those from: 221-B Building (stairwell number 1 operating gallery heating, ventilation, and air conditioning, steam condensate and sanitary water), 225-B Building (pool cell heat exchanger raw water and pool cell demineralized water flushes), and from 282-B and 282-BA (emergency well pumps). Additional sources that can or could contribute to the 24 inch diameter effluent pipeline include those from the 221-B Building (condenser and heat exchanger raw water and steam jet condensate).

The effluent B Plant cooling water sources discharging into the 15 inch diameter effluent pipeline are from the 221-B Building (Cells 5 through 39). The 15 inch diameter effluent pipeline receives waste cooling water (once-through) from tank cooling coils considered to have a potential for possible contact with significant amounts of radioactive solutions should a leak occur. Differential pressures between the tank cooling coils and the tank solutions preclude inadvertent releases to the 15 inch diameter sewer.

Currently, the total flow in the combined 24 inch effluent pipeline is normally about 1,300 gallons per minute with the majority of the flow being from the waste encapsulation storage facility cell heat exchangers. A portion of the waste cooling water in the 24 inch diameter effluent pipeline is routed through the 221-BG monitoring station off-line monitors to monitor for gamma and beta contamination. If the cooling water has radioactive contamination one of two flow-through retention basins (designated as 207-B on Figure B-28) would provide minimal detainment.

The 207-B Retention Basins are concrete lined with an overall size of 246 feet long, 123 feet wide, and 6.5 feet deep. The retention facility is equally divided into two 500,000 gallon capacity retention basins. Cooling water typically flows through one of the retention basins and exits into a pipe which discharges in the 216-B-3-3 ditch, for disposal in the $B$ Pond complex. If the radiation monitors detect radioactive contamination in the cooling water stream, the outlet from the 207-B retention basins can be automatically or manually closed, eliminating discharge to the B Pond system. The 207-B retention basins provide a second containment facility for radioactively contaminated cooling water downstream of the 216-B-59B retention basin. Radioactive contaminated cooling water contained in the 207-B retention basin can be pumped back to B Plant for reprocessing.

An additional facility to which radioactive contaminated cooling water from the 207-B retention basin can be disposed of in an emergency basis, after both retention facilities are at capacity, is the 216-B-63 trench/ditch. The 216-B-63 trench/ditch is an open, unlined ear 'ien trench, approximately, 4 feet wide at the bottom, 1400 feet long and 10 feet deep. The 216-B-63 trench/ditch has never been used for emergency disposal of radioactive cooling water from B Plant. 


\subsubsection{221-B Building Discharge to the 24 in Effluent Pipeline (Sources 1} and 8). Effluent B Plant cooing waier is primarily generated by the condensers in Cell 22 and discharges to the 24 inch diameter effluent pipeline. A steam condensate cooler and vessel vent number 2 steam jet condensate and surface condenser also discharge to the 24 inch diameter effluent pipeline. The flowrate from the preceding sources is included in the 100 gallons per minute of miscellaneous flows from the 221-B Building.

An existing but currently inactive condenser in Cell 23 may, in the future contribute to the effluent B Plant cooling water stream. This effluent, a once-through cooling water, is considered a potentially or slightly contaminated, Category F, waste and is referred to as Source 1.

Effluent from the Stairwell number 1 operating gallery heating, ventilation, and air conditioning system is steam condensate and sanitary water and discharges to the 24 inch diameter effluent pipeline. This effluent is considered a Category A waste and is referred to as Source 8 .

1.6.3.2 Waste Encapsulation and Siorage Facility Effluent (Source 2). The discharged effluent from the 225-B Building is demineralized water flushed from pool cells and raw water from single pass pool cell heat exchangers. The demineralized water discharged is a batch release of non-radioactive foul water not meeting the waste encapsulation storage facility pool cell storage specifications. This effluent is considered a potentially or slightly contaminated, Category F, waste and is referred to as Source 2.

1.6.3.3 The 212-B Cask Loadout Station Effluent (Source 3). Sources from the 212-B Cask Loadout Station are inactive and do not contribute to the cooling water effluent pipeline. This effluent is considered a potentially or slightly contaminated, Category F, waste and is referred to as Source 3.

1.6.3.4 Emergency Well Pump Effluent (Source 4). The deep well pumps 282-B and 282-BA discharge into the B Plant cooling water effluent pipeline during their biweekly testing. This effluent is considered a potentially or slightly contaminated, Category F, waste and is referred to as Source 4.

1.6.3.5 221-B Building Discharge to the 15 inch Diameter Effluent Pipeline (Source 5). Six subheaders collect the discharge from process cells into the 15 inch diameter effluent pipeline. The process cells and subheaders are as follows:

$\begin{array}{lcccccc}\text { Subheader } & 1 & 2 & 3 & 4 & 5 & 6 \\ \text { Cells } & (36 \text { to } 39) & (28 \text { to } 35) & (20 \text { to } 27) & (10 \text { to } 19) & (6 \text { to } 9) & \text { (5) }\end{array}$

Each of the six subheaders to the 15 inch effluent pipeline sewer has a crossover line, with valving, to allow any subheader to be routed to the 24 inch diameter effluent pipeline. The cross-over lines allow isolation and diversion capabilities, if required. This effluent is considered a potentially or slightly contaminated, Category F, waste and is referred to as Source 5. 
1.6.3.6 221-BB Building Steam Condensate (Sources 6 and 7). B Plant steam condensate is only evolved during the operation of the waste concentrator (E-23-3) in Cell 23. The B Plant steam condensate condenst effluent, Source 6 , and the B Plant steam condensate monitor heat exchancer, efflu. . Source 7 , are considered oncethrough cooling water, Category D, wastes that discharge to the 24 inch diameter effluent pipeline from the 221-BB Building. 
DOE/RL-93-61, Rev. 0
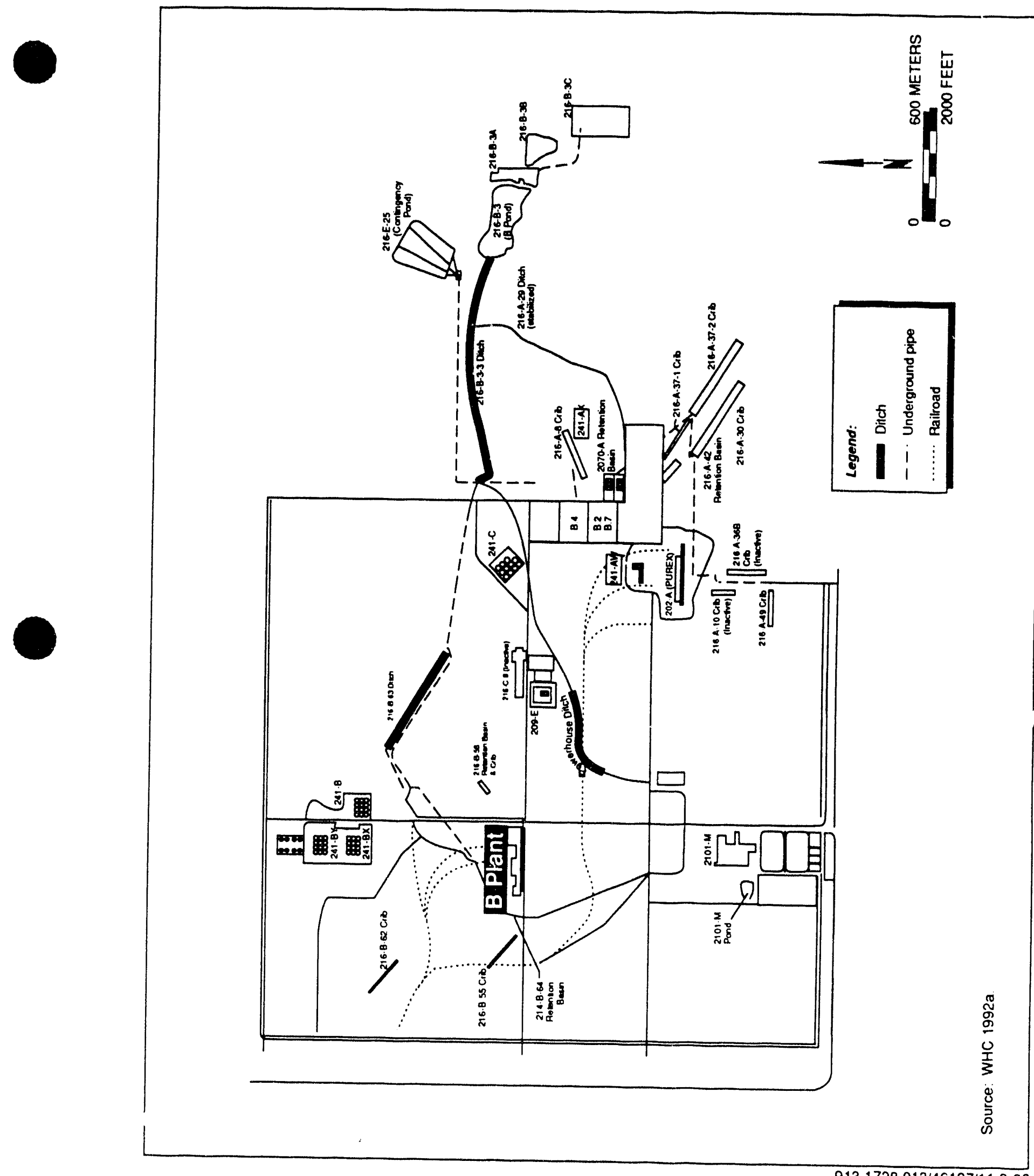

Figure B-25. Location of the B Plant Within the 200 East Area. 


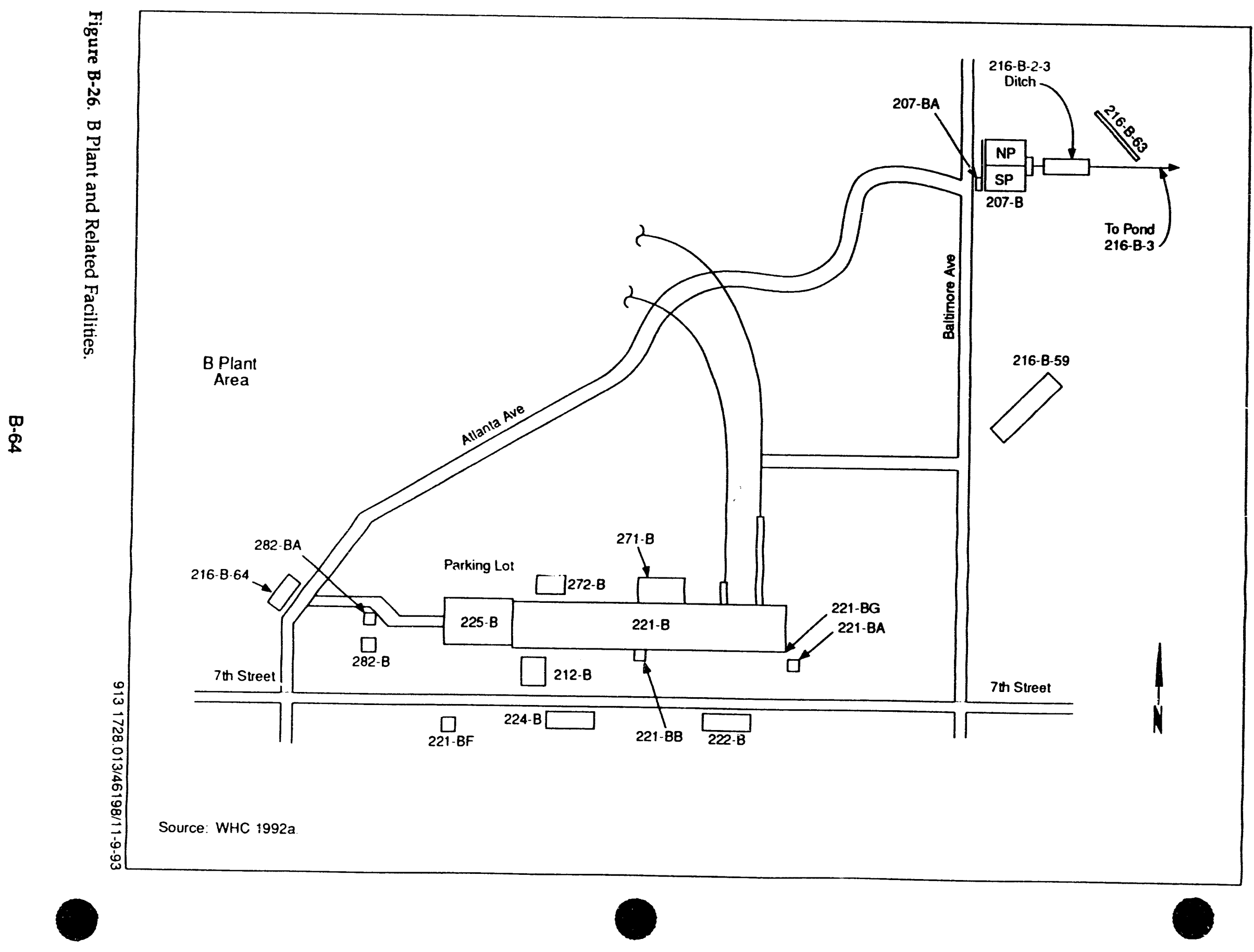

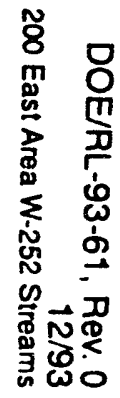




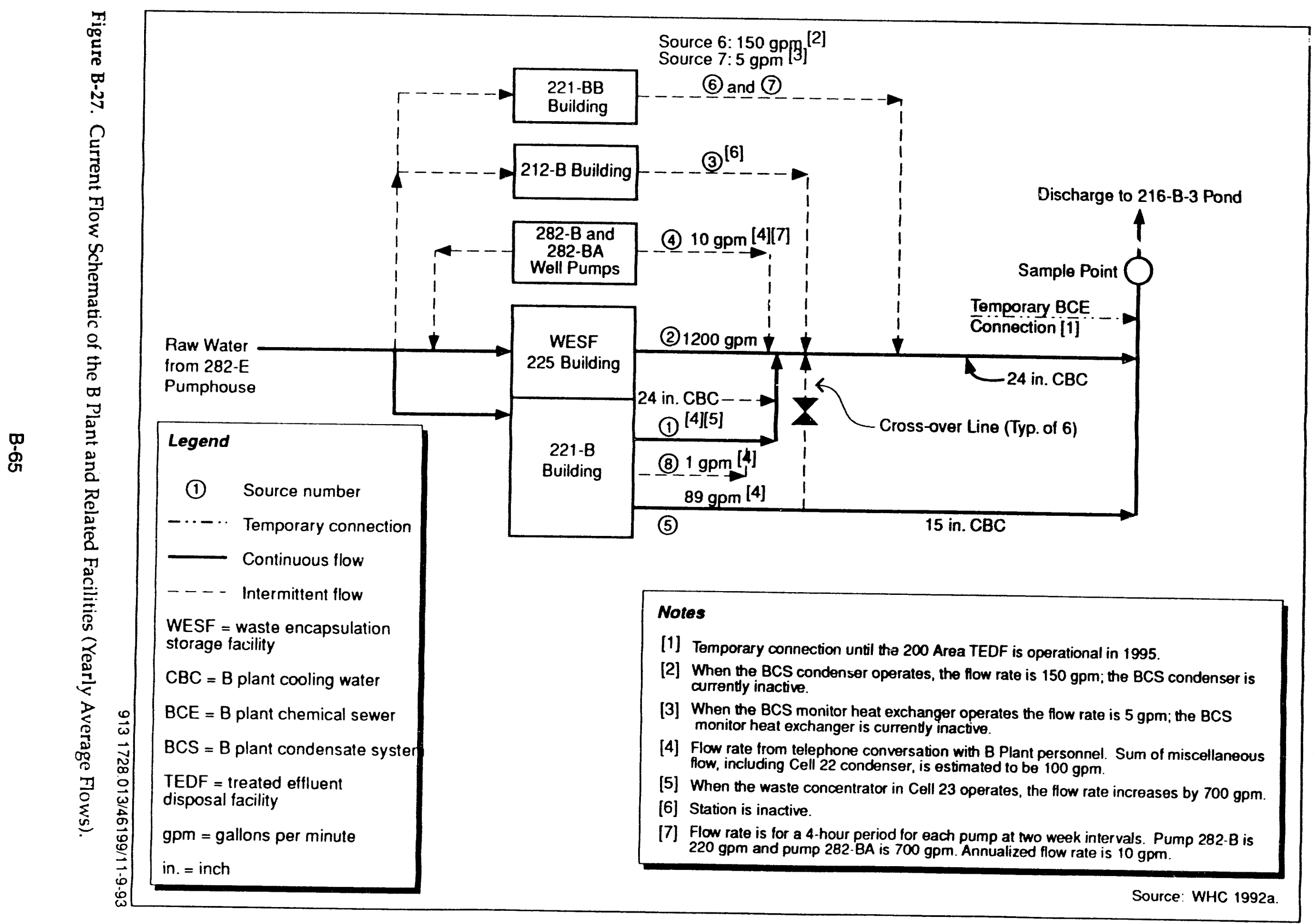




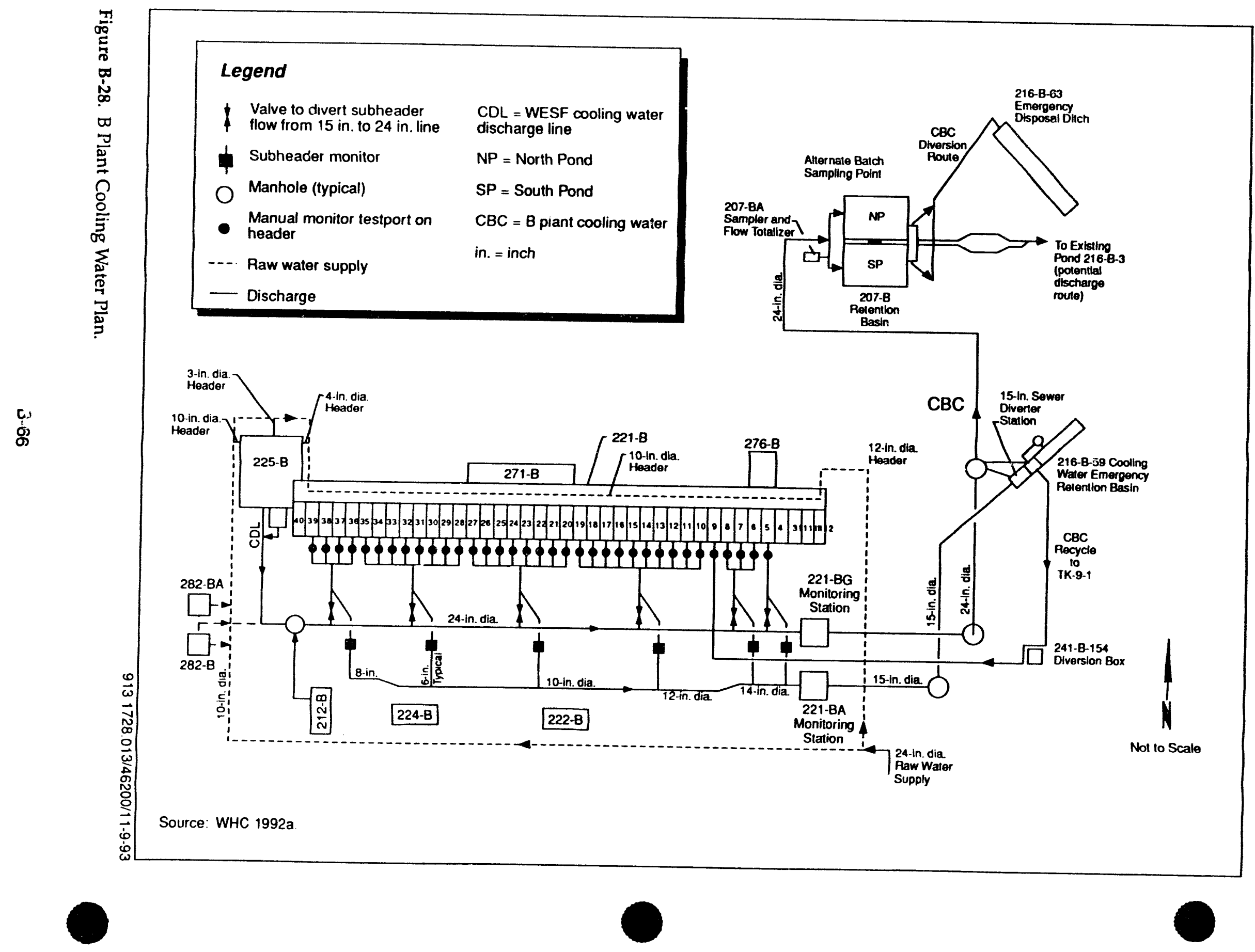




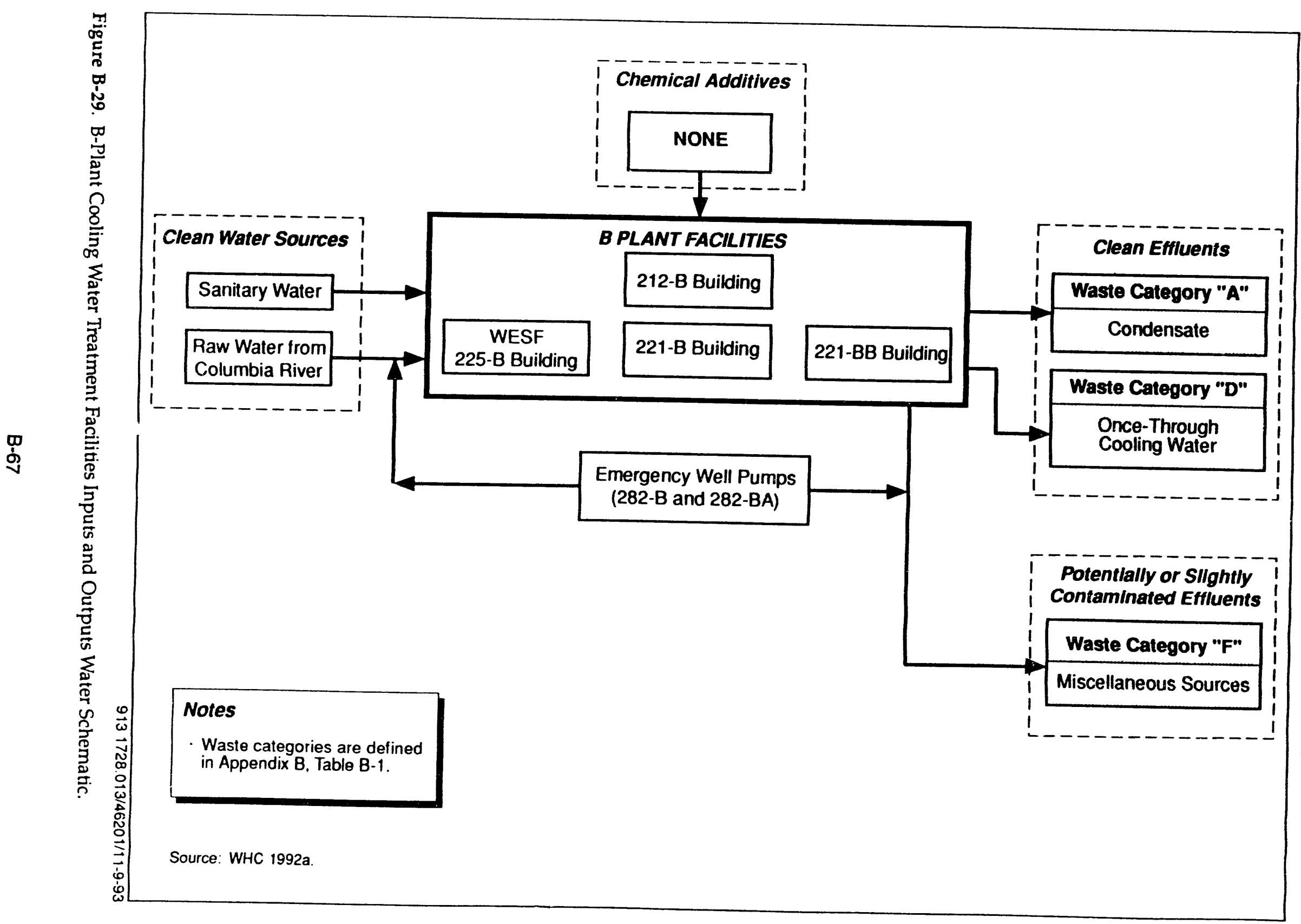


TABLE B-7. B-PLANT COOLING WATER EFFLUENT SOURCES

\begin{tabular}{|c|c|c|c|c|c|c|c|}
\hline \multirow{2}{*}{$\begin{array}{l}\text { Source } \\
\text { No. }\end{array}$} & \multirow[b]{2}{*}{ Source Stream } & \multirow{2}{*}{ Source Building } & \multirow{2}{*}{$\begin{array}{c}\text { Source } \\
\text { Calegory [4] }\end{array}$} & \multirow{2}{*}{$\begin{array}{l}\text { Effluent } \\
\text { Water } \\
\text { Type }\end{array}$} & \multirow{2}{*}{$\begin{array}{c}\text { Flow } \\
\text { Type [5] }\end{array}$} & \multicolumn{2}{|c|}{ Estimaled Flowrate } \\
\hline & & & & & & gpm & Status \\
\hline 1 & Condensers Cells $22 \& 23$ & 221-B & $\mathbf{F}$ & Raw & l/C & $-|6|[3]$ & Inactive [10] \\
\hline 2 & WESF-Pool Cell Flush \& Exchangers & 225-B & $\mathbf{F}$ & Raw & c & $1,200[1]$ & Active \\
\hline 3 & Cask Station & 212-B & $\mathbf{P}$ & Raw & & - & Inactive \\
\hline 4 & Emergency Well Pumps & 282-B \& 282-BA & $\mathbf{F}$ & Well & $\mathbf{I}$ & $10[2][3]$ & Active \\
\hline 5 & 221-B Process Cells Cooling Water (Cells 5 through 39) & 221-B & $\mathbf{P}$ & Raw & I/C & $89[3]$ & Active \\
\hline 6 & BCS Condenser & 221-BB & D & Raw & i/C & $-[8]$ & Inactive \\
\hline 7 & BCS Monilor Heat Exchanger & 221-8B & D & Raw & I/C & $-[9]$ & Inactive \\
\hline 8 & Stairwell 1, O.G. HVAC & 221-B & $\mathbf{A}$ & $\begin{array}{l}\text { Condenser and } \\
\text { Sanitary Water } \\
\text { [7] }\end{array}$ & $\mathbf{I}$ & $1[3]$ & Active \\
\hline & & & & & & TOTAL 1,300 & \\
\hline
\end{tabular}

Source: WTIC 1992a

NOTES:

11] Individual sources are not measured, lotal flow is estimated at $1,200 \mathrm{gpm}$.

121 Flow rate is for a 4-hour period for each pump at 2 week intervals. Pump 282-B is $220 \mathrm{gpm}$ and Pump 282-BA is $700 \mathrm{gpm}$. Annualized flow rale is $10 \mathrm{gPm}$

13) Flow rate from lelephone conversation with B Plant Personnel. Sum of miscellaneous flow, including cell 22 condenser, is estimated to be $100 \mathrm{gPm}$.

14) Source category defined in Table B-1.

[5] I = intermittent, $C$ = continuous, I/C = continuous when operating.

16) When the waste concentrator in Cell 23 operates, the flow rate increases by $700 \mathrm{gpm}$

17) Steam condensale and sanitary water.

[8] When the BCS Condenser operates the flowrate is $150 \mathrm{gpm}$.

(9) When the BCS Monitor Heat Exchanger operates the flow rate is $5 \mathrm{gpm}$

(10) The condenser in cell 22 is active and the condenser in cell 23 is inactive.

$B C S=B$ Plant steam condensate

gPm $=$ gallons per minute

HVAC = Heating, Ventilation, and Air Conditioning

O.G. = operating gallery

WESP = waste enscapulation storage facility 
2.0 INCLUDE A PRODUCTION SCHEMATIC FLOW DLAGRAM OF THE PROCESS AND SERVICE ACTIVITIES DESCRIBED ABOVE ON A SEPARATE SHEET.

Schematic flow diagrams from the Phase II Liquid Effluent Program (Project W-252) Wastewater Engineering Report and BAT/AKART Studies (WHC 1992a) for each of the six waste streams are presented in Section 1.0. See Figures B-4, B-7, B-12, B-19, B-24 and B-29.

3.0 LIST RAW MATERIALS AND PRODUCTS.

3.1 242-A EVAPORATOR COOLING WATER

\subsection{2-A EVAPORATOR STEAM CONDENSATE}

Concentrated liquid radioactive/hazardous waste

\section{RAW MATERIALS}

Approximately 120 gallons per minute when operating

\section{PRODUCTS}

Approximately 60 gallons per minute when operating

\begin{tabular}{|l|l|}
\hline \multicolumn{1}{|c|}{ RAW MATERIALS } \\
\hline \multicolumn{1}{|c|}{ Type } & \multicolumn{1}{c|}{ Quantity } \\
\hline $\begin{array}{l}\text { Non-concentrated liquid } \\
\text { radioactive/hazardous waste. }\end{array}$ & $\begin{array}{l}\text { Approximately 120 gallons per minute } \\
\text { when operating }\end{array}$ \\
\hline $\begin{array}{l}\text { Concentrated liquid } \\
\text { radioactive/hazardous waste }\end{array}$ & $\begin{array}{l}\text { Approximately } 60 \text { gallons per minute } \\
\text { Phen operating }\end{array}$ \\
\hline
\end{tabular}




\subsection{1-A TANK FARM COOLING WATER}

\begin{tabular}{|l|l|l|}
\hline \multicolumn{2}{|c|}{ Type } & RAW MATERIALS \\
\hline \multicolumn{2}{|c|}{ Type } & \multicolumn{1}{c|}{ Quantity } \\
\hline None & None \\
\hline & PRODUCTS \\
\hline None & None \\
\hline
\end{tabular}

\subsection{4-AR VAULT COOLING WATER}

\begin{tabular}{|c|c|}
\hline Type & Quantity \\
\hline None & None \\
\hline 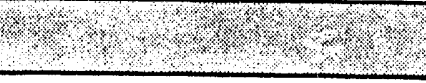 & UCTS \\
\hline None & None \\
\hline
\end{tabular}

\subsection{4-E POWER PLANT}

\begin{tabular}{|l|l|}
\hline \multicolumn{1}{|c|}{ Type } & \multicolumn{1}{c|}{ Quantity } \\
\hline Coal & Approximately 30,000 tons per year \\
\hline Sodium Chloride & Approximately 20,200 pounds per month \\
\hline Alum & Approximately 4,250 pounds per month \\
\hline Chlorine & Approximately 650 pounds per month \\
\hline Polyquest 683 & Approximately 730 pounds per month \\
\hline Raw Water & $\begin{array}{l}\text { Approximately } 21,119,000 \text { gallons per } \\
\text { month }\end{array}$ \\
\hline PRODUCTS \\
\hline Steam for heat and power generation & Approximately 500,000 pounds per year \\
\hline Sanitary Water & $\begin{array}{l}\text { Approximately } 21,119,000 \text { gallons per } \\
\text { month }\end{array}$ \\
\hline
\end{tabular}


DOE/RL 93-61, Rev 0

200 East Area W-252 Streams

\subsection{B PLANT COOLING WATER}

\begin{tabular}{|l|l|l|}
\hline \multicolumn{2}{|c|}{ RAW MATERIALS } \\
\hline & Type & \multicolumn{1}{c|}{ Quantity } \\
\hline None & None \\
\hline & PRODUCTS \\
\hline None & None \\
\hline
\end{tabular}


DOE/RL 93-61, Rev 0 $12 / 93$

200 East Area W-252 Streams

This page intentionally left blank. 
DOE/RL 93-61, Rev 0 $12 / 93$

200 East Area W-252 Streams

\section{APPENDIX C}

\section{PLANT OPERATIONAL CHARACTERISTICS}


DOE/RL 93-61, Rev 0

$12 / 93$

200 East Area W-252 Streams

This page intentionally left blank.

C-ii 
DOE/RL 93-61, Rev 0 $12 / 93$

200 East Area W-252 Streams

\section{CONTENTS}

1.0 IDENTIFY THE WASTE STREAM FOR EACH OF THE PRODUCTION PROCESSES OR ACTIVITIES DESCRIBED IN SECTION B.1. ASSIGN AN IDENTIFICATION NUMBER .

1.1 242-A EVAPORATOR COOLING WATER .............

1.2 242-A EVAPORATOR STEAM CONDENSATE $\ldots \ldots \ldots \ldots \ldots \ldots$ C-2

1.3 241-A TANK FARM COOLING WATER ............. C-3

1.4 244-AR VAULT COOLING WATER .............. C-4

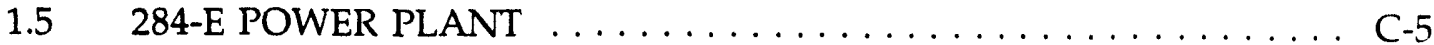

1.6 B PLANT COOLING WATER $\ldots \ldots \ldots \ldots \ldots \ldots \ldots$ C 6

2.0 ON A SEPARATE SHEET, DESCRIBE IN DETAIL THE TREATMENT AND DISPOSAL OF ALL WASTE WATERS AS DESCRIBED ABOVE. INCLUDE A SCHEMATIC FLOW DIAGRAM FOR ALL WASTE WATER TREATMENT AND DISPOSAL SYSTEMS . . . . . . . . . . . . . C-6

3.0 INDICATE TREATMENT PROVIDED TO EACH WASTE STREAM IDENTIFIED ABOVE. $\ldots \ldots \ldots \ldots \ldots \ldots \ldots \ldots \ldots \ldots \ldots \ldots$ C-7

4.0 DESCRIBE ANY PLANNED WASTE WATER TREATMENT

IMPROVEMENTS OR CHANGES IN WASTE WATER $\ldots \ldots \ldots \ldots \ldots \ldots \ldots$. . . .

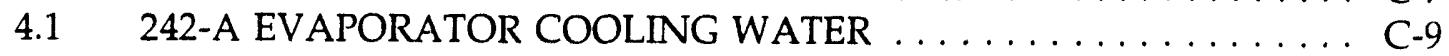

4.2 242-A EVAPORATOR STEAM CONDENSATE $\ldots \ldots \ldots \ldots \ldots \ldots .$.

4.3 241-A TANK FARM COOLING WATER $\ldots \ldots \ldots \ldots \ldots \ldots \ldots \ldots$ C-18

4.4 244-AR VAULT COOLING WATER $\ldots \ldots \ldots \ldots \ldots \ldots \ldots \ldots \ldots$ C-21

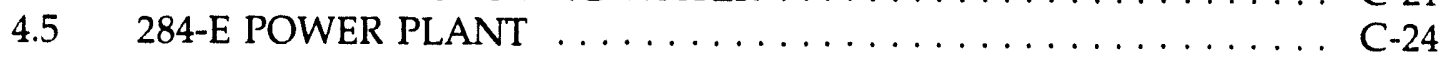

4.6 B PLANT COOLING WATER $\ldots \ldots \ldots \ldots \ldots \ldots \ldots$ C-27

5.0 IF PRODUCTION PROCESSES ARE SUBJECT TO SEASONAL VARIATIONS, PROVIDE THE FOLLOWING INFORMATION. WRITE "YES" FOR EACH MONTH WASTE STREAM IS PRODUCED . . . . . . . . C-33

6.0 SHIFT INFORMATION $\ldots \ldots \ldots \ldots \ldots \ldots \ldots \ldots \ldots \ldots \ldots \ldots$

6.1 242-A EVAPORATOR COOLING WATER ........... C-33

6.2 242-A EVAPORATOR STEAM CONDENSATE $\ldots \ldots \ldots \ldots \ldots \ldots$ C-33

6.3 241-A TANK FARM COOLING WATER ............. C-33

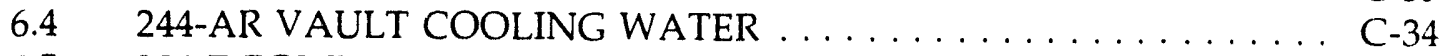

6.5 284-E POWER PLANT $\ldots \ldots \ldots \ldots \ldots \ldots \ldots \ldots \ldots \ldots \ldots$ C-34

6.6 B PLANT COOLING WATER $\ldots \ldots \ldots \ldots \ldots \ldots \ldots \ldots \ldots$ C-34

7.0 LIST ALL INCIDENTAL MATERIALS LIKE OIL, PAINT, GREASE,

SOLVENTS, SOAPS, CLEANERS, THAT ARE USED OR STORED ON-

SITE. (USE ADDITIONAL SHEETS IF NECESSARY) . . . . . . . . . . . . C C-35

7.1 242-A EVAPORATOR COOLING WATER ............ C-35

7.2 242-A EVAPORATOR STEAM CONDENSATE .......... C-35

$7.3 \quad 241-$ A TANK FARM COOLING WATER ............ C-35 
CONTENTS (Cont.)

$7.4 \quad 244-A R$ VAULT COOLING WATER $\ldots \ldots \ldots \ldots \ldots \ldots \ldots$ C-36

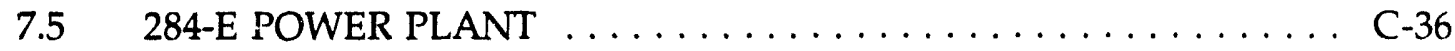

7.6 B PLANT COOLING WATER $\ldots \ldots \ldots \ldots \ldots \ldots \ldots \ldots \ldots \ldots$

8.0 DESCRIBE ANY WATER RECYCLING OR MATERIAL RECLAIMING

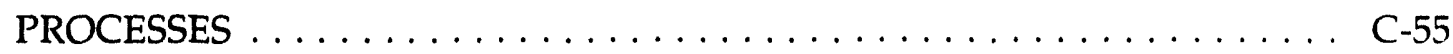

9.0 DOES THIS FACILITY HAVE $\ldots \ldots \ldots \ldots \ldots \ldots \ldots \ldots \ldots \ldots \ldots \ldots$

\section{FIGURES}

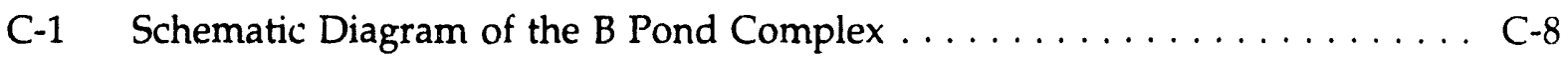

C-2 Proposed 242-A Evaporator Cooling Water Schematic . . . . . . . . . . C-11

C-3 Selected Alternative: Flow Schematic for 242-A Evaporator

Cooling Water Source Control and Discharge to a

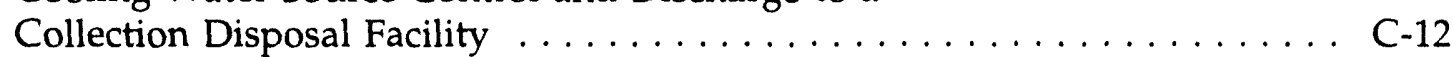

C-4 Selected Alternative: Flow Schematic for 242-A Evaporator After

Planned and Additional Source Control .................. C-16

C-5 Selected Alternative: Flow Schematic for 241-A Tank Farm

Cooling Water After Planned Source Control . . . . . . . . . . . . . . . . . C-19

C-6 Selected Alternative: Flow Schematic After Additional 244-AR Vault Cooling Water Source Controls ... . . . . . . . . . . . . . C-22

C-7 Selected Alternative: Flow Schematic for 284-E Powerplant After Applying Effluent Guidelines, Transfer Technology, Additional Source Controls with Discharge to Collection/Disposal Facility . . . . . . . . C-25

C-8 Non-Contact Closed-Loop Designs Schematic for B Plant Cooling Water . . . . . . . . . . . . . . . . . . . . . . . . . . . . . . . . . C-29

C-9 Selected Alternative: Flow Schematic of B Plant Cooling Water After Source Controls - Collection/Disposal Facility Discharge . . . . . . . . C-30 


\section{CONTENTS (Cont.)}

\section{TABLES}

C-1 Selected Alternative: Estimated Effects After 242-A Evaporator Cooling Water Source Control for Discharge to a Collectio.?/Disposal

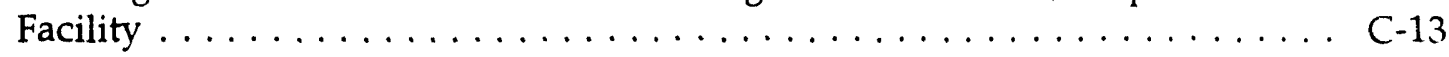

C-2 Selected Alternative: Estimated Effects of Additional 242-A Evaporator Steam Condensate Source Control . . . . . . . . . . . . . . C-17

C-3 Selected Alternative: Estimated Effects of Planned 241-A Tank Farm Cooling Water Source Controls . . . . . . . . . . . . . . . . . C-20

C-4 Selected Alternative: Estimated Effects of Additional 244-AR Vault Cooling Water Source Controls ... . . . . . . . . . . . . . C-23

C-5 Selected Alternatives - Estimated Effects of Technology Transfer, Source Controls at 284-E Power Plant . . . . . . . . . . . . . . . . . C C-26

C-6 Selected Alternative: Estimated Effects of B Plant Cooling Water Source Controls - Collection/Disposal Facility Discharge - Case A ..... C - 31

C-7 Selected Alternative: Estimated Effects of B Plant Cooling Water Source Controls - Collection/Disposal Facility Discharge - Case B . . . . . . C-32 
DOE/RL 93-61, Rev 0 $12 / 93$

200 East Area W-252 Streams

This page intentionally left blank. 


\subsection{IDENTIFY THE WASTE STREAM FOR EACH OF THE PRODUCTION PROCESSES} OR ACTIVITIES DESCRIBED IN SECTION B.1. ASSIGN AN IDENTIFICATION NUMBER.

Note: These streams and respective Waste Stream ID \#'s are identical to thoie presented in the Phase II Liquid Effluent Program (Project W-252) Wastewater Engineering Report and BAT/AKART Studies (WHC, 1992a).

\section{$1.1 \quad$ 242-A EVAPORATOR COOLING WATER}

\begin{tabular}{|l|l|l|l|}
\hline \multicolumn{1}{|c|}{ Process } & \multicolumn{1}{|c|}{ Waste Stream Name } & \multicolumn{1}{|c|}{$\begin{array}{c}\text { Batch or } \\
\text { Continuous } \\
\text { Process }\end{array}$} & $\begin{array}{c}\text { Waste } \\
\text { Stream ID\# }\end{array}$ \\
\hline Condenser Cooling Water & $\begin{array}{l}\text { 242-A Evaporator Cooling } \\
\text { Water }\end{array}$ & Continuous & 1 \\
\hline $\begin{array}{l}\text { Air Compressor Cooling } \\
\text { Water }\end{array}$ & $\begin{array}{l}\text { 242-A Evaporator Cooling } \\
\text { Water }\end{array}$ & Continuous & 2 \\
\hline $\begin{array}{l}\text { Emergency Steam Turbine } \\
\text { Condensate }\end{array}$ & $\begin{array}{l}\text { 242-A Evaporator Cooling } \\
\text { Water }\end{array}$ & $\begin{array}{l}\text { Batch/ } \\
\text { Intermittent }\end{array}$ & 3 \\
\hline $\begin{array}{l}\text { Stream Trap Condensate } \\
\text { 242-A Evaporator Cooling } \\
\text { Water }\end{array}$ & $\begin{array}{l}\text { Batch/ } \\
\text { Intermittent }\end{array}$ & 4 \\
\hline $\begin{array}{l}\text { Compressed Air Dryer } \\
\text { Discharge }\end{array}$ & $\begin{array}{l}\text { 242-A Evaporator Cooling } \\
\text { Water }\end{array}$ & $\begin{array}{l}\text { Batch/ } \\
\text { Intermittent }\end{array}$ & 5 \\
\hline $\begin{array}{l}\text { Water Filter Catch Pan } \\
\text { Drainage }\end{array}$ & $\begin{array}{l}\text { 242-A Evaporator Cooling } \\
\text { Water }\end{array}$ & $\begin{array}{l}\text { Batch/ } \\
\text { Intermittent }\end{array}$ & 6 \\
\hline $\begin{array}{l}\text { HVAC Room Floor Drain } \\
\text { 242-A Evaporator Cooling } \\
\text { Water }\end{array}$ & $\begin{array}{l}\text { Batch/ } \\
\text { Intermittent }\end{array}$ & 7 \\
\hline $\begin{array}{l}\text { Steam System Relief Valve } \\
\text { Condensate }\end{array}$ & $\begin{array}{l}\text { Water Evaporator Cooling } \\
\text { Water }\end{array}$ & $\begin{array}{l}\text { Batch/ } \\
\text { Intermittent }\end{array}$ & 9 \\
\hline Water & $\begin{array}{l}\text { Batch/ } \\
\text { Intermittent }\end{array}$ & 9 \\
\hline
\end{tabular}


DOE/RL 93-61, Rev 0

$12 / 93$

200 East Area W-252 Streams

\begin{tabular}{|c|c|c|c|}
\hline Process & Waste Stream Name & $\begin{array}{l}\text { Batch or } \\
\text { Continuous } \\
\text { Process }\end{array}$ & $\begin{array}{l}\text { Waste } \\
\text { Stream ID\# }\end{array}$ \\
\hline Condenser Cooling Water & $\begin{array}{l}\text { 242-A Evaporator Steam } \\
\text { Condensate }\end{array}$ & Continuous & 1 \\
\hline $\begin{array}{l}\text { Steam Condensate from } \\
\text { Heating Jacket }\end{array}$ & $\begin{array}{l}\text { 242-A Evaporator Steam } \\
\text { Condensate }\end{array}$ & $\begin{array}{l}\text { Batch/ } \\
\text { Intermittent }\end{array}$ & $2 \mathrm{~A}$ \\
\hline $\begin{array}{l}\text { Raw Water from Cooling } \\
\text { Jacket }\end{array}$ & $\begin{array}{l}\text { 242-A Evaporator Steam } \\
\text { Condensate }\end{array}$ & $\begin{array}{l}\text { Batch/ } \\
\text { Intermittent }\end{array}$ & $2 \mathrm{~B}$ \\
\hline $\begin{array}{l}\text { Purging System Steam Trap } \\
\text { Condensate }\end{array}$ & $\begin{array}{l}\text { 242-A Evaporator Steam } \\
\text { Condensate }\end{array}$ & Continuous & 3 \\
\hline Vaculiın Pump Seal Water & $\begin{array}{l}\text { 242-A Evaporator Steam } \\
\text { Condensate }\end{array}$ & $\begin{array}{l}\text { Batch/ } \\
\text { Intermittent }\end{array}$ & 4 \\
\hline Steam Strainer Condensate & $\begin{array}{l}\text { 242-A Evaporator Steam } \\
\text { Condensate }\end{array}$ & Continuous & 5 \\
\hline Steam Separator Condensate & $\begin{array}{l}\text { 242-A Evaporator Stearn } \\
\text { Condensate }\end{array}$ & Continuous & 6 \\
\hline $\begin{array}{l}\text { Steam Separator Strainer } \\
\text { Condensate }\end{array}$ & $\begin{array}{l}\text { 242-A Evaporator Steam } \\
\text { Condensate }\end{array}$ & Continuous & 7 \\
\hline $\begin{array}{l}\text { Seal Water Pressure Control } \\
\text { Valve Discharge }\end{array}$ & $\begin{array}{l}\text { 242-A Evaporator Steam } \\
\text { Condensate }\end{array}$ & $\begin{array}{l}\text { Batch/ } \\
\text { Intermittent }\end{array}$ & 8 \\
\hline $\begin{array}{l}\text { Micro Filter Catch Pan } \\
\text { Drainage }\end{array}$ & $\begin{array}{l}\text { 242-A Evaporato: Steam } \\
\text { Condensate }\end{array}$ & $\begin{array}{l}\text { Batch/ } \\
\text { Intermittent }\end{array}$ & 9 \\
\hline $\begin{array}{l}\text { Seal Water Pumps and Filter } \\
\text { Catch Pan Drainage }\end{array}$ & $\begin{array}{l}\text { 242-A Evaporator Steam } \\
\text { Condensate }\end{array}$ & $\begin{array}{l}\text { Batch/ } \\
\text { Intermittent }\end{array}$ & 10 \\
\hline $\begin{array}{l}\text { R-C-1 Sampler/Monitor } \\
\text { Cooler Raw Water Discharge }\end{array}$ & $\begin{array}{l}\text { 242-A Evaporator Steam } \\
\text { Condensate }\end{array}$ & Continuous & 11 \\
\hline
\end{tabular}


DOE/RL 93-61, Rev 0

$12 / 93$

200 East Area W-252 Streams

\subsection{1-A TANK FARM COOLING WATER}

\begin{tabular}{|c|c|c|c|}
\hline Process & Waste Stream Name & $\begin{array}{l}\text { Batch or } \\
\text { Continuous } \\
\text { Process }\end{array}$ & $\begin{array}{c}\text { Waste } \\
\text { Stream ID\# }\end{array}$ \\
\hline $\begin{array}{l}\text { A-401 Condensers Cooling } \\
\text { Vater }\end{array}$ & $\begin{array}{l}\text { 241-A Tank Farm Cooling } \\
\text { Water }\end{array}$ & Continuous & 1 \\
\hline $\begin{array}{l}\text { A-401 Building condenser- } \\
\text { facility floor drain }\end{array}$ & $\begin{array}{l}\text { 241-A Tank Farm Cooling } \\
\text { Water }\end{array}$ & $\begin{array}{l}\text { Batch/ } \\
\text { Intermittent }\end{array}$ & 2 \\
\hline $\begin{array}{l}\text { A-701 Building compressor- } \\
\text { facility drains, including } \\
\text { compressor Cooling Water }\end{array}$ & $\begin{array}{l}\text { 241-A Tank Farm Cooling } \\
\text { Water }\end{array}$ & Continuous & 3 \\
\hline $\begin{array}{l}\text { A-701 Building compressor- } \\
\text { facility drains, including } \\
\text { compressor Cooling Water }\end{array}$ & $\begin{array}{l}\text { 241-A Tank Farm Cooling } \\
\text { Water }\end{array}$ & $\begin{array}{l}\text { Continuous } \\
\text { (When } \\
\text { operating) }\end{array}$ & $3 \mathrm{~A}$ \\
\hline $\begin{array}{l}\text { Compressor air receiver tank } \\
\text { blowdown }\end{array}$ & $\begin{array}{l}\text { 241-A Tank Farm Cooling } \\
\text { Water }\end{array}$ & $\begin{array}{l}\text { Batch/ } \\
\text { Intermittent }\end{array}$ & $3 B$ \\
\hline $\begin{array}{l}\text { Emergency Cooling Water } \\
\text { System - cold water sump } \\
\text { overflow }\end{array}$ & $\begin{array}{l}\text { 241-A Tank Farm Cooling } \\
\text { Water }\end{array}$ & $\begin{array}{l}\text { Batch/ } \\
\text { Intermittent }\end{array}$ & 4 \\
\hline $\begin{array}{l}\text { Emergency Cooling Water } \\
\text { System - deep well makeup } \\
\text { water bypass }\end{array}$ & $\begin{array}{l}\text { 241-A Tank Farm Cooling } \\
\text { Water }\end{array}$ & $\begin{array}{l}\text { Batch/ } \\
\text { Intermittent }\end{array}$ & 5 \\
\hline $\begin{array}{l}\text { Emergency Cooling Water } \\
\text { System cooling tower } \\
\text { blowdown }\end{array}$ & $\begin{array}{l}\text { 241-A Tank Farm Cooling } \\
\text { Water }\end{array}$ & $\begin{array}{l}\text { Batch / } \\
\text { Intermittent }\end{array}$ & 6 \\
\hline $\begin{array}{l}\text { Emergency Cooling Water } \\
\text { System drain }\end{array}$ & $\begin{array}{l}\text { 241-A Tank Farm Cooling } \\
\text { Water }\end{array}$ & $\begin{array}{l}\text { Batch/ } \\
\text { Intermittent }\end{array}$ & 7 \\
\hline
\end{tabular}


DOE/RL 93-61, Rev 0

$12 / 93$

200 East Area W-252 Streams

\begin{tabular}{|c|c|c|c|}
\hline Process & Waste Stream Name & $\begin{array}{l}\text { Batch or } \\
\text { Continuous } \\
\text { Process }\end{array}$ & $\begin{array}{c}\text { Waste } \\
\text { Stream ID\# }\end{array}$ \\
\hline $\begin{array}{l}\text { Heating, Ventilation, and Air } \\
\text { Conditioning System Cooler } \\
\text { Drains }\end{array}$ & 244-AR Vault Cooling Water & $\begin{array}{l}\text { Continuous } \\
\text { (when } \\
\text { operating) }\end{array}$ & 1 \\
\hline $\begin{array}{l}\text { Heating, Ventilation, and Air } \\
\text { Conditioning System Heater } \\
\text { Condensate }\end{array}$ & 244-AR Vault C ng Wates & $\begin{array}{l}\text { Continuou } \\
\text { when } \\
\text { operating) }\end{array}$ & 2 \\
\hline Air Compressor Co ing Water & 244-AR Vault Coolm Water & Continuous & 3 \\
\hline Air Compressor Condensate & 244-AR Vault Cooling Water & Continuous & 4 \\
\hline Evaporative Cooling Blowdown & 244-AR Vault Cooling Water & Continuous & 5 \\
\hline Vessel Vent Heater Condensate & 244-AR Vault Cooling Water & Continuous & 6 \\
\hline $\begin{array}{l}\text { Evaporative Cooling System } \\
\text { Overflow }\end{array}$ & 244-AR Vault Cooling Water & $\begin{array}{l}\text { Batch/ } \\
\text { Intermittent }\end{array}$ & 7 \\
\hline Upset Vessel Cooling & 244-AR Vault Cooling Water & $\begin{array}{l}\text { Continuous } \\
\text { (when } \\
\text { operating) }\end{array}$ & 8 \\
\hline $\begin{array}{l}\text { Closed-Loop Cooling System } \\
\text { Drain }\end{array}$ & 244-AR Vault Cooling Water & $\begin{array}{l}\text { Batch/ } \\
\text { Intermittent }\end{array}$ & 9 \\
\hline Eye Wash Station & 244-AR Vault Cooling Water & $\begin{array}{l}\text { Batch/ } \\
\text { Intermittent }\end{array}$ & 10 \\
\hline $\begin{array}{l}\text { Jet Gang Valve Area Floor } \\
\text { Drain }\end{array}$ & 244-AR Vault Cools G Water & $\begin{array}{l}\text { Batch/ } \\
\text { Intermittent }\end{array}$ & 11 \\
\hline Steam Tra! ainage & 244-AR Vault Cooling Water & Continuous & 12 \\
\hline $\begin{array}{l}\text { TK-002 \& } 004 \text { Heating } \\
\text { Condensate }\end{array}$ & 244-AR Vault Cooing Water & $\begin{array}{l}\text { Batch/ } \\
\text { Intermittent }\end{array}$ & 13 \\
\hline Water Softening Regenerant & 244-AR Vault Cooling Water & $\begin{array}{l}\text { itch / } \\
\text { intermittent }\end{array}$ & 14 \\
\hline Backflow Preventer Drain & 244-AR Vault Cooling Water & $\begin{array}{l}\text { Batch/ } \\
\text { Intermittent }\end{array}$ & 15 \\
\hline $\begin{array}{l}\text { Air Compressor Aftercooler } \\
\text { Cooling }\end{array}$ & 244-AR Vault Cooling Water & $\begin{array}{l}\text { Batch/ } \\
\text { Intermittent }\end{array}$ & 16 \\
\hline
\end{tabular}


DOE/RL 93-61, Rev 0

$12 / 93$

200 East Area W-252 Streams

1.5 284-E POWER PLANT

2

3

4

\begin{tabular}{|c|c|c|c|}
\hline Process & Waste Stream Name & $\begin{array}{l}\text { Batch or } \\
\text { Continuous } \\
\text { Process }\end{array}$ & $\begin{array}{c}\text { Waste } \\
\text { Stream ID\# }\end{array}$ \\
\hline Reservoir Overflow & 284-E Power Plant & $\begin{array}{l}\text { Batch/ } \\
\text { Intermittent }\end{array}$ & 1 \\
\hline Filter Backwash & 284-E Power Plant & $\begin{array}{l}\text { Batch/ } \\
\text { Intermittent }\end{array}$ & 2 \\
\hline Cooling Water & 284-E Power Plant & Continuous & 3 \\
\hline $\begin{array}{l}\text { Boiler Blowdown - } \\
\text { continuous }\end{array}$ & 284-E Power Plant & Continuous & $4 \mathrm{~A}$ \\
\hline $\begin{array}{l}\text { Boiler Blowdown - } \\
\text { intermittent }\end{array}$ & 284-E Power Plant & $\begin{array}{l}\text { Batch / } \\
\text { Intermittent } \\
\end{array}$ & $4 B$ \\
\hline Water Softener Regenerant & 284-E Power Plant & $\begin{array}{l}\text { Batch/ } \\
\text { Intermittent }\end{array}$ & 5 \\
\hline Clearwell Overflow & 284-E Power Plant & $\begin{array}{l}\text { Batch/ } \\
\text { Intermittent }\end{array}$ & 6 \\
\hline Settling Basin Drain & 284-E Power Plant & $\begin{array}{l}\text { Batch/ } \\
\text { Intermittent }\end{array}$ & 7 \\
\hline Floor/Trench Drains & 284-E Power Plant & $\begin{array}{l}\text { Batch/ } \\
\text { Intermittent }\end{array}$ & $8 \mathrm{~A}$ \\
\hline Floor/Trench Drains & 284-E Power Plant & $\begin{array}{l}\text { Batch/ } \\
\text { Intermittent }\end{array}$ & $8 B$ \\
\hline
\end{tabular}

18

19

20 


\subsection{B PLANT COOLING WATER}

\begin{tabular}{|c|c|c|c|}
\hline Process & Waste Stream Name & $\begin{array}{l}\text { Batch or } \\
\text { Continuous } \\
\text { Process }\end{array}$ & $\begin{array}{l}\text { Waste } \\
\text { Stream } \\
\text { ID\# }\end{array}$ \\
\hline Condensers Cells $22 \& 23$ & B Plant Cooling Water & $\begin{array}{l}\text { Continuous } \\
\text { (when } \\
\text { operating) }\end{array}$ & 1 \\
\hline $\begin{array}{l}\text { Waste Encapsulation Storage Facility } \\
\text { - Pool Cell Flush and Exchangers }\end{array}$ & B Plant Cooling Water & Continuous & 2 \\
\hline Cask Station & B Plant Cooling Water & $\begin{array}{l}\text { Batch/ } \\
\text { Intermittent }\end{array}$ & 3 \\
\hline Emergency Well Pumps & B Plant Cooling Water & $\begin{array}{l}\text { Batch/ } \\
\text { Intermittent }\end{array}$ & 4 \\
\hline $\begin{array}{l}\text { 221-B Process Cells Cooling Water } \\
\text { (Cells } 5 \text { through } 39 \text { ) }\end{array}$ & B Plant Cooling Water & $\begin{array}{l}\text { Continuous } \\
\text { (when } \\
\text { operating) }\end{array}$ & 5 \\
\hline $\begin{array}{l}\text { B Plant Steam Condensate } \\
\text { Condenser }\end{array}$ & B Plant Cooling Water & $\begin{array}{l}\text { Continuous } \\
\text { (when } \\
\text { operating) }\end{array}$ & 6 \\
\hline $\begin{array}{l}\text { B Plant Steam Condensate Monitor } \\
\text { Heat Exchanger }\end{array}$ & B Plant Cooling Water & $\begin{array}{l}\text { Continuous } \\
\text { (when } \\
\text { operating) }\end{array}$ & 7 \\
\hline $\begin{array}{l}\text { Stairwell 1, Operating Gallery } \\
\text { Heating, Ventilation, and Air } \\
\text { Conditioning }\end{array}$ & B Plant Cooling Water & $\begin{array}{l}\text { Batch / } \\
\text { Intermittent }\end{array}$ & 8 \\
\hline
\end{tabular}

\subsection{ON A SEPARATE SHEET, DESCRIBE IN DETAIL THE TREATMENT AND DISPOSAL OF ALL WASTE WATERS AS DESCRIBED ABOVE. INCLUDE A SCHEMATIC FLOW DIAGRAM FOR ALL WASTE WATER TREATMENT AND DISPOSAL SYSTEMS.}

No treatment is provided for any of the six waste streams just prior to disposal, although some of the raw water is treated prior to, and during use as described in Attachment B, Section 1. All six streams are disposed in the 216-B-3 Ponds via the 216B-3-3 ditch (Figure H3.0-1). Schematic flow diagrams for the waste water treatment and disposal systems from the Phase II Liquid Effluent Program (Project W-252) Wastewater Engineering Report and BAT/AKART Studies (WHC, 1992a) are presented for each of the six waste streams in Attachment $B$, Section 1.0. See Figures B$6, \mathrm{~B}-9, \mathrm{~B}-14, \mathrm{~B}-20, \mathrm{~B}-25$, and B-28. 
3.0 INDICATE TREATMENT PROVIDED TO EACH WASTE STREAM IDENTIFIED ABOVE.

No treatment is provided to any of the six waste streams.

\subsection{DESCRIBE ANY PLANNED WASTE WATER TREATMENT IMPROVEMENTS OR CHANGES IN WASTE WATER DISPOSAL METHODS.}

The six 200 East Area W-252 waste streams are currently disposed of in the B Pond Complex via the 216-B-3-3 ditch which discharges into the main lobe of the B Pond Complex (Figure C-1). The main lobe of the B Pond Complex currently overflows into the A-lobe which in turn overflows into the C-lobe (Figure C-1). This permit application is specifically written to address disposal of the six 200 East Area W-252 streams in the B Pond Complex.

Proposed improvements to the waste water transfer system from the facilities producing the waste streams to the disposal site at the B Pond Complex consist of closing the 216-B-3-3 ditch and temporarily routing the waste streams directly into the A-lobe of the B Pond complex through the existing contingency pond pipeline and existing unused bypass pipeline into A-lobe. The temporary routing of the streams through A-lobe is planned to occur during the staged closure of both the main and $A$-Lobes and the construction of project X-009 during 1994. Project X-009 proposes to reroute the existing bypass pipeline so the streams will discharge into either $\mathrm{B}$ - or $\mathrm{C}$ lobes (Figure C-1) (WHC 1993a). Project X-009 construction is planned for the Fall of 1993 with completion in the Spring of 1994.

Proposed improvements to the ponds themselves include a staged Resource Conservation and Recovery Act closure the B Pond system during 1994. The staged closure consists of clean closure of A-, B- and C-lobes, with the A-lobe backfilled after closure. The main lobe and the 216-B-3-3 ditch will be closed under an integrated work/closure plan which involves staged backfilling of the facilities. The remaining B- and C-lobes will serve as the disposal site for the six 200 East Area W-252 Streams.

The sections that follow, which discuss the Best Available Technology/All Known and Reasonable Treatment (BAT/AKART) selected for each of the six waste streams, refer to a collection/disposal facility for routing the waste water discharge after implementation of BAT/AKART by October 1997. The six 200 East Area W-252 Streams are currently planned to be routed to the Project W-049H Treated Effluent and Disposal Facility for final disposal, but other alternatives, including continued discharge to the $\mathrm{B}-$ and C-lobes in the B Pond Complex, are being considered. 


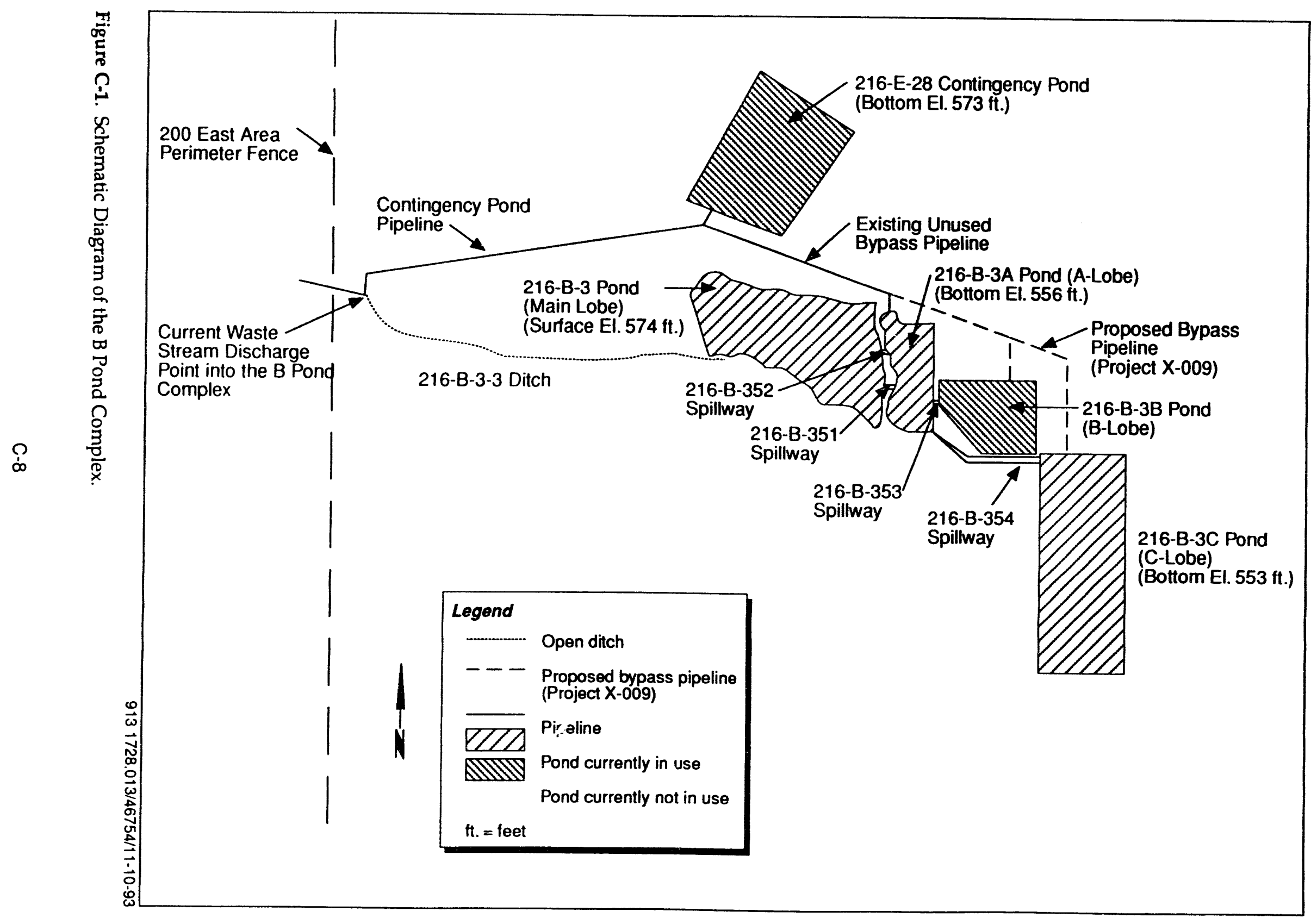




\subsection{2-A EVAPORATOR COOLING WATER}

The following information is excerpted from WHC 1992a, Appendix B.2, Sections 4.3 and 5.3. Source controls and discharge to a treated effluent disposal facility were selected as BAT/AKART for the main flow of the 242-A Evaporator Cooling Water (WHC 1992a). Minor contributor sources will be handled in other appropriate ways. The selection process utilized a design heat load condition of 25,000,000 British Thermal Units per hour.

The BAT/AKART source controls system includes a heat exchanger to transfer waste heat from a primary closed loop to a secondary loop having a wet cooling tower to dissipate waste heat.

This selected alternative proposes to add a non-contact, closed-loop, corrosioninhibiting cooling water system. As shown in Figure C-2, this cooling water system would use a heat exchanger to transfer waste heat from the primary closed loop to a secondary loop with a wet cooling tower to dissipate the waste heat, minimizing water usage. Blowdown will be discharged to a collection/disposal facility. To minimize the impact on the collection, disposal facility, the cooling tower cycles would be limited to two. The primary loop includes the water side of the present condenser, and will have suitable corrosion inhibitors added. The primary and secondary loop flowrates were calculated based on the waste heat design load and reasonable approach temperature assumptions.

The primary loop flowrate was assumed to be 3,650 gallons per minute (gpm), and the heat load to be 25,000,000 British Thermal Units per hour (both based on existing data); the resultant temperature rise in the primary cooling water loop is 14 degrees Fahrenheit. The operating temperatures of the primary cooling water loop are 79 degrees Fahrenheit ( 5 degrees Fahrenheit above the cold water temperature) and 93 degrees fahrenheit ( 79 degress Fahrenheit +14 degrees Fahrenheit). The secondary cooling water loop inlet temperature ( 74 degrees Fahrenheit) to the shell and tube heat exchanger was based on a 7 degrees Fahrenheit temperature approach (wet bulb 67 degress Fahrenheit + 7 degress Fahrenheit) and the outlet temperature was set at 90 degrees Fahrenheit ( 3 degrees Fahrenheit below the primary cooling water inlet).

The circulating water flowrate in the secondary loop of the non-contact cooling water system was calculated to be 3,200 gallons per minute.

Other source controls are as follows:

1. A heat pump, or chiller, will be used to regulate the air compressor (Source 2) water jacket temperature; water flow will be closed-loop.

2. Steam condensate from the emergency steam turbine, steam traps, and steam relief valves (Sources 3,4 and 8) will be collected for reuse as cooling tower make-up or returned to the steam plant.

3. The water filter catch pan (Source 6) will be sized to prevent liquid from overflowing. 
4. Floor drains (Source 7) will be plugged and administratively controlled to prevent spills from entering the drain. A standpipe in the drains will permit air washer drainage but prevent floor spillage from entering.

5. Condensate from the air receiver (Source 9) will be collected and allowed to evaporate back into the atmosphere.

The source control methods are summarized in Table C-1. Figure C-3 shows the flow of effluent sources after the source control measures have been implemented. 


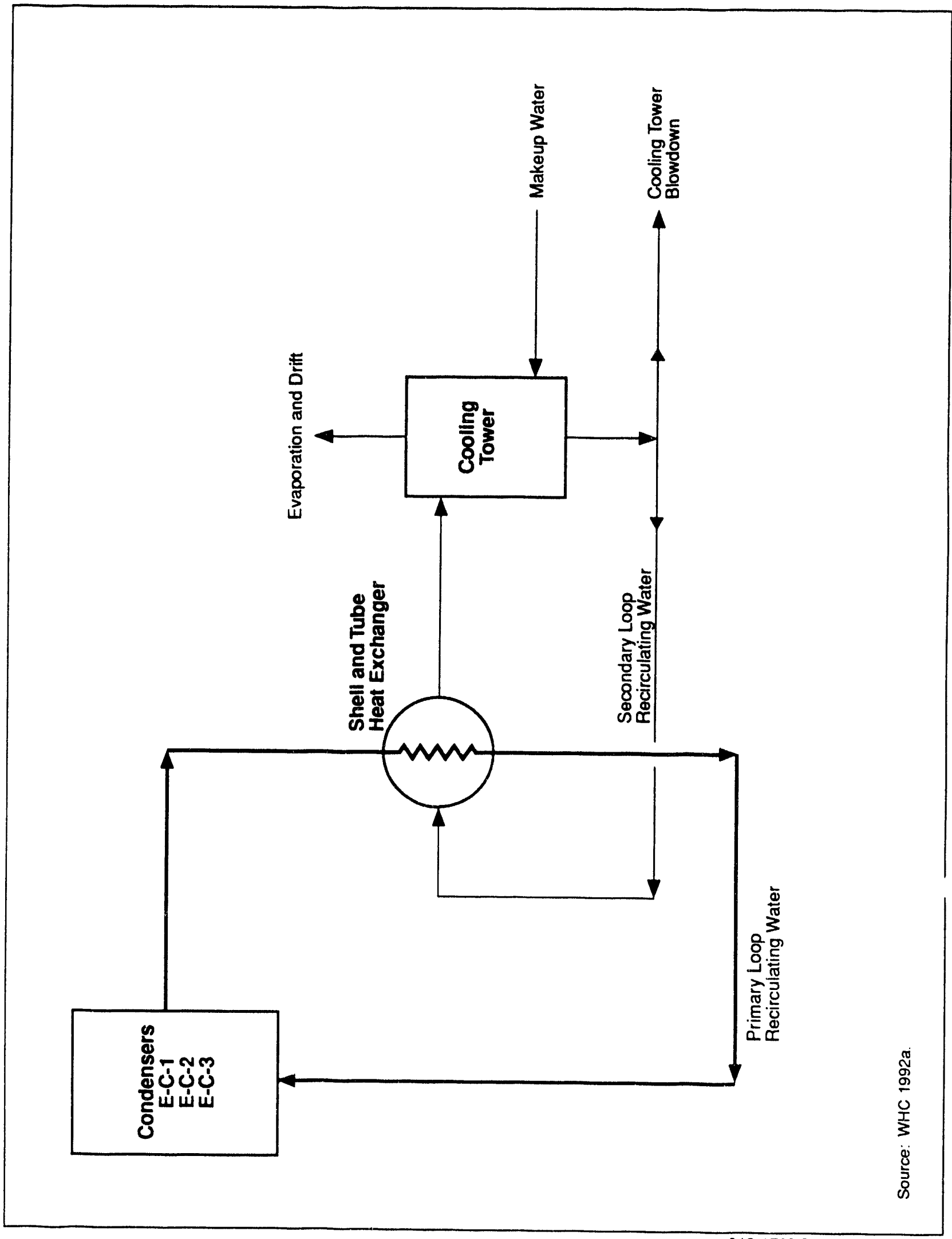

$9131728.013 / 46202 / 11-10-93$

Figure C-2. Proposed 242-A Evaporator Cooling Water Schematic. 


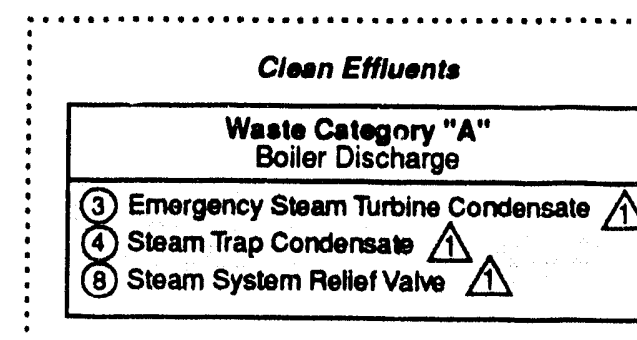

Waste Catexory " $\mathrm{C}$ " Miscellaneous Clean Effluents

(5) Compressed Air Dryer Discharge (Planned Eliminination)

(6) Water Filter Catch Pan $\triangle$

(7) HVAC Room Floor Drains $\triangle$

(9) Compressed Air Receiver Condensate $A$

Waste Category "D" nce-Through Cooling Water

(2) Air Compresser Cooling Water 1

Waste Category "F" Potentially Contaminated Cooling Water

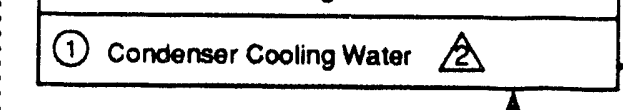

\section{Note}

- Waste categories are defined in Appendix B, Table B-1.

Shaded sources are eliminated or reduced.

\section{Legend}

(1) Source number

M] Flow monitor

[S. Flow proportional sampler

Continuous llow

- Intermittent flow

(1) Sources modified or removed by this allernative. (source controls)

(2) Treatment selected by technology ir-nster method (BATIAKART)

HVAC - heating, ventilation, and air conditioning

BAT/AKART - best available technology/all known and reasonable treatment

Figure C-3. Selected Alternative: Flow Schematic for 242-A Evaporator Cooling Water Source Control and Discharge to a Collection Disposal Facility. 
IABIIE C-1. SEI.FCTIED ALITERNATIVE: Estimated Fffects After 242-A Evaporator Cooling Water Source Control for Discharge to a Collection/Disposal Facility

\begin{tabular}{|c|c|c|c|c|c|c|}
\hline $\begin{array}{c}\text { Source } \\
\text { No. }\end{array}$ & Source Stream & $\begin{array}{l}\text { Source } \\
\text { Building }\end{array}$ & $\begin{array}{c}\text { Source } \\
\text { Treatment } \\
\text { Material }\end{array}$ & $\begin{array}{l}\text { Treatment or } \\
\text { Source Control } \\
\text { Alternative }[1]\end{array}$ & $\begin{array}{c}\text { Effluent } \\
\text { Water Type }\end{array}$ & $\begin{array}{c}\text { Estimated } \\
\text { Annualized Flow } \\
\text { Rate } \\
(\mathrm{gpm})[2]\end{array}$ \\
\hline 1 & Condenser Cooling Water & $242-\mathrm{A}$ & $\begin{array}{l}\text { Technology } \\
\text { Transfer }\end{array}$ & F-6 & Raw & 5.6 \\
\hline 2 & Air Compressor Cooling Water & $242-A$ & $\begin{array}{l}\text { Technology } \\
\text { Transfer }\end{array}$ & D-2 & None & $\mathbf{0}$ \\
\hline 3 & Emergency Steam Turbine Condensate & $242-A$ & Reuse & A-1 & $\begin{array}{c}\text { Steam } \\
\text { Condensate }\end{array}$ & Negligible \\
\hline 4 & Steam Trap condensate & $242-A$ & Reuse & A-1 & $\begin{array}{c}\text { Steam } \\
\text { Condensate }\end{array}$ & Negligible \\
\hline 5 & Compressed Air Dryer Discharge [3] & 242-A & $\begin{array}{c}\text { Planned } \\
\text { Elimination }\end{array}$ & C-0 & $\begin{array}{c}\text { Planned } \\
\text { Elimination }\end{array}$ & 0 \\
\hline 6 & Water Filter Catch Pan & $242-A$ & $\begin{array}{c}\text { Flow } \\
\text { Regulation }\end{array}$ & $C-0$ & Raw & Negligible \\
\hline 7 & IIVAC Room Floor Drains & $242-A$ & $\begin{array}{c}\text { Flow } \\
\text { Regulation }\end{array}$ & $C-0$ & $\begin{array}{c}\text { Raw/ } \\
\text { Condensate }\end{array}$ & Negligible \\
\hline 8 & Steam System Relief Valve & $242-A$ & Reuse & $A-1$ & $\begin{array}{c}\text { Steam } \\
\text { Condensate }\end{array}$ & Negligible \\
\hline 9 & Compressed Air Receiver Condensate & $242-A$ & $\begin{array}{c}\text { Flow } \\
\text { Regulation }\end{array}$ & IC -2 & $\begin{array}{c}\text { Air } \\
\text { Moisture }\end{array}$ & Negligible \\
\hline
\end{tabular}

Source: WHC 1992a

\section{NOTES:}

11) Source category defined in Appendix B, Table B-1.

12) Average flow rate based on total annual volume of cooling tower blowdown

[3] Source planned to be elininated with the use of an electric heater.

$\mathrm{gpm}=$ gallons per minute

IIVAC = Heating, Ventilation, and Air Conditioning 


\subsection{2-A EVAPORATOR STEAM CONDENSATE}

The following information is excerpted from WHC 1992a, Appendix B.7, Sections 4.2 and 5.2. Additional source control was selected as BAT/AKART for the 242-A Evaporator Steam Condensate to eliminate this stream (WHC 1992a). This alternative includes recycling the condensate streams to the 284 East Powerplant, converting once through cooling water systems to closed loop cooling water systems and discharging the remainder of the streams to a collection/disposal facility.

The waste stream is composed of several types of effluent. The selected alternative, therefore, includes a number of source controls identified as appropriate for application to individual sources or for groups of similar sources.

Specific, additional source controls include: return steam condensate streams (Sources 2A, 3, 5, 6, and 7) to the 284 East Powerplant, and discharge waste water streams (Sources 8, 9, and 10) to a collection/disposal facility. Radiation monitoring, $\mathrm{pH}$ monitoring, and sampling with periodic analysis would be used to ensure effluent quality. The treatment system influent would be monitored for radioactivity. If radioactivity is detected, the stream would be diverted to a double shell tank. Source 4 has already been eliminated.

Source 1 would be eliminated by adding a $r \cdots$ secondary steam heat exchanger to heat the liquid in the existing heat exchanger. $T$ xisting heat exchanger is used to heat and evaporate the waste liquid. The spent $f$ from the new secondary heat exchanger would be recycled to the 284-E Powert. $t$. Sources $2 B$ and 11 would be eliminated hy converting to air cooled, closed-loop cooling water systems as shown in Figure C-4.

The combined flow from all existing waste $\mathrm{u}$ r streams would total $33.9 \mathrm{gpm}$. Alternative 2 would eliminate more than 99 perce: if the waste water stream being discharged to the environment. In addition, it would produce a very small quantity of secondary waste (less than one 55 gallon drum per year).

Additional source controls are described in Table C-2, and consist of:

- Recycling all condensate streams excep ,urce 1 to the 284 East Powerplant. This employs simple transfer of the liquids from the Evaporator to 284 East Powerplant. The condensate streams would be treated by activinted carbon and ion exchange to remove trichlorometi ine, arsenic, and al num before entering the powerplant.

- Adding a steam heat exchanger to heat the fluid in "... existin eam heat exchanger that is used to evaporate the quid wast ed to Er rator 242-A. The spent fluid from the new steam heat exchanger would be recycled to the 284 East Powerplant. This change would eliminate Source 1. 
DOE/RL 93-61, Rev 0

$12 / 93$

200 East Area W-252 Streams

- Converting once-through cooling water systems to closed-loop cooling water systems that employ commonly used heat exchange equipment.

- Collecting and transferring Sources 8, 9, and 10 to a collection/disposal facility. 


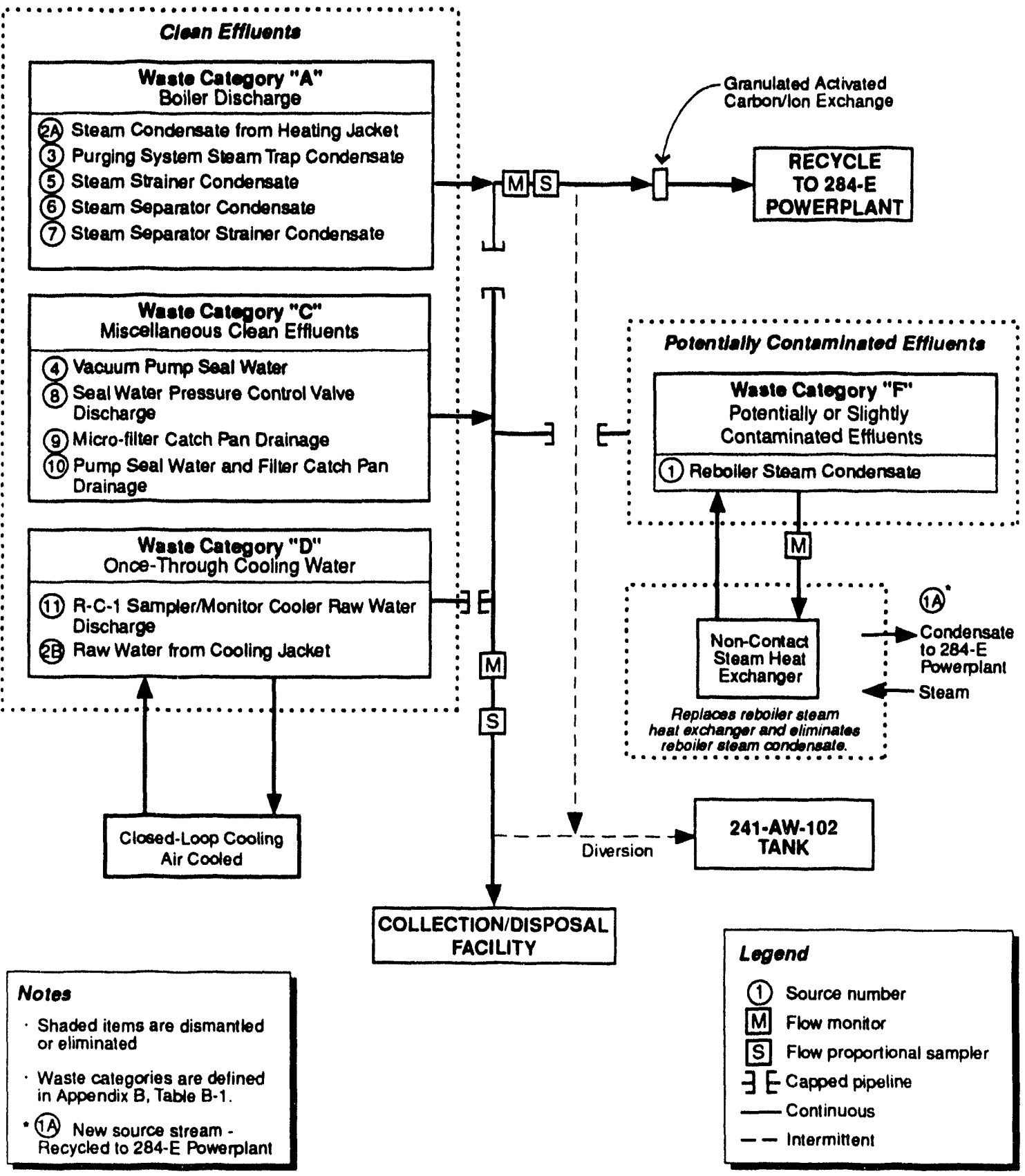

Source: WHC 1992a.

$9131728.013 / 46204 / 11-10-93$

Figure C-4. Selected Alternative: Flow Schematic for 242-A Evaporator After Planned and Additional Source Control. 
TABI I: C-2. Selected Alternative: listimated Fiffects of Additional 242-A Evaporator Steam Condensate Source Control.

\begin{tabular}{|c|c|c|c|c|c|c|}
\hline $\begin{array}{l}\text { Sesurce } \\
\text { No. }\end{array}$ & Senrce & $\begin{array}{l}\text { Sumurce } \\
\text { Building }\end{array}$ & $\begin{array}{l}\text { Source } \\
\text { Trestment } \\
\text { Mteasure }\end{array}$ & $\begin{array}{l}\text { Treatiment or } \\
\text { Sinurce Control } \\
\text { Alterisutive [1] }\end{array}$ & $\begin{array}{l}\text { Erflue'm } \\
\text { Walter } \\
\text { type: }\end{array}$ & 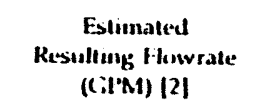 \\
\hline 1 & Rebuiler Steam Cundensate & $242 \cdot A$ & $\begin{array}{l}\text { Switch to steam heating system } \\
\text { with secondary heating loop (stream } \\
\text { 1A) }\end{array}$ & F.1 & Condensule & OONIE, OOU \\
\hline IA & Secondary $\mid 1 / X$ Steam Condensale $|i|$ & $242 \cdot \mathrm{A}$ & Recycle to 28. E Area Steam Plant & F-1 & Condensate & 6801.01151 \\
\hline $2 \mathrm{~A}$ & Steam Condensate from Heatmg Jackets & 242-A & Recycle to 284-E Area Steam Plant & A-1 & Conderisate & O.OUE,0O \\
\hline 2B & Raw Water from Cooling lackels & 242-A & $\begin{array}{l}\text { Switch to Closed Loop Cooling } \\
\text { Water }\end{array}$ & D.1 & Raw Water & OONE $+(0)$ \\
\hline 3 & Purging System Steam Trap Condensale & $242-A$ & Recycle to 284-E Area Steam Plant & A-1 & Condensale & OE $00,(x)$ \\
\hline 4 & Vacuum Pump Seal Water $|3|$ & $242-A$ & Punp Removed from Service & c & Raw Waler & OOOE: (O) \\
\hline 5 & Stesin Strainer Condensute & 242-A & Recycle o 284-E Area Steam Plant & $A-1$ & Condensate & O COE,$(x)$ \\
\hline 6 & Steain Separator Conderisate & $242-A$ & Recycle to 284-E Area Steam Plant & A-1 & Condensule & $0.00 \mathrm{H},(x)$ \\
\hline 7 & Stean: Water Pressure Control Valve Discharge & $242-A$ & Recycle to 284-E Area Steam Plant & A-1 & Condensulte & OOOE $(\mathbf{x})$ \\
\hline 8 & Seal Water Pressure Contro! Valve Discharge & $242-A$ & Discharge to W.0491I Type Facility & C.3 & Raw Water & $<2 .(0) E-1) 2$ \\
\hline 9 & Micro Filter Catch Pan Drsillage & $242-A$ & Discharge to W-04911 Type Facilily & C.3 & Raw Water & $<2$ OOE 02 \\
\hline 10 & $\begin{array}{l}\text { Seal Water Pumps and Filter Catth Pan } \\
\text { Drainage }\end{array}$ & 242-A & Discharge to W-04911 Type Facility & C.3 & Raw Water & 2 UONE-02 \\
\hline \multirow[t]{3}{*}{11} & $\begin{array}{l}\text { R-C-1 Sampler/Monitur Couler Raw Water } \\
\text { Discharge }\end{array}$ & 242-A & $\begin{array}{l}\text { Switch to Closed Loop Cooling } \\
\text { Water }\end{array}$ & D.1 & Raw Walter & ONOE: +00 \\
\hline & & & & & & TOTAL. $<6800.01151$ \\
\hline & & & & & & 1OTAL. <6 MUE. $02|6|$ \\
\hline
\end{tabular}

Solurce: WIIC 1992a

NOTES:

(11) Source categories are defined in Appendix B. Table B-1

12) Average flow rate is based on tolal atinual flow divided by 526,000 ininutes (1 year)

13] This source stream has beten eliminated since the completion of sampling periond.

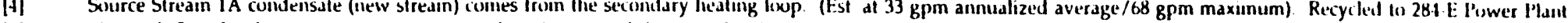

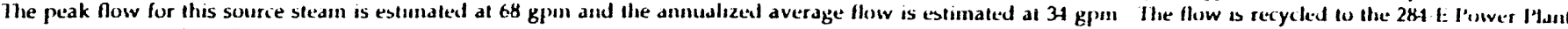

|0| This tlow gines to the effluent collection/disposal system.

$H / X=$ heat exchanger

gpm = gallons per munute 


\subsection{1-A TANK FARM COOLING WATER}

The following information is excerpted from WHC 1992a, Appendix B.1, Sections 4.2 and 5.2. Planned source controls were selected as BAT/AKART for the 241-A Tank Farms cooling water and associated streams (WHC 1992a). This selection includes a closed-loop cooling system for the tank off-gas condenser cooling and a closed-loop liquid cooling system for instrument air compressors. The closed-loop cooling water systems replace the once-through cooling water system.

Cooling water will be recirculating from condenser to the evaporative cooling towers, which requires make-up from sanitary water. The blowdown from the cooling tower will be the major (99.92 percent) effluent discharging to a collection/disposal facility. The instrument air compressor once-through cooling water will be eliminated by applying a liquid closed-loop cooling system with air cooler. Other contributors in the current status will be eliminated.

The following are brief descriptions of the recommended actions:

Source Stream 1. Replace the A-401 condenser cooling with a closed loop cooling water system with wet cooling towers and glycol chillers. There would be two coolingwater loops using sanitary water.

Replace the A-701 Building compressor once-through cooling water system with an air-cooled chiller. No waste water would be generated by this system, except blowdown from the compressor air dryer receiver tank. This blowdown will be intermittent and negligible, reducing Source 3 .

The following six streams will be eliminated:

- Compressor and after cooler cooling water (Sources 3 and $3 \mathrm{~A}$ )

- Emergency cooling water system cold water sump overflow (Source 4)

- Emergency cooling water system - deep well makeup water bypass (Source 5)

- Emergency cooling water system blowdown (Source 6)

- $\quad$ Emergency cooling water system drain (Source 7).

Since the potential radioactive sources would be eliminated and the flowrate greatly reduced from this wastestream, the treated 241-A Tank Farm cooling water wastestream would be discharged to a collection/disposal facility. The active sources at the 241-A Tank Farm Cooling Water system after implementation of the source control measures are summarized in Table C-3. Figure C -5 shows the flow of effluent sources after these source control measures have been implemented. 

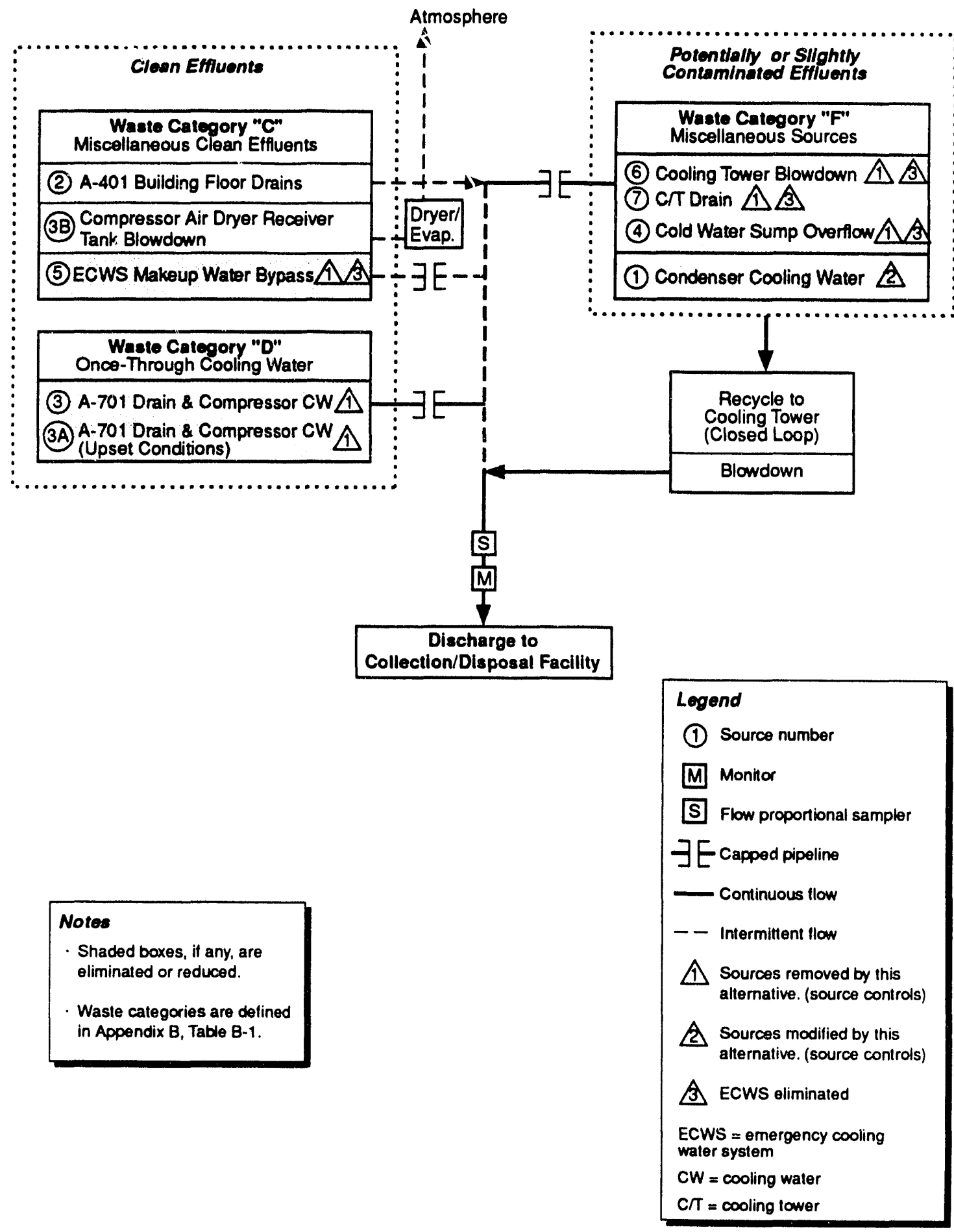

Source: WHC 1992a.

$9131728.013 / 46174 / 11-9-93$

Figure C-5. Selected Alternative: Flow Schematic of 241-A Tank Farm Cooling Water After Planned Source Control. 
TABI.E C-3. Selected Alternative: Estimated Effects of Planned 241-A Tank Farm Cooling Water Source Controls

\begin{tabular}{|c|c|c|c|c|c|}
\hline $\begin{array}{c}\text { Source } \\
\text { No. }\end{array}$ & Source Stream [1] & $\begin{array}{c}\text { Source Treatment } \\
\text { Measure }\end{array}$ & $\begin{array}{c}\text { BAT } \\
\text { Option [2] }\end{array}$ & $\begin{array}{c}\text { Effluent } \\
\text { Water Type }\end{array}$ & $\begin{array}{c}\text { Estimated } \\
\text { Resulting lilowrate } \\
(\text { gpus })[3 \mid\end{array}$ \\
\hline 1 & A-401 Condensors Cooling Water Blowdown & $\begin{array}{l}\text { Closed-loop cooling } \\
\text { water system }\end{array}$ & $\mathbf{E}$ & $\begin{array}{c}2 \times \text { Sanitary } \\
\text { Water }\end{array}$ & 20) $|4|$ \\
\hline 2 & A-401 Building Condensor-Facility Floor Drain & None & N/A & $\begin{array}{c}\text { Sanitary } \\
\text { Water }\end{array}$ & Negligible $(<0.016)$ \\
\hline 3 & $\begin{array}{l}\text { A-701 Building Compressor-Facility Drains, } \\
\text { Including Compressor Cooling Water }\end{array}$ & $\begin{array}{l}\text { Closed-loop cooling } \\
\text { system }\end{array}$ & D-3 & None & 0 \\
\hline $3 A$ & $\begin{array}{l}\text { A-701 Building Compressor-Facility Drains, } \\
\text { Including Compressor Cooling Water (upset) }\end{array}$ & Eliminated & N/A & $N / A$ & 0 \\
\hline $3 B$ & Compressor Air Receiver Tank Blowdown & None & C-2 & $\begin{array}{c}\text { Raw Water } \\
\text { [5] }\end{array}$ & Negligible \\
\hline 4 & ECWS Cold Water Sump Overflow [2] & Eliminated & N/A & N/A & $\mathbf{0}$ \\
\hline 5 & ECWS Deep Well Makeup Water Bypass [2] & Eliminated & N/A & $\mathrm{N} / \mathrm{A}$ & 0 \\
\hline 6 & ECWS Cooling Tower Blowdown [2] & Eliminated & N/A & N/A & $\mathbf{0}$ \\
\hline 7 & ECWS Drain [2] & Eliminated & N/A & N/A & $\mathbf{0}$ \\
\hline & & & & & TOTAL. 20 \\
\hline
\end{tabular}

Source: WIIC 1992a

NOTES:

[1] All sources are in 241-A Tank Farms area.

[2] Source control options from Appendix B, Table B-1.

[3] Average flow rate based on total annual flow divided by 526,000 minutes (1 year).

[4] Estimated $40 \mathrm{gpm}$ cooling tower makeup with equal evaporation rate, and blowdown rate $10 \mathrm{MM}$ Btu/hr cooling requirement.

[5] Assumed air moisture is similar to raw water quality.

BAT = best available technology

ECWS = emergency cooling water system

gpm = gallons per minute

$\mathrm{N} / \mathrm{A}=$ not applicable

$\mathrm{Btu} / \mathrm{hr}=$ British thermal units per hour 


\subsection{4-AR VAULT COOLING WATER}

The following information is excerpted from WHC 1992a, Appendix B.4, Sections 4.2 and 5.2. The additional source controls alternative was selected as BAT/AKART for the 244-AR Vault Cooling Water affluent stream (WHC 1992a). This selection includes replacing the air compressor and after cooler cooling water system with a closed-loop system and replacing the vessel vent steam heater with electric heaters.

The 244-AR Vault will serve as an interim holding and transfer facility for neutralized current acid waste received from the tank farms prior to transfering waste to a pre-treatment facility for processing. In the selected alternative, the $244-\mathrm{AR}$ vault cooling water would continue to discharge to B Pond and several additional source control measures would be applied to reduce both the potential for inadvertent discharge of radioactive constituents and the quantity of water discharged by the wastestream.

Facility modifications are required to reduce the potential for radioactive contributions to the cooling water wastestream. The vessel vent steam heater (Source 6) would be replaced with an electric heater. Using this approach, vessel vent steam condensate would no longer exist. Although the flowrate associated with this source is small, a potential source of radioactive contamination would be eliminated. Prior to closed-cooling water loop drainage, the contents, as required by procedure, would be sampled and verified to be acceptable (e.g. free of radioactive contamination) before discharge to the 244-AR Vault cooling water wastestream.

Additional source control measures to be taken to reduce discharge volume include: modification of the raw water-cooled compressor (Source 3) and aftercooler (Source 16) to allow use of closed-loop cooling water with heat rejection to an air-cooled heat exchanger. The source streams 3 and 16 will be eliminated.

With the elimination of the potentially radioactive sources and the continuous clean sources, the 244-AR Vault cooling water wastestream would consist of cooling tower blowdown and intermittent sources such as equipment drainages, water-softener regenerant, and eye-wash station discharges. The wastestream flow would be discharged to a collection/disposal facility.

The additional source control measures for the active wastestream sources at the 244-AR Vault are summarized in Table C-4. Figure C- 6 shows the flow of effluent sources after the existing and additional source control measures have been implemented. 


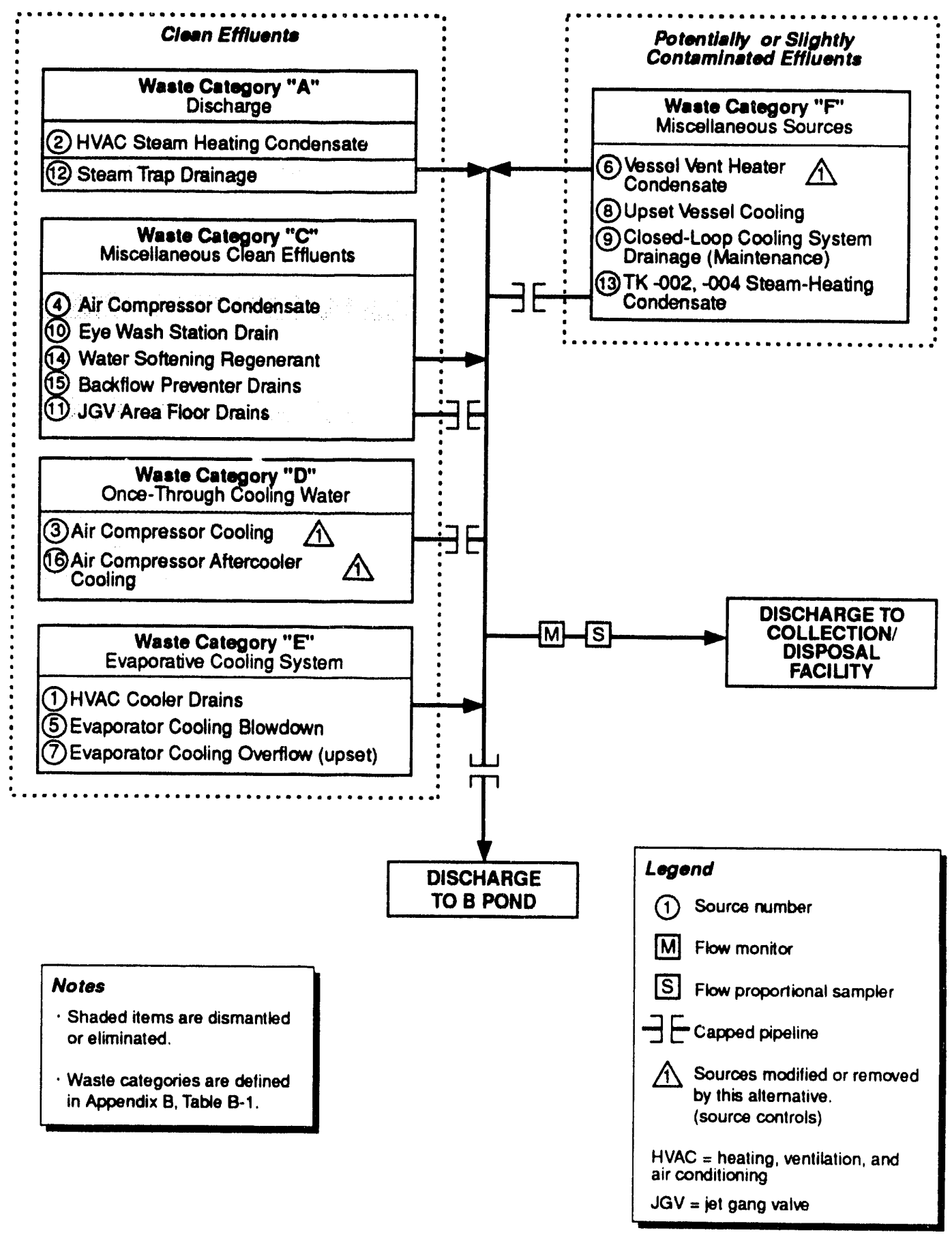

Source: WHC 1992a.

$9131728.013 / 46182 / 11-9-93$

Figure C-6. Selected Alternative: Flow Schematic After Additional 244-AR Vault Cooling Water Source Controls. 
TABILE C-4. Selected Alternative: Fstimated Effects of Additional 244-AR Vault Cooling Water Source Controls

\begin{tabular}{|c|c|c|c|c|c|c|}
\hline $\begin{array}{l}\text { Source } \\
\text { No. }\end{array}$ & Suurce Stream & $\begin{array}{l}\text { Source } \\
\text { Building }\end{array}$ & $\begin{array}{l}\text { Additional } \\
\text { Measure }\end{array}$ & $\begin{array}{l}\text { BAT Source } \\
\text { Control |1] }\end{array}$ & $\begin{array}{c}\text { Estimated } \\
\text { Eflluem Option } \\
\text { Type }\end{array}$ & $\begin{array}{l}\text { Resulting Waters } \\
\text { Flosv (g|min) |2| }\end{array}$ \\
\hline 1 & IIVAC System Coxiler Drains & 244-AR & None & E-1 & Sanitary & $50(1): 1(10)$ \\
\hline 2 & IIVAC System Ilester Comulensule & 2.44-AR & None & A-2 & Condensale & $20 E_{1}(M)$ \\
\hline 3 & Air Compressur Coxlling Water & 244-AR & $\begin{array}{l}\text { Replace once-through } \\
\text { cooling with closed-koup }\end{array}$ & D.1 & Raw Water & $\mathbf{0}$ \\
\hline 4 & Air Conpressor Condensate & 244-AR & & $C-1$ & Raw Water & 7.5E-02 \\
\hline 5 & Evaporative Couling Blowdown & 244-AR & None & E-2 & 2X Suftened Raw & $40 E \div(10)$ \\
\hline 6 & Vessel Vent lleater Conclensate & 244-AR & $\begin{array}{l}\text { Replace steam heater } \\
\text { with electric heater }\end{array}$ & F-6 & Cundensite & 0 \\
\hline 7 & Evaporative C(xiling System Overflow & 244-AR & None & E-0 & 2X Softened Raw & 0 \\
\hline 8 & Upset Vessel rixilung & 244-AR & None & $\mathbf{F}-1$ & Raw & $20 \mathrm{EE}-112$ \\
\hline 9 & Clused 1.xpe C(x)ling System Drain & 244-AR & None & $\mathbf{F}-\mathbf{3}$ & Suftened Raw & 1.0E 01 \\
\hline 10 & Eye Wash Station & 244-AR & None & C-3 & Sanitary & $1.0 \mathrm{E}-03$ \\
\hline 11 & JCV Area Fl(x)r Drain & 244-AR & N/A & & Condensate & Terminated \\
\hline 12 & Stean Trap Drainage & $244-A R$ & & $A-4$ & Condensate & $10 E, 00$ \\
\hline 13 & TK .012 \& (x)4 Ileating Condensate & 244-AR & N/A & & Condensate & Terminated \\
\hline 14 & Waler Sofftening Regenerant & 244-AR & None & $C-3$ & Raw $|3|$ & $16 \mathrm{E}-01$ \\
\hline 15 & Backflusv Preventer Drain & 244-AR & None & C-3 & Raw & 2.0E-0H \\
\hline \multirow[t]{2}{*}{16} & Air Compressor Aftercouler $C(x) l u n g$ & 244-AR & $\begin{array}{l}\text { Replace once-through } \\
\text { cooling with closed - loop? }\end{array}$ & D-1 & Raw & o \\
\hline & & & & & & IOIAL. I 24E.UI \\
\hline
\end{tabular}

Source: IVIIC 1992a

NOT7:S:

[1] Source control options from Appendix B. Table B.1.

12] Average flow rate based on tutul anmual flow divsted by 526,000 minutes (1 year).

111 Calcium, Magnesium, and chlonde concentrations are increased to reflect anticipaled

concentrations resulting from the ivaler softenteing resin lind regenerdion process.

gpm $=$ galluns per minute

IIVAC = Heating, Ventulation, and Air Condutuming

JiV = Jet Gang Valve

$\mathrm{N} / \mathrm{A}=$ not applicalle 


\subsection{4-E POWER PLANT}

The following information is excerpted from WHC 1992a, Appendix B.3, Sections 4.3 and 5.3. Additional source controls plus in-plant treatment were selected as BAT/AKART for 284-E Powerplant Wastewater (WHC 1992a). This BAT/AKART determination includes installing flow and turbidity meters, two thickeners and sludge drying beds to treat the filter backwash, dual level control systems to prevent overflows, plugs or standpipes for the floor and trench drains and additional instrumentation to optimize backwashing. Clarified water will be recycled to the raw water reservoir.

All remaining sources will be discharged to the collection/disposal facility. Secondary waste sludge from the filter backwash will be disposed on the Hanford Site.

This selected alternative proposes to install a:1tomated level control to replace existing manual level control for the 282-E Reservir and 283-E Clearwell. Depending on filter solid loading, the backwash frequency $c y$ would be adjusted. The only water potentially discharging to the 216-B Ditch under tins alternative would be raw water. This would occur only in the unlikely event that the 282-E Reservoir level controls failed.

The floor and trench drains would continue 0 be administratively controlled to prevent spills from tntering the sewer system. The 284-E Powerplant cooling water, boiler blowdown, water softener regenerant and floor/trench drains shall be discharged to a collection/disposal facility.

The source control measures identified for the remaining waste water source are summarized in Table C-5. Figure C-7 shows the flow of effluent sources after the existing and additional source control measures have been implemented and technology transfer applied to the filter backwash source stream. The flow rates and concentrations will change as a consequence of implementing the source control measures. 


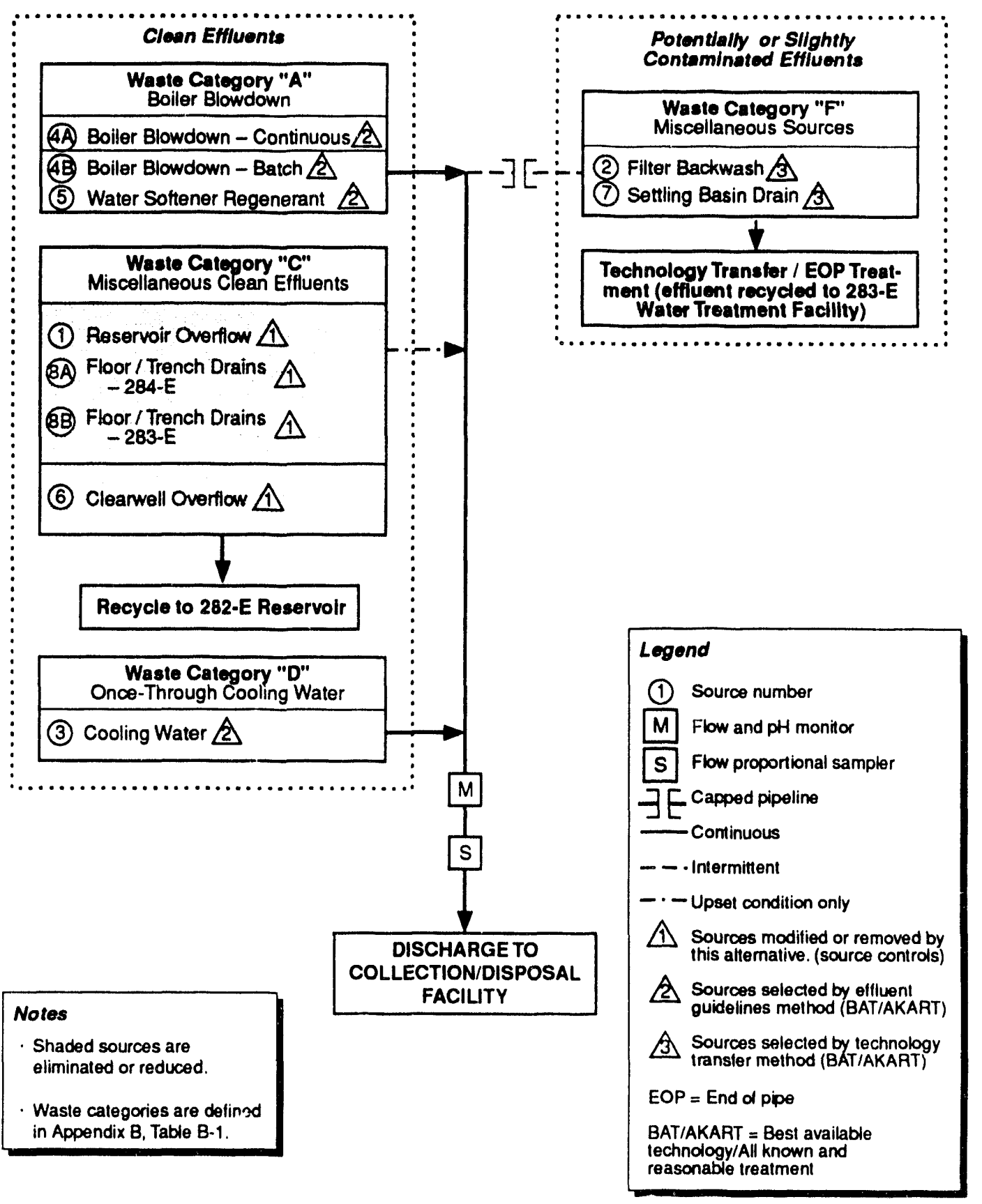

Source: WHC 1992a.

$9131728.013 / 46205 / 11-10-93$

Figure C-7. Selected Alternative: Flow Schematic for 284-E Powerplant After Applying Effluent Guidelines, Transfer Technology, Additional Source Controls With Discharge to Collection/Disposal Facility. 
TABL.E C-5. Selected Alternatives - Estimaled Effects of Technology Transfer, Source Controls at 284-E Power P'lant.

\begin{tabular}{|c|c|c|c|c|c|c|}
\hline $\begin{array}{l}\text { Source } \\
\text { No. }\end{array}$ & Source Stream & $\begin{array}{l}\text { Source } \\
\text { Building }\end{array}$ & $\begin{array}{c}\text { Source } \\
\text { Treatment } \\
\text { Measure }\end{array}$ & $\begin{array}{l}\text { Treatment or } \\
\text { Soruce Control } \\
\text { Alternate [1] }\end{array}$ & $\begin{array}{l}\text { Effluent } \\
\text { Water } \\
\text { Type }\end{array}$ & $\begin{array}{l}\text { Estimated } \\
\text { Resultimg liluw } \\
\text { Rate }(\mathrm{glm})|2|\end{array}$ \\
\hline 1 & Reservoir Overflow & 282-E & Auto Level Control & $\mathrm{C}-\mathrm{0}$ & Raw & $0.0 \mathrm{E}-1$ \\
\hline 2 & Filter Backwash & 283-E & $\begin{array}{c}\text { Tech. Transfer } \\
\text { Treatment }\end{array}$ & F-3 [3] & Sanitary & $0.00 \mathrm{E}+1$ \\
\hline 3 & Cooling Water & 284-E & None & $A-4[4]$ & Sanitary & $5.00 \mathrm{E}+1$ \\
\hline $4 A$ & Boiler Blowdown - continuous & 284-E & None & $A-4[4]$ & $6 \times$ Sanitary & $2.41 \mathrm{E}+1$ \\
\hline 4B & Boiler Blowdown - intermittent & 284-E & None & $A-4[4]$ & 6x Sanilary & $2.3 \mathrm{E}+0$ \\
\hline 5 & Water Softener Regenerant & 284-E & None & $A-4[4]$ & $36 \times$ Sanitary & $6.8 \mathrm{E}+0$ \\
\hline 6 & Clearwell Overflow & 283-E & Auto Level Control & $C-0$ & Sanitary & Negligible [5] \\
\hline 7 & Settling Basin Drain & 283-E & $\begin{array}{l}\text { Tech. Transfer } \\
\text { Treatment }\end{array}$ & F-3 [3] & Raw & Negligible [5] \\
\hline $8 A$ & Floor/Trench Drains & 284-E & Flow Regulation & $C-0$ & Raw & Negligible [5] \\
\hline \multirow[t]{2}{*}{$8 B$} & Floor/Trench Drains & 283-E & Flow Regulation & $C \cdot 0$ & Sanitary & Negligible [5] \\
\hline & & & & & & TOTAL $8.32 \mathrm{E}+1$ \\
\hline
\end{tabular}

Source: WIIC 1992a

NOTES:

[1] Source control options from Appendix B, Table B-1.

(2) Average flow rate based on total annual flow divided by 526,000 minutes (1 year)

3] Technology transfer.

[4] Effluent guidelines.

[5] Flow rate is less than $0.02 \mathrm{gpm}$.

gem = gallons per minute 


\subsection{B PLANT COOLING WATER}

The following information is excerpted from WHC 1992a, Appendix B.8, Sections 4.3 and 5.3. Source controls (non-contact, closed-loop cooling water system) were selected as BAT/AKART for the B Plant Cooling Water (WHC 1992a). The selection process evaluated two design heat load conditions, either 7,000,000 British Thermal Units per hour (Case A) or 25,000,000 British Thermal Units per hour (Case B). The only difference between the two cases is operation of the E-23-3 concentrator. The BAT / AKART selection was the same for both design heat loads. Based on current program information, the Case A operating condition was used for the anticipated design parameters and discussion in WHC 1992a.

The BAT/AKART source controls system includes a heat exchanger to transfer waste heat from a primary closed loop to a secondary loop with a wet cooling tower to dissipate waste heat. The cooling tower blowdown would be pumped to a collection/disposal facility for final disposal.

This selected alternative proposes to add a non-contact, closed-loop cooling water system to minimize water usage and to discharge the blowdown to a collection/disposal facility. A non-contact, closed-loop cooling water system would be provided by this alternative. As shown in Figure C-8, this cooling water system would use a heat exchanger to transfer waste heat from the primary closed loop to a secondary loop with a wet cooling tower to dissipate the waste heat. The blowdown from the cooling tower would be discharged to a collection/disposal facility. To minimize the impact on the collection/disposal facility, the cooling tower cycles would be limited to two. The amount of both the cooling tower makeup and blowdown are increased by reducing the cycles of concentration.

The primary and secondary loop flowrates were calculated based on the waste heat design loads for Cases A and B. All eight source streams, if active, could be handled by the closed-loop cooling water system, so that the B Plant effluent would only consist of cooling tower blowdown which would be a category E stream.

In Case $\mathrm{A}$, the primary closed-loop flowrate was assumed to be 1,300 gallons per minute with a heat load of 7,000,000 British Thermal Units per hour (both based on existing data); the resultant temperature rise in the primary cooling water loop is 11 degrees Fahrenheit. The operating temperatures of the primary cooling water loop are 79 degrees Fahrenheit ( 5 degrees Fahrenheit above the cold water temperature) and 90 degrees Fahrenheit (79 degrees Fahrenheit plus 11 degrees Fahrenheit). The secondary cooling water loop inlet temperature (74 degrees Fahrenheit) to the shell-and-tube heat exchanger was based on a 7 degrees Fahrenheit temperature approach (wet bulb 67 degrees Fahrenheit plus 7 degrees Fahrenheit) and the outlet temperature was set at 87 degrees Fahrenheit ( 3 degrees Fahrenheit below the primary cooling water inlet). The circulating water flowrate in the secondary loop of the non-contact cooling water system for Case A was then calculated to be 1,100 gallons per minute.

In Case B, the primary closed-loop maximum circulating water temperature was assumed at 95 degrees Fahrenheit (WHC 1992a) with a heat load of 25,000,000 British Thermal Units per hour. The maximum temperature rise of the primary cooling water 
1 loop was limited to 16 degrees Fahrenheit (95 degrees Fahrenheit to 79 degrees

Fahrenheit). The primary loop circulating water flowrate was then calculated to be 3,200 gallons per minute. The inlet temperature of the secondary cooling water loop to the shell and tube heat exchanger was 74 degrees Fahrenheit, and the outlet temperature was set at 92 degrees Fahrenheit ( 3 degrees Fahrenheit below the primary cooling water inlet). The circulating water flowrate in the secondary loop of the non-contact cooling water system for Case B was then calculated to be 2,800 gallons per minute.

The source control measures identified for the effluent B Plant cooling water sources are summarized in Tables C-6 and C-7. Figure C-9 shows the flow of effluent sources after the source control measure (a non-contact, closed-loop cooling tower) has been implemented. The non-contact, closed-loop cooling tower (see Figure C-8) would reduce the amount of cooling water, a desired goal, and the blowdown would be discharged to a collection/disposal facility. A new cooling tower would likely use sanitary water to reduce the concentration of suspended solids in the cooling tower. Sanitary water constituent concentrations will be multiplied by the cycles of concentration and used for water quality comparisons. 
DOE/RL-93-61, Rev. 0
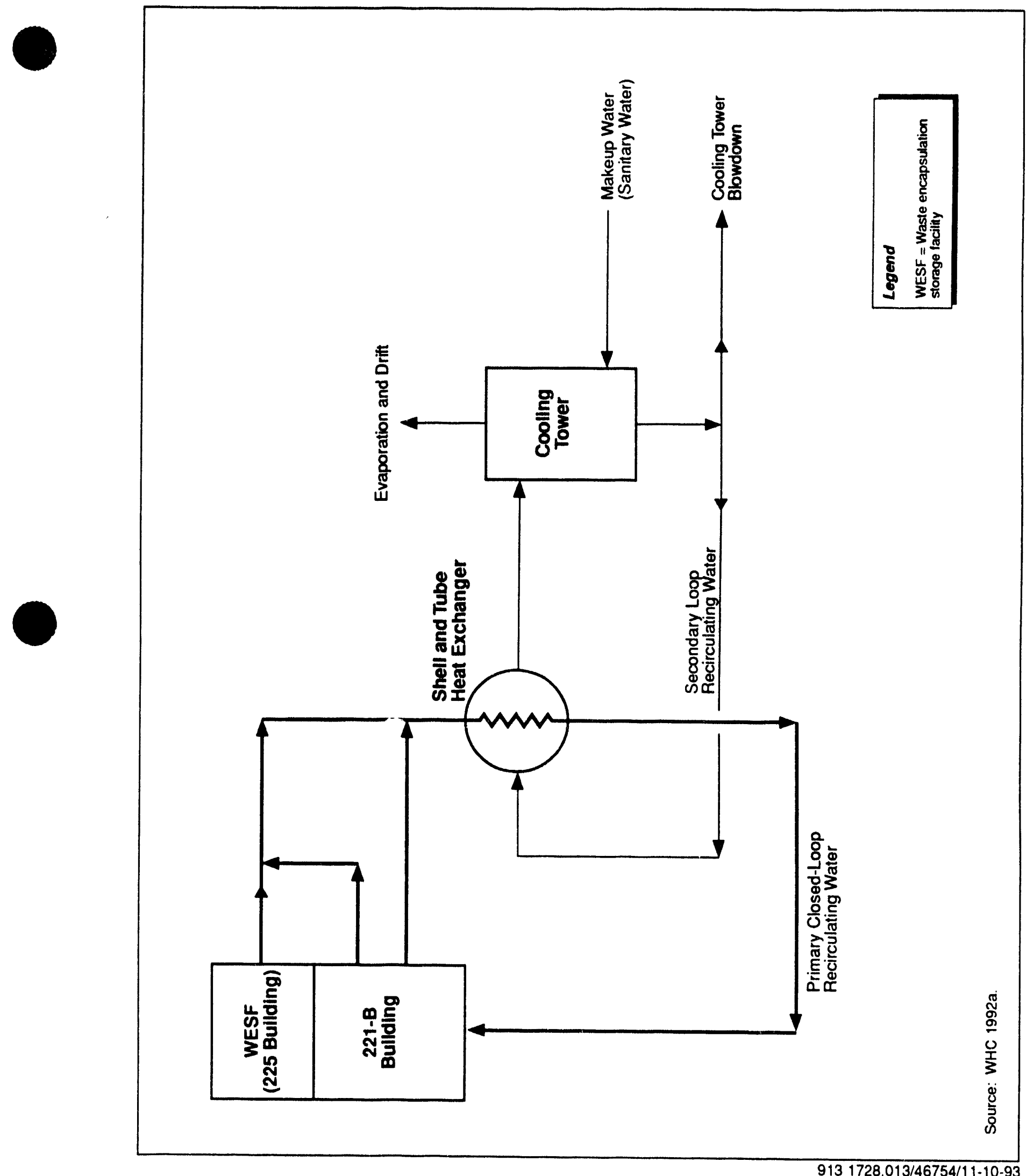

Figure C-8. Non-Contact Closed-Loop Designs Schematic for B Plant Cooling Water. 


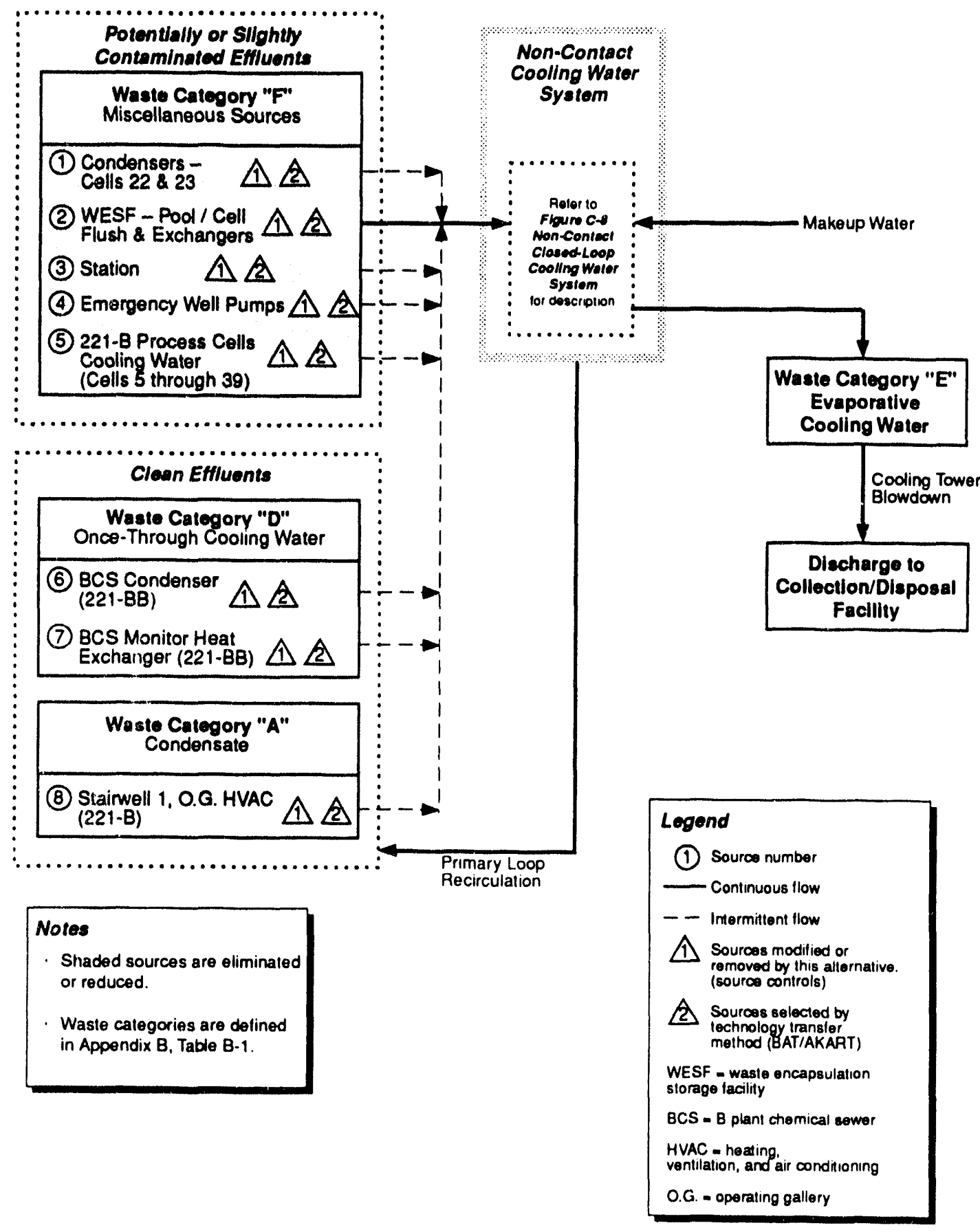

Source: WHC 1992a

$9131728.013 / 46207 / 11 \cdot 10-93$

Figure C-9. Selected Alternative: Flow Schematic of B Plant Cooling Water After Source Controls Collection/Disposal Facility Discharge. 
TABILE C-6. Selected Allernative: Fistimated Effects of B Plant Cooling Water Source Controls -

Collection/Disposal Facility Discharge - Case A

\begin{tabular}{|c|c|c|c|c|c|c|}
\hline $\begin{array}{l}\text { Source } \\
\text { No. }\end{array}$ & Source Stream & Source Builting & $\begin{array}{c}\text { Source } \\
\text { Treatment Material }\end{array}$ & $\begin{array}{l}\text { Treatment or } \\
\text { Source Control } \\
\text { Alternative [1] }\end{array}$ & $\begin{array}{l}\text { Fifluent } \\
\text { Type }\end{array}$ & $\begin{array}{c}\text { Estimated Resulting } \\
\text { Waslewater } \\
\text { Flow Rate ( }(\mathrm{gl})\end{array}$ \\
\hline 1 & Condensers Cesill $22 \& 23$ & $221-13$ & Suurce Control [2] & E-2 & Sanitary & - \\
\hline 2 & WESF-Pool Cell Flush \& Exchangers & 225-B & Source Control [2] & E-2 & Sanitary & 12.92 \\
\hline 3 & Cask Station & $212-B$ & Source Control [2] & E-2 & Sanitary & $\cdots$ \\
\hline 4 & Emergency Well l'umps & $282-B \& 282-B A$ & Source Control [2] & E-2 & Sanitary & 0.11 \\
\hline 5 & $\begin{array}{l}\text { 221-B-Process Cells Cooling Water } \\
\text { (Cells } 5 \text { through 39) }\end{array}$ & 221-B & Source Control [2] & E-2 & Sanitary & 0.96 \\
\hline 6 & BCS Condenser Catch Pan & 221-BB & Source Control [2] & E-2 & Sanitary & -- \\
\hline 7 & BCS Monitor Heat Exchanger & 221-BB & Source Control [2] & E-2 & Sanitary & - \\
\hline 8 & Stairwell 1, O.G. IVAC & 221-B & Source Control [2] & E-2 & Sanitary & 0.01 \\
\hline & & & & & TOTAL. & TOTAL 14.00 \\
\hline
\end{tabular}

Source: WHC 1992a

\section{NOTES:}

[1] Source control is non-contact closed-loop cooling water.

[2] Technology transfer.

gpm = gallons per minute

WESF $=$ Waste encapsulation Storage Facility

BCS $=$ B l'lant steam condensate

O.G. = Operating gallery

HVAC = Heating, Ventilation, and Air Conditioning 
TABIE: C-7. Selected Alternative: Estimated Effects of B Plant Cooling Water Source Controls Collection/Disposal Facility Discharge - Case B

\begin{tabular}{|c|c|c|c|c|c|c|}
\hline $\begin{array}{l}\text { Source } \\
\text { No. }\end{array}$ & Source Stream & Source Building & $\begin{array}{l}\text { Source } \\
\text { Treatment } \\
\text { Material }\end{array}$ & $\begin{array}{l}\text { Treatment or } \\
\text { Source Contro| } \\
\text { Alternative }|1|\end{array}$ & $\begin{array}{l}\text { I:ffluent } \\
\text { Type }\end{array}$ & $\begin{array}{c}\text { Estimated } \\
\text { Resulting } \\
\text { Wastewaler } \\
\text { Flow Rate (gpm) }\end{array}$ \\
\hline 1 & Conctensers Cells 22 and 23 & 221-B & $\begin{array}{l}\text { Source Control } \\
\qquad[2]\end{array}$ & E-2 & Sanitary & $35.00[3]$ \\
\hline 2 & $\begin{array}{l}\text { WESF-Pool Cell Flush and } \\
\text { Exchangers }\end{array}$ & $225-B$ & $\begin{array}{l}\text { Source Control } \\
\qquad[2]\end{array}$ & $\mathrm{E}-2$ & Sanitary & 12.92 \\
\hline 3 & Cask Station & $212-B$ & $\begin{array}{l}\text { Source Control } \\
\qquad[2]\end{array}$ & E-2 & Sanitary & -- \\
\hline 4 & Emergency Well Pumps & $282-B \& 282-B A$ & $\begin{array}{l}\text { Source Control } \\
\qquad[2]\end{array}$ & $\mathrm{E}-2$ & Sanilary & 0.11 \\
\hline 5 & $\begin{array}{l}\text { 221-B-Process Cells Cooling Water } \\
\text { (Cells } 5 \text { through 39) }\end{array}$ & $221-B$ & $\begin{array}{l}\text { Source Control } \\
\qquad[2]\end{array}$ & E-2 & Sanitary & 0.96 \\
\hline 6 & BCS Condenser & $221-B B$ & $\begin{array}{l}\text { Source Control } \\
\qquad[2]\end{array}$ & E-2 & Sanitary & $\cdots[3]$ \\
\hline 7 & BCS Monitor lleat Exchanger & 221-BB & $\begin{array}{l}\text { Source } C_{L} \ldots \text { rol } \\
{[2]}\end{array}$ & E-2 & Sanitary & $\cdots|3|$ \\
\hline \multirow[t]{2}{*}{8} & Stairwell 1, O.G. HVAC & $221-B$ & $\begin{array}{l}\text { Source Control } \\
\qquad[2]\end{array}$ & $\mathrm{E}-2$ & Sanitary & 0.01 \\
\hline & & & & & & TOIAI. 49.100 \\
\hline
\end{tabular}

Source: WHC 1992a

\section{NOTES:}

(1) Source control is non-contact closed-loop cooling water.

(2) Technology transfer.

[3] Combined flow from Sources 1, 6, and 7 .

gpm = gallons per minute

WESF = Waste Encapsulation Storage Facility 
5.0 IF PRODUCTION PROCESSES ARE SUBIECT TO SEASONAL VARIATIONS, PROVIDE THE FOLLOWING INFORMATION. WRITE "YES" FOR EACH MONTH WASTE STREAM IS PRODUCED.

None of the six streams are subject to seasonal variations, but some of the waste streams that form the six streams are subject to operational variations, which are described in Attachment B, Section 1.

\subsection{SHIFT INFORMATION}

\subsection{2-A EVAPORATOR COOLING WATER}

a. Number of shifts per work day:

b. Number of work days per week:

c. Average number of work days per year:

d. Maximum number of work days per year:

e. Number of employees per shift:

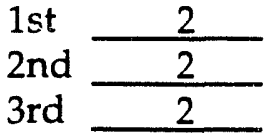

1 st 2nd 3rd

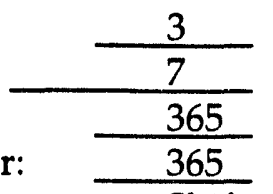
Shift start times

\subsection{2-A EVAPORATOR STEAM CONDENSATE}

a. Number of shifts per work day:

b. Number of work days per week:

c. Average number of work days per year:

d. Maximum number of work days per year:

e. Number of employees per shift:

\begin{tabular}{|c|c|c|}
\hline 2 & 1st & $7: 30 \mathrm{am}$ \\
\hline 2nd & 2nd & $3: 30 \mathrm{pm}$ \\
\hline 3 rd & $3 \mathrm{rd}$ & $11: 30 \mathrm{pm}$ \\
\hline
\end{tabular}

\subsection{1-A TANK FARM COOLING WATER}

a. Number of shifts per work day:

b. Number of work days per week:

c. Average number of work days per year:

d. Maximum number of work days per year:

e. Number of employees per shift:

\begin{tabular}{l}
$\frac{\frac{3}{7}}{\frac{365}{365}}$ \\
$\frac{365 i f t}{\text { Shift times }}$ \\
$\frac{7: 30 \mathrm{am}}{3: 30 \mathrm{pm}}$ \\
\hline $11: 30 \mathrm{pm}$ \\
\hline
\end{tabular}

$\begin{array}{ll}\text { 1st } & \frac{7: 30 \mathrm{am}}{2} \\ & \frac{3: 30 \mathrm{pm}}{11: 30 \mathrm{pm}}\end{array}$

Note: The first shift has 50 employees Monday through Friday and 15 employees on weekends and holidays. 


\subsection{4-AR VAULT COOLING WATER}

a. Number of shifts per work day:

b. Number of work days per week:

c. Average number of work days per year:

d. Maximum number of work days per year:

e. Number of employees per shift:

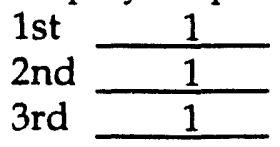

1 st

2nd

3rd

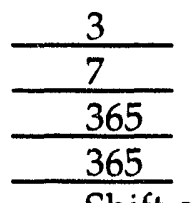

Shift start times

7:30 am

$3: 30 \mathrm{pm}$

$11: 30 \mathrm{pm}$

\subsection{4-E POWER PLANT}

a. Number of shifts per work day:

b. Number of work days per week:

c. Average number of work days per year:

d. Maximum number of work days per year:

e. Number of employees per shift:
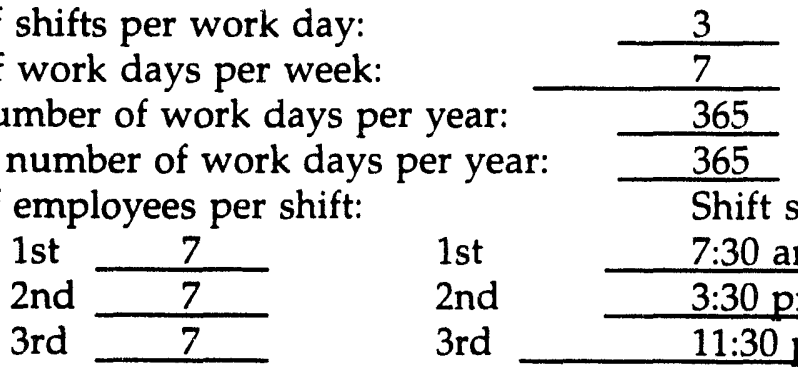

1 st

2nd

3rd

Shift start times $7: 30 \mathrm{am}$ $3: 30 \mathrm{pm}$ $11: 30 \mathrm{pm}$

Note: Monday through Friday, excluding holidays, 11 additional employees are present in the first shift.

\subsection{B PLANT COOLING WATER}

a. Number of shifts per work day:

b. Number of work days per week:

c. Average number of work days per year:

d. Maximum number of work days per year:

e. Number of employees per shift:
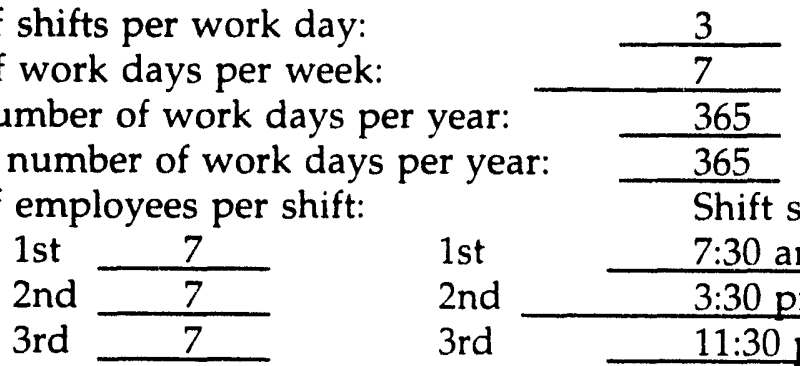

\begin{tabular}{ll} 
1st & $7: 30 \mathrm{am}$ \\
\cline { 2 - 2 } 3rd & $3: 30 \mathrm{pm}$ \\
\cline { 2 - 2 } & $11: 30 \mathrm{pm}$
\end{tabular}

Note: Monday through Friday, excluding holidays, 102 additional employees are present in the first shift. 
7.0 LIST ALL INCIDENTAL MATERIALS LIKE OI, PAINT, GREASE, SOLVENTS, SOAPS, CLEANERS, THAT ARE USED OR STORED ON-STTE. (USE ADDITIONAL SHEETS IF NECESSARY

Data for incidental materials is compiled from those items listed on the Hazardous Material Inventory Database maintained by WHC. Additionally, site checks of all material storage areas in the six facilities were conducted and any materials in containers 5 gallons or greater in size were included in the incidental materials list. Material/ Quantity stored for each waste stream area are listed below.

\subsection{2-A EVAPORATOR COOLING WATER}

Diesel Fuel/ 1000 gallons

Gas Mix, ARCH 4 90/10 (P-10)/470 cubic feet

Antifoam C-1/*

Antifoam $B(R)$ Silicone Emulsion ${ }^{*}$

Antifoam $10 /^{*}$

Unspecified corrosion inhibitor $/^{*}$

*Indicates none currently on site, but planned for use when facility is restarted.

\subsection{2-A EVAPORATOR STEAM CONDENSATE}

Diesel Fuel/ 1000 gallons

Gas Mix, ARCH 4 90/10 (P-10)/ 470 cubic feet

Antifoam $\mathrm{C}-1{ }^{*}$

Antifoam $B(R)$ Silicone Emulsion ${ }^{*}$

Antifoam 10/*

Unspecified corrosion inhibitor/*

*Indicates none currently on site, but planned for use when facility is restarted.

\subsection{1-A TANK FARM COOLING WATER}

Rubinate/ 55 gallons

Gas Mix, ARCH 4 90/10 (P-10)/ 470 cubic feet

Aerospray 70A Binder, American Cyanamid/ $<1$ gallon

Amercoat 187/ <1 gallon

BWE 3000/ 55 gallons

Dow Corning 3-5000/ 220 gallons

Isocyanate / $<1$ gallon

Methynol/ 110 gallons

Polyol Resin Component B / <1 gallon

Super Stripe Traffic Paint, Yellow TY13/ 1788 ounces

Turco Decon 4521/ 110 gallons. 


\subsection{4-AR VAULT COOLING WATER}

Diesel Fuel/ 530 gallons

Glycol /*

*Glycol is not stored at the 244-AR Vault facility, but glycol is stored in a nearby material shed for makeup to the primary compressor glycol cooling system.

\subsection{4-E POWER PLANT}

Dearborn Code 267/ 2 ounces

Dearborn Code 516/ 8 ounces

Dearborn Code 519/ 40 ounces

Dearborn Code 529/ 37 ounces

Dearborn Code 533/ 1 ounce

Dearborn Code 535/ 58 ounces

Dearborn Code 552/ 32 ounces

Dearborn Code 555/ 192 ounces

Dearborn Code 567/ 117 ounces

Dearborn Code 570/ 100 ounces

Dearborn Code 571/ 16 ounces

Dearborn Code 572/ 32 ounces

Dearborn Code 575/ 184 ounces

Dearborn Code 597/ 128 ounces

Dearborn Code 602/ 1 ounce

Dearborn Code 610/ <1 ounce

Chlorine/ 1549 liters

Acetylene/ 390 cubic feet

Air/ 233 cubic feet

Argon/ 1695 cubic feet

Nitrogen/ $<1$ cubic foot

Oxygen/ 1410 cubic feet

Propane/ 239 cubic feet

Sodium Chloride/ 77968 liters

\subsection{B PLANT COOLING WATER}

See the attached list from the Hazardous Material Inventory Database operated by Westinghouse Hanford Company (WHC). 
mazaroOUS MAIERIAL IIVEETORY OATABASE

\section{$-$ \\ Report ? GEMERAIE DAIA COLECTION TORHS \\ rllename \& ни102224.118 \\ Run by 2 opssualser}

Report Dete: 05/25/93 09:17m

@ู

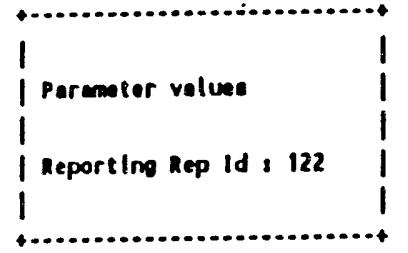


Rep Id 122 . DUPAOULER JAHES $C_{2}$

$$
\text { Date collectlon form }
$$

\begin{tabular}{|c|c|c|c|c|c|c|c|c|c|c|c|c|}
\hline Paclller $i$ & $\begin{array}{l}\text { Rep } \\
\text { loc }\end{array}$ & $\begin{array}{l}\text { Datolled } \\
\text { location }\end{array}$ & MSOS & Neme & Local keme & Cninr size von & Contalner Irpe & Im Id & $\begin{array}{l}\text { Provlous } \\
\text { aunilley voy }\end{array}$ & oty & vom & $\begin{array}{l}\text { oty } \\
\text { Uned }\end{array}$ \\
\hline \multirow[t]{3}{*}{2728} & ESHP & & 11236 & $\begin{array}{l}\text { GSI-112 ALL PURPOSE } \\
\text { CLEAMER }\end{array}$ & $\begin{array}{l}\text { GSI III ALL } \\
\text { PURPOSE }\end{array}$ & I ar & $\begin{array}{l}\text { PLASIIC sotriles } \\
\text { OR JUGS }\end{array}$ & 3773 & o or & $\ldots$ & 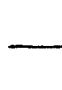 & _ \\
\hline & & & 1649 & PROPANE & $\begin{array}{l}\text { PROPAME - } \\
\text { IURMER }\end{array}$ & 14.1 y102 & CrLIMDER & 3774 & O YIOL & _ & . & \\
\hline & & & 1649 & propane & PROPAME fUEL & 16.1 v102 & CrLIROER & $3 m 2$ & o uroz & & & \\
\hline
\end{tabular}


Rep 1d: 123, DUPAOUIER, IANES C. Dete collection form

Contacts HERBESL SHLIH

\begin{tabular}{|c|c|c|c|c|c|c|c|c|c|c|c|c|}
\hline facllley & $\begin{array}{l}\text { Rep } \\
\text { loc }\end{array}$ & $\begin{array}{l}\text { Delalled } \\
\text { Location }\end{array}$ & MSOS & $M=m$ & local Nemen & Cntnr s12e vor & Contelner Inpe & Imv id & $\begin{array}{l}\text { Prevlous } \\
\text { ounentlty von }\end{array}$ & oty & vor & $\begin{array}{l}\text { oty } \\
\text { Uoed }\end{array}$ \\
\hline $2 \pi 18$ & 11SHP & INSIRUMENI SHOR & 11621 & $\begin{array}{l}\text { ANII-SIAIIC QUIK-FAEERE. } \\
\text { MS-260AS }\end{array}$ & $\begin{array}{l}\text { ANII-SIATIC } \\
\text { CUICK-FR }\end{array}$ & 1 las & can & 323 & o los & 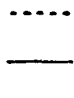 & 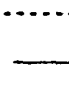 & - \\
\hline
\end{tabular}


Rep Id: 123 , DUPAOUIER_L JMESSC,

$$
\text { Dete Collection forn }
$$

contect: LL YABAUHSEE

\begin{tabular}{|c|c|c|c|c|c|c|c|c|c|c|c|c|}
\hline reclller & $\begin{array}{l}\text { Rep } \\
\text { Loc }\end{array}$ & $\begin{array}{l}\text { Detalled } \\
\text { locatlon }\end{array}$ & MSOS & Mamo & Locel Niem & Cnter slze von & Contaliner Irpe & $\begin{array}{l}\text { Iose } \\
\text { Inv id }\end{array}$ & $\begin{array}{l}\text { Prevlous } \\
\text { owentley uan }\end{array}$ & oir & von & $\begin{array}{l}\text { oty } \\
\text { Used }\end{array}$ \\
\hline \multirow{7}{*}{ 2258 } & 2ANes & 2258 & 1329 & MEIHAMOL & MEIMANOL & s GAL & cAn & 276 & $5 \mathrm{GAL}$ & & & \\
\hline & & & 2039 & PETRoLein ETHER & PEIROLEUN ETHER & $5 \mathrm{Gal}$ & CAN & $2 n 0$ & $.25 \mathrm{GAL}$ & & & \\
\hline & & & 1105 & SOOILA HYDROXIDE, $100 X$ & $\begin{array}{l}\text { SOOIUH } \\
\text { MYOROXIDE }\end{array}$ & $5.5 \mathrm{las}$ & ING & 201 & 10 LES & & & \\
\hline & & & 1506 & SOOILM MIIRAIE & $\begin{array}{l}\text { SOOILA } \\
\text { MITRAIE }\end{array}$ & 32 Los & Ma & 283 & 15 LAS & - & $\ldots$ & 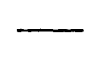 \\
\hline & & & 20038 & IAR-GOW & IAR-CON & $20 \mathrm{Gul}$ & SIEEL DRLW & 293 & $20 \mathrm{GAL}$ & - & - & _ \\
\hline & & & $36 \pi 0$ & $\begin{array}{l}\text { IAISOOIUA PHOSPHAIE } \\
\text { DCDECAHTDRAIE }\end{array}$ & $\begin{array}{l}\text { IRISOOIUN } \\
\text { PHOSPHAIE }\end{array}$ & 100 LAs & Ino & 296 & 200 L8S & 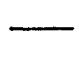 & ـ & - \\
\hline & & & 16360 & IERACOL & SOLVEMT ALCOHOL & S call & CAN & 298 & $10 \mathrm{GAL}$ & & & \\
\hline
\end{tabular}


$05 / 25 / 93$

haZARDOUS MUIERIAL IMVEMTOAY DATABASE

Rep 1d: 122 . QUPAOUIER, JAMES $C$,

$$
\text { Date Collection form }
$$

contecel diln payts

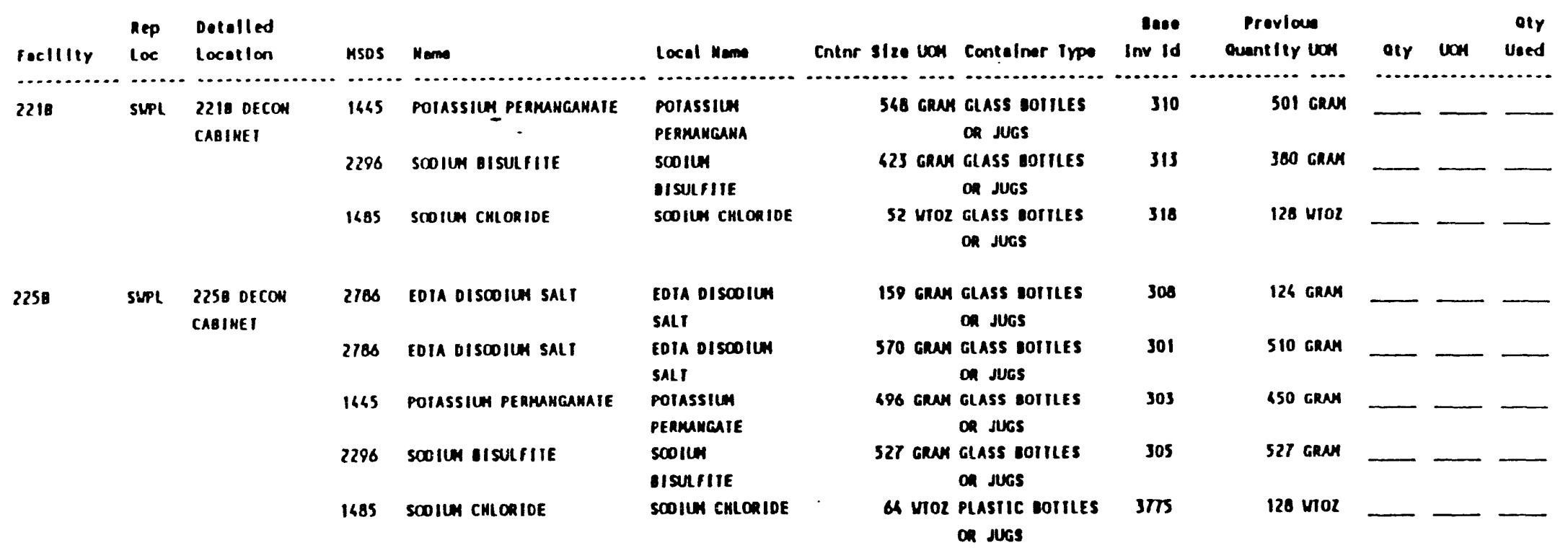

on Jugs 
Rep Id: 123, DUPAOUIER, JMMES $C_{2}$

$$
\text { Dete collectlon form }
$$

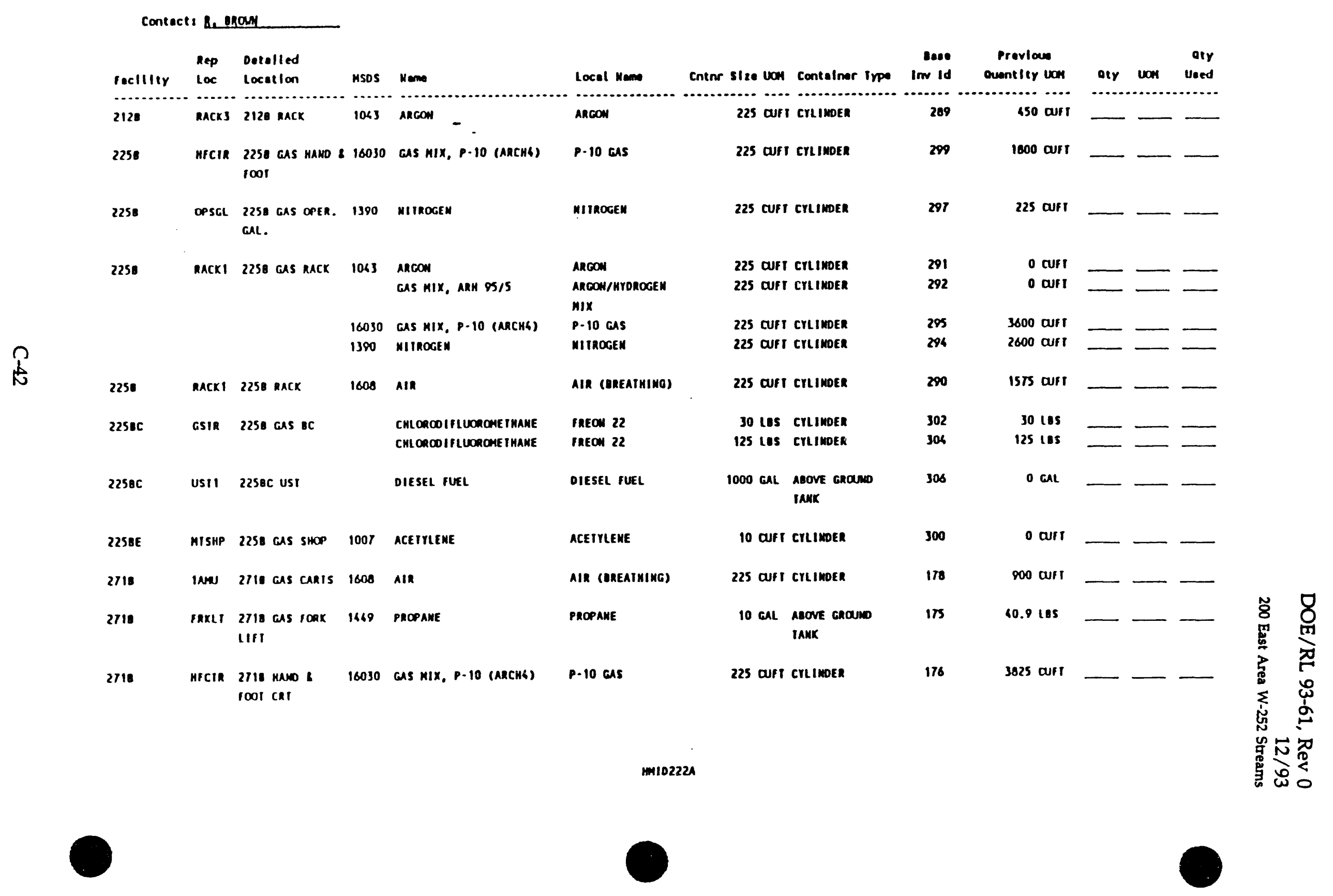




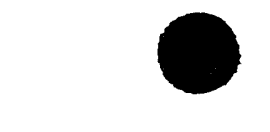

$05 / 25 / 93$

MAIAROOUS MUIERIAL IUVEMTORT OATABASE

Rep Id: 123 . pUPROUIER. JNAES C.

$$
\text { Dete collection rora }
$$

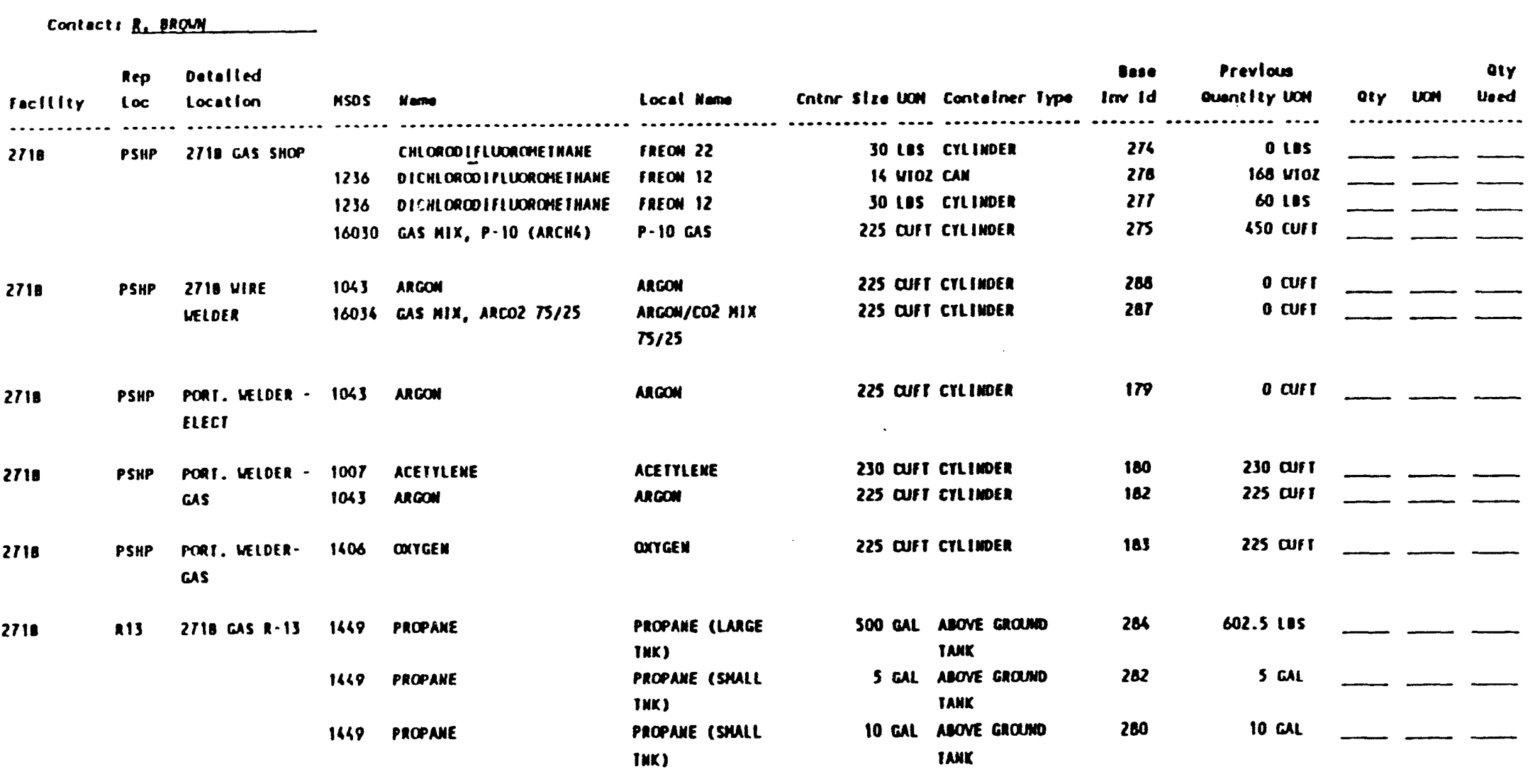


Rep 1d: 122 . DUPAOUIER JMAES $C_{2}$

$$
\text { Data Colloction form }
$$

Contect! be Bgons

\begin{tabular}{|c|c|c|c|c|c|c|c|c|c|c|c|c|}
\hline facllley & $\begin{array}{l}\text { Rep } \\
\text { Loc }\end{array}$ & $\begin{array}{l}\text { Dotalled } \\
\text { Locetion }\end{array}$ & HSOS & Nemo & Local nam & Cnenr slze von & Conteliner Irpe & $\begin{array}{l}\text { Dose } \\
\text { Inv Id }\end{array}$ & $\begin{array}{l}\text { Provlous } \\
\text { anent ley uan }\end{array}$ & oiy & von & $\begin{array}{r}\text { oty } \\
\text { Ueed }\end{array}$ \\
\hline \multirow{12}{*}{2718} & ........ & 2Z18 as Rack & 1007 & ACEIYLENE & ACEITLEME & 10 ars & CrIUDER & 109 & 30 aff I & & & \\
\hline & RACKL & C2IS WAS RACK & 1000 & ACE MUERE & ACETIIETLE & & & 270 & 10 curt & & & \\
\hline & & & 1007 & ACE IYLEME & ACEITLENE & $10 \mathrm{curt}$ & CrLIMDER & 180 & 200 Cuf I & & & \\
\hline & & & 1007 & ACEIrLEME & ACEIrLEME & 230 Cuft & CYLIMDER & 185 & sm curl & & & \\
\hline & & & 1008 & $A \mid R$ & AIR (BREATMIMG) & 225 Cuf I & CrLIMOER & 186 & 1600 cuf I & & & \\
\hline & & & 1043 & ARGON & ARCOM & 225 CUF I & Cri INOER & 107 & I350 art & & & \\
\hline & & & 1095 & CARBOW DIOXIDE & CARBOW DIOXIDE & 225 Cuf I & CrLINDER & 191 & 450 aff & - & $\ldots$ & \\
\hline & & & 16036 & GAS MIX, ARCO2 $75 / 25$ & $\begin{array}{l}\text { ARCON/CO2-MIX } \\
\text { ARCO }\end{array}$ & 225 Cff I & CrLIMDER & 190 & 450 Cuf & & & \\
\hline & & & 16030 & GAS $M 1 X, P-10$ (ARCHG) & p-10 GAS & 225 aff I & CrLIMDER & 194 & ISTs art & - & $\ldots$ & - \\
\hline & & & 1390 & MIIROCEN & $\begin{array}{l}\text { MITROGEM } \\
\text { OXYGEM }\end{array}$ & 225 aff & Crlineen & $\begin{array}{l}192 \\
193\end{array}$ & $\begin{array}{l}225 \text { arf } \\
2025 \text { arf }\end{array}$ & & & \\
\hline & & & 1649 & PROPAME & PROPAME & $5 \mathrm{Gal}$ & CYLIMOER & 197 & $10 \mathrm{cll}$ & & - & - \\
\hline & & & 1669 & propane & PRCPAME & $10 \mathrm{cal}$ & CrLINDER & $\begin{array}{l}196 \\
198\end{array}$ & $\begin{array}{l}10 \mathrm{cAl} \\
336 \mathrm{vIOZ}\end{array}$ & & & \\
\hline 2718 & eucx & GAS EURMIKG & 1007 & ACETIYLNE & & 230 cuft & CrLIIDER & irs & 230 auf & & & \\
\hline & & CART & 1606 & OXYGEM & & 225 art & CYLIDEE & 174 & 225 aff T & & & \\
\hline 2828 & 12028 & 2258 IAMK 2828 & & DIESEL IUEL & DIESEL FUEL & $200 \mathrm{GAL}$ & $\begin{array}{l}\text { ABOVE GaOAno } \\
\text { IANK }\end{array}$ & 309 & $150 \mathrm{cal}$ & & & \\
\hline $2828 A$ & $1828 A$ & $\begin{array}{l}225 \cdot \text { tAMK } 202 \\
81\end{array}$ & & DIESEL IUEL & DIESEL IUEL & $250 \mathrm{CAl}$ & $\begin{array}{l}\text { asove caone } \\
\text { Inik }\end{array}$ & 307 & $187.5 \mathrm{cal}$ & & & \\
\hline
\end{tabular}




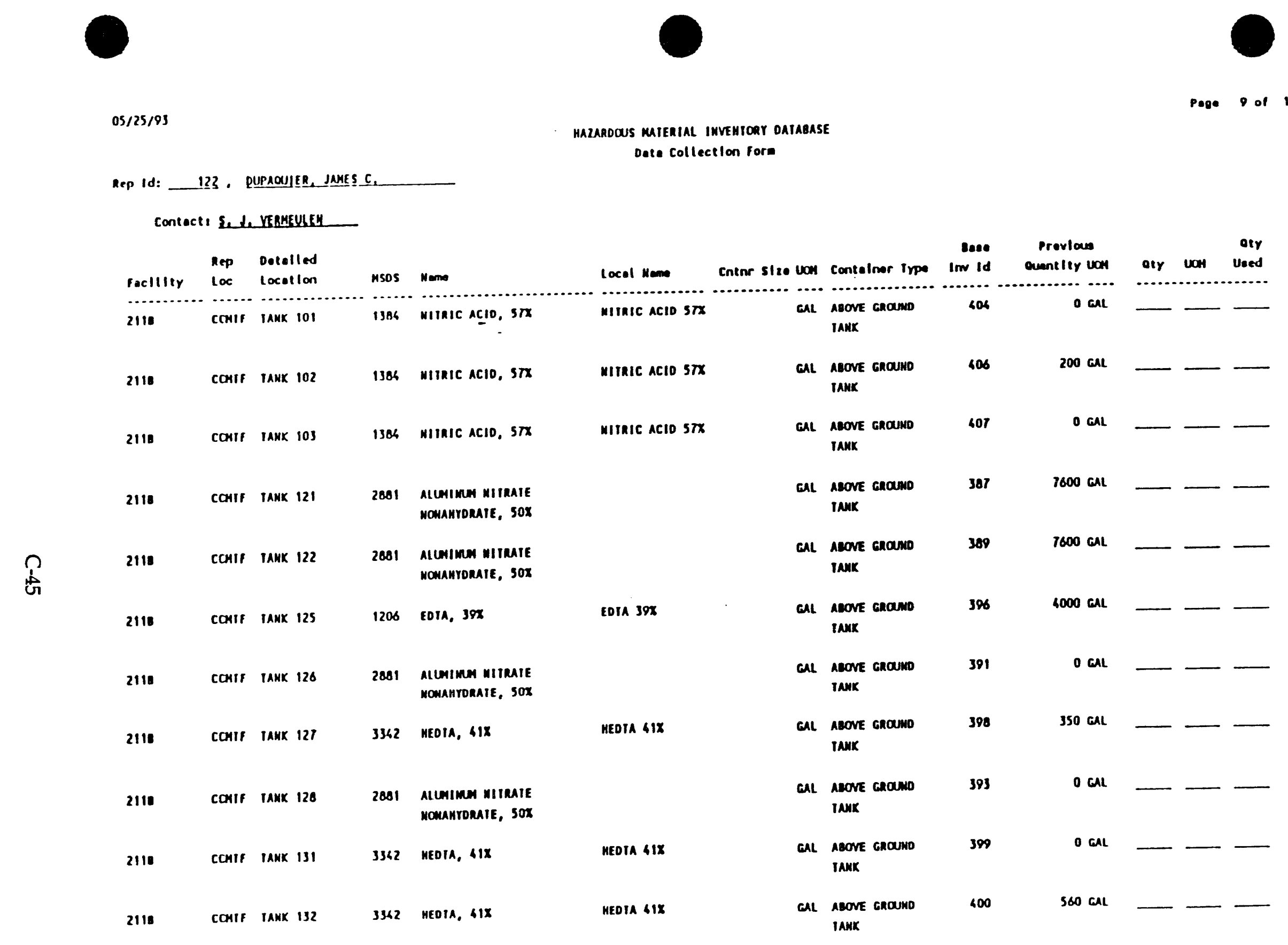




\section{HAZARDOUS MUIERIAL IMVEMTORY DATAOASE}

Dele collection fora

Rep Id: 123 . OUPAOUIER, JAMES $C_{2}$

Contect1 s, L. VERMEULEM

\begin{tabular}{|c|c|c|c|c|c|c|c|c|c|c|c|}
\hline recllley & $\begin{array}{l}\text { Rep } \\
\text { loc }\end{array}$ & $\begin{array}{l}\text { Detulled } \\
\text { locotion }\end{array}$ & HSOS & nemen & Locel neme & Cnters stee von & Contelner Iype & Inv Id & $\begin{array}{l}\text { Prevlowa } \\
\text { Quentity uon }\end{array}$ & aty & von \\
\hline 2118 & conif & IANK iss & $33<2$ & MEOIA, b|X & MEDIA GIX & oul & $\begin{array}{l}\text { MLOVE GROUNO } \\
\text { IANK }\end{array}$ & 601 & $3600 \mathrm{chl}$ & 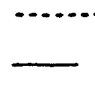 & \\
\hline 2111 & conif & IANK 161 & 1105 & SCOIUA YYDROXIOE, SOX & $\begin{array}{l}\text { soolun } \\
\text { nronoxioe sox }\end{array}$ & ouL & $\begin{array}{l}\text { ABOVE GROND } \\
\text { TANK }\end{array}$ & $\$ 12$ & $250 \mathrm{GAL}$ & & \\
\hline 2118 & CCMIF & IAKK 162 & 1105 & SCOILM HYOROXIOE, SOX & $\begin{array}{l}\text { SOOIUA } \\
\text { MYDROXIDE SOX }\end{array}$ & onL & $\begin{array}{l}\text { ABOVE GROWNO } \\
\text { JAMK }\end{array}$ & 415 & $250 \mathrm{cAl}$ & & \\
\hline 2110 & CONIf & IANK 163 & 1105 & SCOILA MYOROXIDE, SOX & $\begin{array}{l}\text { SOOILM } \\
\text { MYOROXIDE } 50 X\end{array}$ & oAl & $\begin{array}{l}\text { ABOVE GROUND } \\
\text { IAMK }\end{array}$ & 617 & $13000 \mathrm{cAl}$ & 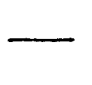 & \\
\hline 2120 & cosin & 2120 & 18237 & CLEAM UP IV & CLEAMUP IV & Les & 120 & $3 n$ & $600 \mathrm{lBS}$ & {[} & _. \\
\hline $21 \pi 8$ & GSIR & DEMIMERALIIER & 1520 & serfunic ACIO, 93X & $\begin{array}{l}\text { serfunic AcID. } \\
\text { 93x }\end{array}$ & $55 \mathrm{cal}$ & $\begin{array}{l}\text { MOU MEIALLIC } \\
\text { DRUA }\end{array}$ & 370 & $220 \mathrm{GAL}$ & . & \\
\hline 225BE & MS & $\begin{array}{l}\text { MORIHSIDE/FINA } \\
\text { CABS }\end{array}$ & $1823 r$ & CIEAM UP IV & CLEAHUP IV & $5 \mathrm{chl}$ & CAM & 445 & $25 \mathrm{Gal}$ & 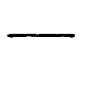 & 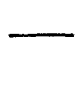 \\
\hline 27158 & PISIR & PAIKI STORAGE & 10237 & CLEAM UP IV & CLEAMUP IV & $5 \mathrm{GAL}$ & DAG & 43 & $25 \mathrm{GAL}$ & - & \\
\hline 2710 & INA & SW CORMER & 10237 & CLEAM UP IV & CLEAMP IV & s all & CAM & 439 & $25 \mathrm{cll}$ & & \\
\hline
\end{tabular}


$05 / 25 / 93$

MaZnNoOUS MATERIAL InVEMTORY DATAEASE

Dete Collection form

Rep Id: 122, PUPAOUIER JWAES C.

Contocts sete renafulay

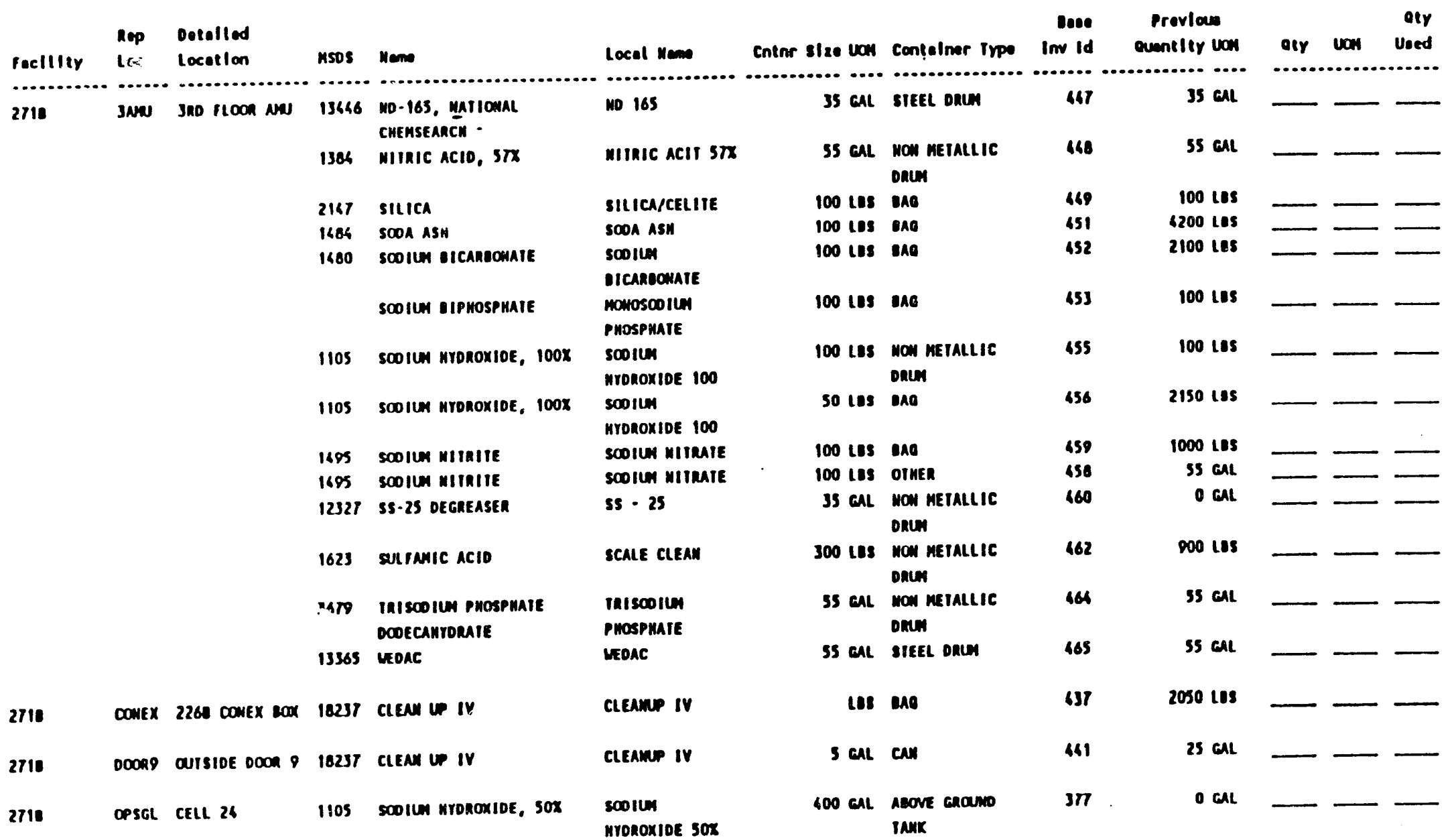


Rep Idt 122, pUPAOUIFR. dNAES C.

$$
\text { Date collection form }
$$

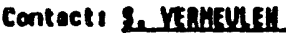

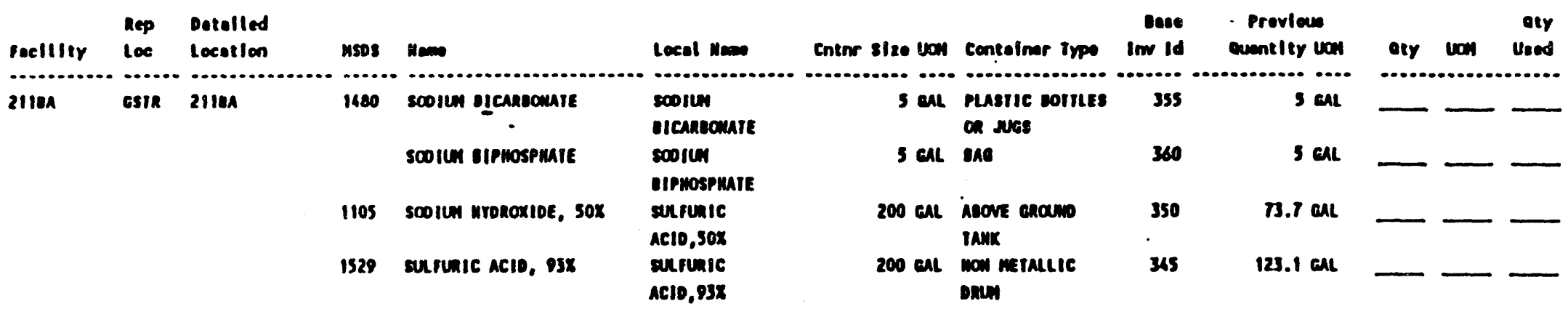




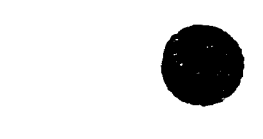

$05 / 25 / 93$

MAZARDOWS MATERIAL IUVENTOAY DATABASE

Dete collection form

Rep Idt 123 . pupsoulEg. JaMke C.

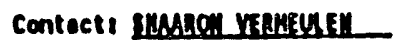

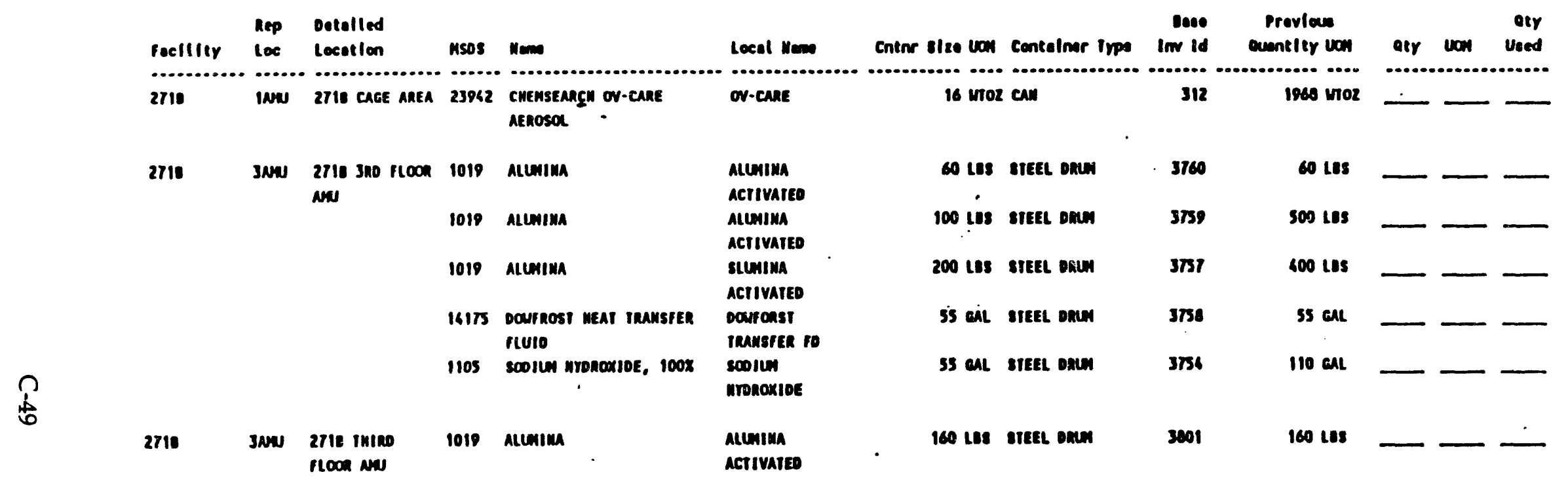


Rep Idt 122 - PUPAOUIER, dNAES C.

Dota collectlon form

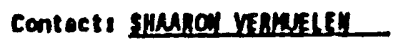

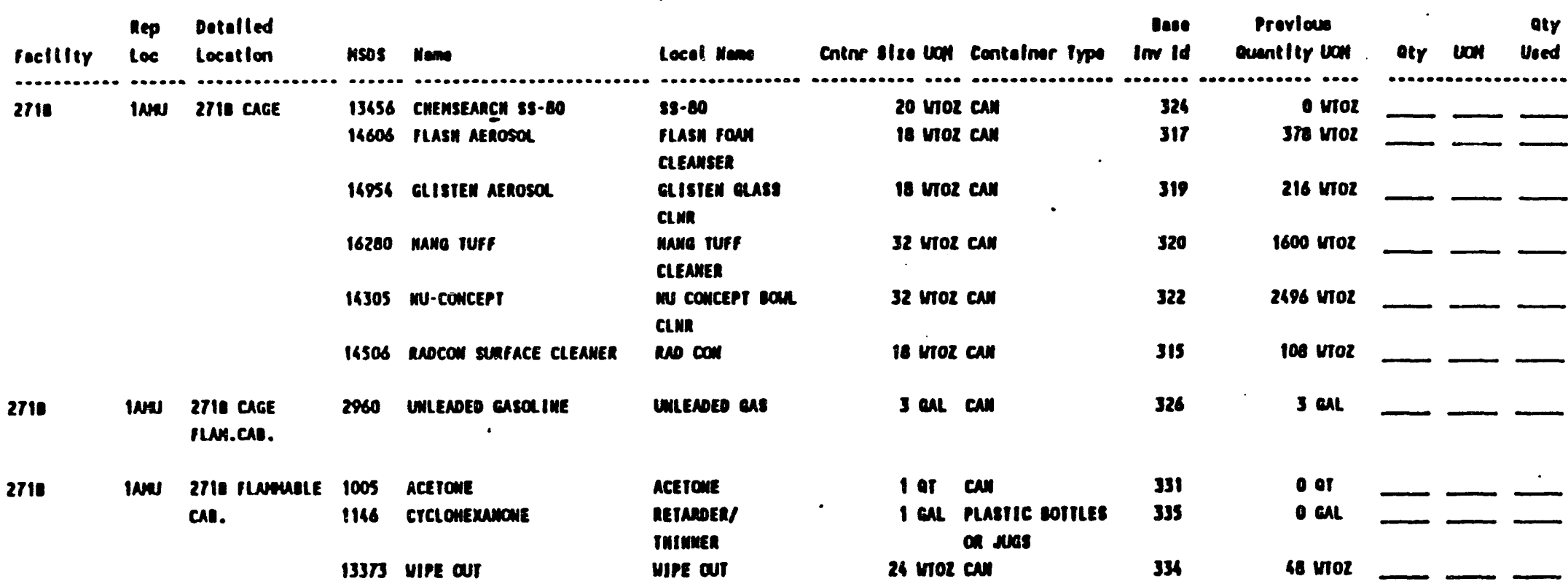

m10222a 
Rep Idt 122. PUPAOUIER. ANMES $C_{2}$

MAZARDOUS MATERLAL IUVENIOAY DATADASE

$$
\text { Dete collectlon fora }
$$

\section{Contects SHMROH Vegherstell}

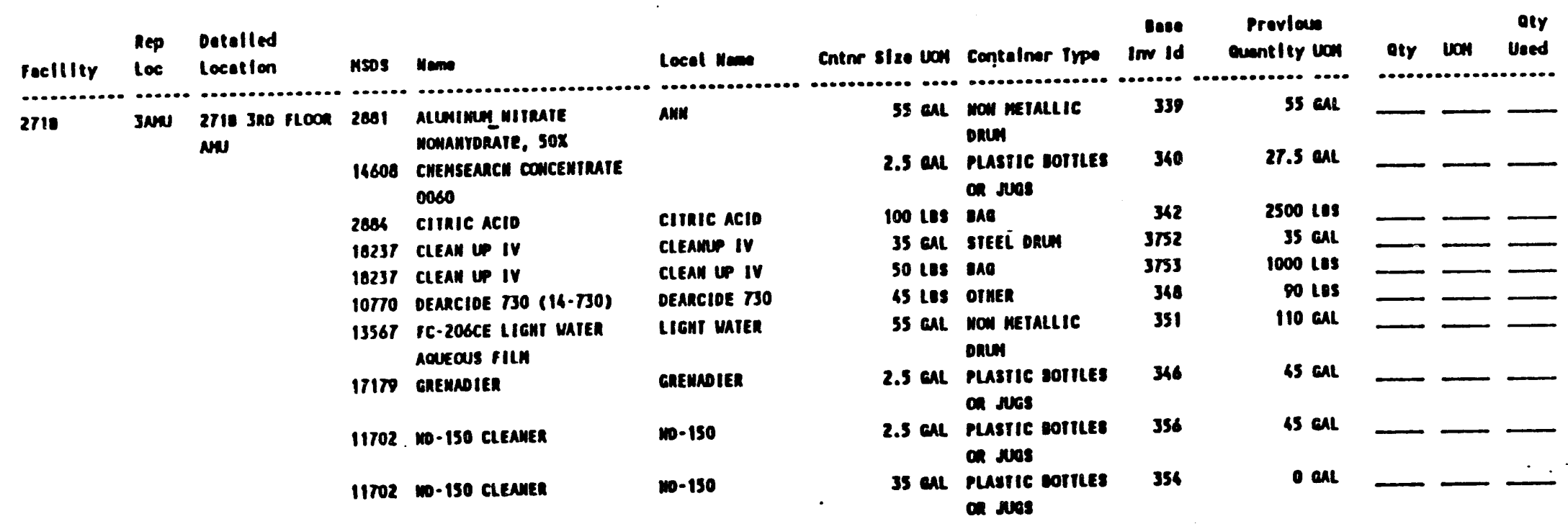




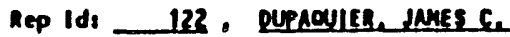

$$
\text { Dete collection form }
$$

Coneseti In voos

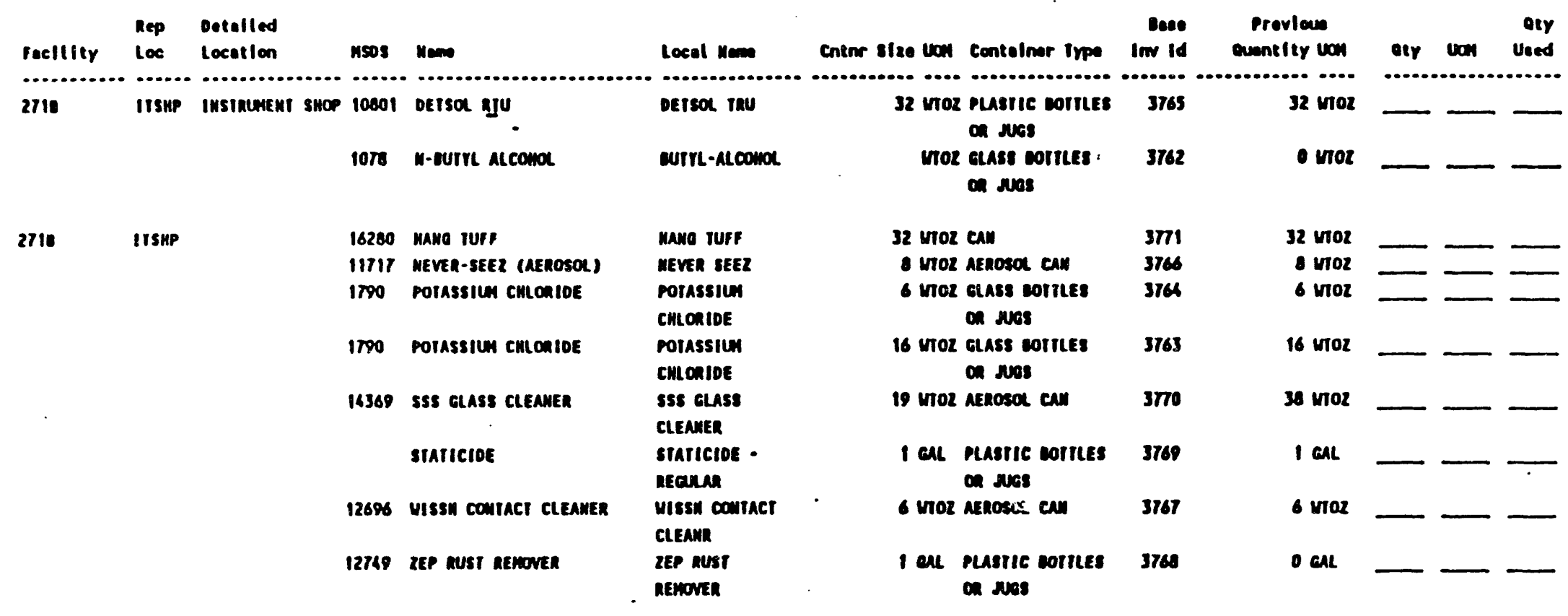


MAZAROOUS MATERIAL INVENTOAT DATABASE

Date collection form

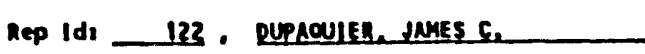

Contoct: SIAL JOWFE

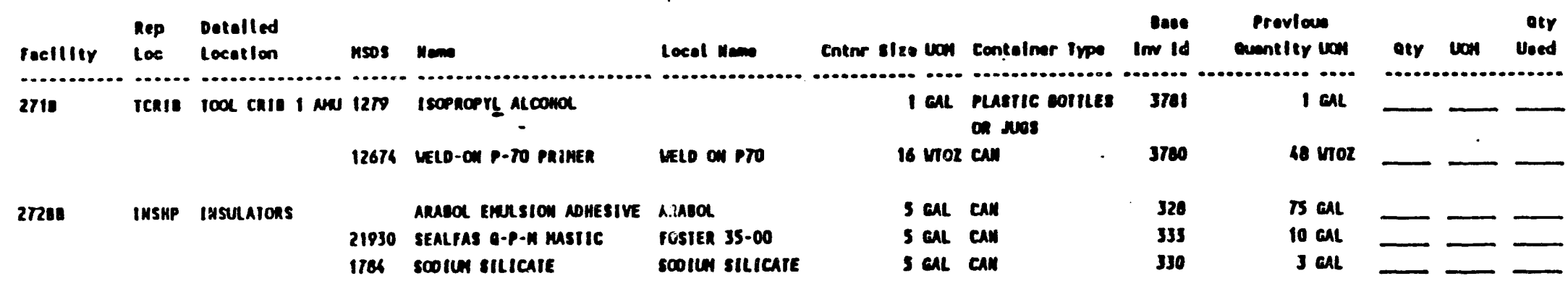


DOE/RL 93-61, Rev 0

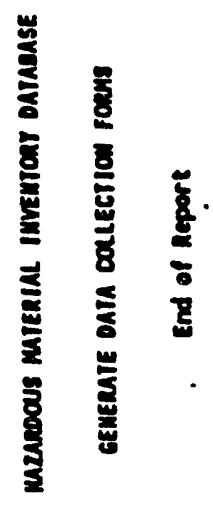

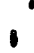




\subsection{DESCRIBE ANY WATER RECYCLING OR MATERIAL RECLAIMING PROCESSES.}

There are presently no water recycling or material reclaiming processes related to any of the six facility waste streams.

\subsection{DOES THIS FACILTTY HAVE:}

Spill Control and Containment Plan (per 40 CFR 112)

Emergency Response Plan (per WAC 173-303-350)

Runoff, spillage, or leak control plan (per WAC 173-216-110(f))

\begin{tabular}{c} 
Yes \\
$\bar{X}$ Yes \\
\hline$X$ Yes
\end{tabular}

$\underline{X}$ No

10

11

12

13

14

15

Notes: - This response applies to all six facilities.

- A Spill Control and Containment Plan (per 40 CFR 112) is being developed for the 200 Areas at this time by WHC.

16 
DOE/RL 93-61, Rev 0

$12 / 93$

200 East Area W-252 Streams

This page intentionally left blank.

C-56 
DOE/RL 93-61, Rev 0 $12 / 93$

200 East Area W-252 Streams

\section{APPENDIX D}

\section{WATER CONSUMPTION AND WATER LOSS}


DOE/RL 93-61, Rev 0

$12 / 93$

200 Eas! Area W-252 Streams

This page intentionally left blank.

D-ii 


\section{CONTENTS}

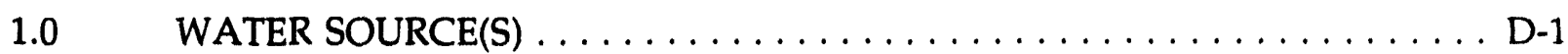

1.1242 -A EVAPORATOR COOLING WATER .............. D-1

1.2 242-A EVAPORATOR STEAM CONDENSATE . . . . . . . . . D-1

1.3241 -A TANK FARM COOLING WATER .............. D-1

1.4 244-AR VAULT COOLING WATER $\ldots \ldots \ldots \ldots \ldots \ldots \ldots \ldots \ldots \ldots$ D-2

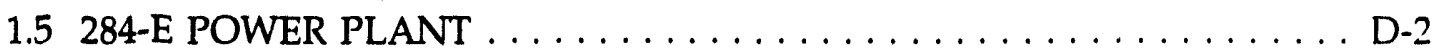

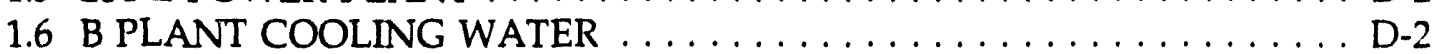

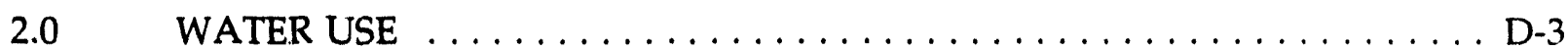

2.1242 -A EVAPORATOR COOLING WATER $\ldots \ldots \ldots \ldots \ldots \ldots \ldots$ D-3

2.2242 -A EVAPORATOR STEAM CONDENSATE $\ldots \ldots \ldots \ldots \ldots \ldots$ D-3

2.3241 -A TANK FARM COOLING WATER .............. D-3

2.4244 -AR VAULT COOLING WATER $\ldots \ldots \ldots \ldots \ldots \ldots \ldots \ldots$ D-4

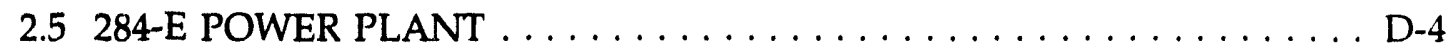

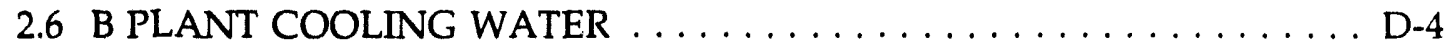

3.0 ATTACH A LINE DRAWING SHOWING THE WATER FLOW THROUGH THE FACILITY. INDICATE SOURCE OF INTAKE WATER, OPERATIONS CONTRIBUTING WASTE WATER TO THE EFFLUENT, AND TREATMENT UNITS LABELED TO CORRESPOND TO THE MORE DETAILED DESCRIPTIONS IN ITEM C. CONSTRUCT A WATER BALANCE ON THE LINE DRAWING SHOWING AVERAGE FLOWS BETWEEN INTAKES, OPERATIONS, TREATMENT UNITS, AND OUTFALLS. IF A WATER BALANCE CANNOT BE DETERMINED (E.G., FOR CERTAIN MINING ACTIVITIES), PROVIDE A PICTORIAL DESCRIPTION OF THE NATURE AND AMOUNT OF ANY SOURCES OF WATER AND ANY COLLECTION OR TREATMENT MEASURES 
DOE/RL 93-61, Rev 0 $12 / 93$

200 East Area W-252 Streams

This page intentionally left blank.

D-iv 


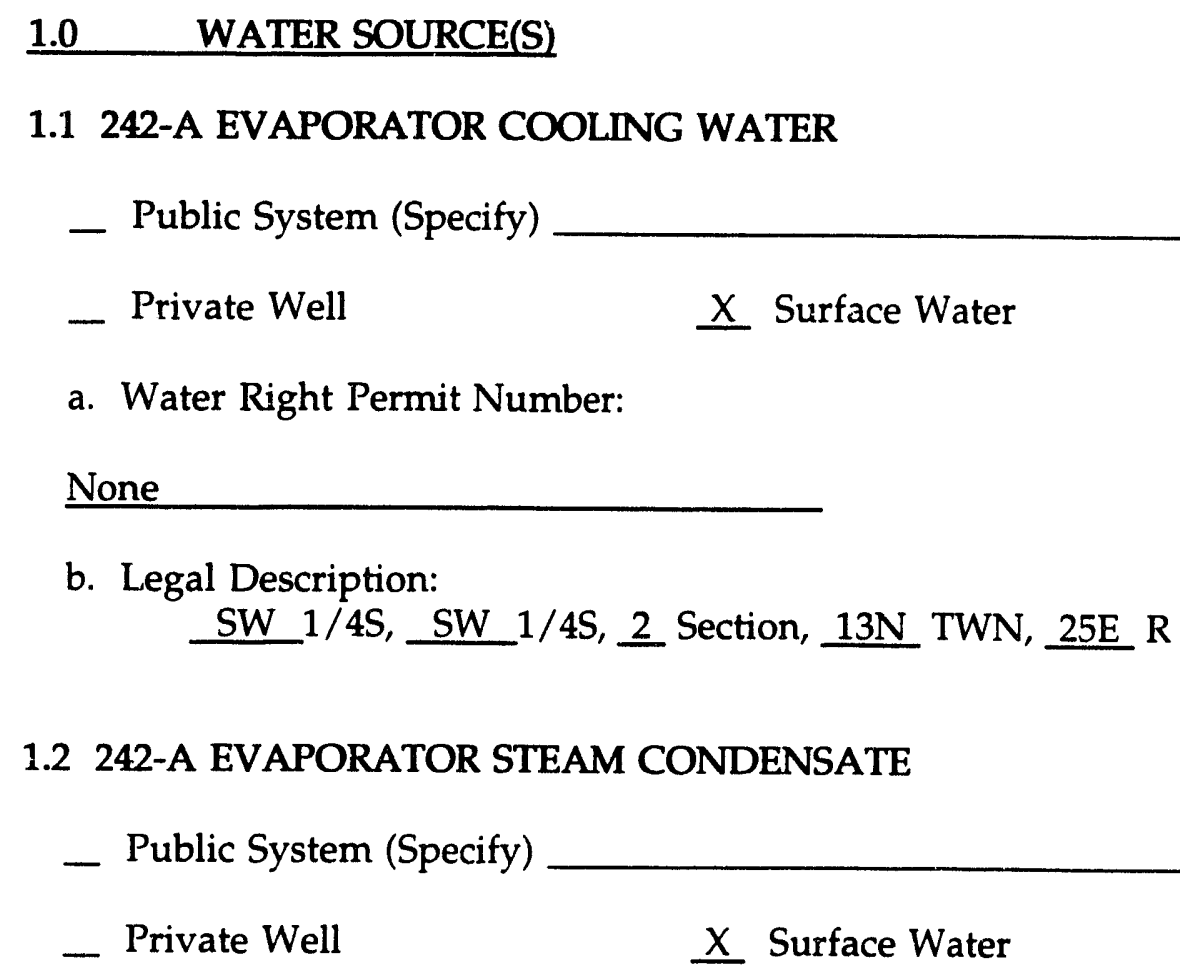

a. Water Right Permit Number:

None

b. Legal Description:

SW 1/4S, SW 1/4S, 2 Section, 13N TWN, 25E R

\subsection{2-A EVAPORATOR STEAM CONDENSATE}

_ Public System (Specify)

_ Private Well $\underline{X}$ Surface Water

a. Water Right Permit Number:

None

b. Legal Description:

SW 1/4S, SW 1/4S, 2 Section, WN, 25E R

\subsection{1-A TANK FARM COOLING WATER}

— Public System (Specify)

$\underline{X}$ Private Well $\underline{X}$ Suriace Water

a. Water Right Permit Number:

None

b. Legal Description: Surface Water SW 1/4S, SW 1/4S, 2 Section, 13N TWN, 25E R

Legal Description: Private Well

SE 1/4S, NE 1/4S, 2 Section, 12N TWN, 26E R 


\subsection{4-AR VAULT COOLING WATER}

_ Public System (Specify)

_ Private Well $\underline{X}$ Surface Water

a. Water Right Permit Number:

None

b. Legal Description: Surface Water SW 1/4S, SW 1/4S, 2 Section, 13N TWN, 25E R

\subsection{4-E POWER PLANT}

_ Public System (Specify)

_ Private Well $\underline{X}$ Surface Water

a. Water Right Permit Number:

None

b. Legal Description:

SW 1/4S, SW 1/4S, 2 Section, 13N TWN, 25E R

\subsection{B PLANT COOLING WATER}

_ Public System (Specify)

$\underline{X}$ Private Well $\underline{X}$ Surface Water

a. Water Right Permit Number:

None

b. Legal Description: Surface Water SW 1/4S, SW 1/4S, 2 Section, 13N TWN, 25E R

Legal Description: Private Well SE 1/4S, NE 1/4S, 3 Section, 12N TWN, 26E $R$ 


\subsection{WATER USE:}

The water use calculations are based on data extracted from WHC 1992a. The maximum water usage was calculated by summing all of the flows described in Sections 1.1 through 1.6 in Appendix B. Average flows were calculated using the flow data presented in Tables B-2 through B-7 in Sections 1.1 through 1.6 of Appendix B. All water usage quantities are rounded to the nearest 100 gallons per day. Maximum water usage for the 284-E Power Plant is calculated by summing the maximum flows from substreams 2 through $8 \mathrm{~B}$ and adding 3,000,000 gallons of flow per day for the reservoir overflow (Source 1) which represents the total capacity of the reservoir.

\subsection{2-A EVAPORATOR COOLING WATER}

a. Indicate total water use: Gallons per day (average): $\underline{590,400}$

Gallons per day (maximum): $\underline{5,282,000}$

b. Is water metered?

$\underline{X}$ Yes $\quad$ No

Note: Water is metered on outflow waste stream not inflow of raw water.

\subsection{2-A EVAPORATOR STEAM CONDENSATE}

a. Indicate total water use: Gallons per day (average): 51,000

Gallons per day (maximum): 101,000

b. Is water metered?

$\underline{X}$ Yes $\quad-$ No

Note: Water is metered on outflow waste stream not inflow of raw water.

\subsection{1-A TANK FARM COOLING WATER}

a. Indicate total water use: Gallons per day (average): $\underline{878,400}$

Gallons per day (maximum): $\underline{892,800}$

b. Is water metered? $\quad \underline{X}$ Yes _No

Note: Water is metered on outflow waste stream not inflow of raw water. 


\subsection{4-AR VAULT COOLING WATER}

a. Indicate total water use: Gallons per day (average): 23,400 Gallons per day (maximum): 126,800

b. Is water metered?

$\underline{X}$ Yes

- No

Note: Water is metered on outflow waste stream not inflow of raw water.

\subsection{4-E POWER PLANT}

a. Indicate total water use: Gallons per day (average): 158,400 Gallons per day (maximum): $6,605,700$

b. Is water metered? $\quad$ Yes $\quad \underline{X}$ No

\subsection{B PLANT COOLING WATER}

a. Indicate total water use: Gallons per day (average): $1,872,000$

Gallons per day (maximum): $\underline{4,413,600}$

b. Is water metered?

$\underline{X}$ Yes

- No

Note: Water is metered on outflow waste stream not inflow of raw water. 
3.0 ATTACH A LINE DRAWING SHOWING THE WATER FLOW THROUGH THE FACILITY. INDICATE SOURCE OF INTAKE WATER, OPERATIONS CONTRIBUTING WASTE WATER TO THE EFFLUENT, AND TREATMENT UNITS LABELED TO CORRESPOND TO THE MORE DETAILED DESCRIPTIONS IN ITEM C. CONSTRUCT A WATER BALANCE ON THE LINE DRAWING SHOWING AVERAGE FLOWS BETWEEN INTAKES, OPERATIONS, TREATMENT UNITS, AND OUTFALLS. IF A WATER BALANCE CANNOT BE DETERMINED (E.G., FOR CERTAIN MINING ACTIVITIES), PROVIDE A PICTORIAL DESCRIPTION OF THE NATURE AND AMOUNT OF ANY SOURCES OF WATER AND ANY COLLECTION OR TREATMENT MEASURES.

Schematic flow diagrams from the Phase II Liquid Effluent Program (Project W-252) Waste water Engineering Report and BAT/AKART Studies (WHC 1992a) for each of the six waste streams are presented in Appendix B, Section 1.0. Because inflow water to the six waste stream facilities is not metered, a complete water balance cannot be determined. Outflow rates for each component of the six waste streams are presented on the schematic flow diagrams and the on tables in Appendix B, Section 1.0. The schematic flow diagrams and tables, with corresponding page numbers, that relate to each waste stream are listed below:

\begin{tabular}{lll} 
WASTE STREAM & SCHEMATIC & TABLE \\
CONTAINING & FLOW DIAGRAM & OUTFLOW RATES \\
\hline
\end{tabular}

242-A Evaporator Cooling Water 242-A Evaporator Steam Condensate 241-A Tank Farm Cooling Water 244-AR Vault Cooling Water 284-E Power Plant B Plant Cooling Water
Figure B-3, page B-9

Figure $B-6$, page $B-16$

Figure $B-11$, page $B-26$

Figure $B-17$, page $B-40$

Figure $B-22$, page $B-52$

Figure B-27, page B-63
Table B-2, page B-12

Table B-3, page B-19

Table B-4, page B-29

Table B-5, page B-43

Table B-6, page B-55

Table B-7, page B-66 
DOE/RL 93-61, Rev 0

$12 / 93$

200 East Area W-252 Streams

This page intentionally left blank.

D-6 


\section{APPENDDX E}

\section{WASTEWATER INFORMATION}


DOE/RL 93-61, Rev 0

200 East Area W-252 Streams

This page intentionally left blank 
DOE/RL 93-61, Rev 0

$12 / 93$

200 East Area W-252 Streams

\section{CONTENTS}

1.0 PROVIDE MEASUREMENTS FOR THE PARAMETERS LISTED BELOW, UNLESS WAIVED BY THE PERMITTING AUTHORITY. ALL ANALYTICAL METHODS USED TO MEET THESE REQUIREMENTS SHALL, UNLESS APPR.OVED OTHERWISE IN WRITING BY ECOLOGY, CONFORM TO THE GUIDELINES ESTABLISHING TEST PROCEDURES FOR THE ANALYSIS OF POLLUTANTS CONTAINED IN 40 CODE OF FEDERAL REGULATIONS (CFR)

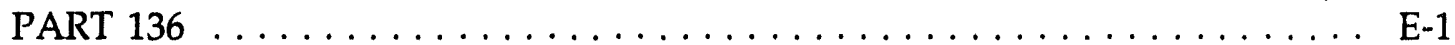

2.0 WASTE WATER CHARACTERISTICS FOR TOXIC POLLUTANTS $\ldots \ldots \ldots$ E-17

\section{TABLES}

E-1 Summary of Analytical Results for 242-A Evaporator Cooling Water ........................... E-2

E-2 Summary of Analytical Results for 242-A Evaporator Steam Condensate . . . . . . . . . . . . . . . . . . . . E

E-3 Summary of Analytical Results for 241-A Tank Farm Cooling Water ................................

E-4 Positive Sample Results for 241-A Tank Farm Cooling Water . . . . . . . . . . E-5

E-5 Summary of Analytical Results for 244-AR Vault Cooling Water . . . . . . . . E E-6

E-6 Positive Sampie Results for 244-AR Vault Cooling Water . . . . . . . . . . . . E E-7

E-7 Summary of Analytical Results for 284-E Powerplant Waste Water Stream . . E-8

E-8 Positive Sample Results for 284-E Powerplant Waste Water Stream . . . . . . . . E-9

E-9 Summary Analytical Results for the B Plant Cooling Water Stream ............................... E-14

E-10 Positive Sample Results for B Plant Cooling Water . . . . . . . . . . . . . E-15

E-11 242-A Evaporator Cooling Water Waste Water Characterizaiton Analytical Results . . . . . . . . . . . . . . . . . E-18

E-12 242-A Evaporator Steam Condensate Waste Water Characterization Analytical Results . . . . . . . . . . . . . . . . . . E-20

E-13 241-A Tank Farm Cooling Water Waste Water Characterization Analytical Results . . . . . . . . . . . . . . . . . . . E-22

E-14 244-AR Vault Cooling Water Waste Water Characterization Analytical Resilts . . . . . . . . . . . . . . . . . . . E-24

E-15 284-E Power Plant Waste Water Characterization Analytical Results . . . . . . . . . . . . . . . . . . . . . . . E-26

E-16 B-Plant Cooling Water Waste Water

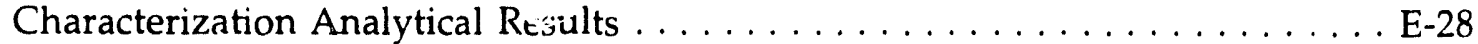


DOE/RL 93-61, Rev 0 $12 / 93$

200 East Area W-252 Streams

This page intentionally left blank.

\section{E-iv}


1.0 PROVIDE MEASUREMENTS FOR THE PARAMETERS LISTED BELOW, UNLESS WAIVED BY THE PERMITTING AUTHORTYY. ALL ANALYTICAL METHODS USED TO MEET THESE REQUIREMENTS SHALL, UNLESS APPROVED OTHERWISE IN WRITING BY ECOLOGY, CONFORM TO THE GUIDELINES ESTABLISHING TEST PROCEDURES FOR THE ANALYSIS OF POLLUTANTS CONTAINED IN 40 CODE OF FEDERAL REGULATIONS (CFR) PART 136.

Waste water analytical data summaries for the 241-A Tank Farm Cooling Water and the 244-AR Vault Cooling Water are included $f$ om the validated round one sampling results, which were obtained in accordance with the approved sampling and analysis plans for these waste water streams (WHC 1992b and WHC 1992c). For the remaining four streams, validated data from implementation of the approved sampling and analysis plans was not available at the time this document was prepared, so data from the Phase II Liquid Effluent Program (Project W-252) Waste Water Engineering Report and BAT/AKART Studies (WHC 1992a) is included for the 242-A Evaporator Cooling Water, 242-A Evaporator Steam Condensate, 284-E Power Plant Waste Water, and B Plant Cooling Water Streams. 
Table E-1. Summary of Analytical Results for 242-A Evaporator Cooling Water

\begin{tabular}{|c|c|c|c|}
\hline Parameter/CAS No. & $\begin{array}{c}\text { Concentrations Measured } \\
(\mu \mathrm{g} / \mathrm{L})^{(1)}\end{array}$ & Analytical Method & Detection Limit $(\mu \mathrm{g} / \mathrm{L})$ \\
\hline $\mathrm{pH}$ (pH units) & 6.2 and 8.04 & pH-Fld & $\mathrm{NP}$ \\
\hline Conductivity ( $\mu \mathrm{mhos}$ ) & 165 & COND-Fld & NP \\
\hline Total Dissolved Solids & 76,000 & SM-208B & 5,000 \\
\hline Total Suspended Solids & NA & NA & NA \\
\hline BOD (5 day) & $\mathrm{NA}$ & NA & $\mathrm{NA}$ \\
\hline COD & NA & NA & NA \\
\hline Ammonia-N & 63 & ASTM (1986) & 50 \\
\hline TKN-N & NA & NA & NA \\
\hline Nitrate-N & 1,190 & IC & 500 \\
\hline Ortho-phosphate-P & NA & NA & NA \\
\hline Total-phosphate-P & 1,000 & IC & 1,000 \\
\hline Total Oil \& Grease & $\mathrm{NA}$ & $\mathrm{NA}$ & NA \\
\hline Calcium/7440-70-2 & 19,300 & ICP & 50 \\
\hline Magnesium /7439-95-4 & 4,540 & ICP & 50 \\
\hline Sodium/7440-23-5 & 2,350 & ICP & 200 \\
\hline Potassium / 7440-09-7 & 801 & ICP & 100 \\
\hline Chloride & 1,100 & IC & 500 \\
\hline Sulfate & 10,500 & IC & 500 \\
\hline Fluoride & 450 & IC & NR \\
\hline Cadmium/7440-43-9 & ND & ICP & 2 \\
\hline Chromium/7440-49-3 & 10.4 & ICP & 10 \\
\hline Lead /7439-92-1 & 12.6 & USEPA， \#7421 & 5 \\
\hline Mercury/7439-97-6 & 0.105 & USEPA， \#7470 & 0.1 \\
\hline Selenium $/ 7782-49-2$ & 5 & USEPA， \#7740 & 5 \\
\hline Silver/7440-22-4 & 10 & ICP & 10 \\
\hline Copper/7440-50-8 & 73.6 & ICP & 10 \\
\hline Iron $/ 7439-89-6$ & 104 & ICP & 30 \\
\hline Manganese & 14.2 & ICP & 5 \\
\hline Zinc/7440-66-6 & 47.8 & $I C P$ & 5 \\
\hline Barium /7440-39-3 & 31.2 & ICP & 6 \\
\hline Total Coliform & NA & $\mathrm{NA}$ & NA \\
\hline
\end{tabular}

Source - WHC 1992a

NA - Not Analyzed

ND - Not detected at the reported detection limit

NP - Not Provided

NR - Not Reported

ICP - Inductively coupled plasma, USEPA-6010

IC - Ion Chromatography, EPA-600/4-84-01

Fld - Field Measurement

(1) Three sets of dato are provided in (WHC 1992a) since there are three different sampling sites associated with the 242-A Evaporator Cooling Water Stream. The value reported in the "Concentrations Measured" column is the highest value reported of the three respective sampling sites, with the exception of the value for $\mathrm{pH}$. The $\mathrm{pH}$ results for two of the three sampling sites was 6.02 and the $\mathrm{pH}$ for the third sampling site was 8.02 . 
DOE/RL 93-61, Rev 0

$12 / 93$

200 East Area W-252 Streams

Table E-2. Summary of Analytical Results for 242-A Evaporator Steam Condensate

\begin{tabular}{|c|c|c|c|}
\hline Parameter/CAS No. & $\begin{array}{c}\text { Concentrations Measured } \\
(\mu \mathrm{g} / L)^{(3)}\end{array}$ & Analytica! Method & Detection Limit $(\mu \mathrm{g} / \mathrm{L})$ \\
\hline $\mathrm{pH}$ (pH units) & 8.04 & pH-Fld & NP \\
\hline Conductivity ( $\mu$ mhos) & 165 & COND-Fld & $\mathrm{NP}$ \\
\hline Total Dissolved Solids & 76,000 & $\mathrm{SM}-208 \mathrm{~B}$ & 5,000 \\
\hline Total Suspended Solids & NA & NA & $\mathrm{NA}$ \\
\hline BOD (5 day) & NA & $\mathrm{NA}$ & $\mathrm{NA}$ \\
\hline COD & $\mathrm{NA}$ & NA & $\mathrm{NA}$ \\
\hline Ammonia-N & 63 & ASTM (1986) & 50 \\
\hline TKN-N & $\overline{N A}$ & NA & NA \\
\hline Nitrate-N & 550 & IC & 500 \\
\hline Ortho-phosphate-P & NA & NA & NA \\
\hline Total-phospinate-P & ND & IC & 330 \\
\hline Total Oil \& Grease & $\mathrm{NA}$ & NA & NA \\
\hline Calcium $/ 7440-70-2$ & 19,300 & ICP & 50 \\
\hline Magnesium/7439-95-4 & 4,540 & ICP & 50 \\
\hline Sodium/7440-23-5 & 2200 & ICP & 200 \\
\hline Potassium/7440-09-7 & 750 & ICP & 100 \\
\hline Chloride & 1,100 & IC & 500 \\
\hline Sulfate & 10,500 & IC & 500 \\
\hline Fluoride $^{(2)}$ & 129 & ISE & NR \\
\hline Cadmium, $/ 7440-43-9(1)$ & 0.17 & ICP & 5 \\
\hline Chromium/7440-49-3 & ND & ICP & 10 \\
\hline Lead /7439-92-1 & 5.5 & USEPA, $\# 7421$ & 2 \\
\hline Mercury/7439-97-6 & 0.105 & USEPA， \#7470 & 0.1 \\
\hline Selenium $/ 7782-49-2^{(2)}$ & 1.7 & USEPA， $\# 7740$ & 2 \\
\hline Silver $/ 7440-22-4^{(2)}$ & 3.3 & ICP & 10 \\
\hline Copper/7440-50-8 & 11 & ICP & 1 \\
\hline Iron/7439-89-6 & 84 & $\mathrm{ICP}$ & 30 \\
\hline Manganese & 14.2 & ICP & 5 \\
\hline Zinc/7440-66-6 & 18.7 & ICP & 5 \\
\hline Barium /7440-39-3 & 31.2 & ICP & 6 \\
\hline Total Coliform & $\mathrm{NA}$ & $\overline{N A}$ & $\mathrm{NA}$ \\
\hline
\end{tabular}

Source - WHC 1992a

NA - Not Analyzed

ND - Not detected at the reported detection limit

NP - Not Provided

NR - Not Reported

ICP - Inductively coupled plasma, USEPA-6010

IC - Ion Chromatography, EPA-600/4-84-01

ISE - Fluoride-Low Detection Limit, ASTM-D1179-80-B

Fld - Field Measurement

${ }^{(1)}$ The reported result for cadmium, $0.17 \mu \mathrm{g} / \mathrm{L}$, is significantly below the method detection limit of $5 \mu \mathrm{g} / \mathrm{L}$. An explanation is not provided for this discrepancy in (WHC 1992a).

${ }^{(2)}$ The reported results for fluoride, selenium, and silver are also below the associated method detection limits. Therefore, the results for these three analytes may be considered estimated, and are most likely usable results.

${ }^{(3)}$ The values reported in the "Concentrations Measured" column in the table above were obtained from the baseline characteristics of this stream provided in (WHC 1992a), Appendix B.7, Table 2-2. 
Table E-3. Summary of Analytical Results for 241-A Tank Farm Cooling Water.

\begin{tabular}{|c|c|c|c|}
\hline Parameter/CAS No. & $\begin{array}{l}\text { Concentrations } \\
\text { Measured }\end{array}$ & Analytical Method & Detection Limit \\
\hline $\mathrm{pH}$ (pH units) & 8 & SW- $846^{2}, 9040$ & 0.1 \\
\hline Conductivity ( $\mu \mathrm{mhos} / \mathrm{cm})$ & 139 & SW- $-846^{2}, 9050$ & 6 \\
\hline Total Dissolved Solids (mg/L) & 93 & $\mathrm{EPA}^{3}, 160.1$ & 5 \\
\hline Total Suspended Solids (mg/L) & ND & $\mathrm{EPA}^{3}, 160.2$ & 5 \\
\hline BOD (5 day) & NA & NA & NA \\
\hline $\operatorname{COD}(\mathrm{mg} / \mathrm{L})$ & ND & $\mathrm{EPA}^{3}, 410.1$ & 5 \\
\hline Ammonia- $\mathrm{N}(\mathrm{mg} / \mathrm{L})$ & ND & $\mathrm{EPA}^{3}, 350.2$ & 0.1 \\
\hline TKN-N & NA & NA & NA \\
\hline Nitrate+Nitrite- $\mathrm{N}^{4}$ (mg-N/L) & 0.25 & EPA, 353.3 & 0.1 \\
\hline Ortho-phosphate-P & NA & NA & NA \\
\hline Total-phosphate-P (mg/L) & 0.052 & $\mathrm{E} ? \mathrm{P}^{3}, 365.2$ & 0.020 \\
\hline Total Oil \& Grease (mg/L) & ND & $\mathrm{EPA}^{3}, 413.2$ & 5 \\
\hline Calcium $/ 7440-70-2(\mu \mathrm{g} / \mathrm{L})$ & 21300 & SW-846 2,60010 & 50 \\
\hline Magnesium/7439-95-4 $(\mu \mathrm{g} / \mathrm{L})$ & 5145 & SW- $846^{2}, 6010$ & 50 \\
\hline Sodium/7440-23-5 $(\mu \mathrm{g} / \mathrm{L})$ & 2090 & SW-846 ${ }^{2}, 6010$ & 200 \\
\hline Potassium $/ 7440-09-7(\mu \mathrm{g} / \mathrm{L})$ & ND & S! $246^{2}, 6010$ & 877 \\
\hline Chloride $(\mathrm{mg} / \mathrm{L})$ & 1.15 & $E P A^{3}, 300.0$ & 0.25 \\
\hline Sulfate & NA & NA & NA \\
\hline Fluoride $(\mathrm{mg} / \mathrm{L})$ & ND & $\mathrm{EPA}^{3}, 300.0$ & 0.5 \\
\hline Cadmium / 7440-43-9 $(\mu \mathrm{g} / \mathrm{L})$ & ND & SW- $846^{2}, 6010$ & 4 \\
\hline Chromium/7440-49-3 $(\mu \mathrm{g} / \mathrm{L})$ & ND & SW- $846^{2}, 6010$ & 7 \\
\hline Lead/7439-92-1 $(\mu \mathrm{g} / \mathrm{L})$ & 4.1 & SW- $846^{2}, 7421$ & 2 \\
\hline Mercury/7439-97-6 $(\mu \mathrm{g} / \mathrm{L})$ & ND & SW-846 ${ }^{2}, 7470$ & 0.1 \\
\hline Selenium $/ 7782-49-2(\mu \mathrm{g} / \mathrm{L})$ & ND & $S W-846^{2}, 7740$ & 2 \\
\hline Silver $/ 7440-22-4(\mu \mathrm{g} / \mathrm{L})$ & ND & $5 W-846^{2}, 6010$ & 7 \\
\hline Copper /7440-50-8 ( $\mu \mathrm{g} / \mathrm{L})$ & ND & SW- $846^{2}, 6010$ & 9 \\
\hline $\operatorname{Iron} / 7439-89-6(\mu \mathrm{g} / \mathrm{L})$ & ND & SW-846 ${ }^{2}, 6010$ & 10 \\
\hline Manganese $(\mu \mathrm{g} / \mathrm{L})$ & 3.4 & $S W-846^{2}, 6010$ & 2 \\
\hline Zinc $/ 7440-66-6(\mu \mathrm{g} / \mathrm{L})$ & ND & $S W-846^{2}, 6010$ & 8 \\
\hline Barium $/ 7440-39-3(\mu \mathrm{g} / \mathrm{L})$ & ND & $S W-846^{2}, 6010$ & 5 \\
\hline Total Coliform & $\mathrm{NA}$ & NA & $\overline{N A}$ \\
\hline
\end{tabular}

Source - Validate results from Round 1 Sampling in accordance with WHC $1992 \mathrm{~b}$.

NA - Not Aralyzed

ND - Not detected at the reported detection limit

${ }^{1}$ The value reported in the Concentration Measured column is the mean of the associated concentrations in samples Bi)8777 and B08778 which were collected from the 241-A Tank Farm Warm "ater Sump.

2EPA 1986, Test Methods for Evaluating Solid Waste (SW-846), Third Edition, United States Environmental Protection Agency, Office of Solid Waste and Emergency Response, Washington, D.C.

${ }^{3}$ EPA 1979, Metiods for Chemical Analysis of Water and Wastes, EPA-600/4-79-020, United States Environmental Protection Agency, Environmental Monitoring and Support Laboratory, Cincinnati, Ohio.

${ }^{4}$ Nitrate + nitrite- $\mathrm{N}$ was reported in place of nitrate- $\mathrm{N}$ since the nitrate- $\mathrm{N}$ analysis was not performed by the laboratory. 
DOE/RL 93-61, Rev 0

$12 / 93$

200 East Area W-252 Streams

4

5

6

7

8

\begin{tabular}{|c|c|c|c|}
\hline \multicolumn{2}{|l|}{ HEIS NO: } & B08778 & B0877 \\
\hline \multicolumn{2}{|l|}{ DATE COLLECTED: } & $03 / 03 / 93$ & $03 / 03 / 93$ \\
\hline \multicolumn{2}{|l|}{ LOCATION: } & $\begin{array}{l}\text { 241-A Tank Farm Warm } \\
\text { Water Sump }\end{array}$ & $\begin{array}{c}\text { 241-A Tank Farm Warm } \\
\text { Water Sump }\end{array}$ \\
\hline ANALYSIS & COMPOUND OR ANALYTE & RESULT & RESULT \\
\hline \multirow[t]{5}{*}{ METALS } & Calcium $(\mu \mathrm{g} / \mathrm{L}$ ) & 20900 & 21700 \\
\hline & Lead $(\mu \mathrm{g} / \mathrm{L})$ & 4.4 & 3.8 \\
\hline & Magnesium $(\mu \mathrm{g} / \mathrm{L}$ ) & 5040 & 5250 \\
\hline & Manganese $(\mu \mathrm{g} / \mathrm{L})$ & 3.2 & 3.6 \\
\hline & Sodium $(\mu \mathrm{g} / \mathrm{L})$ & 2040 & 2140 \\
\hline \multirow[t]{8}{*}{ GENERAL CHEMISTRY } & Chloride $(\mathrm{mg} / \mathrm{L})$ & 1.2 & 1.1 \\
\hline & Nitrate+Nitrite-N (mg-N/L) & 0.25 & 0.24 \\
\hline & Total Organic Carbon (mg/L) & 0.89 & 0.89 \\
\hline & $\mathrm{pH}$ (pH units) & 7.9 & 8 \\
\hline & Phosphate, as $\mathrm{P}(\mathrm{m} \mathcal{C} / \mathrm{L})$ & 0.058 & 0.046 \\
\hline & Specific Conductance ( $\mu \mathrm{mhos} / \mathrm{cm})$ & 146 & 131 \\
\hline & Total Dissolved Solids (mg/L) & 86 & 99 \\
\hline & Total Organic Halides $(\mu \mathrm{g} / \mathrm{L})$ & ND $^{1}$ & 29 \\
\hline ORGANOPHOSPHATE PESTICIDES & Monocrotophos $(\mu \mathrm{g} / \mathrm{L})$ & $\mathrm{ND}^{2}$ & 4.8 \\
\hline \multirow[t]{2}{*}{ RADIOCHEMISTRY } & Gross Beta $(\mathrm{pCi} / \mathrm{L})$ & 2.5 & 2.2 \\
\hline & Americium-241 (pCi/L) & $\mathrm{ND}^{3}$ & 0.089 \\
\hline
\end{tabular}

12

13

14

15

16

18

19

20

21

Table E-4. Positive Sample Results for 241-A Tank Farm Cooling Water.

Source - Validated results from Round 1 Sampling in Accordance with WHC 1992b.

$\mathrm{ND}^{1}$ - Not Detected at a detection limit of $20 \mu \mathrm{g} / \mathrm{L}$

$N^{2}$ - Not Detected at a detection limit of $1 \mu \mathrm{g} / \mathrm{L}$

$N^{3}$ - Not Detected at a detection limit of $0.07 \mathrm{pCi} / \mathrm{L}$

Stream Sample Evaluation

A total of four samples per year are scheduled to be collected from the 241-A Tank Farm Cooling Stream for two consecutive years (WHC 1992b). According to the 241-A Tank Farm Cooling Water Sampling and Analysis Plan, (WHC 1992b), the four samples collected each year consist of two samples collected under normal operation (raw cooling water), and two collected during emergency cooling water system operation.

The samples collected to date, HEIS Nos. B08777, B08778, and B08779 (raw water), were analyzed and validated results reported for all of the parameters required by the associated Sampling and Analysis Plan, as listed below.

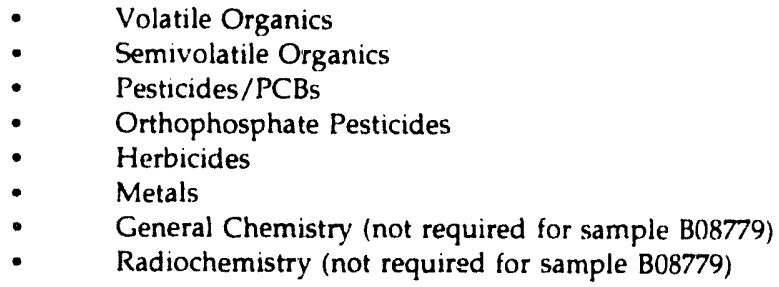

All associated sample results for samples B08777 and B08778 were undetected with the exception of the compounds or analytes included in Table E-4 (stream samples only). 
DOE/RL 93-61, Rev 0

$12 / 93$

200 East Area W-252 Streams

Table E-5. Summary of Analytical Results for 244-AR Vault Cooling Water.

\begin{tabular}{|c|c|c|c|}
\hline Parameter/CAS No. & $\begin{array}{l}\text { Concentrations } \\
\text { Measured }^{1}\end{array}$ & $\begin{array}{l}\text { Analytical } \\
\text { Method }\end{array}$ & Detection Limit \\
\hline $\mathrm{pH}$ (pH units) & 8 & SW- $846^{2}, 9040$ & 0.1 \\
\hline Conductivity ( $\mu \mathrm{mhos} / \mathrm{cm}$ ) & 146 & SW- $846^{2}, 9050$ & 6 \\
\hline Total Dissolved Solids (mg/L) & 90 & $\mathrm{EPA}^{3}, 160.1$ & 5 \\
\hline Total Suspended Solids (mg/L) & ND & $\mathrm{EPA}^{3}, 160.2$ & 5 \\
\hline BOD (5 day) & $\overline{\mathrm{NA}}$ & NA & $\mathrm{NA}$ \\
\hline $\operatorname{COD}(\mathrm{mg} / \mathrm{L})$ & $\overline{\mathrm{ND}}$ & $\mathrm{EPA}^{3}, 410.1$ & 5 \\
\hline Ammonia-N (mg/L) & ND & $\mathrm{EPA}^{3}, 350.2$ & 0.1 \\
\hline TKN-N & $\mathrm{NA}$ & NA & $\mathrm{NA}$ \\
\hline Nitrate+Nitrate- $\mathrm{N}^{4}(\mathrm{mg}-\mathrm{N} / \mathrm{L})$ & 0.23 & $\mathrm{EPA}^{3}, 353.3$ & 0.1 \\
\hline Ortho-phosphate-P & $\mathrm{NA}$ & NA & $\mathrm{NA}$ \\
\hline Total-phosphate-P (mg/L) & 0.033 & $\mathrm{EPA}^{3}, 365.2$ & 0.020 \\
\hline Total Oil \& Grease $(\mathrm{mg} / \mathrm{L})$ & $\mathrm{ND}$ & $\mathrm{EPA}^{3}, 413.2$ & 5 \\
\hline Calcium/7440-70-2 $(\mu \mathrm{g} / \mathrm{L})$ & 22100 & SW- $846^{2}, 6010$ & 50 \\
\hline Magnesium/7439-95-4 ( $\mu \mathrm{g} / \mathrm{L})$ & 2900 & SW- $846^{2}, 6010$ & 50 \\
\hline Sodium $/ 7440-23-5(\mu \mathrm{g} / \mathrm{L})$ & 2720 & SW- $346^{2}, 6010$ & 200 \\
\hline Potassium/7440-09-7 ( $\mu \mathrm{g} / \mathrm{L})$ & $\overline{\mathrm{ND}}$ & SW-846 ${ }^{2}, 6010$ & 877 \\
\hline Chloride (mg/L) & 1.9 & $\mathrm{EPA}^{3}, 300.0$ & 0.25 \\
\hline Sulfate & $\mathrm{NA}$ & $\mathrm{NA}$ & $\mathrm{NA}$ \\
\hline Fluoride $(\mathrm{mg} / \mathrm{L}$ ) & $\overline{\mathrm{ND}}$ & $\mathrm{EPA}^{3}, 300.0$ & 0.5 \\
\hline Cadmium/7440-43-9 ( $\mu \mathrm{g} / \mathrm{L})$ & $\overline{N D}$ & $\mathrm{EPA}^{3}, 300.0$ & 4 \\
\hline Chromium/7440-49-3 ( $\mathrm{gg} / \mathrm{L})$ & $\mathrm{ND}$ & SW- $846^{2}, 6010$ & 7 \\
\hline Lead /7439-92-1 $(\mu \mathrm{g} / \mathrm{L})$ & $\overline{\mathrm{ND}}$ & SW- $846^{2}, 7421$ & 2 \\
\hline Mercury /7439-97-6 ( $\mu \mathrm{g} / \mathrm{L})$ & ND & SW- $846^{2}, 7470$ & 0.1 \\
\hline Selenium $/ 7782-49-2(\mu \mathrm{g} / \mathrm{L})$ & ND & SW- $846^{2}, 7740$ & 2 \\
\hline Silver $/ 7440-22-4(\mu \mathrm{g} / \mathrm{L})$ & $\overline{\mathrm{ND}}$ & SW- $846^{2}, 6010$ & 7 \\
\hline Copper $/ 7440-50-8(\mu \mathrm{g} / \mathrm{L})$ & 19.2 & SW- $846^{2}, 6010$ & 10 \\
\hline Iron $/ 7439-89-6(\mu \mathrm{g} / \mathrm{L})$ & $\mathrm{ND}$ & SW- $846^{2}, 6010$ & 10 \\
\hline Manganese $(\mu \mathrm{g} / \mathrm{L})$ & 7.1 & SW-846', 6010 & 2 \\
\hline Zinc $/ 7440-66-6(\mu \mathrm{g} / \mathrm{L})$ & 55 & $\mathrm{SW}-846^{2}, 6010$ & $\frac{2}{8}$ \\
\hline Barium $/ 7440-39-3(\mu \mathrm{g} / \mathrm{L})$ & $\mathrm{ND}$ & SW- $846^{2}, 6010$ & 5 \\
\hline Total Coliform & $\overline{N A}$ & $\overline{\mathrm{NA}}$ & $\overline{N A}$ \\
\hline
\end{tabular}

Source - Validated results from Round 1 sampling in accordance with WHC 1992c.

NA - Not Analyzed

ND - Not detected at the reported detection limit

${ }^{1}$ The value reported in the Concentration Measured column is the concentration in sample B08776 which was collected from the 244-AR Tank Farm Manhole number 1.

2 EPA 1986, Test Methods for Evaluating Solid Waste (SW-846). Third Edition, United States Environmental Protection Agency,

Office of Solid Waste and Emergency Response, Washington, D.C.

${ }^{3}$ EPA 1979, Methods for Chemical Analysis of Water and Wastes, EPA-600/4-79-020, United States Environmental Protection Agency, Environmental Monitoring and Support Laboratory, Cincinnati, Ohio.

${ }^{4} \mathrm{Nitrate}+$ nitrite- $\mathrm{N}$ was reported in place of nitrate- $\mathrm{N}$ since the nitrate- $\mathrm{N}$ analysis was not performed by the laboratory. 
DOE/RL 93-61, Rev 0

$12 / 93$

200 East Area W-252 Streams

3

4

5

6

7

8

Table E-6. Positive Sample Results for 244-AR Vault Cooling Water

\begin{tabular}{|c|c|c|}
\hline \multicolumn{2}{|l|}{ HEIS NO: } & B08776 \\
\hline \multicolumn{2}{|l|}{ DATE COLLECTED: } & $03 / 03 / 93$ \\
\hline \multicolumn{2}{|l|}{ LOCATION: } & $\begin{array}{l}\text { 244-AR Tank Farm } \\
\text { Manhole Number }\end{array}$ \\
\hline ANALYSIS & COMPOUND OR ANALYTE & Result $(\mu \mathrm{g} / \mathrm{L})$ \\
\hline \multirow[t]{6}{*}{ METALS } & Calcium & 22,100 \\
\hline & Copper & 19.2 \\
\hline & Magnesium & 2,900 \\
\hline & Manganese & 7.1 \\
\hline & Sodium & 2,720 \\
\hline & Zinc & 55 \\
\hline \multirow[t]{8}{*}{ GENERAL CHEMISTRY } & Chloride & 1,900 \\
\hline & Nitrate+Nitrite-N $(\mu \mathrm{g}-\mathrm{N} / \mathrm{L})$ & 230 \\
\hline & Total Organic Carbon & 1,200 \\
\hline & $\mathrm{pH}$ (pH units) & 8 \\
\hline & Phosphate, as $\mathrm{P}$ & 33 \\
\hline & Specific Conductance $(\mu \mathrm{mhos} / \mathrm{cm})$ & 146 \\
\hline & Total Dissolved Solids & 90,000 \\
\hline & Total Organic Halides & 30.8 \\
\hline ORGANOPHOSPHATE PESTICIDES & Tetraethyldithiopyrophosphate (TEPP) & 0.23 \\
\hline
\end{tabular}

Source - Validated from Round 1 sampling in accordance with WHC 1992c.

Stream Sample Evaluation

Sample No. B08776 was collected from the 244-AR Tank Farm Manhole number 1, and was analyzed for the following parameters in accordance with the 244-AR Vault Cooling Water Sampling and Analysis Plan, (WHC 1992c).

- Volatile Organics

- Semivolatile Organics

- Pesticides/PCBs

- Orthophosphate Pesticides

- Herbicides

- Metals

- General Chemistry

- Radiochemistry

The Sampling and Analysis plan requires a total of four samples to be collected and analyzed over a two year time period. However, the validated results from Round 1 sampling evaluated consisted of only one sample in which all sample results were undetected, with the exception of the compounds or analytes included in Table E-6. 
DOE/RL 93-61, Rev 0

$12 / 93$

200 East Area W-252 Streams

1 Table E-7. Summary of Analytical Results for the 284-E Powerplant Waste Water Stream.

\begin{tabular}{|c|c|c|c|}
\hline Parameter/CAS No. (Units) & Concentrations Measured ${ }^{1}$ & Analytical Method & Detection Limit \\
\hline $\mathrm{pH}$ (pH units) & 9.3 & SW- $846^{2}, 9040$ & 0.1 \\
\hline Conductivity $(\mu \mathrm{mho} / \mathrm{cm})$ & 8460 & SW- $846^{2}, 9050$ & h \\
\hline Total Dissolved Solids (mg/L) & NA & $\mathrm{NA}$ & $\mathrm{NA}$ \\
\hline Total Suspended Solids ( $\mathrm{mg} / \mathrm{L}$ ) & NA & NA & NA \\
\hline 5 Day BOD $(\mathrm{mg} / \mathrm{L})$ & NA & NA & NA \\
\hline $\operatorname{COD}(\mathrm{mg} / \mathrm{L})$ & 78 & $\mathrm{EPA}^{3}, 410.1$ & 30 \\
\hline Ammonia-N (mg/L) & 0.09 & $\mathrm{EPA}^{3}, 350.3$ & 0.05 \\
\hline TKN-N & $\mathrm{NA}$ & NA & NA \\
\hline Nitrate-N (mg/L) & ND & $\mathrm{EPA}^{3}, 300.0$ & 0.2 \\
\hline Ortho-phosphate-P & NA & NA & NA \\
\hline Total-phosphate-P & NA & NA & NA \\
\hline Total Oil \& Grease & $\mathrm{NA}$ & $\mathrm{NA}$ & $\mathrm{NA}$ \\
\hline Calcium $/ 7440-70-2$ & $\mathrm{NA}$ & NA & $\mathrm{NA}$ \\
\hline Magnesium/7439-95-4 & NA & NA & NA \\
\hline Sodium $/ 7440-23-5$ & NA & NA & $\mathrm{NA}$ \\
\hline Potassium /7440-09-7 & $\mathrm{NA}$ & NA & $\mathrm{NA}$ \\
\hline Chloride (mg/L) & 2028 & $\mathrm{EPA}^{3}, 300.0$ & 0.2 \\
\hline Sulfate $(\mathrm{mg} / \mathrm{L})$ & 174 & $\mathrm{EPA}^{3}, 300.0$ & 1 \\
\hline Fluoride $(\mathrm{mg} / \mathrm{L})$ & 1.04 & $\mathrm{EPA}^{3}, 300.0$ & 0.1 \\
\hline Cadmium $/ 7440-43-9(\mu \mathrm{g} / \mathrm{L})$ & ND & SW- $846^{2}, 6010$ & 1.4 \\
\hline Chromium $/ 7440-49-3(\mu \mathrm{g} / \mathrm{L})$ & 5.94 & SW- $846^{2}, 6010$ & 3.3 \\
\hline Lead /7439-92-1 $(\mu \mathrm{g} / \mathrm{L})$ & 8.2 & SW- $846^{2}, 7421$ & 1.5 \\
\hline Mercury /7439-97-6 $(\mu \mathrm{g} / \mathrm{L})$ & ND & SW- $846^{2}, 7470$ & 0.10 \\
\hline Selenium $/ 7782-49-2(\mu \mathrm{g} / \mathrm{L})$ & ND & SW- $846^{2}, 7740$ & 2.3 \\
\hline Silver $/ 7440-22-4(\mu \mathrm{g} / \mathrm{L})$ & ND & SW- $846^{2}, 6010$ & 3.4 \\
\hline Copper $/ 7440-50-8(\mu \mathrm{g} / \mathrm{L})$ & 56 & $S W-846^{2}, 60110$ & 2.9 \\
\hline Iron/7439-89-6 & $\mathrm{NA}$ & NA & NA \\
\hline Manganese & NA & $\mathrm{NA}$ & NA \\
\hline Zinc/7440-66-6 $(\mu \mathrm{g} / \mathrm{L})$ & 53 & SW-846 2,60110 & NR \\
\hline Barium $/ 7440-39-3(\mu \mathrm{g} / \mathrm{L})$ & 297 & SW-846 2,60110 & NR \\
\hline Total Coliform & NA & NA & NA \\
\hline
\end{tabular}

Source - Validated results from Round 1 ampling in accordance with WHC 1992

NA - Not Analyzed ND - Not detecte - at the reported detection limit NR - Not Reported

${ }^{1}$ The value reported in the "Concentration Measured" column is the mean of the associated concentrations in the samples which were coliected from ine 284 I: Powerplant Waste Water Streams.

${ }^{2}$ EPA 1986, Test Methods for Evaluating Solid Waste (SW-846). Third Edition, United States Environmental Protection Agency, Office of Snlid Waste and Emergency Response, Washington, D.C.

${ }^{3}$ EP. . 1979, Methods for Chemical Analysis of Water and Wastes, EPA-600/4-79-020, United States Environmental Protection Agency, Environmental Monitoring and Support Laboratory, Cincinnati, Ohio. 
Table E-8. Postive Results for 284-E Power Plant Waste Water Samples (Page 1 of 5)

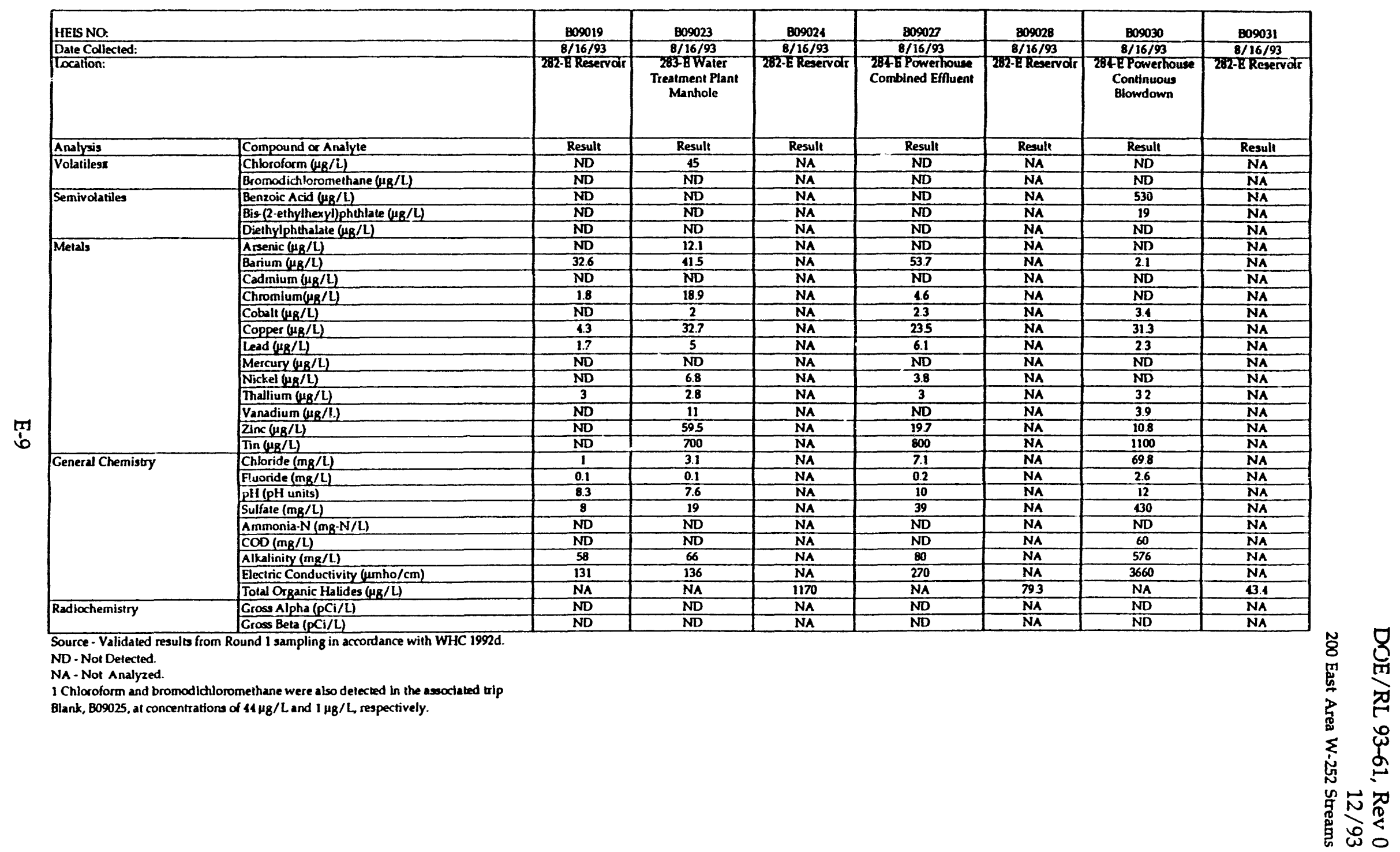


Table E-8. Postive Results for 284-E Power Plant Waste Water Samples (Page 2 of 5)

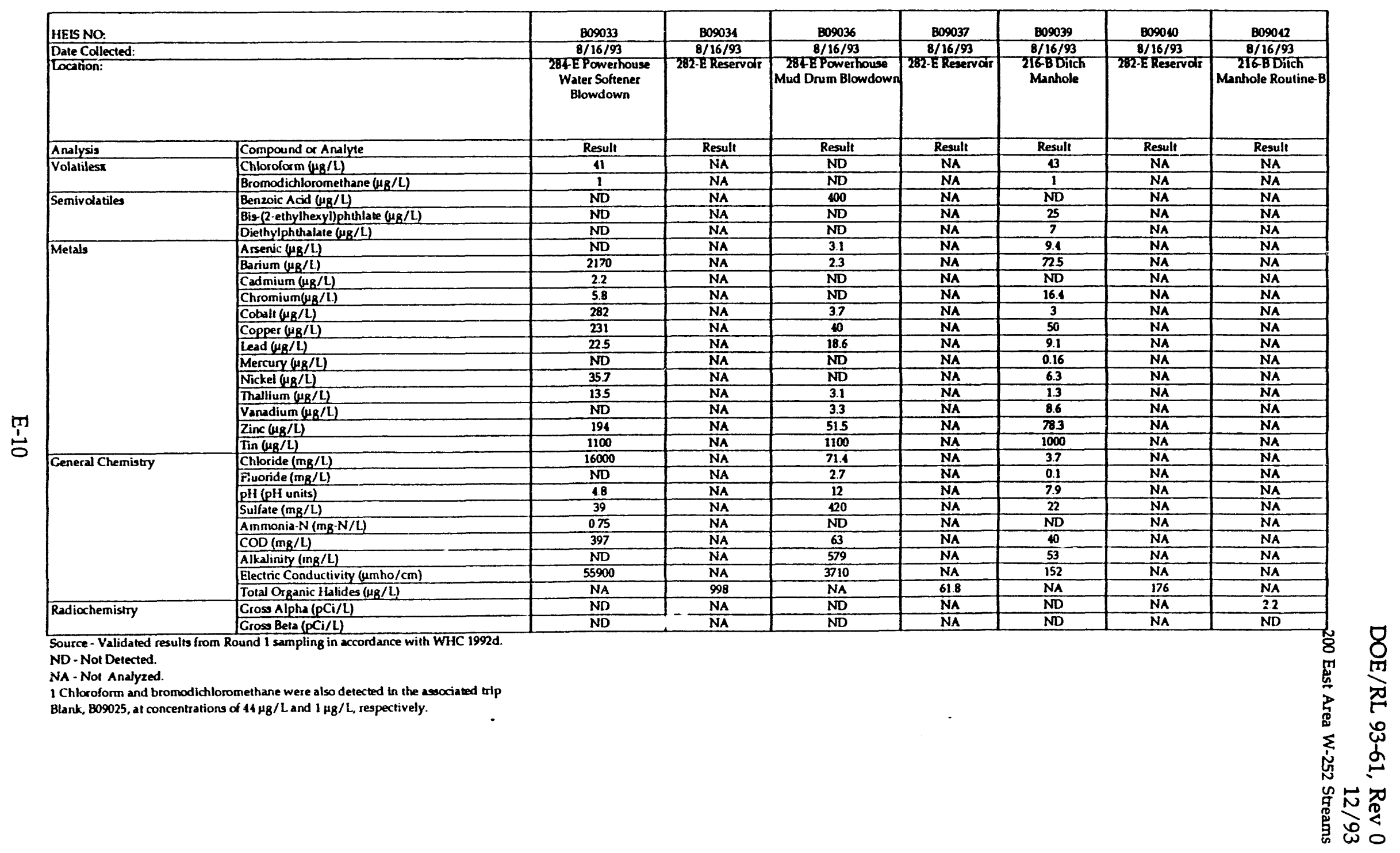


Table E-8. Postive Results for 284-E Power Plant Waste Water Samples (Page 3 of 5)

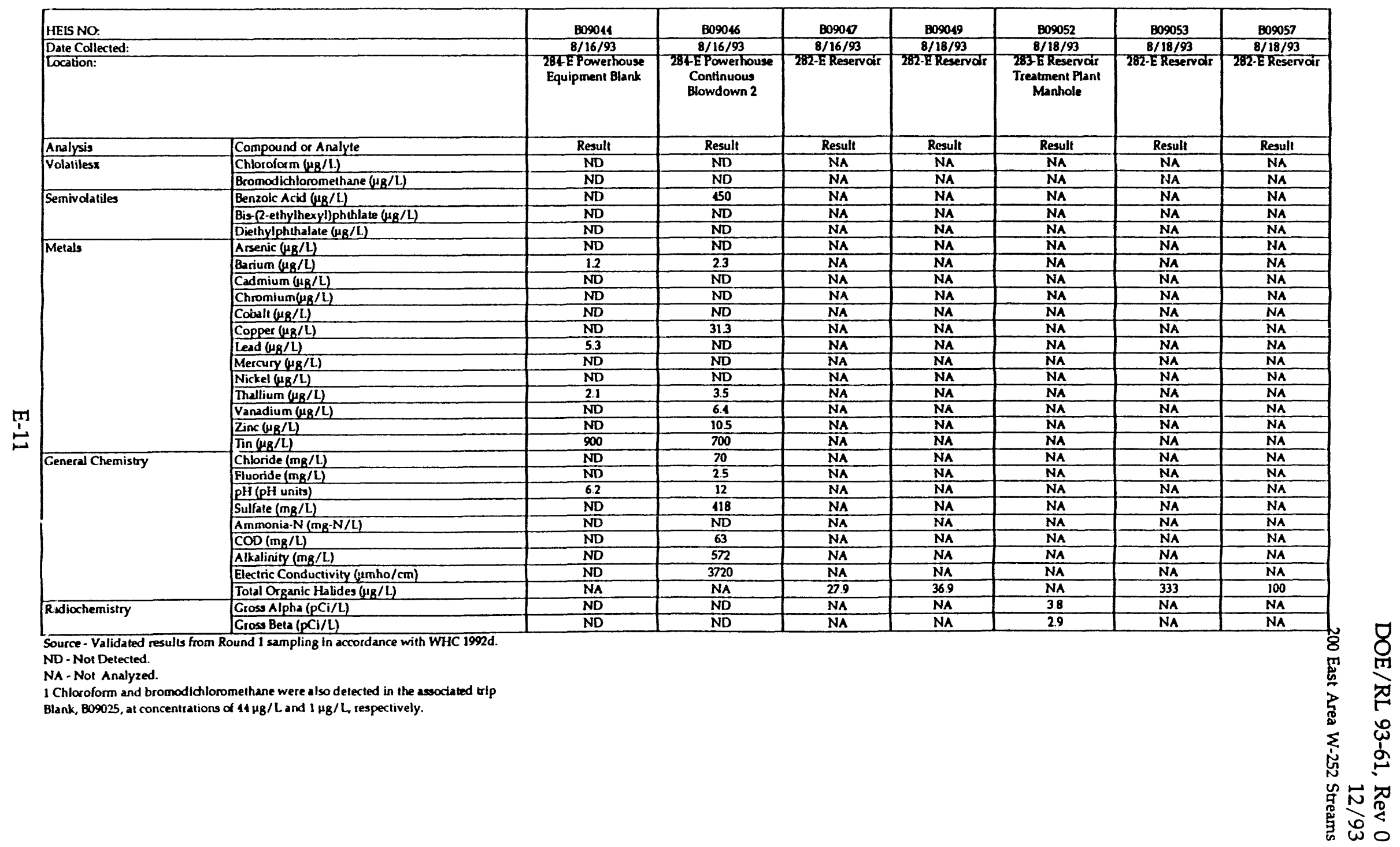


Table E-8. Postive Results for 284-E Power Plant Waste Water Samples (Page 4 of 5)

\begin{tabular}{|c|c|c|c|c|c|c|c|c|}
\hline \begin{tabular}{|l} 
HEIS NO: \\
Date Collected: \\
Location:
\end{tabular} & & $\frac{809060}{\frac{8 / 18 / 93}{282-8 / \text { Reservoir }}}$ & $\frac{B 09063}{\frac{8 / 18 / 93}{282-E \text { Reservoir }}}$ & $\frac{B 09066}{\frac{8 / 18 / 93}{282-8 \text { Reservar }}}$ & $\frac{\text { B09068 }}{\frac{8 / 18 / 93}{216-8 D D i t c h}}$ & $\frac{809069}{\frac{8 / 18 / 93}{202-E \text { Reservor }}}$ & $\frac{809072}{\frac{8 / 18 / 93}{282-\text { E Reservdr }}}$ & $\frac{B 09074}{8 / 18 / 93}$ \\
\hline Analysls & Compound or Analyle & Result & Result & Result & Result & Result & Result & Result \\
\hline \multirow[t]{2}{*}{ Volatilest } & Chloroform ( $\mathrm{Hg} / \mathrm{L})$ & NA & NA & NA & NA & NA & NA & NA \\
\hline & Bromodidiloromethane ( $\mathrm{\mu g} / \mathrm{L}$ ) & NA & NA & NA & NA & NA & NA & NA \\
\hline \multirow[t]{3}{*}{ Semivolatiles } & Benzoic Acid $\left(\mu_{B} / \mathrm{L}\right)$ & NA & NA & NA & NA & NA & NA & NA \\
\hline & Bis-(2-ethylhexyl)phichlate $\left(\mu_{\mathrm{g}} / \mathrm{L}\right)$ & NA & NA & NA & NA & NA & NA & NA \\
\hline & Diethy!phthalate $(\mu \mathrm{g} / \mathrm{L})$ & NA & NA & NA & NA & NA & NA & NA \\
\hline \multirow[t]{13}{*}{ Metals } & Arsenic $(\mu / / L)$ & NA & NA & NA & NA & NA & NA & NA \\
\hline & Barium $(\mu g / \mathrm{L})$ & NA & NA & NA & NA & NA & NA & Nh \\
\hline & Cadmium $(\mu 8 / L)$ & NA & NA & NA & NA & NA & NA & NA \\
\hline & Chromium $(\mu \mathrm{g} / \mathrm{l})$ & NA & NA & NA & NA & NA & NA & NA \\
\hline & Cobalt $(\mu \mathrm{g} / \mathrm{L} / \mathrm{L})$ & NA & NA & NA & NA & NA & NA & NA \\
\hline & Copper $(\mu 8 / \mathrm{L})$ & NA & $\mathrm{NA}$ & NA & NA & NA & NA & NA \\
\hline & Lead $(\mu g / L)$ & NA & NA & NA & NA & NA & NA & NA \\
\hline & Mercury $(\mu / \mathrm{L} / \mathrm{L})$ & NA & NA & NA & NA & NA & NA & NA \\
\hline & Nickel $\left(\mu_{8} / \mathrm{L}\right)$ & NA & NA & NA & NA & NA & NA & NA \\
\hline & Thallium $\left(\mu_{g} / \mathrm{L}\right)$ & NA & NA & NA & NA & NA & NA & NA \\
\hline & Vanadium $\left(\mu_{8} / \mathrm{L}\right)$ & NA & NA & NA & NA & NA & NA & NA \\
\hline & Zinc $\left(\mu_{8} / \mathrm{L}\right)$ & NA & NA & NA & NA & NA & NA & NA \\
\hline & $\operatorname{Tin}(\mu g / L)$ & NA & NA & NA & NA & NA & NA & NA \\
\hline \multirow{9}{*}{ General Chemistry } & Chloride (mg/L) & NA & NA & NA & NA & NA & NA & NA \\
\hline & Fluoride $(\mathrm{mg} / \mathrm{L})$ & $\mathrm{NA}$ & NA & NA & NA & NA & NA & NA \\
\hline & $\mathrm{pH}$ (pH units) & NA & NA & NA & NA & NA & NA & NA \\
\hline & Sulfate (mg/t) & NA & NA & $\mathrm{NA}$ & NA & $\mathrm{NA}$ & $\mathrm{NA}$ & NA \\
\hline & Ammonia-N (mg-N/L) & $\mathrm{NA}$ & $\mathrm{NA}$ & NA & NA & NA & NA & NA \\
\hline & $\operatorname{COD}(\mathrm{mg} / \mathrm{l})$ & NA & NA & NA & $\mathrm{NA}$ & NA & NA & NA \\
\hline & Alkalinity (mg/L) & NA & NA & NA & NA & NA & $\mathrm{NA}$ & NA \\
\hline & Electric Conductivity $(\mu \mathrm{mho} / \mathrm{cm})$ & NA & NA & NA & NA & NA & NA & NA \\
\hline & Total Organic Halides $\left(\mu_{8} / \mathrm{L}\right)$ & 68.8 & 1110 & 13.7 & NA & 335 & 245 & 158 \\
\hline \multirow[t]{2}{*}{ Radiochemistry } & Gross Alpha (pCi/L) & NA & NA & NA & 24 & NA & NA & NA \\
\hline & Gross Beta (pCi/L) & NA & NA & NA & 2.5 & NA & NA & NA \\
\hline
\end{tabular}

Source - Validated results from Round I sampling in accord ance with WIIC 1992d. ND - Not Detected.

NA - Not Analyzed.

1 Chloroform and bromodichloromethane were also detected in the assoctated tip

Blank, B09025, at concentrations of $44 \mu \mathrm{g} / \mathrm{L}$ and $1 \mu \mathrm{g} / \mathrm{L}$, respectively. 
Table E-8. Positive Results for 284-E Powerplant Waste Water Samples (Page 5 of 5)

\section{Stream Sample Evaluation}

A total of eight samples and one equipment blank (HEIS number B09044) were collected and analyzed for the full set of parameters, as listed below, in accordance with the 284-E Area Powerplant Process Waste Water Streams Sampling and Analysis Plan (WHC 1992d).

- Volatile Organics

- Semivolatile Organics

- Pesticidies/ PCBs

- Organophosphorus Pesticidies

- Herbicidies

- Metals

- General Chemistry

- Radiochemistry

In addition to the required nine samples as referenced above, several samples were collected and analyzed for total organic halides (TOX) and radiochemistry parameters.

Ten trip blank samples were analyzed for volitile organics, of which sample B09025 contained chloroform and bromodichloromethane at concentrations of $44 \mu \mathrm{g} / \mathrm{L}$, and $1 \mu \mathrm{g} / \mathrm{L}$, respectively. Also, trip blank samples B09032, B09035, and B09077 contained methylene chloride at concentrations of $2 \mu \mathrm{g} / \mathrm{L}, 3 \mu \mathrm{g} / \mathrm{L}$, and $3 \mu \mathrm{g} / \mathrm{L}$ respectively.

The samples were analyzed for all of the parameters required by the associated sampling and analysis plan (WHC 1992d), with the exception of the additional metals: aluminum, calcium, iron, magnesium, manganese, potassium, and sodium. The validated results for the round 1 sampling in accordance with WHC 1992d were reported as undetected with the exception of the results summarized in Table E-8. 
Table E-9. Summary of Analytical Results for the B Plant Cooling Water Stream.

\begin{tabular}{|c|c|c|c|}
\hline Parameter/CAS No. & Concentrations Measured $^{1}$ & Analytical Method & Detection Limit \\
\hline $\mathrm{pH}$ (pH units) & 8.2 & SW- $846^{2}, 9040$ & 0.1 \\
\hline Conductivity $(\mu \mathrm{mho} / \mathrm{cm})$ & 134 & $\mathrm{EPA}^{3}, 120.1$ & 6 \\
\hline Total Dissolved Solids (mg/L) & 106 & $\mathrm{EPA}^{3}, 160.1$ & 5 \\
\hline Total Suspended Solids ( $\mathrm{mg} / \mathrm{L}$ ) & ND & $\mathrm{EPA}^{3}, 160.2$ & 5 \\
\hline 5 Day BOD $(\mathrm{mg} / \mathrm{L})$ & ND & $E P^{3}, 405.1$ & 2 \\
\hline $\operatorname{COD}(\mathrm{mg} / \mathrm{L})$ & ND & $\mathrm{EPA}^{3}, 410.1$ & 30 \\
\hline Ammonia- $N$ (mg-N/L) & 0.07 & $\mathrm{EPA}^{3}, 350.2$ & 0.05 \\
\hline TKN-N & NA & NA & NA \\
\hline Nitrate + Nitrite- $\mathrm{N}^{4}(\mathrm{mg}-\mathrm{N} / \mathrm{L})$ & ND & $\mathrm{EPA}^{3}, 353.3$ & 0.25 \\
\hline Ortho-phosphate-P & NA & NA & NA \\
\hline Total-phosphate-P $(\mathrm{mg} / \mathrm{L})$ & ND & $\mathrm{EPA}^{3}, 365.2$ & 0.05 \\
\hline Total Oil \& Grease (mg/L) & ND & SW- $846^{2}, 9070$ & 5 \\
\hline Calcium / 7440-70-2 & NA. & NA & NA \\
\hline Magnesium/7439-95-4 & NA & NA & NA \\
\hline Sodium / 7440-23-5 & NA & NA & NA \\
\hline Potassium / 7440-09-7 & NA & NA & NA \\
\hline Chloride (mg/L) & 1.4 & $\mathrm{EPA}^{3}, 300.0$ & 0.2 \\
\hline Sulfate $(\mathrm{mg} / \mathrm{L})$ & 10.8 & $\mathrm{EPA}^{3}, 375.4$ & 1 \\
\hline Fluoride (mg/L) & 0.2 & $\mathrm{EP}_{\mathrm{i}}{ }^{3}, 300.0$ & 0.1 \\
\hline Cadmium/7440-43-9 $(\mu \mathrm{g} / \mathrm{L})$ & ND & $S W-846^{2}, 6010$ & 1.4 \\
\hline Chromium/7440-49-3 $(\mu \mathrm{g} / \mathrm{L})$ & ND & $S W-846^{2}, 6010$ & 3.3 \\
\hline Lead $/ 7439-92-1(\mu \mathrm{g} / \mathrm{L})$ & 27 & SW- $846^{2}, 7421$ & 1.5 \\
\hline Mercury/7439-97-6 $(\mu \mathrm{g} / \mathrm{L})$ & ND & $\mathrm{SW}-846^{2}, 7470$ & 0.10 \\
\hline Selenium $/ 7782-49-2(\mu \mathrm{g} / \mathrm{L})$ & ND & SW $-846^{2}, 7740$ & 3.3 \\
\hline Silver $/ 7440-22-4(\mathrm{mg} / \mathrm{L})$ & ND & SW- $846^{2}, 6010$ & 3.3 \\
\hline Copper $/ 7440-51,(\mu \mathrm{g} / \mathrm{L})$ & 75 & SW- $846^{2}, 6010$ & 2.9 \\
\hline Iron $/ 7439-89-6$ & NA & NA & NA \\
\hline Manganese & NA & NA & NA \\
\hline Zinc $/ 7440-66-6(\mu \mathrm{g} / \mathrm{L})$ & 14.2 & $S W-846^{2}, 6010$ & NR \\
\hline Barium / 7440-39-3 $(\mu \mathrm{g} / \mathrm{L})$ & 37.3 & SW- $-846^{2}, 6010$ & NR \\
\hline Total Coliform & NA & NA & NA \\
\hline
\end{tabular}

Source - Validated results from Round 1 sampling in accordance with WHC 1992e.

NA - Not Analyzed ND - Not detected at the reported detection limit R - Not Recorded

1The value reported in the "Concentration Measured" column is the mean of the associated concentration in the samples collected from the B-Plant Cooling Water Stream.

2 EPA 1986, Test Methods for Evaluating Solid Waste (SW-846), Third Edition, United States Environmental Protection Agency, Office of Solid Waste and Emergency Response, Washington, D.C.

${ }^{3}$ EPA 1979, Methods for Chemical Analysis of Water and Wastes, EPA-600;4-79-020, United States Environmental Protection Agency,

Environmental Monitoring and Support Laboratory, Cincinnati, Ohio.

${ }^{4}$ Nitrate + nitrite- $N$ was reported in place of nitrate- $N$ since the nitrate- $N$ analysis was not performed by the laboratory. 
Table E-10. Positive Sample Results for B Plant Cooling Water. (Page 1 of 2)

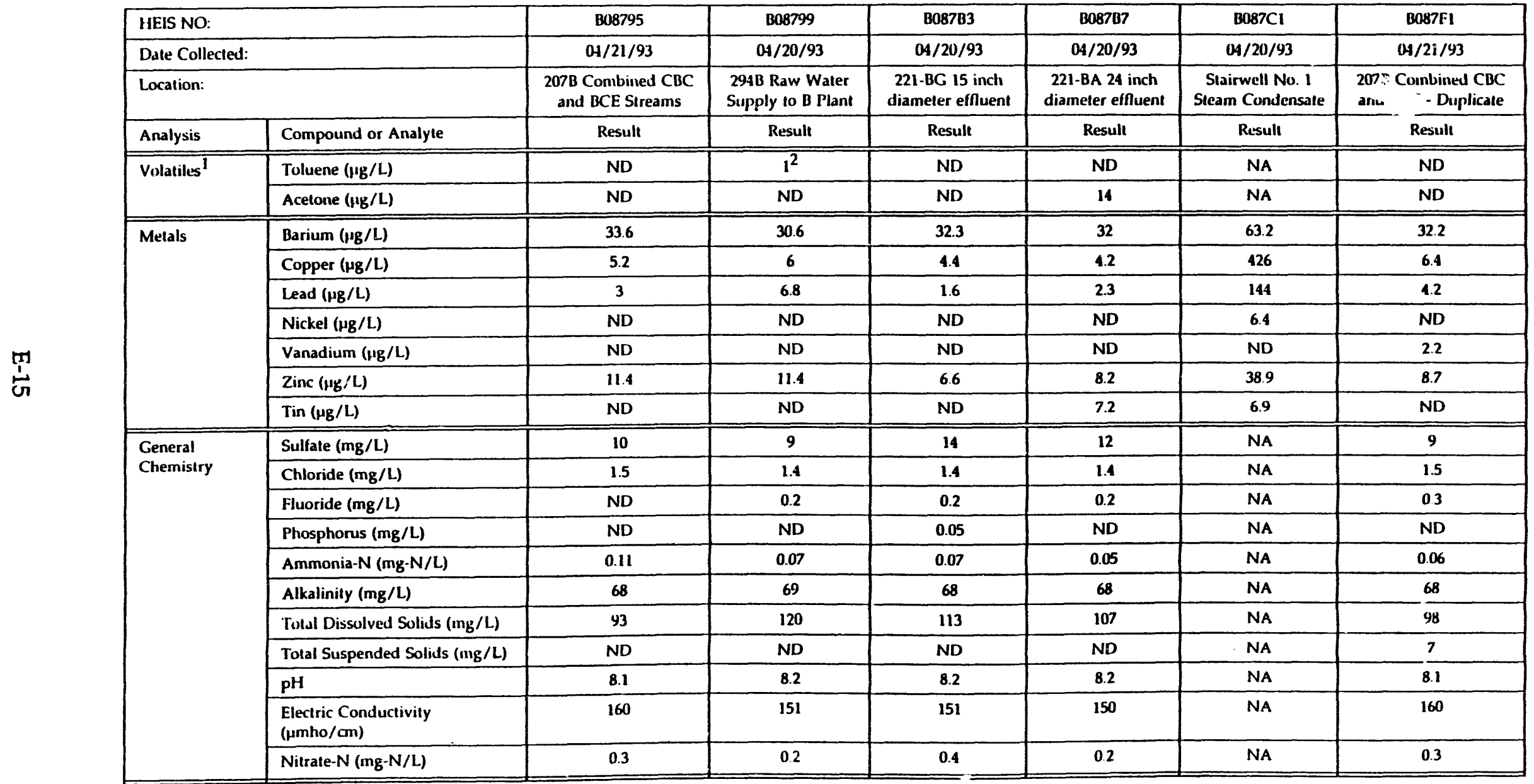


Table E-10. Positive Sample Results for B Plant Cooling Water. (Page 2 of 2)

\begin{tabular}{|c|c|c|c|c|c|c|c|}
\hline \multicolumn{2}{|l|}{ HEIS NO: } & B08795 & B08799 & B087B3 & B087B7 & BO87CI & B087FI \\
\hline \multicolumn{2}{|l|}{ Date Collected: } & $04 / 21 / 93$ & $04 / 20 / 93$ & $04 / 20 / 93$ & $04 / 20 / 93$ & $04 / 20 / 93$ & $04 / 21 / 93$ \\
\hline \multicolumn{2}{|l|}{ l.ocation: } & $\begin{array}{l}\text { 207B Combined CBC } \\
\text { and BCE Streams }\end{array}$ & $\begin{array}{l}\text { 294B Raw Water } \\
\text { Supply to B Plant }\end{array}$ & $\begin{array}{c}\text { 221-BG } 15 \text { inch } \\
\text { diameter effluent }\end{array}$ & $\begin{array}{c}221-B A 24 \text { inch } \\
\text { diameter effluent }\end{array}$ & $\begin{array}{c}\text { Stairwell No. } 1 \\
\text { Steam Contlensate }\end{array}$ & $\begin{array}{l}\text { 207B Combined CBC } \\
\text { and BCE - Duplicate }\end{array}$ \\
\hline Analysis & Compound or Analyte & Result & Result & Result & Result & Result & Result \\
\hline \multirow[t]{6}{*}{ Radiochemistry } & Gross Beta $(p \mathrm{Ci} / \mathrm{L})$ & ND & 2 & 2.7 & 2.3 & NA & ND \\
\hline & Uranium 233/234 (pCi/L) & 0.42 & 0.24 & 0.23 & 0.4 & NA & 0.28 \\
\hline & Uranium 238 ( $\mathrm{pCi} / \mathrm{L}$ ) & 0.23 & 0.2 & 0.21 & 0.31 & NA & 0.28 \\
\hline & Total Uranium $(\mu \mathrm{g} / \mathrm{L})$ & 0.85 & 0.77 & 0.68 & 0.68 & NA & 0.86 \\
\hline & Stronium-89 $(\mathrm{pCi} / \mathrm{L})$ & ND & ND & ND & 0.35 & NA & ND \\
\hline & Tritium (pCi/L) & 330 & ND & ND & ND & NA & ND \\
\hline
\end{tabular}

Source - Validaled results from Round 1 sampling in accordance with WHC 1992e.

ND - Not Detected

NA - Not Analyzed

1 The positive results for toluene and acetone should be evaluated with uncertainty since they are common laboratory contaminants.

2 Toluene was also detected in the associated trip blanks (HEIS Nos. B087B2 and B087F3) both at a concentration of 1 ug/L.

\section{Stream Sample Evaluation}

A total of five samples were collected, analyzed, and validated results reported for all of the parameter in accordance with the B Plant Cooling Water Sampling and Analysis I'lan, (WHC 1992e) as listed below:

$\begin{array}{ll}: & \text { Volatile Organics } \\ : & \text { Semivolatile Organics } \\ : & \text { Pesticides/PCBs } \\ : & \text { Organophosphorus Pesticides } \\ : & \text { Herbicides } \\ : \quad & \text { Metals } \\ \text { - } & \text { Reneral Chemistry } \\ & \text { Radiochemistry }\end{array}$

In atdition to the required five samples, one sample was also collected from the Stairwell number 1 Steam Condensate, B087Cl, and analyzed for metals only. Also, liree trip blank samples, HEIS Nos. B087B2, B087F3, B098F4, were analyzed for volatile organics and contained low levels of toluene at a concentration of $1 \mu \mathrm{gg} / \mathrm{L}$. in samples B087B2 and B087F3, and inethylene chloride was detected in sample B098F4 at a concentration of $3 \mu \mathrm{g} / \mathrm{L}$. All associated results for the six samples were reported as undetected with the exception of the results summarized in Table E-10. 
DOE/RL 93-61, Rev 0

$12 / 93$

200 East Area W-252 Streams

\subsection{WASTE WATER CHARACTERISTICS FOR TOXIC POLLUTANTS}

The intent of this question is to determine which chemicals are or might be present in the process water or waste water. For each chemical listed below:

a. Use the letter $A$ in the ABST column if the chemical is not likely to be present breause it is not used in the production process or used on site.

b. Use the letter $S$ in the ABST column if the chemical may be present because it is used on site, but the chemical is not used in the production process.

c. Use the letter $P$ in the PRST column if the chemical is likely to be present because it is used in the production process, but the effluent has not been tested.

d. Use the letter $K$ in the PRST column if the effluent has been tested and found to be present

Attach the analytical results.

Tables detailing the waste water characteristics for toxic pollutants for each of the six facilities are included as follows:

Waste Stream

242-A Evaporator Cooling Water

242-A Evaporator Steam Condensate

241-A Tank Farm Cooling Water

244-AR Vault Cooling Water

284-E Power Plant Waste Water

B Plant Cooling Water
Table Number

E-11

$\mathrm{E}-12$

E-13

E-14

E-15

E-16

Analytical results used in completing the following Waste Water Characteristics for Toxic Pollutanis tables are available for the 242-A Evaporator Cooling Water, 242-A Evaporator Steam Condensate, 284-E Power Plant Waste Water, and the B Plant Cooling Water Streams in WHC 1992a. Analytical results for the 241-A Tank Farm Cooling Water Stream and the 244-AR Vault Cooling Water Stream in accordance with the approved SAPs (WHC 1992b and WHC 1992c, respectively), are available on request. 
Table E-11. 242-A Evaporator Cooling Water Waste Water Characterization Analytical Results

Waste Water Characterization for Toxic Pollutants (Page 1 of 2)

\begin{tabular}{|c|c|c|c|}
\hline ABST / PAST & CONSTITUENT/CAS NO. & ABST / PAST & CONSTITUENT/CAS No. \\
\hline $\mathbf{A}$ & Acrylamide/79-06-1 & A & 1,2 Dichloropropane/78-87-5 \\
\hline A & Acrylonitrile/107-13-1 & A & 1,3 Dichloropropene/542-75-6 \\
\hline A & Aldrin/309-00-2 & A & Dichlorvos/62.73-7 \\
\hline A & Aniline/62-53-3 & A & Dieldrin/60-57-1 \\
\hline A & Aramite/140-57-8 & A & 3.3' Dimethoxybenzidine/119-90-4 \\
\hline$\star$ & Arsenic $/ 7440-38-2$ & A & 3,3 Dimethylbenzidine/119-93-7 \\
\hline A & Azobenzene/103-33-3 & A & 1,2 Dimethylhydrazine/540-73-8 \\
\hline A & Benzene/71-43-2 & A & 2,4 Dinitrotoluene/121-14-2 \\
\hline A & Benzidine/92-87-5 & A & 2.6 Dinitrotoluene/606-20-2 \\
\hline A & Benzo(a)pyrene/50-32-8 & A & 1,4 Dioxane/123-91-1 \\
\hline $\mathbf{A}$ & Benzotrichloride/98-07-7 & A & 1,2 Diphenylhydrazine/122-66-7 \\
\hline A & Benzyl chloride/100-44-7 & A & Endrin $/ 72-20-8$ \\
\hline A & Bis(chloroethyl)ether/111-44-4 & A & Epichlorohydrin/106-89-8 \\
\hline A & Bis(chloromethyl)ether/542-88-1 & A & Ethyl acrylate/140-88-5 \\
\hline A & $\begin{array}{l}\text { Bis(2-ethylhexyl)phthalate/ } \\
117-81-7\end{array}$ & $A$ & Ethylene dibromide/106-93-4 \\
\hline A & Bromodichloromethane $/ 75-27-4$ & A & Ethyiene thioureae/96-45-7 \\
\hline A & Bromotorm $775-25-2$ & A & Folpet/133-07-3 \\
\hline A & Carbazole/86-74-8 & A & Furmecyclox/60568-05-0 \\
\hline A & Carbon tetrachloride/56-23-5 & A & Heptachlor $/ 76-44-8$ \\
\hline A & Chlordane/57-74-9 & A & Heptachlor epoxide/1024-57-3 \\
\hline A & Chlorodibromomethane/124-48-1 & A & Hexachlorobenzene/118-74-1 \\
\hline $\mathrm{K}(1)$ & Chloroform/67-66-3 & $\mathbf{A}$ & $\begin{array}{l}\text { Hexachlorocyclohexane (alpha)/ } \\
319-84-6\end{array}$ \\
\hline A & Chlorthalonil/1897-45-6 & A & $\begin{array}{l}\text { Hexachlorocyclohexane (tech.)/ } \\
608-73-1\end{array}$ \\
\hline A & $2,4-D / 94-75-7$ & A & $\begin{array}{l}\text { Hexachlorodibenzo-p-dioxin, mix } \\
\text { 19408-74-3 }\end{array}$ \\
\hline A & DDT/50-29-3 & A & $\begin{array}{l}\text { Hydrazine/hydrazine sulfate/ } \\
302-01-2\end{array}$ \\
\hline
\end{tabular}


DOE/RL 93-61, Rev 0

$12 / 93$

200 East Area W-252 Streams

Table E-11. 242-A Evaporator Cooling Water Waste Water Characterization Analytical Results

Waste Water Characterization for Toxic Pollutants (Page 2 of 2)

\begin{tabular}{|c|c|c|c|}
\hline ABST / PRST & CONSTITUENT/CAS NO. & ABST / PRST & CONSTITUENT/CAS NO. \\
\hline A & Diallate/2303-16-4 & A & Lindane/58-89-9 \\
\hline A & 1.2 Dibromoethane/106-93-4 & A & 2 Methylaniline/100-61-8 \\
\hline A & 1,4 Dichlorobenzene/106-46-7 & A & $\begin{array}{l}2 \text { Methylaniline hydrochloride/ } \\
636-21-5\end{array}$ \\
\hline A & 3,3 Dichlorobenzidine/91-94-1 & A & $\begin{array}{l}\text { 4,4' Methylene bis(N,N- } \\
\text { dimethyl)aniline/101-61-1 }\end{array}$ \\
\hline A & 1,1 Dichloroethane/75-34-3 & A & $\begin{array}{l}\text { Methylene chioride } \\
\text { (dichloromethane)/75-09-2 }\end{array}$ \\
\hline A & 1,2 Dichloroethane/107-06-2 & A & Mirex/2385-85-5 \\
\hline A & Nitrofurazone/59-87-0 & A & O-phenylenediamine/106-50-3 \\
\hline A & $\begin{array}{l}N \text {-nitrosodiethanolamine/ } \\
1116-54-7\end{array}$ & A & Propylene oxide/75-56-9 \\
\hline A & $\mathrm{N}$-nitrosodiethylamine/55-18-5 & A & $\begin{array}{l}\text { 2,3,7,8-Tetrachlorodibenzo-p- } \\
\text { dioxin 1746-01-6 }\end{array}$ \\
\hline A & $\mathrm{N}$-nitrosodimethylamine/62-75-9 & A & Tetrachloroethylene/127-18-4 \\
\hline A & $\mathrm{N}$-nitrosodiphenylamine/86-30-6 & A & 2.4 Toluenediamine/95-80-7 \\
\hline A & $\begin{array}{l}\text { N-nitroso-di-n-propylamine/ } \\
621-64-7\end{array}$ & A & 0-Toluidine/95-53-4 \\
\hline A & $\mathrm{N}$-nitrosopyrrolidine/930-55-2 & A & Toxaphene/8001-35-2 \\
\hline A & $\begin{array}{l}\text { N-nitroso-di-n-butylamine/ } \\
924-16-3\end{array}$ & A & Trichloroethylene/79-01-6 \\
\hline A & $\begin{array}{l}N \text {-nitroso-n-methylethylamine/ } \\
\text { 10595-95-6 }\end{array}$ & A & 2,4,6-Trichlorophenol/88-06-2 \\
\hline A & PAH/NA & A & Trimethyl phosphate/512-56-1 \\
\hline A & PBBs/NA & A & Vinyl chloride $/ 75-01-4$ \\
\hline A & PCBs/1336-36-3 & & \\
\hline
\end{tabular}

Source - WHC $1992 a$

(1) Chloroform was detected at a concentration of 11.8 parts per billion (ppb) with a detection limit of 5 ppb.

Note: Tested and not Found. (") in the ABST column. 
Table E-12. 242-A Evaporator Steam Condensate Waste Water Characterization Analytical Results

Waste Water Characterization for Toxic Pollutants (Page 1 of 2)

\begin{tabular}{|c|c|c|c|c|}
\hline \multicolumn{2}{|c|}{ ABST / PRST } & CONSTITUENT/CAS NO. & ABST / PRST & CONSTITUENT/CAS NO. \\
\hline A & & Acrylamide/79-06-1 & A & 1,2 Dichloropropane/78-87-5 \\
\hline A & & Acrylonitrile/107-13-1 & A & 1,3 Dichloropropene/542-75-6 \\
\hline A & & Aldrin/309-00-2 & A & Dichlorvos/62-73-7 \\
\hline A & & Aniline/62-53-3 & A & Dieldrin/60-57-1 \\
\hline & & Aramite/140-57-8 & A & 3,3' Dimethoxybenzidine/119-90- \\
\hline & & Arsenic/7440-38-2 & A & 3,3 Dimethylbenzidine/119-93-7 \\
\hline & & Azobenzene/103-33-3 & A & 1,2 Dimethylhydrazine/540-73-8 \\
\hline A & & Benzene/71-43-2 & A & 2,4 Dinitrotoluene/121-14-2 \\
\hline A & & Benzidine/92-87-5 & A & 2,6 Dinitrotoluene/606-20-2 \\
\hline A & & Benzo(a)pyrene/50-32-8 & A & 1,4 Dioxane/123-91-1 \\
\hline & & Benzotrichloride/98-07-7 & $\mathbf{A}$ & 1,2 Diphenylhydrazine/122-66-7 \\
\hline A & & Benzyl chloride/100-44-7 & A & Endrin $72-20-8$ \\
\hline A & & Bis(chloroethyl)ether/111-44-4 & A & Epichlorohydrin/106-89-8 \\
\hline A & & Bis(chloromethyl)ether/542-88-1 & A & Ethyl acrylate/140-88-5 \\
\hline A & & $\begin{array}{l}\text { Bis(2-ethylhexyl)phthalate/ } \\
117-81-7\end{array}$ & A & Ethylene dibromide/106-93-4 \\
\hline A & & Bromodichloromethane $/ 75-27-4$ & A & Ethylene thioureae/96-45-7 \\
\hline A & & Bromoform $75-25-2$ & A & Folpet/133-07-3 \\
\hline A & & Carbazole/86-74-8 & A & Furmecyciox/60568-05-0 \\
\hline A & & Carbon tetrachloride/56-23-5 & A & Heptachlor/76-44-8 \\
\hline A & & Chlordane/57-74-9 & A & Heptachlor epoxide/1024-57-3 \\
\hline A & & Chlorodibromomethane/124 & A & Hexachlorobenzene/118-74-1 \\
\hline & $\mathrm{K}(2)$ & Chloroform/67-66-3 & A & $\begin{array}{l}\text { Hexachlorocyclohexane (alpha)/ } \\
319-84-6\end{array}$ \\
\hline A & & Chlorthalonil/1897-45-6 & A & $\begin{array}{l}\text { Hexachlorocyclohexane (tech.)/ } \\
608-73-1\end{array}$ \\
\hline A & & $2,4-D / 94-75-7$ & A & $\begin{array}{l}\text { Hexachlorodibenzo-p-dioxin, } \\
\text { mix 19408-74-3 }\end{array}$ \\
\hline A & & DDT/50-29-3 & A & $\begin{array}{l}\text { Hydrazine/hydrazine sulfate/ } \\
302-01-2\end{array}$ \\
\hline A & & Diallate/2303-16-4 & A & Lindane/58-89-9 \\
\hline
\end{tabular}


Table E-12. 242-A Evaporator Steam Condensate Waste Water Characterization Analytical Results

Waste Water Characterization for Toxic Pollutants (Page 2 of 2)

\begin{tabular}{|c|c|c|c|}
\hline ABST / PRST & CONSTITUENT/CAS NO. & ABST / PRST & CONSTITUENT/CAS NO. \\
\hline A & 1,2 Dibromoethane/106-93-4 & A & 2 Methylaniline/100-61-8 \\
\hline A & 1,4 Dichlorobenzene/106-46-7 & A & $\begin{array}{l}2 \text { Methylaniline hydrochloride/ } \\
636-21-5\end{array}$ \\
\hline A & 3,3' Dichlorobenzidine/91-94-1 & A & $\begin{array}{l}\text { 4,4' Methylene bis(N,N- } \\
\text { dimethyl)aniline/101-61-1 }\end{array}$ \\
\hline A & 1.1 Dichloroethane $/ 75-34-3$ & A & $\begin{array}{l}\text { Methylene chloride } \\
\text { (dichloromethane)/75-09-2 }\end{array}$ \\
\hline A & 1,2 Dichloroethane/107-06-2 & A & Mirex/2385-85-5 \\
\hline A & Nitrofurazone/59-87-0 & A & O-phenylenediamine/106-50-3 \\
\hline A & $\begin{array}{l}\text { N-nitrosodiethanolamine/ } \\
1116-54-7\end{array}$ & A & Propylene oxide/75-56-9 \\
\hline A & $\mathrm{N}$-nitrosodiethylamine/55-18-5 & A & $\begin{array}{l}2,3,7,8-T e t r a c h l o r o d i b e n z o-p- \\
\text { dioxin 1746-01-6 }\end{array}$ \\
\hline A & $\mathrm{N}$-nitrosodimethylamine/62-75-9 & A & Tetrachloroethylene/127-18-4 \\
\hline A & $N$-nitrosodiphenylamine/86-30-6 & A & 2,4 Toluenediamine/95-80-7 \\
\hline A & $\begin{array}{l}\text { N-nitroso-di-n-propylamine/ } \\
621-64-7\end{array}$ & A & 0-Toluidine/95-53-4 \\
\hline A & N-nitrosopyrrolidine/930-55-2 & A & Toxaphene/8001-35-2 \\
\hline A & $\begin{array}{l}\text { N-nitroso-di-n-butylamine/ } \\
\text { 924-16-3 }\end{array}$ & A & Trichloroethylene $/ 79-01-6$ \\
\hline A & $\begin{array}{l}\text { N-nitroso-n-methylethylamine/ } \\
\text { 10595-95-6 }\end{array}$ & A & 2,4,6-Trichlorophenol/88-06-2 \\
\hline A & PAH/NA & A & Trimethyl phosphate/512-56-1 \\
\hline A & PBBS/NA & A & Vinyl chloride/75-01-4 \\
\hline A & PCBs/1336-36-3 & & \\
\hline
\end{tabular}

Source - WHC 1992a

(1) Two tables were provided in the Best Available Technology/All Known and Reasonable Treatment (BAT/AKART) for the 242-A Evaporator Steam Condensate (WHC 1992a). Table 2.2 provides information concerning the baseline characteristics of the stream and Table 2-3 provides the estimated current status characteristics of the stream. Arsenic is reported as undetected at 1.70 parts per billion (ppb) in Table 2.2. however, is reported as detected at $1.72 \mathrm{ppb}$ in Table 2-3. Theretore, the actual presence or absence of arsenic in the waste water could not clearly be determined.

(2) Chlorotorm was detected at a concentration of $28 \mathrm{ppb}$ with a detection limit of 5 ppb.

Note: Tested and not Foind. (") in the ABST column. 
Table E-13. 241-A Tank Farm Cooling Water Waste Water Characterization Analytical Results

Waste Water Characterization for Toxic Pollutants (Page 1 of 2)

\begin{tabular}{|c|c|c|c|}
\hline ABST / PRST & CONSTITUENT/CAS NO. & ABST / PRST & CONSTITUENT/CAS NO. \\
\hline A & Acrylamide/79-06-1 & • & 1,2 Dichloropropane/78-87-5 \\
\hline$\star$ & Acrylonitrile/107-13-1 & - & 1,3 Dichloropropene/542-75-6 (1) \\
\hline 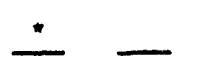 & Aldrin/309-00-2 & - & Dichlorvos/62-73-7 \\
\hline * & Aniline/62-53-3 & - & Dieldrin/60-57-1 \\
\hline * & Aramite/140-57-8 & A & 3,3' Dimethoxybenzidine/1 19-90-4 \\
\hline$*$ & Arsenic/7440-38-2 & . & 3,3 Dimethylbenzidine/119-93-7 \\
\hline A & Azobenzene/103-33-3 & A & 1,2 Dimethylhydrazine/540-73-8 \\
\hline * & Benzene/71-43-2 & * & 2,4 Dinitrotoluene/121-14-2 \\
\hline A & Benzidine/92-87-5 & * & 2,6 Dinitrotoluene/606-20-? \\
\hline$*$ & Benzo(a)pyrene/50-32-8 & * & 1,4 Dioxane/123-91-1 \\
\hline A & Benzotrichloride/98-07-7 & A & 1,2 Diphenylhydrazine/122-66-7 \\
\hline A & Benzyl chloride/100-44-7 & 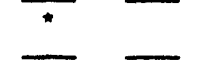 & Endrin $/ 72-20-8$ \\
\hline * & Bis(chloroethyl)ether/111-44-4 & A & Epichlorohydrin/106-89-8 \\
\hline A & Bis(chloromethyl)ether/542-88-1 & A & Ethyl acrylate/140-88-5 \\
\hline * & $\begin{array}{l}\text { Bis(2-ethylhexyl)phthalate/ } \\
117-81-7\end{array}$ & * & Ethylene dibrornide/106-93-4 \\
\hline 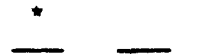 & Bromodichloromethane $/ 75-27-4$ & A & Ethylene thioureae/96-45-7 \\
\hline " & Bromoform $/ 75-25-2$ & A & Folpet/133-07-3 \\
\hline A & Carbazole/86-74-8 & A & Furmecyclox/60568-05-0 \\
\hline$\star$ & Carbon tetrachloride/56-23-5 & * & Heptachlor/76-44-8 \\
\hline * & Chlordane/57-74-9(2) & * & Heptachlor epoxide/1024-57-3 \\
\hline 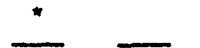 & Chlorodibromomethane/124-48-1 & * & Hexachiorobenzene/118-74-1 \\
\hline * & Chloroform $67-66-3$ & * & $\begin{array}{l}\text { Hexachlorocyclohexane (alpha)/ } \\
319-84-6\end{array}$ \\
\hline A & ChlorthaloniV1897-45-6 & A & $\begin{array}{l}\text { Hexachlorocyclohexane (tech.)/ } \\
608-73-1\end{array}$ \\
\hline * & $2,4-0 / 94-75-7$ & A & $\begin{array}{l}\text { Hexachlorodibenzo-p-dioxin, mix/ } \\
\text { 19408-74-3 }\end{array}$ \\
\hline * & DDT/50-29-3 & A & Hydrazine/hydrazine sulfate/ $302-01-2$ \\
\hline - & Diallate/2303-16-4 & * & Lindane/58-89-9 \\
\hline
\end{tabular}


DOE/RL 93-61, Rev 0

$12 / 93$

200 East Area W-252 Streams

Table E-13. 241-A Tank Farm Cooling Water Waste Water Characterization Analytical Results

Waste Water Characterization for Toxic Pollutants (Page 2 of 2)

\begin{tabular}{|c|c|c|c|}
\hline ABST / PRST & CONSTITUENT/CAS NO. & ABST / PRST & CONSTITUENTICAS NO. \\
\hline 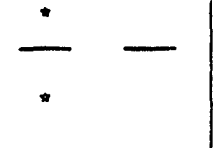 & $\begin{array}{l}\text { 1,2 Dibromoethane/106-93-4 } \\
\text { 1,4 Dichlorobenzene/106-46-7 }\end{array}$ & $\frac{A}{A}$ & $\begin{array}{l}2 \text { Methylaniline/100-61-8 } \\
2 \text { Methylaniline hydrochloride/ } \\
636-21-5\end{array}$ \\
\hline * & 3,3' Dichlorobenzidine/91-94-1 & A & $\begin{array}{l}\text { 4,4' Methylene bis(N,N- } \\
\text { dimethyl)aniline/101-61-1 }\end{array}$ \\
\hline * & 1,1 Dichloroethane/75-34-3 & * & $\begin{array}{l}\text { Methylene chloride } \\
\text { (dichloromethane)/75-09-2 }\end{array}$ \\
\hline * & 1,2 Dichloroethane/107-06-2 & A & Mirex/2385-85-5 \\
\hline A & Nitrofurazone/59-87-0 & ॠ & O-phenylenediamine/106-50-3 \\
\hline A & $\begin{array}{l}N \text {-nitrosodiethanolamine/ } \\
1116-54-7\end{array}$ & A & Propyiene oxide/75-56-9 \\
\hline * & $\mathrm{N}$-nitrosodiethylamine/55-18-5 & A & $\begin{array}{l}\text { 2,3,7,8-Tetrachlorodibenzo-p-dioxin/ } \\
\text { 1746-01-6 }\end{array}$ \\
\hline * & $\mathrm{N}$-nitrosodimethylamine/62-75-9 & * & Tetrachloroethylene/127-18-4 \\
\hline * & N-nitrosodiphenylamine/86-30-6 & A & 2,4 Toluenediamine/95-80-7 \\
\hline * & $\begin{array}{l}\text { N-nitroso-di-n-propylamine/ } \\
621-64-7\end{array}$ & • & o-Toluidine/95-53-4 \\
\hline * & $\mathrm{N}$-nitrosopyrrolidine/930-55-2 & * & Toxaphene/8001-35-2 \\
\hline * & $\begin{array}{l}N \text {-nitroso-di-n-butylamine/ } \\
924-16-3\end{array}$ & * & Trichloroethylene/79-01-6 \\
\hline * & $\begin{array}{l}\text { N-nitroso-n-methylethylamine/ } \\
\text { 10595-95-6 }\end{array}$ & * & 2,4,6-Trichlorophenol/88-06-2 \\
\hline$*$ & PAH/NA & A & Trimethyl phosphate/512-56-1 \\
\hline A & PBBs/NA & - & Vinyl chloride $/ 75-01-4$ \\
\hline 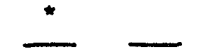 & PCBs/1336-36-3 (3) & & \\
\hline
\end{tabular}

Source - Validated results from Round 1 sampling in accordance with WHC $1992 \mathrm{~b}$.

(1) cis-1,3-Dichloropropene (CAS No. 10061-01-5)

(2) alpha-Chordane and gamma-Chiordane (CAS No. 5103-71-9 and 5103-74-2, respectively)

(3) The PCBs were analyzed according to the Environmental Protection Agency (EPA) Statement of Work (SOW) 1988, in which the PCBs are identified as seven different arochlor compounds as defined below:

- Aroclor-1016 (CAS No. 12674-11-2) - Arodor-1221 (CAS No. 11104-28-2)

- Aroclor-1232 (CAS No. 11141-16-5) - Aroclor-1242 (CAS No. 53469-21-9)

- Aroclor-1248 (CAS No. 12672-29-6) - Aroclor-1254 (CAS No. 11097-69-1)

- Arodor-1260 (CAS No. 110\%6-82-5)

Note: Tested and not found. (") in the ABST column 
Table E-14. 244-AR Vault Cooling Water Waste Water Characterization Analytical Results

Waste Water Characterization for Toxic Pollutants (Page 1 of 2)

\begin{tabular}{|c|c|c|c|}
\hline ABST / PRST & CONSTITUENT/CAS NO. & ABST / PRST & CONSTITUENTICAS No. \\
\hline$A$ & Acrylamide/79-06-1 & 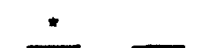 & 1,2 Dichloropropane/78-87-5 \\
\hline * & Acrylonitrile/107-13-1 & 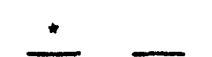 & 1.3 Dichloropropene/542-75-6 $(1)$ \\
\hline * & Aldrin/309-00-2 & * & Dichlorvos/62-73-7 \\
\hline$\star$ & Aniline/62-53-3 & $\star$ & Dieldrin/60-57-1 \\
\hline$\div$ & Aramite/140-57-8 & A & 3,3' Dimethoxybenzidine/119-90-4 \\
\hline 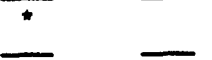 & Arsenic $/ 7440-38-2$ & $*$ & 3,3 Dimethylbenzidine/119-93-7 \\
\hline A & Azobenzene/103-33-3 & A & 1,2 Dimethyihydrazine/540-73-8 \\
\hline " & Benzene/71-43-2 & * & 2,4 Dinitrotoluene/121-14-2 \\
\hline A & Benzidine/92-87-5 & 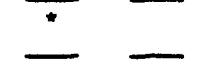 & 2,6 Dinitrotoluene/606-20-2 \\
\hline \# & Benzo(a)pyrene/50-32-8 & $*$ & 1,4 Dioxane/123-91-1 \\
\hline A & Benzotrichloride/98-07-7 & A & 1,2 Diphenylhydrazine/122-66-7 \\
\hline A & Benzyl chloride/100-44-7 & $*$ & Endrin $/ 72-20-8$ \\
\hline 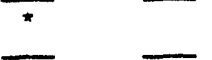 & Bis(chloroethyl)ether/111-44-4 & A & Epichlorohydrin/106-89-8 \\
\hline A & Bis(chloromethyl)ether/542-88-1 & A & Ethy! acrylate/140-88-5 \\
\hline * & $\begin{array}{l}\text { Bis(2-ethylhexyl)phthalate/ } \\
117-81-7\end{array}$ & * & Ethylene dibromide/106-93-4 \\
\hline 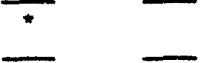 & Bromodichloromethane/75-27-4 & A & Ethylene thioureae/96-45-7 \\
\hline * & Bromoform $/ 75-25-2$ & A & Folpet/133-07-3 \\
\hline A & Carbazole/86-74-8 & A & Furmecyclox/60568-05-0 \\
\hline * & Carbon tetrachloride/56-23-5 & 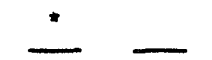 & Heptachlor $/ 76-44-8$ \\
\hline * & Chlordane/57-74-9(2) & * & Heptachlor epoxide/1024-57-3 \\
\hline 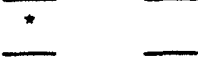 & Chlorodibromomethane/124-48-1 & 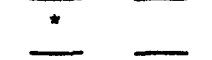 & Hexachlorobenzene/118-74-1 \\
\hline * & Chlorotorm/67-66-3 & - & $\begin{array}{l}\text { Hexachlorocyclohexane (alpha)/ } \\
\text { 319-84-6 }\end{array}$ \\
\hline A & Chlorthalonil/1897-45-6 & A & $\begin{array}{l}\text { Hexachlorocyclohexane (tech.)/ } \\
608-73-1\end{array}$ \\
\hline * & $2,4-D / 94-75-7$ & A & $\begin{array}{l}\text { Hexachlorodibenzo-p-dioxin, mix } \\
\text { 19408-74-3 }\end{array}$ \\
\hline * & DDT/50-29-3 & A & $\begin{array}{l}\text { Hydrazine/hydrazine sulfate/ } \\
302-01-2\end{array}$ \\
\hline ॠ & Diallate/2303-16-4 & * & Lindanc/58-89-9 \\
\hline " & 1,2 Dibromoethane/106-93-4 & A & 2 Methylaniline/100-51-8 \\
\hline
\end{tabular}


Table E-14. 244-AR Vault Cooling Water Waste Water Characterization Analytical Results

Waste Water Characterization for Toxic Pollutants (Page 2 of 2)

\begin{tabular}{|c|c|c|c|}
\hline ABST / PRST & CONSTIIUENT/CAS NO. & ABST / PRST & CONSTTUUENT/CAS No. \\
\hline * & 1,4 Dichlorobenzene/106-46-7 & A & $\begin{array}{l}2 \text { Methylaniline hydrochloride/ } \\
636-21.5\end{array}$ \\
\hline * & 3,3' Dichlorobenzidine/91-94-1 & A & $\begin{array}{l}\text { 4,4' Methylene bis(N,N- } \\
\text { dimethyl)aniline/101-61-1 }\end{array}$ \\
\hline - & 1,1 Dichloroethane/75-34-3 & - & $\begin{array}{l}\text { Methylene chloride } \\
\text { (dichloromethane)/75-09-2 }\end{array}$ \\
\hline * & 1,2 Dichloroethane/107-06-2 & A & Mirex/2385-85-5 \\
\hline A & Nitrofurazone/59-87-0 & * & O-phenylenediamine/106-50-3 \\
\hline A & $\begin{array}{l}\text { N-nitrosudiethanolamine/ } \\
1116-54-7\end{array}$ & A & Propylene oxide/75-56-9 \\
\hline * & $\mathrm{N}$-nitrosodiethylamine/55-18-5 & A & $\begin{array}{l}\text { 2,3,7,8-Tetrachlorodibenzo-p- } \\
\text { dioxin 1746-01-6 }\end{array}$ \\
\hline * & $\mathrm{N}$-nitrosodimethylamine/62-75-9 & " & Tetrachloroethylene/127-18-4 \\
\hline * & $\mathrm{N}$-nitrosodiphenylamine/86-30-6 & A & 2,4 Toluenediamine/95-80-7 \\
\hline * & $\begin{array}{l}\text { N-nitroso-di-n-propylamine/ } \\
621-64-7\end{array}$ & . & O-Toluidine/95-53-4 \\
\hline * & $\mathrm{N}$-nitrosopyrrolidine/930-55-2 & * & Toxaphene/8001-35-2 \\
\hline . & $\begin{array}{l}\text { N-nitroso-di-n-butylamine/ } \\
924-16-3\end{array}$ & . & Trichloroethylene/79-01-6 \\
\hline * & $\begin{array}{l}\text { N-nitroso-n-methylethylamine/ } \\
\text { 10595-95-6 }\end{array}$ & * & 2,4,6-Trichlorophenol/88-06-2 \\
\hline * & PAH/NA & A & Trimetnyl phosphate/512-56-1 \\
\hline A & PBBs/NA & * & Vinyl chloride/75-01-4 \\
\hline * & $\mathrm{PCBs} / 1336-36-3(3)$ & & \\
\hline
\end{tabular}

Source - Validated results from Round 1 sampling in accordance with WHC 1992C.

(1) cis-1,3-Dichloropropene (CAS No. 10061-01-5).

(2) alpha-Chlordane and gamma-Chlordane (CAS No. 5103-71.9 and 5103-74-2, respectively).

(3) The PCBs were analyzed according to the EPA Statement of Work (SOW) 1988, in which the PCBs are identified as seven different arochlor compounds as defined below:

- Arocior-1016 (CAS No. 12674-11-2) - Arocior-1221 (CAS No. 11104-28-2)

- Arocior-1232 (CAS No. 11141-16-5) - Aroclor-1242 (CAS No. 53469-21-9)

- Arocior-1248 (CAS No. 12672-29-6) - Arocior-1254 (CAS No. 11097-69-1)

- Arocior-1260 (CAS No. 11096-82-5)

Note: Tested and not found. (") in the ABST column. 
Table E-15. 284-E Power Plant Waste Water Characterization Analytical Results

Waste Water Characterization for Toxic Pollutants (Page 1 of 2)

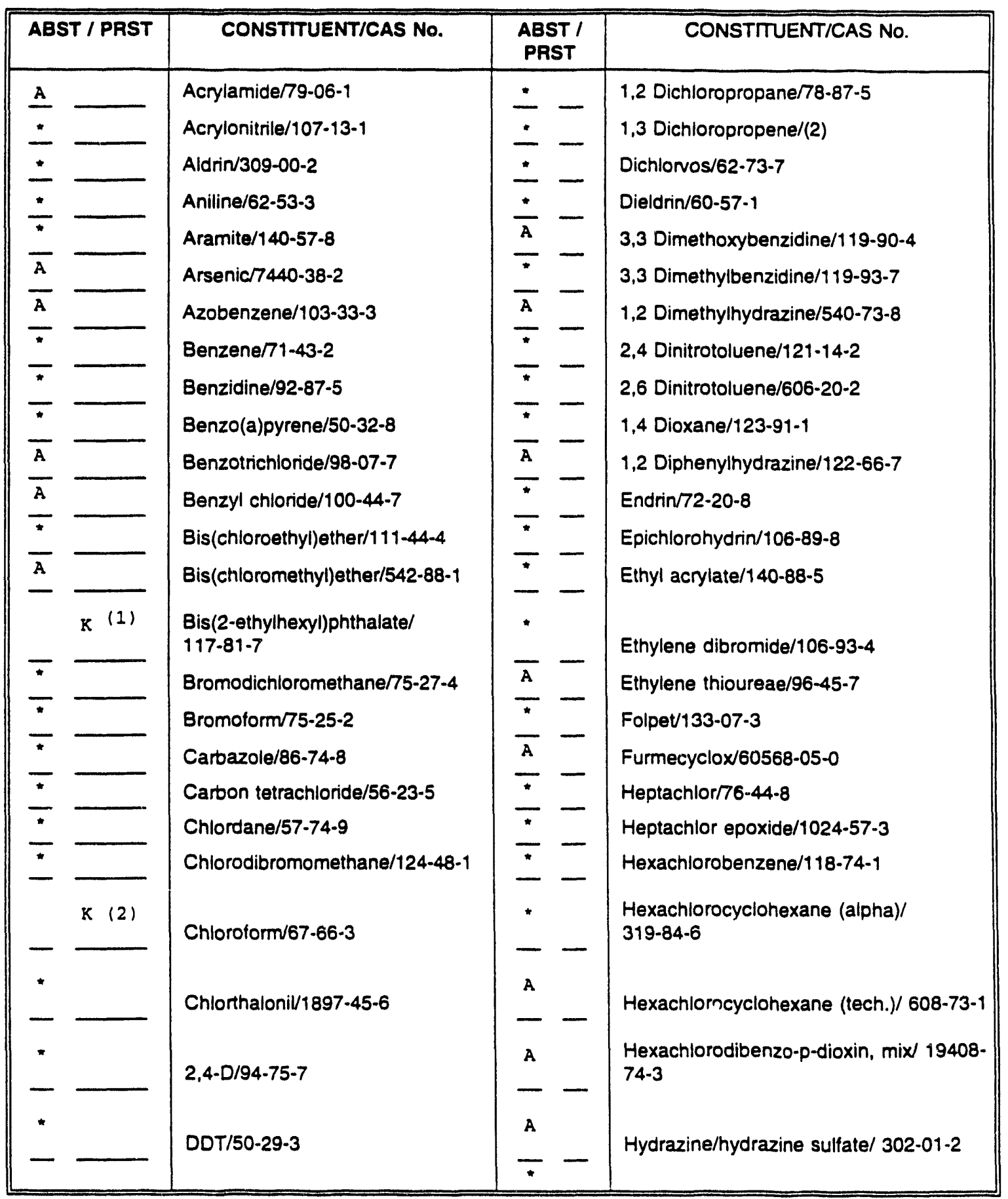


DOE/RL 93-61, Rev 0

$12 / 93$

200 East Area W-252 Streams

Table E-15. 284-E Power Plant Waste Water Characterization

Analytical Results

Waste Water Characterization for Toxic Pollutants (Page 2 of 2)

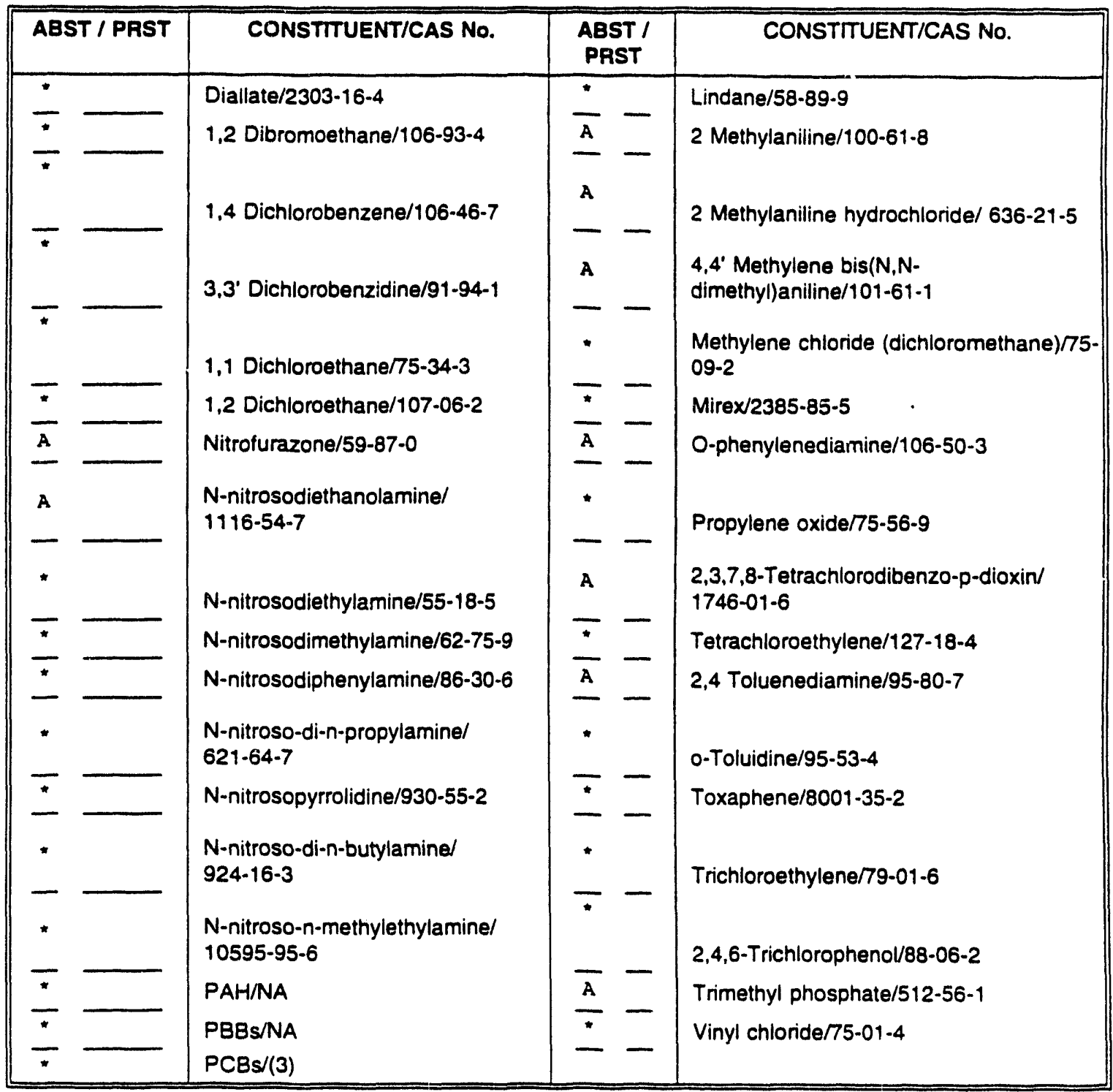

Source - WHC $1992 d$

The presence of bis(2-ethylhexyl)phthalate should be evaluated with uncertainty since only low levels (19 $\mu g / L$ and $25 \mu g /$ ) were detected. and bis(2-othylhexyl)phthalate is a known common laboratory contaminant.

2 cis-1,3-Dichloropropene (CAS No. 10061-01-5) and trans-1,3-Dichloropropene (CAS No. 10061-02-6).

3 The PCBs were identified as seven different arochlor compounds as defined below:

- Arochior-1016 (CAS No. 12674-11-2) - Arochlor-1221 (CAS No. 11104-28-2)

- Arochlor-1232 (CAS No. 11141-16-5) - Arochllor-1242 (CAS No. 53469-21-9)

- Arochlor-1248 (CAS No. 12672-29-6) - Arochlor-1254 (CAS No. 11097-69-1)

- Arochlor-1260 (CAS No. 11096-82-5)

NOTE: Tested and not tound. (") in the ABST column. 
Table E-16. B-Plant Cooling Water Waste Water Characterization Analytical Results

Waste Water Characterization for Toxic Pollutants (Page 1 of 2)

\begin{tabular}{|c|c|c|c|}
\hline ABST / PRST & CONSTITUENT/CAS NO. & ABST / PRST & CONSTITUENT/CAS NO. \\
\hline A & Acrylamide 79-06-1 & * & 1,2 Dichloropropane/78-87-5 \\
\hline * & Acrylonitrile/107-13-1 & * & 1.3 Dichloropropene/542.75-6 \\
\hline - & Aldrin/309-00-2 & * & Dichlorvos/62.73-7 \\
\hline * & Aniline/62-53-3 & * & Dieldrin/60-57-1 \\
\hline - & Aramite/140-57-8 & A & 3,3' Dimethoxybenzidine/1 19-90-4 \\
\hline A & Arsenic/7440-38-2 & * & 3,3 Dimethylbenzidine/1 19-93-7 \\
\hline A & Azobenzene/103-33-3 & A & 1,2 Dimethylhydrazine/540-73-8 \\
\hline * & Benzene/ $/ 71.43-2$ & ” & 2,4 Dinitrotoluene/121-14-2 \\
\hline * & Benzidine/92-87.5 & * & 2,6 Dinitrotoluene/606-20-2 \\
\hline${ }^{*}$ & Benzo(a)pyrene/50-32-8 & * & 1,4 Dioxane/123-91-1 \\
\hline A & Renzotrichloride/98-07-7 & A & 1,2 Diphenylhydrazine/122-66-7 \\
\hline A & Eenzyl chloride/100-44-7 & * & Endrin $/ 72-20-8$ \\
\hline * & Bis(chloroethyl)ether $/ 111-44-4$ & * & Epichlorohydrin/106-89-8 \\
\hline A & Bis(chloromethyl)ether/542-88-1 & " & Ethyl acrylate/140-88-5 \\
\hline * & $\begin{array}{l}\text { Bis(3-ethylhexyl)phthalate/ } \\
117-81-7\end{array}$ & * & Ethylene dibromide/106-93-4 \\
\hline * & Bromodichloromethane $/ 75-27-4$ & A & Ethylene thioureae/96-45-7 \\
\hline * & Bromotorm $75-25-2$ & • & Folpet/133-07-3 \\
\hline " & Carbazole/86-74-8 & A & Furmecyclox/60568-05-0 \\
\hline * & Carbon tetrachloride/56-23-5 & - & Heptachlor $/ 76-44-8$ \\
\hline * & Chlordane/57-74-9 & - & Heptachlor epoxide/1024-57-3 \\
\hline * & Chlorodibromomethane/124-48-1 & $*$ & Hexachlorobenzene/118-74-1 \\
\hline * & Chloroform/67-66-3 & . & $\begin{array}{l}\text { Hexachlorocyclohexane (alpha)/ } \\
319-84-6\end{array}$ \\
\hline * & ChlorthaloniV1897-45-6 & A & $\begin{array}{l}\text { Hexachlorocyclohexane (tech.)/ } \\
608-73-1\end{array}$ \\
\hline - & 2,4-D/94-75-7 & A & $\begin{array}{l}\text { Hexachlorodibenzo-p-dioxin, mix/ } \\
\text { 19408-74-3 }\end{array}$ \\
\hline * & DDT/50-29-3 & A & $\begin{array}{l}\text { Hydrazine/hydrazine sulfate/ } \\
302-01-2\end{array}$ \\
\hline " & Diallate/2303-16-4 & " & Lindane/58-89-9 \\
\hline
\end{tabular}


Table E-16. B-Plant Cooling Water Waste Water Characterization Analytical Results

Waste Water Characterization for Toxic Pollutants (Page 2 of 2)

\begin{tabular}{|c|c|c|c|}
\hline ABST / PRST & CONSTITUENTICAS NO. & ABST / PAST & CONSTITUENTICAS NO. \\
\hline 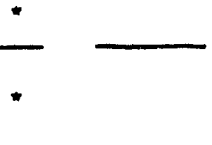 & $\begin{array}{l}\text { 1,2 Dibromoethane/106-93-4 } \\
\text { 1,4 Dichlorobenzene/106-46-7 }\end{array}$ & $\frac{A}{A}$ & $\begin{array}{l}2 \text { Methylaniline/100-61-8 } \\
2 \text { Methylaniline hydrochloride/ } \\
636-21-5\end{array}$ \\
\hline$*$ & 3,3' Dichlorobenzidine/91-94-1 & A & $\begin{array}{l}\text { 4,4' Methylene bis(N.N- } \\
\text { dimethyl)aniline/101-61-1 }\end{array}$ \\
\hline - & 1.1 Dichloroethane/75-34-3 & . & $\begin{array}{l}\text { Methylene chloride } \\
\text { (dichloromethane)/75-09-2 }\end{array}$ \\
\hline * & 1,2 Dichloroethane/107-06-2 & * & Mirex/2385-85-5 \\
\hline A & Nitrofurazone/59-87-0 & A & O-phenylenediamine/106-50-3 \\
\hline$\star$ & $\begin{array}{l}\text { N-nitrosodiethanolamine/ } \\
1116-54-7\end{array}$ & * & Propylene oxide/75-56-9 \\
\hline$\star$ & $N$-nitrosodiethylamine/55-18-5 & A & $\begin{array}{l}2,3,7,8-T e t r a c h l o r o d i b e n z o-p- \\
\text { dioxin/ 1746-01-6 }\end{array}$ \\
\hline$\star$ & $\mathrm{N}$-nitrosodimethylamine/62-75-9 & " & Tetrachloroethylene/127-18-4 \\
\hline * & $\mathrm{N}$-nitrosodiphenylamine/86-30-6 & A & 2.4 Toluenediamine/95-80-7 \\
\hline$\star$ & $\begin{array}{l}\text { N-nitroso-di-n-propylamine/ } \\
621-64.7\end{array}$ & * & 0-Toluidine/95-53-4 \\
\hline$\star$ & $\mathrm{N}$-nitrosopyrrolidine/930-55-2 & - & Toxaphene/8001-35-2 \\
\hline * & $\begin{array}{l}\mathrm{N} \text {-nitroso-di-n-butylamine/ } \\
924-16-3\end{array}$ & $\bullet$ & Trichloroethylene $799-01-6$ \\
\hline * & $\begin{array}{l}\text { N-nitroso-n-methylethylamine/ } \\
10595-95-6\end{array}$ & . & 2,4,6-Trichlorophenol/88-06-2 \\
\hline * & PAH/NA & A & Trimethyl phosphate/512-56-1 \\
\hline * & PBBs/NA & * & Vinyl chloride $/ 75-01-4$ \\
\hline * & PCBs/1336-36-3 & & \\
\hline
\end{tabular}

Source - WHC $1992 a$

(1) Cis 1,3-Dichloropropene (CAS No. 10061-01-5) and trans-1,3 Dichloropropene (CAS No. 10061-02-6).

(2) The PCBs were identified as seven different arochlor compounds as defined below:

- Arochlor-1016 (CAS No. 12674-11-2) - Arochlor-1221 (CAS No. 11104-28-2)

- Arochlor-1232 (CAS No. 11141-16-5) - Arochlor-1242 (CAS No. 53469-21-9)

- Arochlor-1248 (CAS No. 12672-29-6) - Arochlor-12547(CAS No. 11097-69-1)

- Arochlor-1260 (CAS No. 11096-82-5)

Note: Tested and not found. (") in the ABST column. 
DOE/RL 93-61, Rev 0

$12 / 93$

200 East Area W-252 Streams

This page intentionally left blank. 
DOE/RL 93-61, Rev 0

$12 / 93$

200 East Area W-252 Streams

\section{APPENDIX F}

\section{STORMWATER}

F-i 
DOE/RL 93-61, Rev 0

$12 / 93$

200 East Area W-252 Streams

This page intentionally left blank. 
DOE/RL 93-61, Rev 0

$12 / 93$

200 East Area W-252 Streams

\section{CONTENTS}

1.0 DO YOU HAVE A STORMWATER NATIONAL POLLUTANT

DISCHARGE ELIMINATION SYSTEM (NPDES) PERMIT? . . . . . . . . . F-1

2.0 HAVE YOU APPLIED FOR A STORMWATER NATIONAL

POLLUTANT DISCHARGE ELIMINATION SYSTEM (NPDES)

PERMIT?

3.0 ARE YOU COVERED OR HAVE YOU APPLIED FOR COVERAGE

UNDER A GENERAL OR GROUP STORMWATER PERMIT? . . . . . . . . . F-1

4.0 DESCRIBE THE SIZE OF THE STORMWATER COLLECTION AREA. . . . F F-1

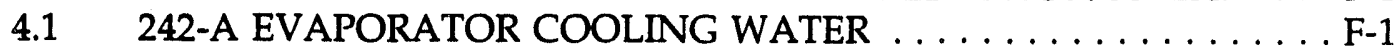

4.2 242-A EVAPORATOR STEAM CONDENSATE $\ldots \ldots \ldots \ldots \ldots \ldots$ F-1

4.3 241-A TANK FARM COOLING WATER $\ldots \ldots \ldots \ldots \ldots \ldots \ldots$ F-2

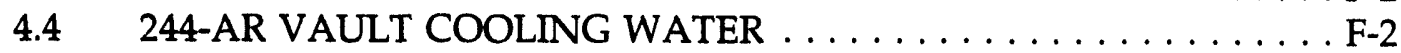

$4.5 \quad 284-\mathrm{E}$ POWER PLANT $\ldots \ldots \ldots \ldots \ldots \ldots \ldots \ldots \ldots \ldots$. $\ldots \ldots \ldots \ldots$

4.6 B PLANT COOLING WATER $\ldots \ldots \ldots \ldots \ldots \ldots \ldots$. $\ldots \ldots \ldots$

5.0 DESCRIBE THE STORMWATER MANAGEMENT SYSTEMS. . . . . . . . F-2

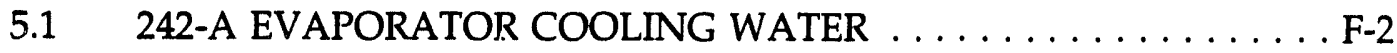

5.2 242-A EVAPORATOR STEAM CONDENSATE $\ldots \ldots \ldots \ldots \ldots \ldots$ F-2

5.3 241-A TANK FARM COOLING WATER ............ F-3

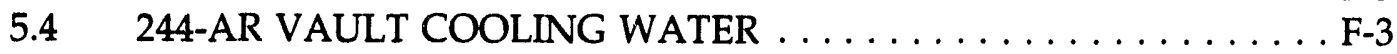

$5.5 \quad 284$-E POWER PLANT $\ldots \ldots \ldots \ldots \ldots \ldots \ldots \ldots \ldots \ldots \ldots$ F-3

5.6 B PLANT COOLING WATER $\ldots \ldots \ldots \ldots \ldots \ldots \ldots$ F-3

6.0 ATTACH A MAP SHOWING STORMWATER

DRAINAGE/COLLECTION AREAS, DISPOSAL AREAS AND

DISCHARGE POINTS $\ldots \ldots \ldots \ldots \ldots \ldots \ldots \ldots \ldots$ F-3

\section{FIGURES}

F-1 General Notes and Legend - Stormwater Drainage System and Material Storage Areas . . . . . . . . . . . . . . . . . . . . F-5

F-2 242-A Evaporator Stormwater Drainage Systems and Material

Storage Areas . . . . . . . . . . . . . . . . . . . . F-6 


\section{CONTENTS (CONT.)}

\section{FIGURES}

F-3 241-A Tank Farm Stormwater Drainage Systems and Material Storage Areas . . . . . . . . . . . . . . . . . . . . . . F-7

F-4 244-AR Vault Stormwater Drainage Systems and Material

Storage Areas . . . . . . . . . . . . . . . . . . . . . . F-8

F-5 284-E Power Plant Stormwater Drainage Systems and Materials

Storage Areas . . . . . . . . . . . . . . . . . . . . . . F-9

F-6 B Plant Stormwater Systems and Material Storage Area . . . . . . . . . F-10 
1.0 DO YOU HAVE A STORMWATER NATIONAL POLLUTANT DISCHARGE ELIMINATION SYSTEM (NPDES) PERMIT?

Note: This answer applies to all six facilities.

-Yes $\quad$ XNo

2.0 HAVE YOU APPLIED FOR A STORMWATER NATIONAL POLLUTANT DISCHARGE ELIMINATION SYSTEM (NPDES) PERMIT?

Note: This answer applies to all six facilities.

-Yes $\quad \underline{X}$ No

3.0 ARE YOU COVERED OR HAVE YOU APPLIED FOR COVERAGE UNDER A GENERAL OR GROUP STORMWATER PERMIT?

Note: This answer applies to all six facilities.

XYes $\quad$ No

4.0 DESCRIBE THE SIZE OF THE STORMWATER COLLECTION AREA.

4.1 242-A EVAPORATOR COOLING WATER
a. Unpaved Area
approximately 37,674 square feet
a. Paved Area approximately 38,018 square feet
a. Other Collection Areas (Roofs) approximately 11,324 square feet

\subsection{2-A EVAPORATOR STEAM CONDENSATE}
a. Unpaved Area
a. Paved Area
a. Other Collection Areas (Roofs)

approximately 37,674 square feet approximately 38,018 square feet approximately 11,324 square feet 


\subsection{1-A TANK FARM COOLING WATER}

a. Unpaved Area

a. Paved Area

a. Other Collection Areas (Roofs)

\subsection{4-AR VAULT COOLING WATER}

a. Unpaved Area

a. Paved Area

a. Other Collection Areas (Roofs)

\subsection{4-E POWER PLANT}

a. Unpaved Area

a. Paved Area

a. Other Collection Areas (Roofs)

\subsection{B PLANT COOLING WATER}

a. Unpaved Area

a. Paved Area

a. Other Collection Areas (Roofs) approximately 32,787 square feet approximately 10,872 square feet approximately 7,029 square feet

approximately 35,521 square feet approximately 12,034 square feet approximately 12,981 square feet

approximately 467,158 square feet approximately 107,720 square feet approximately 94,562 square feet

\subsection{DESCRIBE THE STORMWATER MANAGEMENT SYSTEMS.}

Note: The Hanford Site is implementing a stormwater pollution prevention program as described in WHC 1993b.

\subsection{2-A EVAPORATOR COOLING WATER}

STORMWATER is discharged to the ground via two downspouts, directly from the buildings, and from the paved areas.

\subsection{2-A EVAPORATOR STEAM CONDENSATE}

STORMWATER is discharged to the ground via two downspouts, directly from the buildings, and from the paved areas. 


\subsection{1-A TANK FARM COOLING WATER}

STORMWATER is discharged directly to the ground from roof areas and paved areas.

\subsection{4-AR VAULT COOLING WATER}

STORMWATER is discharged to the ground via three downspouts, paved areas, and directly from roof areas.

\subsection{4-E POWER PLANT}

Stormwater is discharged to the ground via downspouts, directly from roof areas, and from paved areas.

\subsection{B PLANT COOLING WATER}

Three street drains and one yard drain are connected to the B Plant Chemical Sewer which is combined with the B Plant Cooling Water and disposed of in the 216-B-3 Ponds. The B Plant chemical sewer is temporarily combined with the B Plant cooling water until the 200 Area Treated Effluent Disposal Facility is operational.

One street drain is connected to a small french drain which discharges directly to the ground.

Downspouts from the roof areas discharge water to paved areas which route the water to the street and yard drains mentioned above. Limited amounts of stormwater may discharge directly from the paved areas to the ground.

\subsection{ATTACH A MAP SHOWING STORMWATER DRAINAGE/COLLECTION AREAS, DISPOSAL AREAS AND DISCHARGE POINTS.}

See Figure F-1 for the legend to the facility figures, Figure F-2 for the 242-A Evaporator Cooling Water and 242-A Evaporator Steam Condensate area, Figure F-3 for the 241-A Tank Farm Cooling Water area, Figure F-4 for the 244-AR Vault Cooling Water area, Figure F-5 for the 284-E Power Plant area, and Figure F-6 for the B Plant Cooling Water area. The figures depict stormwater boundaries that were selected to allow calculation of the stormwater collection areas (Section 4.0) for each facility. With the exception of B Plant, the only drainage/collection areas consist of roofs and downspouts shown on the figures. B Plant has additional street and yard drains that are collection area and are shown of Figure F-6. For all facilities but B Plant, no specific disposal areas and discharge points are shown because the stormwater is 
1 discharged directly to the ground in all of the unpaved areas. The B Plant Facility, in 2 addition to directly discharging stormwater to the ground, also has one street drain that is connected to a french drain for disposal of the stormwater (Figure F-5), three street drains, and one yard drain which are connected into the B Plant Chemical Sewer B Plant chemical sewer for disposal currently in the B Pond Complex. 


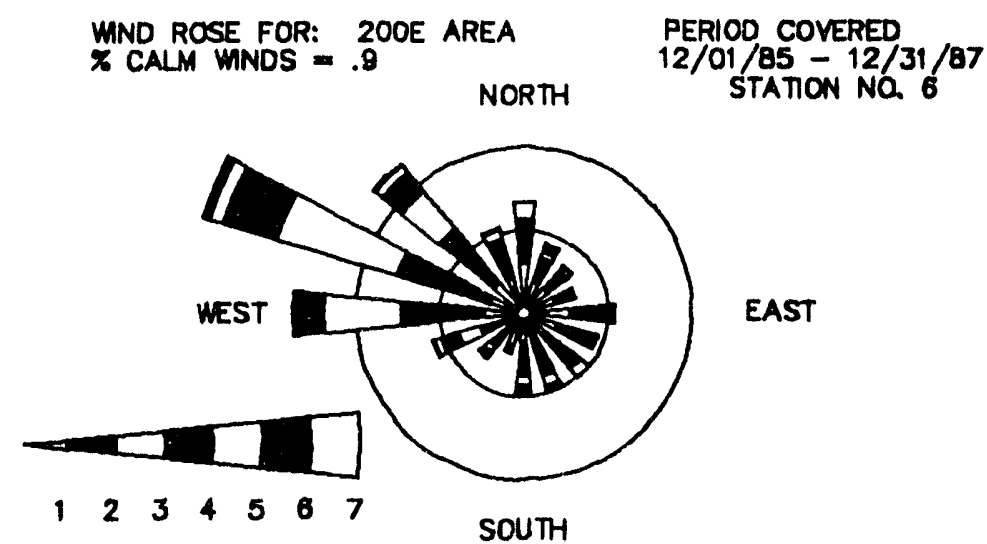

PADOLES INDICATE DIRECTION WIND IS COMING FROM. RADIAL GRIDS REPRESENT 5.0\% AND 10.0\% OCCURRENCE.

MND CLASS

MILES/HOUR

$1-0-=$

$>1.0-3.0$

3-=-二 $\quad$ 8.0 $=12.0$

$4-13.0-180$

$5-19.0-24.0$

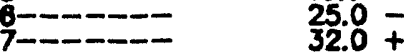

\section{WIND ROSE}

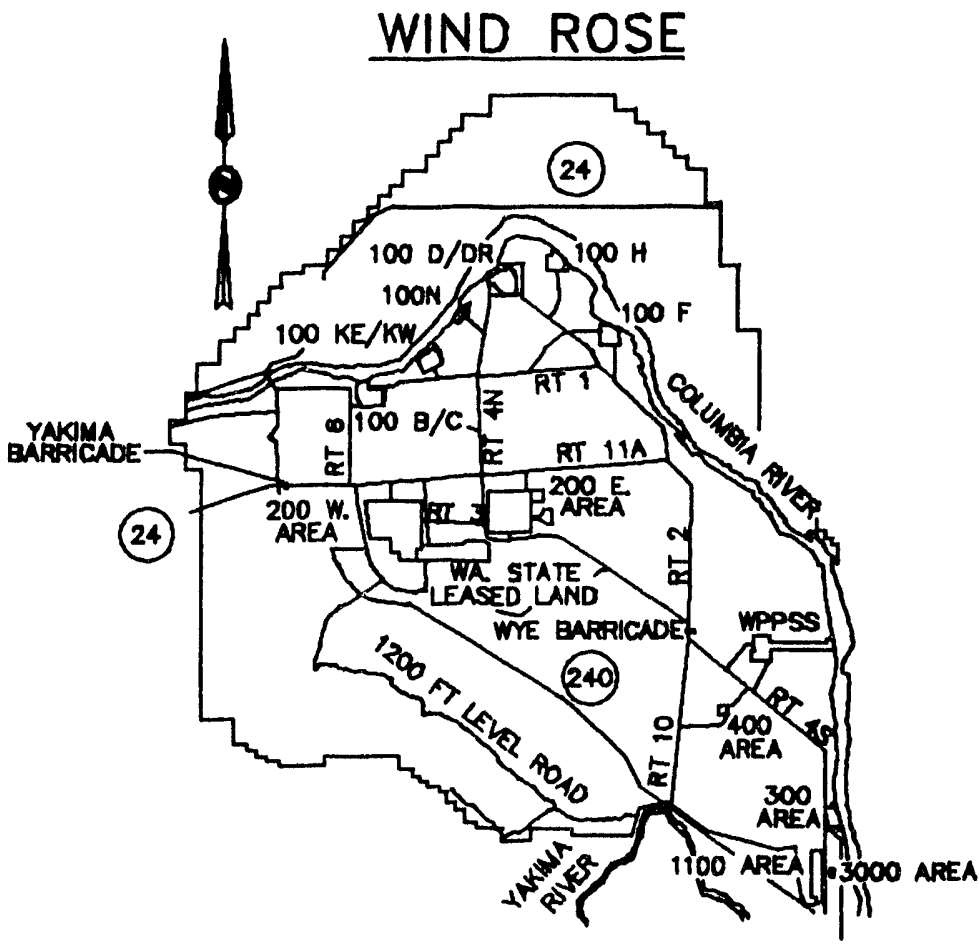

KEEY PLAN

SCALE: NONE

H-13-000178 242-A EVAPORATOR STORMWATER

DRAINAGE SYS \& MATL STORAGE AREAS

241-A TANK FARM STORMWATER

H-13-000179 DRAINAGE SYS \& MATL STORAGE AREAS

H-13-000180 244-AR VAULT STORMWATER

H-13-000180 DRAINAGE SYS \& MATL STORAGE AREAS

H-13-000181 284-E POWER PLANT STORMWATER

H-13-000182 B-PLANT STORMWATER DRAINAGE

H-13-000182 SYSTEMS \& MATERIAL STORAGE AREAS

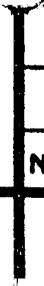

REF NUMBER

TILE

REFERAENCE

$\mathrm{H}-13-000200$ $\pi .47 .000$ N. 48,000

$E .576,250$ N.136,000

INDEX CONTOUR (METE

INTERMEDIATE CONTOUI

$=$ IMPROVED ROAD

$=$ UNIMPROVED ROAD

HANFORD PLANT COOF (FEET)

WASHINGTON STATE CC (METERS)

ニニニニ DIRT ROAD

= SIDEWALKS\PARKING L

$\longrightarrow$ RAILROADS
1. THIS MAI BY MERR OFFICIAL ENGINEEF THE NAM MAPS WE

2. WASHING: REVISED SOUTH $Z$ HORIZON VERTICAL

COORDIN. CONTOUF

3. HANFOR COVERS GROUND:

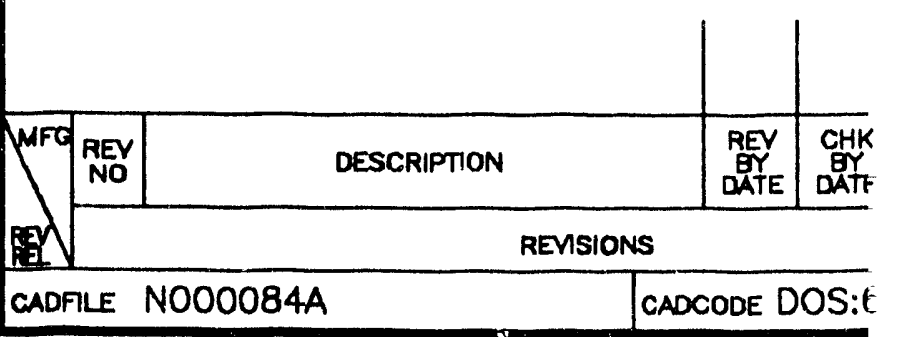


DINATES

ORDINATES

RS)

3

JTS

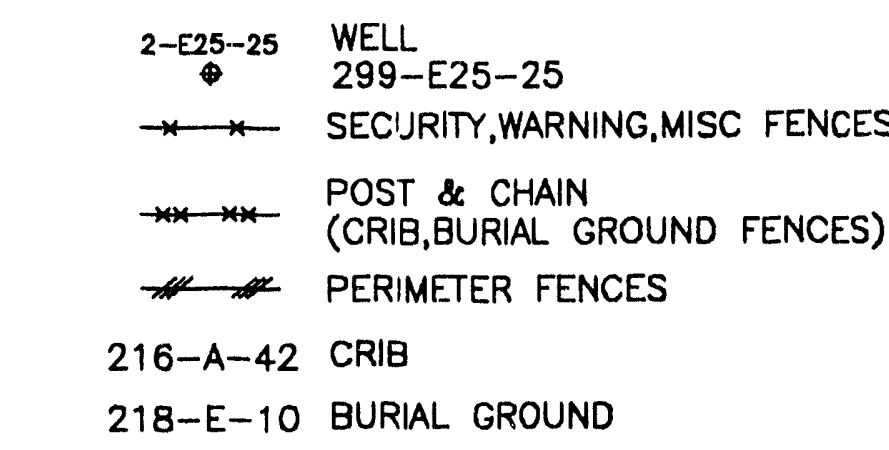

- $\square \mathbb{Z Z A}$

BUILDINGS/STRUCTURES/TOWERS

242-A BUIL.DING NUMBER

RZZ MOEIL OFFICES

() O TANKS
CHEMICAL \RADIOACTIVE STORAGE FACILITIES

RADIOACTIVE MATERIAL

STAGING AREA

EFता SEPTIC TILE FIELD

STORM DRAIN AND TILE FIELD (FRENCH DRAIN)

WASTE OIL

FLAMMABLE MATERIAL

STORAGE LOCKER

DOWNSPOUTS

STORM DRAINS

\section{GENERAL NOTES}

2 IS BASED ON AERIAL PHOTOGRAPHY FLOWN ON 6-24-89. THE TOPOGRAPHIC MAP WAS PREPARED CK \& COMPANY AND CERTIFIED TO MEET NATIONAL MAP ACCURACY STANDARDS.

COPIES OF THE MERRICK MAPS THAT SHOW THE CERTIFICATE ARE LOCATED IN THE WESTINGHOUSE ING FILES AS DRAWING NUMBERS $\mathrm{H}-2-79476$ SHEET 1 AND $\mathrm{H}-2-79477$ SHEET 1 THRU 37. ES OF PHYSICAL FEATURES AND THE TITLE BLOCK OF THE H-13-000201 THROUGH H-13-000237 RE ADDED BY WESTINGHOUSE HANFORD COMPANY.

ON COORDINATE SYSTEM: THE OFFICIAL STATE PLANE COORDINATE SYSTEM AS DEFINED BY THE CODE OF WASHINGTON (RCW). THE HANFORD SITE LIES WITHIN THE WASHINGTON COORDINATE SYSTEM, DNE. THIS GRID COVERS THE ENTIRE SITE AND USES X (EASTINGS) AND $Y$ (NORTHINGS) COORDINATES.

AL DATUM: NAD-83 LAMBERT PROJECTIOHS

DATUM: NATIONAL GEODETIC SURVEY

DATUM AS PROVIDED BY KAISER

ENGINEERS HANFORD.

NTES ARE SHOWN AS METERS.

$S$ ARE SHOWN AS 0.5 METERS.

PLANT GRID: A LOCAL GRID SYSTEM WITH ITS INITIAL POINT NORIHEAST OF THE 400 AREA. IT 200 EAST AND 200 WEST AREA AS WELL AS GENERAL SITE WORK SUCH AS WELLS AND BURIAL . COORDINATES ARE SHOWN AS FEET.

Figure F-1

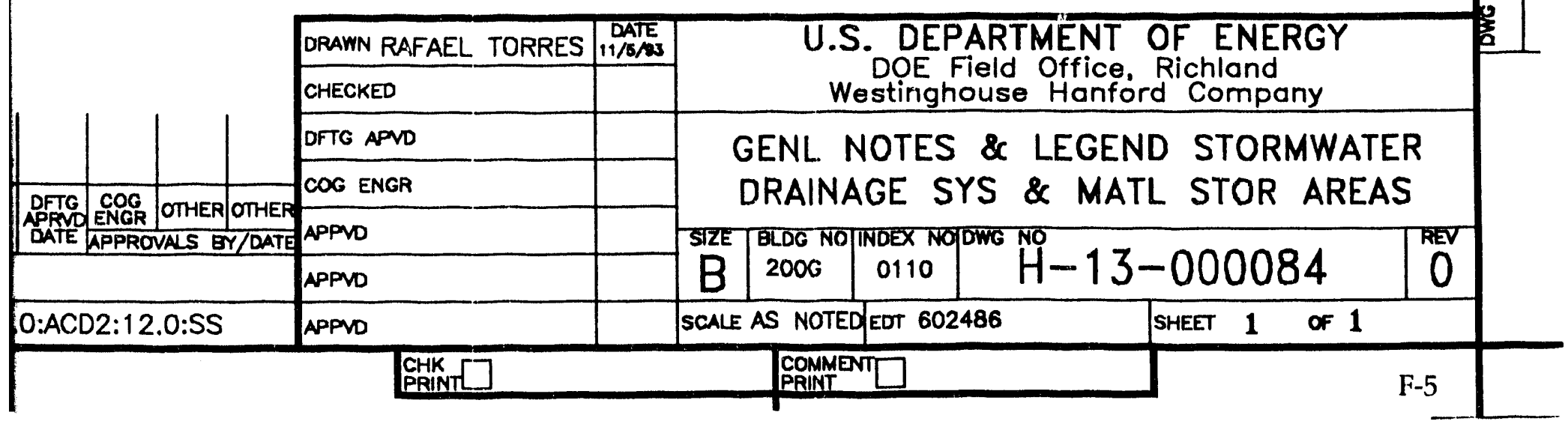




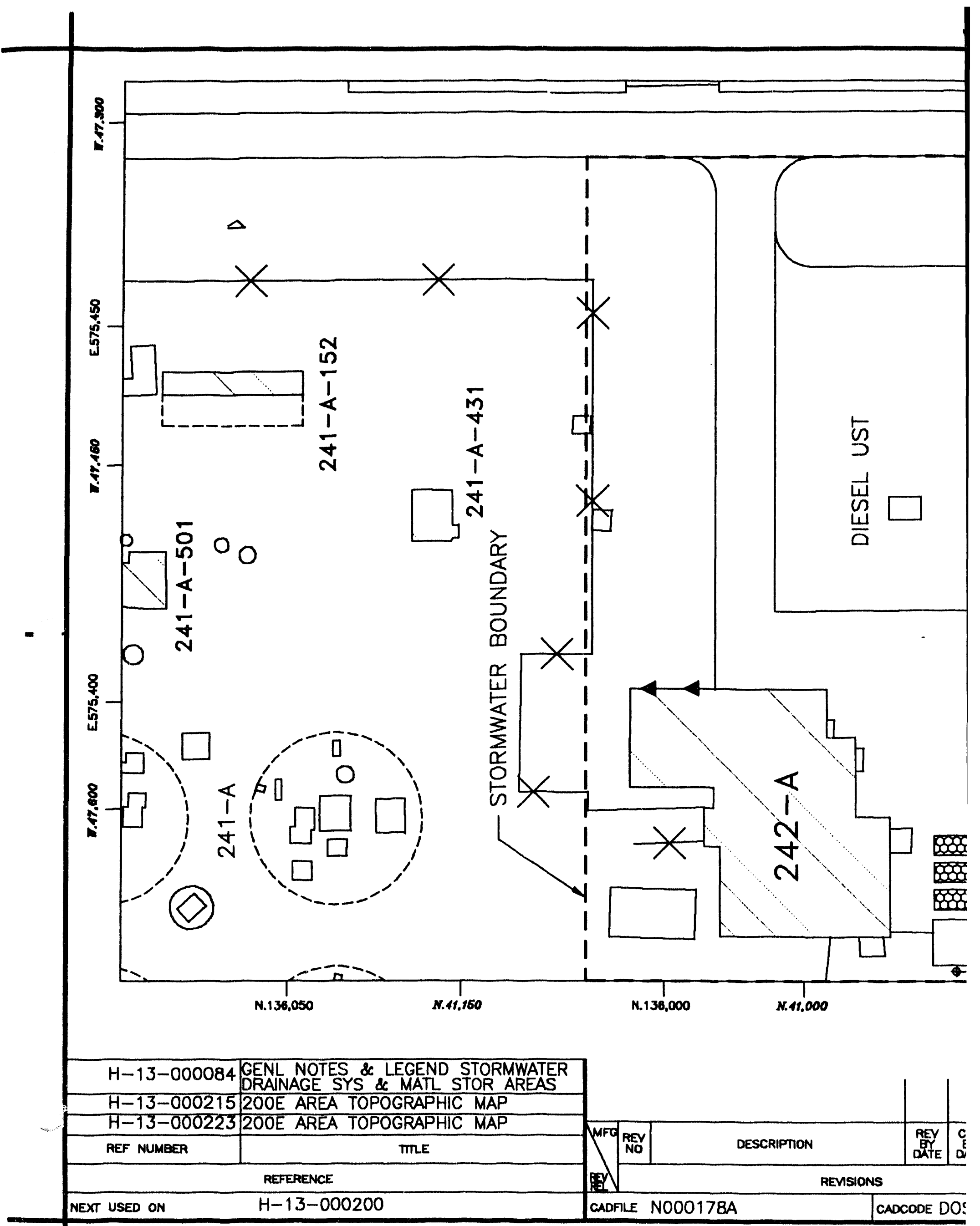




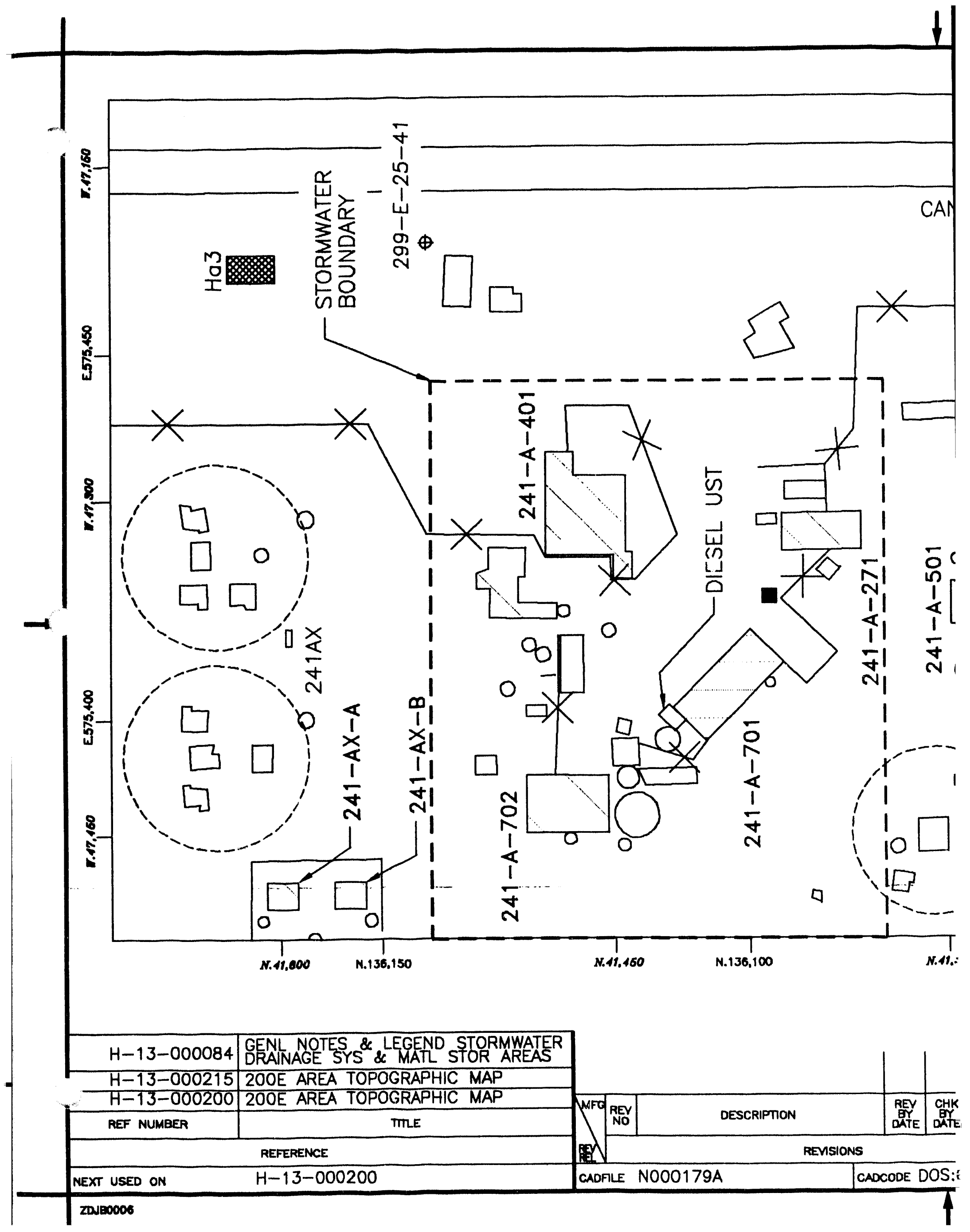




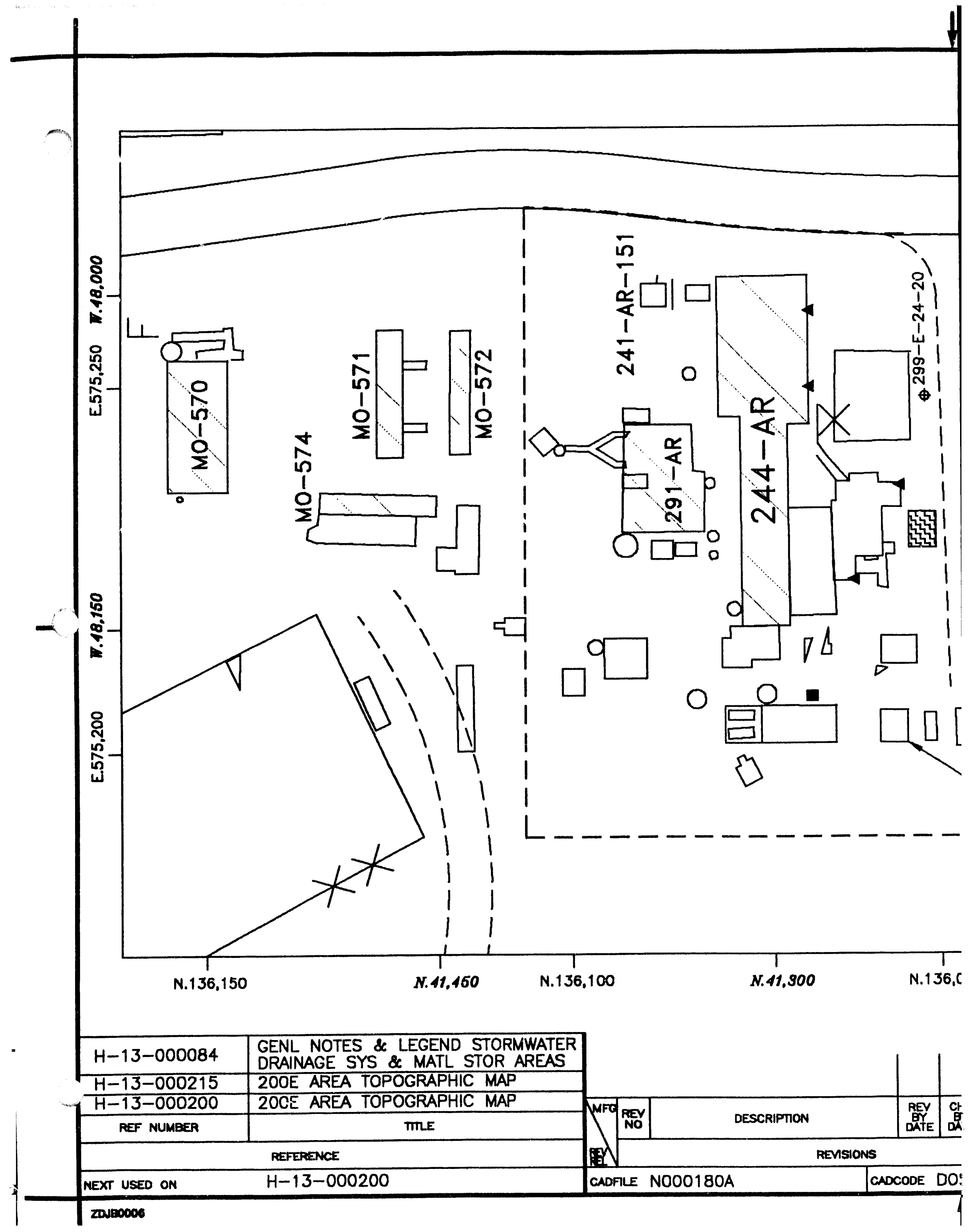


DOE/RL 93-61, Rev 0

$12 / 93$

201) East Area W-252 Streams

\section{BUFFALO AVE.}
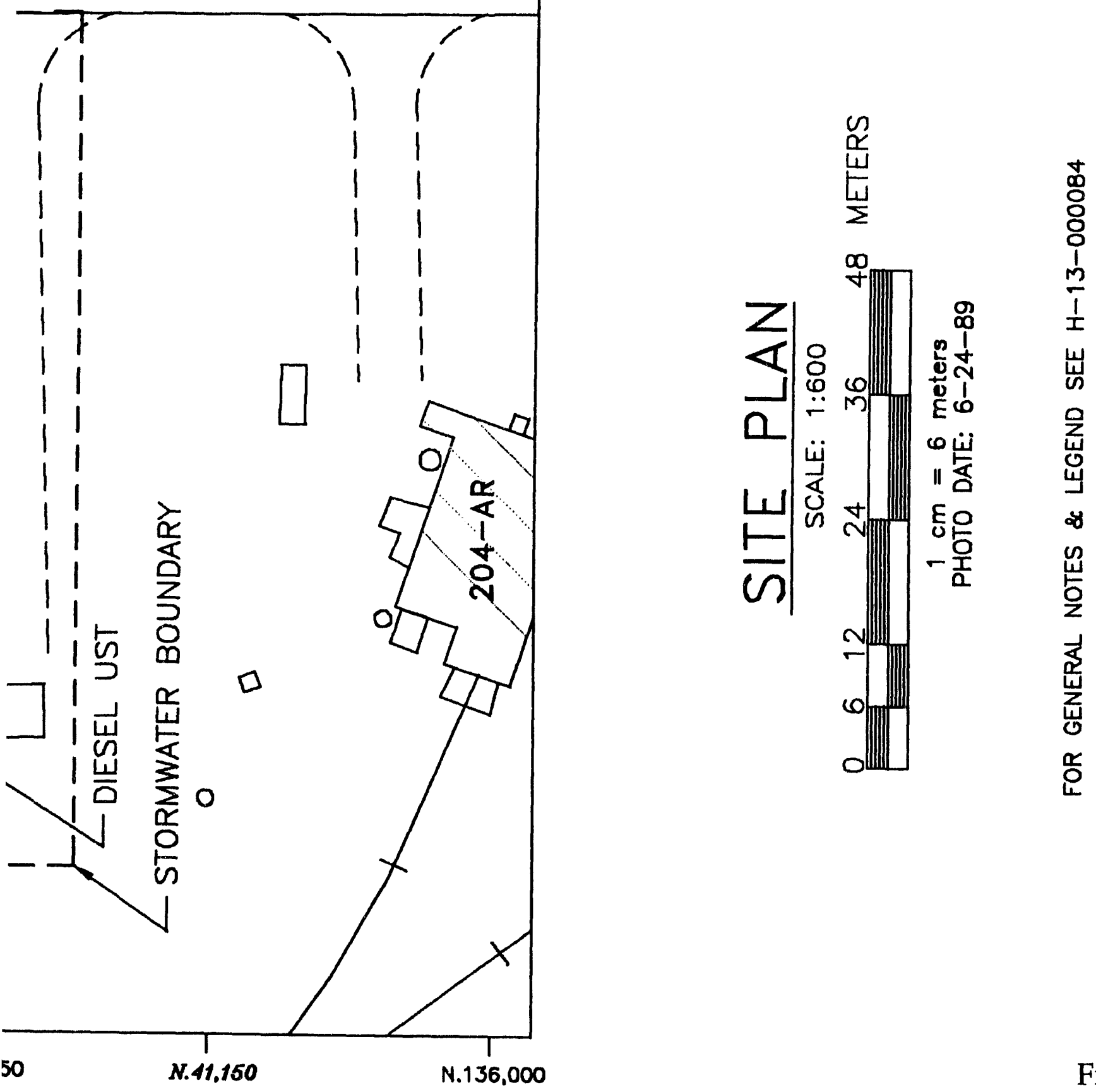

Figure F-4

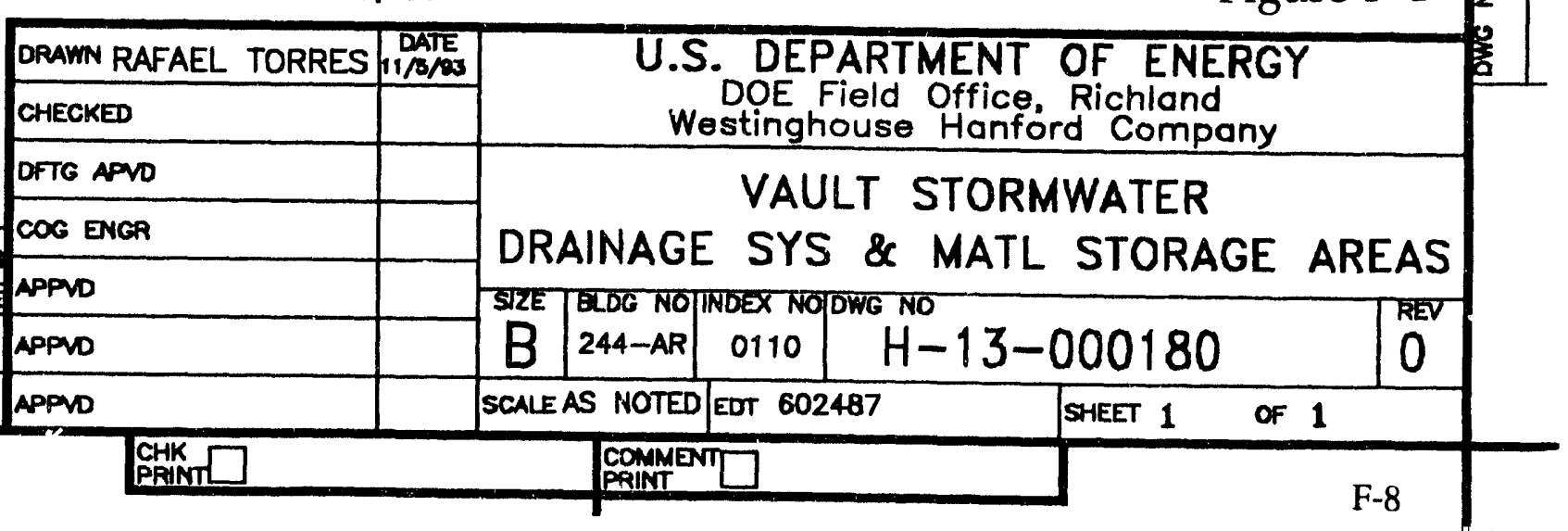




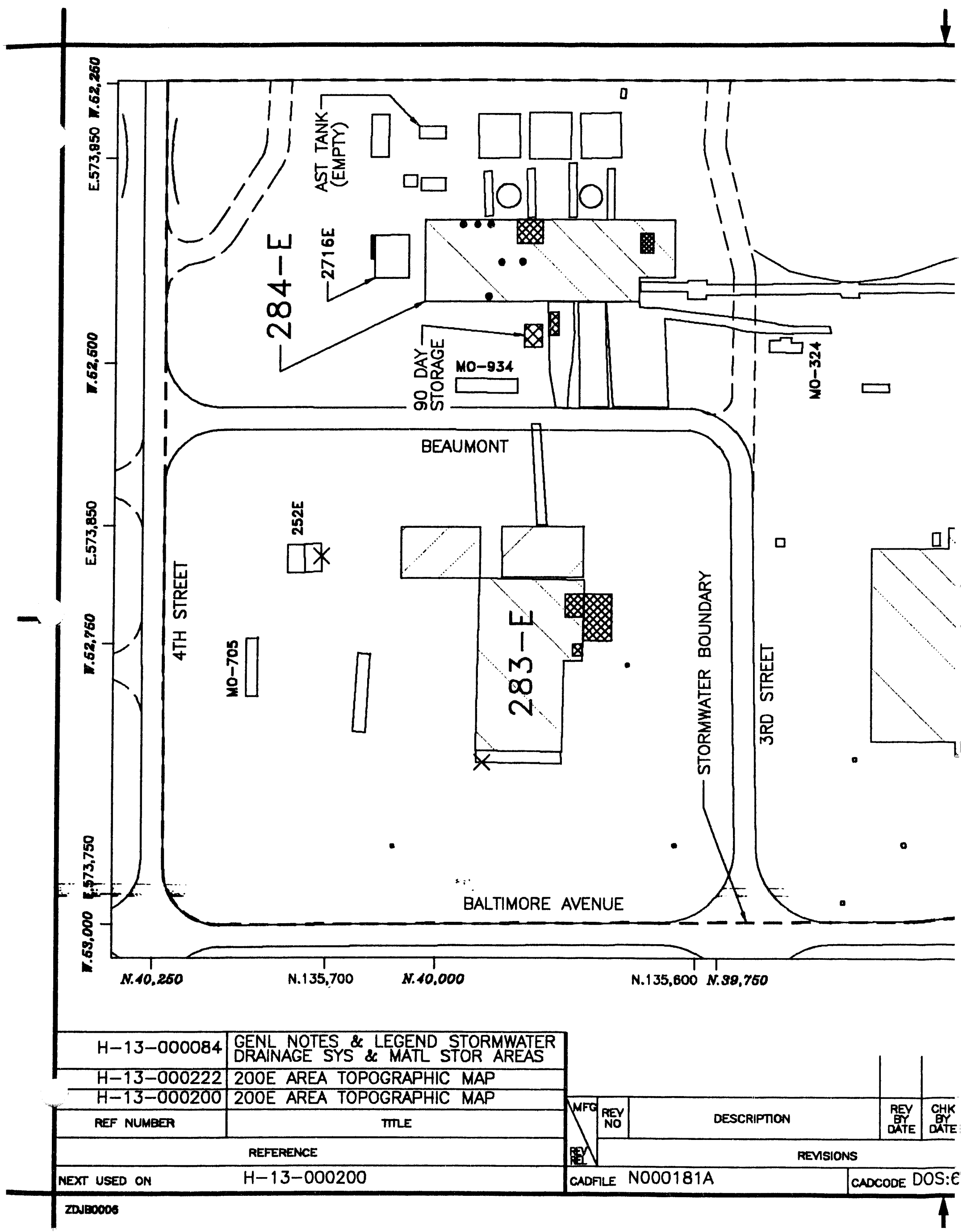




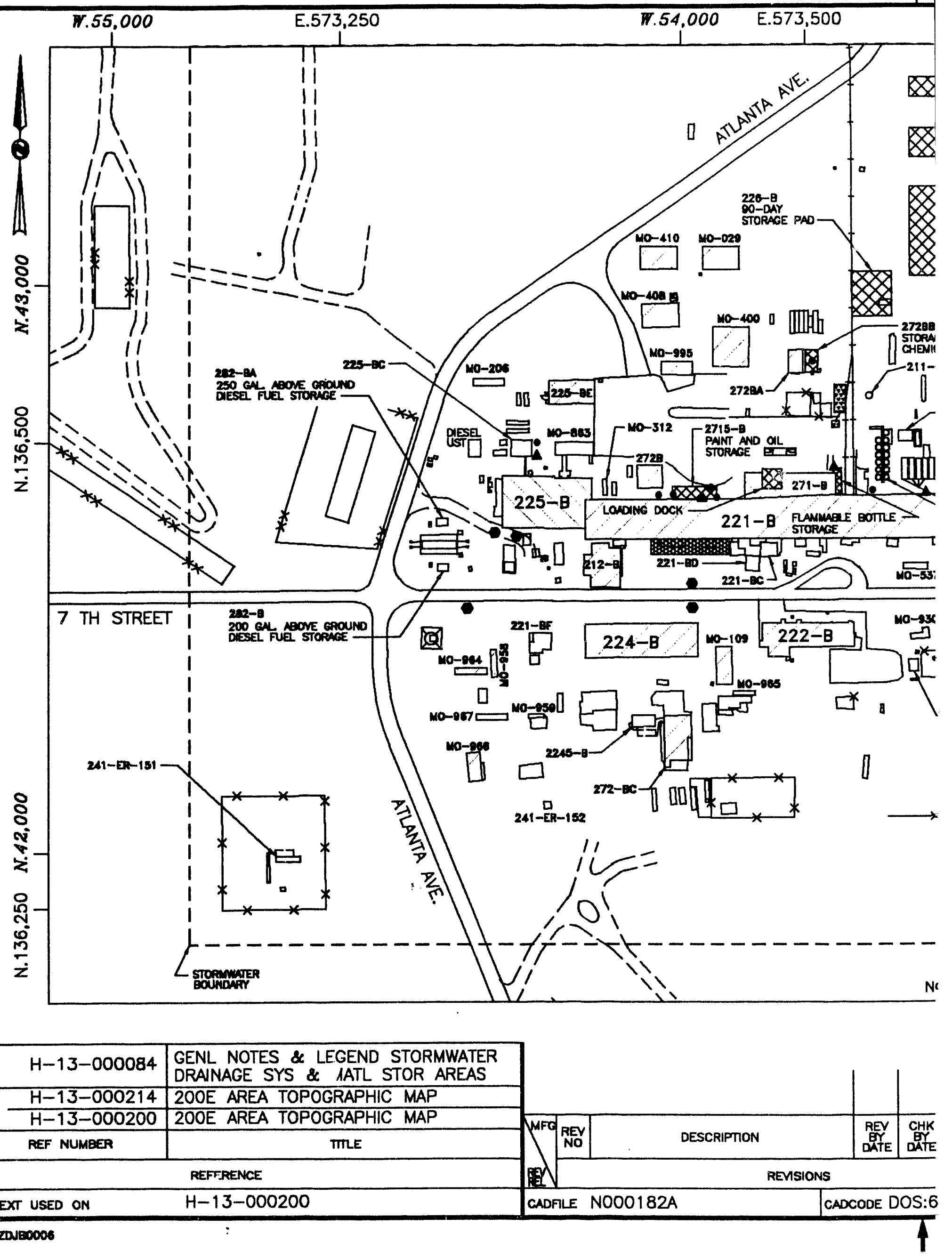




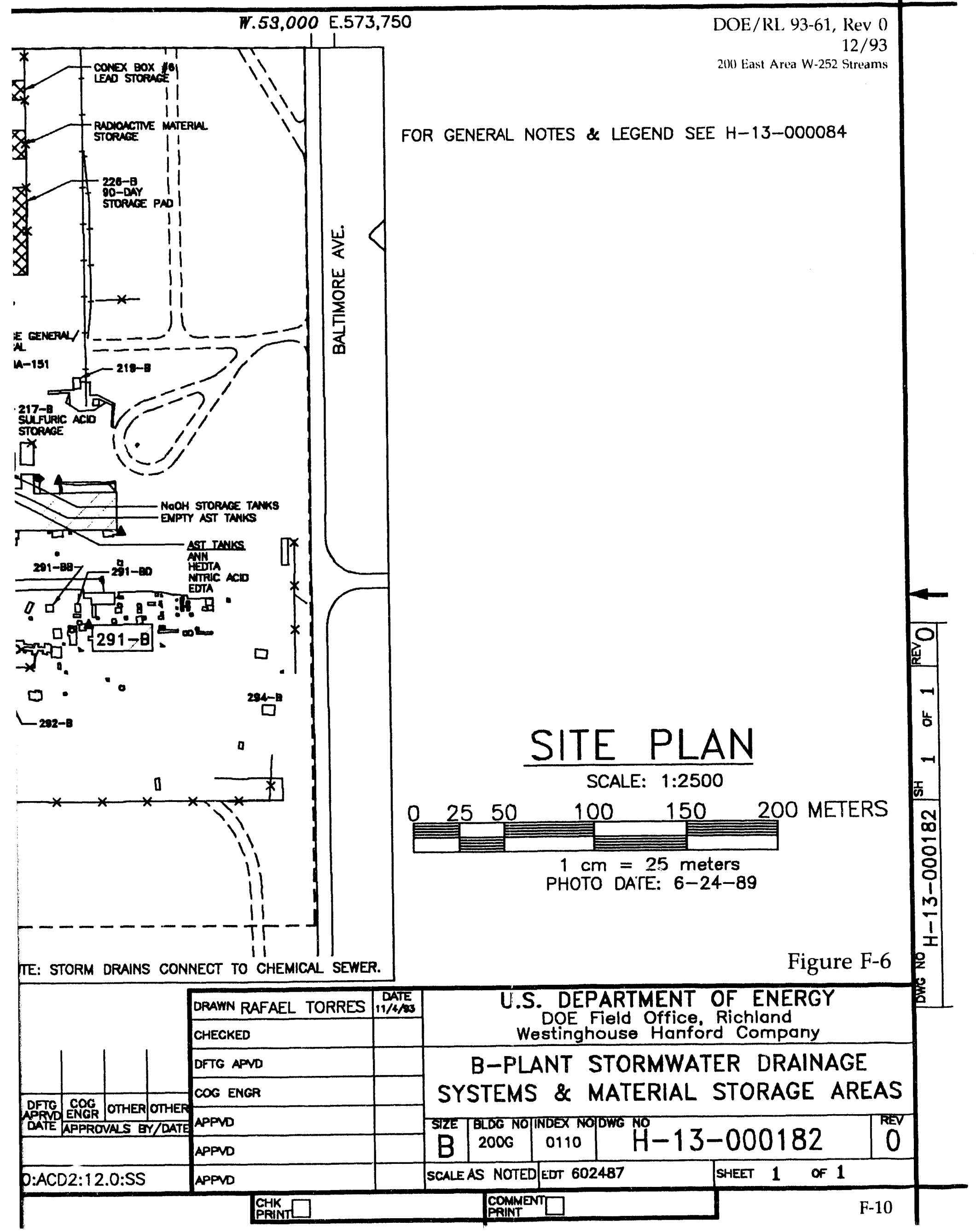


DOE/RL 93-61, Rev 0

$12 / 93$

200 East Area W-252 Streams

\section{APPENDIX G}

\section{OTHER INFORMATION}

G-i 
DOE/RL 93-61, Rev 0

$12 / 93$

200 East Area W-252 Streams

This page intentionally left blank. 
DOE/RL 93-61, Rev 0 $12 / 93$ 200 East Area W-252 Streams

\section{CONTENTS}

1.0 DESCRIBE LIQUID WASTES OR SLUDGES BEING GENERATED THAT ARE

NOT DISPOSED OF IN THE WASTE STREAM(S) $\ldots \ldots \ldots \ldots \ldots \ldots \ldots \ldots$ G-1

1.1242 -A EVAPORATOR COOLING WATER $\ldots \ldots \ldots \ldots \ldots \ldots \ldots \ldots$ G-1

1.2 242-A EVAPORATOR STEAM CONDENSATE . . . . . . . . . . . . G-1

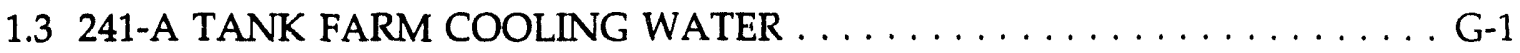

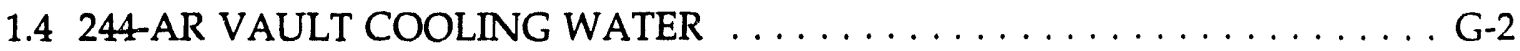

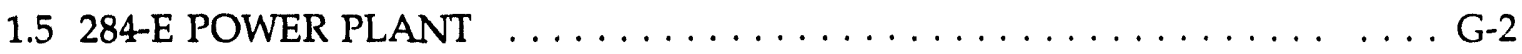

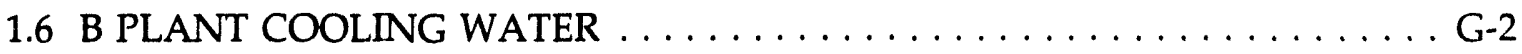

2.0 DESCRIBE THE STORAGE AREAS FOR RAW MATERIALS, PRODUCTS,

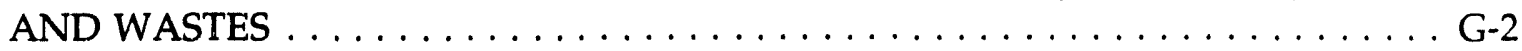

2.1242 -A EVAPORATOR COOLING WATER $\ldots \ldots \ldots \ldots \ldots \ldots \ldots \ldots$ G-2

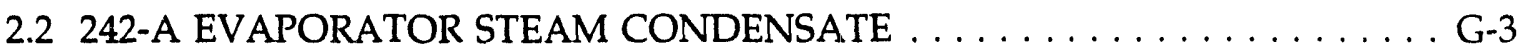

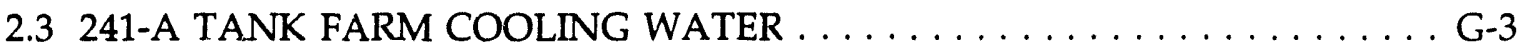

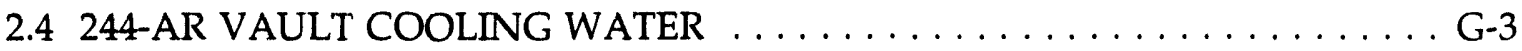

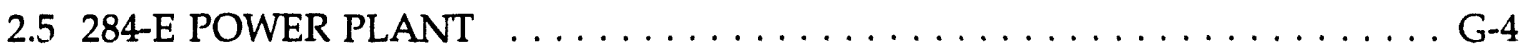

2.6 B PLANT COOLING WATER $\ldots \ldots \ldots \ldots \ldots \ldots \ldots \ldots \ldots \ldots \ldots \ldots \ldots$

3.0 HAVE YOU DESIGNATED YOUR WASTES ACCORDING TO THE

PROCEDURES OF DANGEROUS WASTE REGULATIONS, CHAPTER 173-303

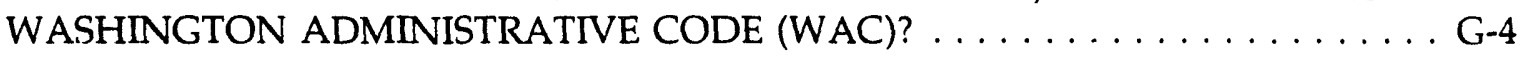

4.0 WASTE HAULED OFF-SITE BY: $\ldots \ldots \ldots \ldots \ldots \ldots \ldots \ldots \ldots \ldots$

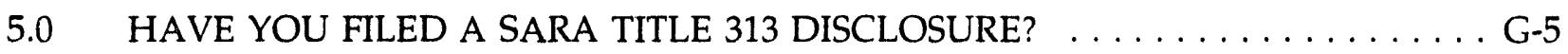


DOE/RL 93-61, Rev 0

200 East Area W-252 Streams

This page intentionally left blank.

G-iv 


\subsection{DESCRIBE LIQUID WASTES OR SLUDGES BEING GENERATED THAT ARE NOT} DISPOSED OF IN THE WASTE STREAM(S).

\section{$1.1 \quad$ 242-A EVAPORATOR COOLING WATER}

- The sanitary sewer from the facility is disposed of to a septic tank and drain field system.

- The Radioactive/Hazardous waste lines that flow through the facility are disposed of in the 241-AW Tank Farm. These Radioactive/Hazardous wastes are not generated at this facility, but are piped through the facility to evaporate water from the waste stream and concentrate the waste for disposal in the tank farm listed above.

- Process condensate from the evaporation and concentration of the radioactive/hazardous wastes is directed to the Liquid Effluent Retention Facility and will be subsequently directed to the 200 Area Effluent Treatment Facility for disposal, when the Effluent Treatment Facility is operational.

\subsection{2-A EVAPORATOR STEAM CONDENSATE}

- The sanitary sewer from the facility is disposed of to a septic tank and drain field system.

- The Radioactive/Hazardous waste lines that flow through the facility are disposed of in the 241-AW Tank Farm. These Radioactive/Hazardous wastes are not generated at this facility, but are piped through the facility to evaporate water from the waste stream and concentrate the waste for disposal in the tank farm listed above.

\section{$1.3 \quad 241-A$ TANK FARM COOLING WATER}

- The sanitary sewer from the facility is disposed of to a septic tank and drain field system.

Process condensate from the evaporation and concentration of the radioactive/hazardous wastes is directed to the Liquid Effluent Retention Facility and subsequently directed to the 200 Area Effluent Treatment Facility for disposal.

Waste oil is disposed of in a 55 gallon drum stored outside in an uncovered area. 


\subsection{4-AR VAULT COOLING WATER}

- The sanitary sewer from the facility is disposed of to a septic tank and drain field system.

- The 244-AR Vault is currently inactive, but when it did operate, radioactive/hazardous waste from $B$ Plant was sent to the 244-AR Vault, prior to disposal in the AY Tank Farm (102 AY Tank).

- Waste oil is disposed of in a 55 gallon drum stored outside in an uncovered area.

\subsection{4-E POWER PLANT}

- The 284-E Power Plant ash waste water is disposed of in the ash disposal basin.

- The coal ramp is washed with raw water and the waste water is discharged to a basin.

\subsection{B PLANT COOLING WATER}

- B Plant Chemical Sewer temporarily is combined with the B Plant Cooling Water and is discharged to the B Ponds. The B Plant chemical sewer is temporarily combined with the B Plant cooling water until the 200 Area Treated Effluent Disposal Facility is operational.

- Low Level Radioactive Liquid is generated in maintaining the radioactive waste stored in B Plant and is temporarily stored in a 900 gallon tank in B Plant, prior to transfer to the double shell underground storage tanks in the 242-AW Tank Farm.

\subsection{DESCRIBE THE STORAGE AREAS FOR RAW MATERIALS, PRODUCTS, AND WASTES.}

\subsection{2-A EVAPORATOR COOLING WATER}

Raw Materials: Dilute Radioactive/Hazardous wastes are stored in double shell tanks in the 241-AW Tank Farm prior to processing by the 242-A Evaporator.

Products: Concentrated Radioactive/Hazardous wastes are stored in double shell tanks in the 241-AW Tank Farm after the waste are concentrated by evaporation in the 242-A Evaporator. 
Wastes: The sanitary sewer from the facility is disposed of to a septic tank and drain field system. The solids are retained in the septic tank prior to periodic pumping and disposal off site. Radioactive/hazardous wastes are stored in double shell tanks in the 241-AW Tank Farm. Process condensate is stored at the Liquid Effluent Retention Facility prior to disposal at the 200 Area Effluent Treatment Facility.

\subsection{2-A EVAPORATOR STEAM CONDENSATE}

Raw Materials: Dilute Radioactive/Hazardous wastes are stored in double shell tanks in the 241-AW Tank Farm prior to processing by the 242-A Evaporator.

Products: Concentrated Radioactive/Hazardous wastes are stored in double shell tanks in the 241-AW Tank Farm after the wastes are concentrated by evaporation in the 242-A Evaporator.

Wastes: The sanitary sewer from the facility is disposed of to a septic tank and drain field system. The solids are retained in the septic tank prior to periodic pumping and disposal off site. Radioactive/hazardous wastes are stored in double shell tanks in the 241-AW Tank Farm. Process condensate is stored at the Liquid Effluent Retention Facility prior to disposal at the 200 Area Effluent Treatment Facility.

\section{$2.3 \quad$ 241-A TANK FARM COOLING WATER}

Raw Materials: None

Products: None

Wastes: The sanitary sewer from the facility is disposed of to a septic tank and drain field system. The solids are retained in the septic tank prior to periodic pumping and disposal off site. Waste oil is disposed of in a 55 gallon drum stored outside on an uncovered asphalt surface.

\section{$2.4 \quad$ 244-AR VAULT COOLING WATER}

Raw Materials: None

Products: None

Wastes: The sanitary sewer from the facility is disposed of to a septic tank and drain field system. The solids are retained in the septic tank prior to periodic pumping and disposal off site. Waste oil is disposed of in a 55 gallon drum stored outside on an uncovered gravel surface. When the facility was operating, radioactive/hazardous waste from B Plant was sent to the 244-AR Vault and stored in the vault facility, prior to disposal in the AY Tank Farm (102 AY Tank). 


\subsection{4-E POWER PLANT}

Raw Materials: Coal is stored outside in a pile on a gravel surface.

Products: Steam is used to generate electricity and is distributed through steam lines to other facilities for heating.

Wastes: The 284-E Power Plant ash waste water is disposed of in the ash disposal basin. The coal ramp waste water is discharged to a basin.

\subsection{B PLANT COOLING WATER}

Raw Materials: None

Products: None

Wastes: Low Level Radioactive ' quid is generated in maintaining the radioactive waste stored in B Plant and is temporarıy stored in a 900 gallon tank in B Plant, prior to transfer to the double shell underground storage tanks in the 242-AW Tank Farm.

\subsection{HAVE YOU DESIGNATED YOUR WASTES ACCORDING TO THE PROCEDURES OF} DANGEROUS WASTE REGULATIONS, CHAPTER 173-303 WAC?

$\underline{X}$ Yes $\quad$ No

Note: This answer applies for all six streams.

\subsection{WASTE HAULED OFF-SITE BY:}

Note: This information applies to all six facilities.

$\underline{X}$ Wastehauler $\mathrm{X}$ Self _Other (identify)

Name: WHC Sanitary Systems Maintenance

Address: P.O. Box 1970, MSIN \# S4-61

City/State: Richland, WA 99352

Telephone: (509) 373-5786

Name: Super Pump

Address: Route 2, Box 2911-B

City/State: Kennewick, WA 99337

Telephone: (509) 582-6529 
DOE/RL 93-61, Rev 0

200 East Area W-252 Streams

5.0 HAVE YOU FILED A SARA TITLE 313 DISCLOSURE?

$3 \quad X$ Yes $\quad$ No

5 Note: This answer applies for all six streams.

6 
DOE/RL 93-61, Rev 0

200 East Area W-252 Streams

This page intentionally left blank. 
DOE/RL 93-61, Rev 0

$12 / 93$

200 East Area W-252 Streams

\section{APPENDIX $\mathbf{H}$}

SITE ASSESSMENT

$\mathrm{H}-\mathrm{i}$ 
DOE/RL 93-61, Rev 0

$12 / 93$

200 East Area W-252 Streams

This page intentionally left blank.

$\mathrm{H}$-ii 


\section{CONTENTS}

1.0 GIVE THE LEGAL DESCRIPTION OF THE LAND TREATMENT SITE(S). GIVE THE ACREAGE OF EACH LAND TREATMENT SITE(S). ATTACH A COPY OF THE CONTRACT(S) AUTHORIZING USE OF THE LAND FOR TREATMENT . . . . . . . . . . . . . . . . . . . . . . . H 1

2.0 LIST ALL ENVIRONMENTAL CONTROL PERMITS OR APPROVALS NEEDED FOR THIS PROJECT; FOR EXAMPLE, SEPTIC TANK PERMITS, SLUDGE APPLICATION PERMITS, OR AIR EMISSIONS PERMITS . . . . . . H H $2.1 \quad 242$-A EVAPORATOR COOLING WATER . . . . . . . . . . H-1 2.2 242-A EVAPORATOR STEAM CONDENSATE $\ldots \ldots \ldots \ldots \ldots \ldots$ H-1

2.3 241-A TANK FARM COOLING WATER $\ldots \ldots \ldots \ldots \ldots \ldots \ldots \ldots \mathrm{H}-2$

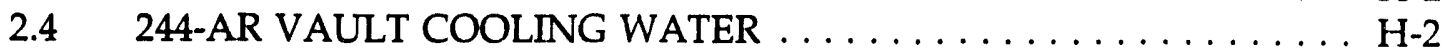

$2.5 \quad$ 284-E POWER PLANT $\ldots \ldots \ldots \ldots \ldots \ldots \ldots \ldots \ldots \ldots \ldots$ H $\ldots \ldots \ldots \ldots$

2.6 B PLANT COOLING WATER $\ldots \ldots \ldots \ldots \ldots \ldots \ldots \ldots$ H 2

3.0 ATTACH A TOPOGRAPHIC MAP WITH CONTOUR INTERVALS USED BY USGS.

4.0 IDENTIFY ALL WELLS WITHIN 500 FEET OF THE SITE. ATTACH WELL LOGS WHEN AVAILABLE AND ANY AVAILABLE WATER QUALITY DATA . . . . . . . . . . . . . . . . . . . H 4

5.0 DESCRIBE SOILS ON THE SITE USING INFORMATION FROM LOCAL SOIL SURVEY REPORTS . . . . . . . . . . . . . . . . . . . . H H 61

6.0 DESCRIBE THE REGIONAL GEOLOGY AND HYDROGEOLOGY WITHIN ONE MILE OF THE SITE. (SUBMIT ON SEPARATE SHEET.) . . . H-63

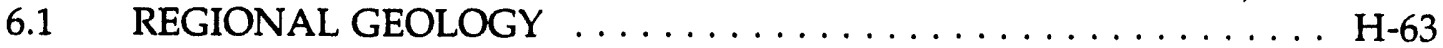

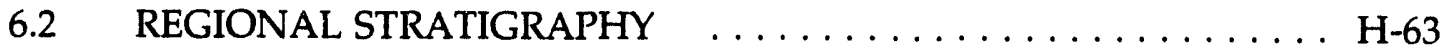
6.2.1 Columbia River Basalt Group and the Ellensburg Formation

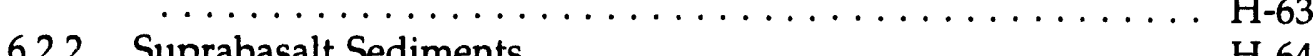

6.3 REGIONAL GEOLOGIC STRUCTURE .................. H-64

6.4 LOCA. . . . . . . . . . H 65

LOCAL GEOLOGY ........................ H-66

6.4 .1 Ringold Formation $\ldots \ldots \ldots \ldots \ldots \ldots \ldots \ldots$. . . . . 66

6.4.2 Hanford formation $\ldots \ldots \ldots \ldots \ldots \ldots \ldots \ldots \ldots$. . . . . 67

6.4.3 Holocene Surficial Deposits . . . . . . . . . . . . . . . . H-67

6.5 REGIONAL HYDROGEOLOGY . . . . . . . . . . . . . . . . H-69

6.6 LOCAL HYDROGEOLOGY . . . . . . . . . . . . . . . . H-69

7.0 LIST THE NAMES AND ADDRESSES OF CONTRACTORS OR CONSULTANTS WHO PROVIDED INFORMATION AND CITE SOURCES OF INFORMATION BY TITLE AND AUTHOR 


\title{
CONTENTS (CONT.)
}

\author{
FIGURES
}

H-1 200 East Area $W-252$ Facilities $\ldots \ldots \ldots \ldots \ldots \ldots \ldots \ldots \ldots \ldots \ldots \ldots$

H-2 Hanford Site Soils Map . . . . . . . . . . . . . . . . . . H 62

H-3 Geologic Interpretation of the Suprabasalt Sediments, Based on Boreholes in the Vicinity of the 216-B-3 Pond . . . . . . . . . . . . . . . H-68

H-4 December 1991 Water Table Elevations in the Vicinity of the 200 East Area and the B Pond Complex . . . . . . . . . . . . H-71

\section{PLATES}

H-1 B Pond Disposal Complex $\ldots \ldots \ldots \ldots \ldots \ldots \ldots \ldots \ldots$ Pocket 1 
1.0 GIVE THE LEGAL DESCRIPTION OF THE LAND TREATMENT SITE(S). GIVE THE ACREAGE OF EACH LAND TREATMENT SITE(S). ATTACH A COPY OF THE CONTRACT(S) AUTHORIZING USE OF THE LAND FOR TREATMENT.

Legal Description:

The land treatment sites have the following acreages:

216-B-3 Pond: approximately 35 acres;

216-B-3A Pond: approximately 11 acres;

216-B-3B Pond: approximately 11 acres;

216-B-3C Pond: approximately 41 acres;

216-B-3-3 Trench: approximately 2.5 acres;

284-E Powerhouse Ditch: approximately 1.6 acres.

A specific contract authorizing use of the B Ponds for a land treatment site does not exist, but the Hanford Site was created to serve as a research and production facility for federal government nuclear projects by the U.S. Government. The Hanford Site has been in use since the early 1940's and all disposal facilities, such as the B Ponds, have been authorized by the U.S. Government.

2.0 LIST ALL ENVIRONMENTAL CONTROL PERMITS OR APPROVALS NEEDED FOR THIS PROIECT; FOR EXAMPLE, SEPTIC TANK PERMITS, SLUDGE APPLICATION PERMITS, OR AIR EMISSIONS PERMITS.

The following apply to this project:

- Hanford Site Radioactive Air Emissions Permit: Number FF-01;

- Hanford Site Dangerous Waste Permit: Number WA7890008967;

- $\quad$ Resource Conservation and Recovery Act interim status for B Pond System (to B Pond units).

Additional permits specific to each facility are listed below.

\subsection{2-A EVAPORATOR COOLING WATER}

- Underground Storage Tank Permit, Tank Number 242-A-1;

- Dangerous Waste Permit, interim status.

\subsection{2-A EVAPORATOR STEAM CONDENSATE}

- Underground Storage Tank Permit, Tank Number 242-A-1.

\subsection{1-A TANK FARM COOLING WATER}

- Underground Storage Tank Permit, Tank Number 241-A-701; 
- Underground Storage Tank Permit, Tank Number 241-A-701-2;

- Dangerous Waste Permit, interim status.

\subsection{4-AR VAULT COOLING WATER \\ - Underground Storage Tank Permit, Tank Number 244-AR.}

\subsection{4-E POWER PLANT}

- No facility specific environmental control permits.

\subsection{B PLANT COOLING WATER \\ - $\quad$ Underground Storage Tank Permit, Tank Number TK-101; \\ - Dangerous Waste Permit, interim status.}

\subsection{ATTACH A TOPOGRAPHIC MAP WITH CONTOUR INTERVALS USED BY USGS. SHOW THE FOLLOWING ON THIS MAP:}

a. Location and name of internal and adjacent streets,

b. Surface water drainage systems,

c. Water supply and other wells within 500 feet of the site,

d. Surface water diversions within 500 feet of the site,

e. Chemical and product handling and storage facilities,

f. Infiltration sources, such as drainfields, lagoons, dry wells, and abandoned wells within 500 feet of the site,

g. Waste water and cooling water discharge points with ID numbers (See Section C.1),

h. Other activities and land uses within $1 / 4$ mile of the site.

Plate H-1 shows the above listed items with the exception of item e (chemical and product handling and storage areas). Figure $\mathrm{H}-1$ serves as a location map for the facilities in relation to B Pond and the Powerhouse Waste Water Ditch. The chemical and product handling and storage areas are shown on the facility maps in Appendix $F$, Section 6, because the disposal site is not located adjacent to any of the six facilities that are producing waste streams and have chemical and product handling and storage areas.

Waste water and cooling water discharge points are shown for each of the six waste streams, which include all component substreams prior to discharge. 


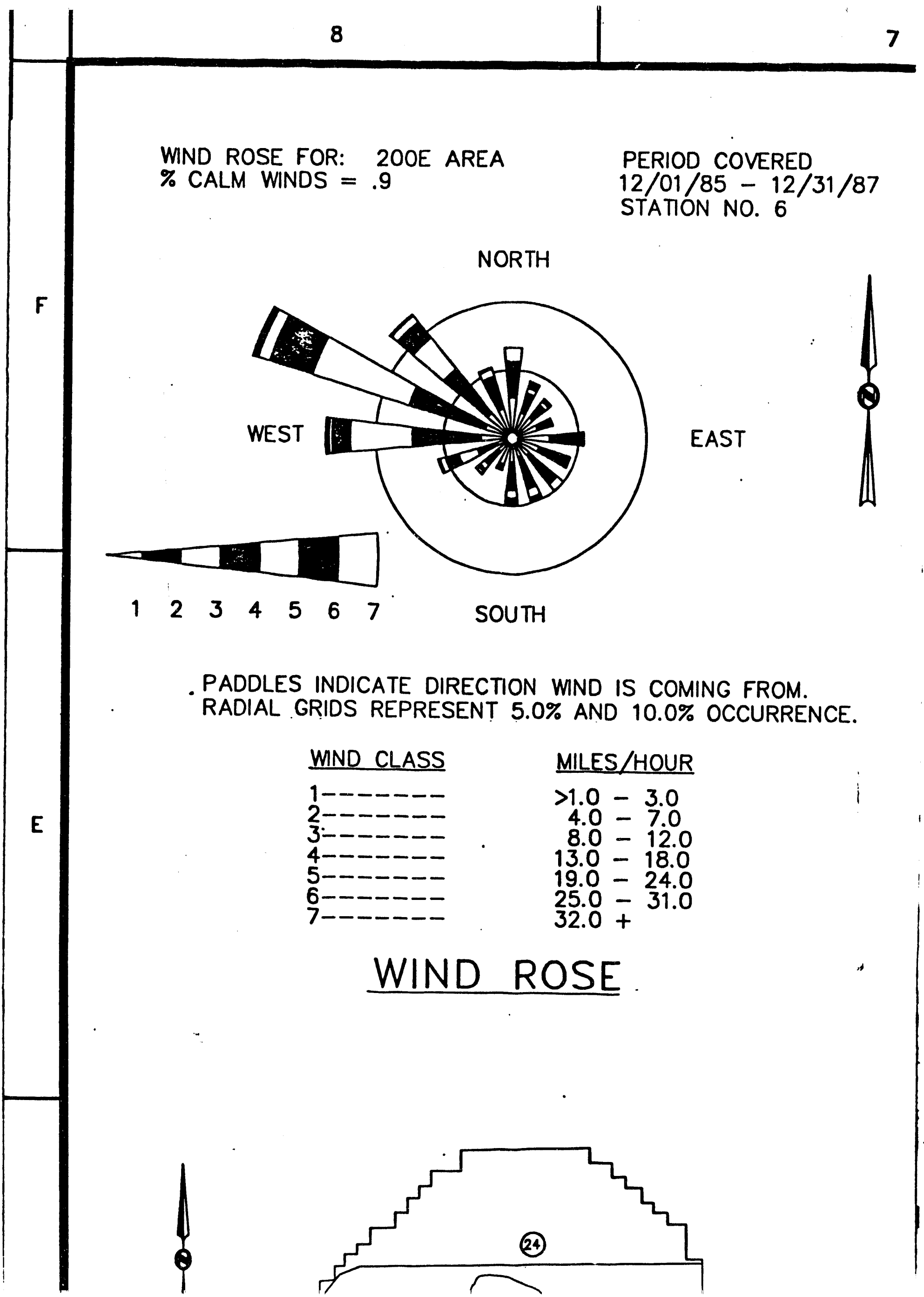


.D

$/ 31 / 87$ $\begin{array}{ll}8 & 8 \\ 8 & 8 \\ n & 5\end{array}$

$\underset{8}{8} \quad: \quad \frac{0}{h}$

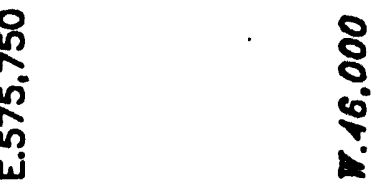

8
8
0
0
ن

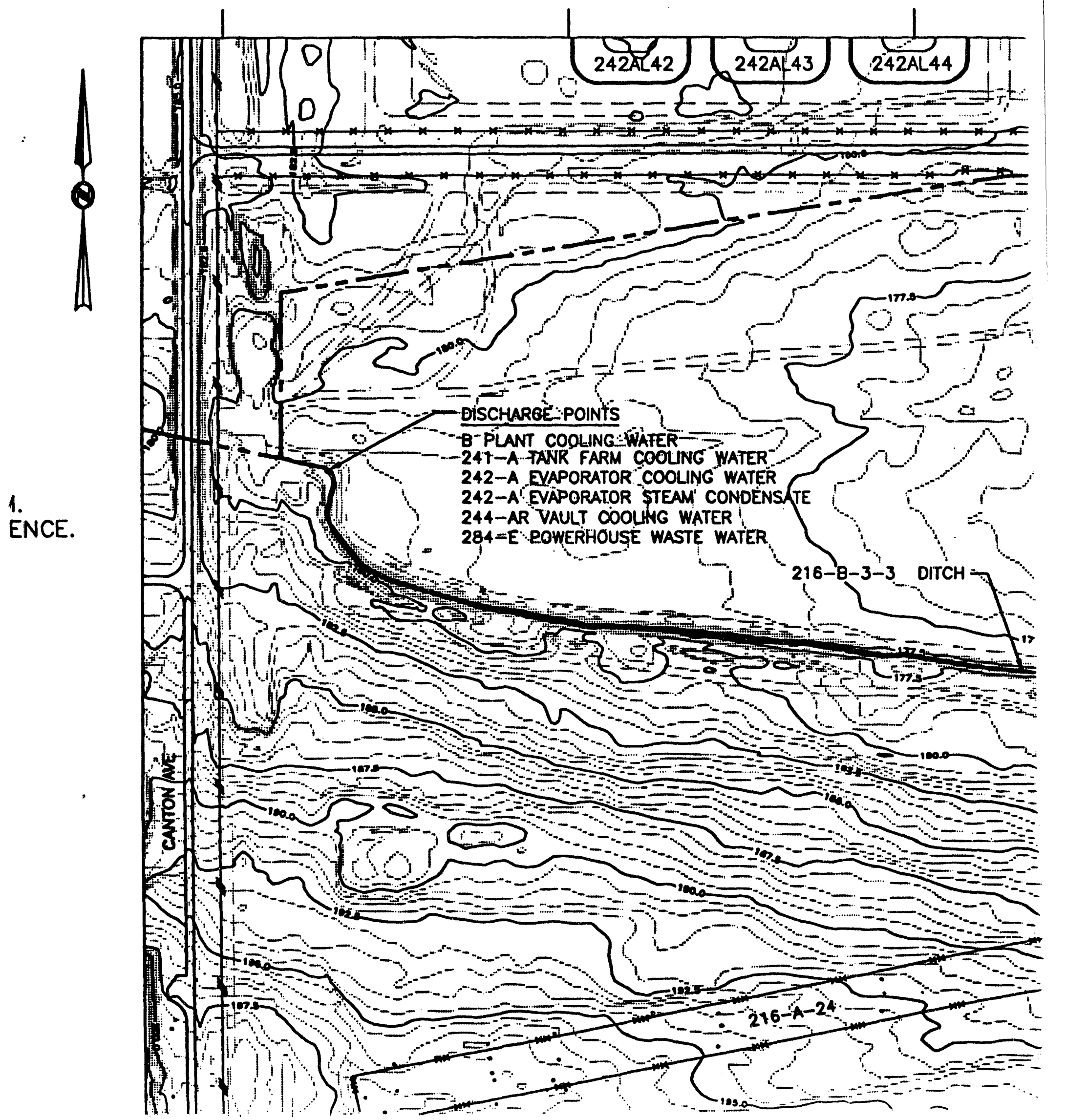




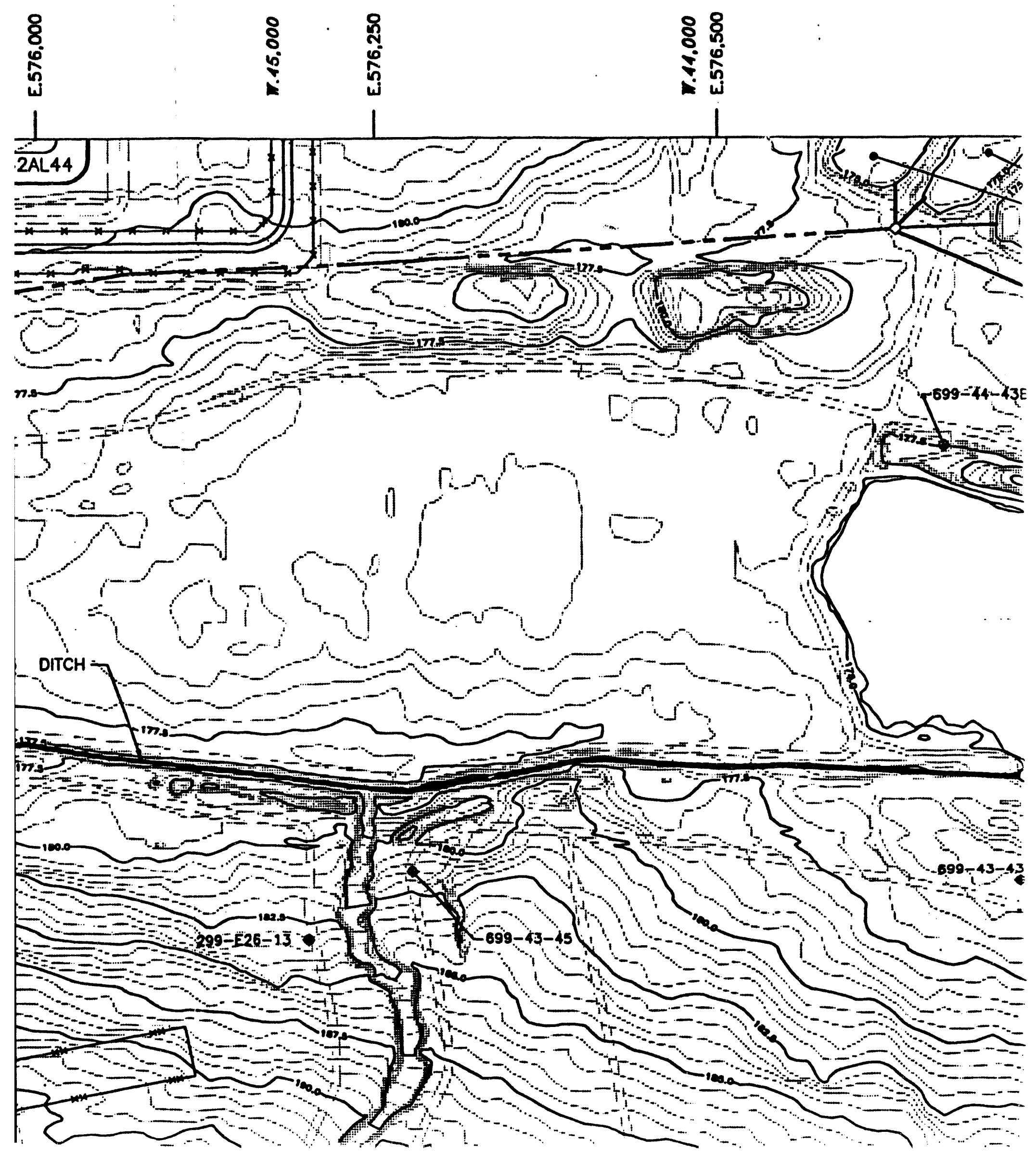




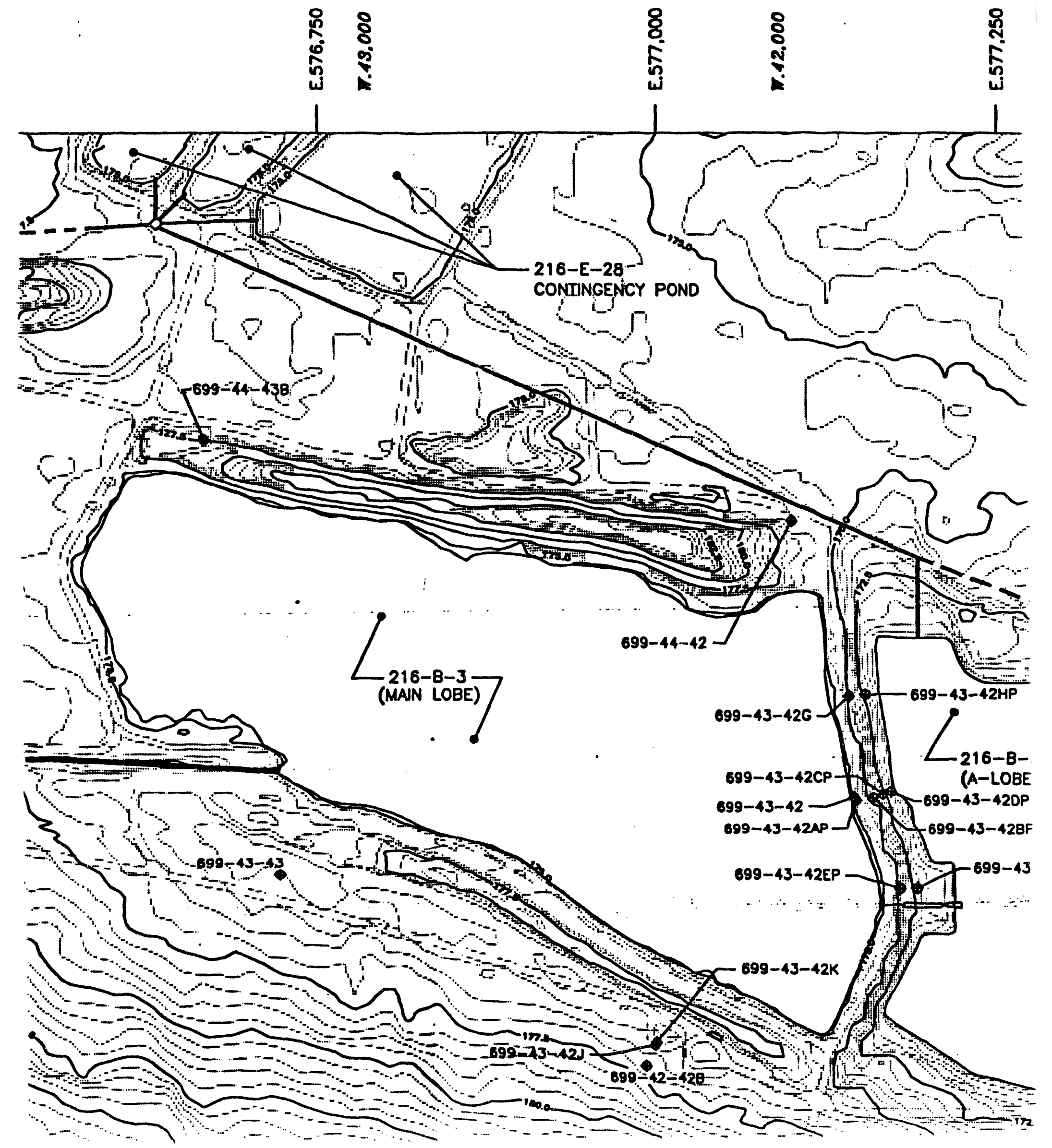




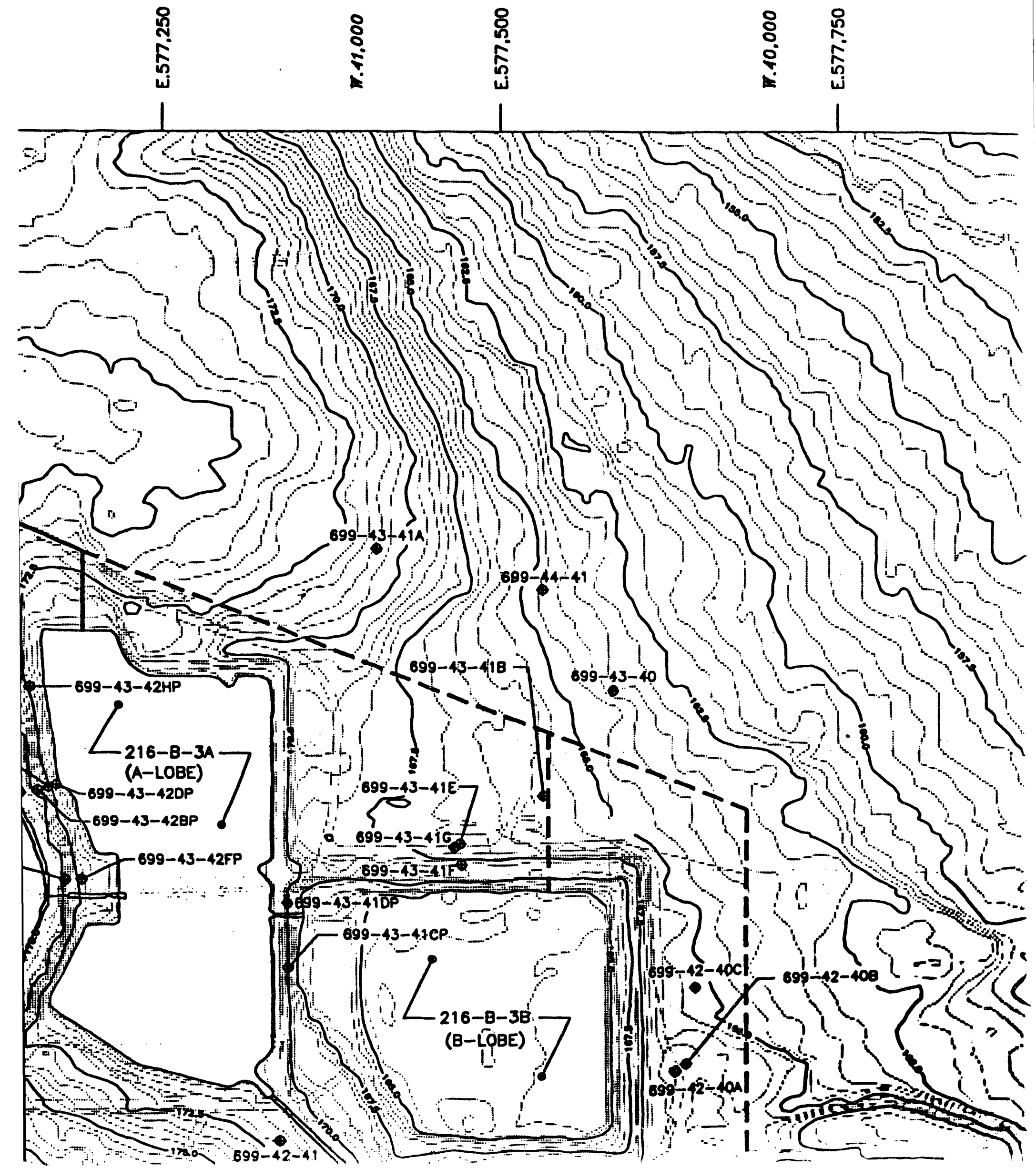


DOE/RL 93-61, $\operatorname{Rev} 0$

$12 / 93$

200 East Area W-252 Streams

88
80
0
0
w.

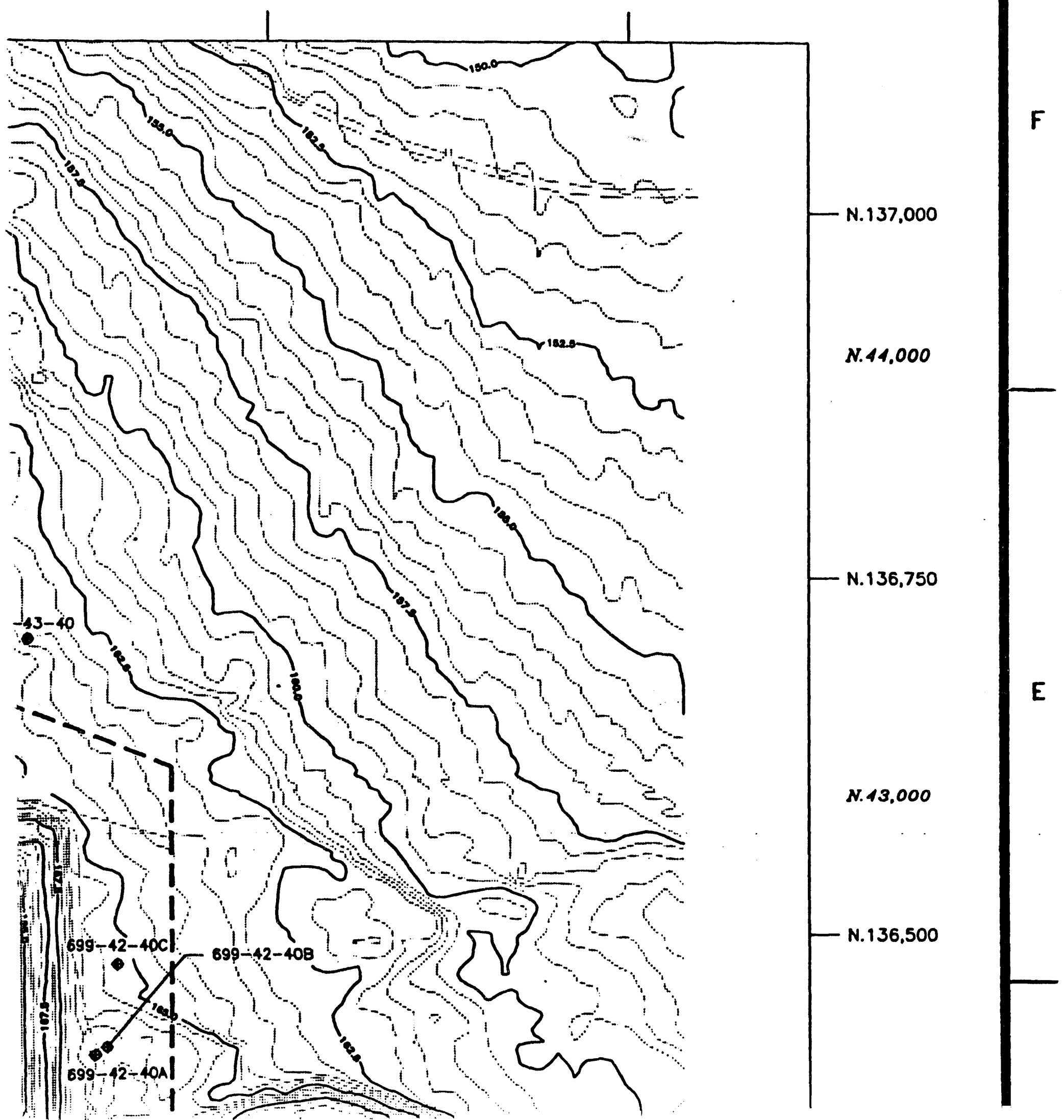




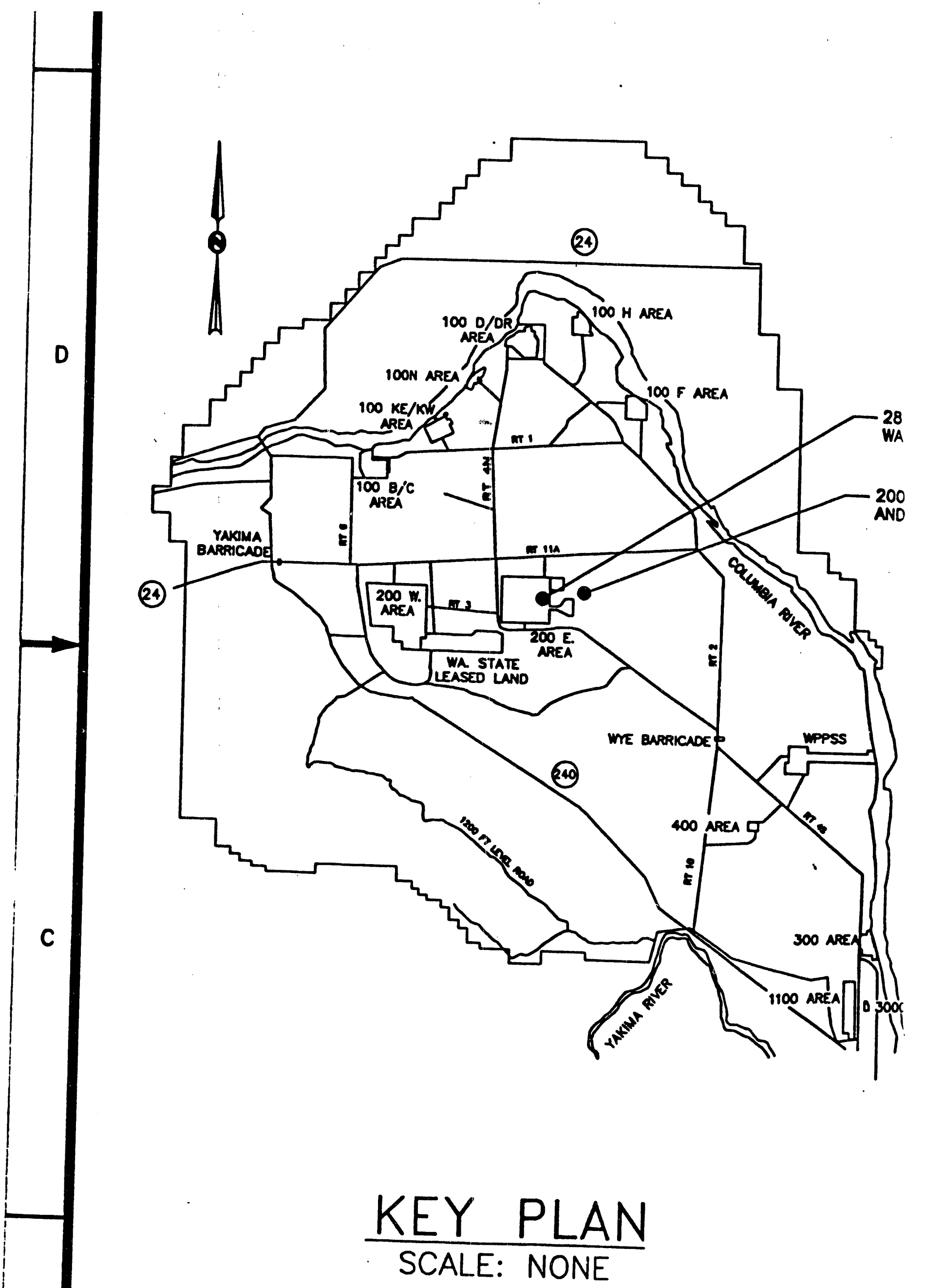




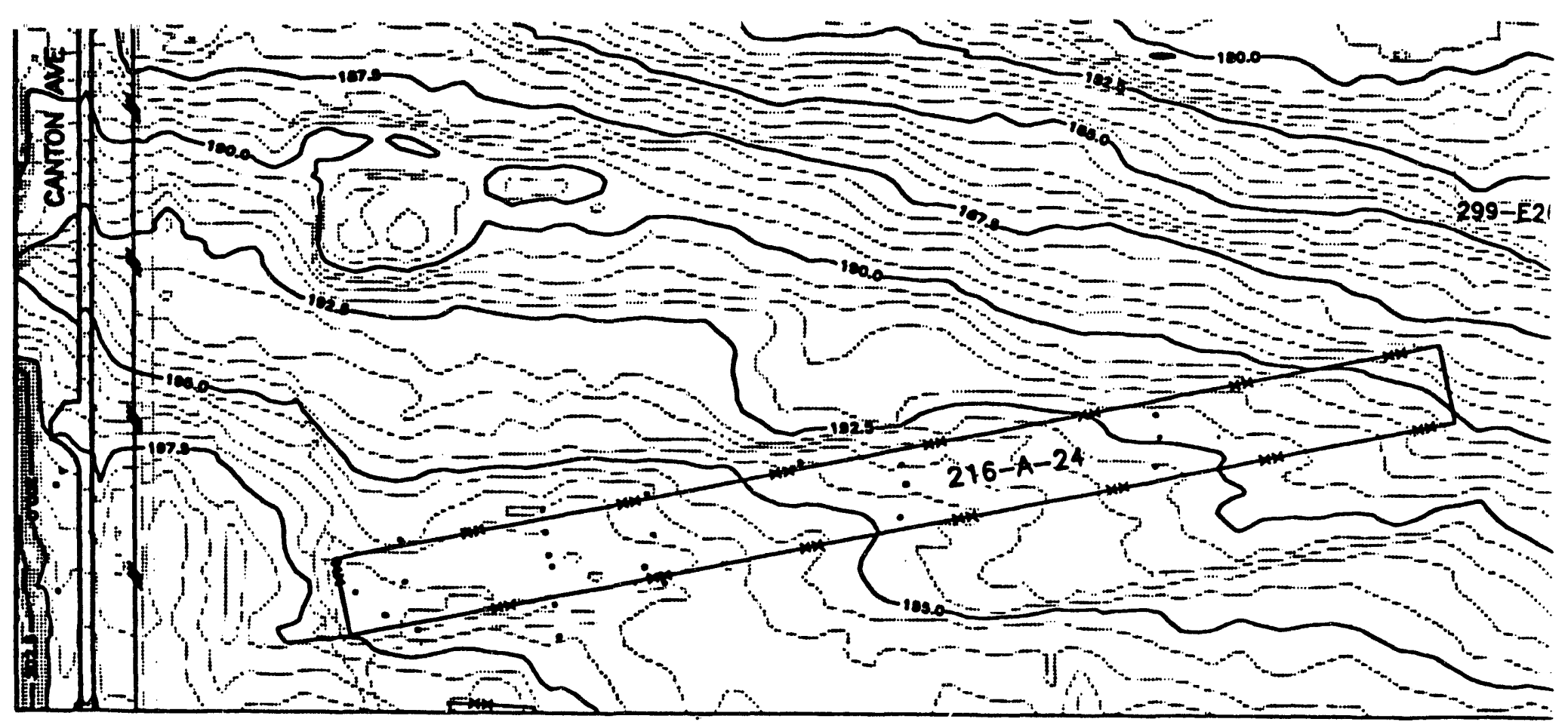

'OWERHOUSE

ATER DITCH

B-PONDS

-B DITCH

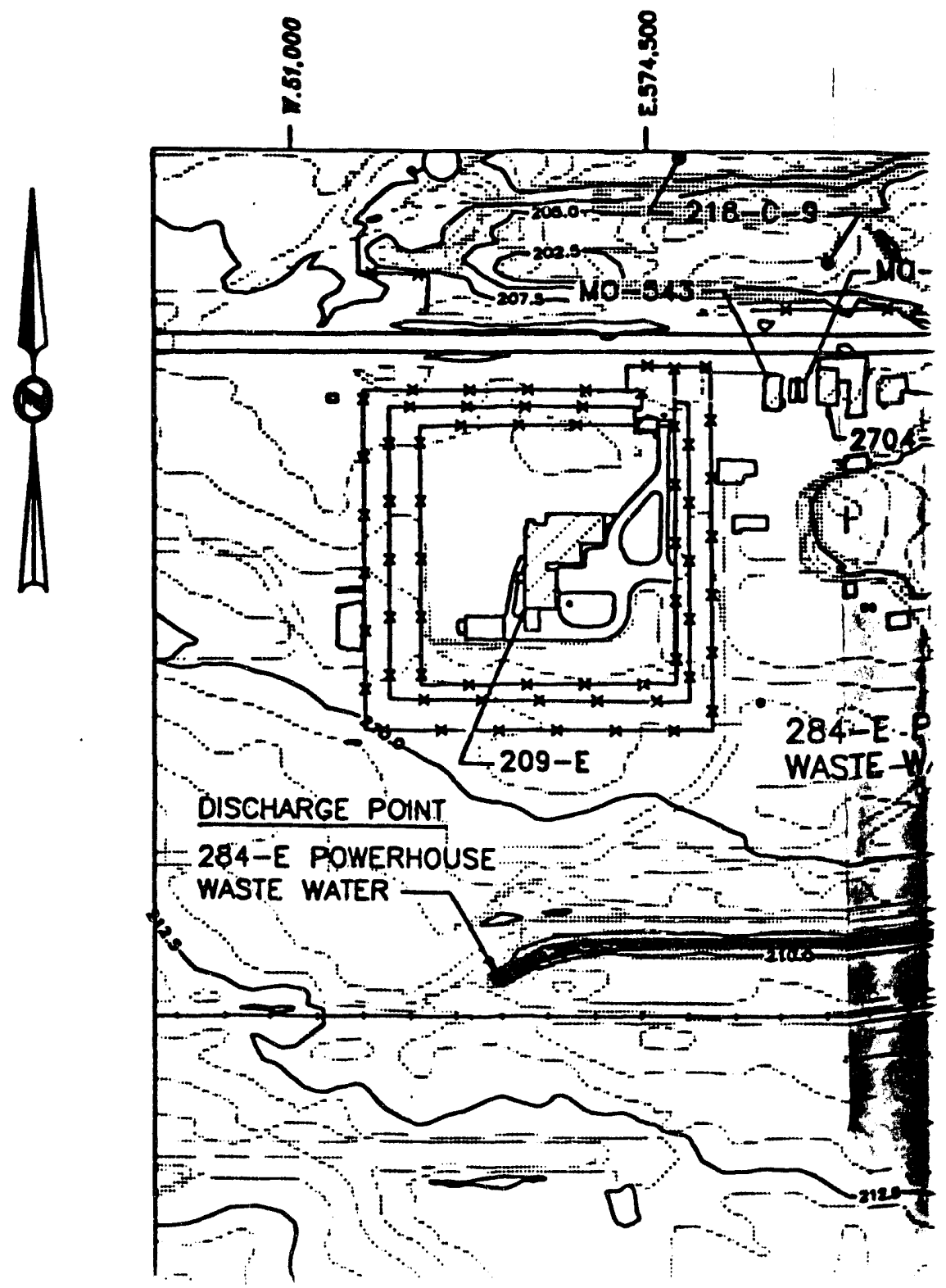



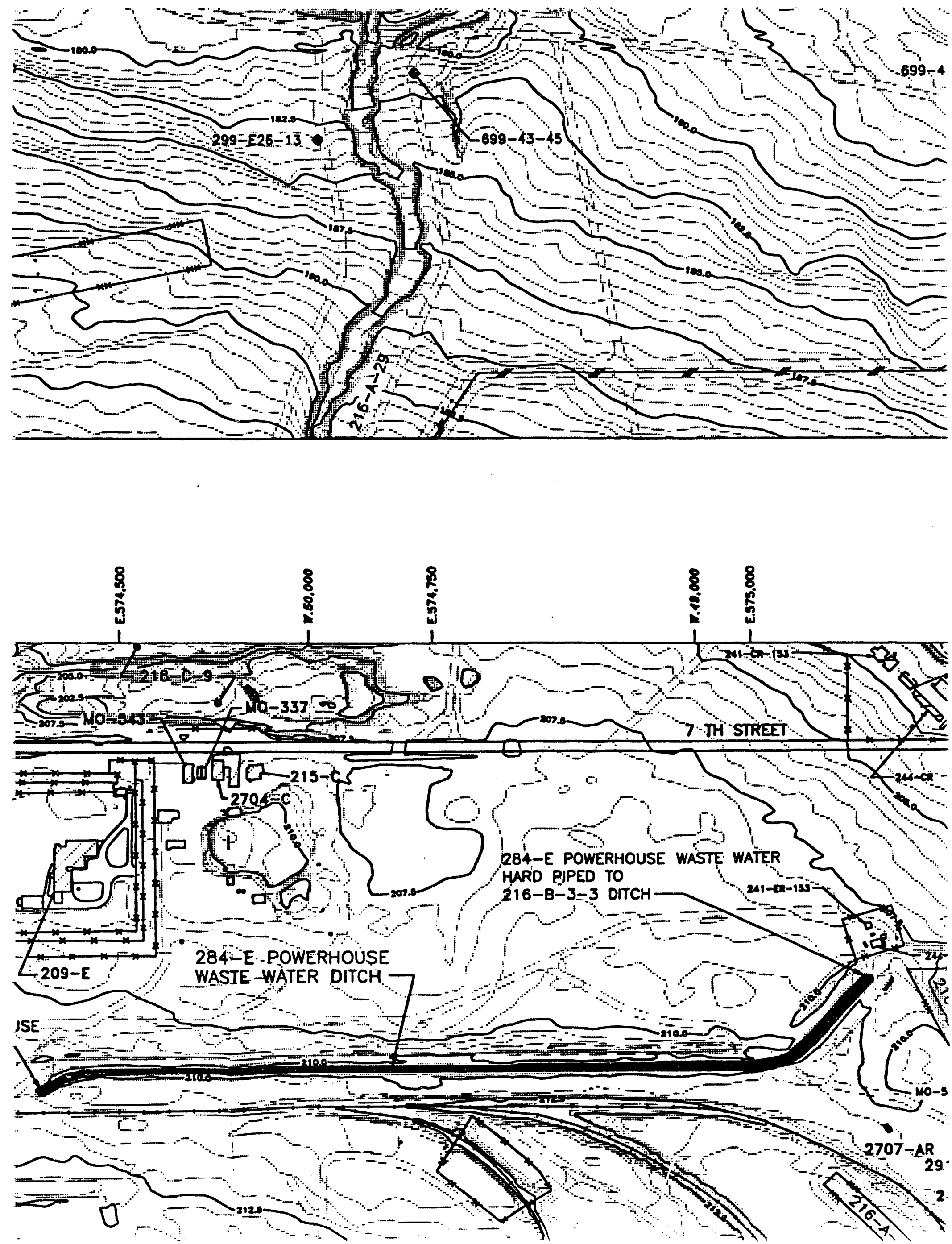


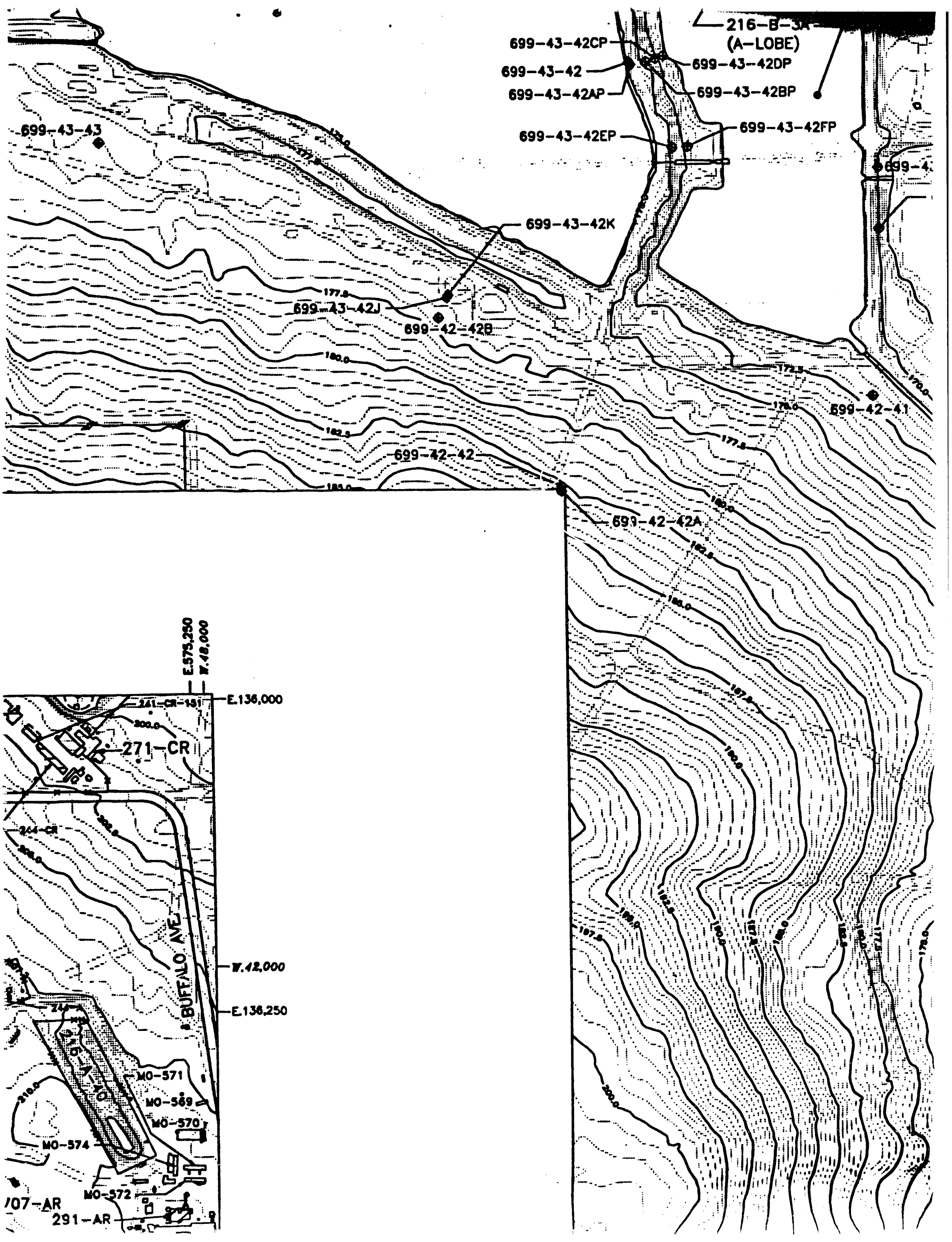




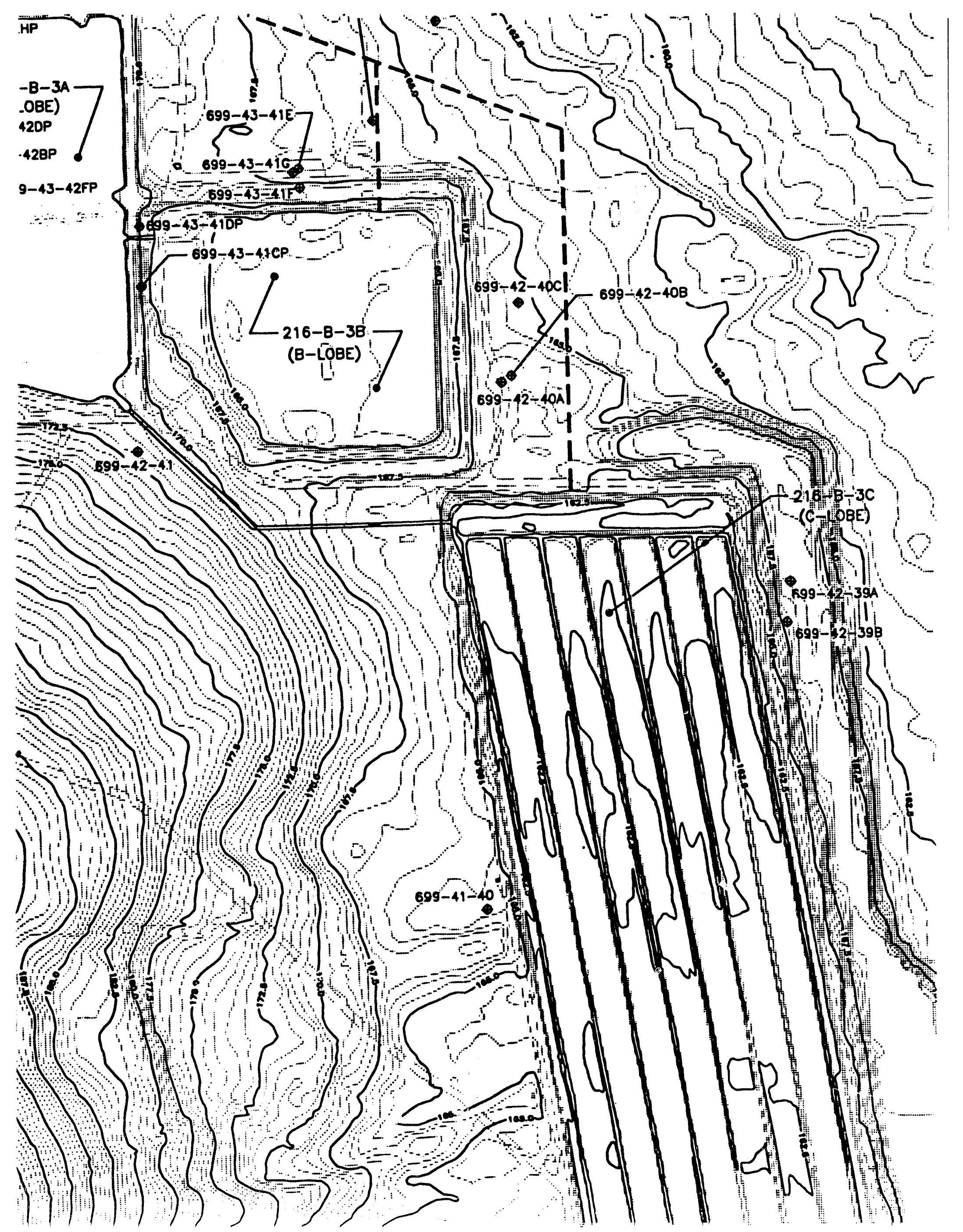




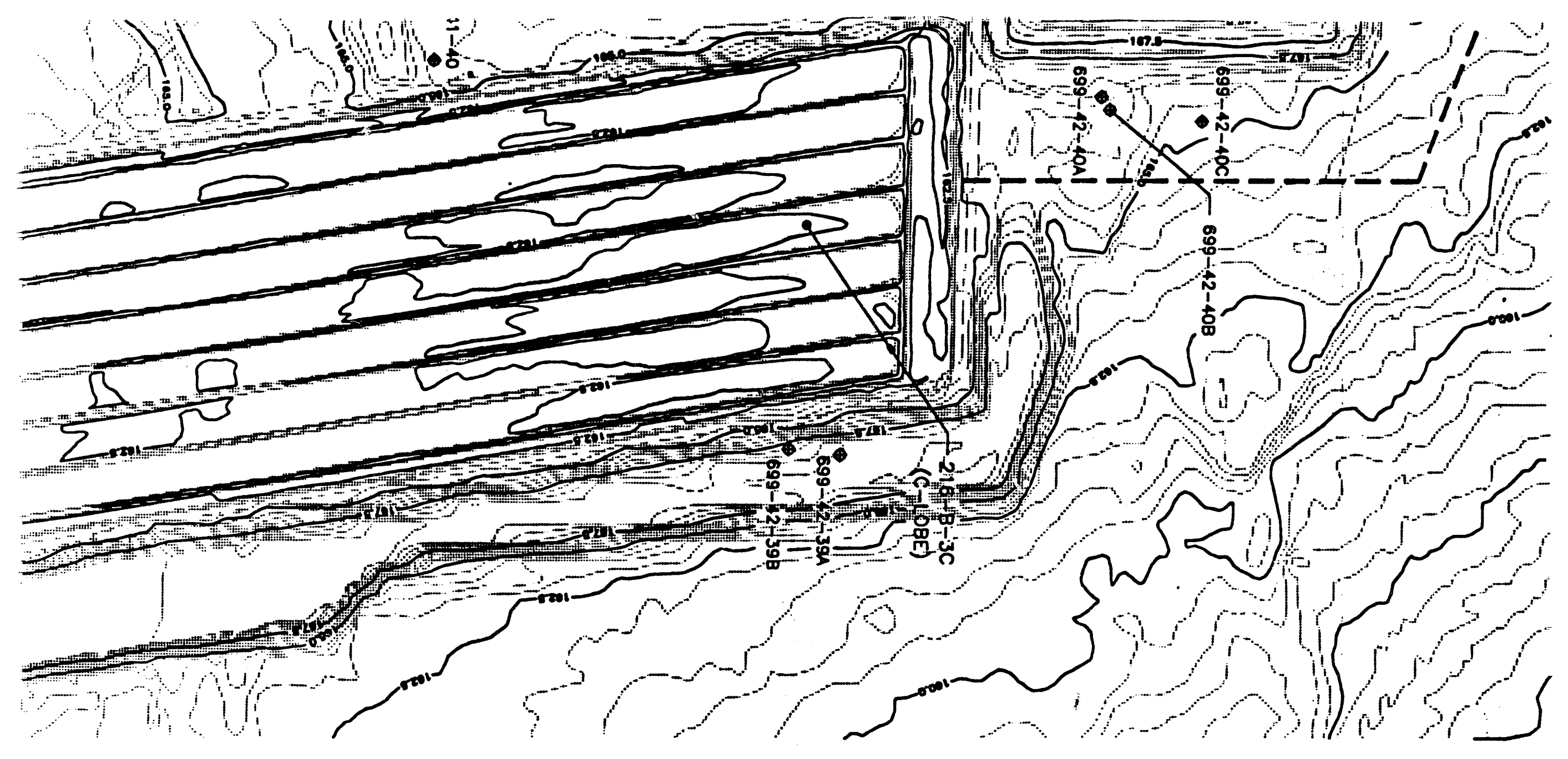

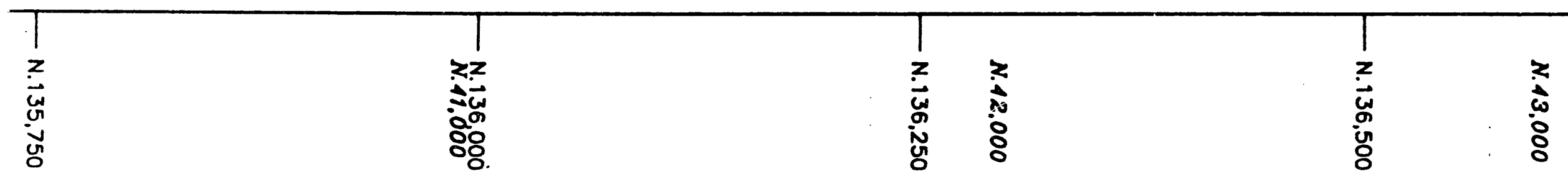




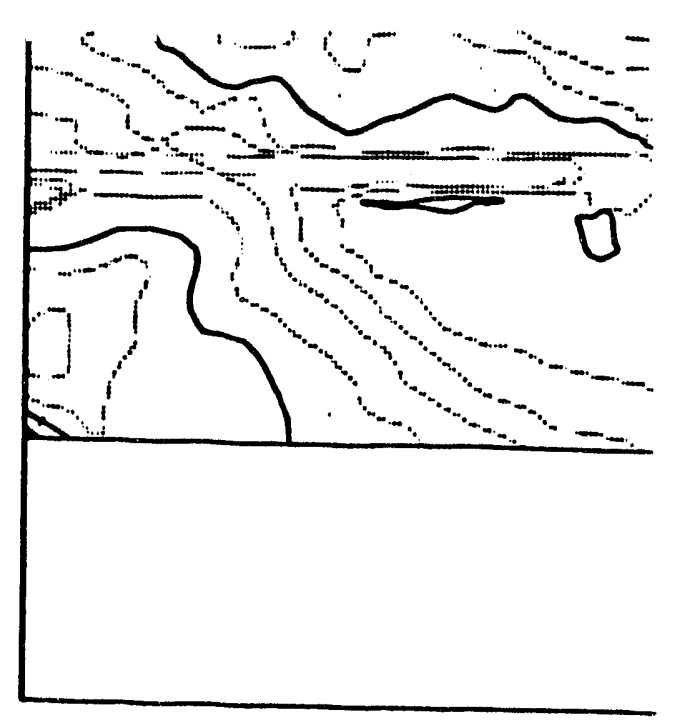

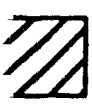

BUILDINGS/STRUCTURES/TOWERS

?-A BUILDING NUMBER

* SECURITY,WARNING,MISC FENCES

* POST \& CHAIN

(CRIB,BURIAL GROUND FENCES)

- PE PERIMETER FENCES

-..- PIPELINES

) () TANKS

$i-42$ C/RIB

:-10 BURIAL GROUND

PROPOSED BYPASS PIPELINE (PROJECT $X$-009)

EXISTING UNUSED BYPASS PIPELINE

CONTINGENCY POND PIPELINE

\section{GENERAL}

1. THIS MAP IS BASED ON AERIAL PHOTOGRAPHY FLOWI BY MERRICK \& COMPANY AND CERTIFIED TO MEET N OFFICIAL COPIES OF THE MERRICK MAPS THAT SHOW ENGINEERING FILES AS DRAWING NUMBERS $\mathrm{H}-2-794$; THE NAMES OF PHYSICAL FEATURES AND THE TITLE B MAPS WERE ADDED BY WESTINGHOUSE HANFORD COM.

2. WASHINGTON COORDINATE SYSTEM: THE OFFICIAL STA REVISED CODE OF WASHINGTON (RCW). THE HANFORI SOUTH ZONE. THIS GRID COVERS THE ENTIRE SITE A HORIZONTAL DATUM: NAD-83 LAMBERT PROJECTIONS

VERTICAL DATUM: NATIONAL GEODETIC SURVEY DATUM AS PROVIDED BY KAISER ENGINEERS HANFORD.

COORDINATES ARE SHOWN AS METERS. CONTOURS ARE SHOWN AS O.5 METERS.

3. HANFORD PLANT GRID: A LOCAL GRID SYSTEM WITH COVERS 200 EAST AND 200 WEST AREA AS WELL AS GROUNDS. COORDINATES ARE SHOWN AS FEET. 


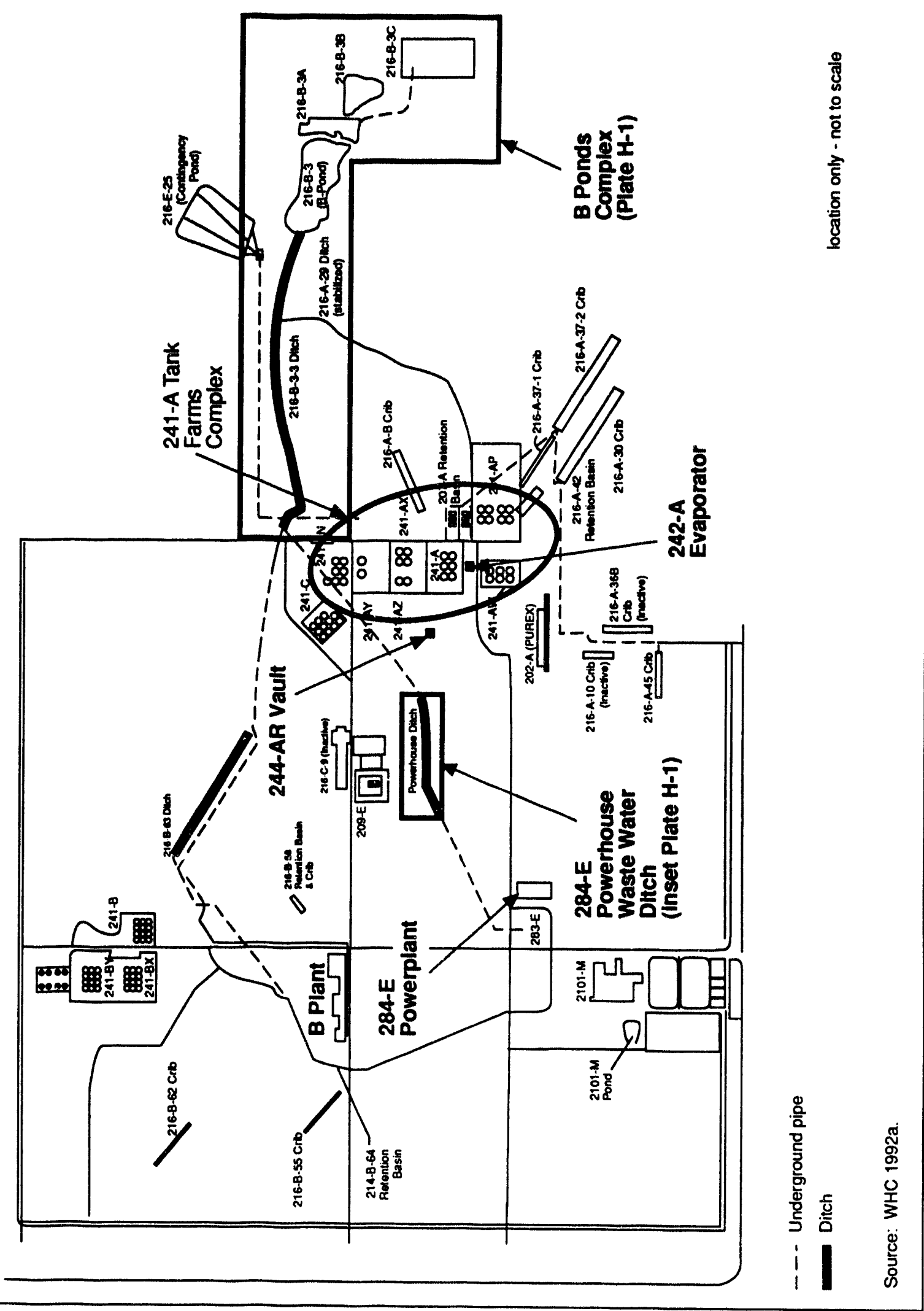

$9131728.013 / 47607 / 11-10-93$

Figure H-1. 200 East Area W-252 Facilities Location Map. 
4.0 IDENTIFY ALL WELLS WITHIN 500 FEET OF THE SITE. ATTACH WELL LOGS WHEN AVAILABLE AND ANY AVAILABLE WATER OUALTTY DATA.

Monitoring wells within 500 feet of the B Pond Complex and the 216-B-3-3 Ditch which transmits the waste water from the six streams to the $B$ Pond Complex include:

$\begin{array}{ll}699-40-39 & 699-43-41 \mathrm{DP} \\ 699-40-40 \mathrm{~A} & 699-43-42 \\ 699-40-40 \mathrm{~B} & 699-43-42 \mathrm{~J} \\ 699-41-40 & 699-43-42 \mathrm{~K} \\ 699-42-39 \mathrm{~A} & 699-43-42 \mathrm{AP} \\ 699-42-40 \mathrm{~A} & 699-43-42 \mathrm{BP} \\ 699-42-40 \mathrm{~B} & 699-43-42 \mathrm{CP} \\ 699-42-40 \mathrm{C} & 699-43-4-\mathrm{DP} \\ 699-42-41 & 699-43-42 \mathrm{EP} \\ 699-42-42 & 699-43-42 \mathrm{FP} \\ 699-42-42 \mathrm{~A} & 699-43-42 \mathrm{GP} \\ 699-42-42 \mathrm{~B} & 699-43-42 \mathrm{HP} \\ 699-43-40 & 699-43-43 \\ 699-43-41 \mathrm{~A} & 699-43-45 \\ 699-43-41 \mathrm{~B} & 699-44-41 \\ 699-43-41 \mathrm{E} & 699-44-42 \\ 699-43-41 \mathrm{~F} & 699-44-43 \mathrm{~B}\end{array}$

$699-43-41 G$ $699-43-41 C P$

The following well logs from the 216-B-3 Pond System Closure/Postclosure Plan, (DOE-RL 1990) are attached.
699-40-39
$699-42-40 \mathrm{~A}$
$699-43-41 E$
699-43-42J
$699-43-45$
$699-44-43 B$

$699-41-40$

699-42-42B

$699-43-41 \mathrm{~F}$

699-43-43

699-44-42

The following well logs obtained from the WHC Geosciences Department project files, are also attached.

$$
\begin{aligned}
& 699-40-40 A \\
& 699-42-39 A \\
& 699-42-41 \\
& 699-43-41 G
\end{aligned}
$$

699-40-40B

$699-42-40 \mathrm{C}$

699-43-40

299-E26-13

No wells are present within 500 feet of the powerhouse waste water ditch shown in the inset on Plate H-1. 
DOE/RL 93-61, Rev 0

$12 / 93$

200 East Area W-252 Streams

$699-40-39$ (BP-5)
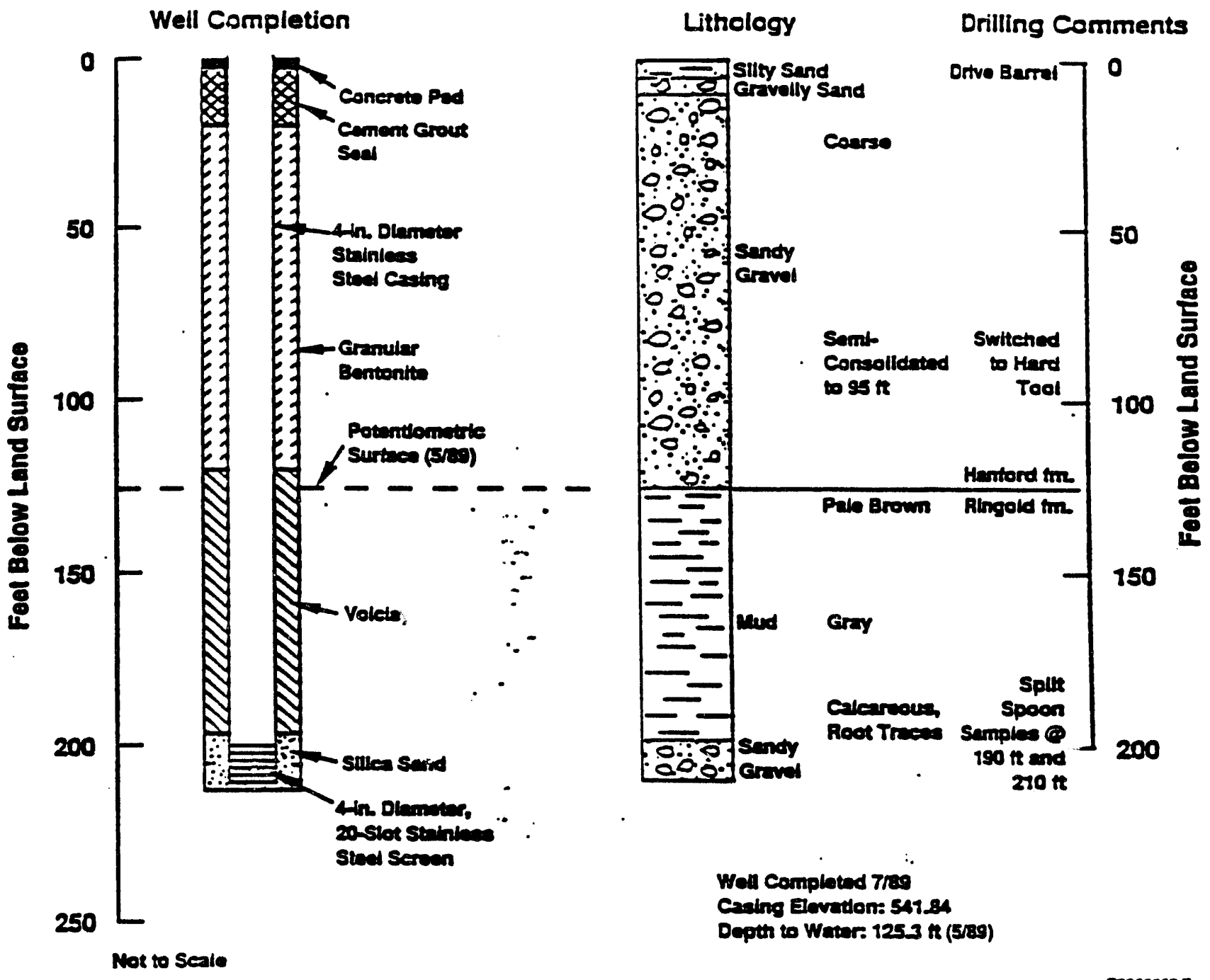

reaner 
DOE/RL 93-61, Rev 0

$12 / 93$

200 East Area W-252 Streams
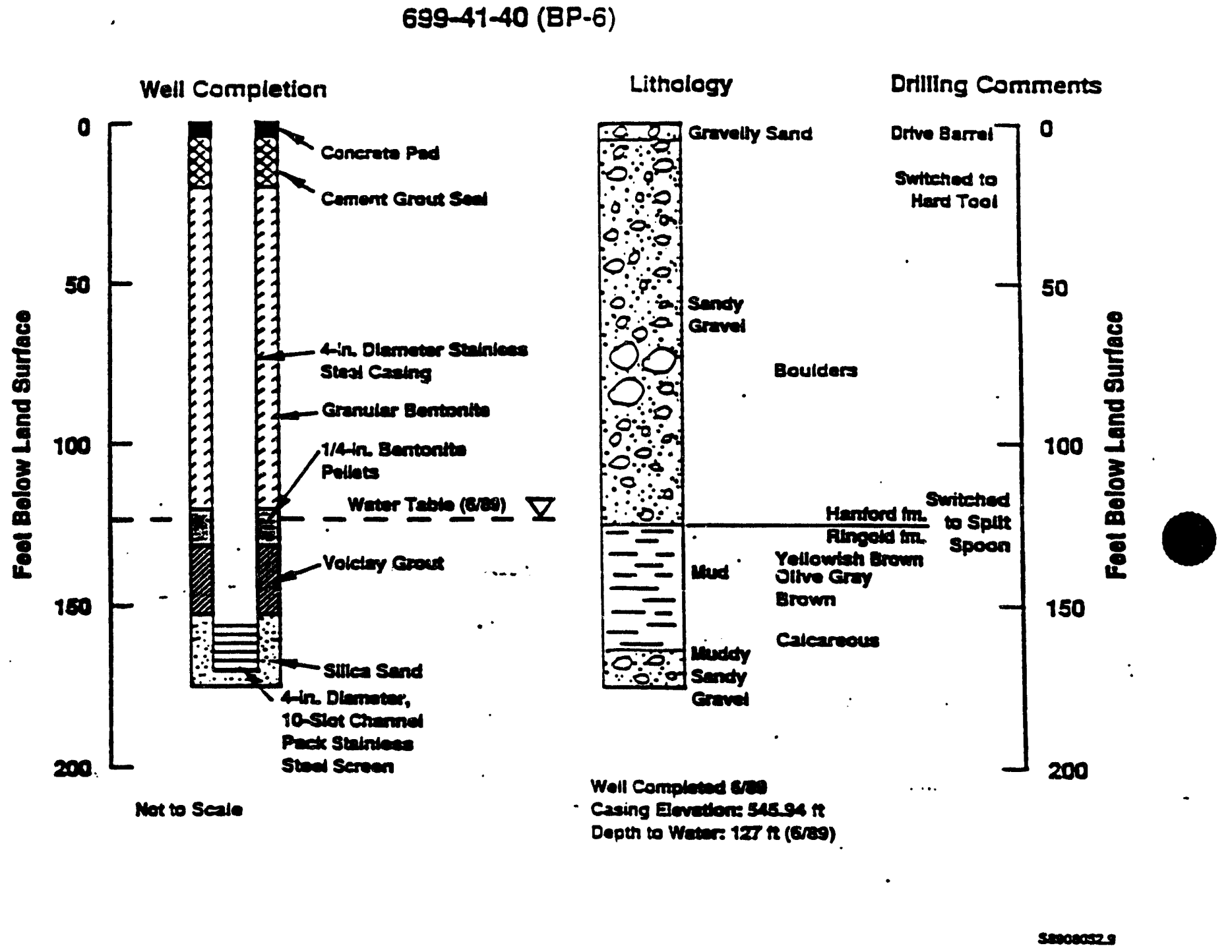


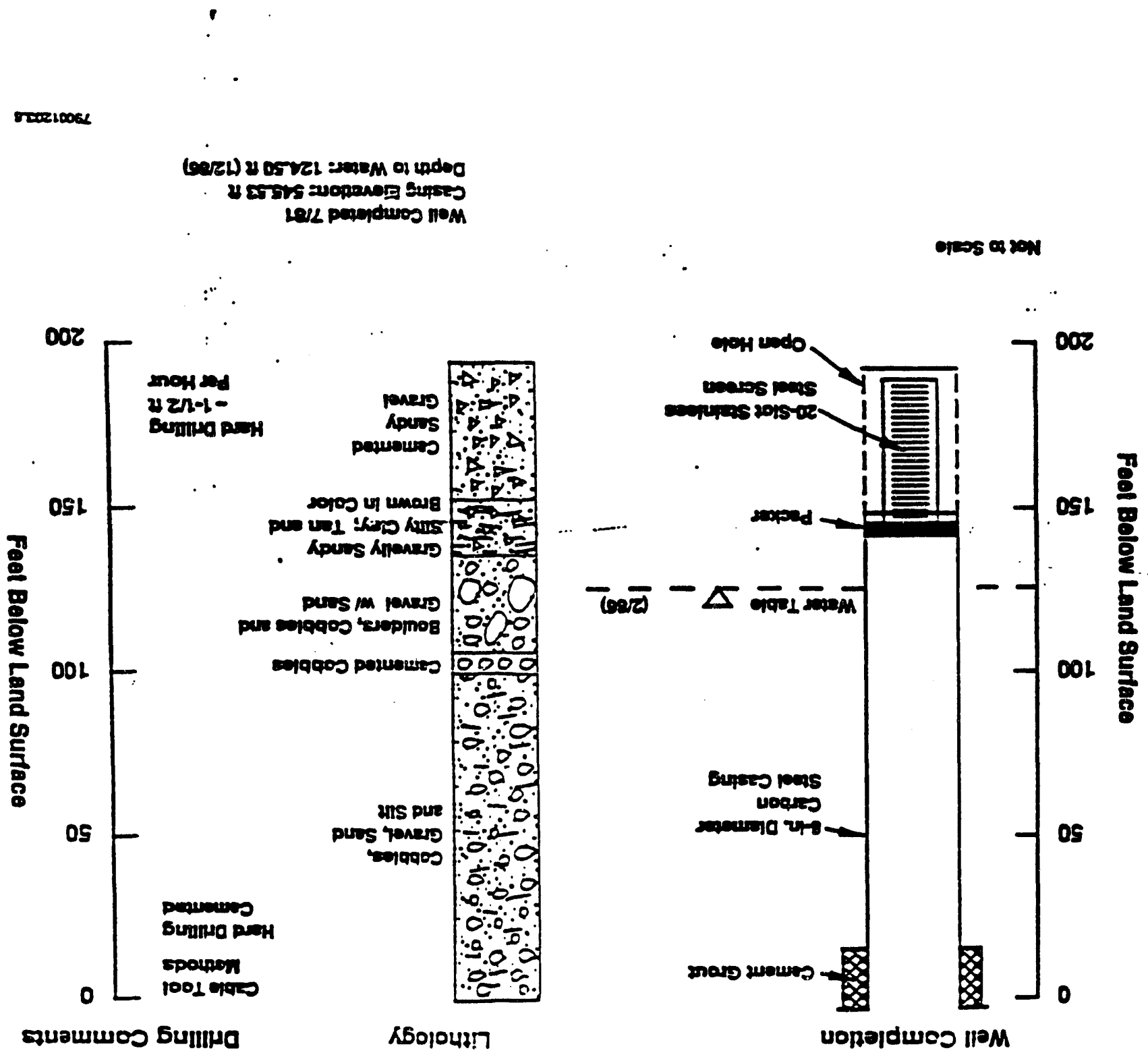

$\forall 0 t-2 t-669$ 
DOE/RL 93-61, Rev 0

$12 / 93$

200 East Area W-252 Streams

$699-42-42 B(B P-10)$

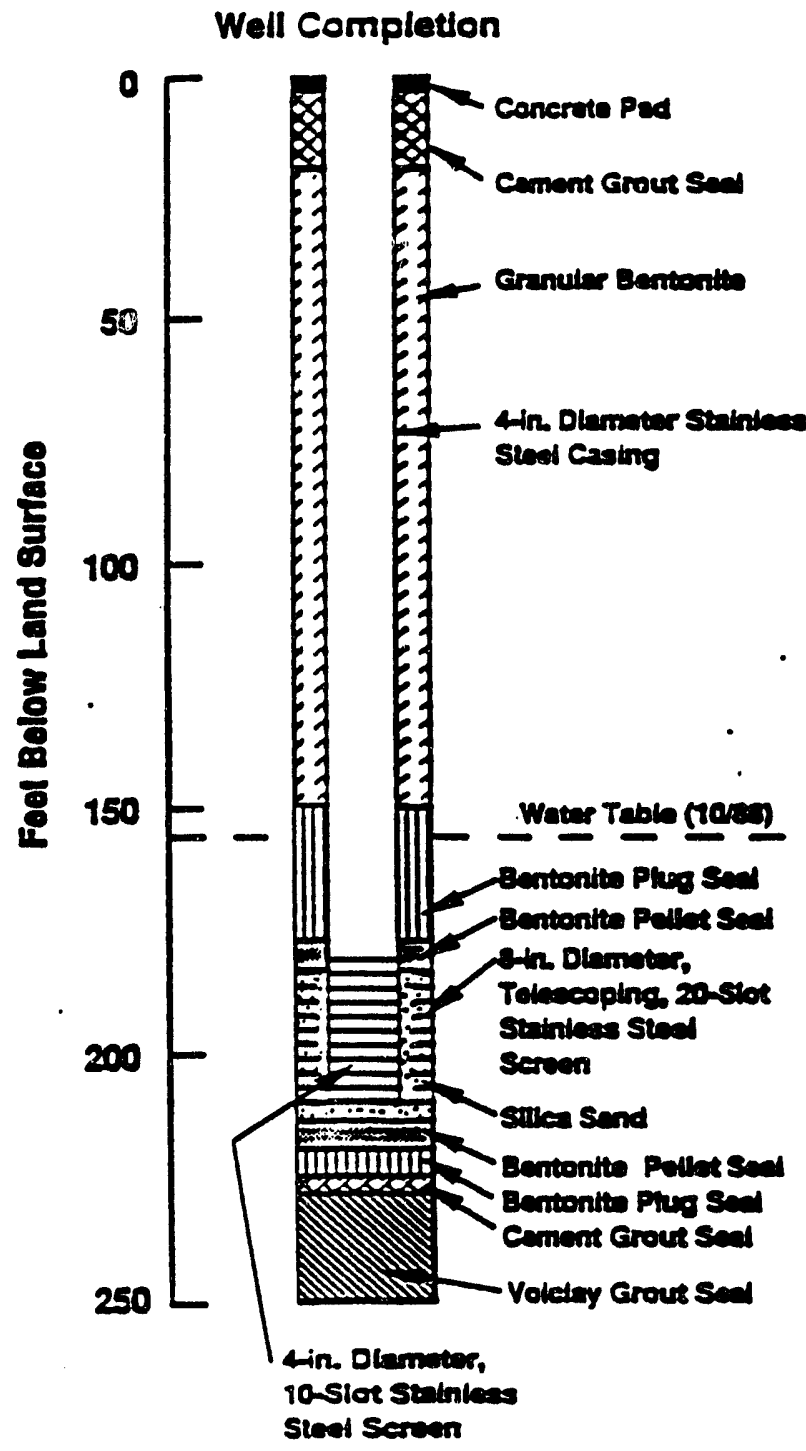

Not to Seale

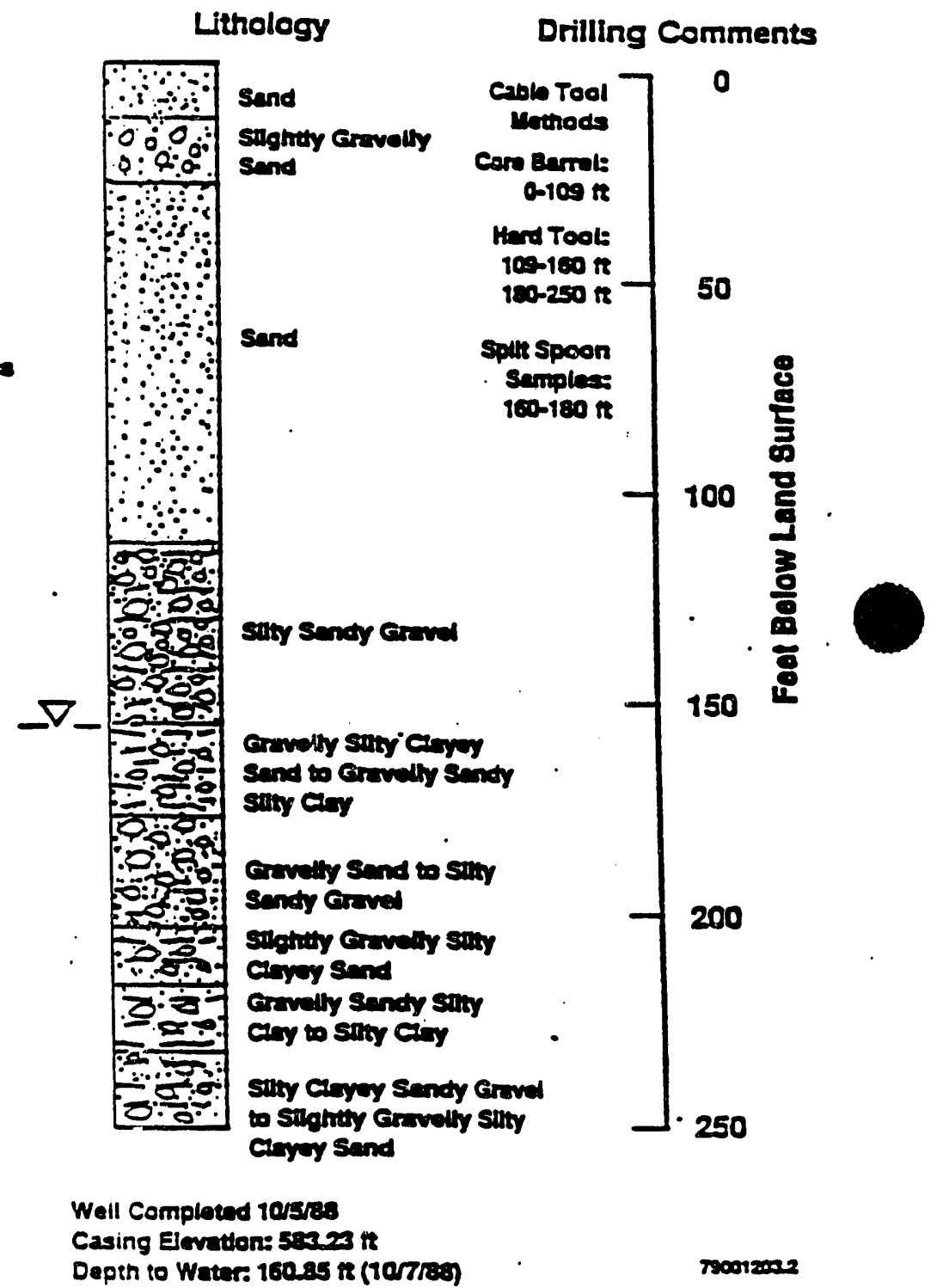


DOE/RL 93-61, Rev 0

$12 / 93$

200 East Area W-252 Streams

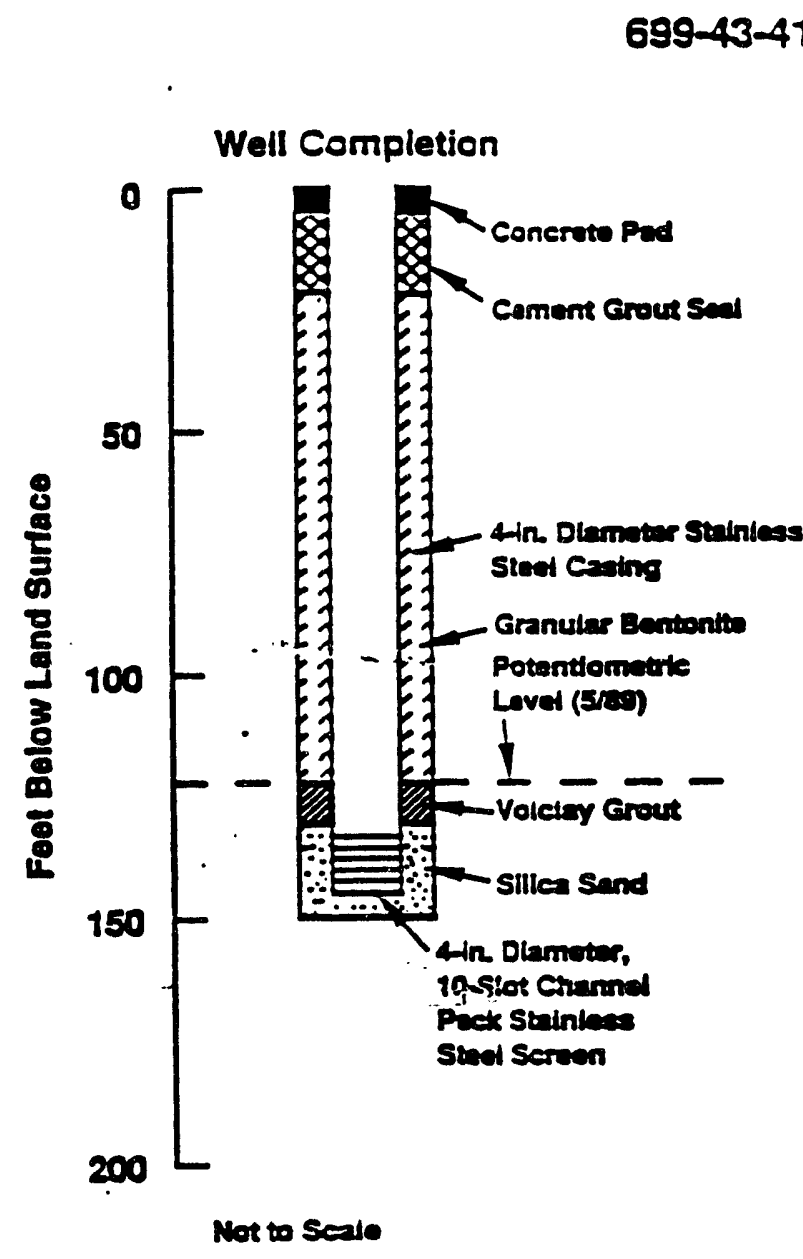

Lithology

Drilling Comments

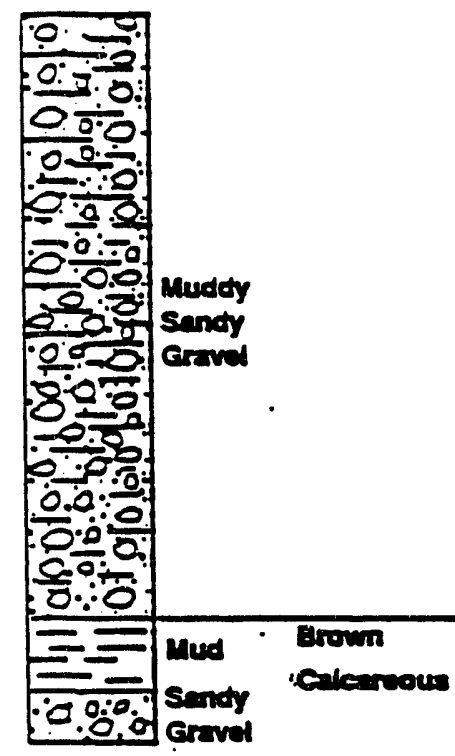

Hard Tool]

0

Anterd tom

50

9

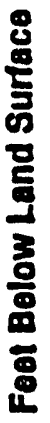

150

Wall Completed soo

200

Casing Eevedors seases it

Depth to Wetwor 125 as in (ENeq)

stopess 
DOE/RL 93-61, Rev 0
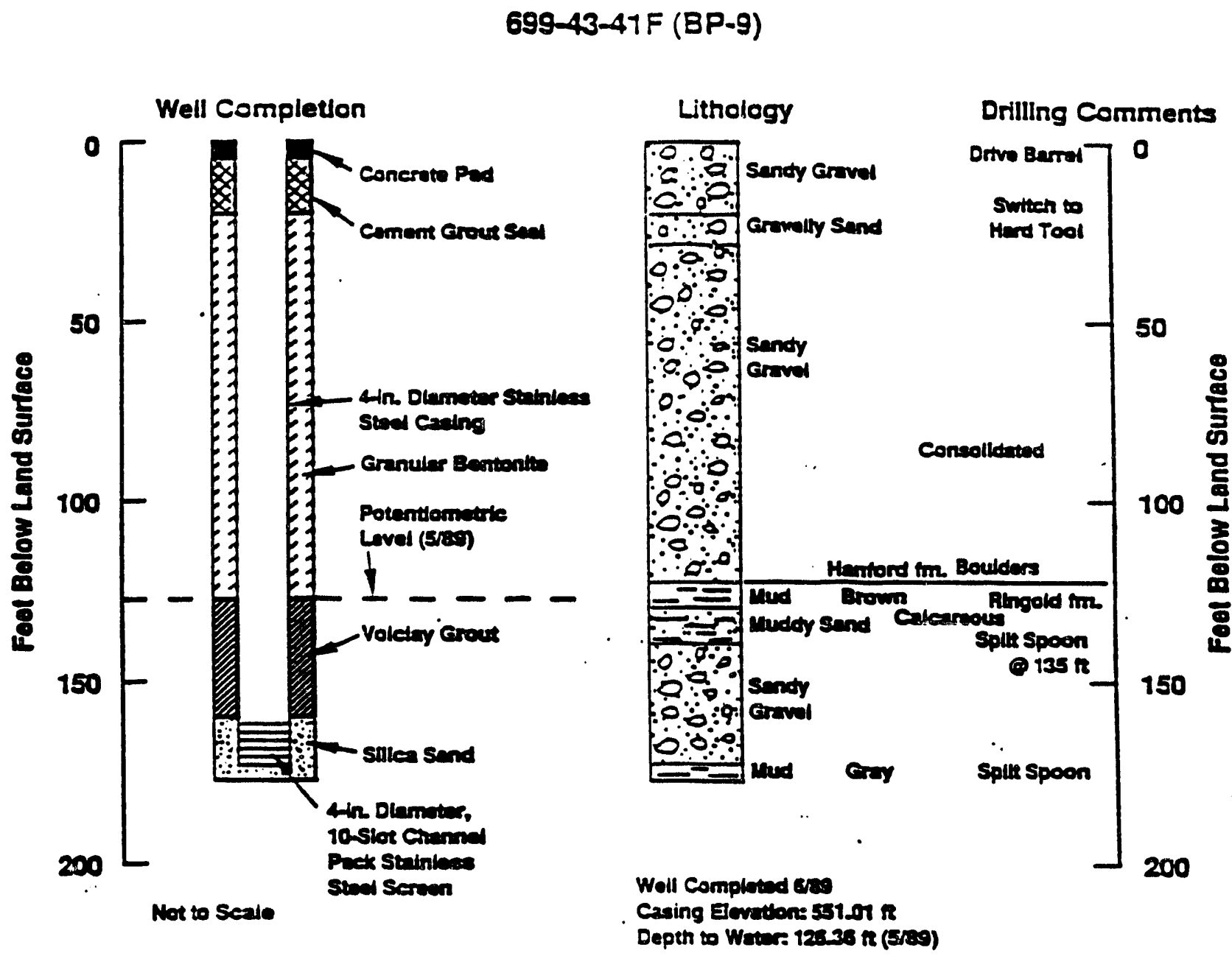

secoenz 
DOE/RL 93-51, Rev 0

$12 / 93$

200 East Area W-252 Streams

\section{$699-43-42 \mathrm{~J}(\mathrm{BP}-7)$}

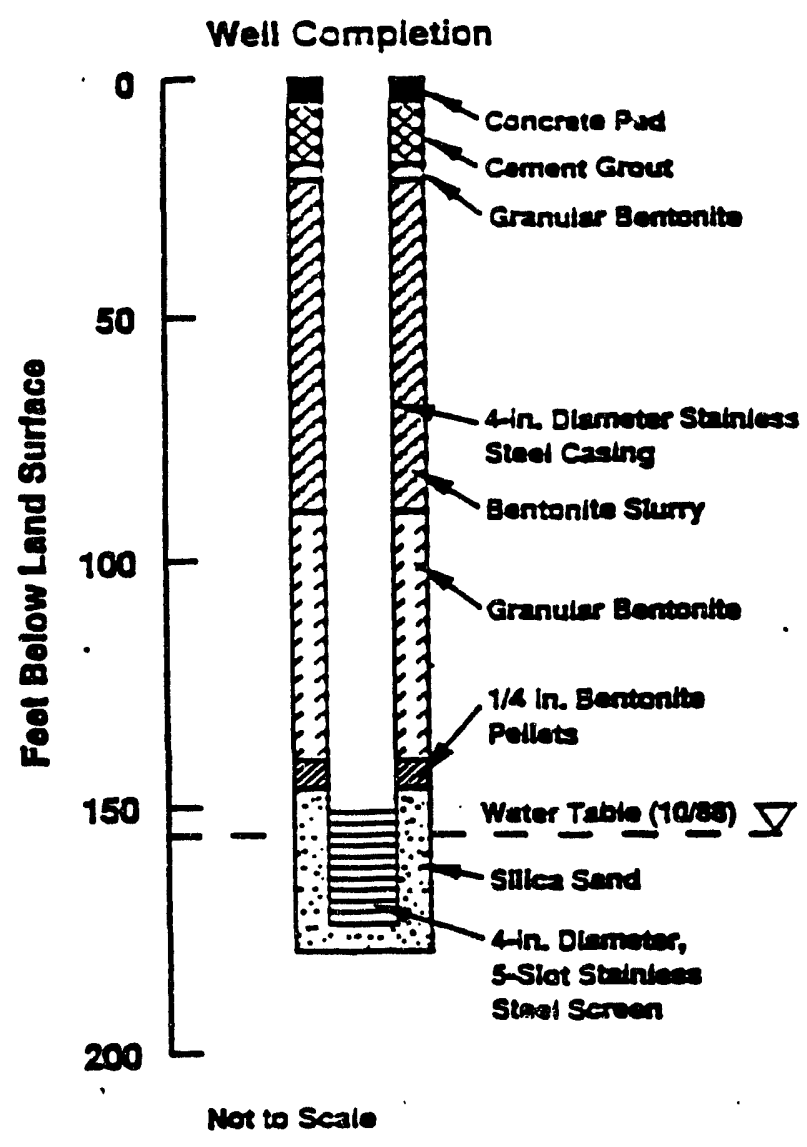

Lithology

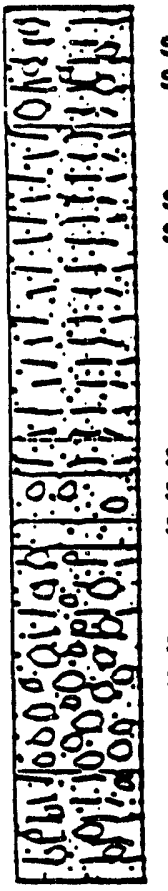

Silghtry Gravelly Sundy

Sut to Sandy Graved

silty send to sughry

Suty Sent

Sand (sat fors o $93 \mathrm{~m}$

sughuty Gravelty send

Sand

Sandy Gruval to

stiny sendy Graved

Grmolly Sandy Swy

Cirs to Gervelly suby

compy send

Well Complated $9 / 210$

Casing Eevation Ser.63 in

Depth to Water: $197.1 \mathrm{n}$ (107roe)
Drilling Comments

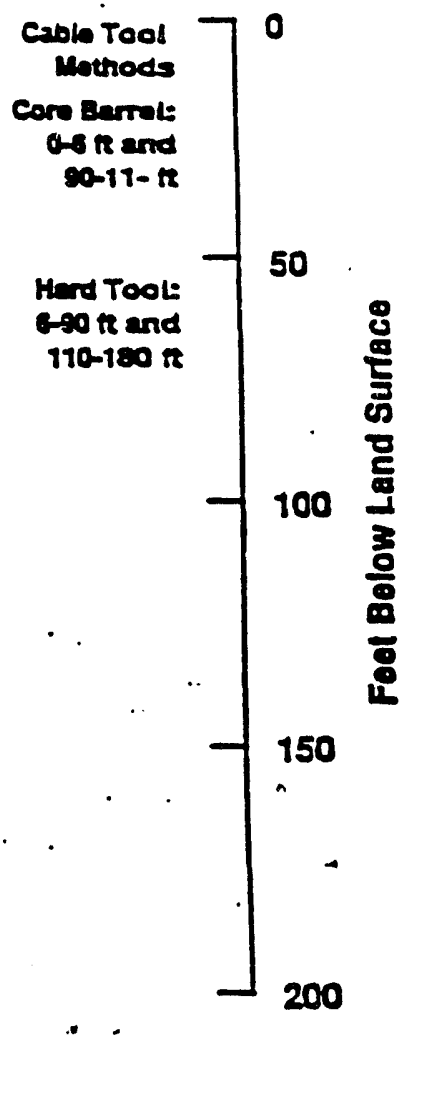

790012001 
DOE,'RL 93-61, Rev 0 $12 / 93$

200 East Area W-252 Streams

$699-43-43$ (BP-8)
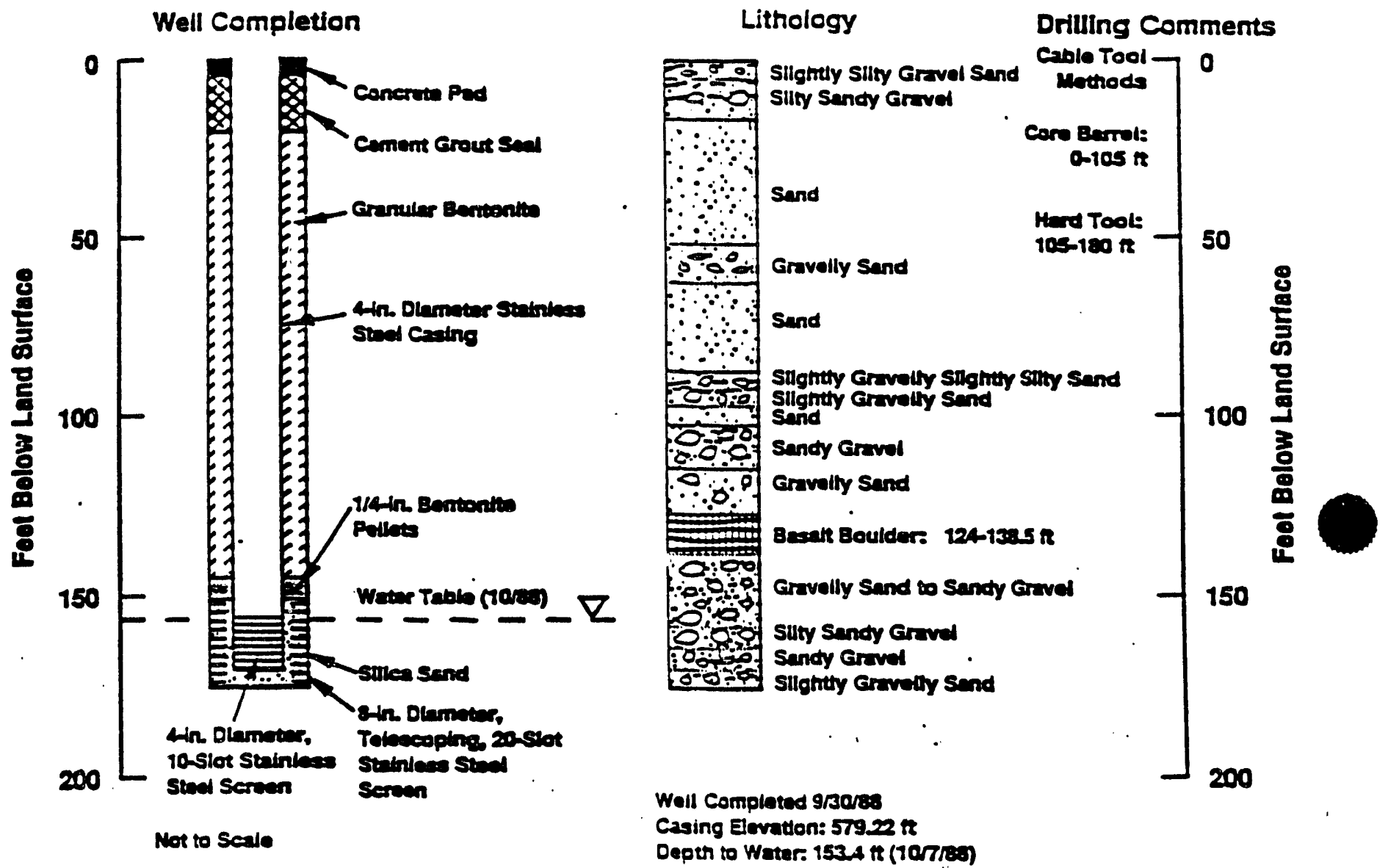

Troorasese 
DOE/RL 93-61, Rev 0

$12 / 93$

200 East Area W-252 Streams

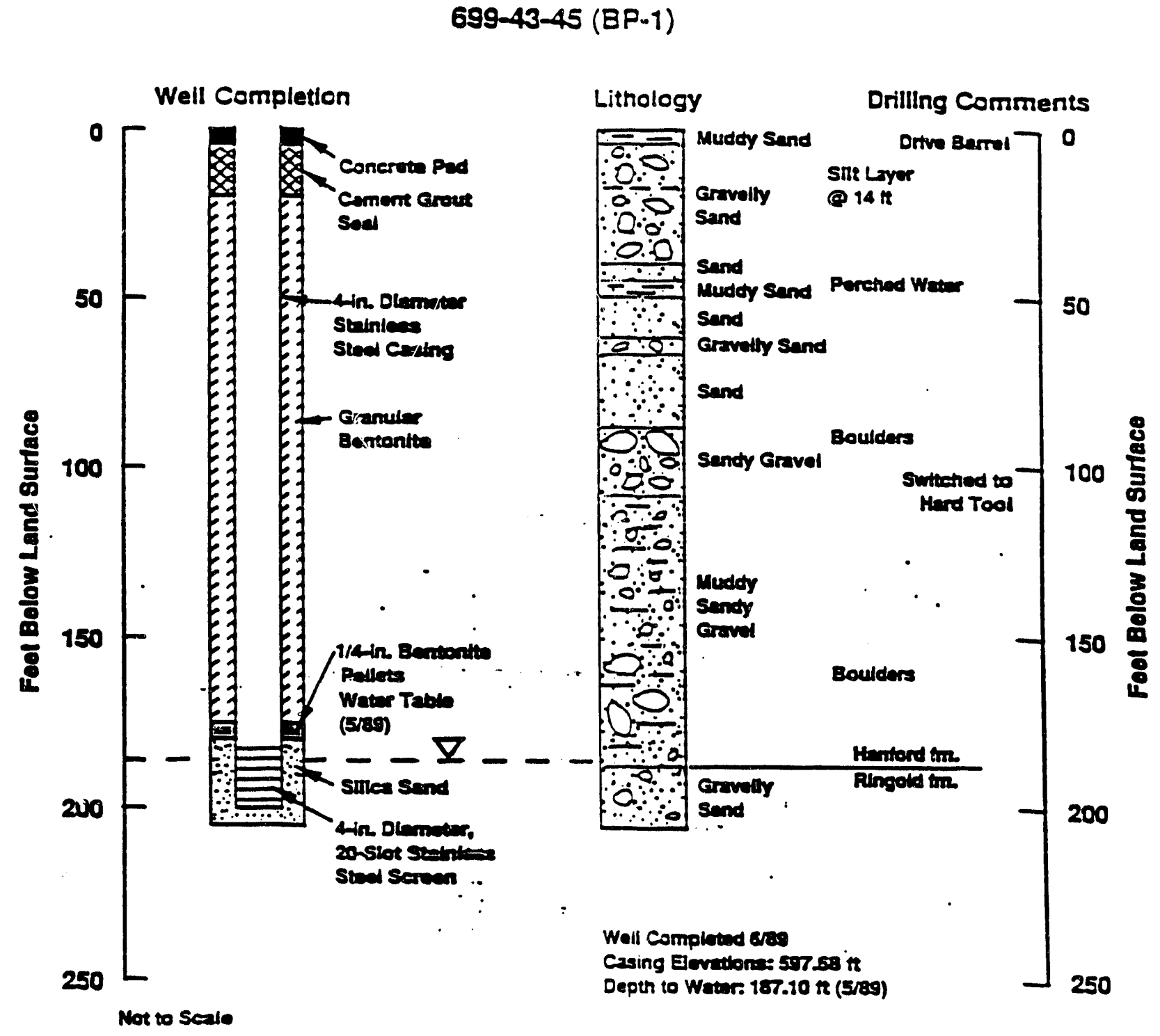

500000214 
DOE/RL 93-61, Rev 0

$12 / 93$

200 East Area W-252 Streams

$699-44-42(B P-3)$

Well Completion

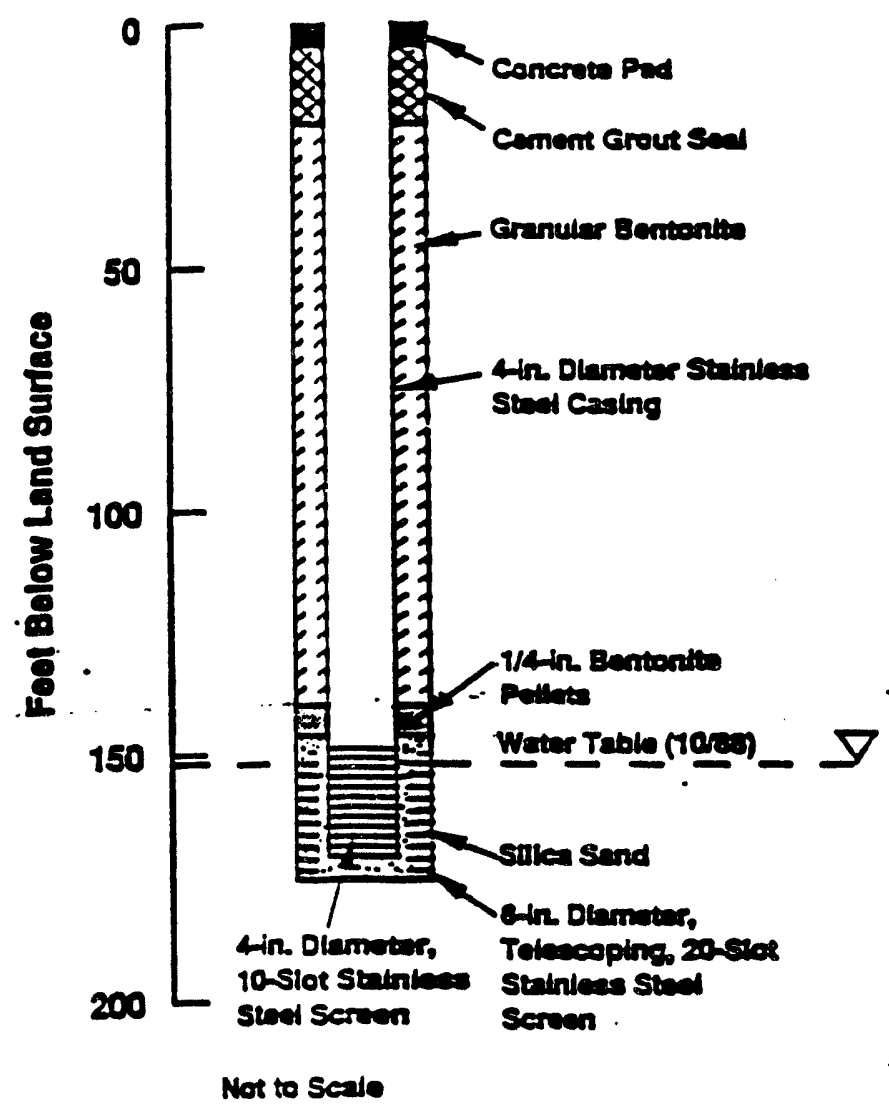

Lithology

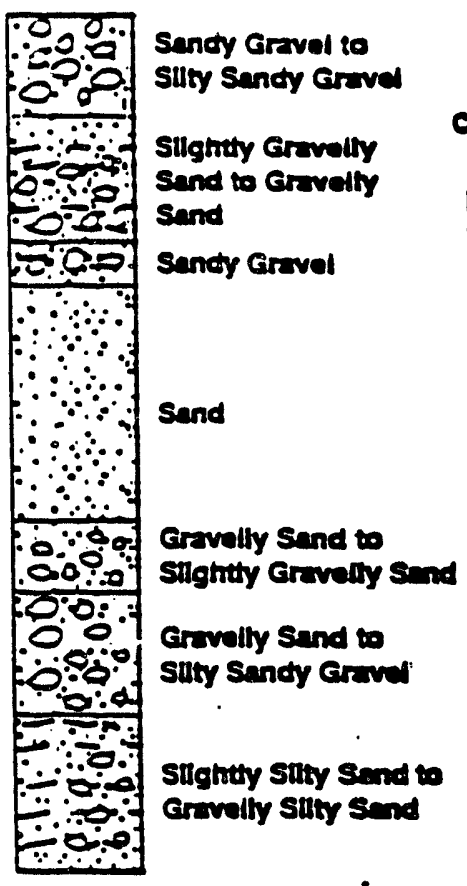

Wall Complated grops

Casing Eovetion: $57922 \mathrm{n}$

Depth to Wetare 1534 it (10rrien)
Drilling Comments

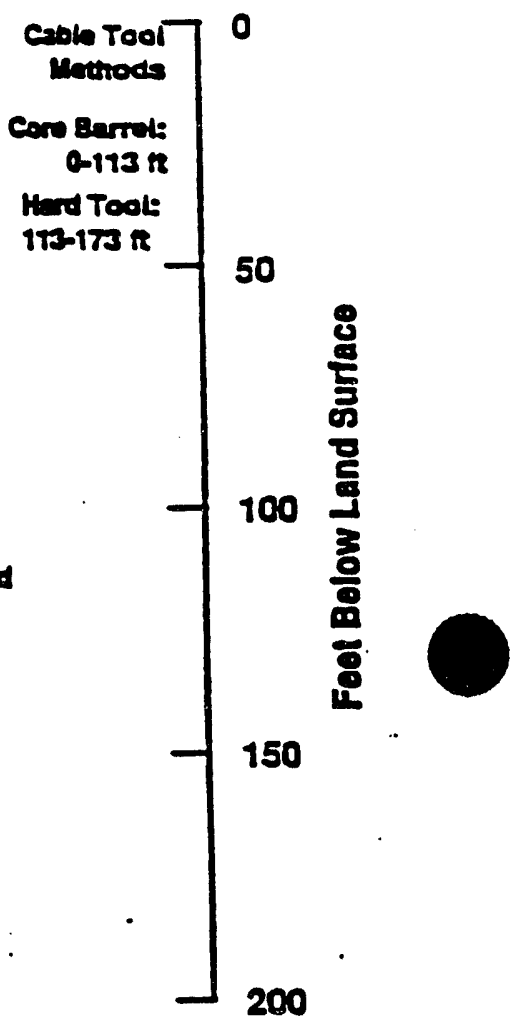

200

790012017 
DOE/RL 93-61, Rev 0

$12 / 93$

200 East Area W-252 Streams

$699-44-43 B(B P-2)$
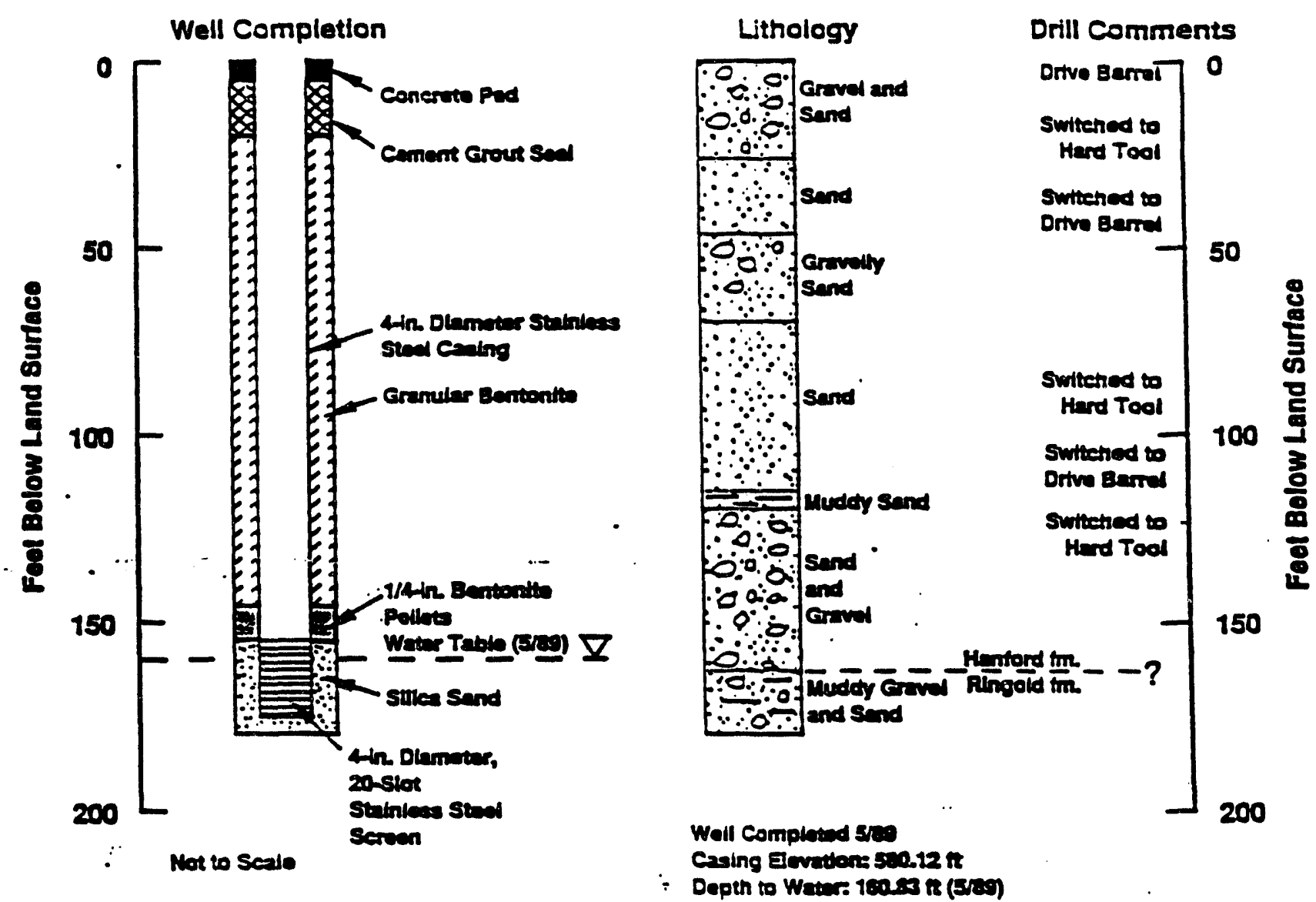

50000024 
DOE/RL 93-61, Rev 0

$12 / 93$

200 East Area W-252 Streams

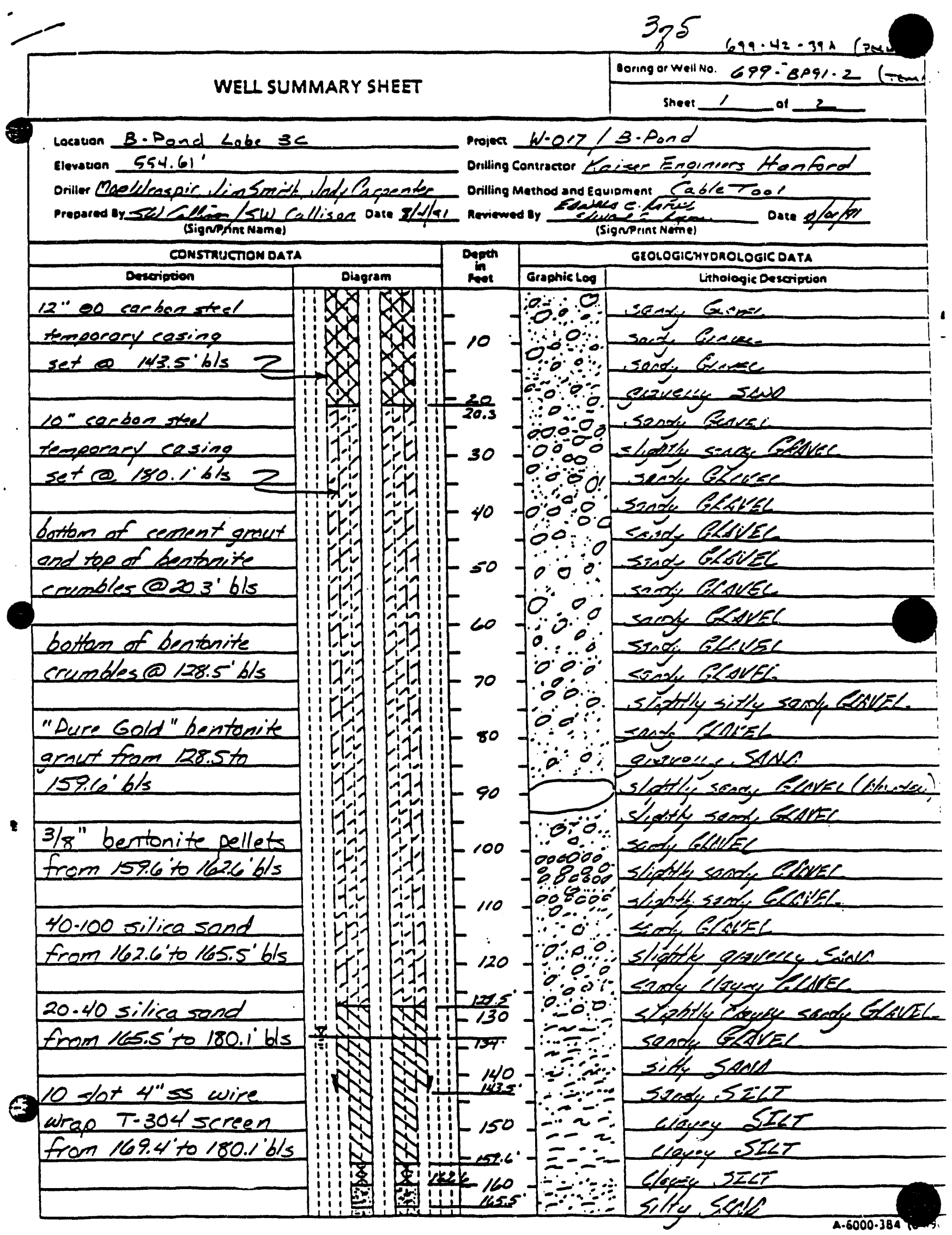




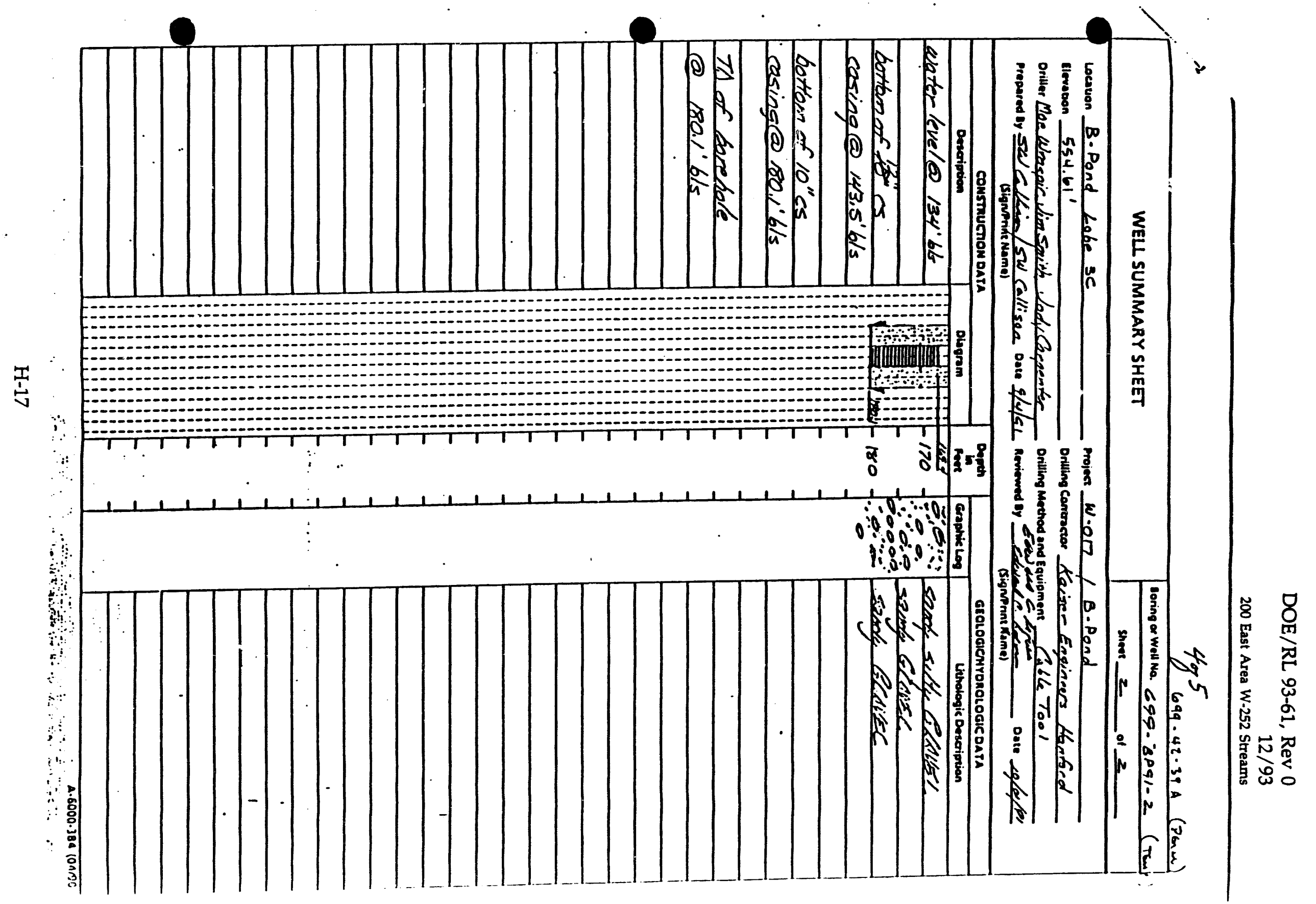


DOE/RL 93-61, Rev 0

$12 / 93$

200 East Area W-252 Streams

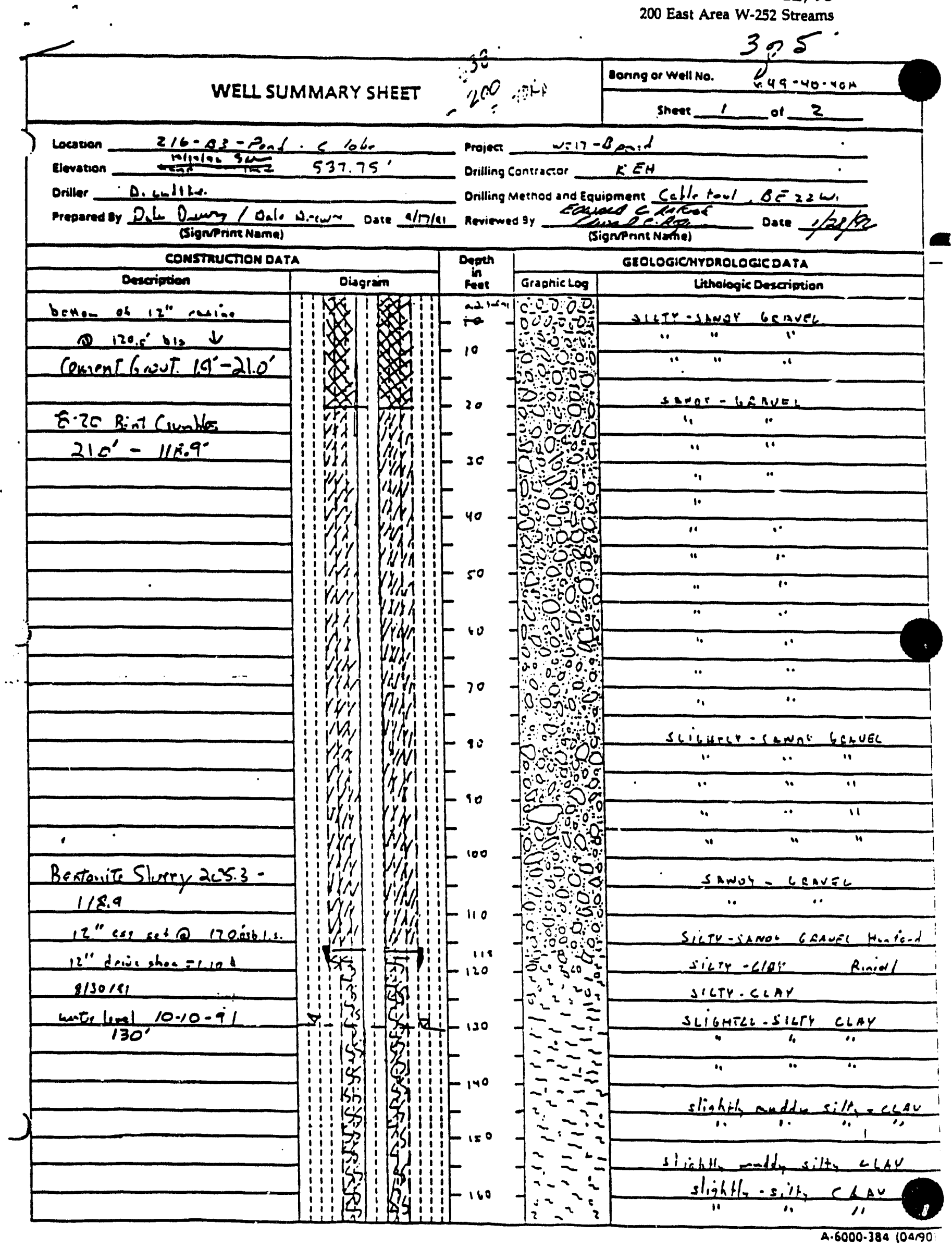

$\mathrm{H}-18$ 
DOE/RL 93-61, Rev 0

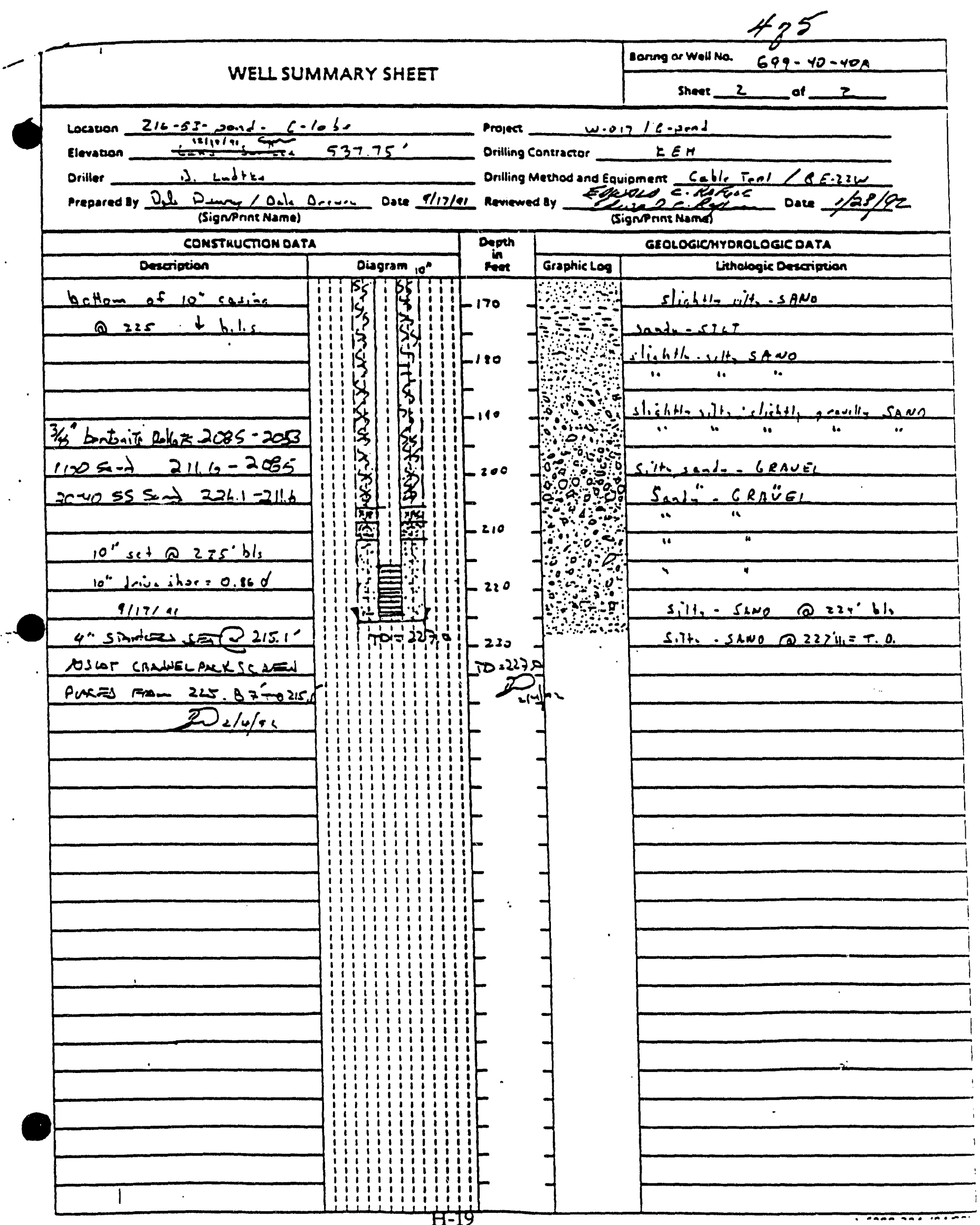




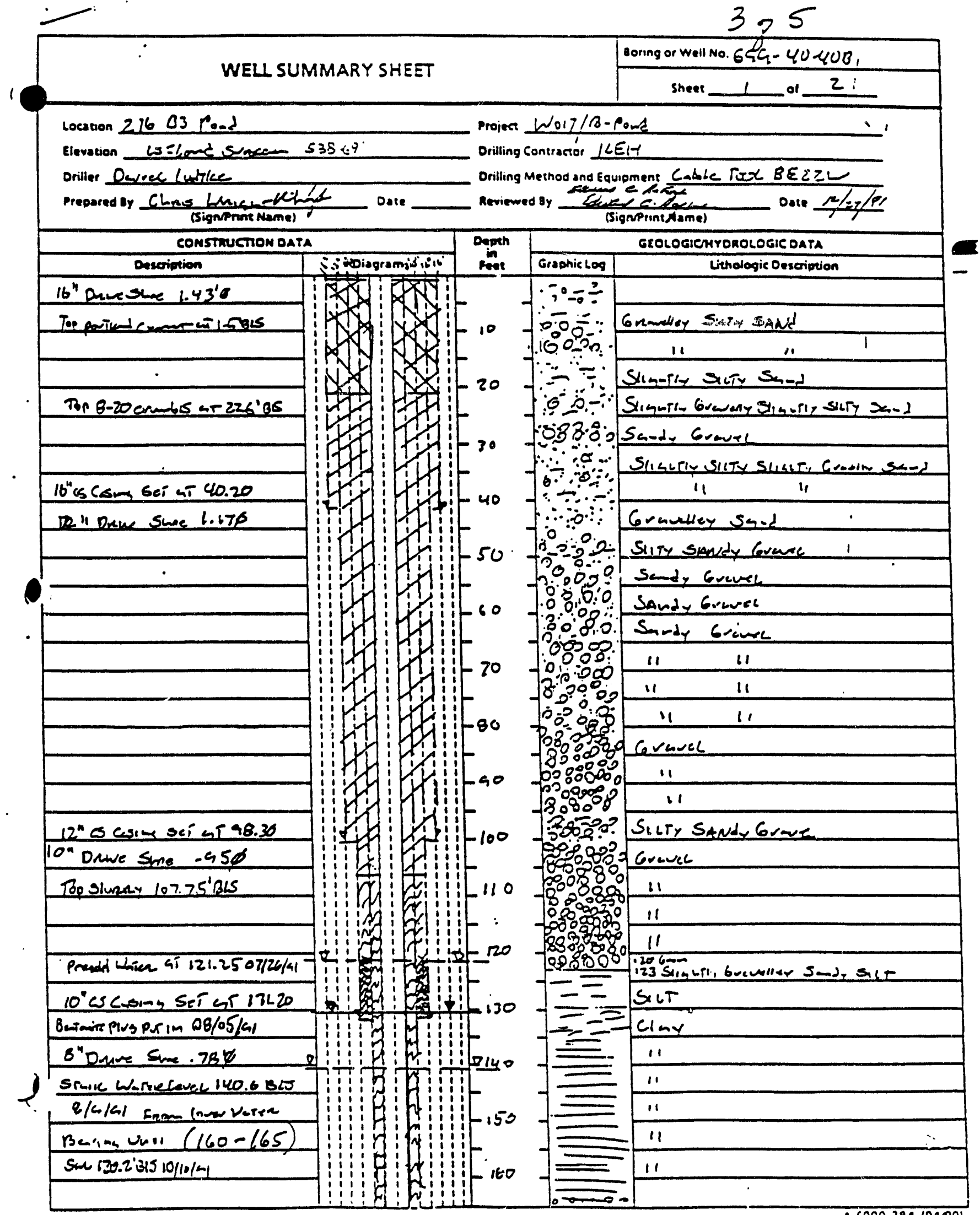


DOE/RL 93-61, Rev 0

$12 / 93$

200 East Area W-252 Streams

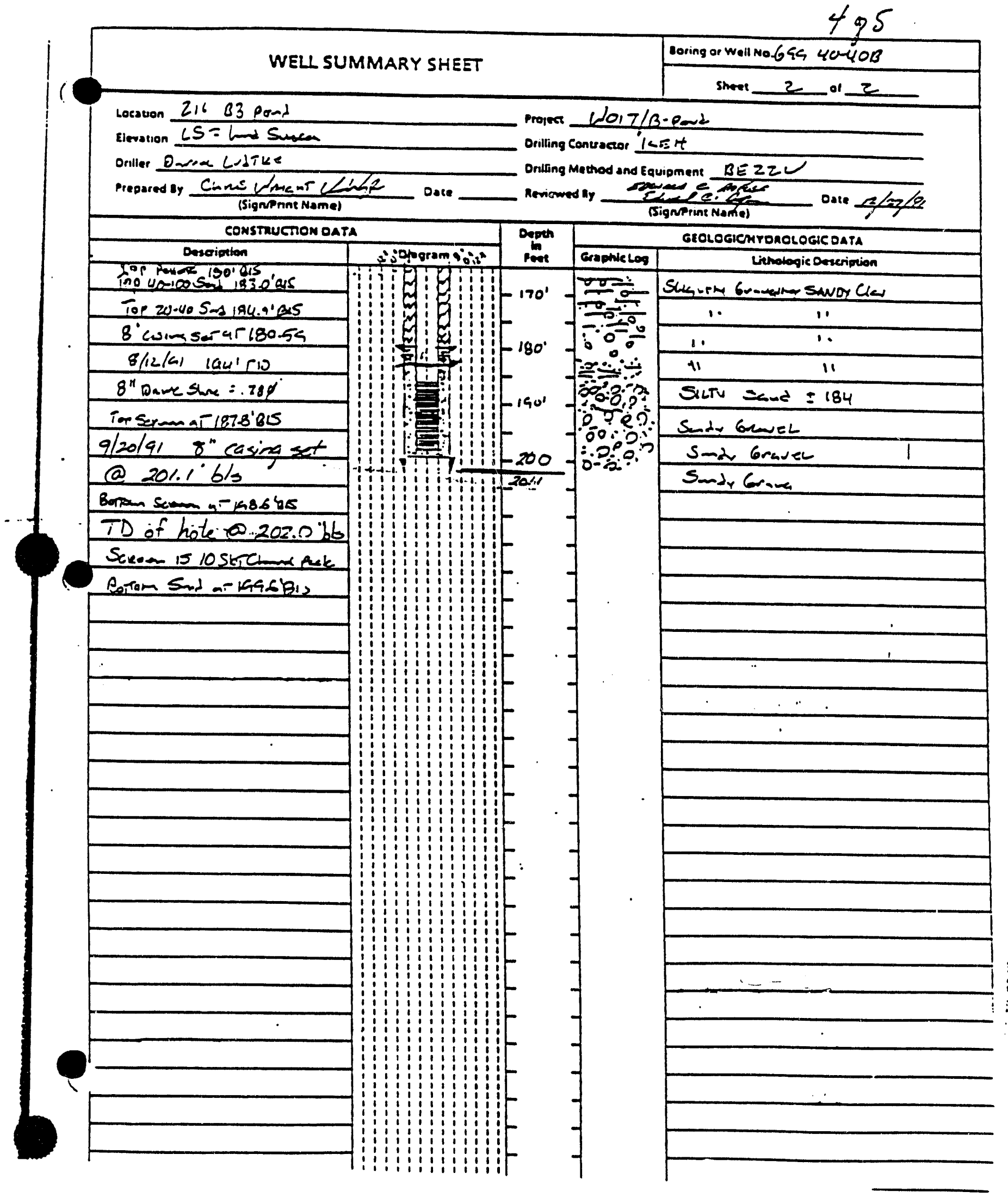

H-21 


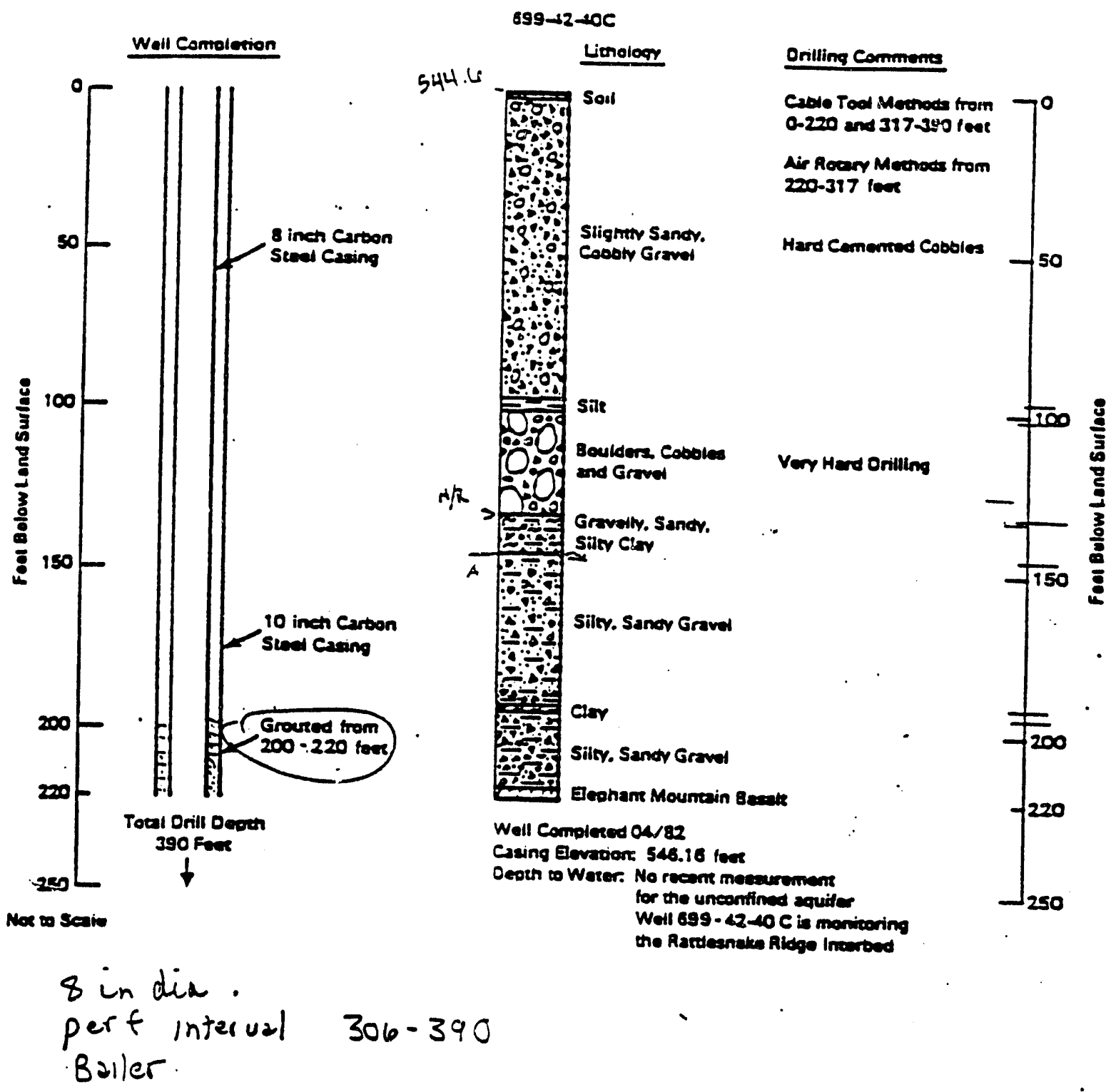


DOE/RL 93-61, Rev 0

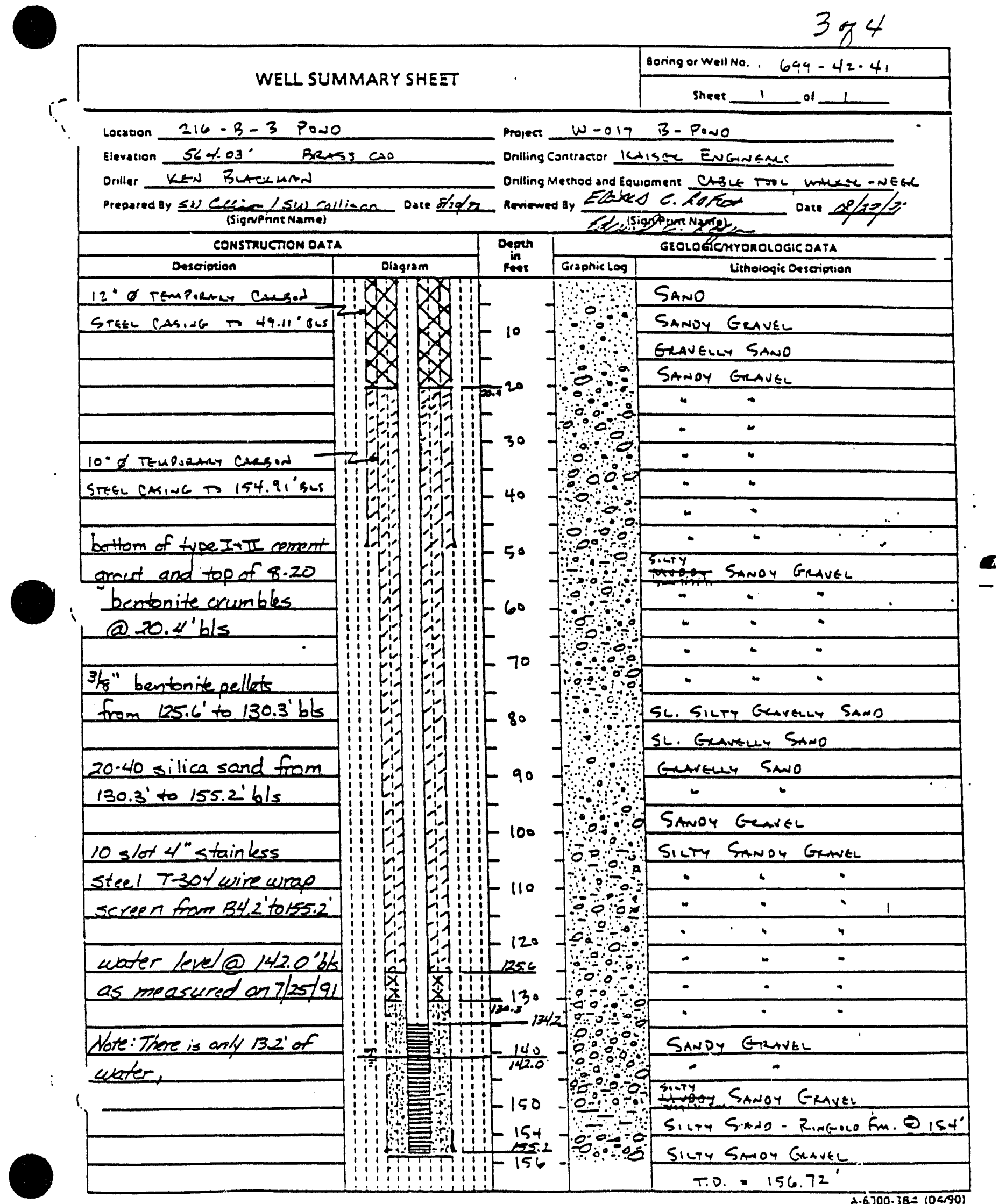




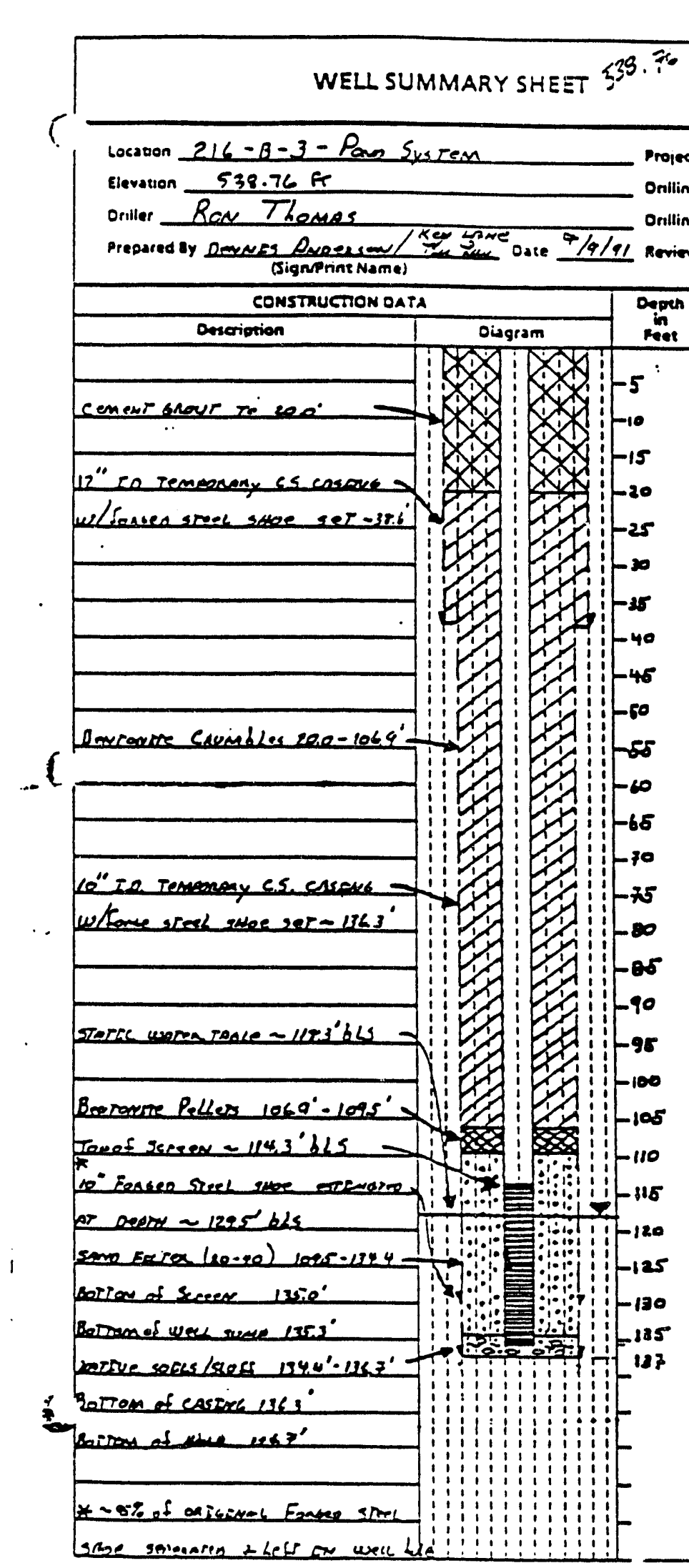

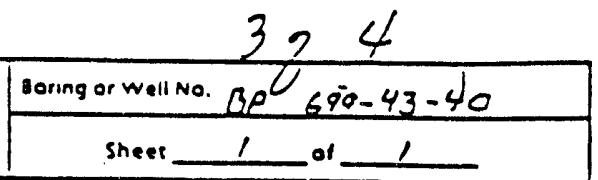 Orlling Mernod and Eaurament carce rool - wouker yeer

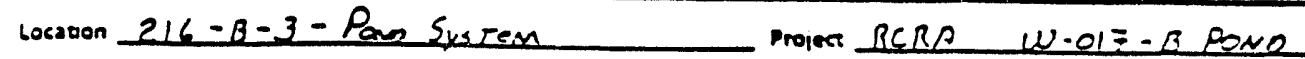
Elevation $538.76 \mathrm{FF}$ Dniling Coneractor KEH oriller Rav Thomes

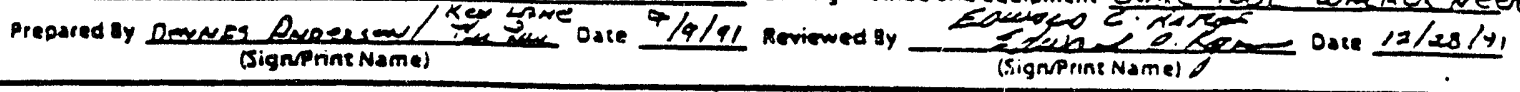

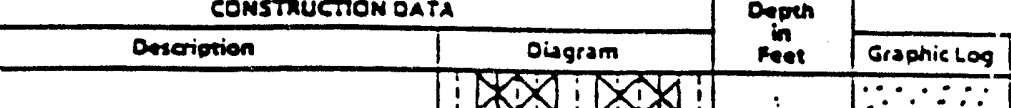
GEOLOGICHYDROLOGICOATA Lithologic Deseriprion fó0:0 sRber canay CRAVEL 10.000. -웅ㅇㅇㅇ. - 0 0.0. -ioo 1.웅. ¿000 100.0 :0.0: 7.0. 00 -0;0; .00 $-0.00$ - 0. 00.0 - $\dot{0} 0$. $0 \cdot \dot{0} 0$ 100 . $.0: 0$ a. 0 : $\because 000$ $0.0 \cdots$ $\because \because 0: 0$ $0.0 \dot{0}$ $\therefore 0.0$ 100 $0,0-0$ 0.0 00. $1: 0$. 10 $\infty_{0.0}$ $\therefore: 0_{0.0}$ 10.0ं0. swimey gavely shar SANO

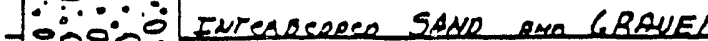

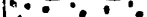
$\because \therefore \circ \circ$ INTER Beaved sero GRAUEL: STenty sanay GRBWEL

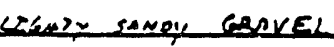
GRQVEI GBDVEL ganvecey son SacoY GROUEL SOXOY GRAVEL Crovel conerer whance sava sevey Grovel sevoy c86 el savey GREVEL SAMAY GRAVEL SMUPY GROVEL Soray GROVEL Sexoy CRRVEL samaY CRAVEL saroy GRQUEL Soony CRAVEL SNOY GROVEL SQNBY CRQUEL SaroY GROUEL 1.

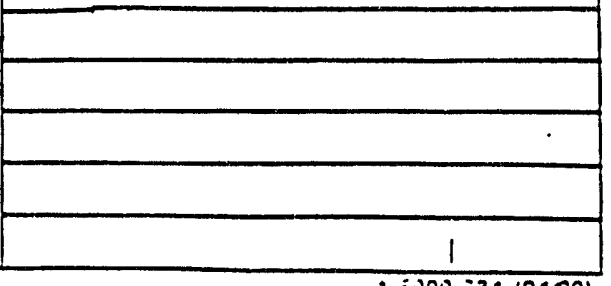


DOE/RL 93-61, Rev 0 $12 / 93$

200 East Area W-252 Streams

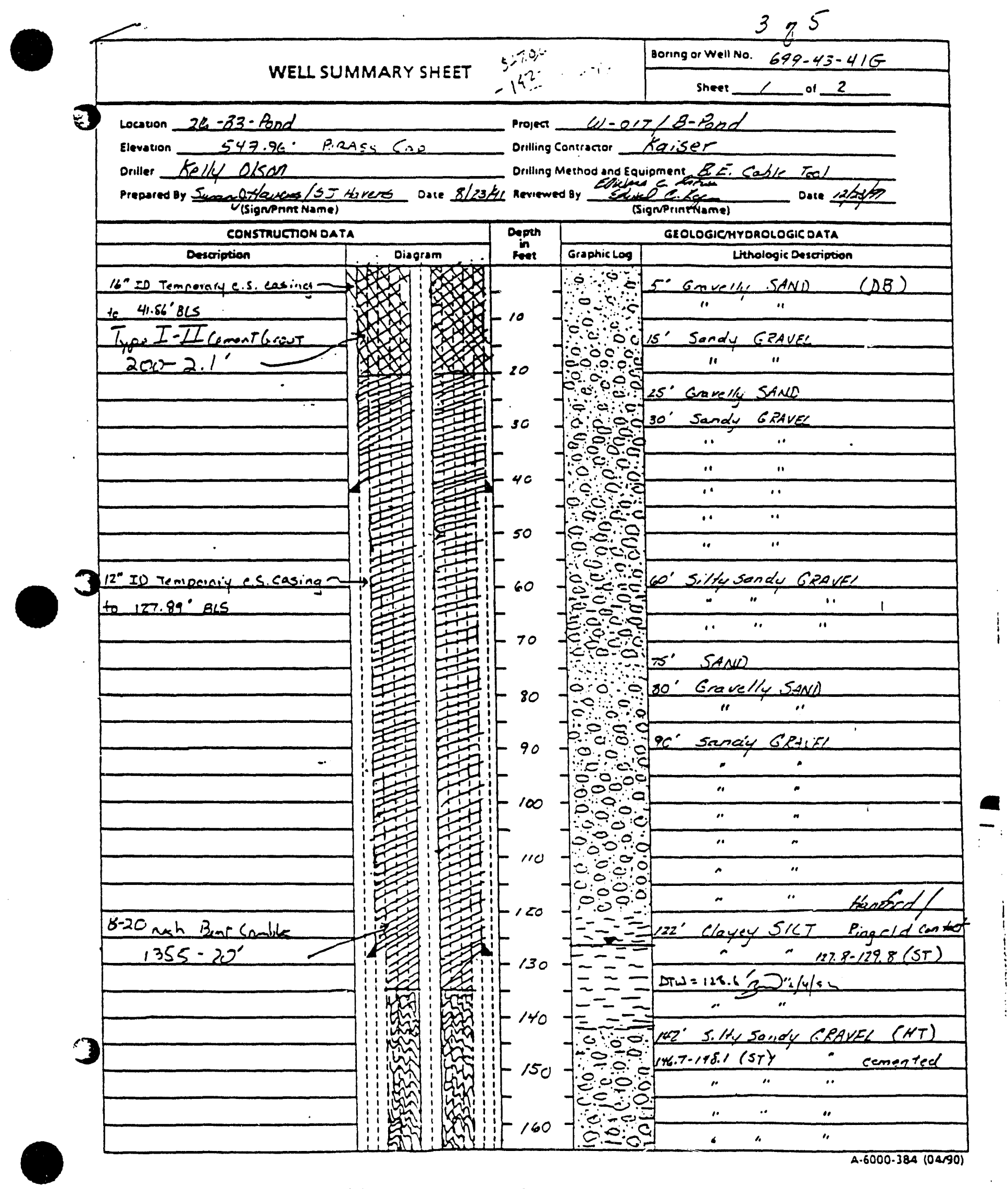


DOE/RL 93-61, Rev 0

$12 / 93$

200 East Area W-252 Streams

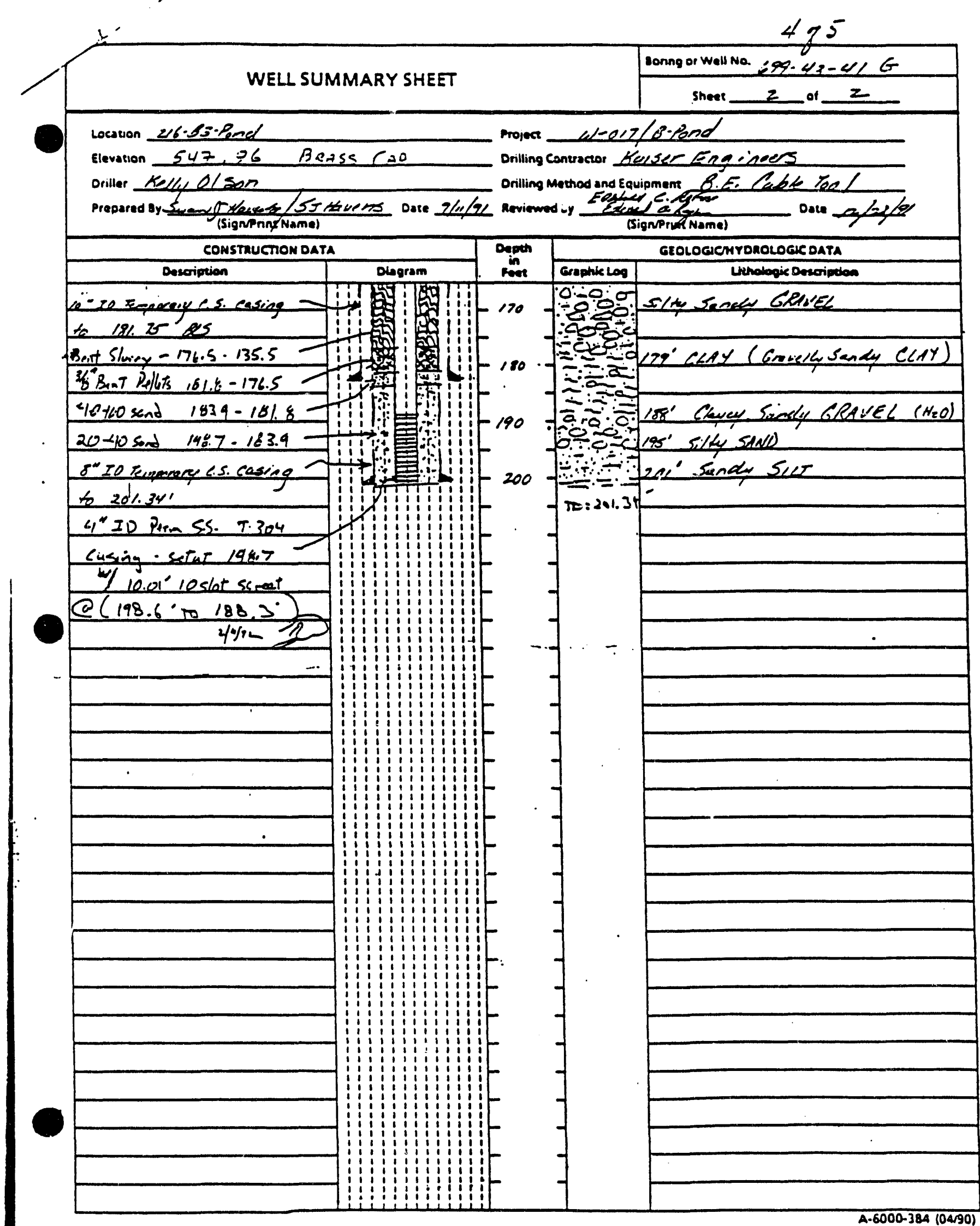




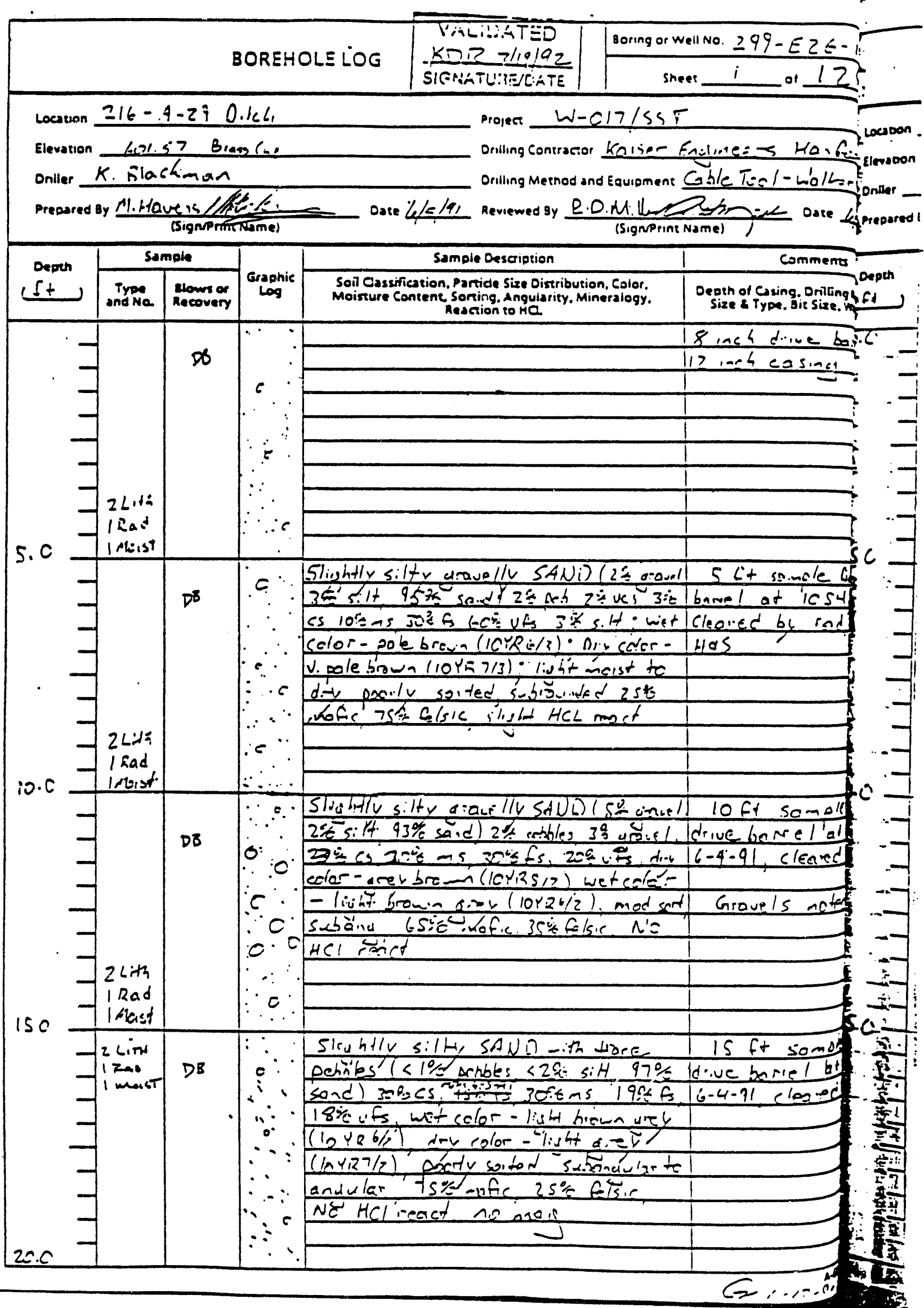


DOE/RL 93-61, Rev 0

$12 / 93$

200 East Area W-252 Streams

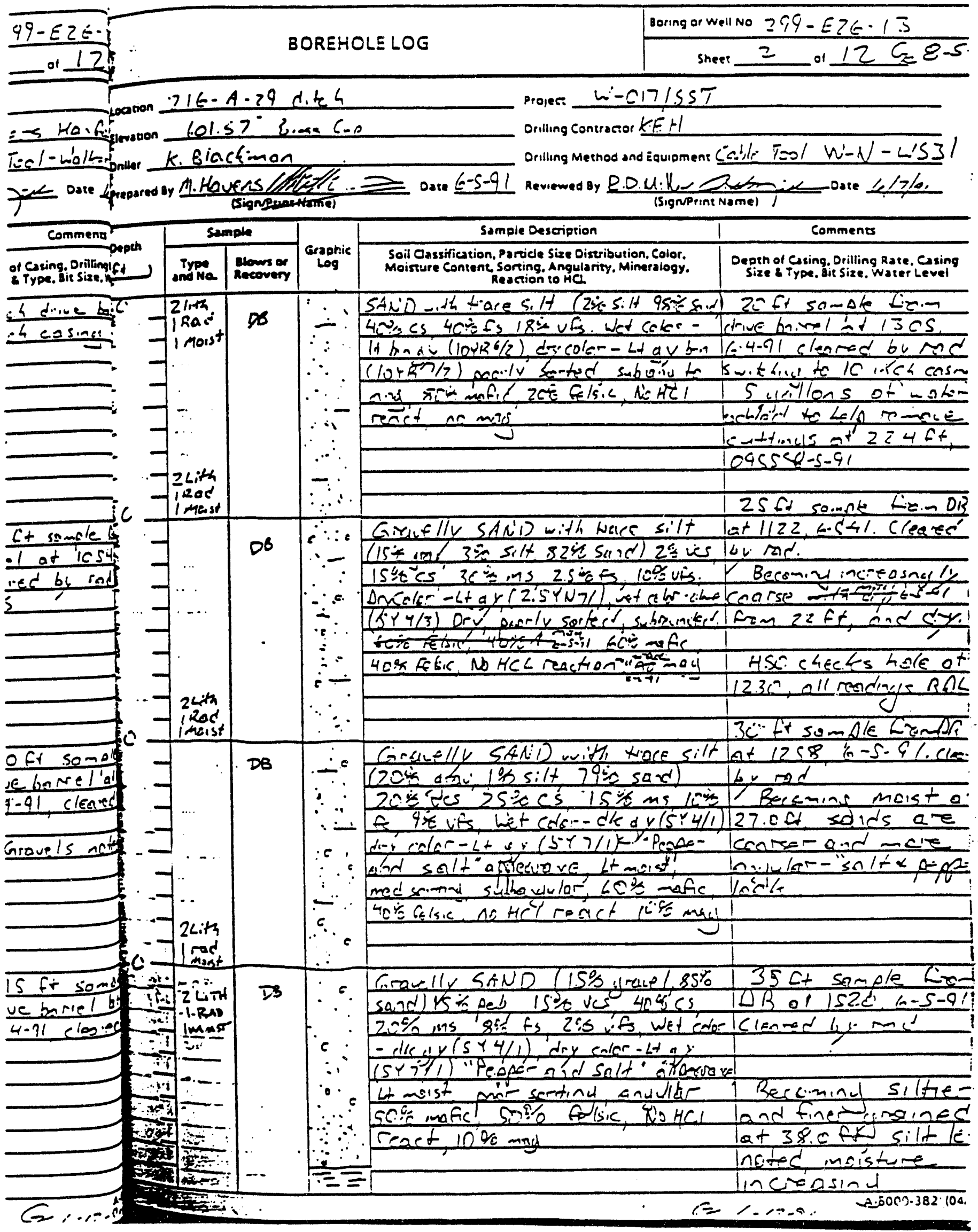


DOE/RL 93-61, Rev 0

$12 / 93$

200 East Area W-252 Streams

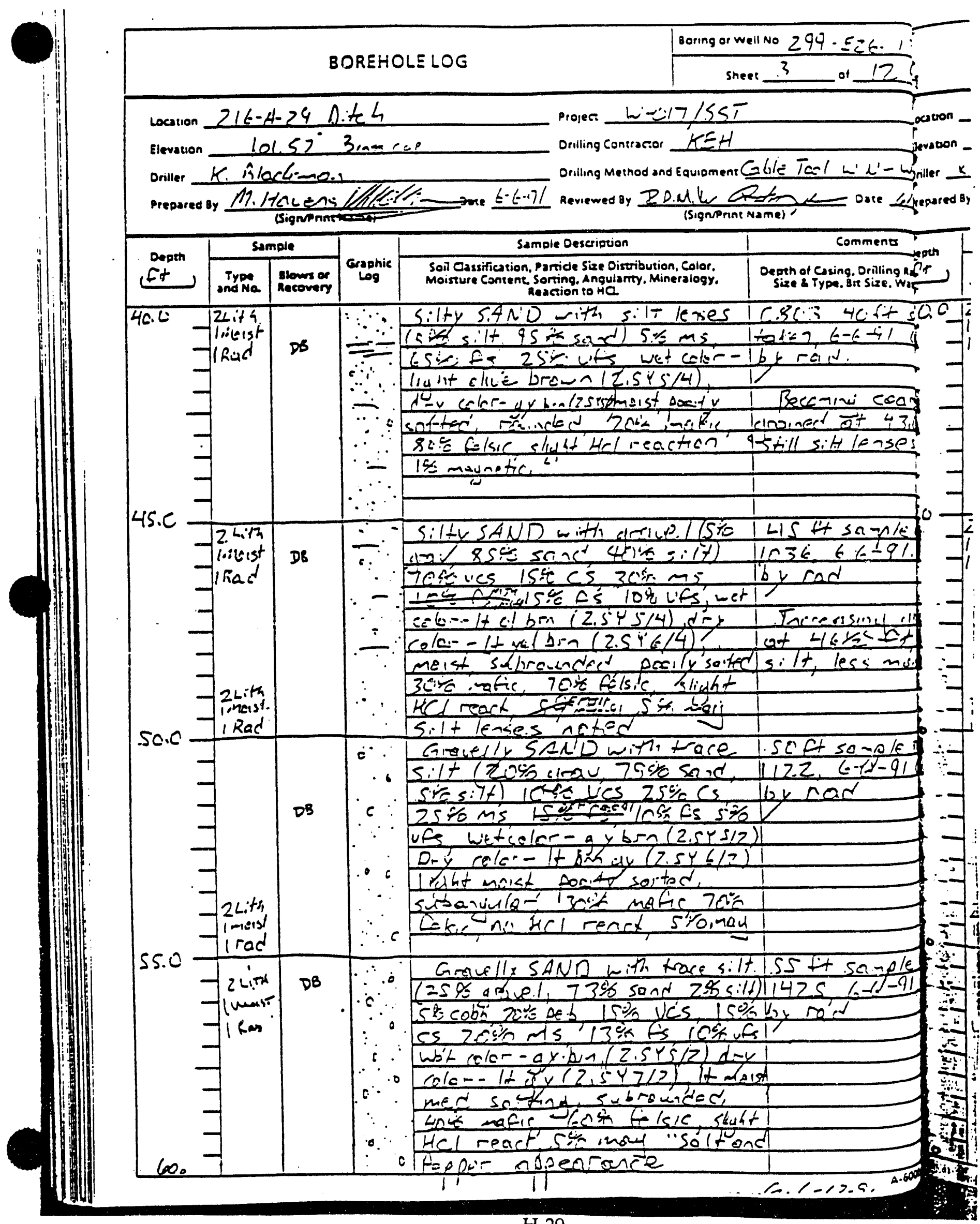


DOE/RL 93. :1, Rev 0

$12 / 93$

200 East Area W-252 Streams

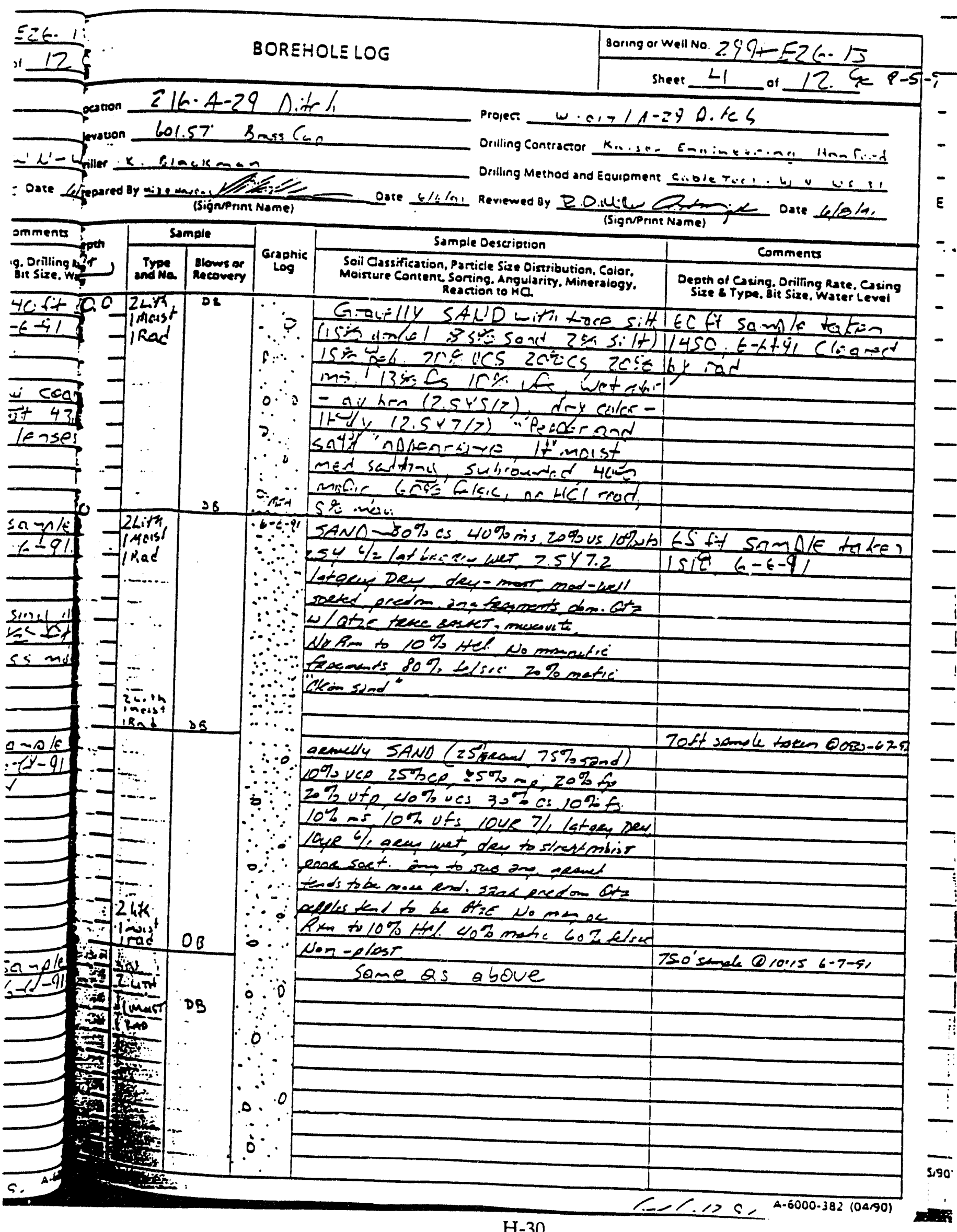


DOE/RL 93-61, Rev 0

$12 / 93$

200 East Area W-252 Streams

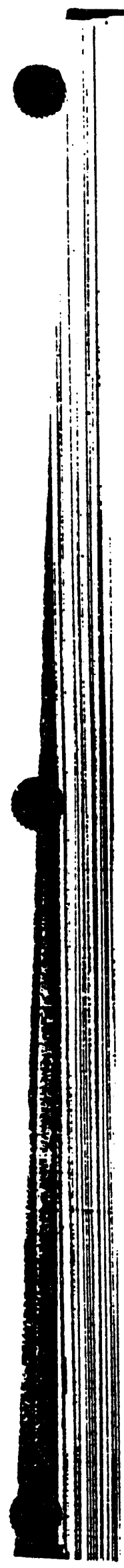

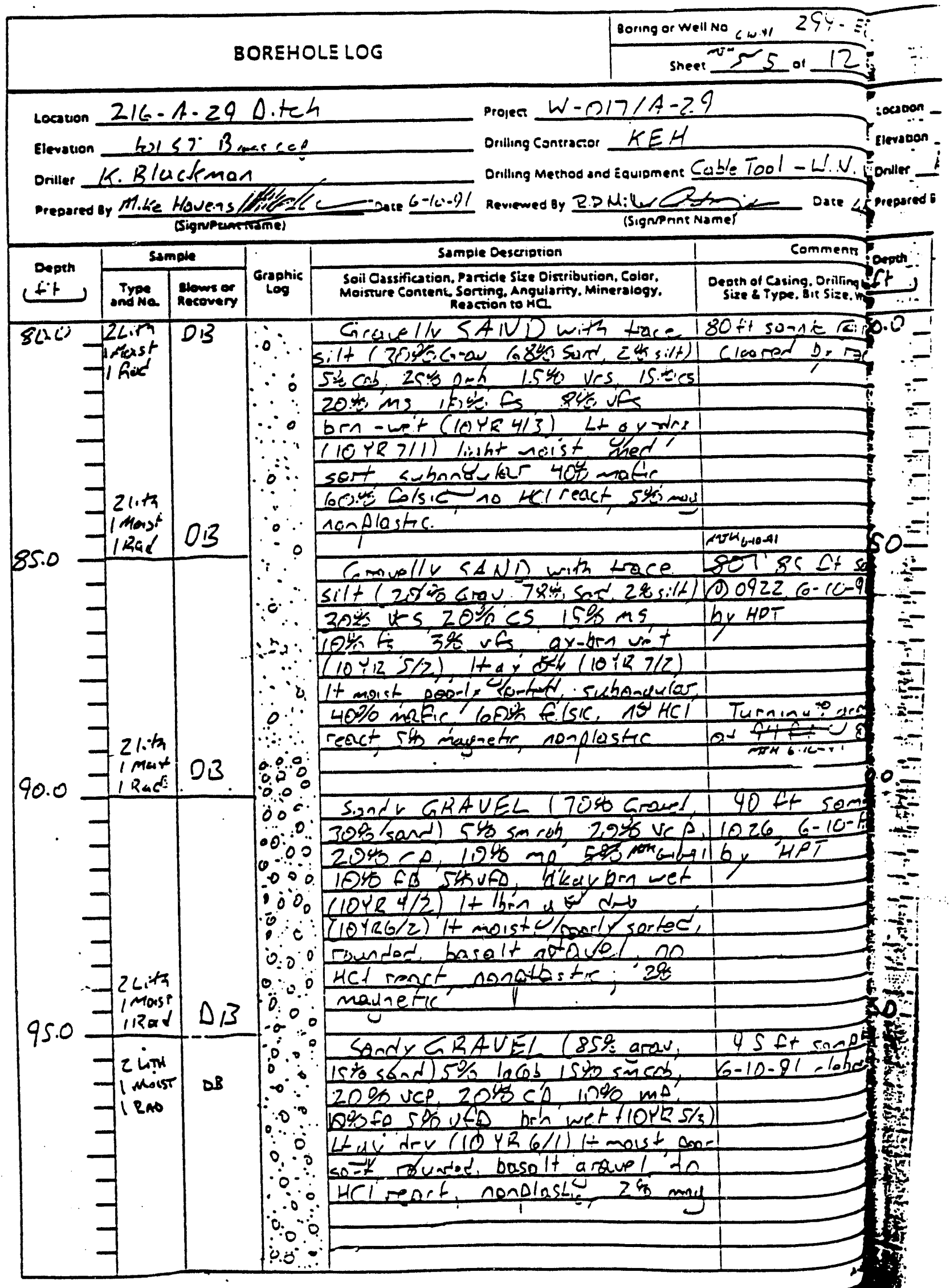




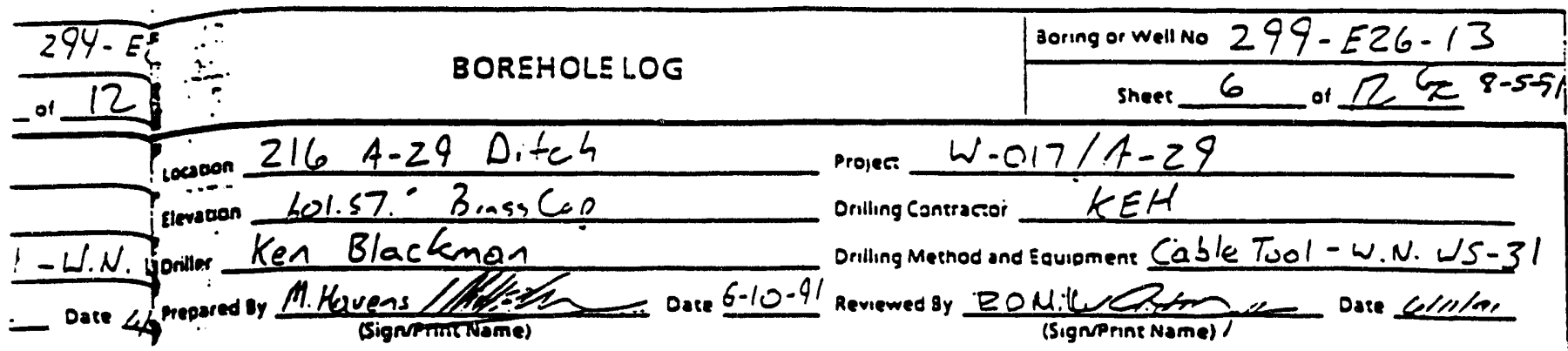

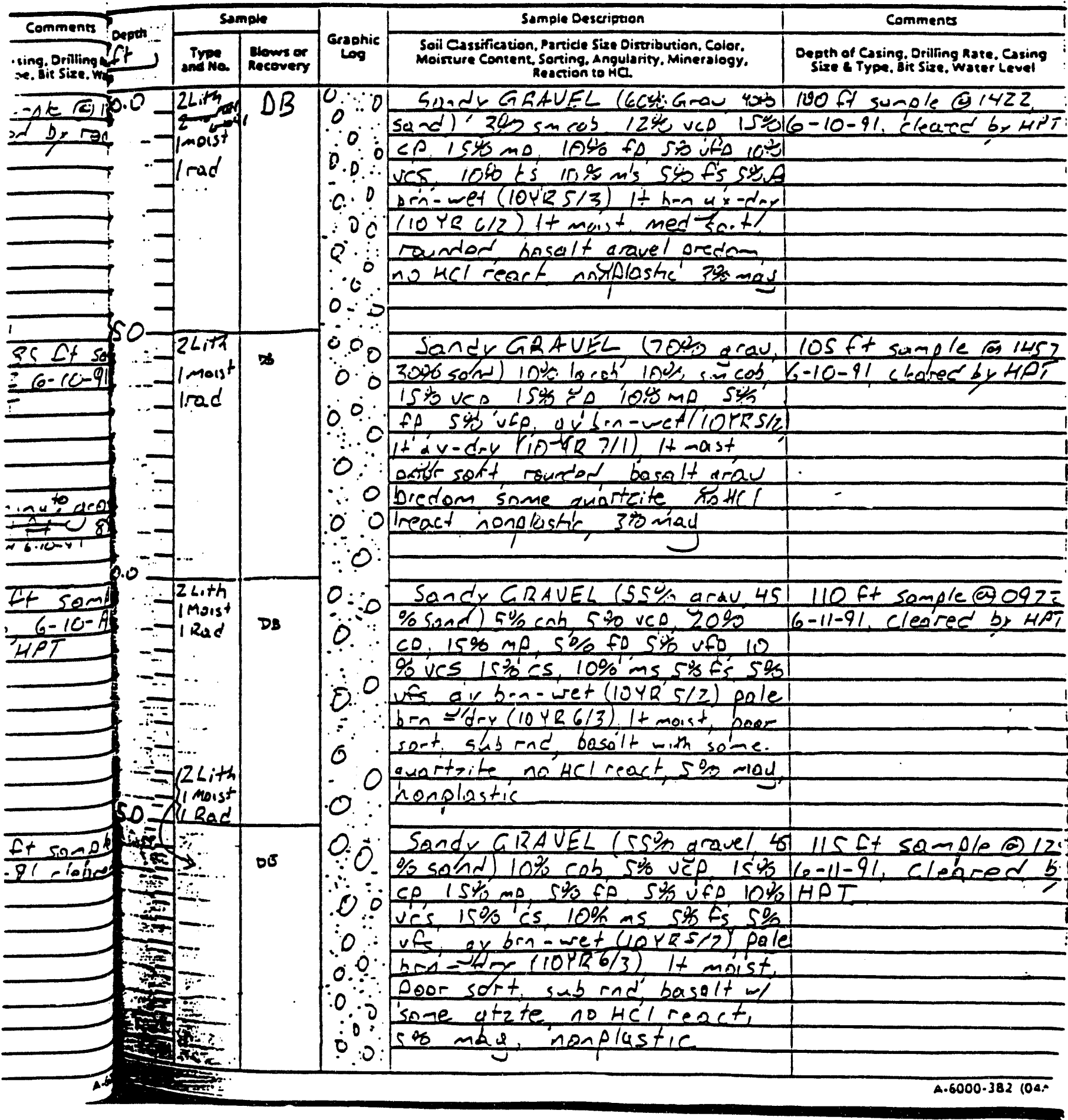




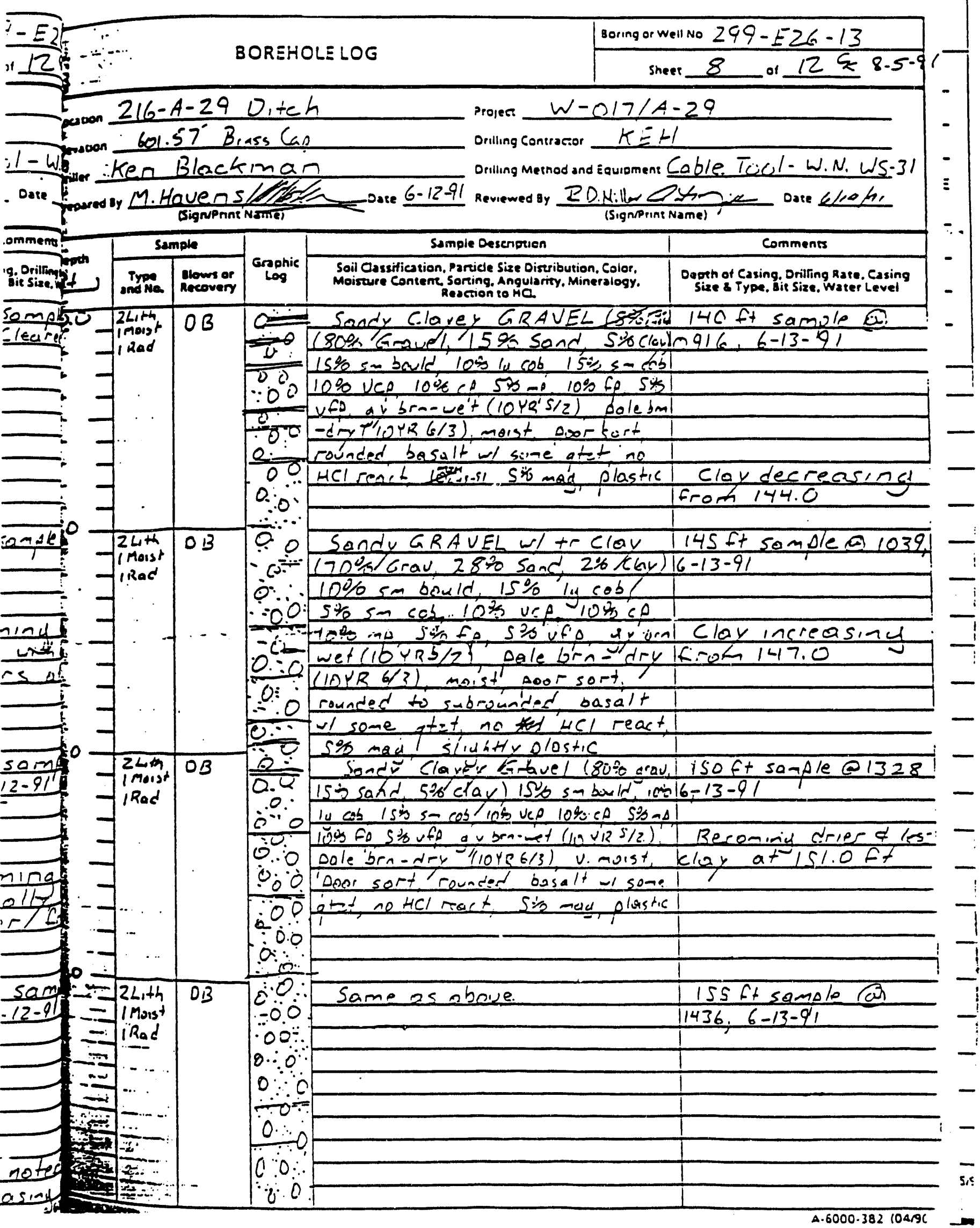


OE/RL 93-61, Rev 0

$12 / 93$

200 East Area W-252 Streams

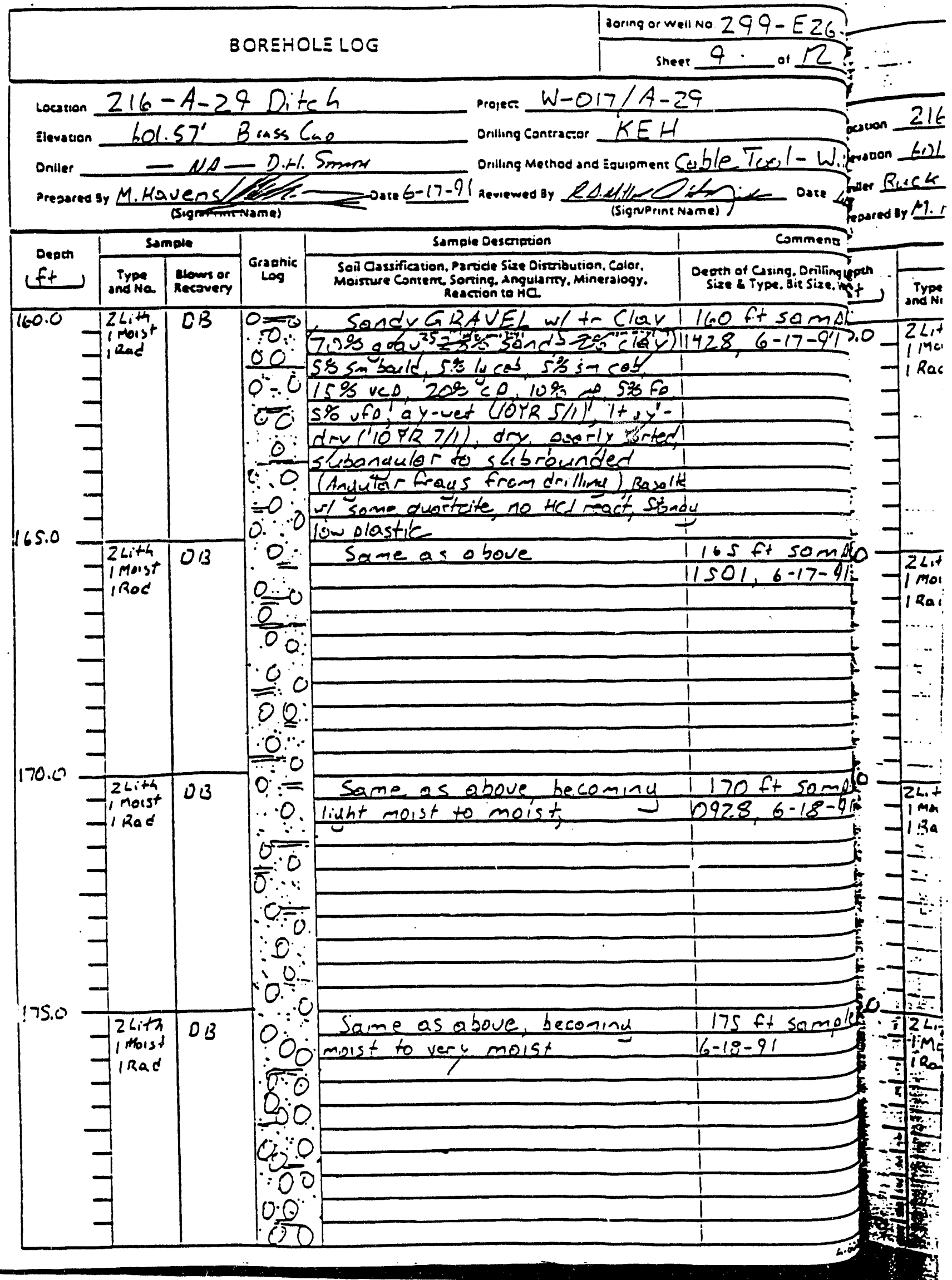




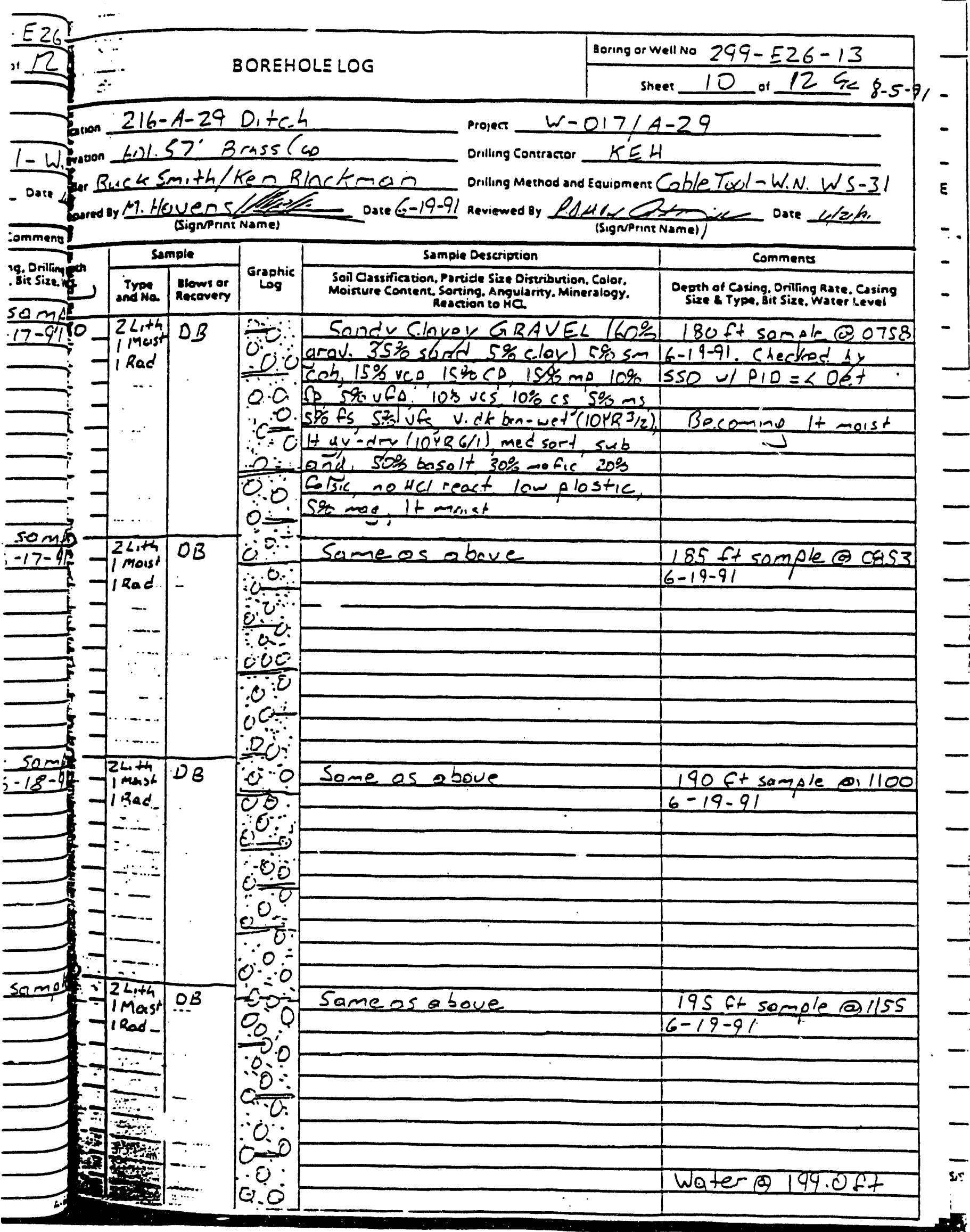


DOE/RL 93-61, Rev 0

$12 / 93$

200 East Area W-252 Streams

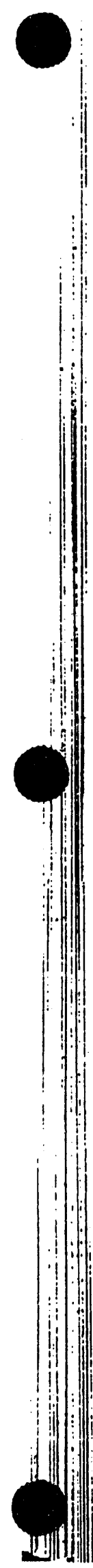

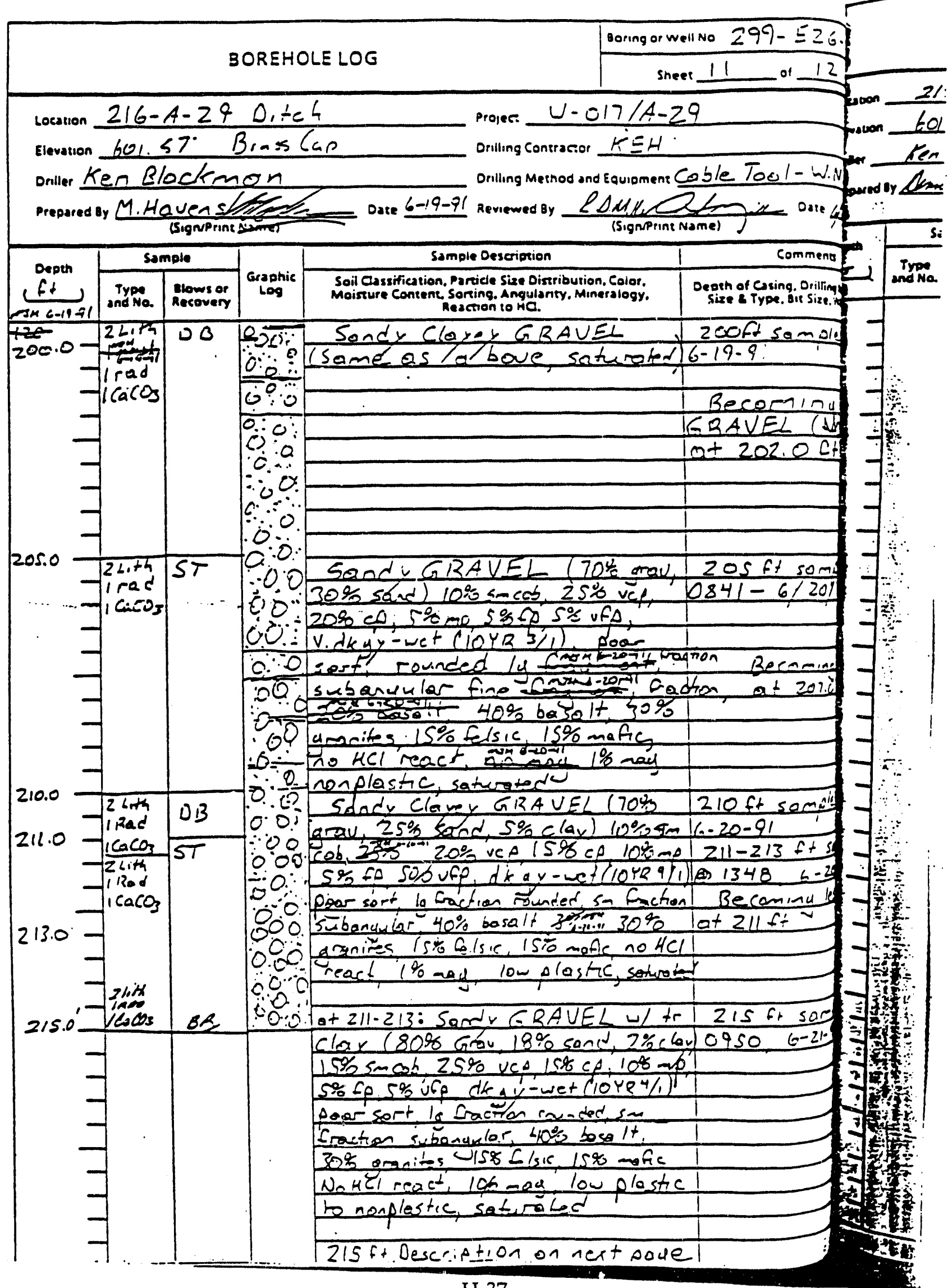



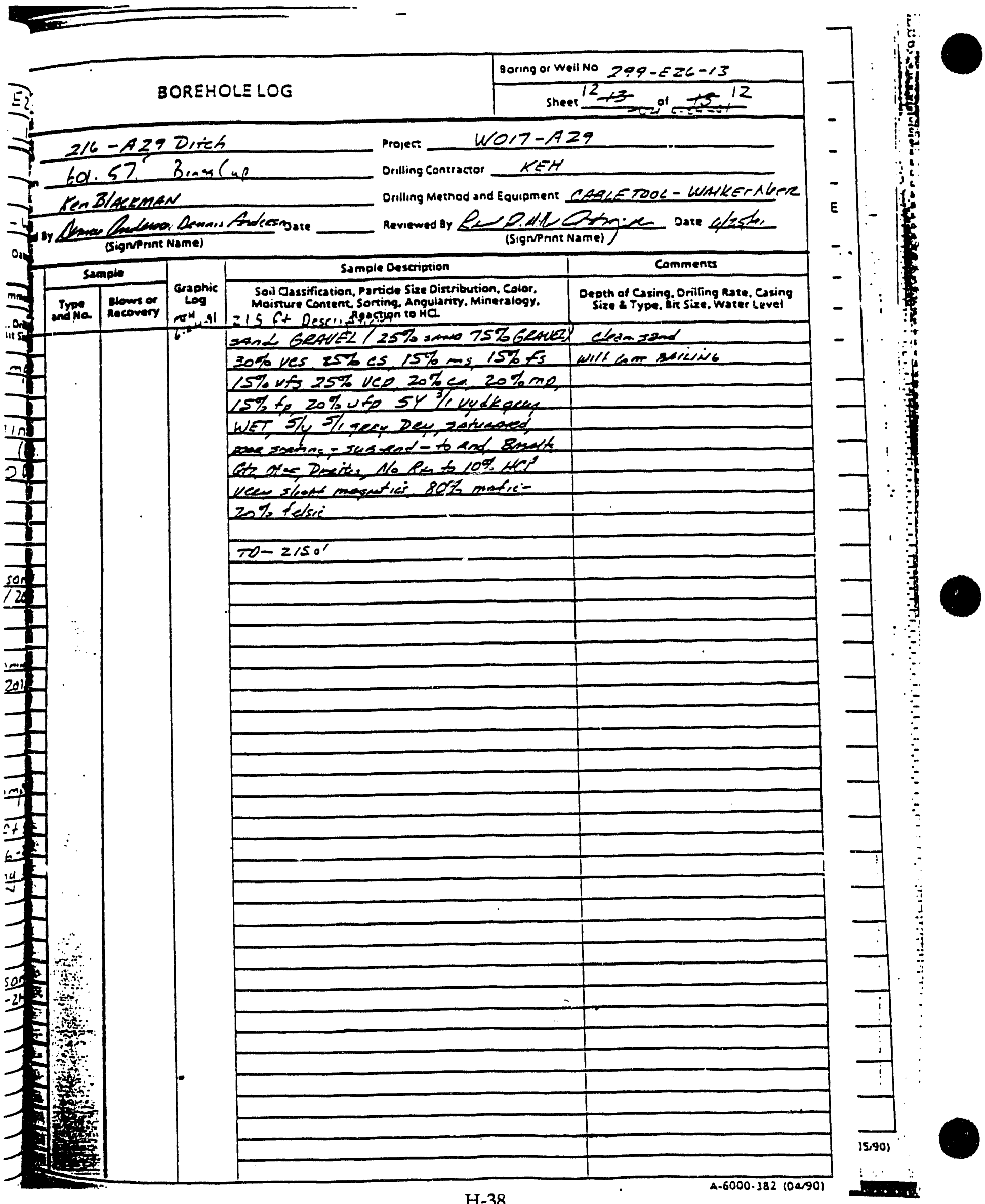
B Pond System water quality data from the latest published quarterly monitoring report entitled Quarterly Report of RCRA Groundwater Monitoring Data for Period October 1, 1992 through December 31, 1992 (DOE-RL 1993) are attached. The following sections, tabler, and figures from DOE-RL (1993) are not reformatted for this permit application. Ars explanation of the tables and figures enclosed is discussed in Section 1.4 on page 1-13 of DOE-RL 1993. Quarterly groundwater monitoring data for previous quarters is also available. 
DOE/RL 93-61, Rev 0

$12 / 93$

200 East Area W-252 Streams

\section{S.l INTRODUCTION}

The 216-B-3 Pond System is located east of the 200 East Area and consists of a main pond, three interconnected lobes for waste water disposal, and several ditches leading to the ponds (Figures 1-1 and 6-1). These surface impoundments cover approximately 41.3 hectares (102 acres). Table 6-1 lists the groundwater wells and their monitoring status.

The 216-8-3 Pond System groundwater monitoring well locations are shown in Figure 6-1. Detection monitoring began at the $B$ Pond System in November 1988 and continued through June 1990, when assessment monitoring was scheduled to begin because of elevated levels of TOX in two downgradient monitoring wells (699-43-41E and 699-43-41F). Assessment monitoring actually began in June 1991 when groundwater sampling on the Hanford Site resumed, following a hiatus, as described in the Groundwater Quality Assessment Plan for the 216-B-3 Pond System (Harris 1990).

Three new downgradient wells; 699-40-36, 699-41-35, and 699-42-37 were added to the 216-8-3 Pond groundwater monitoring network since the last quarterly reporting period. These wells were drilled specifically to evaluate stratigraphy and groundwater quality for the planning stages of the W-049H Treated Effluent Disposal Facility (TEDF) (Davis 1992; Delaney 1993).

\subsection{WATER LEVEL DATA}

Water levels were measured in all wells during the October through December period, as shown in Table 6-2. Some of these measurements are suspected of error because they depart from historical trends or differ significantly from contemporaneous measurements taken in other nearby wells. These measurements were taken as follows: December 15, 1992 and December 16, 1992 in well 299-E18-1; December 15, 1992 in well 699-42-40A; and, December 15, 1992 in well 699-42-42J.

\subsection{WATER CHEMISTRY DATA}

Groundwater samples were scheduled for collection at all B Pond System wells during the October through December 1992 period for analysis of CIPs, drinking water parameters, groundwater quality parameters, site-specific parameters, and assessment monitoring parameters in accordance with Harris (1990). All wells scheduled for this quarter's sampling were sampled in October, except the new wells in the W-049H Facility $(699-40-36,699-41-35$, and 699-42-37) and well 299-E18-1, all of which were sampled in December. Analytical results from $B$ Pond wells unavailable as of the writing of this report will be reported in future quarterly reports. 

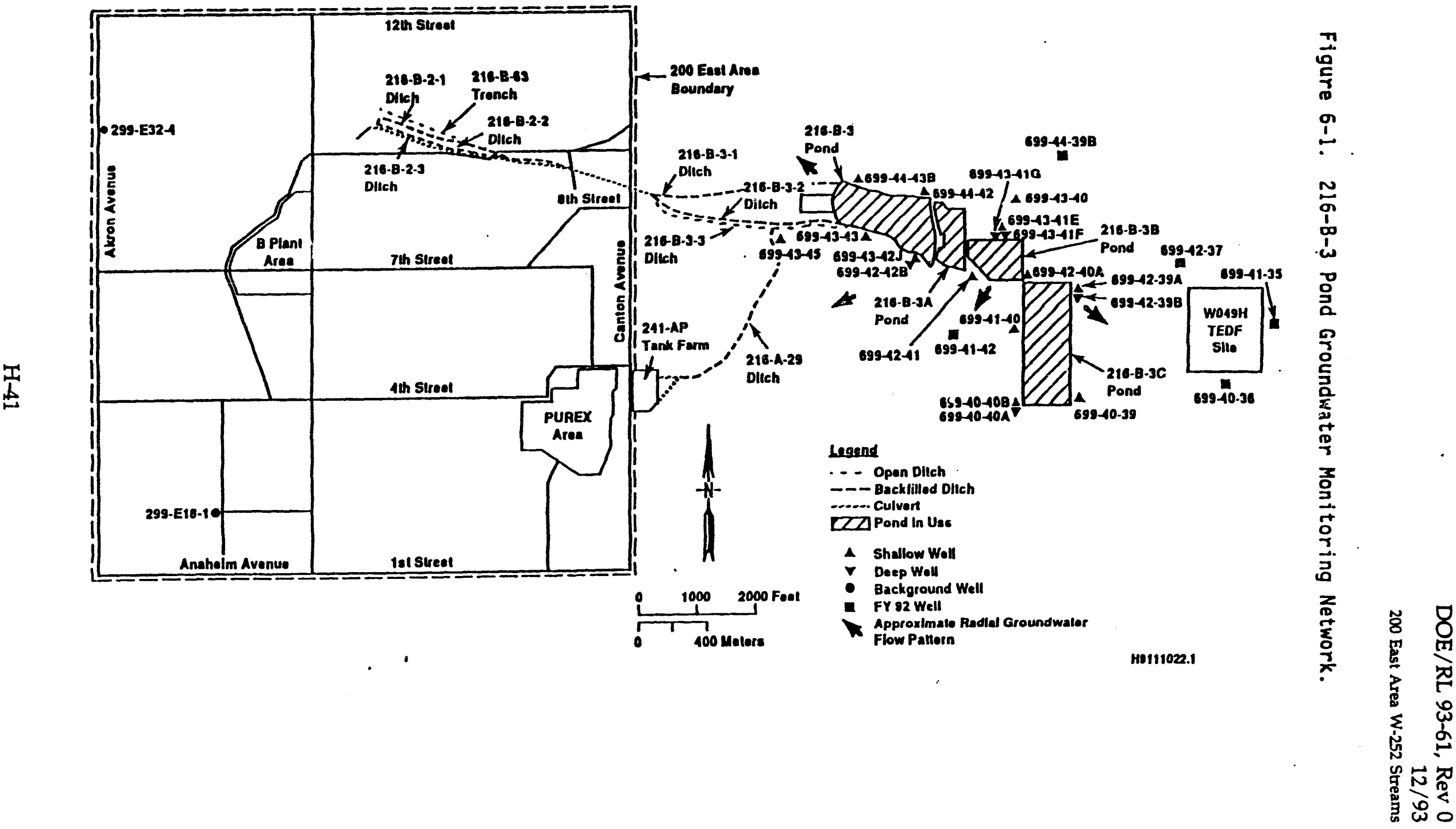
DOE/RL 93-61, Rev 0 $12 / 93$

200 East Area W-252 Streams

Table 6-1. Monitoring Well Purpose and Sampling Schedule for the 216-B-3 Pond System Network. (sheet 1 of 2)

\begin{tabular}{|c|c|c|c|c|}
\hline Well no. & $\begin{array}{l}\text { Relative } \\
\text { position }\end{array}$ & $\begin{array}{c}\text { Hydrogeologic } \\
\text { unit }\end{array}$ & $\begin{array}{l}\text { Sampling } \\
\text { frequency }\end{array}$ & $\begin{array}{l}\text { Sample date: } \\
\text { 4th Qtr } 1992 \\
\end{array}$ \\
\hline 299-E18-1 & Upgradient & Hanford: Water Table & Semiannually & $12 / 16 / 92$ \\
\hline 299-E32-4 & Upgradient & Hanford: Water Table & Semiannually & not scheduled \\
\hline $699-40-39$ & Downgradient & $\begin{array}{l}\text { Ringold: Upper } \\
\text { Semiconfined }\end{array}$ & Quarterly & $10 / 20 / 92$ \\
\hline $699-40-40 A$ & Downgradient & $\begin{array}{l}\text { Ringold: Lower } \\
\text { Semiconfined }\end{array}$ & Quarterly & $10 / 21 / 92$ \\
\hline $699-40-40 B$ & Downgradient & $\begin{array}{l}\text { Ringold: Upper } \\
\text { Semiconfined }\end{array}$ & Quarteriy & $10 / 21 / 92$ \\
\hline $699-41-40$ & Downgradient & $\begin{array}{l}\text { Ringold: Upper } \\
\text { Semiconfined }\end{array}$ & Quarteriy & $10 / 20 / 92$ \\
\hline $699-42-39 A$ & Downgradient & $\begin{array}{l}\text { Ringold: Upper } \\
\text { Semiconfined }\end{array}$ & Quarterly & $10 / 21 / 92$ \\
\hline $699-42-39 B$ & Downgradient & $\begin{array}{l}\text { Ringold: Lower } \\
\text { Semiconfined }\end{array}$ & Quarterly & $10 / 20 / 92$ \\
\hline $699-42-40 A$ & Downgradient & $\begin{array}{l}\text { Ringold: Upper } \\
\text { Semiconfined }\end{array}$ & Semiannually & not scheduled \\
\hline $699-42-41$ & Downgradient & Ringold: Water Table & Quarterly & $10 / 22 / 92$ \\
\hline $699-42-42 B$ & Downgradient & $\begin{array}{l}\text { Ringold: Lower } \\
\text { Unconfined }\end{array}$ & Semiannually & $10 / 20 / 92$ \\
\hline $699-43-40$ & Downgradient & Ringold: Water Table & Quarterly & $10 / 22 / 92$ \\
\hline $699-43-41 E$ & Downgradient & $\begin{array}{l}\text { Ringold: Upper } \\
\text { Semiconfined }\end{array}$ & Quarterly & $10 / 20 / 92$ \\
\hline $699-43-41 F$ & Downgradient & $\begin{array}{l}\text { Ringold: Lower } \\
\text { Semiconfined }\end{array}$ & Quarterly & $10 / 21 / 92$ \\
\hline $699-43-41 G$ & Downgradient & $\begin{array}{l}\text { Ringold: Bottom of } \\
\text { Semiconfined }\end{array}$ & Quarterly & $10 / 28 / 92$ \\
\hline $699-43-42 J$ & Downgradient & Ringold: Water Table & Semiannually & $10 / 22 / 92$ \\
\hline $699-43-43$ & Downgradient & Ringold: Water Table & Semiannually & $10 / 26 / 92$ \\
\hline $699-43-45$ & Downgradient & Ringold: Water Table & Quarterly & $10 / 26 / 92$ \\
\hline $699-44-42$ & Downgradient & Ringold: Water Table & Semiannualiy & $10 / 22 / 92$ \\
\hline $699-40-36^{1}$ & Downgradient & $\begin{array}{l}\text { Ringold: Top of } \\
\text { Confined }\end{array}$ & Quarterly & $12 / 21 / 92$ \\
\hline
\end{tabular}


DOE/RL 93-61, Rev 0

Table 6-1. Monitoring Well Purpose and Sampling Schedule for the 216-B-3 Pond System Network. (sheet 2 of 2)

\begin{tabular}{|c|c|c|c|c|}
\hline Well no, & $\begin{array}{c}\text { Relative } \\
\text { position }\end{array}$ & $\begin{array}{c}\text { Hydrogeologic } \\
\text { unit }\end{array}$ & $\begin{array}{c}\text { Sampling } \\
\text { frequency }\end{array}$ & $\begin{array}{c}\text { Sample date: } \\
\text { 4th Otr 1992 }\end{array}$ \\
\hline $699-41-35^{1}$ & Downgradient & $\begin{array}{c}\text { Ringold: Top of } \\
\text { Confined }\end{array}$ & Quarterly & $12 / 21 / 92$ \\
\hline $699-42-37^{1}$ & Downgradient & $\begin{array}{c}\text { Ringold: Top of } \\
\text { Confined }\end{array}$ & Quarterly & $12 / 22 / 92$ \\
\hline $699-44-438$ & Downgradient & Ringold: Water Table & Quarterly & $10 / 22 / 92$ \\
\hline
\end{tabular}

'Wells shared with the $\mathrm{W}-\mathrm{O} 49 \mathrm{H}$ Treated Effluent Disposal Facility.

The constituent list and summary of results available are provided in Table 6-3. The results of the available analyses, for constituents with at least one detected value, are reported in Table 6-4. Results of analyses for CIPs are reported in Table 6-5.

Wells 699-40-39, 699-41-40, 699-42-41, 699-42-42B, 699-43-41E, 699-43-42J, 699-44-42, and 699-44-438 were scheduled only for analyses of CIP during the October through December 1992 sampling period. All ToX data are flagged " $A$ " because of an ongoing laboratory audit (see Section 1.2.5).

Potential problems with chemistry data exists in samples collected from wells 699-42-41 and 699-42-39A. Contamination to groundwater from stencil paint used on temporary casing may be possibly affecting analytical results in these wells. Data from these wells will be tracked to identify any anomalous results. A potential problem with chemistry data also exists in samples collected for well 699-43-40. This well does not comply with WAC 173-160-520 because a portion of the temporary casing shoe was accidently detached from the temporary 8-in. casing during well construction. The shoe is lodged adjacent to the stainless steel screen interval. Data from this well will be tracked indefinitely to identify any anomalous results. All data with potential problems are flagged with a "p" in the data tables.

Chromium values in unfiltered samples exceeded the DWS in wells 699-40-40A, 699-40-40B, 699-42-39A, 699-42-39B, 699-43-43, and 699-43-45. The value for coliform bacteria apparentiy exceeded the OWS in well 699-40-40B. All wells in the network analyzed for iron in unfiltered samples exceeded the DWS for this constituent except wells 699-41-35 and 699-43-41G. The DWS for iron in filtered samples was exceeded in well 699-42-39B. Manganese in unfiltered samples exceeded the DWS in all wells in the network analyzed for this constituent except in wells 699-43-43 and 699-43-45. The DWS for manganese in filtered samples was exceeded in wel1s 699-40-36, 699-40-40A, 699-40-40B, 699-41-35, 699-42-37, 699-42-39B (two samples), and 699-43-41G. The nitrate DWS was exceeded by results from well 699-43-43. Because this is an exceptionally high value for nitrate in this well, as compared to historical analyses, a RADE has been submitted for this result. Tritium exceeded DWS in wells 699-42-39A, 699-42-39B, and 699-43-41G. Turbidity exceeded the DWS in upgradient well 299-E18-1 and 
DOE/RL 93-61, Rev 0

downgradient wells 699-40-40A, 699-40-40B, and 699-42-39A. The standard for the upper 7 imit of $\mathrm{pH}$ was exceeded in wells $699-40-39,699-41-40,699-43-41 \mathrm{E}$, and 699-43-416.

A RADE was also submitted for each of the following results shown in Table 6-4: iron, in a filtered sample from well 699-42-39B (taken 10/28/92); coliform, from well 699-40-40B (taken 10/21/92); and zinc, in a filtered sample from well 699-40-40B (taken 10/21/92). These data would normally be flagged " $R$ ", but were submitted after the deadline for the attachment of flags. 
DOE/RL 93-61, Rev 0 $12 / 93$

200 East Area W-252 Streams

Table 6-2. RCRA Water Level Measurement Report 216-8-3 Pond System - Fourth Quarter. (sheet 1 of 3)

Well Date $\quad \begin{gathered}\text { Depth to } \\ \text { water (ft) }\end{gathered} \quad \begin{gathered}\text { Water level } \\ \text { elevation } \\ \text { above msi (ft) }\end{gathered}$

Wells Monitoring the Unconfined Aquifer at the Water Table 299-E18-1

$\begin{array}{ll}10 / 19 / 92 & 317.65 \\ 11 / 03 / 92 & 317.98 \\ 11 / 11 / 92 & 317.83 \\ 12 / 15 / 92 & 317.97 \\ 12 / 15 / 92 & 317.22 \\ 12 / 16 / 92 & 317.22\end{array}$

402.65

$299-E 32-4$

$12 / 18 / 92$

284.05

$402.32 \star$

402.47

402.33

$403.08 *+$

403.08*t

$699-42-40 A$

$10 / 21 / 92$

$10 / 22 / 92$

$11 / 11 / 92$

$12 / 15 / 92$

$12 / 28 / 92$

124.72

124.77

124.59

123.13

126.23

401.83

$699-42-41$

$10 / 21 / 92$

$10 / 22 / 92$

$11 / 11 / 92$

$12 / 15 / 92$

147.14

146.96

146.99

146.25

420.81

420.76*

420.94

$422.40+$

419.30*

$699-43-40$

$10 / 20 / 92$

$10 / 22 / 92$

$11 / 11 / 92$

$12 / 15 / 92$

123.19

123.39

123.35

122.73

419.93

420.11*

420.08

420.82

$6 y 9-43-42 J$

$10 / 20 / 92$

163.24

163.20

$10 / 22 / 92$

$11 / 11 / 92$

$12 / 15 / 92$

$12 / 28 / 92$

163.23

162.73

163.22

418.80

418.60 *

418.64

419.26

$699-43-43$

$10 / 21 / 92$

$10 / 26 / 92$

164.55

164.46

$11 / 11 / 92$

164.53

$12 / 15 / 92$

164.42

418.44

418.48 *

418.45

418.95+

418.46*

$699-43-45$

$10 / 20 / 92$

$10 / 26 / 92$

194.09

194.05

$11 / 11 / 92$

194.17

414.82

414.91 *

414.84

414.95

699-43-45

$12 / 15 / 92$

194.26

403.59

403.63 *

403.51

403.42 
DOE/RL 93-61, Rev 0

Table 6-2. RCRA Water Level Measurement Report 216-B-3 Pond System - Fourth Quarter. (sheet 2 of 3)

\begin{tabular}{|c|c|c|c|}
\hline Well & Date & $\begin{array}{l}\text { Depth to } \\
\text { water (ft) }\end{array}$ & $\begin{array}{l}\text { Water level } \\
\text { elevation } \\
\text { above msl (ft) }\end{array}$ \\
\hline \multicolumn{4}{|c|}{ Wells Monitoring the Unconfined Aquifer at the Water Table } \\
\hline $699-44-42$ & $\begin{array}{l}10 / 20 / 92 \\
10 / 22 / 92 \\
11 / 11 / 92 \\
12 / 15 / 92\end{array}$ & $\begin{array}{l}158.80 \\
158.73 \\
158.77 \\
158.56\end{array}$ & $\begin{array}{l}420.42 \\
420.49 \star \\
420.45 \\
420.66\end{array}$ \\
\hline $699-44-43 B$ & $\begin{array}{l}10 / 21 / 92 \\
10 / 22 / 92 \\
11 / 11 / 92 \\
12 / 15 / 92\end{array}$ & $\begin{array}{l}164.64 \\
164.64 \\
164.71 \\
164.74\end{array}$ & $\begin{array}{l}415.48 \\
415.48 \star \\
415.41 \\
415.38\end{array}$ \\
\hline \multicolumn{4}{|c|}{ Wells Monitoring Confined or Semi-Confined Aquifer } \\
\hline $699-40-36$ & $12 / 21 / 92$ & 117.84 & *6 \\
\hline $699-40-39$ & $\begin{array}{l}10 / 20 / 92 \\
10 / 21 / 92 \\
11 / 11 / 92 \\
12 / 15 / 92\end{array}$ & $\begin{array}{l}129.47 \\
129.49 \\
129.65 \\
129.38\end{array}$ & $\begin{array}{l}412.37^{\star} \\
412.35 \\
412.19 \\
412.46\end{array}$ \\
\hline $699-40-40 A$ & $\begin{array}{l}10 / 20 / 92 \\
10 / 21 / 92 \\
11 / 11 / 92 \\
12 / 15 / 92\end{array}$ & $\begin{array}{l}129.96 \\
129.86 \\
130.08 \\
129.73\end{array}$ & $\begin{array}{l}411.04 \\
411.14 * \\
410.92 \\
411.27\end{array}$ \\
\hline $699-40-40 B$ & $\begin{array}{l}10 / 20 / 92 \\
10 / 21 / 92 \\
11 / 11 / 92 \\
12 / 15 / 92\end{array}$ & $\begin{array}{l}130.64 \\
130.67 \\
130.75 \\
130.40\end{array}$ & $\begin{array}{l}411.33 \\
411.30 * \\
411.22 \\
411.57\end{array}$ \\
\hline $699-41-35$ & $12 / 21 / 92$ & 108.24 & $\% 6$ \\
\hline $699-41-40$ & $\begin{array}{l}10 / 21 / 92 \\
11 / 11 / 92 \\
12 / 15 / 92\end{array}$ & $\begin{array}{l}130.85 \\
131.06 \\
130.49\end{array}$ & $\begin{array}{l}415.09 \\
414.88 \\
415.45\end{array}$ \\
\hline $699-42-37$ & $12 / 22 / 92$ & 104.68 & .6 \\
\hline $699-42-39 A$ & $\begin{array}{l}10 / 20 / 92 \\
10 / 21 / 92 \\
11 / 11 / 92 \\
12 / 15 / 92\end{array}$ & $\begin{array}{l}139.77 \\
139.82 \\
139.98 \\
139.22\end{array}$ & $\begin{array}{l}418.16 \\
418.11^{*} \\
417.95 \\
418.71\end{array}$ \\
\hline
\end{tabular}


DOE/RL 93-61, Rev 0 $12 / 93$

200 East Area W-252 Streams

Table 6-2. RCRA Water Level Measurement Report 216-B-3 Pond System - Fourth Quarter. (sheet 3 of 3)

Well Date $\quad \begin{gathered}\text { Depth to } \\ \text { water (ft) }\end{gathered} \begin{gathered}\text { Water level } \\ \text { elevation } \\ \text { above msi (ft) }\end{gathered}$

Wells Monitoring Confined or Semi-Confined Aquifer

$699-42-39 B$

$10 / 20 / 92$

$10 / 21 / 92$

$10 / 28 / 92$

$11 / 11 / 92$

$12 / 15 / 92$

$699-43-41 E$

$699-43-41 F$

$699-43-41 G$

$10 / 20 / 92$

$10 / 20 / 92$

$11 / 11 / 92$

$12 / 15 / 92$

$10 / 20 / 92$
$10 / 21 / 92$
$11 / 11 / 92$
$12 / 15 / 92$

$10 / 20 / 92$

$10 / 28 / 92$

$11 / 11 / 92$

$12 / 15 / 92$
140.15
139.82
140.08
140.38
139.64

130.57

130.56

130.82

130.19

130.72

130.67

130.86

130.23

135.68

135.40

135.80

135.21
417.96

418.29*

418.03*

417.73

418.47

420.29

420.30*

420.04

420.67

420.29

420.34 *

420.15

420.78

415.45

415.73*

415.33

415.92

Well Monitoring the Unconfined Aquifer Below the Water Table $699-42-42 B$

$\begin{array}{ll}10 / 20 / 92 & 166.46 \\ 10 / 20 / 92 & 166.40 \\ 11 / 11 / 92 & 166.47 \\ 12 / 15 / 92 & 166.18\end{array}$

416.77

416.83*

416.76

417.05

NOTES: 1. Water level elevations are calculated by subtracting the measured depth to water from the surveyed elevation for the well.

2. Depth-to-water values are transcribed from field records.

3. Elevations marked with an $n \star n$ "were measured at the time of sampling.

4. Elevations marked with a " + " are outside of the expected range, and are suspected of error.

5. To convert feet to meters multiply by 0.3048 .

6. Final surveyed elevations not yet available. 
Table 6-3. Constituent List and Summary of Results for the 216-8-3 Pond

Data for Reporting Period October 1, 1992, through December 31, 1992. (sheet 1 of 6 )

CONTAMINATION INDICATOR PARMETERS

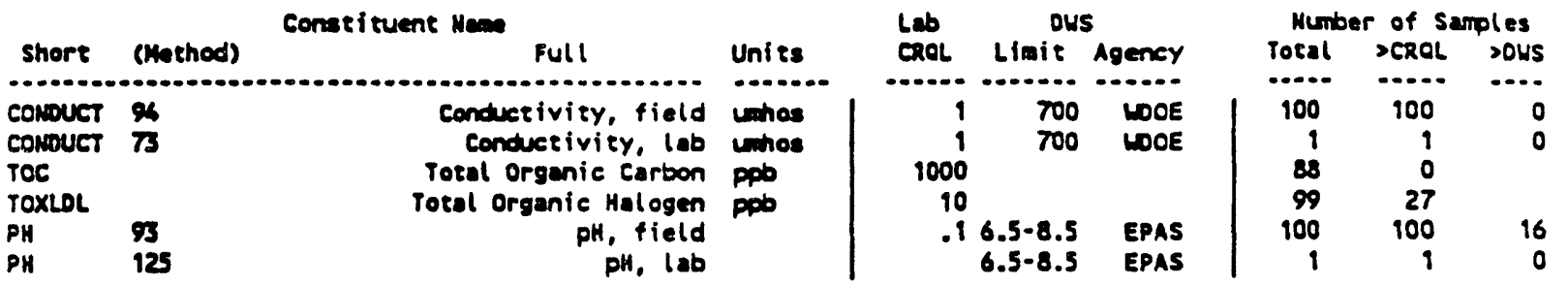

DRINKING MATER PARAMETERS

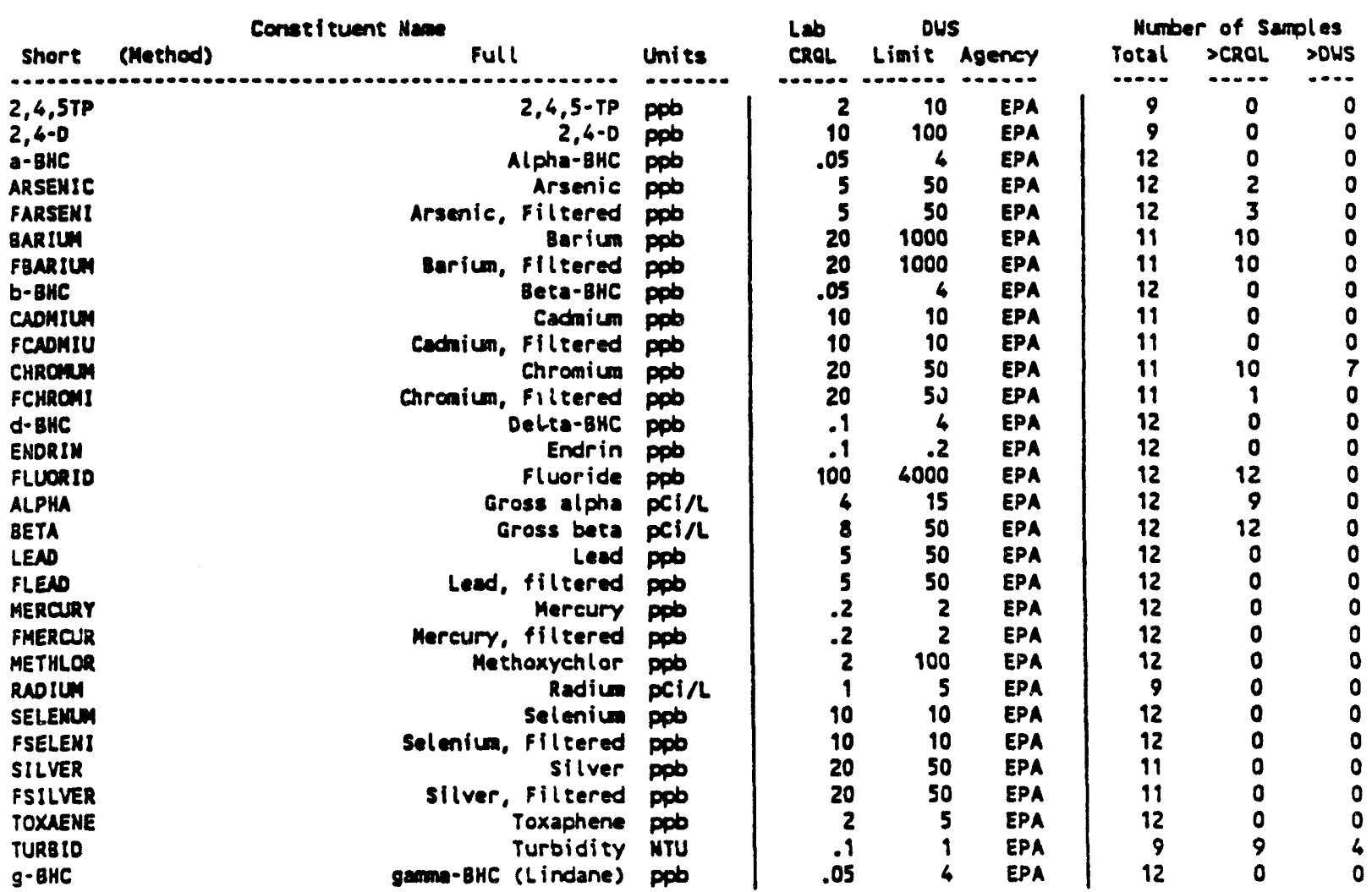

GRONOWATER WALITY PARANETERS

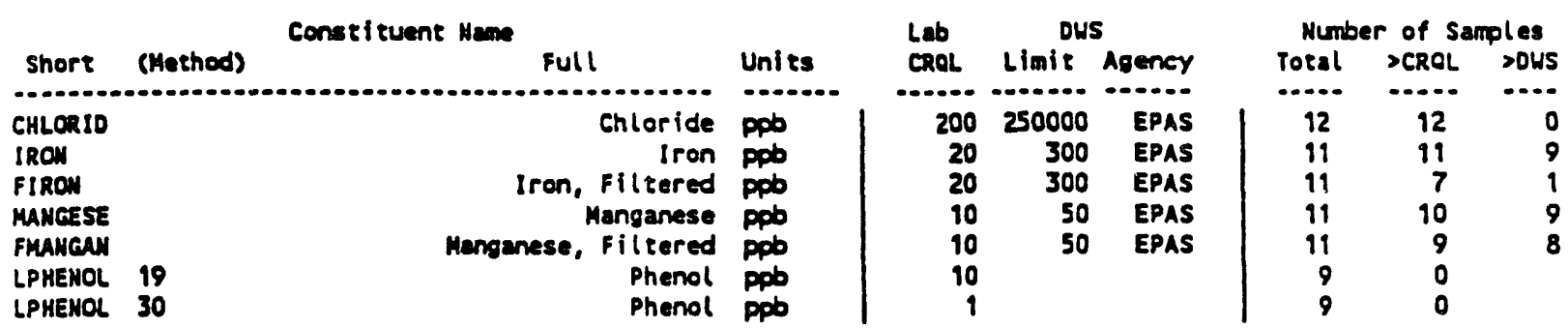


Table 6-3. Constituent List and Summary of Results for the 216-8-3 Pond Data for Reporting Period October 1, 1992, through December 31, 1992.

(sheet 2 of 6 )

GROUMDUATER QUALITY PARUMETERS

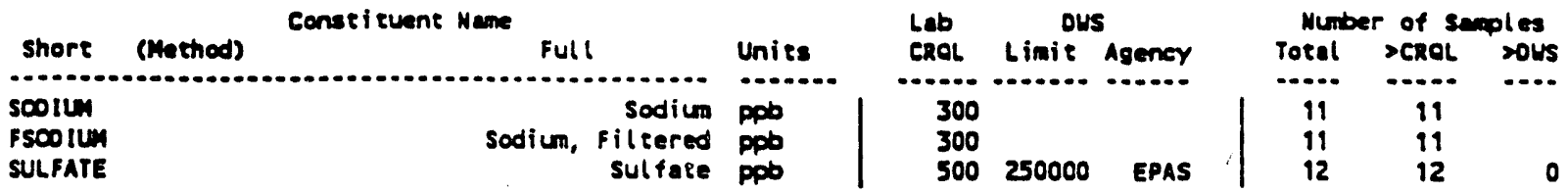

SITE SPECIFIC AND OTHER CONSTITUENTS

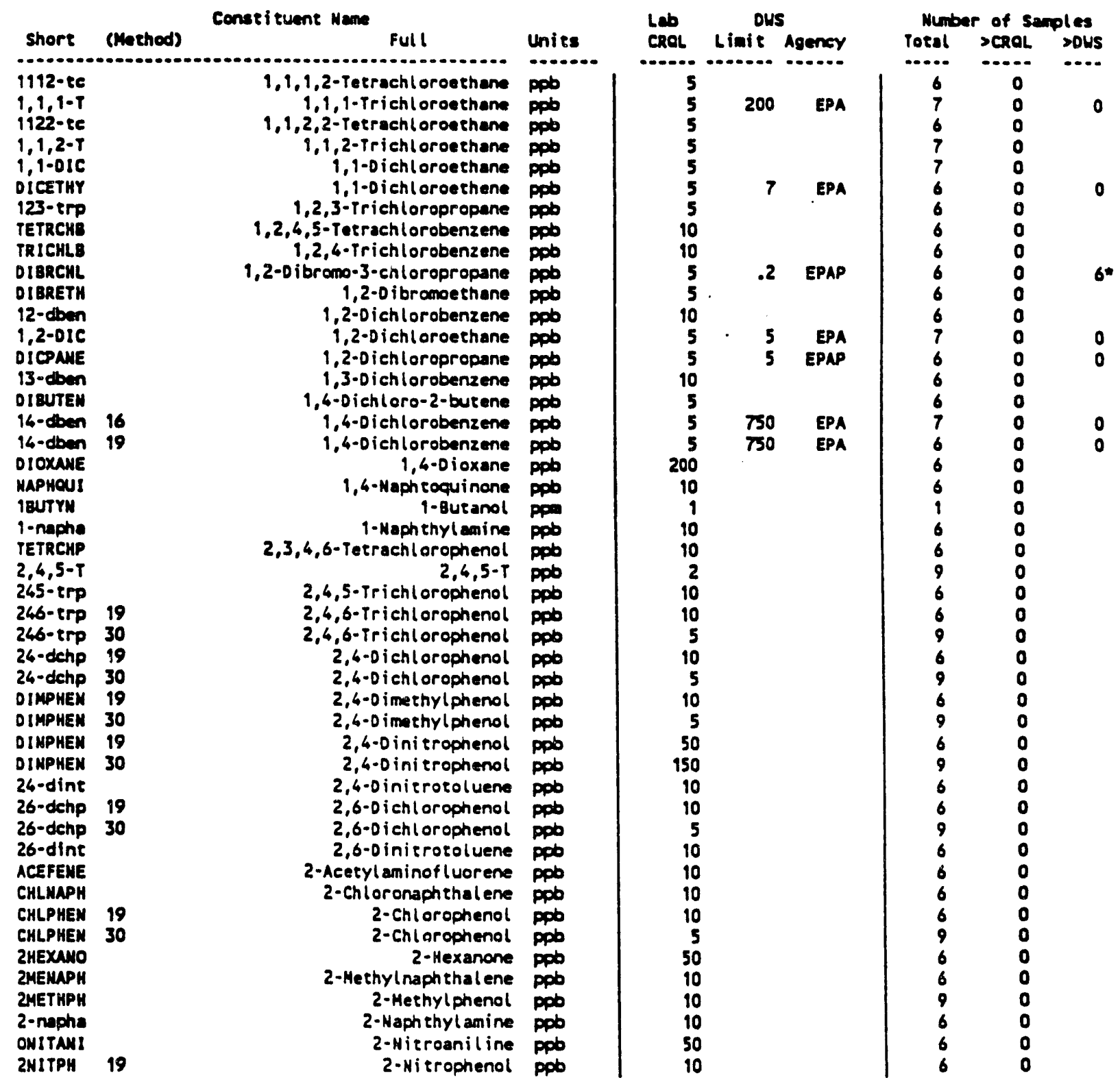


Table 6-3. Constituent List and Summary of Results for the 216-B-3 Pond

Data for Reporting Period October 1, 1992, through December 31, 1992.

(sheet 3 of 6 )

SITE SPECIFIC NDO OTHER CONSTITUENTS

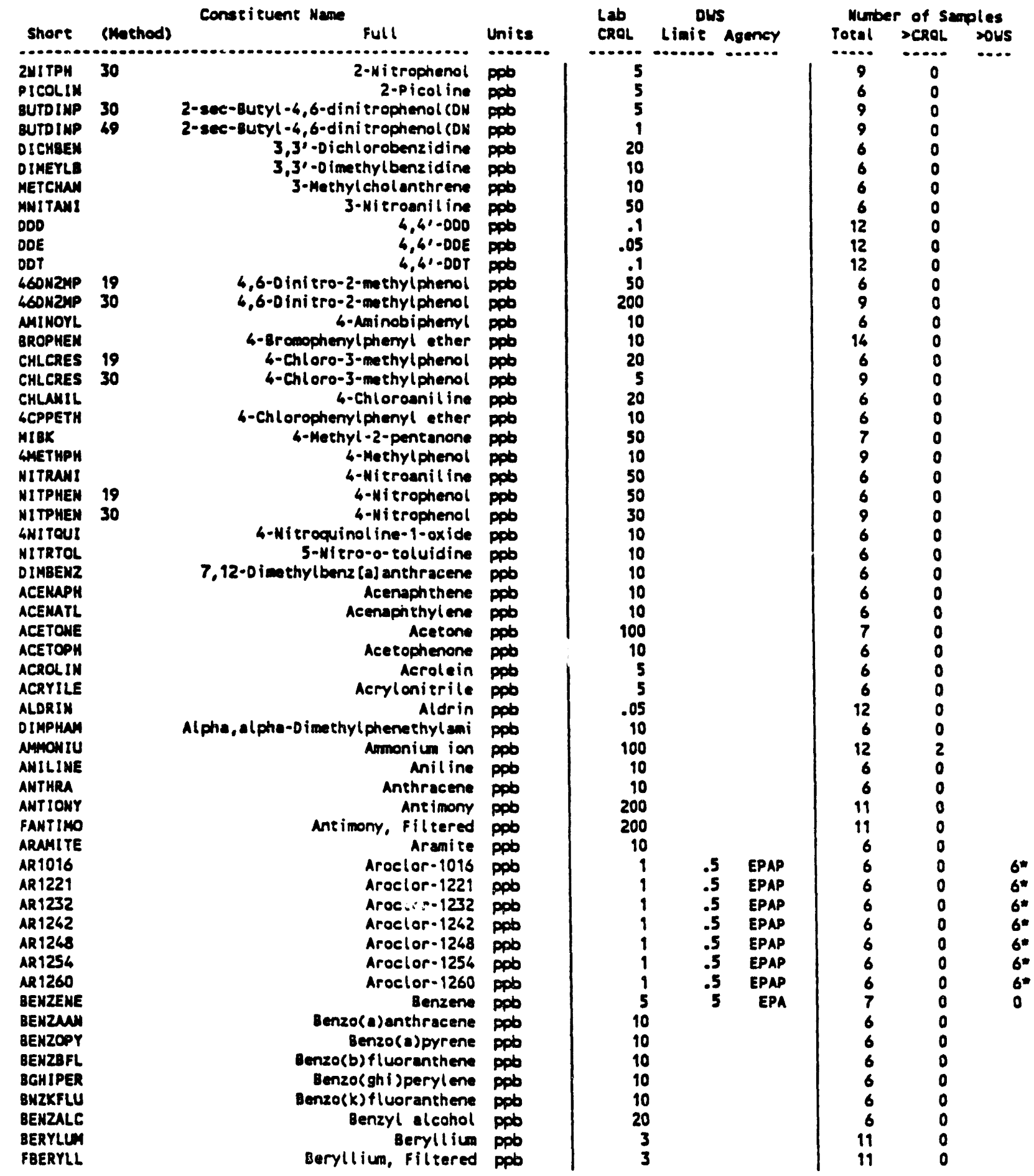


DOE/RL 93-61, Rev 0

Table 6-3. Constituent List and Summary of Results for the 216-B-3 Pond Data for Reporting Period October 1, 1992, through December 31, 1992.

(sheet 4 of 6 )

SITE SPECIFIC ND OTHER CONSTITUENTS

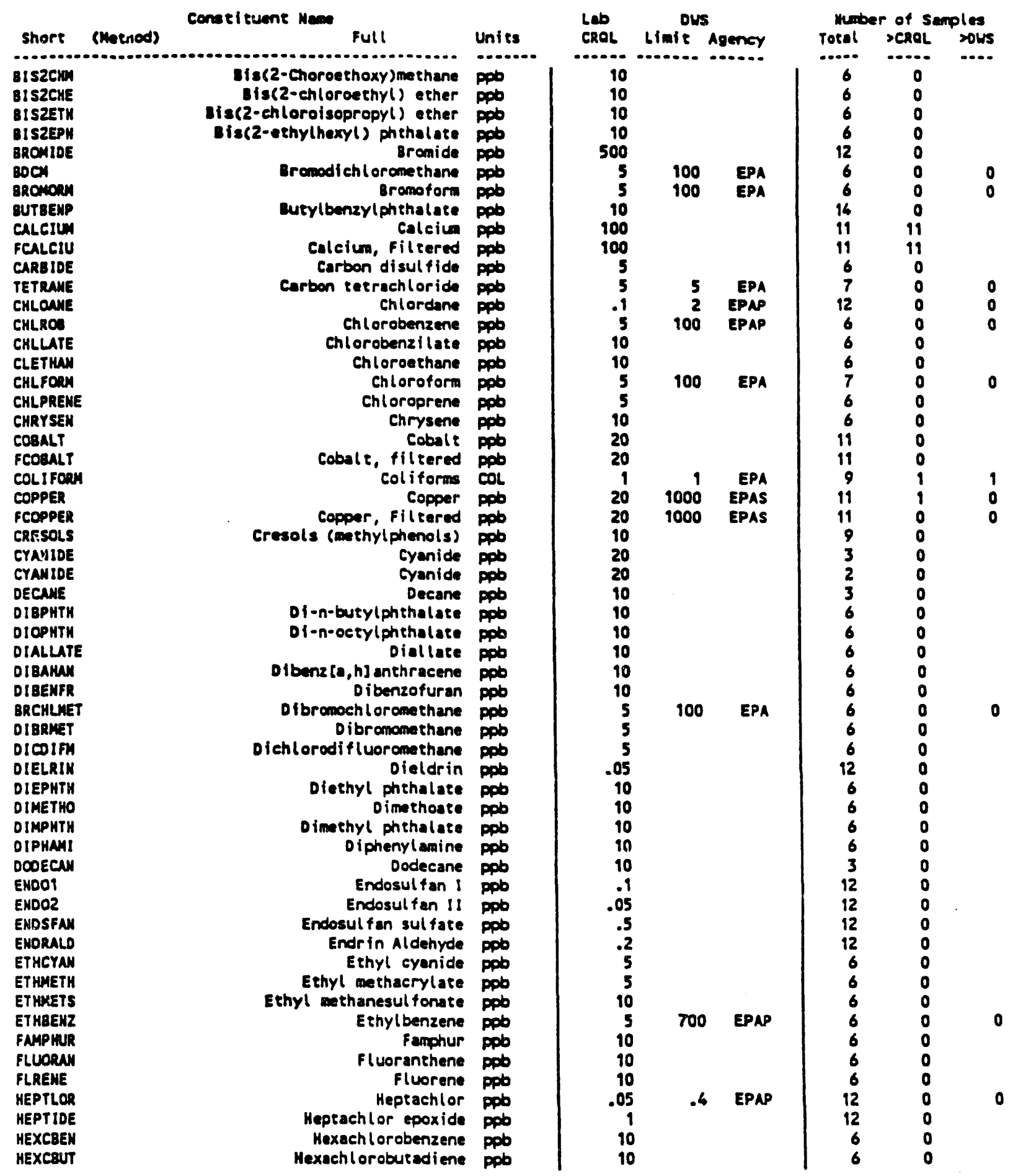


Table 6-3. Constituent List and Summary of Results for the 216-8-3 Pond Data for Reporting Period October 1, 1992, through December 31, 1992.

(sheet 5 of 6 )

SITE SPECIFIC AMO OTHER CONSTITUEMTS

\begin{tabular}{|c|c|c|c|c|c|c|c|c|c|}
\hline & & Consti tuent Nam & & Lab & OUS & & Numb & $r$ of $s$ & ples \\
\hline Short & (Mothod) & Ful l & Units & CROL & Limit & Agency & Total & $>$ CROL & sous \\
\hline 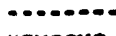 & & 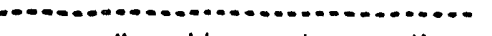 & $\ldots+\infty$ & $\ldots \ldots$ & & $\ldots \ldots$ & $\cdots \ldots$ & $\cdots \infty$ & $\cdots$ \\
\hline HEXCETC & & Hexachlorocyclopentadiene & ppob & 10 & & & 6 & 0 & \\
\hline HEXCETH & & Hexachloroethane & pob & 10 & & & 6 & 0 & \\
\hline HEXACHL & & Hexach lorophene & pob & 10 & & & 6 & 0 & \\
\hline HEXAENE & & Hexachloropropene & ppo & 10 & & & 6 & $\mathbf{0}$ & \\
\hline LHYORAz & & Hydrazine & ppob & 30 & & & 11 & $\mathbf{0}$ & \\
\hline IHDENOP & & Indeno(1,2,3-cd)pyreme & ppo & 10 & & & 6 & 0 & \\
\hline $1-12940$ & & Iodine-129, lou derection & $\mathrm{pcill}$ & 1 & $\boldsymbol{1}$ & EPAR & 3 & 1 & 0 \\
\hline I sosut & & Isobutyl alcohol & ppb & 200 & & & 6 & $\mathbf{0}$ & \\
\hline Isconin & & Isodrin & $\mathbf{p o b}$ & 10 & & & 6 & 0 & \\
\hline ISOPHER & & I saphorone & $\boldsymbol{p h}$ & 10 & & & 6 & 0 & \\
\hline ISOSOLE & & Isosafrole & pob & 10 & & & 6 & 0 & \\
\hline KEPONE & & Kepone & ppob & 10 & & & 6 & 0 & \\
\hline KEROSEN & & Kerosene & ppob & 10000 & & & 6 & 0 & \\
\hline ManES & & Magnesium & $p p b$ & 100 & & & 11 & 11 & \\
\hline FMAGNES & & Magnesium, Filcered & ppb & 100 & & & 11 & 11 & \\
\hline METHACR & & Methacryl onitrile & $p p b$ & 5 & & & 6 & $\mathbf{0}$ & \\
\hline METHAPY & & Methapyrilene & ppob & 10 & & & 6 & 0 & \\
\hline IODONET & & Methyl Iodide & ppb & 5 & & & 6 & 0 & \\
\hline METHBRO & & Methyl bromide & ppo & 10 & & & 6 & 0 & \\
\hline METHCHL & & Mechyl chloride & ppo & 10 & & & 6 & $\mathbf{0}$ & \\
\hline METHONE & & Methyl ethyl ketone & ppob & 100 & & & 7 & $\mathbf{0}$ & \\
\hline METACRY & & Methyl methacrylare & ppo & 5 & & & 6 & $\mathbf{0}$ & \\
\hline METMSUL & & Methyt methanesulfonare & ppob & 10 & & & 6 & 0 & \\
\hline METHYCH & & Methylene chloride & pob & 5 & & & 7 & 0 & \\
\hline DIPRNIT & & N-Nitroso-di-n-dipropylamine & ppb & 10 & & & 6 & $\mathbf{0}$ & \\
\hline MNIBUTY & & N-Mitrosodi-n-butylanine & ppo & 10 & & & 6 & $\mathbf{0}$ & \\
\hline NHIOIEY & & $N-N i t r o s o d i e t h y l a m i n e$ & pob & 10 & & & 6 & 0 & \\
\hline NHIDIME & & N-Mitrosodimethylamine & ppo & 10 & & & 6 & 0 & \\
\hline NMOIPKA & & N-Nitrosodiphemylanine & ppo & 10 & & & 6 & 0 & \\
\hline NHIMETH & & N-Nitrosomethylethylanine & pob & 10 & & & 6 & 0 & \\
\hline NNIMORP & & N-Nitrosomorphol ine & $p p b$ & 10 & & & 6 & 0 & \\
\hline NHIPIPE & & N-Mitrosopiperidine & pob & 10 & & & 6 & 0 & \\
\hline MAPHTHA & & Maphthalene & ppo & 10 & & & 9 & 0 & \\
\hline NICXEL & & Nickel & ppo & 30 & & & 11 & 6 & \\
\hline FNICXEL & & Nickel, Filsered & ppb & 30 & & & 11 & 0 & \\
\hline MITRATE & & Nitrate & ppo & 200 & 45000 & EPA & 12 & 11 & 1 \\
\hline NITRITE & & Mitrite & ppb & 200 & 3300 & EPAP & 12 & 0 & $\mathbf{0}$ \\
\hline MITBENZ & & Nitrobenzen & ppb & 10 & & & 6 & 0 & \\
\hline NITRPYR & & Nitrosopyrrolidine & ppo & 10 & & & 6 & 0 & \\
\hline TRIPHOS & & 0,0,0-Triethyl phosphorothioate & ppo & 10 & & & 6 & 0 & \\
\hline DIPHOS & & 0,0-diethyl0-2-pyraziny (phosphor & pob & 10 & & & 6 & 0 & \\
\hline PARATHS & & Parathion & pob & 10 & & & 6 & 0 & \\
\hline PENTCHB & & Pentachlorobenzene & ppb & 10 & & & 6 & 0 & \\
\hline PENTACH & & Pentachloroethane & ppob & $\mathbf{5}$ & & & 6 & 0 & \\
\hline PENTCHN & & Pentachloronitrobenzene (PCNB) & pob & 10 & & & 6 & 0 & \\
\hline PENTCHP & 19 & Pentachlorophenol & Ppo & 50 & 200 & EPAP & 9 & 0 & 0 \\
\hline PENTCHP & 30 & Pentachlorophenol & Ppo & 100 & 200 & EPAP & 9 & 0 & 0 \\
\hline PHENTIM & & Phenacetin & ppo & 10 & & & 6 & 0 & \\
\hline PHENAMT & & Pheranthrene & $p p$ & 10 & & & 6 & 0 & \\
\hline РНОSPHA & & Phosphate & ppo & 400 & & & 12 & $\mathbf{0}$ & \\
\hline Potasty & & Potassium & ppo & 300 & & & 11 & 11 & \\
\hline FPotass & & Potassium, Filtered & ppo & 300 & & & 11 & 11 & \\
\hline PRONIOE & & Pronanide & ppo & 10 & & & 6 & 0 & \\
\hline PYRENE & & Pyrene & pob & 10 & & & 6 & 0 & \\
\hline PYRIDIN & & Pyridine & ppo & 5 & & & 6 & 0 & \\
\hline SAFROL & & Safrol & ppo & 10 & & & 6 & 0 & \\
\hline STYRENE & & styrene & ppob & 5 & 5 & EPAP & 6 & 0 & 0 \\
\hline
\end{tabular}


DOE/RL 93-61, Rev 0

Table 6-3. Constituent List and Summary of Results for the 216-B-3 Pond Data for Reporting Period October 1, 1992, through December 31, 1992.

(sheet 6 of 6 )

SITE SPECIFIC ANO OTHER CONSTITUENTS

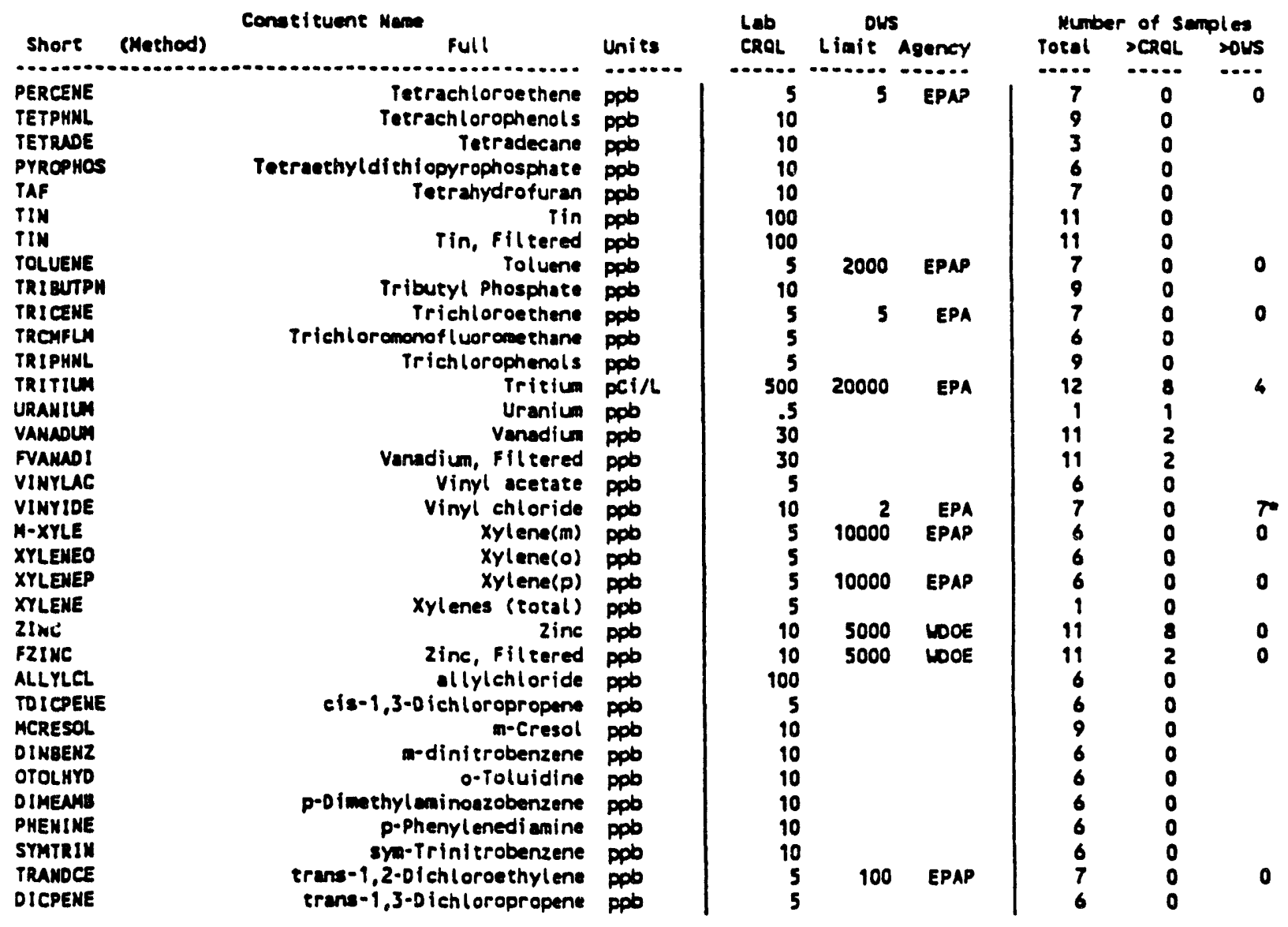

For explanation of this table, see section 1.4 of report. 
Table 6-4. Constituents with at Least One Detected Value for the 216-B-3 Pond Data for Reporting Period October 1, 1992, through December 31, 1992.

(sheet 1 of 5 )

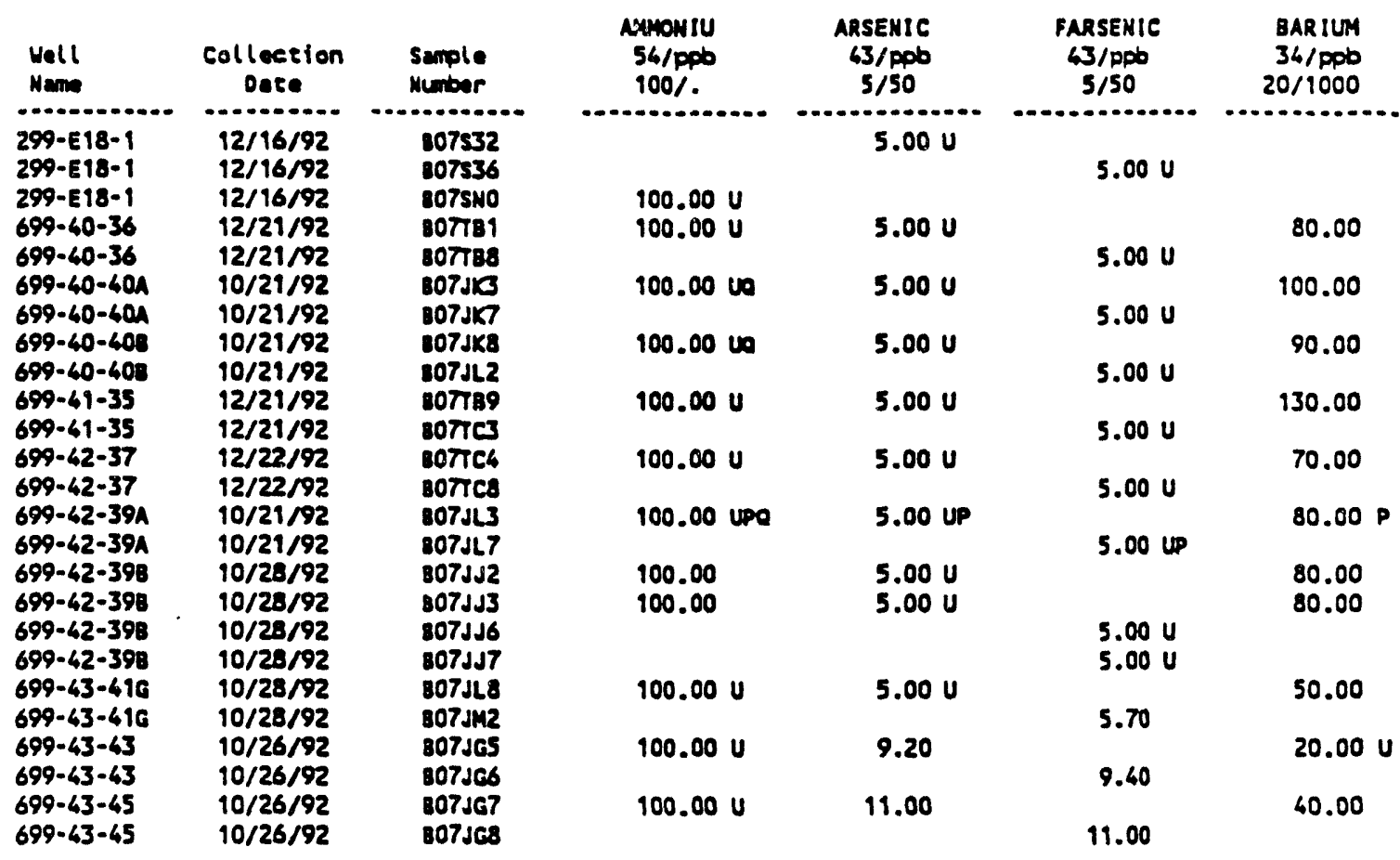

\begin{tabular}{|c|c|c|c|c|c|c|}
\hline $\begin{array}{l}\text { Nell } \\
\text { Nama }\end{array}$ & $\begin{array}{c}\text { Collection } \\
\text { Date }\end{array}$ & $\begin{array}{l}\text { Sample } \\
\text { Mumber }\end{array}$ & $\begin{array}{l}\text { FBARIUA } \\
34 / \text { ppb } \\
20 / 1000\end{array}$ & $\begin{array}{l}\text { calciun } \\
34 / \text { ppb } \\
100 \%\end{array}$ & $\begin{array}{l}\text { PCALCIUM } \\
34 / \text { ppb } \\
100 \%\end{array}$ & $\begin{array}{c}\text { CHLOR1O } \\
126 / \text { Ppb } \\
200 / 250000 \mathrm{~s}\end{array}$ \\
\hline $\begin{array}{l}299-E 18-1 \\
699-40-36 \\
699-40-36 \\
699-40-40 A \\
699-40-40 A \\
699-40-408 \\
699-40-408 \\
699-41-35 \\
699-41-35 \\
699-42-37 \\
699-42-37 \\
699-42-39 A \\
699-42-39 A \\
699-42-398 \\
699-42-398 \\
699-42-398 \\
699-42-398 \\
699-43-616 \\
699-43-416 \\
699-43-43 \\
699-43-43 \\
699-43-45 \\
699-43-45\end{array}$ & $\begin{array}{l}12 / 16 / 92 \\
12 / 21 / 92 \\
12 / 21 / 92 \\
10 / 21 / 92 \\
10 / 21 / 92 \\
10 / 21 / 92 \\
10 / 21 / 92 \\
12 / 21 / 92 \\
12 / 211 / 92 \\
12 / 22 / 92 \\
12 / 22 / 92 \\
10 / 21 / 92 \\
10 / 21 / 92 \\
10 / 28 / 92 \\
10 / 28 / 92 \\
10 / 28 / 92 \\
10 / 28 / 92 \\
10 / 28 / 92 \\
10 / 28 / 92 \\
10 / 26 / 92 \\
10 / 26 / 92 \\
10 / 26 / 92 \\
10 / 26 / 92\end{array}$ & 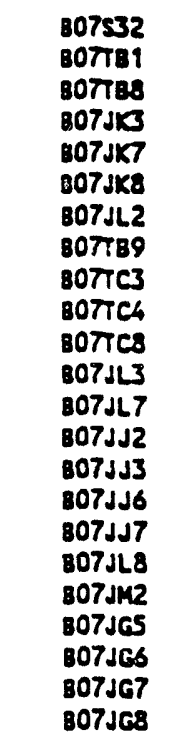 & $\begin{array}{l}80.00 \\
100.00 \\
90.00 \\
120.00 \\
60.00 \\
60.00 \mathrm{P} \\
80.00 \\
80.00 \\
50.00 \\
20.00 \mathrm{U} \\
30.00\end{array}$ & $\begin{array}{l}15000.00 \\
20000.00 \\
24000.00 \\
18000.00 \\
23000.00 \\
31000.00 \mathrm{P} \\
28000.00 \\
29000.00 \\
24000.00 \\
29000.00 \\
28000.00\end{array}$ & $\begin{array}{l}15000.00 \\
20000.00 \\
26000.00 \\
18000.00 \\
23000.00 \\
30000.00 P \\
28000.00 \\
28000.00 \\
24000.00 \\
29000.00\end{array}$ & $\begin{array}{l}7800.00 \\
3100.00 \\
6400.00 \\
4300.00 \\
3400.00 \\
7800.00 \\
8300.00 \mathrm{P} \\
9000.00 \\
9700.00 \\
6100.00 \\
2900.00 \\
2900.00\end{array}$ \\
\hline
\end{tabular}


Table 6-4. Constituents with at Least One Detected Value for the 216-8-3 Pond Data for Reporting Period October 1, 1992, through December 31, 1992.

(sheet 2 of 5 )

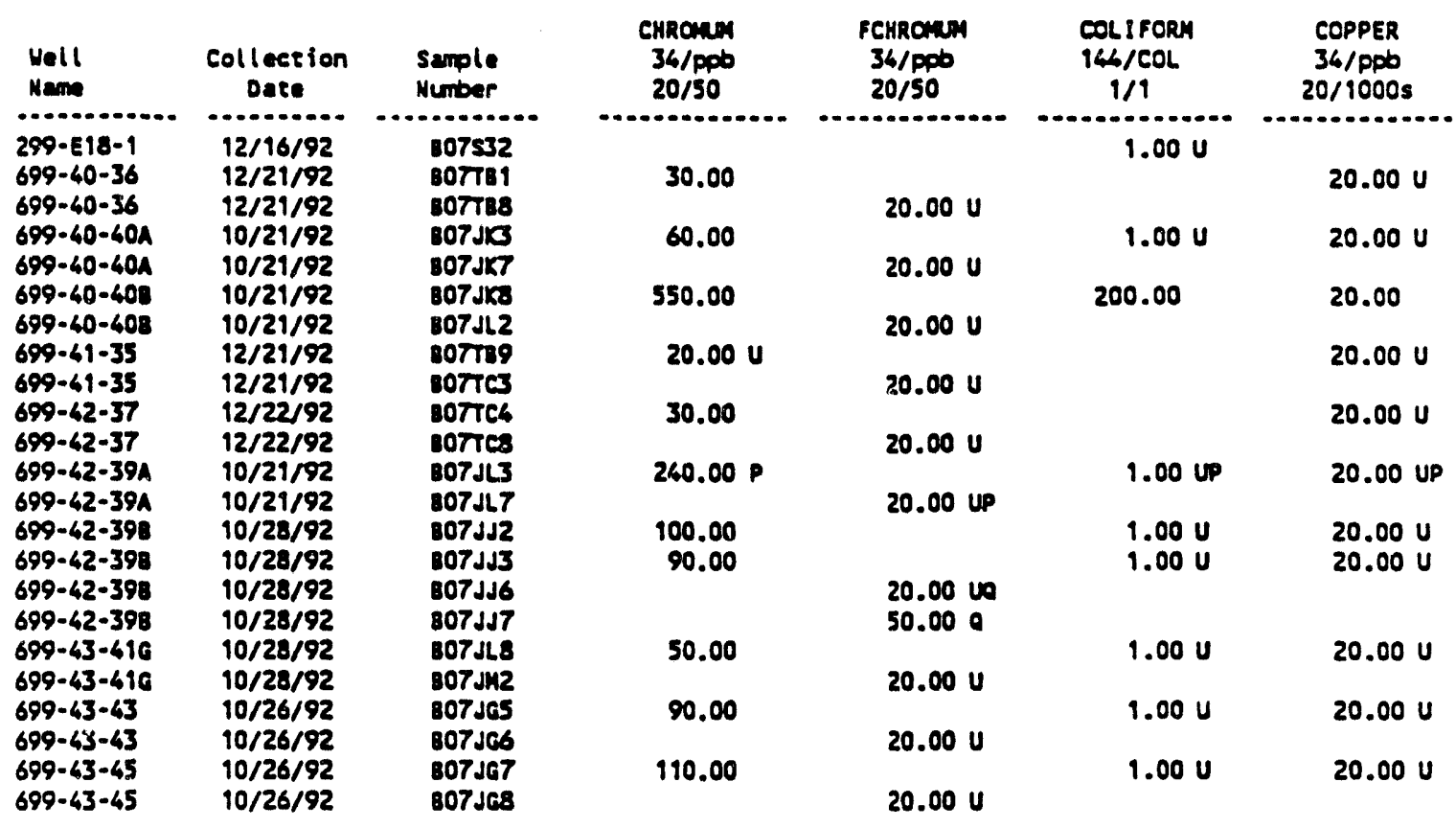

\begin{tabular}{|c|c|c|c|c|c|c|}
\hline $\begin{array}{l}\text { Hell } \\
\text { Mame }\end{array}$ & $\begin{array}{l}\text { Collection } \\
\text { Dote }\end{array}$ & $\begin{array}{l}\text { Sample } \\
\text { Number }\end{array}$ & $\begin{array}{c}\text { FCOPPER } \\
34 / P P B \\
20 / 1000 \text { s }\end{array}$ & $\begin{array}{l}\text { rLuoR 10 } \\
124 / \text { ppo } \\
100 / 4000\end{array}$ & $\begin{array}{c}\begin{array}{c}\text { ALPHA } \\
135 / P C i / L\end{array} \\
. / 15\end{array}$ & $\begin{array}{c}\text { BETA } \\
136 / P C I / L \\
.150 \\
\ldots . . .\end{array}$ \\
\hline $\begin{array}{l}299-E 18-1 \\
699-60-36 \\
600-60-36\end{array}$ & $\begin{array}{r}2 / 16 / 92 \\
12 / 21 / 92 \\
12 / 2192\end{array}$ & $\begin{array}{l}807532 \\
\text { B07781 }\end{array}$ & & $\begin{array}{l}500.00 \\
900.00\end{array}$ & $\begin{array}{l}4.79 \\
4.44\end{array}$ & $\begin{array}{l}8.46 \\
8.24\end{array}$ \\
\hline $\begin{array}{l}699-40-36 \\
699-40-40 A\end{array}$ & $\begin{array}{l}12 / 21 / 92 \\
10 / 21 / 92\end{array}$ & $\begin{array}{l}807888 \\
807 \mathrm{JK3}\end{array}$ & $20.00 \mathrm{U}$ & 900.00 & $1.07 \mathrm{U}$ & 5.61 \\
\hline $\begin{array}{l}699-40-40 A \\
699-40-408\end{array}$ & $\begin{array}{l}10 / 21 / 92 \\
10 / 21 / 92\end{array}$ & $\begin{array}{l}\text { BO7 JK7 } \\
\text { BO7 JKB }\end{array}$ & $20.00 u$ & 500.00 & $1.02 . U$ & 2.30 \\
\hline $699-40-408$ & $10 / 21 / 92$ & B07JL2 & $20.00 \mathrm{U}$ & & & \\
\hline $\begin{array}{l}699-61-35 \\
699-41-35\end{array}$ & $\begin{array}{l}12 / 21 / 92 \\
12 / 21 / 92\end{array}$ & $\begin{array}{l}80 \pi 789 \\
80 \pi c 3\end{array}$ & $20.00 u$ & 800.00 & 7.40 & 8.37 \\
\hline $699-42 \cdot 37$ & $12 / 22 / 92$ & BO7TC4 & & 700.00 & 6.09 & 4.32 \\
\hline $\begin{array}{l}699-42-37 \\
609-42-30\end{array}$ & 12/22/92 & Bo7res & $20.00 \mathrm{U}$ & & $3.35 P$ & \\
\hline $\begin{array}{l}699-42-39 A \\
699-42-39 A\end{array}$ & $\begin{array}{l}10 / 21 / 92 \\
10 / 21 / 92\end{array}$ & $\begin{array}{l}\text { B07JL3 } \\
\text { B07JL7 }\end{array}$ & 20.00 UP & $700.00 \mathrm{P}$ & $3.35 \mathrm{P}$ & $6.35 \mathrm{P}$ \\
\hline $\begin{array}{l}699-42-398 \\
699-42-398\end{array}$ & $\begin{array}{l}10 / 28 / 92 \\
10 / 28 / 92\end{array}$ & $\begin{array}{l}807 J J 2 \\
807 J J 3\end{array}$ & & $\begin{array}{l}800.00 \\
800.00\end{array}$ & $\begin{array}{l}2.77 \\
2.87\end{array}$ & $\begin{array}{l}6.800 \\
4.350\end{array}$ \\
\hline $\begin{array}{l}699-42-398 \\
699-42.398 \\
699-62.398\end{array}$ & $10 / 28 / 92$ & 807156 & $20.00 \mathrm{U}$ & 800.00 & 2.87 & 4.350 \\
\hline $\begin{array}{l}699-42-398 \\
699-43-416 \\
699-43-616\end{array}$ & $\begin{array}{l}10 / 28 / 92 \\
10 / 92 \\
10 / 28 / 92\end{array}$ & $\begin{array}{l}\text { 807JL8 } \\
807 J 112\end{array}$ & $20.00 \mathrm{U}$ & 700.00 & $.96 \mathrm{U}$ & 4.60 \\
\hline $\begin{array}{l}699-43-43 \\
699-43-43\end{array}$ & $\begin{array}{l}10 / 26 / 92 \\
10 / 26 / 92\end{array}$ & $\begin{array}{l}807 j 65 \\
B 07 J 66\end{array}$ & $20.00 \mathrm{U}$ & 200.00 & 1.66 & 8.02 \\
\hline $\begin{array}{l}699-43-45 \\
699-43-45\end{array}$ & $\begin{array}{l}10 / 26 / 92 \\
10 / 26 / 92\end{array}$ & $\begin{array}{l}\text { 807J67 } \\
807 J 68\end{array}$ & $20.00 \mathrm{U}$ & 300.00 & 1.70 & 4.48 \\
\hline
\end{tabular}


DOE/RL 93-61, Rev 0 $12 / 93$

200 East Area W-252 Streams

Table 6-4. Constituents with at Least One Detected Value for the 216-B-3 Pond Data for Reporting Period October 1, 1992, through December 31, 1992. (sheet 3 of 5 )

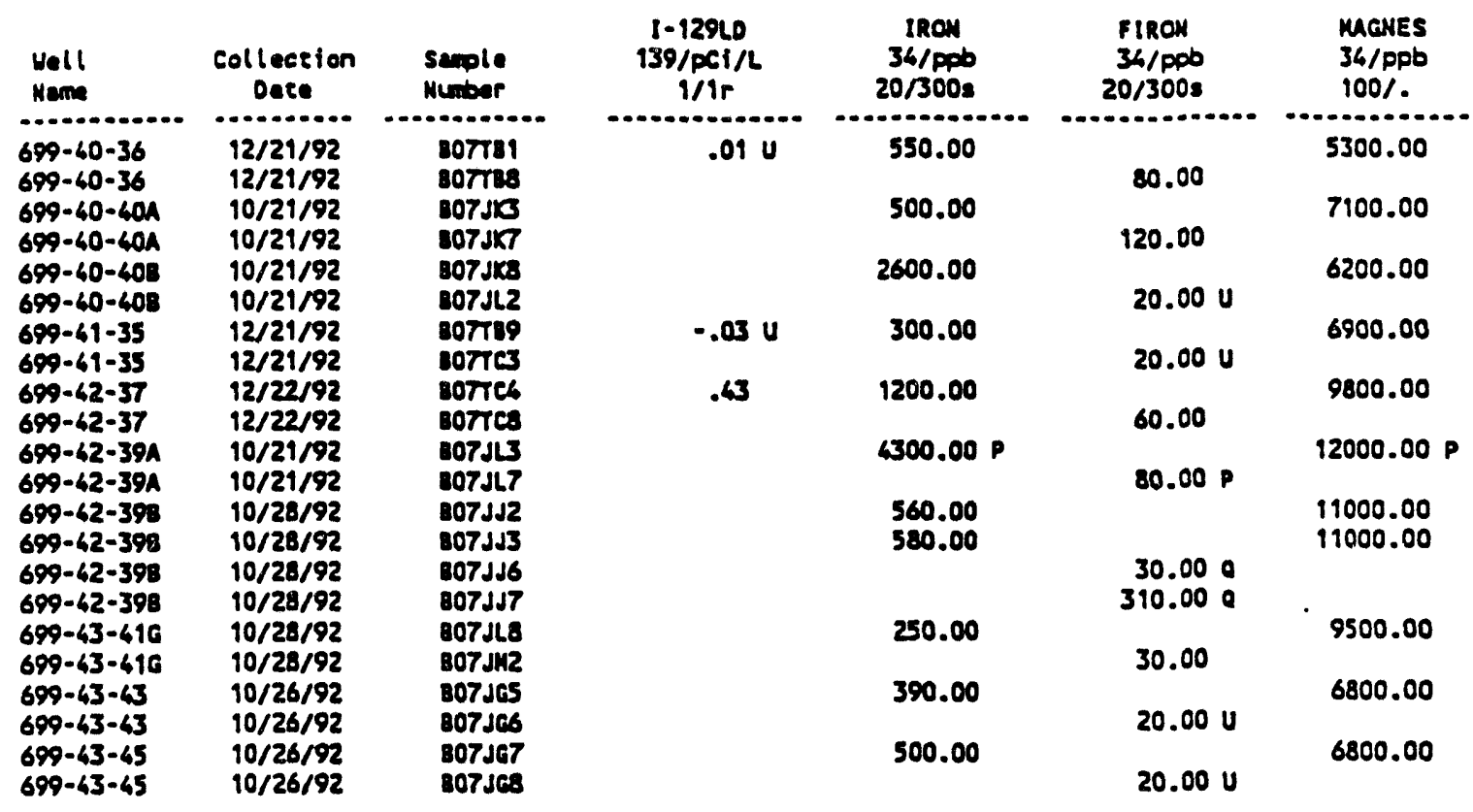

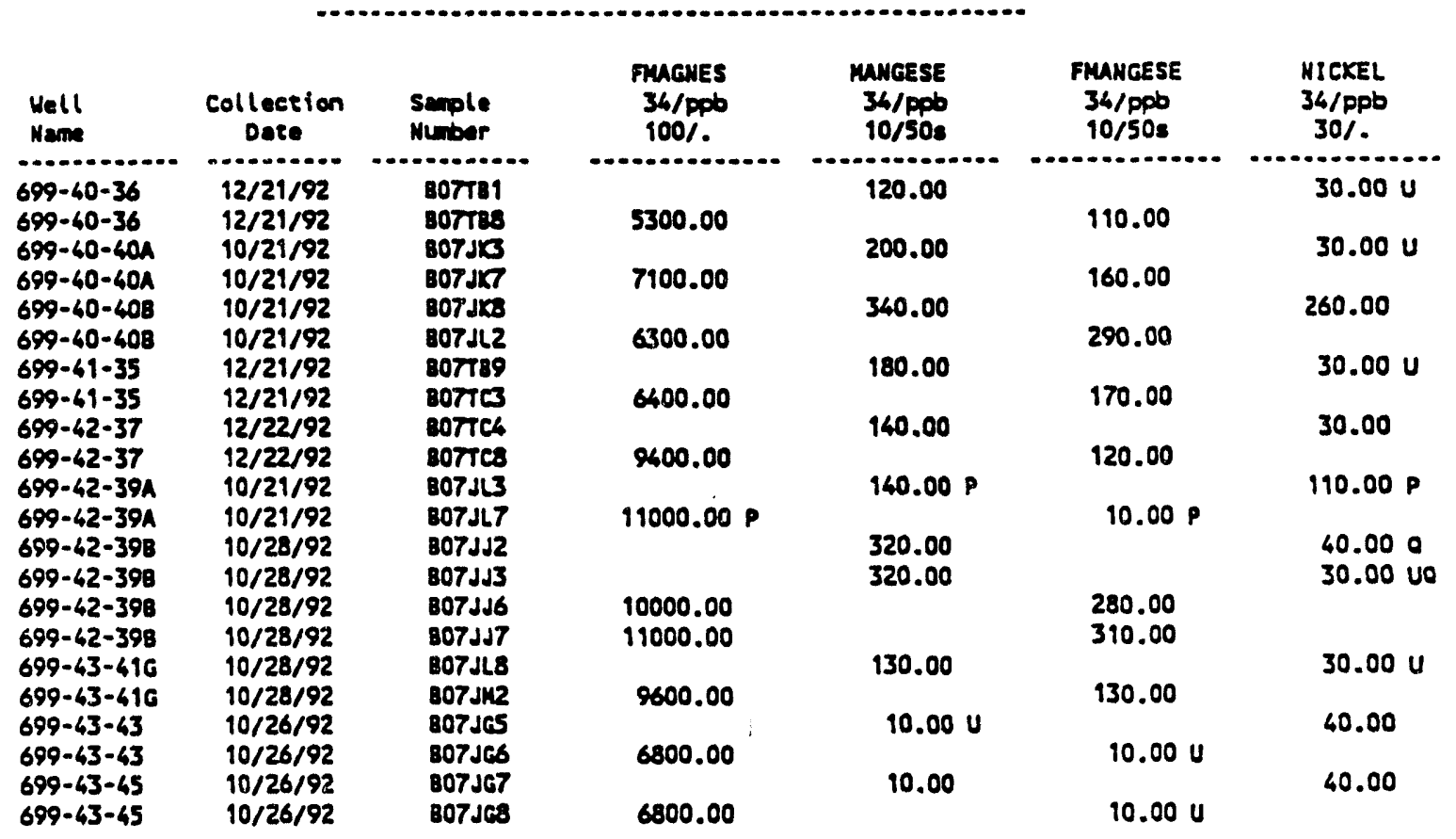


DOE/RL 93-61, Rev 0

Table 6-4. Constituents with at Least One Detected Value for the 216-8-3 Pond Data for Reporting Period October 1, 1992, through December 31, 1992.

(sheet 4 of 5 )

\begin{tabular}{|c|c|c|}
\hline $\begin{array}{l}\text { Woll } \\
\text { Nape }\end{array}$ & $\begin{array}{c}\text { Collection } \\
\text { Date }\end{array}$ & $\begin{array}{l}\text { Sample } \\
\text { Number }\end{array}$ \\
\hline $\begin{array}{l}299-518-1 \\
699-40-36 \\
699-40-36 \\
699-40-401 \\
699-40-401 \\
699-40-408 \\
699-40-408 \\
699-41-35 \\
699-41-35 \\
699-42-37 \\
699-42-37 \\
699-42-391 \\
699-42-391 \\
699-42-398 \\
699-42-398 \\
699-42-398 \\
699-42-398 \\
699-43-416 \\
699-43-416 \\
699-43-43 \\
699-43-43 \\
699-43-45 \\
699-43-45\end{array}$ & $\begin{array}{l}12 / 16 / 92 \\
12 / 21 / 92 \\
12 / 21 / 92 \\
10 / 21 / 92 \\
10 / 21 / 92 \\
10 / 21 / 92 \\
10 / 21 / 92 \\
12 / 21 / 92 \\
12 / 21 / 92 \\
12 / 22 / 92 \\
12 / 22 / 92 \\
10 / 21 / 92 \\
10 / 21 / 92 \\
10 / 28 / 92 \\
10 / 28 / 92 \\
10 / 28 / 92 \\
10 / 28 / 92 \\
10 / 28 / 92 \\
10 / 28 / 92 \\
10 / 26 / 92 \\
10 / 26 / 92 \\
10 / 26 / 92 \\
10 / 26 / 92\end{array}$ & 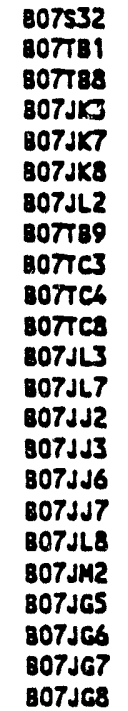 \\
\hline
\end{tabular}

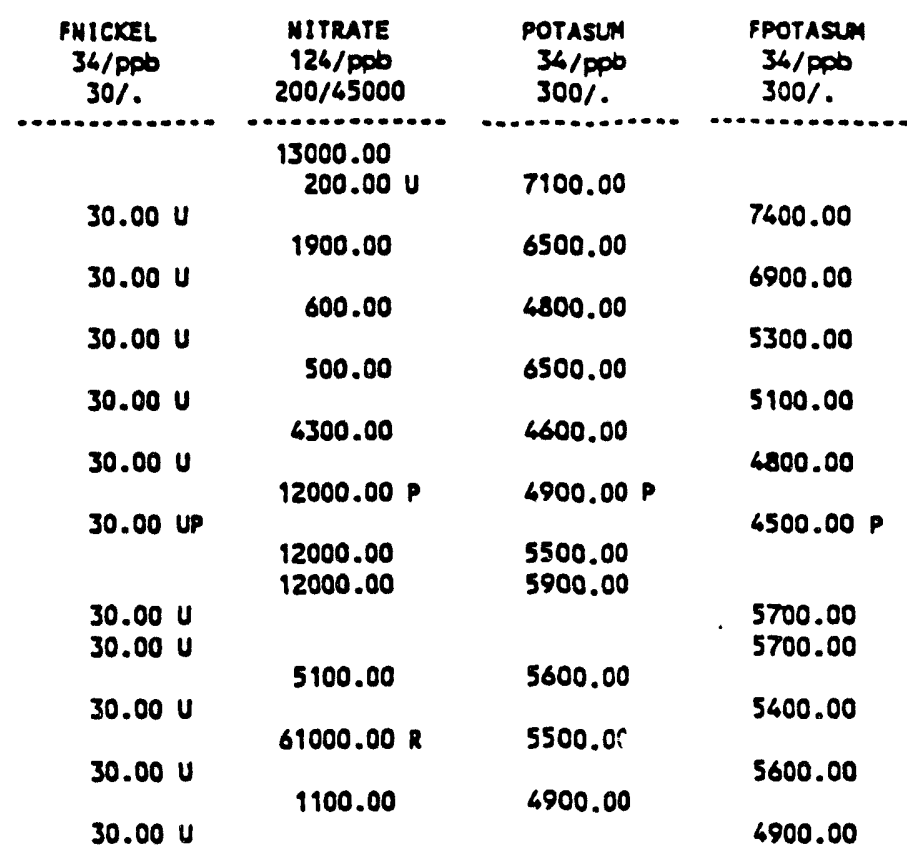

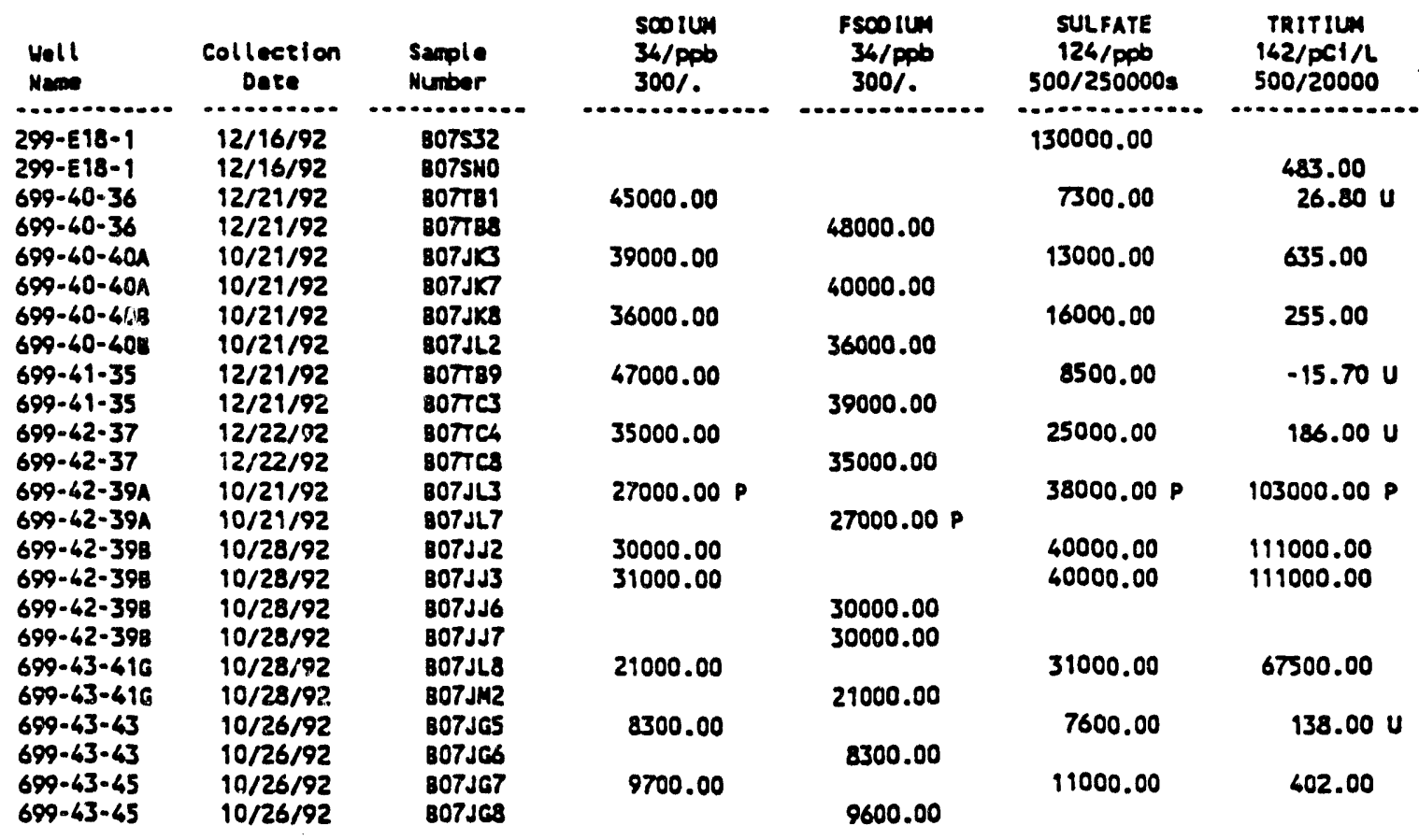


Table 6-4. Constituents with at Least One Detected Value for the 216-8-3 Pond Data for Reporting Period October 1, 1992, through December 31, 1992.

(sheet 5 of 5 )

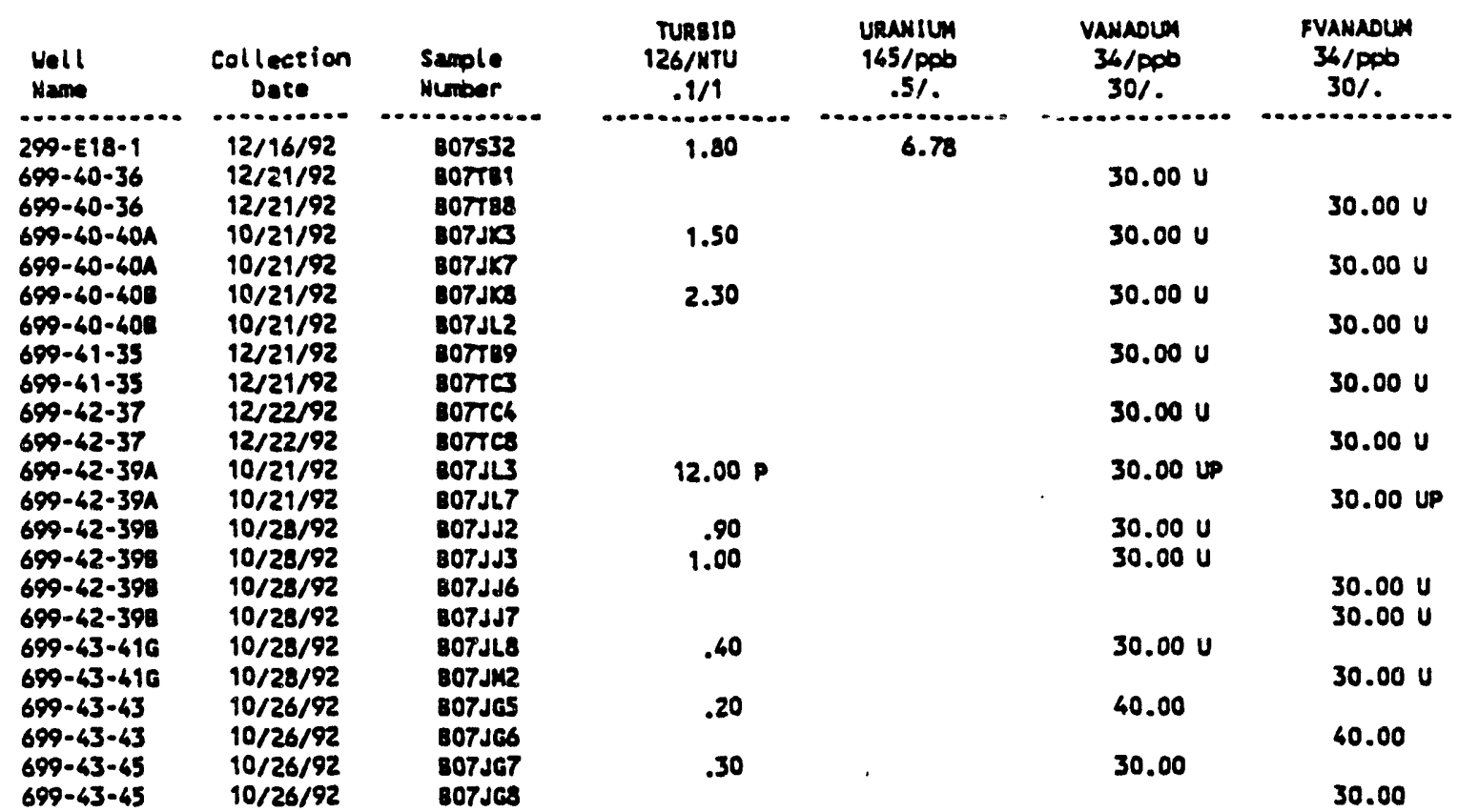

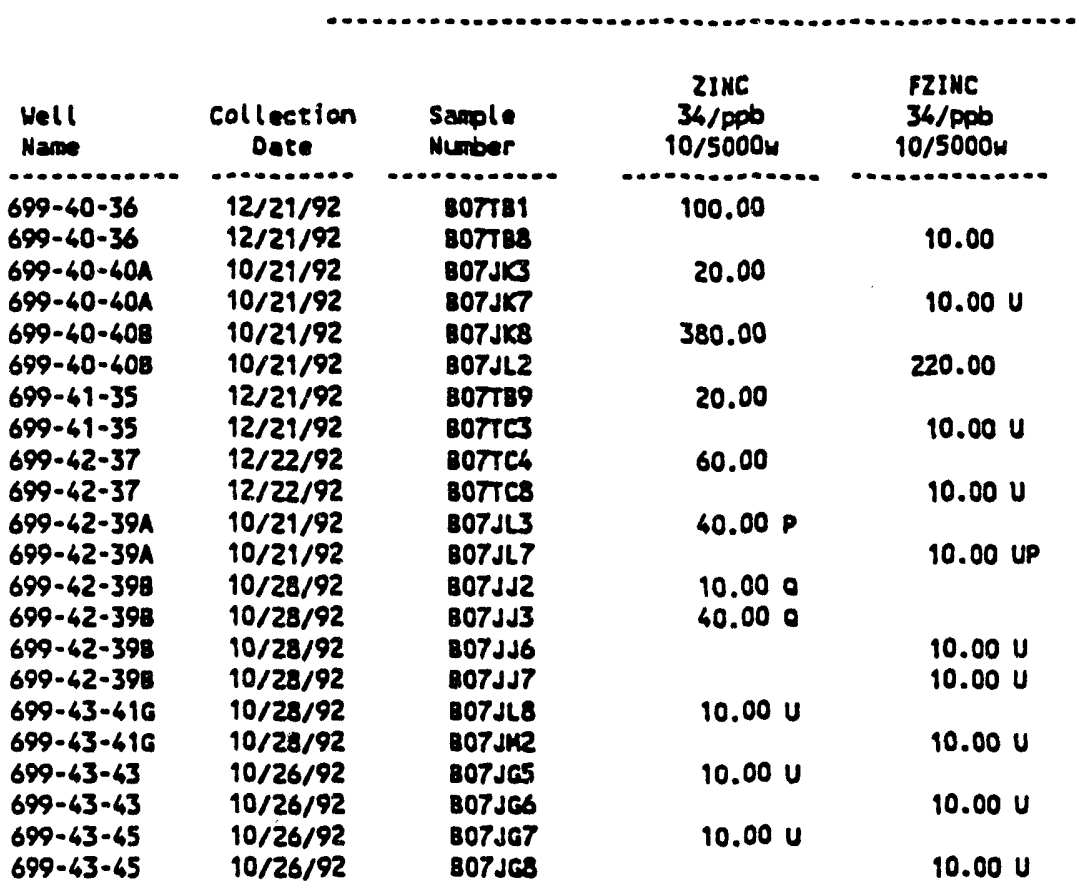

For explanation of this table, see section 1.6 of report. 
Table 6-5. Contamination Indicator Parameters for the 216-B-3 Pond Data for Reporting Period October 1, 1992, through December 31, 1992.

(sheet 1 of 2)

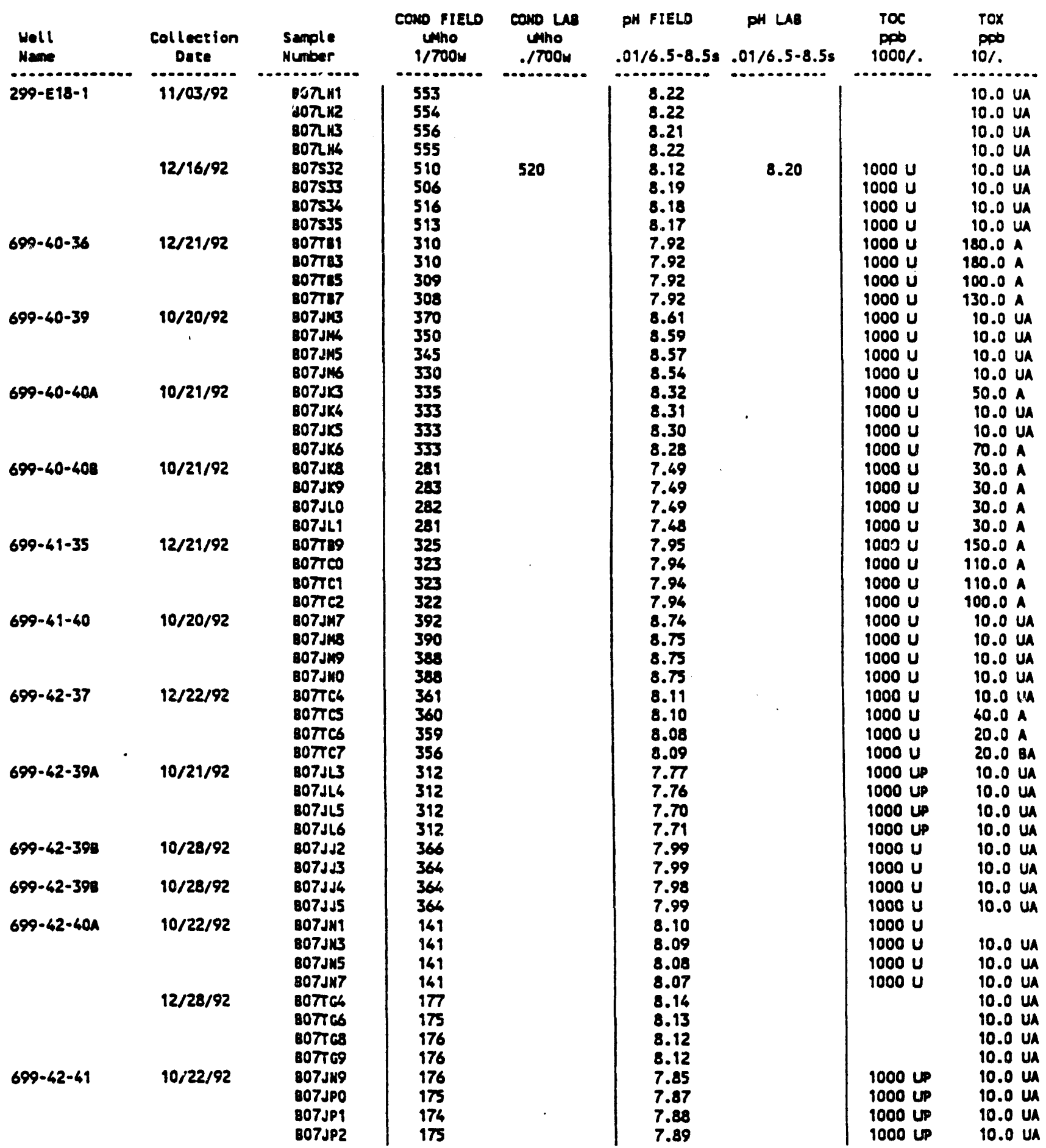


Table 6-5. Contamination Indicator Parameters for the 216-B-3 Pond Data for Reporting Period October 1, 1992, through December 31, 1992.

(sheet 2 of 2 )

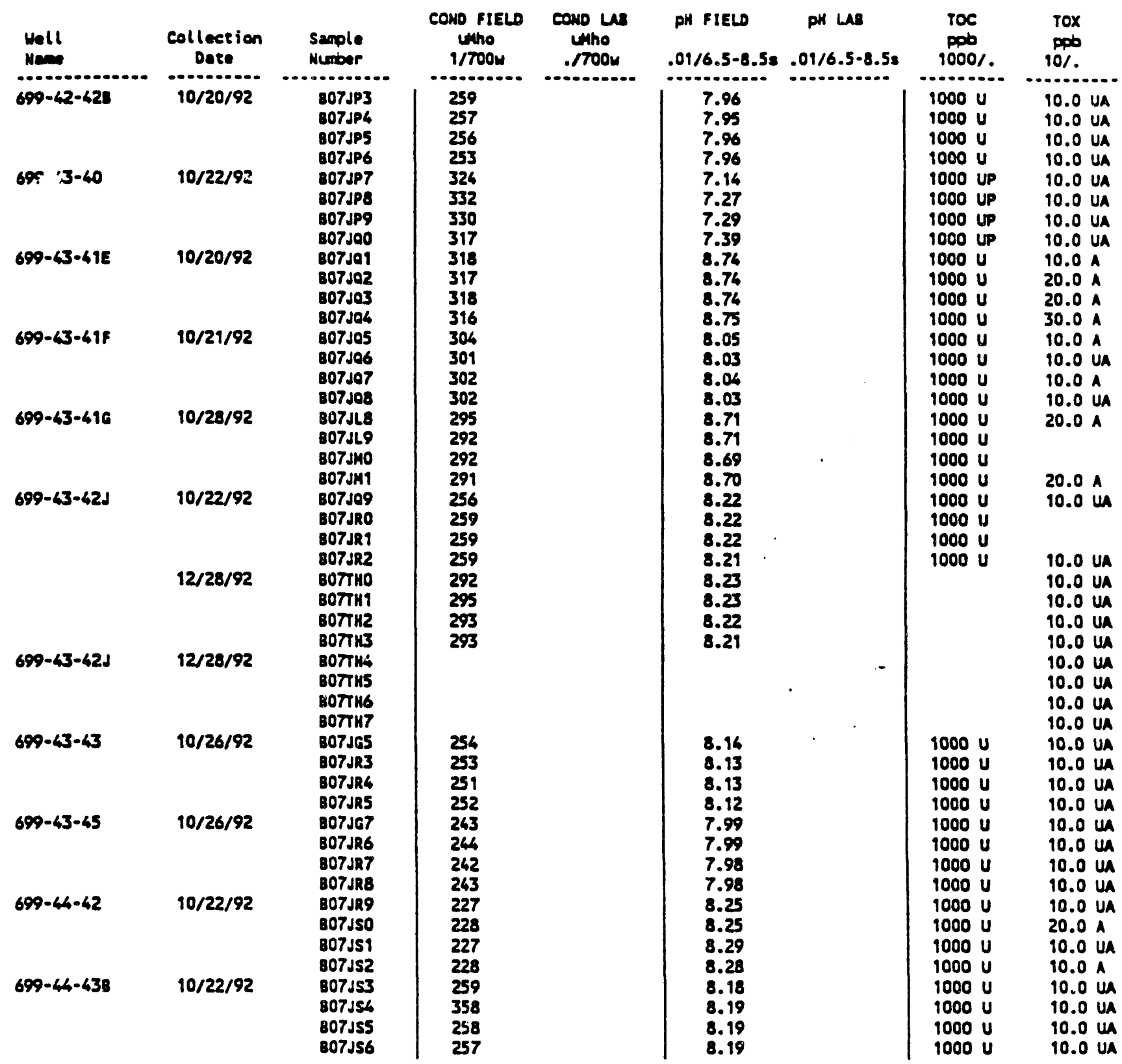

For explanation of this table, see Section 1.4 of report. 
5.0 DESCRIBE SOILS ON THE SITE USING INFORMATION FROM LOCAL SOIL SURVEY REPORTS. (SUBMIT ON SEPARATE SHEET.)

The mort recent study of the soil on the Hanford site was done by Hajek (1966).

The Burbank loamy sand is a dark grayish brown, coarse-textured, excessivelyHajek (1966) presents a soil map and descriptive report of soils in the Benton County portion of the Hanford Site. On the basis of morphologic and genetic characteristics, 13 soil types were identified. An approximate land use capability classification is provided for these soils, on the basis of soil limitations for, and damage risks associated with, agricultural use. Approximate engineering classifications for these soils, using the Unified Soil Classification System, are also provided in Hajek (1966). The soils around B Pond and much of the 200 East Area predominately consists of the two soil types: the Burbank loamy sand and the Rupert sand. Smaller amounts of the Ephrata sandy loam are also present in parts of 200 East. The soil types mapped on the Hanford Site are shown on Figure H-2. The following sections describe the soil present at the B Ponds and 200 East. drained soil underlain by gravel. The surface soil is usually about 16 inches thick but can be as much as 30 inches. The gravel content of the subsoil may range from 20 to 80 percent (by volume). The surface of the Burbank loamy sand is Group SM (silty sand) and the subsoil is group GM (silty gravel) to GP (poorly-graded gravel). Group GM (silty gravel) are coarse-grained soils composed predominantly of gravels with more than 12 percent fines. Group GP (poorly-graded gravel) contains coarse-grained soils that are predominantly well-sorted gravels with less than 5 percent fines.

The Rupert sand represents one of the most extensive soils at the Hanford Site. The soil is a brown to grayish brown, moderately-deep, coarse sand. Rupert soils developed under grass and sagebrush in coarse alluvial deposits mantled by wind-blown sand. Relief characteristically consists of hummocky terraces and dune-like ridges. The surface and subsoil of the Rupert sand were assigned to Group SM (silty sand) which consists of coarse-grained soils composed predominantly of sands with more than 12 percent fines.

The Ephrata sandy loam, occurring to an average depth of 12 inches, is a dark grayish brown, medium-textured soil underlain by deep gravelly material. The topography is generally level. The surface of the Ephrata sandy loam belongs to Group SM (silty sand) to ML (silt), and the subsurface belongs to Group ML (silt). Group ML (silt) are fine-grained soils composed of silts and clays with little or no plasticity. 


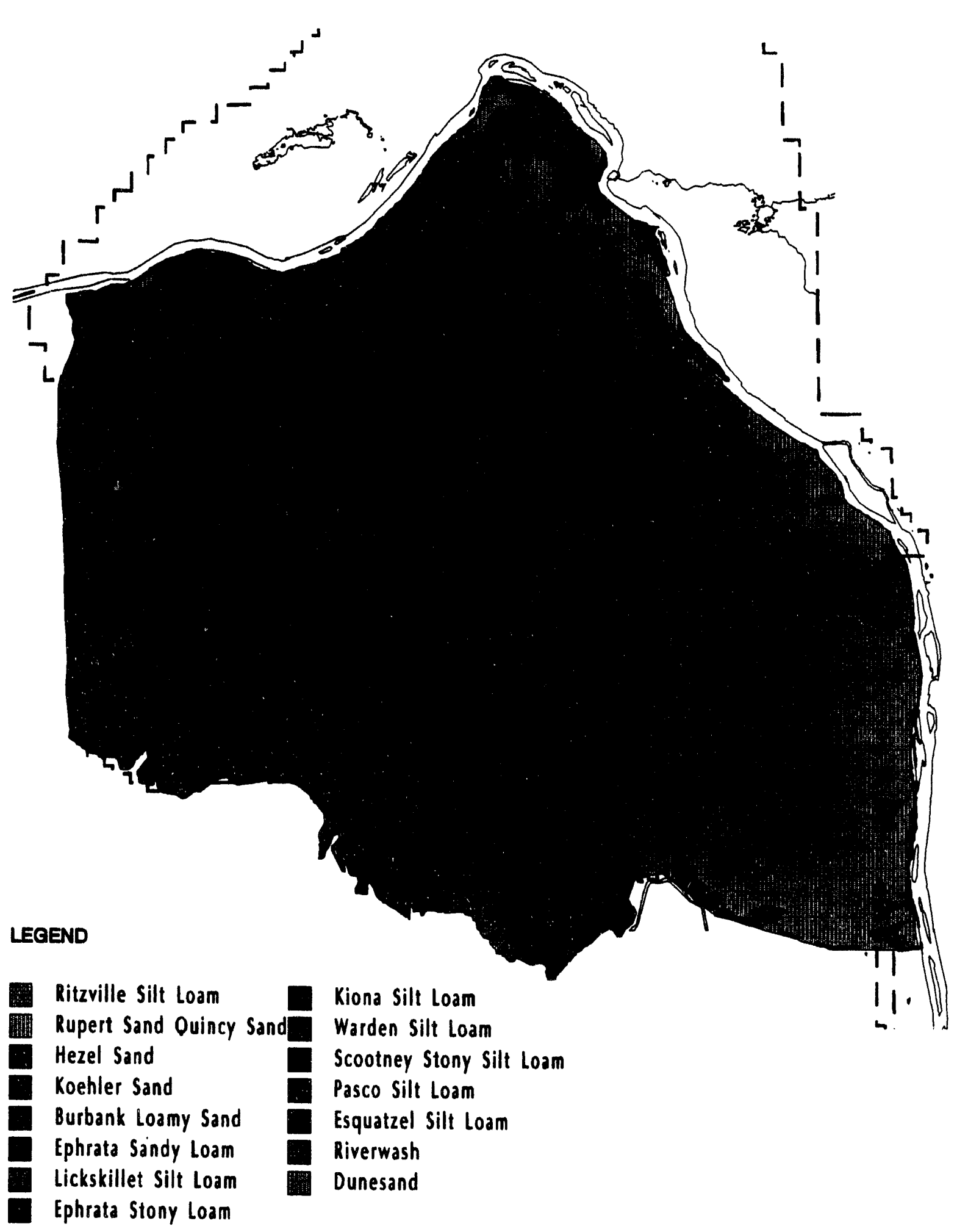

Souroa: Hajek 1938.

Figure H-2. Hanford Site Soils Map.

913 1728.013/plote.em/1/6-28-83 

MILE OF THE SITE. (SUBMIT ON SEPARATE SHEET.)

\subsection{REGIONAL GEOLOGY}

A summary of the regional geologic characteristics of the Pasco Basin and the Hanford Site is presented below in terms of stratigraphy and structure. Regional conditions of the area are described in WHC (1991a) and WHC (1992f), which maybe consulted for additional detail.

\subsection{REGIONAL STRATIGRAPHY}

The Hanford Site lies within the Pasco Basin, a regional structural and topographic, sediment-filled depression. The sediments of the Pasco Basin are underlain by Miocene-age basalt of the Columbia River Basalt Group, a thick sequence of flood basalts that covers a large area in eastern Washington, western Idaho and northeastern Oregon. The sediments overlying the basalts, from oldest to youngest, include: the Miocene-Pliocene Ringold Formation, local alluvial deposits of possible Late Pliocene or probable Early Pleistocene age, local "Palouse" soil of mostly eolian origin, glaciofluvial deposits of the Pleistocene Hanford formation, and surficial Holocene eolian and fluvial sediments. The generalized stratigraphy of the Hanford Site is described below from oldest to youngest, in the order of their deposition.

\subsubsection{Columbia River Basalt Group and the Ellensburg Formation}

The Columbia River Basalt Group consists of an assemblage of tholeiitic, continental flood basalts of Miocene Age with accumulated thickness in excess of 10,000 feet within the Pasco Basin. These flows cover an area of more than 63,000 square miles in Washington, Oregon, and Idaho and have an estimated volume of about 40,800 square miles. The majority of the flows were erupted 14.5 to $17 \mathrm{Ma}$ (DOE 1988).

The Columbia River Basalt Group is formally divided into five formations (from oldest to youngest): Imnaha Basalt, l'icture Gorge Basalt, Grande Ronde Basalt, Wanapum Basalt, and Saddle Mountanns Basalt. Of these, all are present within the Pasco Basin except for the Picture Gorge Basalt. The Saddle Mountains Basalt, divided into the Ice Harbor, Elephant Mountaın. Pomona, Esquatzel, Asotin, Wilbur Creek, and Umatilla Members, forms the uppermost basalt unit throughout most of the Pasco Basin. The Elephant Mountain Member is the uppermost unit beneath most of the Hanford Site except near the 300 Area where the Ice Harbor Member is found and north of the 200 Areas where the Saddle Mountains Basalt has been eroded down to the Umatilla Member in the Gable Gap area (WHC 1991a). The Elephant Mountain Member has also been locally eroded down to the Rattlesnake Ridge interbed, approximately one mile north of the 200 East Area and in the vicinity of the northeast corner of the 200) East Area. On anticlinal ridges bounding the Pasco Basin, erosion has removed the Saddle Mountains Basalt, exposing the Wanapum and Grande Ronde basalts. 
The Ellensburg Formation consists of all sedimentary units that occur between the basalt flows of the Columbia River Basalt Group in the central Columbia Basin (Reidel and Fecht 1981). The Ellensburg Formation generally consists of two main lithologies: volcaniclastics and siliciclastics. The volcaniclastics consist mainly of primary pyroclastic air fall deposits and reworked epiclastics derived from volcanic terrains west of the Columbia Plateau. Siliciclastic strata consist of clastic, plutonic, and metamorphic detritus derived from the Rocky Mountain terrain to the east.

At the Hanford Site, the three uppermost units of the Ellensburg Formation are the Levy interbed, the Rattlesnake Ridge interbed, and the Selah interbed. The Levey interbed is confined to the vicinity of the 300 Area. The Rattlesnake Ridge and Selah interbeds are found beneath most of the Hanford Site (WHC 1992f).

\subsubsection{Suprabasalt Sediments}

The suprabasalt sedimentary sequence at the Hanford Site is up to approximately 750 feet thick in the west-central Cold Creek syncline, while it pinches out against the anticlinal ridges that bound or are present within the Pasco Basin. The suprabasalt sediments are dominated by laterally extensive deposits of the late Miocene to Pliocenerge Ringold Formation and the Pleistocene-age Hanford formation. Locally occurring strata separating the Ringold and Hanford formations are assigned to the informally defined Plio-Pleistocene unit, early "Palouse" soil, and pre-Missoula gravels, which comprise the remainder of the sequence.

6.2.2.1 Ringold Formation. Overlying the Columbia River Basalt Group is the late Miocene to Pliocene-age Ringold Formation (Fecht et al. 1987; DOE 1988). The Ringold Formation accumulated to thicknesses of up to 1,200 feet in the Pasco Basin. On the Hanford Site, the Ringold Formation is up to 600 feet thick in the deepest part of the Cold Creek syncline south of the 200 West Area and 560 feet thick in the western Wahluke syncline near the 100-B Area. The Ringold Formation pinches out against the anticlinal flanks that bound or are present within the Pasco Basin, and is largely absent in the northern and northeastern parts of the 200 East Area and adjacent areas to the north (WHC 1991a; WHC 1992f). The Recent studies of the Ringold Formation (WHC $1991 \mathrm{~b}$ ) indicate it is best described on the basis of sediment facies associations and their distribution. The facies associations have been divided into fluvial gravel, fluvial sand, overbank deposits, lacustrine deposits, and alluvial fans. The lower Ringold contains five separate stratigraphic intervals dominated by fluvial gravels, which have been designated units $A, B, C, D$, and $E$, from oldest to youngest. These gravels units are separated by basin -wide overbank and lacustrine deposits (WHC 1992f). A more detailed discussion of the Ringold Formation stratigraphy can be found in WHC (1991b).

6.2.2.2 Post-Ringold Pre-Hanford Sediments. Thin alluvial deposits situated stratigraphically between the Ringold Formation and Hanford formation are found within the Pasco Basin. The three informally defined units include: (1) the PlioPleistocene unit; (2) the early "Palouse" soil; and (3) the Pre-Missoula gravels. The PlioPleistocene unit and early "Palouse" soil are not found in or near the 200 East Area. They are found to the west of the site area near the eastern boundary of the 200 West Area. The pre-Missoula gravels are not found in the site area. Because of the absence of 
these units from the site area, they will not be discussed further. The Plio-Pleistocene unit and early "Palouse" soil are described in detail in WHC (1991b). The pre-Missoula gravels are discussed in PSPL (1982) and Fecht et al. (1987).

6.2.2.3 Hanford formation. The informally designated Hanford formation consists of unconsolidated, glaciofluvial sediments that were deposited during several episodes of cataclysmic flooding during the Pleistocene Epoch. The sediments are composed of pebble to boulder gravel, fine- to coarse-grained sand, and silt. These sediments are divided into three facies: (1) gravel dominated, (2) sand-dominated, and (3) silt-dominated (WHC 1992f). These facies are referred to as coarse-grained deposits, plane-laminated sand facies, and rhythmite facies, respectively (Baker et al. 1991). The silt-dominated deposits are also referred to as "Touchet" Beds, and the gravel-dominated facies generally correspond to the Pasco gravels.

The Hanford formation is thickest in the vicinity of the 200 Areas where it is up to 350 feet thick (WHC 1992f). The formation was deposited by cataclysmic flood waters that originated from glacial lake Missoula (Fecht et al. 1987; DOE 1988; Baker et al. 1991). The deposits are absent from ridges above approximately 1,180 feet above mean sea level, the highest level of cataclysmic flooding in the Pasco Basin (WHC 1991a).

6.2.2.4 Holocene Surficial Deposits. Holocene surficial deposits consist of silt, sarid, and gravel that form a less than 33 feet veneer across much of the Hanford Site. These sediments were deposited by eolian and alluvial processes.

\subsection{REGIONAL GEOLOGIC STRUCTURE}

The Hanford Site is located within the Pasco Basin near the eastern edge of the Yakima Fold Belt. The Yakima Fold Belt consists of a series of segmented, narrow, asymmetric, east-west trending anticlines separated by broad synclines or basins that, in many cases, contain thick accumulations of Neogene- to Quaternary-aged sediments (DOE 1988; Smith et al. 1989). The Pasco Basin is one of the larger structural basins of the fold belt.

The northern limbs of the anticlines of the Yakima Fold Belt generally dip steeply to the north, or are vertical. The southern limbs generally dip at relatively shallow angles to the south. Thrust or high-angle reverse faults with fault planes that strike parallel or subparallel to the axial trends are principally found on the north sides of the anticlines. The amount of vertical stratigraphic offset associated with these faults varies.

Deformation of the Yakima Folds occurred under north-south compression and was contemporaneous with the eruption of the basalt flows. The fold belt was enlarging during the eruption of the Columbia River Basalt Group and continued to enlarge through the Pliocene, into the Pleistocene, and perhaps to the present.

The Pasco Basin is a structural depression bounded on the north by the Saddle Mountain anticline, on the west by the Umtanum Ridge, Yakima Ridge, and Rattlesnake Hills anticlines, and on the south by the Rattlesnake Mountain anticline. The Palouse slope, a west-dipping monocline, bounds the Pasco Basin on the east. The Pasco Basin is 
divided into the Wahluke and Cold Creek synclines by the Gable Mountain anticline, the eastern extension of the Umtanum Ridge anticline.

The Cold Creek syncline lies between the Umtanum Ridge-Gable Mountain uplift and the Yakima Ridge uplift, and is an asymmetric and relatively flat-bottomed structure. The bedrock of the northern limb dips gently to the south, and the southern limb dips steeply to the north. The deepest parts of the Cold Creek syncline, the Wye Barricade depression and the Cold Creek depression, are located approximately 7.5 miles southeast of the 200 Areas and just to the west-southwest of the 200 West Area, respectively.

\subsection{LOCAL GEOLOGY}

The depth to the top of the Elephant Mountain Member basalt in the vicinity of the B Ponds is approximately 200 feet. Overlying the basalt are the sediments of the Ringold Formation, Hanford formations, and Holocene surfical deposits. The PlioPliestocene unit, early "Palouse" soil and the Pre-Missoula gravels are absent in the vicinity of the B Ponds (WHC 1992f; DOE-RL 1990). The following discussion emphasizes the suprabasalt sediments in the vicinity of the B Ponds. Figure $\mathrm{H}-3$ presents a schematic view of the suprabasalt sediments in the vicinity of the B Ponds.

\subsubsection{Ringold Formation}

The thickness of the Ringold Formation in the vicinity of $B$ Ponds varies from approximately 50 feet to 125 feet (Figure H-3). Overlying the basalt in the vicinity of $B$ Ponds is the fluvial gravels of unit A. Unit A thickens and dips to the south, southwest and southeast, pinches out in the vicinity of the B Ponds. The thickness of unit $A$ around $B$ Pond is between 0 to 100 feet (Figure H-3). Unit A is generally described as a clast-supported granule to cobble gravel with a sandy matrix. Clast composition is variable with basalt, quartzite, porphyritic volcanics, and greenstone being the most common. Associated sands are generally quartzo-feldspathic with basalt content ranging from 5 percent to 25 percent (WHC 1992f).

Overlying unit $A$ is the lower mud sequence. The lower mud sequence overlies basalt in the vicinity of the B Ponds where unit A pinches out, and is the uppermost Ringold unit between the $B$ Ponds and Gable Mountain. The sequence thickens and dips to the south and southwest, similar to unit A. The thickness of the lower mud sequence is approximately 25 feet to 50 feet (Figure $\mathrm{H}-3$ ). The lower mud sequence is composed of overbank and lacustrine deposits which consist of laminated to massive silt, silty fine-grained sand, and paleosols containing variable amounts of pedogenic calcium carbonate. Plane laminated to massive clay with thin silt and sand interbeds characterize the lacustrine deposits. The lacustrine deposits contain some soft-sediment deformation (WHC 1992f). 


\subsubsection{Hanford formation}

In the vicinity of the $B$ Ponds, the sequences comprising the Hanford formation consist mostly of the gravel-dominated and sand-dominated facies. Informally, the Hanford formation can be divided into the upper gravel unit, middle sandy unit, and lower gravel unit (WHC 1992f). Because of variability of the Hanford formation sediments, contacts between these sediments can be difficult to distinguish, especially where the sandy sequence is missing and the upper gravel directly overlies the lower gravel.

The lower gravel sequence consists of coarse-grained basaltic sand and granule to boulder gravel. Other clast types include Ringold and Plio-Pleistocene rip-ups, granite, quartzite and gneiss (WHC 1992g). Discontinuous intervals dominated by the sanddominated facies and localized horizons of silt-dominated deposits also are encountered. Beneath the B Pond, the lower gravel sequence ranges in thickness from approximately 75 to 100 feet (Figure H-3).

The middle sand sequence consists of fine- to coarse-grained sand and granule gravel displaying.plane lamination and bedding. Intercalated horizons typical of both the gravel-dominated and sand-dominated facies also occur within the sequence. The middle sand sequence around B Pond ranges in thickness from 0 to 150 feet (Figure H-3). This unit thins and pinches out north of the B Ponds.

Deposits comprising the upper gravel sequence are typical of the graveldominated facies. Lenticular horizons of sand-dominated and silt-dominated facies are common in the upper gravel sequence. The thickness of the upper gravel ranges from 25 to 50 feet (Figure $\mathrm{H}-3$ ).

\subsubsection{Holocene Surficial Deposits}

Holocene surficial deposits consist of silt, sand and gravel that form a less than 33 feet veneer across much of the Hanford site. These sediments were deposited by a combination of eolian and alluvial processes. Eolian activity in the vicinity of the $B$ Ponds has done little but to locally rework and redistribute surficial deposits. This has produced sheet sands which blanket the surface (WHC 1991a). 
DOE/RL 93-61, Rev 0

$12 / 93$

200 East Area W-252 Streams

This page intentionally left blank.

H-68 


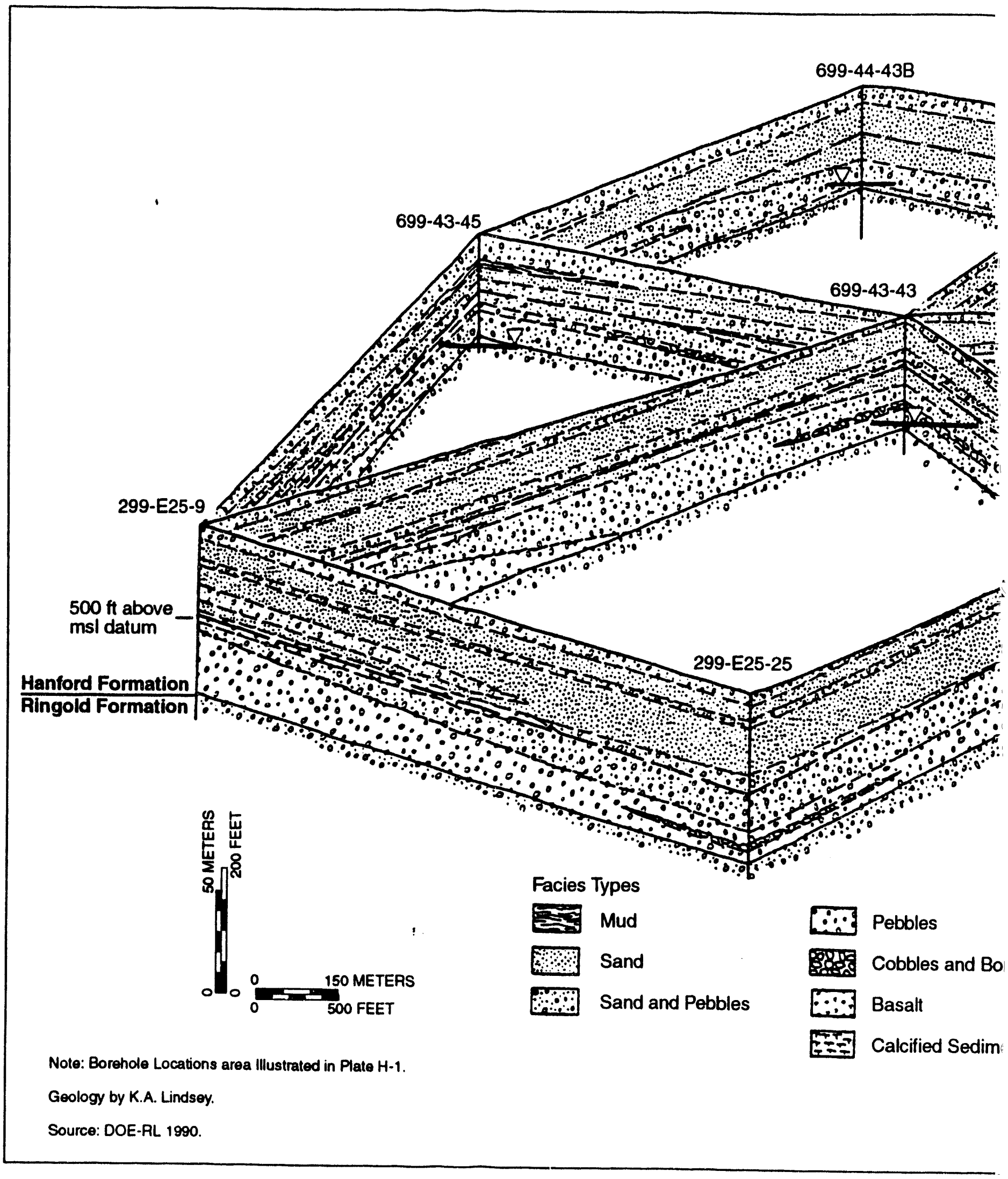



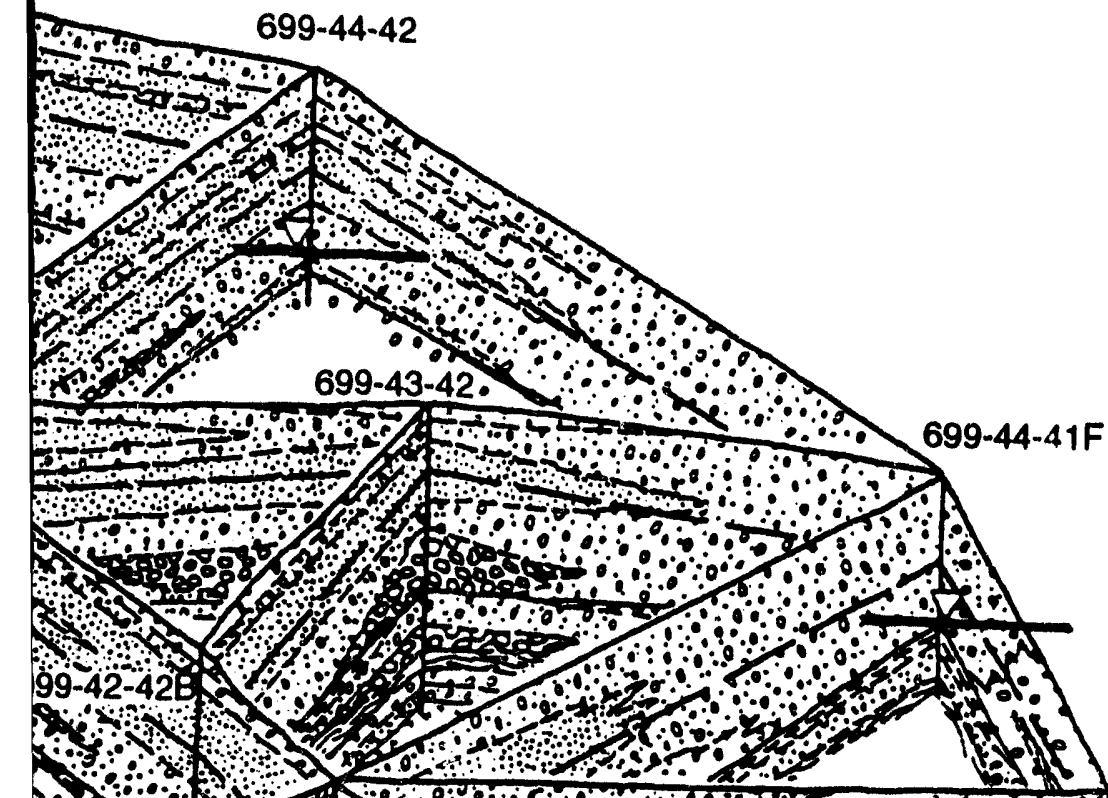

\section{.}

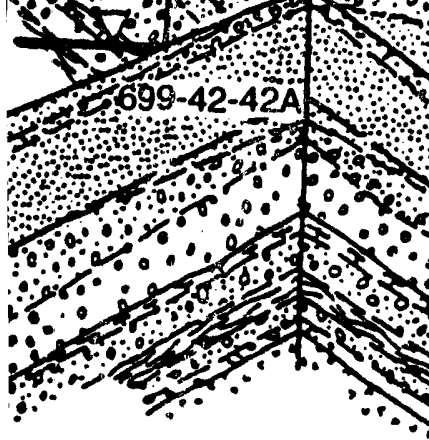

10

_ Inferred Formational Contact

Inferred Facies Contact

Potentiometris Level, 6/89

nts

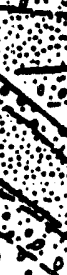




\subsection{REGIONAL HYDROGEOLOGY}

The hydrogeology of the Pasco Basin has been broadly characterized as consisting of four primary hydrogeologic units (DOE 1988). These units correspond to the upper three formations of the Columbia River Basalt Group (Grande Ronde Basalt, Wanapum Basalt, and Saddle Mountains Basalt) and the sedimentary overburden. The basalt aquifers consist of the flood basalts of the Columbia River Basalt Group and relatively minor amounts of intercalated fluvial and volcaniclastic sediments of the Ellensburg Formation. Confined zones in the basalt aquifers are present in the sedimentary interbeds and/or interflow zones that occur between dense basalt flows. The main water-bearing portions of the interflow zones are networks of interconnecting vesicles and fractures of the basalt flow tops and flow bottoms (DOE 1988). The suprabasalt sediment, or uppermost aquifer system, consists of fluvial, lacustrine, and glaciofluvial sediments. This aquifer is regionally unconfined and is contained largely within the Ringold Formation and Hanford formation.

The uppermost aquifer is part of a flow system that is local to the Pasco Basin, as are the uppermost basalt interbed aquifers (Gephart et al. 1979; DOE 1988).

Groundwater in these aquifer systems is probably recharged and discharged locally. Deeper in the basalt, interbed aquifer systems are part of the regional, or interbasin, flow' system, which extends outside the margins of the Pasco Basin (DOE 1988). The uppermost aquifer system is regionally unconfined and occurs within the glaciofluvial sands and gravels of the Hanford formation and the fluvial/lacustrine sediments of the Ringold Formation. Confined to semi-confined aquifers of more limited extent also occur in the suprabasalt sediments of the Pasco Basin. These confined zones are generally located within the local flow system, between the unconfined aquifer and the underlying basalt surface.

\subsection{LOCAL HYDROGEOLOGY}

The principal hydraulic units around the B Ponds are the unsaturated (vadose) zone, the Hanford formation, coarse- and fine-grained facies of the Ringold Formation and the uppermost aquifers within the basalt and interflow aquifer system (DOE-RL 1990). The following discussion focuses on the vadose zone, Hanford formation and the Ringold Formation.

The vadose zone beneath the B Ponds ranges in thickness from 124 to 160 feet. This zone is composed primarily of Hanford formation sediments, consisting of the units described above in Section 2.2. The vadose zone includes some of the fine-grained Ringold Formation where the water table is below the Hanford-Ringold contact. The average moisture content of the unsaturated sediments is between 3 percent and 7 percent (DOE-RL 1990).

The uppermost aquifer in the vicinity of the B Ponds includes a portion of the Hanford formation and the Ringold Formation. The aquifer is approximately 50 to 100 feet thick. The majority of this aquifer is unconfined, but parts of the aquifer are confined or semiconfined by the local presence of fine-grained deposits. The aquifer is unconfined to the west and north of the 216-B-3 Pond, and is confined to the southeast 
part of the ponds, beneath $216-\mathrm{B}-3 \mathrm{C}$ pond. There is no marked differences in the hydraulic head measured in the unconfined and the confined portions of the aquifer (DOE-RL 1990).

The confined aquifer system beneath the B Ponds is found in the Ringold Formation Unit A, which is confied by the fine- grained silt and clay lower mud sequence (DOE-RL 1990).

Effluent discharge to the B Ponds has created a groundwater mound (Figure $\mathrm{H}-4)$. The water table in the vicinity of the B ponds has a concentric radial pattern centered on the B Ponds. Movement of the groundwater in the vicinity of the B Pond is radially away from them. Additional discussion of the hydrogeology in the vicinity of the B Ponds can be found in the 216-B-3 Pond system Closure/Postclosure Plan (DOE-RL 1990). 


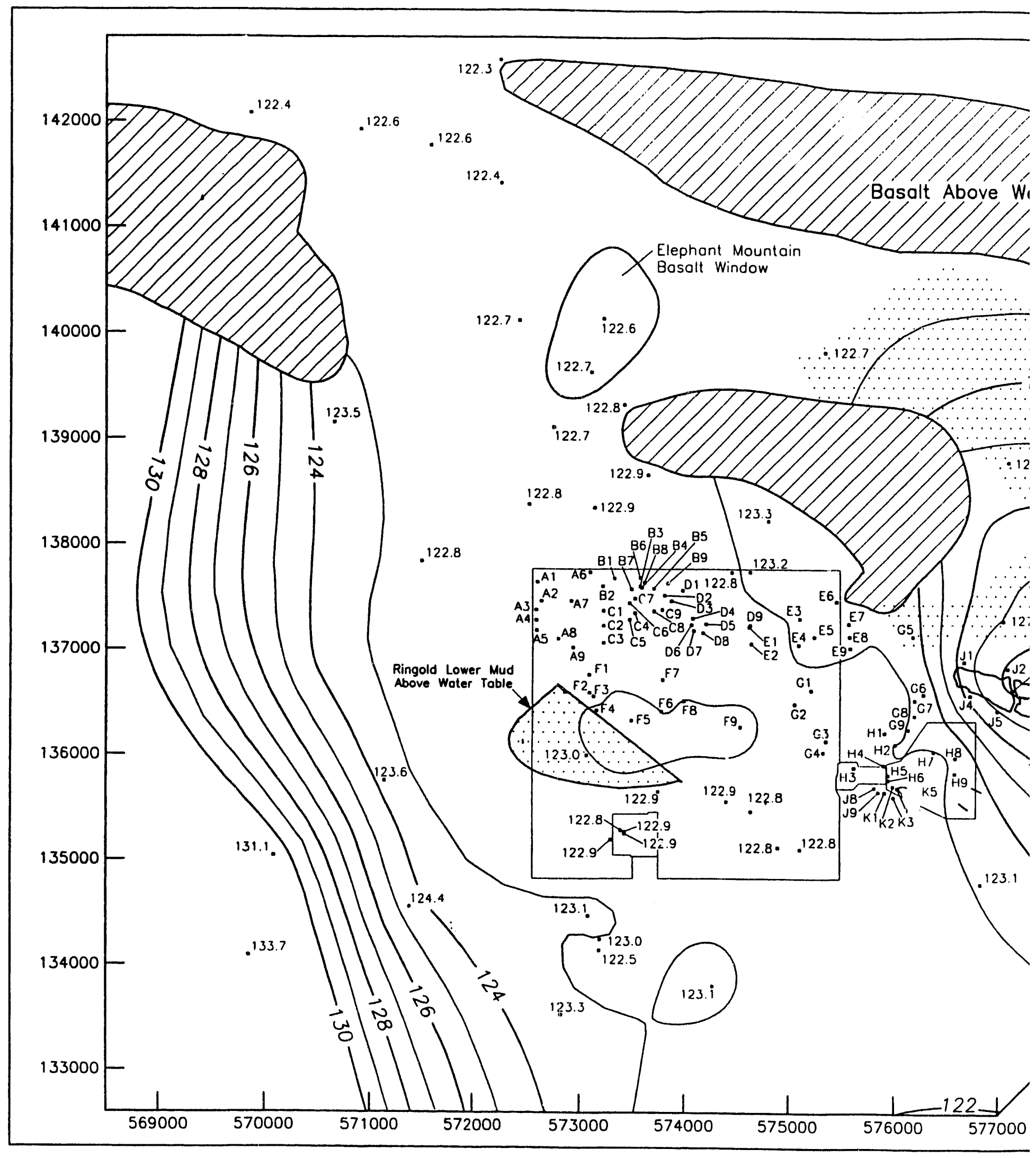




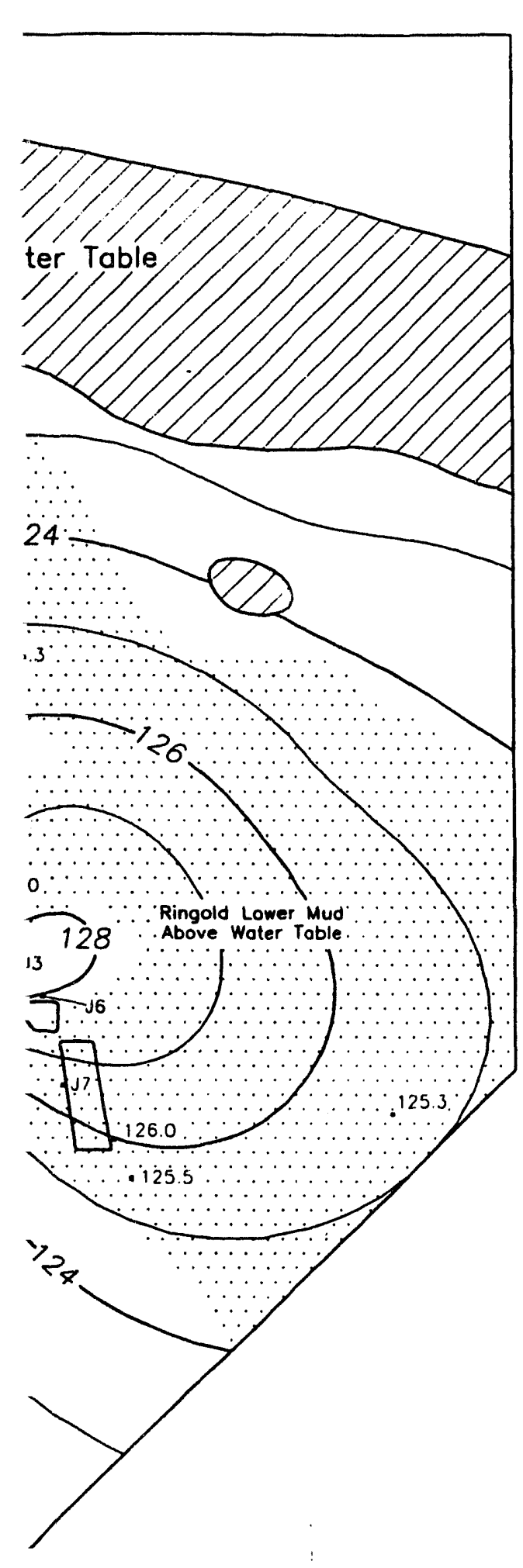

Legend:

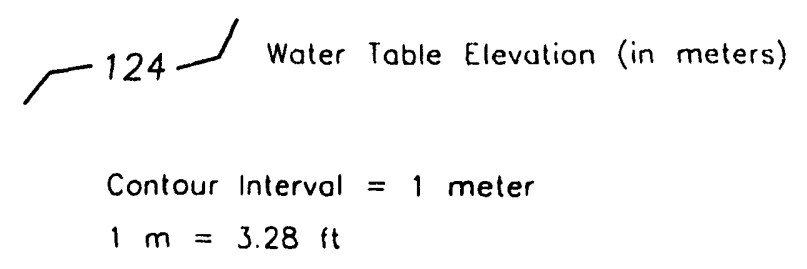

\begin{tabular}{|c|c|c|c|c|}
\hline $\begin{array}{l}A 1-122.9 \\
A 2-122.8 \\
A 3-122.8 \\
A 4-122.8 \\
A 5-122.8 \\
A 6-122.8 \\
A 7-122.8 \\
A 8-122.8 \\
A 9-122.9\end{array}$ & $\begin{array}{l}B 1-122.4 \\
82-122.8 \\
B 3-122.7 \\
B 4-122.8 \\
B 5-122.5 \\
B 6-122.8 \\
B 7-122.9 \\
B 8-122.3 \\
B 9-122.8\end{array}$ & $\begin{array}{l}C 1-122.8 \\
C 2-122.8 \\
C 3-122.8 \\
C 4-122.8 \\
C 5-122.9 \\
C 6-122.8 \\
C 7-122.8 \\
C 8-122.9 \\
C 9-122.9\end{array}$ & $\begin{array}{l}D 1-122.9 \\
D 2-123.3 \\
D 3-122.9 \\
D 4-122.8 \\
D 5-122.8 \\
D 6-122.4 \\
D 7-122.8 \\
D 8-122.9 \\
D 9-122.9\end{array}$ & $\begin{array}{l}E 1-122.9 \\
E 2-122.9 \\
E 3-123.0 \\
E 4-123.0 \\
E 5-123.1 \\
E 6-123.1 \\
E 7-123.1 \\
E 8-123.1 \\
E 9-123.1\end{array}$ \\
\hline $\begin{array}{l}F 1-123.0 \\
F 2-123.0 \\
F 3-122.8 \\
F 4-123.1 \\
F 5-123.2 \\
F 6-123.0 \\
F 7-122.7 \\
F 8-123.0 \\
F 9-123.0\end{array}$ & $\begin{array}{l}G 1-122.9 \\
G 2-122.9 \\
G 3-122.8 \\
G 4-122.8 \\
G 5-123.7 \\
G 6-123.2 \\
G 7-123.1 \\
G 8-123.1 \\
G 9-123.1\end{array}$ & $\begin{array}{l}H 1-122.3 \\
H 2-123.0 \\
H 3-122.9 \\
H 4-123.0 \\
H 5-122.9 \\
H 6-123.0 \\
H 7-123.0 \\
H 8-123.1 \\
H 9-123.2\end{array}$ & $\begin{array}{l}J 1-126.6 \\
J 2-128.1 \\
J 3-128.1 \\
J 4-126.4 \\
J 5-126.9 \\
J 6-128.0 \\
J 7-126.5 \\
J 8-123.0 \\
J 9-123.0\end{array}$ & $\begin{array}{l}K 1-122.9 \\
K 2-122.8 \\
K 3-122.9 \\
K 4-123.0 \\
K 5-123.0\end{array}$ \\
\hline
\end{tabular}

Note: Grid in Lombert

coordinotes (meters), NAD83.

Source: Connelly et al. 1992.

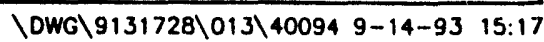

Figure H-4. December 1991 Water Table Elevations in the Vicinity of the 200 East Area and the B-Pond Complex. 
DOE/RL 93-61, Rev 0 $12 / 93$

200 East Area W-252 Streams

$1 \quad 7.0 \quad$ LIST THE NAMES AND ADDRESSES OF CONTRACTORS OR CONSULTANTS

2 WHO PROVIDED INFORMATION AND CITE SOURCES OF INFORMATION BY TITLE

3 AND AUTHOR.

4

5

Consultants:

Golder Associates Inc.

1933 Jadwin Avenue, Suite 125

Richland, WA 99352

SAIC

7601 West Clearwater Boulevard, Suite 450

Kennewick, WA 99352

14

15

16

17

18

A reference list is included in Section 2.0 of the document for all references cited in this permit application. 
DOE/RL 93-61, Rev 0

200 East Area W-252 Streams

This page intentionally left blank. 


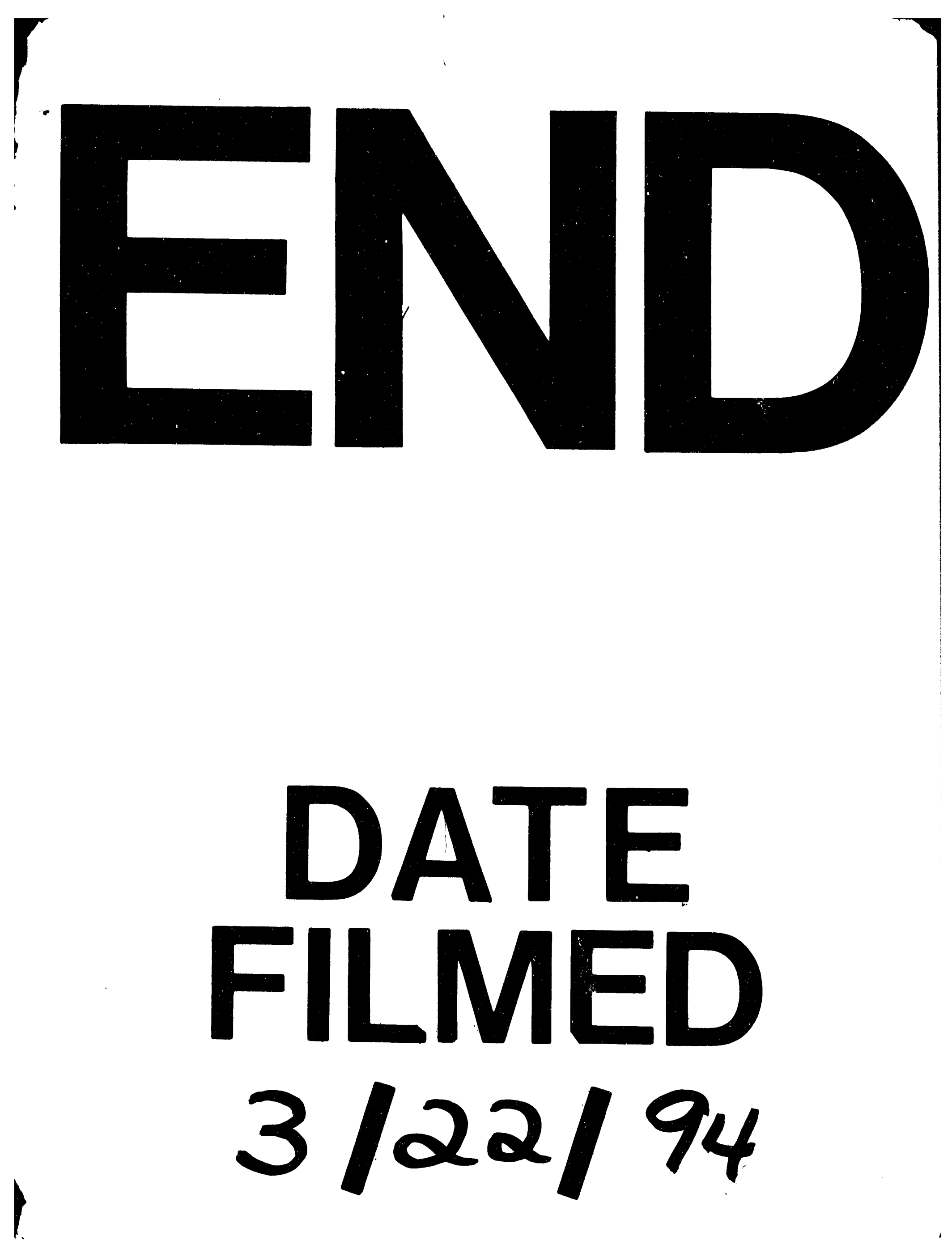


